\title{
Strah od čitanja i ovladavanje vještinom čitanja na stranome jeziku
}

\section{Didović Baranac, Sandra}

Doctoral thesis / Disertacija

2020

Degree Grantor / Ustanova koja je dodijelila akademski / stručni stupanj: University of Zagreb, University of Zagreb, Faculty of Humanities and Social Sciences / Sveučilište u Zagrebu, Filozofski fakultet

https://doi.org/10.17234/diss.2020.5569

Permanent link / Trajna poveznica: https://urn.nsk.hr/urn:nbn:hr:131:649453

Rights / Prava: In copyright/Zaštićeno autorskim pravom.

Download date / Datum preuzimanja: 2023-04-26

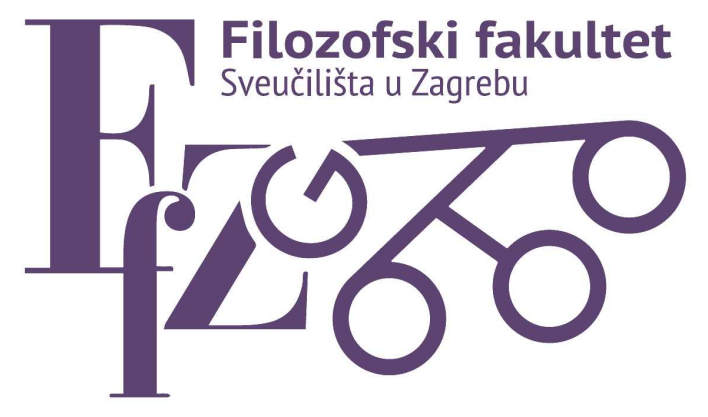

Repository / Repozitorij:

ODRAZ - open repository of the University of Zagreb

Faculty of Humanities and Social Sciences
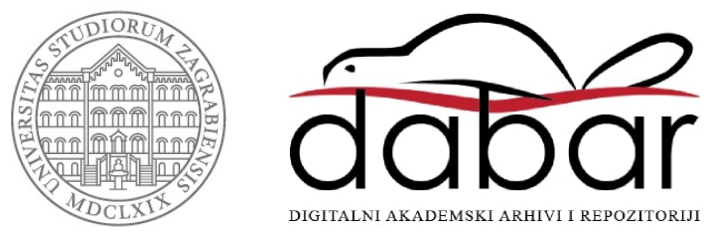
Filozofski fakultet

Sandra Didović Baranac

\section{STRAH OD ČITANJA I OVLADAVANJE VJEŠTINOM ČITANJA NA STRANOME JEZIKU}

DOKTORSKI RAD

Zagreb, 2020. 


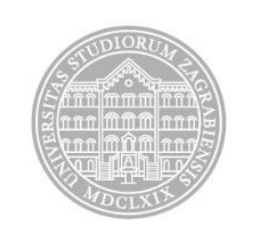

Sveučilište u Zagrebu

Filozofski fakultet

Sandra Didović Baranac

\title{
STRAH OD ČITANJA I OVLADAVANJE VJEŠTINOM ČITANJA NA STRANOME JEZIKU
}

\author{
DOKTORSKI RAD
}

\author{
Mentorica: \\ Prof. dr. sc. Jelena Mihaljević Djigunović
}

Zagreb, 2020. 


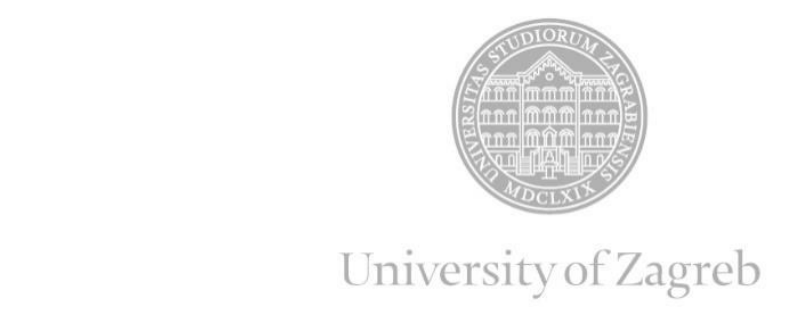

Faculty of Humanities and Social Sciences

Sandra Didović Baranac

\section{FOREIGN LANGUAGE READING ANXIETY AND READING COMPREHENSION IN THE FOREIGN LANGUAGE}

DOCTORAL THESIS

Supervisor:

Prof. Jelena Mihaljević Djigunović, PhD

Zagreb, 2020 


\section{O mentorici:}

Jelena Mihaljević Djigunović rođena je 1953. u Zagrebu. Na Filozofskome fakultetu u Zagrebu diplomirala je engleski jezik i književnost i ruski jezik. Magistrirala je radom iz sintakse engleskoga jezika u funkciji struke, a doktorirala temom Nastava engleskog jezika $i$ motivacija za učenje.

Od 1977. do 1981. godine radila je kao profesorica engleskoga i ruskoga jezika u srednjoj školi u Grubišnom Polju, a zatim četiri godine predavala engleski jezik u Centru za strane jezike u Zagrebu. Od 1985. do umirovljenja 2014. godine radila je na Odsjeku za anglistiku Filozofskoga fakulteta u Zagrebu. U zvanje redovitoga profesora u trajnome zvanju izabrana je 2008. godine. Bila je predstojnica Katedre za metodiku nastave engleskog jezika od 2000. do umirovljenja. Jedna je od osnivačica i prva voditeljica doktorskoga studija Glotodidaktika.

Održala je brojna izlaganja na skupovima, organizirala nekoliko domaćih i međunarodnih znanstvenih skupova, predavala na poslijediplomskim specijalističkim tečajevima za poljske profesore metodike te na doktorskom studiju glotodidaktike Sveučilišta u Pečuhu. Pod njezinim je mentorstvom dosad izrađeno i obranjeno 16 doktorskih disertacija.

Bila je predsjednica Hrvatskoga društva za primijenjenu lingvistiku, kao i njegova predstavnica u AILA-i, te glavna urednica časopisa Strani jezici.

Unutar struke, posebno se bavi afektivnom domenom ovladavanja inim jezikom i usvajanjem engleskoga jezika u ranoj dobi. Sudjelovala je u šest nacionalnih i osam međunarodnih znanstveno-istraživačkih projekata. Objavila je više od 150 znanstvenih i stručnih radova, među kojima i dvanaest knjiga: tri autorske i devet suuredničkih. 
Mojoj djeci, Petri i Brunu, i suprugu Mariu 
Od srca zahvaljujem svojoj mentorici prof. dr. sc. Jeleni Mihaljević Djigunović, koja je još u studentskim danima $u$ meni potaknula interes za glotodidaktikom $i$ istraživanjima $u$ glotodidaktici. Posebno joj zahvaljujem na svim dragocjenim savjetima, stručnoj pomoći $i$ toploj podršci tijekom izradbe ove disertacije.

Zahvaljujem svim učenicama i učenicima i svim školama koji su sudjelovali u provedbi ovoga istraživanja.

Hvala mojim prijateljicama i kolegicama na pomoći i podršci.

Od srca hvala mojoj obitelji i mojoj svekrvi za razumijevanje i svu potporu koju su mi pružali tijekom doktorskoga studija i izradbe ovoga rada.

Zahvalna sam svojim roditeljima koji su me uvijek s ljubavlju podržavali i poticali u učenju $i$ radu. 


\section{SAŽETAK}

Osnovni cilj ovoga rada bio je ispitati odnos straha od čitanja i uspjeha u čitanju na engleskome i njemačkome jeziku u hrvatskome socioedukacijskome kontekstu, uzimajući u obzir motivaciju za učenje jezika. Sudionici istraživanja i za engleski i za njemački jezik bili su isti maturanti koji uče oba jezika. Struktura uzorka omogućila je provedbu poredbenoga istraživanja kojim su se utvrdile sličnosti i razlike u strahu od čitanja među istim sudionicima s obzirom na dva strana jezika. Uzevši u obzir specifičnosti hrvatskoga obrazovnoga konteksta, konstruiran je novi mjerni instrument za mjerenje straha od čitanja. Istraživanjem je potvrđena njegova pouzdanost $\mathrm{i}$ valjanost te se njime utvrdila multidimenzionalnost ispitivanoga konstrukta. Nisu utvrđene razlike u razinama straha od čitanja s obzirom na spol i srednjoškolski smjer. Razina straha za oba jezika je niska, s tim da je razina straha od čitanja za njemački jezik viša. Pri tumačenju toga rezultata osvrnuli smo se na različit status dvaju jezika i moguće razlike u nastavnome i izvannastavnome kontekstu.

U istraživanju su korišteni validirani testovi razumijevanja teksta čitanjem za engleski i njemački jezik te validirani upitnici o motivaciji za učenje obaju jezika (Projekt MZOŠ-a br. 130793: Engleski jezik u Hrvatskoj). Utvrđeno je da je strah negativno povezan s uspjehom u čitanju te da je viša razina straha od čitanja povezana s lošijim uspjehom u učenju jezika. Pokazalo se da je odnos straha od čitanja i uspjeha u čitanju manje izražen nakon uključivanja motivacije kao medijacijske varijable te da je strah negativan prediktor uspjeha u čitanju.

$\mathrm{Na}$ osnovi rezultata istraživanja zaključuje se da je strah od čitanja ometajući faktor u postizanju uspjeha u čitanju na oba jezika te da pritom motivacija ima medijacijsku ulogu. U radu se navode različite metode primjenom kojih se učenici mogu osloboditi straha od čitanja te postići bolji uspjeh u čitanju i cjelokupnom učenju stranoga jezika.

Ključne riječi: strah od čitanja na stranome jeziku, uspjeh u čitanju na stranome jeziku, odnos straha od čitanja i uspjeha u čitanju, konstrukcija mjernoga instrumenta za mjerenje straha od čitanja na stranome jeziku, poredbeno istraživanje, hrvatski socioedukacijski kontekst, multidimenzionalna struktura straha od čitanja na stranome jeziku, negativna povezanost straha od čitanja i uspjeha u čitanju, motivacija kao medijacijska varijabla, strah od čitanja kao prediktor uspjeha u čitanju 


\section{SUMMARY}

Research in the field of second language acquisition (SLA) has indicated that both cognitive learner factors and affective learner factors influence the language learning process. Many SLA researchers have emphasised the importance of studies of affective factors, which contribute to language learning as much as cognitive factors (Horwitz et al., 1986; Horwitz, 1987; MacIntyre and Gardner, 1993a; Mihaljević Djigunović, 1998; Dörnyei, 2005; Mihaljević Djigunović, 2007; Dörnyei and Ryan, 2015). Since the 1980s, numerous researchers have studied foreign language anxiety (FLA) as "a distinct complex of self-perceptions, beliefs, feelings, and behaviors related to classroom language learning arising from the uniqueness of the language learning process" (Horwitz et al., 1986: 128).

SLA researchers have been using different measures of language anxiety, but the first specific measure of FLA was the Foreign Language Classroom Anxiety Scale (FLCAS) developed by Horwitz, Horwitz and Cope (1986). Since FLCAS almost entirely refers to speaking, a number of SLA researchers have concentrated on identifying more specifically the sources of anxiety and the relationship of anxiety to specific language skills.

Saito, Horwitz and Garza (1999) conducted the first study of reading anxiety using the Foreign Language Reading Anxiety Scale (FLRAS). The results showed that foreign language reading anxiety (FLRA) can be distinguished from general foreign language classroom anxiety. It was found that the levels of reading anxiety varied according to the specific target language (Saito et al., 1999).

In a number of reading anxiety studies, researchers have differentiated the components of FLRA that suggest that anxiety is a multi-faceted phenomenon (Matsuda and Gobel, 2001; Zoghi, 2012; Ahmad et al., 2013; Al-Shboul et al., 2013; Zoghi and Alivandivafa, 2014).

Investigating the relationship between FLRA and reading achievement has increasingly attracted the attention of many SLA researchers. In a number of studies conducted in different socioeducational contexts with different target languages, a negative relationship between FLRA and foreign language reading achievement was found (Sellers, 2000; Brantmeier, 2005; Hayati and Ghassemi, 2008; Zhao, 2009; Rai et al., 2011; Huang, 2012; Jafarigohar and Behrooznia, 2012; Cabansag, 2013; Zhao et al., 2013; Mohammadpur and Ghafournia, 2015). 
The issue of sources of FLRA has also attracted the attention of many FLRA researchers. The findings of the studies have revealed that there are two main aspects of FLRA: personal factors and text features. The most common sources of FLRA are: concern about making errors, fear of negative evaluation, unknown vocabulary, unknown grammar, unfamiliar script and writing system, unfamiliar topic, and length of reading text (Zhang, 2000; Kuru-Gonen, 2009; Al-Shboul et al., 2013; Marzec-Stawiarska, 2013; Zhao et al., 2013; Hassaskhah and Joghataeian, 2016). As FLA is culturally and socially determined, it may manifest itself in different ways in different cultural and social contexts. In order to conduct studies of FLRA in different cultural and social contexts, SLA researchers have attempted to devise research instruments specifically targeted at the specific population. Since in Croatia not much FLRA research has been done, a reliable and valid research instrument based on the cultural and social determinants needed to be developed.

This dissertation aimed to examine the relationship between FLRA of Croatian students learning English and German in the Croatian educational context and their English and German reading achievement. English and German learning motivation as the mediating variable was also analysed.

The research attempted to test the following research hypotheses:

1 FLRA is related to foreign language reading achievement.

2a The structure of FLRA varies according to the target language (English/German).

$2 \mathrm{~b}$ The level of FLRA varies according to the target language (English/German).

3 There is no significant difference in students' FLRA with reference to gender.

4 There is no significant difference in students' FLRA with reference to type of school.

5 Motivation is the mediating variable in the relationship between FLRA and reading comprehension.

Data on FLRA were collected by a questionnaire specifically designed for this research, aiming to measure the level of English/German reading anxiety. The participants of this research were 139 fourth grade students from secondary schools in Dubrovnik-Neretva County who learned both English as their first and German as their second foreign language. A comparative study was carried out on the same participants exploring their FLRA with reference to two different languages. The validity and reliability of the new instrument 
employed in this research were confirmed. Our findings show that both English reading anxiety and German reading anxiety are low. The statistical analysis of participants' scores in reading comprehension tests and our FLRA questionnaire shows a statistically significant negative correlation between anxiety and reading comprehension. The research findings indicate differences in the structure and the level of reading anxiety in relation to the foreign language being learned. There are three components of English reading anxiety and five components of German reading anxiety.

The research findings also show that there is a statistically significant difference between the levels of English and German reading anxiety, the level of German reading anxiety being higher than English. A possible explanation can be that in the Croatian educational context, English and German differ essentially in their status and learning environment. There is no statistically significant difference between the levels of English and German reading anxiety in relation to gender and type of school. Regression analysis reveals that English and German learning motivation is the mediating variable in the relationship between English and German reading anxiety and English and German reading achievement. The results also show that FLRA has a significant role in predicting reading achievement.

The questionnaire developed for this research is context specific in the sense that it was developed within a particular socioeducational context. The research instrument constructed for this study could be used to develop future research instruments for other foreign languages in the Croatian socioeducational context or in other cultural contexts.

The findings of this research will enable SLA researchers and foreign language teachers to gain an insight into the correlation between FLRA and reading achievement and the role of motivation as the mediating variable. Foreign language teachers can benefit from a better understanding of the complex phenomenon of FLRA and thus help their students overcome anxiety and improve their reading achievement.

Key words: foreign language reading anxiety, reading achievement, questionnaire development, English, German, Croatian socioeducational context, multidimensional structure of foreign language reading anxiety, negative correlation between reading anxiety and reading comprehension, motivation as mediating variable, foreign language reading anxiety as predictor of reading achievement 


\section{SADRŽAJ}

SAŽETAK

SUMMARY

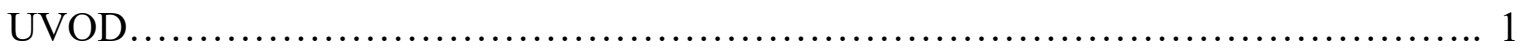

1. STRAH OD JEZIKA U OVLADAVANJU INIM JEZIKOM............................. 4

1.1. Ovladavanje inim jezikom (OVIJ) i individualne razlike u OVIJ-u...................... 4

1.2. Strah od jezika i strah od stranoga jezika............................................................ 7

1.3. Komponente, manifestacije i vrste straha od stranoga jezika................. 14

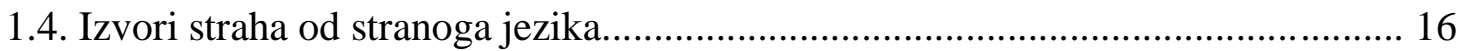

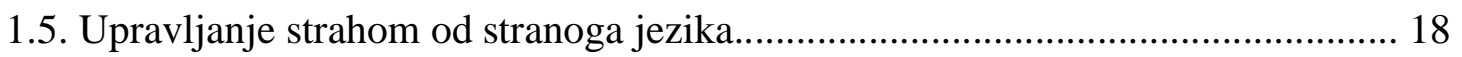

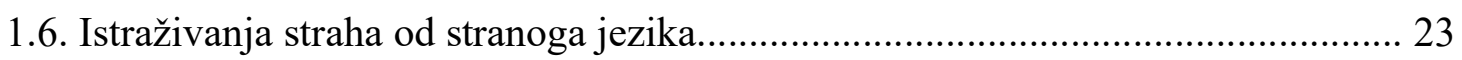

1.6.1. Istraživanja strukture straha od stranoga jezika................................ 23

1.6.2. Istraživanja povezanosti straha od stranoga jezika i uspjeha u učenju stranoga jezika............................................................................ 24

1.6.3. Istraživanja odnosa straha od stranoga jezika i ostalih čimbenika........25

1.6.4. Istraživanja straha od stranoga jezika u Hrvatskoj............................. 27

2. STRAH OD ČITANJA NA STRANOME JEZIKU .................................................... 30

2.1. Istraživanja strukture i izvora straha od čitanja na stranome jeziku.................... 31

2.2. Istraživanja povezanosti straha od čitanja i uspjeha u čitanju na

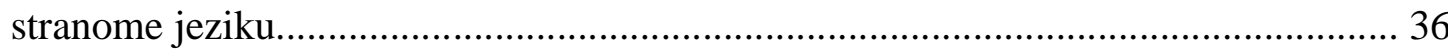

2.3. Istraživanja odnosa straha od čitanja i ostalih čimbenika.................................. 37

2.4. Istraživanja straha od čitanja na stranome jeziku u Hrvatskoj............................. 38

3. ČITANJE - OD DEKODIRANJA DO RAZUMIJEVANJA...................................... 41

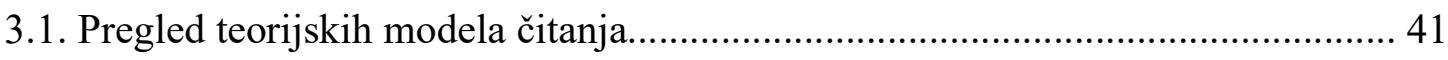

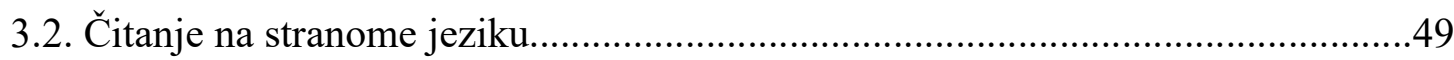

4. MOTIVACIJA U OVLADAVANJU INIM JEZIKOM............................................ 58

4.1. Uvodna razmatranja o motivaciji u OVIJ-u........................................................ 58

4.2. Sociopsihološko razdoblje teorije motivacije...................................................... 59

4.3. Kognitivno-situacijsko razdoblje teorije motivacije........................................... 60

4.4. Procesno usmjereno razdoblje teorije motivacije ................................................. 61

4.5. Od procesno usmjerenoga prema sociodinamičnome razdoblju teorije motivacije. 


\section{ISTRAŽIVANJE STRAHA OD ČITANJA I RAZMIJEVANJE}

ČITANJEM NA ENGLESKOME I NJEMAČKOME JEZIKU.................................. 66

5.1. Uvod 66

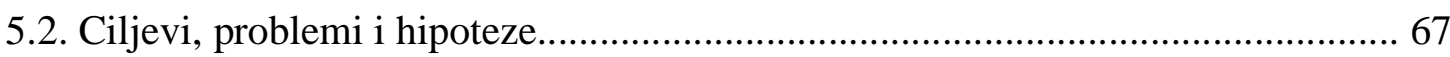

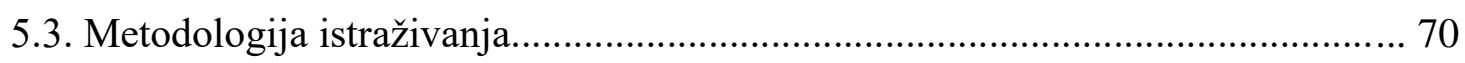

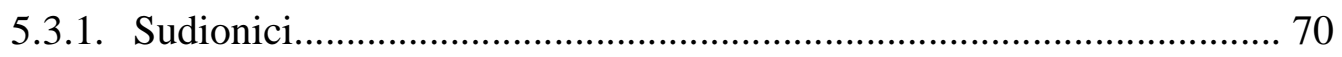

5.3.1.1. Sudionici u fokus grupama i preliminarnome istraživanju.............. 70

5.3.1.2. Sudionici glavnoga istraživanja................................................... 71

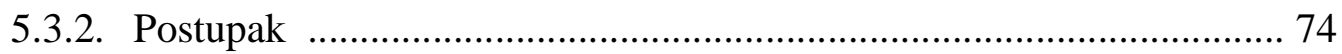

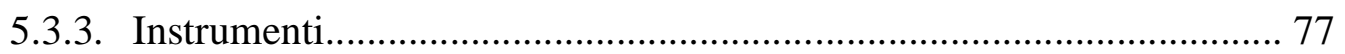

5.3.3.1. Upitnik o motivaciji za učenje engleskoga/njemačkoga jezika........ 79

5.3.3.2. Test razumijevanja teksta čitanjem za engleski jezik

i Test razumijevanja teksta čitanjem za njemački jezik............................... 79

5.3.4. Metode obrade i analize podataka................................................... 81

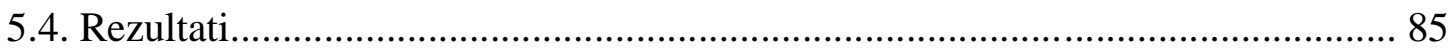

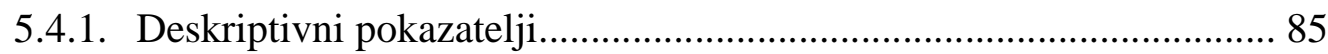

5.4.1.1. Deskriptivni pokazatelji za strah od čitanja na engleskome jeziku.

5.4.1.2. Deskriptivni pokazatelji za strah od čitanja na njemačkome jeziku. 88

5.4.1.3. Deskriptivni pokazatelji za motivaciju

za učenje engleskoga jezika.

5.4.1.4. Deskriptivni pokazatelji za motivaciju za učenje njemačkoga jezika.

5.4.1.5. Deskriptivni pokazatelji za razumijevanje teksta čitanjem

$$
\text { - engleski jezik...... }
$$

5.4.1.6. Deskriptivni pokazatelji za razumijevanje teksta čitanjem - njemački jezik. 98

5.4.2. Normalnost distribucija ključnih varijabli 99

5.4.3. Konstrukcija Upitnika o strahu od čitanja na engleskome jeziku i Upitnika o strahu od čitanja na njemačkome jeziku u preliminarnome istraživanju. 


\subsubsection{Psihometrijska svojstva Upitnika o strahu od čitanja}

na engleskome jeziku u preliminarnome istraživanju.

\subsubsection{Psihometrijska svojstva Upitnika o strahu od čitanja}

na njemačkome jeziku u preliminarnome istraživanju

\subsubsection{Proces selekcije tvrdnji Upitnika o strahu od čitanja}

na engleskome jeziku s pomoću Cronbachova $\alpha$.

5.4.3.4. Proces selekcije tvrdnji Upitnika o strahu od čitanja

na njemačkome jeziku s pomoću Cronbachova $\alpha$.

5.4.4. Faktorska struktura Upitnika za mjerenje straha od čitanja

na engleskome jeziku i Upitnika za mjerenje straha od čitanja na

njemačkome jeziku u glavnome istraživanju.

5.4.4.1. Analiza glavnih komponenti i faktorska analiza Upitnika o strahu od čitanja na engleskome jeziku.

5.4.4.2. Analiza glavnih komponenti i faktorska analiza Upitnika o strahu od čitanja na njemačkome jeziku.

5.4.5. Formiranje subskala na temelju faktorske analize Upitnika o strahu od čitanja na engleskome jeziku i faktorske analize Upitnika o strahu od čitanja na njemačkome jeziku u glavnome istraživanju.

5.4.5.1. Formiranje subskala na temelju faktorske analize Upitnika o strahu od čitanja na engleskome jeziku.....

5.4.5.2. Formiranje subskala na temelju faktorske analize Upitnika o strahu od čitanja na njemačkome jeziku.

5.4.6. Usporedba subskala na temelju faktorske analize

Upitnika o strahu od čitanja na engleskome jeziku i Upitnika o

strahu od čitanja na njemačkome jeziku.

5.4.7. Razlike u strahu od čitanja na engleskome i njemačkome jeziku s obzirom na spol

5.4.7.1. Razlike u strahu od čitanja na engleskome jeziku s obzirom na spol.

5.4.7.2. Razlike u strahu od čitanja na njemačkome jeziku s obzirom na spol.

5.4.8. Razlike u strahu od čitanja na engleskome i njemačkome jeziku s obzirom na srednjoškolski smjer. 
5.4.8.1. Razlike u strahu od čitanja na engleskome jeziku s obzirom na srednjoškolski smjer.

5.4.8.2. Razlike u strahu od čitanja na njemačkome jeziku s obzirom na srednjoškolski smjer.

5.4.9. Razlike u intenzitetu straha od čitanja na engleskome $i$

njemačkome jeziku s obzirom na jezik.

5.4.10. Povezanost straha od čitanja na engleskome i njemačkome jeziku i uspjeha na testu razumijevanja teksta čitanjem na engleskome i njemačkome jeziku.

5.4.10.1.Povezanost straha od čitanja na engleskome jeziku i uspjeha na testu razumijevanja teksta čitanjem na engleskome jeziku.

5.4.10.2. Povezanost straha od čitanja na njemačkome jeziku i uspjeha na testu razumijevanja teksta čitanjem na njemačkome jeziku.

5.4.11. Povezanost straha od čitanja na engleskome i njemačkome jeziku i zaključnih ocjena iz engleskoga i njemačkoga jezika.

5.4.11.1. Povezanost straha od čitanja na engleskome jeziku i zaključnih ocjena iz engleskoga jezika.

5.4.11.2. Povezanost straha od čitanja na njemačkome jeziku i zaključnih ocjena iz njemačkoga jezika.

5.4.12. Povezanost motivacije za učenje engleskoga i njemačkoga jeziku i zaključnih ocjena iz engleskoga i njemačkoga jezika.

5.4.12.1. Povezanost motivacije za učenje engleskoga jezika i zaključnih ocjena iz engleskoga jezika.

5.4.12.2. Povezanost motivacije za učenje njemačkoga jezika

i zaključnih ocjena iz njemačkoga jezika.

5.4.13. Povezanost uspjeha na testu razumijevanja teksta čitanjem

i zaključne ocjene iz trećega razreda.

5.4.13.1. Povezanost uspjeha na testu razumijevanja teksta

čitanjem $i$ zaključne ocjene iz trećega razreda za engleski jezik.

5.4.13.2. Povezanost uspjeha na testu razumijevanja teksta

čitanjem $i$ zaključne ocjene iz trećega razreda za njemački jezik.

5.4.14. Medijacijske analize. 156

5.4.14.1. Testiranje medijacije regresijskim analizama - engleski jezik..... 158

5.4.14.2. Testiranje medijacije regresijskim analizama - njemački jezik.... 162 
5.4.15. Dodatne analize.

5.4.15.1. Regresijski modeli straha od čitanja za engleski

i njemački jezik. 166

5.4.16. Sažetak rezultata prema hipotezama

5.5.1. Tumačenje deskriptivnih pokazatelja straha od čitanja na engleskome i njemačkome jeziku.

5.5.2. Tumačenje deskriptivnih pokazatelja motivacije za učenje engleskoga i njemačkoga jezika.

5.5.3. Tumačenje deskriptivnih pokazatelja razumijevanja teksta čitanjem za engleski i njemački jezik.

5.5.4. Tumačenje metrijskih obilježja i subskala Upitnika o strahu od čitanja na engleskome i Upitnika o strahu od čitanja na njemačkome jeziku u glavnome istraživanju.

5.5.5. Tumačenje razlika u strahu od čitanja na engleskome i njemačkome jeziku s obzirom na spol

5.5.6. Tumačenje razlika u strahu od čitanja na engleskome i njemačkome jeziku s obzirom na srednjoškolski smjer.

5.5.7. Tumačenje razlika u intenzitetu straha od čitanja na engleskome i njemačkome jeziku s obzirom na jezik.

5.5.8. Tumačenje povezanosti straha od čitanja i razumijevanja

teksta čitanjem na engleskome i njemačkome jeziku.

5.5.9. Tumačenje povezanosti straha od čitanja i zaključnih ocjena iz engleskoga i njemačkoga jezika.

5.5.10. Tumačenje povezanosti motivacije za učenje engleskoga

i njemačkoga jezika i zaključnih ocjena iz engleskoga

i njemačkoga jezika

5.5.11. Tumačenje povezanosti razumijevanja teksta čitanjem

i zaključne ocjene iz trećega razreda za engleski i njemački jezik.

5.5.12. Tumačenje rezultata regresijskih analiza za engleski i njemački jezik.

5.5.13. Tumačenje rezultata dodatnih analiza. 


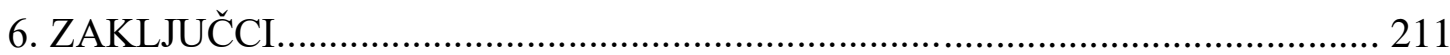

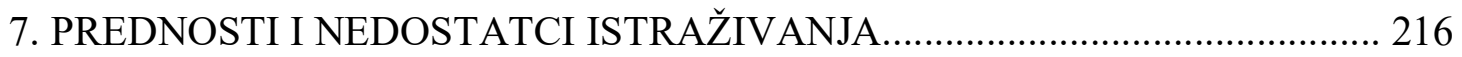

8. IMPLIKACIJE I SMJERNICE ZA BUDUĆA ISTRAŽIVANJA........................ 219

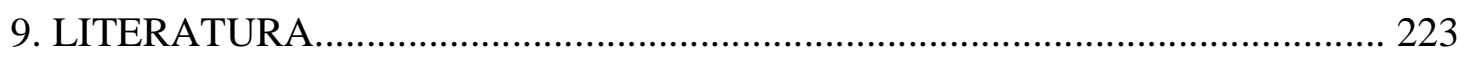

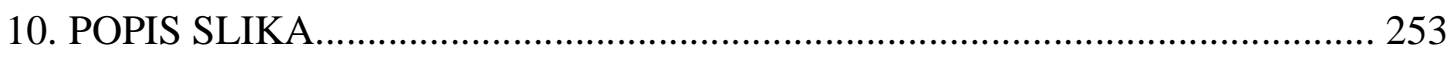

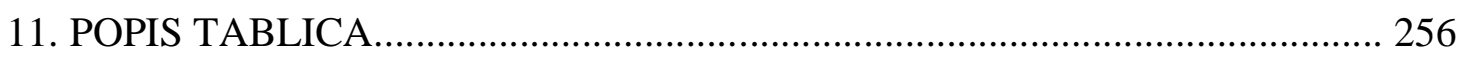

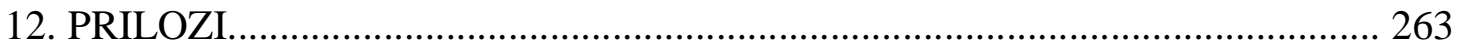

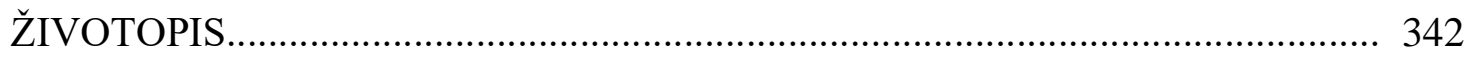

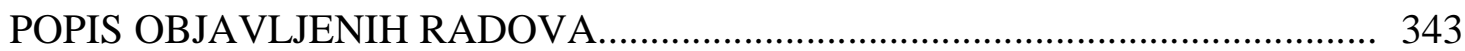




\section{UVOD}

U istraživanjima u području usvajanja drugoga ${ }^{1}$ jezika i u području učenja i poučavanja stranoga $^{2}$ jezika utvrđena je važna uloga individualnih razlika (engl. individual differences) $\mathrm{i}$ njihova povezanost $\mathrm{s}$ uspjehom u usvajanju i učenju jezika. Individualne razlike podrazumijevaju afektivne i kognitivne faktore koji, u interakciji s mnogim drugim važnim varijablama, djeluju na proces učenja jezika. Individualne razlike učenika u procesu poučavanja i učenja stranoga jezika istražuju se u okviru psihologije, psiholingvistike i osobito glotodidaktike kao teorije učenja i poučavanja stranih jezika. Iako su dulji niz godina prevladavala istraživanja koja su se bavila kognitivnim faktorima pri učenju stranoga jezika, pozornost istraživača usmjerila se i na afektivne faktore jer su te dvije skupine faktora $u$ interakciji, te bez afektivnih faktora ni kognitivni ne bi mogli djelovati (Mihaljević Djigunović, 2007). Afektivnim faktorima smatraju se one relevantne emocionalne karakteristike učenika koje određuju njegovu reakciju na situaciju učenja drugoga jezika (Mihaljević Djigunović, 1998).

Proces učenja stranoga jezika vrlo je zahtjevan, često traje godinama i odvija se u različitim nastavnim kontekstima, tijekom različitih razvojnih i životnih razdoblja pojedinca, a prate ga različite emocije, koje mogu biti pozitivne i negativne. Među negativnim emocijama strah od jezika ${ }^{3}$ predstavlja zanimljiv i složen fenomen koji privlači pozornost učenika, nastavnika i istraživača. Riječ je o strahu koji osjećamo pri učenju i uporabi stranoga jezika i posebna je vrsta straha, inherentna iskustvu učenja stranoga jezika (Horwitz i sur., 1986; Horwitz i Young, 1991). Osobna iskustva učenika i korisnika stranoga jezika, empirijski nalazi i teorijska razmatranja o strahu od stranoga jezika ukazuju na to da se radi o složenome fenomenu, povezanom s uspjehom u učenju stranoga jezika. Kako bi se ispitala struktura toga složenoga fenomena razvili su se mjerni instrumenti kojima su provedena istraživanja straha od stranoga jezika u različitim društvenokulturnim kontekstima. Najčešće korišteni mjerni instrument, Upitnik za mjerenje straha od stranoga jezika u razrednoj situaciji (engl. Foreign

\footnotetext{
${ }^{1}$ Pod drugim se jezikom smatra jezik koji u određenom kontekstu predstavlja i službeni jezik zemlje (Mihaljević Djigunović, 2007: 105)

${ }^{2}$ Strani jezik je nematerinski jezik učenika koji nema status službenoga jezika nego se najčešće uči u školi kao školski predmet (Mihaljević Djigunović, 2007: 105)

${ }^{3}$ Za afektivnu pojavu koja usporava ili koči jezični razvoj izraz strah od jezika uvriježio se u hrvatskome znanstvenoistraživačkome nazivlju kao općeprihvaćen naziv za engleski izraz Language Anxiety (LA), te isto tako naziv strah od stranoga jezika za engleski izraz Foreign Language Anxiety (FLA).
} 
Language Classroom Anxiety Scale - FLCAS), prvi je put korišten u ispitivanju straha od jezika koje su proveli Horwitz, Horwitz i Cope (1986) u američkome socioedukacijskome okruženju.

Strah je fenomen svojstven određenome pojedincu, povezan s društvenim obilježjima i očekivanjima šire sredine, kao i s nastavnim okruženjem, specifičan za određenu jezičnu djelatnost, a čak može biti specifičan i za određeni jezični zadatak. Rezultati istraživanja ukazali su na to da je strah povezan s uspjehom te da je često ometajući faktor uspjeha u učenju jezika. Polazeći od složenosti procesa učenja stranoga jezika u kojemu se podrazumijeva ovladavanje jezičnim vještinama slušanja, govorenja, čitanja i pisanja, razvili su se specifični mjerni instrumenti koji su omogućili provođenje istraživanja straha od stranoga jezika s obzirom na određenu jezičnu vještinu. Tako su za ispitivanje straha od čitanja među američkim studentima Saito, Horwitz i Garza (1999) konstruirali mjerni instrument Upitnik o strahu od čitanja na stranome jeziku (engl. Foreign Language Reading Anxiety Scale - FLRAS). Za provođenje istraživanja usvajanja i učenja jezika nužno je razvijati mjerne instrumente koji su specifični za određenu populaciju, a ne tek preuzimati ili adaptirati međunarodno prepoznate mjerne instrumente (Macaro, 2007: 240). Tu su preporuku slijedili istraživači straha od jezika, razvivši vlastite metode i mjerne instrumente za ispitivanje straha od čitanja, primjerice Kuru-Gonen (2009) u Turskoj, Ahmad i suradnici (2013), Al-Shboul i suradnici (2013) u Jordanu, te Zoghi (2012) i Zoghi i Alivandivafa (2014) u Iranu. Reprezentativnost i prototipnost određenoga uzorka i konteksta neizostavno dovodi u pitanje mogućnost uopćavanja nalaza istraživanja i njihovu aplikaciju u drugim kontekstima (Bagarić Medve i Pavičić Takač, 2015). S obzirom na to da je svaki istraživački kontekst specifičan za potrebe istraživanja ovoga doktorskoga rada, konstruiran je poseban mjerni instrument za ispitivanje straha od čitanja na stranome jeziku u hrvatskome socioedukacijskome kontekstu.

Čitanje je jedinstvena ljudska sposobnost kojom čovjek oblikuje civilizaciju i iznimno složen i zahtjevan kognitivni proces koji podrazumijeva aktiviranje i koordinaciju brojnih sposobnosti i znanja kako bi se od dekodiranja stiglo do čitanja s razumijevanjem (Peti-Stantić, 2019). Čitanje na stranome jeziku zamršena je jednadžba koja uključuje faktore vezane uz domenu čitatelja, kao što su čitateljevo znanje, motivacija i fizičke karakteristike, i faktore vezane uz domenu teksta koji se čita (Geld i Stanojević, 2007). U okviru domene čitatelja pojavljuje se i strah kao afektivni faktor koji najintenzivnije može ometati proces učenja, pa tako i proces ovladavanja čitanjem i čitanje s razumijevanjem. Osnovni je cilj ovoga rada ispitati odnos straha od čitanja i razumijevanja teksta čitanjem na stranome jeziku. 
U hrvatskome formalnome socioedukacijskome kontekstu poučava se više stranih jezika koji se razlikuju s obzirom na status, s obzirom na duljinu učenja, te s obzirom na nastavni i izvannastavni kontekst. Većina učenika uči engleski jezik od prvoga dana obveznoga školovanja kao prvi strani jezik, a učenici su engleskomu često izloženi i u izvannastavnome kontekstu. Engleski jezik gubi status stranoga jezika, te poprima status međunarodnoga jezika. Za razliku od engleskoga, njemački jezik ima status stranoga, a ne međunarodnoga jezika, uči se često manji broj godina, a izloženost učenika njemačkomu jeziku u izvannastavnome kontekstu znatno je manja nego izloženost engleskomu jeziku. Međutim, među hrvatskim učenicima prepoznata je korist uporabe ovih obaju stranih jezika (Mihaljević Djigunović i Bagarić, 2007a; Karlak, 2014; Falkoni-Mjehović i sur., 2016) i postoji duga tradicija poučavanja obaju jezika. Budući da autorica ovoga doktorskoga rada i sama poučava engleski i njemački jezik, ta je činjenica predstavljala polazište za provođenje poredbenoga istraživanja straha od čitanja na engleskome i njemačkome jeziku. Najprije se nastojalo utvrditi kakva je struktura straha od čitanja na engleskome i njemačkome jeziku i razina razumijevanja čitanjem na engleskome i njemačkome jeziku. Zatim se ispitalo postoje li razlike u strukturi i intenzitetu straha od čitanja između tih dvaju jezika te postoji li povezanost straha od čitanja i razumijevanja teksta čitanjem na tim dvama jezicima.

S obzirom na važnost motivacije kao jednoga od ključnih afektivnih faktora koji je povezan s uspjehom u učenju stranoga jezika, u ovome radu ispitala se motivacija za učenje engleskoga i njemačkoga jezika, te medijacijski utjecaj motivacije na odnos straha od čitanja i razumijevanja teksta čitanjem. Budući da je uspjeh u učenju stranoga jezika, a tako i uspjeh u čitanju na stranome jeziku, povezan s mnogobrojnim individualnim varijablama, u radu se ispitao odnos straha od čitanja i određenih individualnih varijabli. Kako bi se stekao detaljniji uvid u interakciju ispitanih varijabli, provele su se regresijske analize kojima su se utvrdila uloga straha od čitanja kao prediktora uspjeha u čitanju i motivacije za učenje engleskoga i njemačkoga jezika, te prediktori straha od čitanja za engleski i njemački jezik. 


\section{STRAH OD JEZIKA U OVLADAVANJU INIM JEZIKOM}

\subsection{Ovladavanje inim jezikom (OVIJ) i individualne razlike u OVIJ-u}

Usvajanje drugoga jezika te učenje i poučavanje stranoga jezika procesi su koji se odvijaju svakodnevno u svim dobnim skupinama, od djece mlađe i starije dobi, adolescenata i odraslih, do osoba starije životne dobi. Složeni su to procesi koje odlikuju specifičnosti s obzirom na sociokulturnu sredinu i kontekst usvajanja ili učenja jezika, s obzirom na ciljni jezik, te s obzirom na individualne razlike pojedinaca koji usvajaju ili uče jezik. Ti zahtjevni i dugotrajni procesi pobuđuju interes kako znanstvenika i istraživača iz područja lingvistike, psiholingvistike i primijenjene lingvistike tako i nastavnika, učenika, studenata i polaznika tečajeva jezika.

Prije izlaganja pregleda teorijskih spoznaja i empirijskih istraživanja o ovim složenim procesima, najprije ćemo se osvrnuti na nazivlje koje se koristi u znanstvenoistraživačkoj disciplini koja nastoji unaprijediti razumijevanje raznolikosti i dinamike tih procesa. Radi se o znanstvenoistraživačkoj disciplini koja je nastala na engleskome govornome području 1970-ih godina, a uvriježen joj je akronim u svjetskoj literaturi SLA (skraćeno od Second Language Acquisition Research) (Medved Krajnović, 2009: 95). Nastojeći uspostaviti prikladne hrvatske nazive, Jelaska (2007) za ovu znanstvenoistraživačku disciplinu predlaže naziv ovladavanje inim jezikom (Jelaska, 2007). Također predlaže hrvatske nazive i za ostale pojmove istraživačkoga područja koje se bavi ovladavanjem jezikom. ${ }^{4}$ Akronim SLA u engleskome jeziku i akronim OVIJ u hrvatskome jeziku označavaju i sâm proces ovladavanja inim jezikom i znanstvenoistraživačku disciplinu koja se tim procesom bavi (Medved Krajnović, 2010: 6).

OVIJ kao znanstvenoistraživačka disciplina ima dodira s mnogim znanostima, među kojima najvažniju ulogu imaju tri znanstvenoistraživačka područja - lingvističko, psihološko i sociološko. Istraživanja OVIJ-a temelje se na raznim teorijskim modelima, a jedan od modela koji se često koristi jest socioedukacijski model usvajanja drugoga jezika (prikazan na slici 1.1.)

\footnotetext{
${ }^{4}$ Naziv prvi jezik koristi se u značenju jezika koji je pojedinac prvi usvojio, a naziv ini jezik za sve pojedinčeve jezike osim prvoga usvojenoga. Naziv ini jezik ima dvije podređenice: drugi-prototipno u okolini koja njime govori pa je nužan za sporazumijevanje s njom i strani - prototipno izvan okoline koja njime govori. Naziv ovladavanje koristi se kao naziv koji ima dvije podređenice: usvajanje - prototipno spontano, u prirodnim okolnostima i učenje - prototipno svjesno ili osviješteno, u osmišljenim okolnostima. Naziv ovladavanje kao nadređenica koristi se kada nije važno ili se ne zna je li tko učio ili usvajao neki jezik, odnosno kad ga je i učio i usvajao (Jelaska, 2007).
} 
SOCIOKULTURNA SREDINA
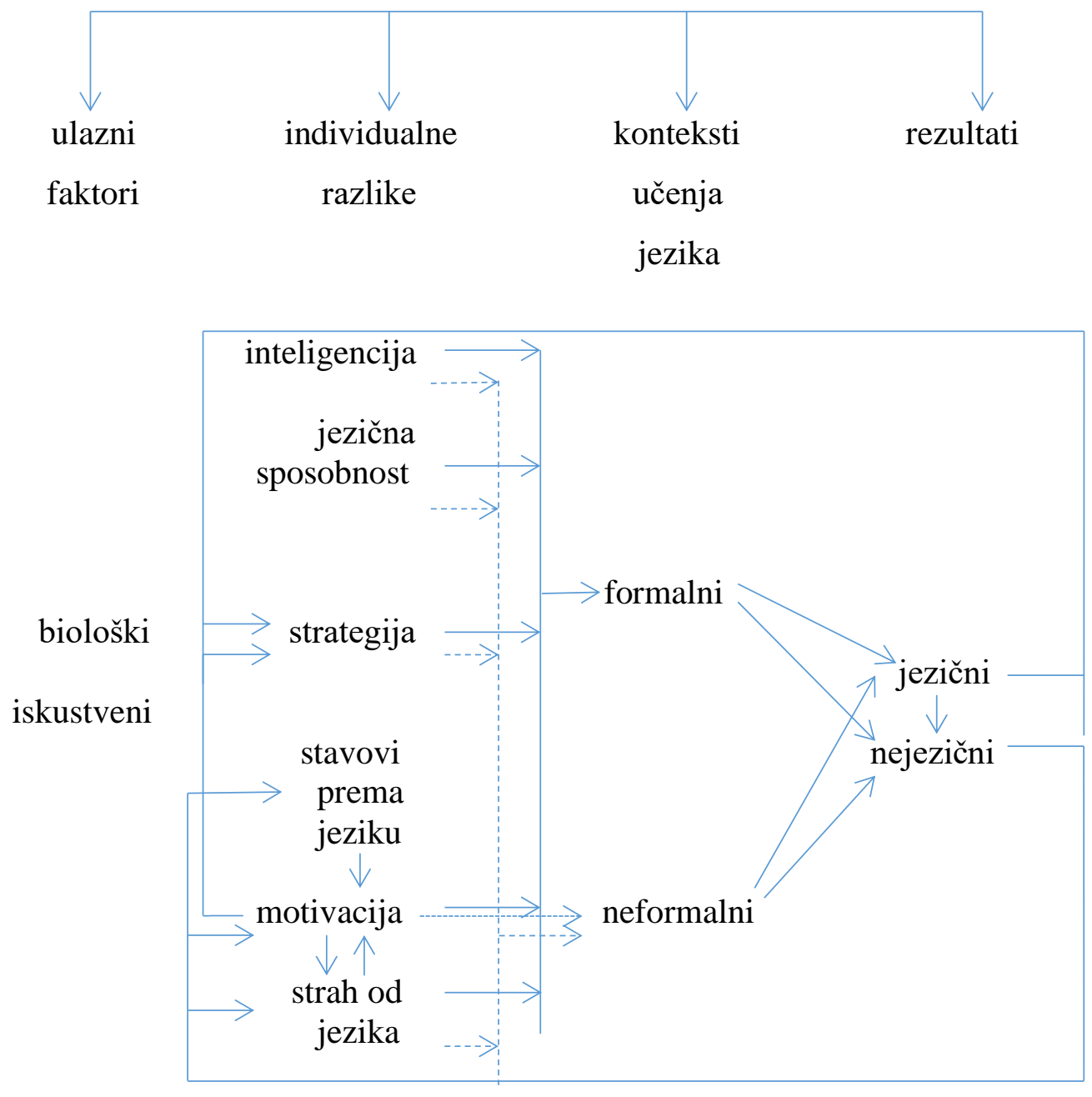

Slika 1.1. Socioedukacijski model usvajanja drugoga jezika (Gardner i MacIntyre, 1993a: 8) 
U socioedukacijskome modelu usvajanja drugoga jezika (v. sliku 1.1.) razlikuju se kognitivni i afektivni faktori i njihova uloga u formalnome ${ }^{5}$ i neformalnome ${ }^{6}$ kontekstu učenja u kojima se ostvaruju jezični i nejezični rezultati. Svi elementi socioedukacijskoga modela djeluju unutar određene sociokulturne sredine, a upravo ona izravno ili neizravno utječe na izloženost drugome jeziku, na status drugoga jezika u zajednici u kojoj učenik uči određeni jezik i na učenikovu percepciju važnosti poznavanja jezika (Mihaljević Djigunović, 1998: 12). Kognitivni su faktori inteligencija, jezična sposobnost i strategije učenja, i oni su relativno neovisni. Afektivni faktori su stavovi, motivacija i strah od jezika, i oni su međusobno povezani. U socioedukacijskome modelu afektivne varijable su one relevantne emocionalne karakteristike učenika koje određuju njegovu reakciju na određenu situaciju (Gardner i MacIntyre, 1993a: 1). Njihovi učinci mogu se akumulirati te dovesti do značajnih razlika u uspjehu u učenju jezika. Prethodni faktori dijele se na biološke i iskustvene. Od bioloških najvažniji su dob i spol, a od iskustvenih iskustva u učenju jezika. Prema tome modelu u formalnim uvjetima učenja svi elementi, osim stavova, izravno utječu na proces učenja, dok u neformalnim uvjetima samo motivacija izravno utječe na rezultate učenja. Socioedukacijski model podrazumijeva da postoji povezanost između formalnoga i neformalnoga konteksta učenja i jezičnih i nejezičnih rezultata. Jezični rezultati podrazumijevaju jezična znanja i vještine i povezani su sa strategijama učenja. Nejezični rezultati podrazumijevaju reakcije na jezične situacije i iskustvo učenja i povezani su s afektivnim faktorima (Gardner i MacIntyre, 1992), među kojima je i strah od jezika koji se može definirati kao strah koji osjećamo u situaciji koja od nas zahtijeva korištenje stranoga jezika kojim potpuno ne vladamo (Gardner i MacIntyre, 1993a: 5).

Gardner i MacIntyre su početkom 1990-ih godina svojim radovima stvorili empirijsko i teorijsko polazište za mnogobrojna ispitivanja individualnih razlika OVIJ-a koja su privukla pozornost istraživača. Individualne razlike postale su jedno od najistraživanijih područja OVIJa jer se spoznalo da je njihova uloga važna u procesu učenju stranoga jezika, da postoji povezanost individualnih razlika $\mathrm{i}$ uspjeha u učenju, te da individualne razlike mogu biti prediktori uspjeha. Među recentnijim istraživačima i teoretičarima OVIJ-a ističe se Dörnyei,

\footnotetext{
${ }^{5}$ Formalni kontekst učenja jezika odnosi se na situacije u kojima se jezik uči izravnom podukom, na primjer u školi. (Mihaljević Djigunović, 1998: 13)

${ }^{6}$ Neformalni kontekst učenja jezika odnosi se na situacije u kojima učenik jezik uči bez izravne poduke, a njegovo sudjelovanje u procesu učenja stvar je njegove osobne volje. (Mihaljević Djigunović, 1998: 13)
} 
koji definira individualne razlike kao karakteristike prema kojima se pojedinci mogu razlikovati jedan od drugoga (Dörnyei, 2005: 1). Individualne razlike su ličnost, jezična sposobnost, motivacija, stilovi učenja, strategije učenja, strah, kreativnost, spremnost na komunikaciju, samopouzdanje i učenička vjerovanja (Dörnyei, 2005; Dörnyei i Ryan, 2015).

U nastavku teorijskoga dijela rada izlažu se razmatranja o strahu od stranoga jezika i strahu od čitanja na stranome jeziku kao važnim individualnim razlikama u procesu učenja stranoga jezika. Najprije se daje pregled teorijskih polazišta, a zatim empirijskih istraživanja za navedena istraživačka područja.

\subsection{Strah od jezika i strah od stranoga jezika}

Nema sumnje da strah utječe na proces učenja stranoga jezika. To vjerojatno možemo posvjedočiti i sami ako se prisjetimo vlastitih iskustava učenja nekoga stranoga jezika, a također možemo i u iskustvu rada kao nastavnici i istraživači OVIJ-a pronaći primjere kojima bismo potkrijepili ovu misao. Nalazi mnogih istraživanja afektivnih faktora u učenju jezika koja su provedena tijekom posljednja tri desetljeća potvrdila su pretpostavku da je strah vjerojatno afektivni faktor koji najintenzivnije ometa proces učenja (Arnold i Brown, 1999: 8). Međutim, već pri konceptualizaciji straha od jezika nailazimo na poteškoće. Postavlja se pitanje je li to jednostavan ili složen koncept, možemo li ga sagledati kao komponentu motivacije ili kao komponentu straha od komunikacije ili je to zaseban fenomen.

Model monitora (engl. The Monitor Model) predstavlja pokušaj prvoga teorijskoga objašnjenja procesa OVIJ-a (Krashen, 1982). Model obuhvaća pet pretpostavki o procesu ovladavanja inim jezikom: pretpostavku o usvajanju i učenju jezika, pretpostavku o monitoru jezične proizvodnje, pretpostavku o prirodnome redoslijedu, pretpostavku o jezičnome unosu i pretpostavku o afektivnome filtru. Upravo pretpostavka o afektivnome filtru (engl. the affective filter hypothesis) pokušaj je objašnjenja zašto neke osobe, iako su izložene velikim količinama razumljivoga unosa, ne uspijevaju ovladati jezikom koji usvajaju. Osobe s neoptimalnim stavovima imat će visok ili jak afektivni filtar - čak i ako razumiju poruku, unos neće stići do dijela mozga koji je odgovoran za usvajanje jezika (Krashen, 1982: 31). To se događa zbog prepreke koju kod takvih osoba stvaraju osjećaji, motivacija, potrebe i strah. Strah pridonosi 
povećanju prepreke, a prepreka onemogućuje pojedincu prihvaćanje jezičnoga unosa (Mihaljević Djigonović, 2002). 1.2. prikazuje Krashenov afektivni filtar (Krashen, 1982: 32).

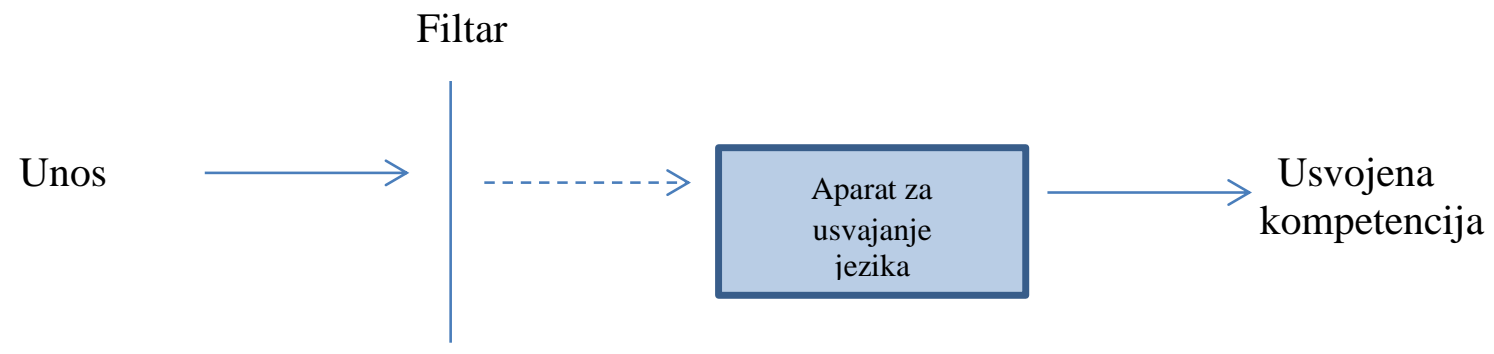

Slika 1.2. Afektivni filtar (Krashen, 1982: 32)

Krashen naglašava ulogu nastavnika u obrazovnome kontekstu jer je upravo on odgovoran učenike izložiti razumljivomu unosu i stvoriti okruženje koje potiče nizak afektivni filtar i nizak strah (engl. low anxiety).

U znanstvenoj literaturi o strahu od jezika često se kao polazišna razmatranja spominju radovi američkoga psihologa Spielbergera koji se 1960-ih i 1970-ih godina bavio proučavanjem straha kao stanja (engl. state anxiety) i straha kao osobine ličnosti (engl. trait anxiety). Prvi pojam odnosi se na relativno stabilnu individualnu osobinu i sklonost pojedinca da bude tjeskoban. Kod drugoga pojma riječ je o prijelaznome emocionalnome stanju za koje su karakteristični subjektivni osjećaji napetosti, nervoze i zabrinutosti popraćeni aktivacijom autonomnoga živčanoga sustava (Spielberger, 1966, 1972).

Međutim, postoji i situacijski strah koji se odnosi na neugodu koju osjećamo u određenome trenutku kao svoju reakciju na konkretnu situaciju (Spielberger, 1983). Proučavajući strah i učenje jezika, MacIntyre i Gardner (1989) opisali su strah koji se može razviti u određenome tipu situacije (engl. situation-specific anxiety). Ispitali su strah koji se razvijao kod kanadskih učenika na nastavi francuskoga jezika kao reakcija na konkretnu situaciju formalnoga učenja francuskoga jezika te utvrdili da je strah od stranoga jezika zasebna manifestacija straha odvojena od općega straha, ali usporediva sa strahom od komunikacije (MacIntyre i Gardner, 1989). Kada se ponavljaju događaji koji pobuđuju takvu reakciju osoba počinje povezivati osjećaj straha s učenjem jezika jer je to naučena emocionalna reakcija. Dakle, strah od jezika pojavljuje se kao posljedica ponovljenih negativnih iskustava tijekom 
učenja jezika. Strah se smanjuje s napredovanjem u učenju i jezičnoj kompetenciji, te povećavanjem broja pozitivnih iskustava (MacIntyre i Gardner, 1989).

Prva razmatranja straha od stranoga jezika kao zasebnoga fenomena različitoga od općega straha i straha specifičnoga za učenje jezika nalazimo kod Horwitz, Horwitz i Cope (1986) koji su posebno konstruiranim Upitnikom za mjerenje straha od stranoga jezika u razrednoj situaciji (FLCAS) proveli istraživanje straha od stranoga jezika u američkome socioedukacijskome kontekstu. Prema tim autorima konceptualna polazišta razmatranja straha od jezika jesu strah od komunikacije, strah od negativne društvene evaluacije i strah od ocjenjivanja.

Strah od komunikacije na stranome jeziku proizlazi iz činjenice da učenik osjeća frustriranost kada se ne uspijeva izraziti ili razumjeti svojega sugovornika. Osobe koje osjećaju nelagodu kada govore pred grupom ljudi osjećat će vrlo vjerojatno slične poteškoće i na nastavi stranoga jezika u razredu, osobito zbog činjenice da imaju ograničenu sposobnost izražavanja na stranome jeziku. Međutim, mora se primijetiti da i one osobe koje ne osjećaju nelagodu ili strah od komunikacije u svakodnevnim situacijama, na nastavi stranoga jezika mogu postati manje aktivne i šutljivije zbog ograničene sposobnosti izražavanja na stranome jeziku.

Strah od negativne društvene evaluacije nastaje jer učenik osjeća bojazan da zbog nedovoljne ovladanosti jezikom neće uspjeti ostvariti društveno prihvaćanje. To je manifestacija straha koja obuhvaća strah zbog procjene drugih, izbjegavanje situacija u kojima se osoba procjenjuje i očekivanje da će se određenu osobu negativno procijeniti (Watson i Friend, 1969). Taj strah može se pojaviti u raznim situacijama, a na nastavi stranoga jezika učenik može imati osjećaj da ga se kontinuirano dvostruko procjenjuje: od strane nastavnika i od strane ostalih učenika. Učestale situacije evaluacije učenika u procesu učenja jezika potiču strah od ocjenjivanja, a on proizlazi iz straha od neuspjeha. Ponekad taj strah može biti povezan i s visokim očekivanjima učenika i s napetošću koje takvo očekivanje uzrokuje.

Strah od ocjenjivanja odnosi se na skup fenomenoloških, fizioloških i bihevioralnih odgovora koji prate zabrinutost zbog mogućih negativnih posljedica koje mogu nastati u situaciji kada se pojedinca ispituje ili procjenjuje (Zeidner, 1998, prema Zeidner i Matthews, 2003). Osobe koje imaju strah od ocjenjivanja doživljavaju situacije u kojima ih se procjenjuje kao situacije koje ih ugrožavaju. Kod njih se pojavljuju pretjerana zabrinutost, poremećaji 
koncentracije, ometajuće misli, napetost, smanjenje samopouzdanja i specifične fiziološke reakcije koje prate navedene pojave. Spielberger (1980) promatra strah od ocjenjivanja kao situacijski specifičnu osobinu ličnosti, a Sarason i suradnici (1995) navode da strah od ocjenjivanja kao osobina ličnosti u situaciji u kojoj se pojedinca procjenjuje dovodi do stanja straha. Horwitz i suradnici (1986) zaključuju da strahovi od komunikacije, negativne društvene evaluacije i ocjenjivanja smanjuju učenikovu uspješnost u učenju jezika.

Horwitz i suradnici (1986) i Horwitz (2016) naglašavaju da strah od stranoga jezika nije jednostavan zbroj prethodno navedenih strahova i nije fenomen koji bi se jednostavno mogao objasniti kombinacijom triju vrste strahova. No, za potpuno razumijevanje straha od jezika potrebno je razumjeti ove opće vrste straha budući da se one manifestiraju tijekom učenja stranoga jezika.

Strah od komunikacije (engl. communication apprehension) jedan je od općih izvora straha od jezika (Horwitz i sur., 1986), a može se definirati kao vrsta sramežljivosti koju karakterizira strah od komuniciranja s ljudima (Mihaljević Djigunović, 2002). Strah od komunikacije odnosi se na sindrom straha koji se povezuje sa stvarnom ili očekivanom komunikacijom s jednom osobom ili više osoba (McCroskey, 1977). U nastavnome procesu nužno je prepoznati učenike koji imaju strah od komunikacije, a kada ih se prepozna oni zahtijevaju posebnu pažnju nastavnika. Strah od komunikacije iznimno je važan za definiranje straha od jezika jer se može pretpostaviti da će osoba koja ima poteškoća u komunikaciji s grupom ljudi imati još više poteškoća kada treba sudjelovati u komunikaciji na stranome jeziku.

McCroskey navodi četiri tipa straha od komunikacije:

- strah kao osobina ličnosti - predstavlja relativno trajnu orijentaciju koju osoba pokazuje prema određenoj komunikaciji u različitim kontekstima

- opći strah vezan uz komunikacijski kontekst - predstavlja relativno trajan strah od komunikacije u određenome tipu konteksta

- $\quad$ komunikacijski strah vezan uz određenu osobu ili grupu ljudi - predstavlja reakciju na situacijske barijere, nije osobina ličnosti

- $\quad$ situacijski strah - predstavlja prolaznu komunikacijsku orijentaciju u komunikaciji s određenom osobom ili grupom ljudi

(McCroskey, 1997). 
Kada govorimo o strahu od komunikacije u nastavnome kontekstu, trebamo uzeti u obzir da je to situacija u kojoj određene osobe imaju autoritet i određuju ostalim osobama sudjelovanje u komunikaciji (Mihaljević Djigunović, 2002). McCroskey i Richmond (1976, 1982) upozoravaju da oni učenici koji su skloni strahu od komunikacije u takvim društvenim situacijama vrlo vjerojatno osjećaju velik strah jer nemaju kontrolu, sramežljivi su i manje govore, a ostali učenici u razredu doživljavaju ih manje pozitivno. Stoga takvi učenici mogu imati i strah od negativne društvene evaluacije jer ih može zabrinjavati i kako će izgledati $u$ očima drugih. Takvi učenici sudjelovanje na nastavi stranoga jezika mogu doživljavati kao prisilno sudjelovanje u komunikaciji, što može pojačati strah od komunikacije i izazvati povlačenje, te tako smanjiti motivaciju (Krashen, 1981). Foss i Reitzel (1991) smatraju da strah od komunikacije i strah od jezika imaju neke zajedničke karakteristike.

Danas je u OVIJ-u općeprihvaćeno da je strah od stranoga jezika složen fenomen koji karakteriziraju doživljaji, vjerovanja, osjećaji i oblici ponašanja pojedinca koji su specifični za razrednu situaciju učenja stranoga jezika i proces učenja stranoga jezika (Horwitz i sur., 1986: 128), te se stoga proučavanju straha od jezika pristupa kao zasebnome fenomenu. Teorijski modeli straha od jezika nisu mnogobrojni, pa tako konceptualizacija straha od jezika koju je ponudila Horwitz sa svojim suradnicima (1986) i nadalje predstavlja osnovno teorijsko polazište u razmatranjima o strahu od jezika. Među recentnijim radovima Kim (2002) je, pokušavši razjasniti teorijsku osnovu straha od jezika, predložila model straha od stranoga jezika (v. sliku 1.3.). 


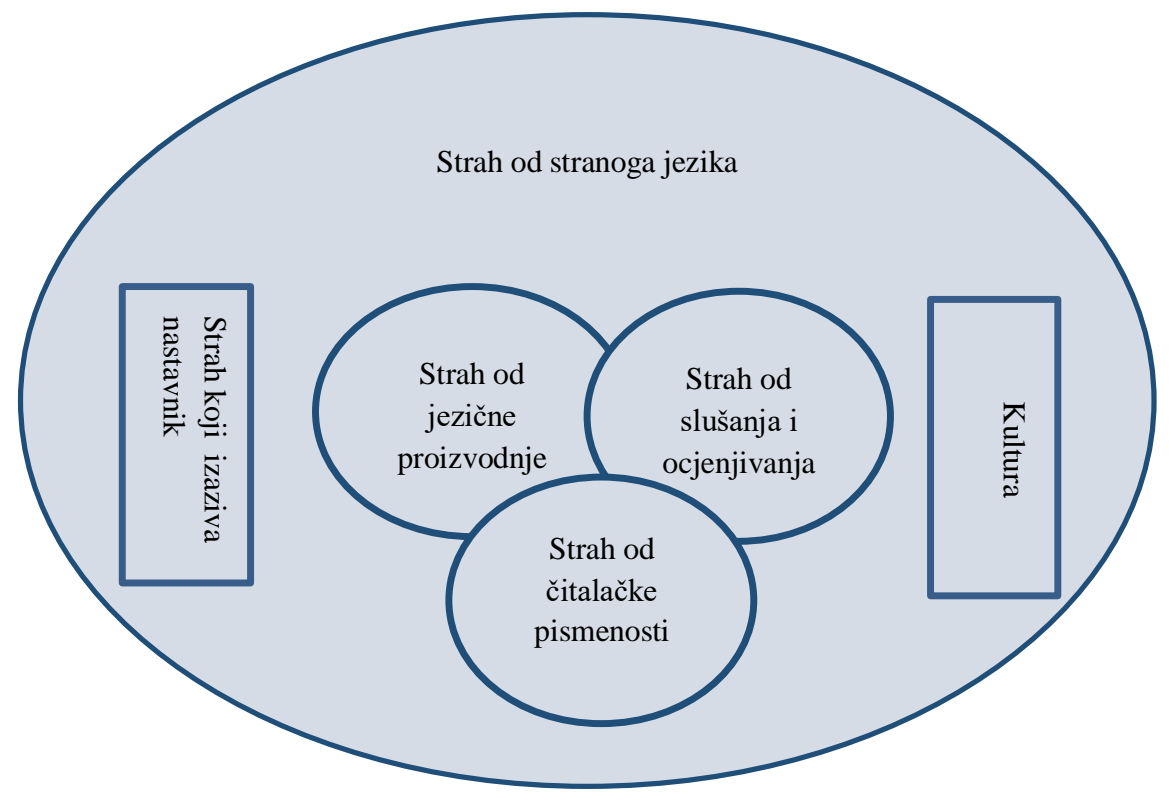

Razredno okruženje učenja stranoga jezika

Slika 1.3. Teorijski model straha od stranoga jezika

(Kim, 2002: 106)

Luo (2013) se osvrnula na kriterij kategorizacije za tri navedena tipa straha u modelu koji je ponudila Kim (2002) te utvrdila da primijenjeni kriterij nije konzistentan. Tako je istaknula da strah od ocjenjivanja ne bi trebao biti naveden samo uz strah od slušanja, nego i uz strah od jezične proizvodnje i strah od čitalačke pismenosti. Luo je nadalje primijetila da nastavnik i poznavanje kulture predstavljaju prije izvore nego manifestacije straha, te zaključila da model koji je ponudila Kim može predstavljati poticaj istraživačima za daljnju doradu i razvoj novih modela (Luo, 2013).

Luo (2011) je polazeći od konceptualizacije koju je izložila Horwitz sa suradnicima (1986) za potrebe svojega doktorskoga rada, a za koji je mentorica bila upravo E. K. Horwitz, izradila upitnik za ispitivanje straha od kineskoga jezika u američkome socioedukacijskome kontekstu, te ponudila teorijski model straha od jezika koji se sastoji od četiriju komponenata (v. sliku 1.4.) 


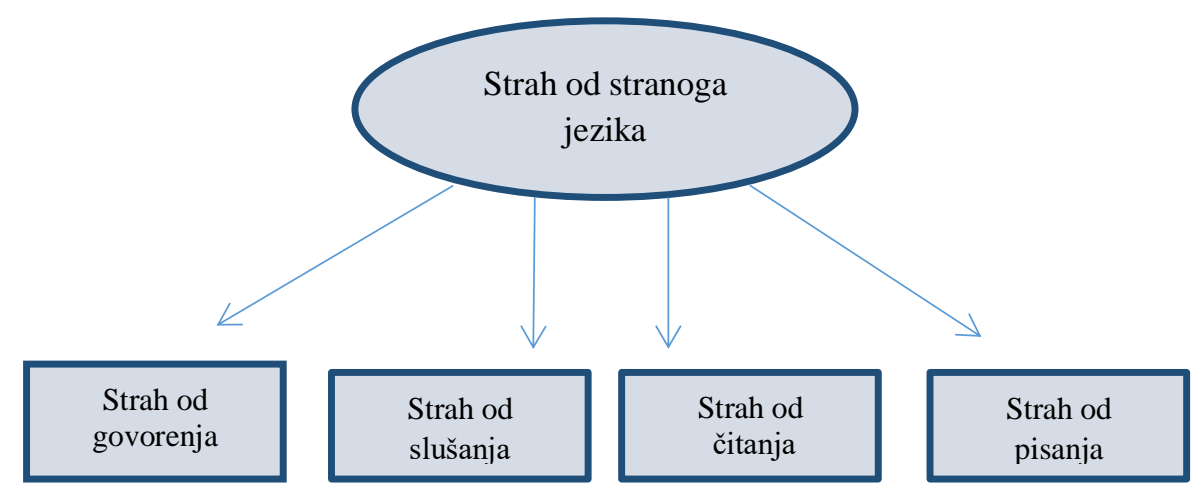

Slika 1.4. Model straha od stranoga jezika koji se sastoji od četiriju komponenata (Luo, 2011: 60)

Ispitujući izvore straha od stranoga jezika kod studenata koji uče kineski na dvama državnima američkima sveučilištima Luo (2011) je predložila model straha od kineskoga jezika koji obuhvaća četiri izvora straha od jezika prikazan na slici 1.5 .

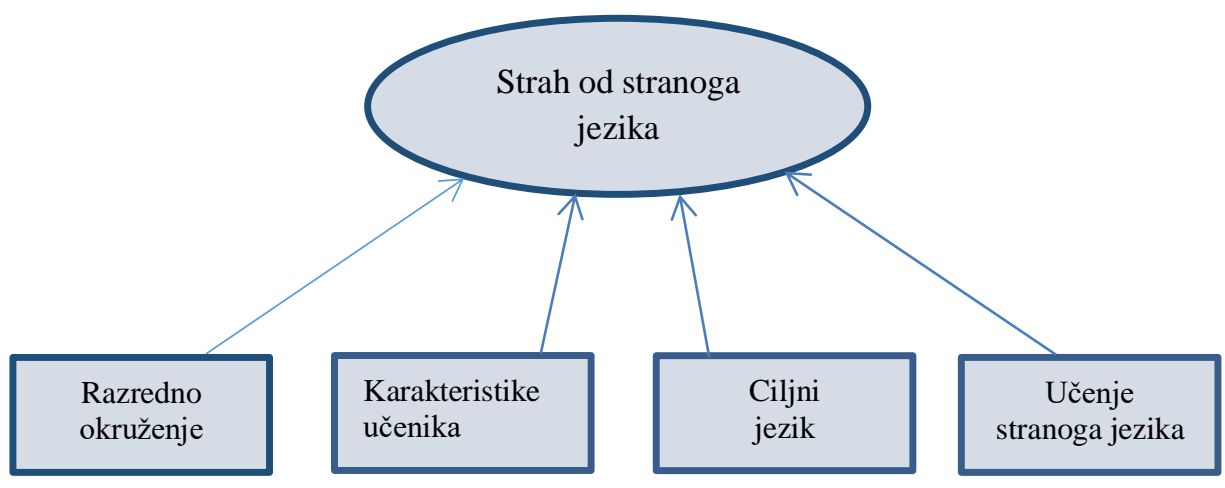

Slika 1.5. Model izvora straha od stranoga jezika koji se sastoji od četiriju dimenzija (Luo, 2011: 59)

Od 1980-ih godina mnogi istraživači OVIJ-a svojim su radovima pridonijeli produbljivanju spoznaja o strahu od stranoga jezika na empirijskoj i na teorijskoj razini. Istraživanja su se provodila u različitim socioedukacijskim kontekstima, uz korištenje kvantitativne i kvalitativne istraživačke metode. $\mathrm{O}$ rezultatima relevantnih istraživanja straha od stranoga jezika i straha od čitanja na stranome jeziku izvijestit će se u potpoglavljima 1.6. Istraživanja straha od stranoga jezika i 2.1. Istraživanja strukture i izvora straha od čitanja na stranome jeziku. 


\subsection{Komponente, manifestacije i vrste straha od stranoga jezika}

Kada se govori o strahu od stranoga jezika, naglašava se da ta taj strah nije jednodimenzionalan fenomen već složen, koji objedinjuje više komponenti, od kojih se, pri njegovu proučavanju, u razmatranje uzimaju četiri komponente: kognitivna, emocionalna, tjelesna i bihevioralna. Kognitivna komponenta odnosi se na zabrinutost (engl. worry), koju Sarason (1986) definira kao zaokupljenost uznemirujućim mislima i zabrinutost zbog prijetećih ili predosjećanih događaja. Ta se komponenta odnosi na zabrinutost pojedinca oko slike o sebi u očima okoline, na negativno samovrednovanje i preokupiranost mislima o sebi, kao i na osjećaj nesposobnosti da se udovolji zahtjevima okoline. Emocionalna komponenta podrazumijeva osjećaj uznemirenosti i neugode. Schwarzer (1986) navodi da se i somatske reakcije (ubrzani puls, crvenilo lica i sl.) mogu povezati s emocionalnom komponentom, koja je donekle i kognitivna komponenta jer pojedinac može biti zaokupljen mislima koje procesuiraju osjećaje koji se tada javljaju. Kod Mihaljević Djigunović (2002) nailazimo na posebno navođenje tjelesne komponente, kao i kod Sinclair (1987) i Sarason (1986). Negativne učinke straha na kognitivnu aktivnost opisao je Eysenck (1979), upozoravajući da zabrinutost i ostale kognitivne aktivnosti koje su povezane sa strahom, a nisu povezane sa zadatkom učenja, ometaju kvalitetu obavljanja određenoga zadatka. Kod osoba koje osjećaju strah odvijaju se dva procesa: obrada informacija koje su važne za obavljanje zadatka i obrada informacija koje su nevažne za obavljanje zadatka (Eysenck, 1979: 364). Veći broj istraživanja ukazao je na to da strah utječe na radnu memoriju i da visoki strah umanjuje kapacitet radne memorije. Osobe koje osjećaju visoki strah kompenziraju smanjeni kapacitet obrade informacija pojačanim naporom, pa tako strah može utjecati i na kvalitetu obavljanja zadatka i na pojačani napor koji određena osoba ulaže u obavljanje toga zadatka (Eysenck, 1979: 365). Zbog pretjerane zaokupljenosti ometajućim mislima, osoba s višom razinom straha postići će vrlo vjerojatno lošiji uspjeh, trebat će više vremena da obavi zadatak, a kvaliteta obavljenoga zadatka bit će manja zbog smetnji tijekom kognitivnih aktivnosti. Četvrta komponenta straha, bihevioralna komponenta, odnosi se na nespretnost, sklonost povlačenju i izdvajanju iz društvenih aktivnosti, te na smetnje u gestama i govoru (Schwarzer, 1986). Bihevioralna reakcija kod visokoga straha može biti i pretjerano komuniciranje. Kod nekih osoba $\mathrm{s}$ visokim strahom zbog osjećaja neugode dolazi do poremećene komunikacije koja postaje pretjerana (Mihaljević Djigunović, 2002). Uz bihevioralnu komponentu najčešće se povezuje sramežljivost jer se sramežljiva osoba i osoba koja ima strah od jezika mogu slično ponašati. Sramežljivost je neugoda koju osjećamo kada smo suočeni s drugim osobama u socijalnoj situaciji u kojoj trebamo aktivno sudjelovati, a nije 
tek nedostatak društvenosti (Buss, 1997). Dva su tipa sramežljivosti: anksiozna sramežljivost i sramežljivost koja proizlazi iz pretjerane usmjerenosti na sebe kada je osoba pretjerano svjesna sebe kao društvenoga bića. Važna je komponenta ovoga drugog tipa sramežljivosti neugoda, a crvenilo lica njegov čest znak.

Različiti su oblici manifestacija straha, primjerice znojenje dlanova, nervoza želuca, ubrzani rad srca i pojačani puls. Uz fiziološke manifestacije, pojavljuju se i izobličeni izgovor glasova te nemogućnost reprodukcije intonacije i ritma. Reakcije koje nastaju zbog uznemirenosti mogu se manifestirati vrpoljenjem, kovrčanjem kose, učestalim prekidanjem drugih, dužim pauzama u govoru ili smanjenom društvenom interakcijom. Horwitz i suradnici utvrdili su da se strah od stranoga jezika manifestira tako da učenici odbijaju upotrebljavati teže jezične iskaze na stranome jeziku i zalede se kada ih nastavnik prozove ili kada trebaju igrati uloge u dijalozima. Učenici znaju određenu gramatičku strukturu, ali kao da zaborave kada je treba upotrijebiti, teško razlikuju određene glasove i strukture i griješe na testovima zbog nervoze, a ponekad i zbog pretjeranoga učenja (Horwitz i sur., 1986). Previše izražen natjecateljski duh u razrednome okruženju, koji potiče pojedinca da se uspoređuje s ostalima, kao i pretjerana želja pojedinca da pridobije odobravanje nastavnika, mogu pridonijeti strahu od jezika u razrednome okruženju (Young, 1991).

U razmatranjima o učincima koje strah i strah od jezika mogu imati spominju se negativni i pozitivni učinci. Istraživači su 1960-ih i 1970-ih godina ispitivali strah koji može utjecati pozitivno (engl. debilitating anxiety) i strah koji može utjecati negativno (engl. debilitating anxiety). Pretpostavilo se da pojedinac može imati visoki pozitivan i negativan strah, ili samo jedan, ali ne drugi, ili niti jedan od oba navedena (Alpert i Haber, 1960: 213). Visoka razina straha može djelovati pozitivno ako je zadatak relativno lak, ali djeluje negativno ako je zadatak težak. Kod učenika većih intelektualnih sposobnosti može djelovati kao pozitivna motivacija, dok će kod učenika manjih intelektualnih sposobnosti djelovati kao negativna motivacija (Spielberger, 1966). Pozitivan strah motivira učenika da se bori (engl. fight) sa zadatkom i potiče ga na djelovanje, dok negativan strah motivira učenika da bježi (engl. flee) od zadatka i potiče ga na izbjegavanje djelovanja (Scovel, 1978). Takav binarni pristup strahu svoje polazište nalazi u razmatranju da je svako učenje popraćeno pozitivnom ili negativnom motivacijom (Scovel, 1978). Prema Gardneru i suradnicima (1992) ono što neki smatraju pozitivnim učinkom straha moglo bi se pripisati motivaciji. Međutim, Horwitz (2016) 
ističe da ne podržava konceptualizaciju pozitivnoga i negativnoga straha jer smatra da ne postoji pozitivan strah niti pozitivan učinak straha.

\subsection{Izvori straha od stranoga jezika}

Mnogobrojna istraživanja straha od jezika koja se provode zadnjih desetljeća korištenjem različitih metodololoških postupaka (upitnika, intervjua, dnevnika) te uključuju i učenike i nastavnike omogućila su uvid u izvore straha od stranoga jezika. Najcjelovitiji pregled potencijalnih izvora straha od jezika ponudila je Young (1991), klasificirajući izvore straha na: (1) osobne i interpersonalne strahove, (2) učenikova vjerovanja o učenju jezika, (3) nastavnikova vjerovanja o poučavanju jezika, (4) interakciju učenik-nastavnik, (5) nastavne aktivnosti i (6) testiranje jezičnoga znanja (Young, 1991).

Osobni i interpersonalni strahovi najčešće su spominjani izvori straha od jezika. Povezuju se s niskim samopouzdanjem pojedinca i natjecateljskim duhom koji se razvija u interpersonalnim odnosima. Osobe nižega samopouzdanja u velikoj mjeri brinu o svojem imidžu, što može potaknuti zabrinutost i strah, kao i nesigurnost u vlastito znanje i vještine. Krashen (1992, u Young 1992) upozorava da je razumijevanje straha u kontekstu učenja jezika blisko razumijevanju fenomena pripadnosti grupi (engl. club membership). Afektivni filtar je nizak kada pojedinac sebe promatra kao pripadnika grupe govornika nekoga stranoga jezika. Koncept pripadnost grupi može se usporediti s konceptom dvaju tipova akulturacije koji je uveo Schumann (1978): prvi se odnosi na socijalnu integraciju, koju pojedinac može ostvariti komunicirajući na jeziku koji uči, a drugi se tip odnosi na nastojanje pojedinca da prihvati životni stil i vrijednosti referentne grupe koja koristi onaj jezik koji on uči. Terell (1992, u Young 1992) sagledava ulogu afektivnoga filtra u odnosu na strah od jezika i uspoređuje niski afektivni filtar s Gardnerovom i Lambertovom integrativnom motivacijom (Gardner i Lambert, 1972). Integrativno orijentirani učenik želi naučiti jezik kako bi mogao komunicirati, ali možda i postati sličan grupi ljudi koji koriste onaj jezik koji on uči. Rardin (1992, u Young, 1992) dovodi u vezu strah od stranoga jezika s osjećajem gubitka vlastitoga identiteta, opisujući to strahom koji pojedinac osjeća pri pomisli da će, ako (na)uči neki drugi jezik, izgubiti sebe.

Učenikova vjerovanja o učenju jezika mogu u velikoj mjeri pridonijeti strahu od stranoga jezika. Horwitz (1988) je u istraživanju među grupom američkih studenata utvrdila 
sljedeća vjerovanja: da je u učenju stranoga jezika važna točnost, a osobito točan naglasak, da su dvije godine dovoljne da se postigne jezična tečnost te da su neki ljudi sposobniji za učenje jezika od drugih. Među tim vjerovanjima neka su nerealna pa upravo onamogu biti izvor straha od jezika. Sudar realnosti i vjerovanja rezultira strahom (Young, 1991).

Nastavnikova vjerovanja o poučavanju jezika mogu biti izvor straha od jezika za učenike, a odražavaju se u nastavnikovim postupcima. Neki nastavnici vjeruju da stalno moraju ispravljati učenike i strogo upozoravati na pogreške kako bi spriječili ponavljanje istih. Međutim, upravo takvi postupci mogu kod učenika izazvati frustraciju i znatno smanjiti samopouzdanje. Kada nastavnik često prekida i ispravlja učenika njihova komunikacija nije uravnotežena: učenik osjeća kao da nastavniku nije stalo do njegova odgovora, a učestalo prekidanje ometa ga u jezičnoj izvedbi.

Vezano uz nastavne aktivnosti, najčešći je izvor straha situacija u kojoj učenik treba govoriti ili čitati pred razredom ili sudjelovati u dijalogu koji se izvodi pred razredom. Young (1990) je u istraživanju među studentima i srednjoškolcima utvrdila da se gotovo $70 \%$ sudionika istraživanja osjeća ugodnije kada ne mora govoriti pred razredom.

Testiranje jezičnoga znanja čest je izvor straha od jezika. Reakcije na zadatke kojima se testira znanje jezika istražili su Madsen i suradnici (1991), primijetivši da neke vrste i tipovi zadataka mogu izazvati strah. Za učenike izvor straha od jezika također predstavljaju zadatci na testu koje nisu ranije rješavali ili ih moraju rješavati pristupom koji njima nije poznat. Primjerice, ako se na satu uvježbavaju komunikacijske aktivnosti, a na testu se provjerava gramatička točnost, to može dovesti do frustracije i straha kod učenika. Strah osjećaju također kada se nalaze u novoj ili nejasnoj situaciji ili tijekom evaluacije (Daly, 1991). Viši stupanj zahtjevnosti evaluacije, nejasniji i manje poznati zadatci i oblici zadataka, potaknut će viši strah kod učenika.

Kako bismo smanjili strah i uklonili izvore straha od jezika potrebno je obratiti pozornost na sve izvore straha te stvarati poticajnu razrednu atmosferu u kojoj će učenici stjecati pozitivna iskustva učenja jezika i napredovati u učenju. 


\subsection{Upravljanje strahom od stranoga jezika}

Borba protiv straha od jezika započinje prepoznavanjem straha, složenoga fenomena postojanje kojega trebaju osvijestiti i učenici i nastavnici te nastojati pronaći metode borbe protiv njega. Neke metode borbe protiv straha može primijeniti i sam učenik (Foss i Reitzel, 1991). Primjerice, može napraviti popis strahova koje osjeća pri učenju stranoga jezika. Taj se popis napiše na ploču i svaka se stavka na popisu komentira u razredu. Na taj način učenik spoznaje da i ostali učenici osjećaju strah i da taj strah neće dovesti do loših posljedica. Metoda crtanja dijagrama straha, pak, jedna je od metoda borbe protiv straha od govorenja pred razredom (Brownell i Katula, 1984). Crtanjem dijagrama učenik primjećuje da strah nije uvijek prisutan $\mathrm{u}$ istome intenzitetu i može proučiti njegov tijek i intenzitet, pri čemu je osobito važno zabilježiti kada je intenzitet straha (engl. speech anxiety peak) najviši. Vođenje dnevnika omogućuje uvid u podatke o tijeku i intenzitetu straha, o temama koje su izazvale strah, o sugovornicima i načinu komunikacije, a uspoređivanje tih podataka među učenicima omogućuje realističniji uvid u sam strah, kao i u uspješniju borbu protiv njega.

Važan korak u svladavanju straha od jezika jest njegovanje pozitivnoga pojma o sebi (Laine, 1987; Mihaljević Djigunović, 2002). Naš pojam o sebi povezan je s načinima na koje sebi objašnjavamo vlastite uspjehe i neuspjehe u učenju, tj. s atribucijama (Weiner, 2010). Osobe koje imaju pozitivan pojam o sebi neuspjeh u učenju jezika pripisuju tome što nisu dovoljno učile, a osobe koje imaju negativan pojam o sebi neuspjeh pripisuju nedostatku darovitosti, odnosno osobini nad kojom nemaju kontrolu (Mihaljević Djigunović, 1998, 2002). Vjera u vlastite sposobnosti, uz pravilno postavljanje ciljeva učenja, dovodi do realizacije realnih očekivanja i do uspjeha u učenju.

Uz pozitivan pojam o sebi i pozitivne stavove u borbi protiv straha od jezika učeniku uvelike pomažu i strategije učenja. Rubin (1975) je, proučavajući strategije učenja među više i manje uspješnim učenicima stranoga jezika, utvrdila karakteristike uspješnoga učenika. Uspješan učenik spreman je pogađati značenje i izložiti se riziku da pogriješi, obraća pozornost na jezične obrasce, vježba i ponavlja. Karakterizira ga jaka potreba za komunikacijom, pa čak i kada naiđe na poteškoću nalazi način da nastavi komunikaciju. Obraća pozornost na kontekst i na ostale sudionike u komunikaciji te, uspoređujući se s drugima, uči iz vlastitih pogrešaka. 
Proučavanju strategija učenja jezika velik je prinos dala je Oxford, klasificirajući strategije učenja na: strategije pamćenja, kognitivne strategije, kompenzacijske strategije, metakognitivne strategije, društvene strategije i afektivne strategije (Oxford, 1990). Afektivna strana učenika ima vjerojatno najveći utjecaj na uspjeh ili neuspjeh u učenju jezika (Oxford, 1990: 140). Uspješni učenici znaju kontrolirati svoje osjećaje i stavove prema učenju. Negativni osjećaji mogu otežati proces učenja, a pozitivni ga osjećaji mogu olakšati. Nastavnici pritom mogu imati važnu ulogu, ali učenikovo samopouzdanje (Clément i sur., 1977; Clément, 1980; Clément i Kruidenier, 1985) i tolerancija nejasnoće (Ely, 1989) primarno su važni u borbi protiv negativnih osjećaja. Budući da su afektivne strategije usmjerene na razvijanje samopouzdanja, ovladavanje afektivnim strategijama može pridonijeti uspjehu u učenju jezika. Slika 1.6. prikazuje afektivne strategije prema Oxford (1990).

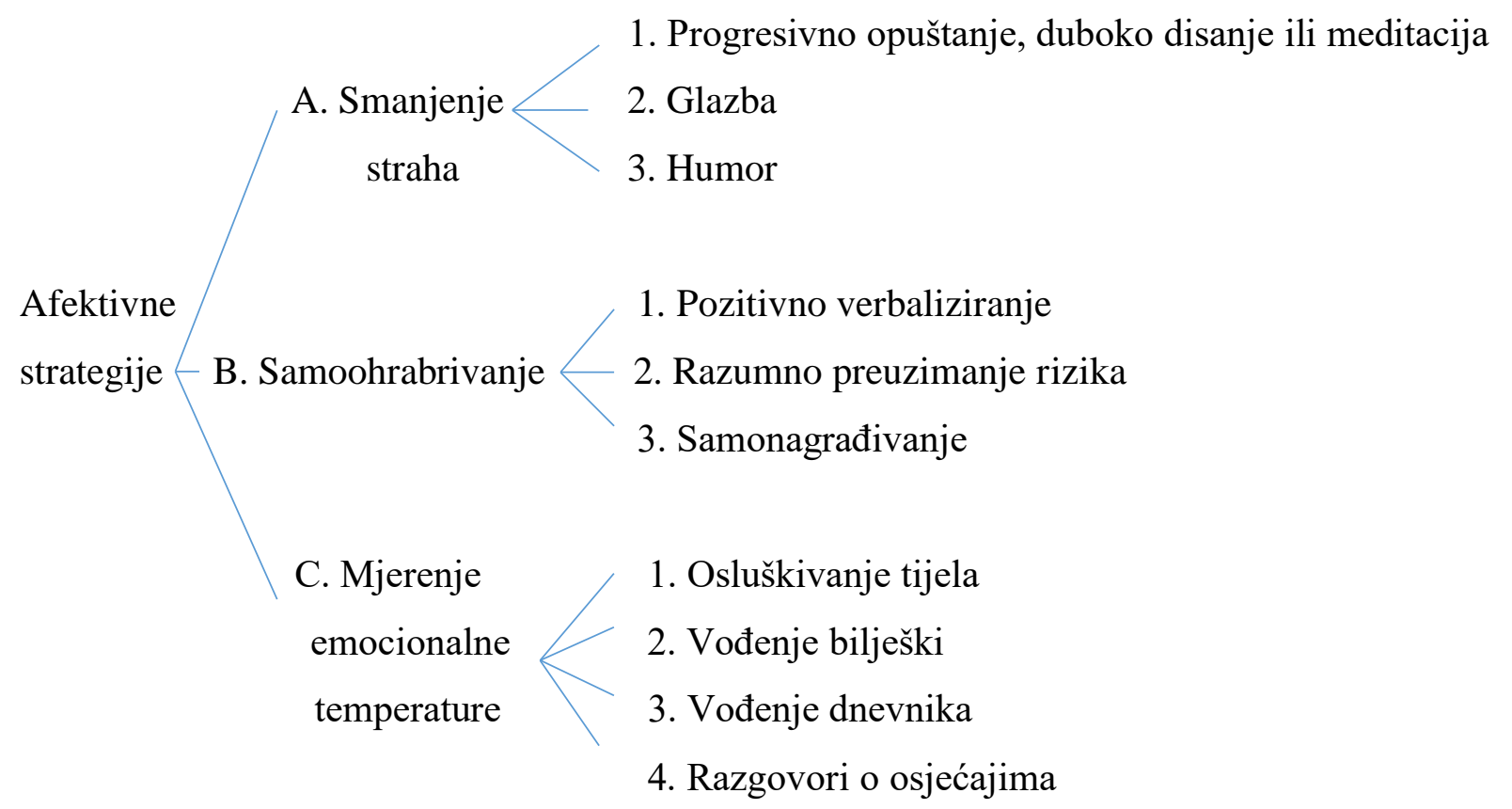

Slika 1.6. Dijagram afektivnih strategija (Oxford, 1990: 141)

Strategije smanjenja straha odnose se na postupke kojima se postiže fizička relaksacija mišića u tijelu, na vratu i na licu, kako bi se tijelo opustilo. Tehnika dubokoga disanja podrazumijeva disanje iz dijafragme, dok meditacija podrazumijeva fokusiranje na određenu sliku ili zvuk. Slušanje glazbe za opuštanje, gledanje filmskih komedija i slušanje viceva djeluje opuštajuće. Samoohrabrivanje uključuje razvijanje pozitivnih misli o sebi i samonagrađivanje. Preuzimanje rizika podrazumijeva poduzimanje određene jezične aktivnosti, uz svjestan rizik 
od moguće pogreške. Spremnost na rizik ovdje podrazumijeva spremnost na prihvatljiv rizik koji neće ugroziti uspjeh u učenju. Učenici trebaju naučiti prepoznati negativne i pozitivne osjećaje, pratiti njihov tijek te, u razgovoru s nastavnikom, prijateljima ili bliskom osobom, spoznati te osjećaje i njihov utjecaj. Strategije učenja, pa tako i afektivne strategije, nisu nepromjenjive: mijenjaju se $\mathrm{s}$ dobi i sa stupnjem učenja, a njihova primjerenost ovisi o kulturnom i socioedukacijskom kontekstu. Stoga je važno spoznati ulogu afektivnih strategija i upoznati se s postupcima koji mogu pridonijeti uspjehu u učenju jezika (Oxford, 1990).

Kao što se služe različitim strategijama učenja, učenici primjenjuju i različite stilove učenja. Termin stil učenja označuje opći pristup učenju jezika (Mihaljević Djigunović, 2002: 120). Neki učenici najbolje uče jezik kada vide predmet ili aktivnost o kojoj uče. Drugi najbolje uče kada imaju uvid u pisani oblik jezičnih iskaza, te često i sami mnogo pišu. Auditivnome tipu učenika dovoljno je da samo čuje što treba naučiti pa ne radi bilješke, nego glasno uvježbava ono što treba zapamtiti. Kinestetički tipovi najbolje pamte ako se mogu kretati dok uče. Osim senzornih, postoje i kognitivni stilovi učenja (Mihaljević Djigunović, 2002). Stilovi učenja se, poput strategija i stavova, mogu mijenjati, a da bi ih mogli mijenjati, učenici ih najprije moraju osvijestiti. Nastavnik učeniku može pomoći prepoznati koji stil učenja primjenjuje, odgovara li mu taj stil te ga po potrebi uputiti na promjenu stila učenja. Nužno je spomenuti i toleranciju nejasnoće za koju se utvrdilo da može biti pozitivno povezana s uspjehom i korištenjem učinkovitih strategija učenja (Oxford, 1990: 142). Utvrđeno je da su učenici s višom tolerancijom nejasnoće spremniji nastaviti voditi komunikaciju na stranome jeziku usprkos činjenici da postoje nejasnoće (Rubin, 1975) te da takvi učenici primjenjuju kreativnije tehnike memoriranja i upotrebe novoga vokabulara od učenika s nižom tolerancijom nejasnoće (Ely, 1989).

U borbi protiv straha od jezika učenici nisu sami, kao što nisu sami u procesu učenja jezika. U formalnome kontekstu učenja jezika nastavnik i učenik nalaze se u specifičnome socioedukcijskome odnosu, u kojemu nastavnik više nije samo prenositelj znanja, kako se to ranije smatralo, već je u osnovi organizator stjecanja i otkrivanja znanja te motiviranja, poticanja i vrjednovanja učenika (Pivac, 2009). On se od specijalista predmetnoga područja mijenja u kreativnoinovativnoga stručnjaka čiji bi angažman trebao biti usmjeren na osposobljavanje učenika da postane kompetentan nositelj svojega osobnoga razvoja (Didović Baranac, 2012). U kurikulumu suvremene škole, škola se promatra kao prostor za život (Hentig, 1997), a odnos učenik-nastavnik promatra se u kontekstu socioemocionalne klime u kojem se 
humani ljudski odnos može zasnivati samo na pozitivnim emocionalnim stavovima (Bratanić, 1991). Stoga se uloga nastavnika i u borbi protiv straha od stranoga jezika promatra u kontekstu kurikuluma suvremene škole. Nastavnik treba stvoriti ugodno i poželjno razredno ozračje u kojemu će se vrijeme i nastavni materijali koristiti učinkovito, a učenici aktivno i bez straha sudjelovati u nastavi (Finocchiaro, 1974; Vilke, 1977).

Dörnyei i Murphy (2004) ističu tri značajke nastavnika kao facilitatora ${ }^{7}$ (engl. facilitator) nastavnoga komunikacijskoga procesa: empatiju (sagledavanje situacije iz perspektive učenika), prihvaćanje (prihvaćanje učenikove osobnosti bez osuđivanja) i integritet (profesionalnost i dosljednost).

S obzirom da učenje stranoga jezika učenike vodi k usvajanju jednoga potpuno novoga i složenoga sustava komunikacije, osnovna pretpostavka za uspješnu nastavu stranoga jezika podrazumijeva da učenik želi govoriti i da se ne boji govoriti i sudjelovati u nastavi. Nastavnik se mora truditi stvoriti opuštenu atmosferu jer se teškoće na koje učenik nailazi udvostručuju na nastavi stranoga jezika, gdje je učeniku strano sve - od ritma i intonacije rečenice i izgovora pojedinih fonema, do načina života izvornih govornika toga jezika (Vilke, 1977). Iako nastavnik ne može utjecati na sve aspekte straha od jezika, njegova je uloga iznimno važna. Najprije se nastavnik treba osloboditi svojih zabluda, a zatim može pomoći učenicima da se i oni oslobode svojih te da smanje strah na najmanju moguću mjeru. Nastavnik ne smije cijelo vrijeme samo poučavati i neprestano ispravljati pogreške učenika, već treba djelovati kao moderator aktivnosti u kojima je naglasak na sadržajnoj komponenti jezične uporabe. Kada su učenici više koncentrirani na sadržajnu komponentu, to im odvraća pozornost od straha te se lakše mogu opustiti (Mihaljević Djigunović, 2002).

Poučavanje metoda svladavanja straha od jezika sastavni je dio poučavanja jezika. Učenicima treba omogućiti da izraze svoje osjećaje i da ovladaju strategijama učenja koje će im pomoći da se oslobode straha i neugode. Za ostvarenje ovih ciljeva potreban je partnerski odnos između učenika i nastavnika (Crookall, 1983).

Praktične savjete za borbu protiv straha od jezika koji su primjenjivi kroz aktivnosti u razrednom okruženju dali su Crookall i Oxford (1991). Prva se aktivnost, kolumna o strahu

\footnotetext{
${ }^{7}$ Nastavnik kao facilitator komunikacijskoga procesa (Medved Krajnović, 2010: 120)
} 
(engl. agony column), temelji na ideji novinskih kolumni u kojima se odgovara na pisma čitatelja koji izlažu određeni problem ili traže savjet. Učenici pišu kratko pismo (oko 200 riječi) o određenom problemu vezanom za strah od jezika, sva se pisma numeriraju, a zatim ih učenici u grupama čitaju. Čitajući tuđa pisma učenici spoznaju da i drugi imaju slične strahove $\mathrm{i}$ pokušavaju pronaći savjete za njih. Pisma se zatim s odgovorima šalju natrag autorima. U zadnjoj fazi aktivnosti u razredu se razgovara o problemima i rješenjima istih. Drugu aktivnost Crookall i Oxford (1991) nazivaju duhovi osvetnici (engl. ghost avengers). Učenici zamišljaju da su umrli i postali članovi udruge duhova osvetnika koja im omogućuje da se osvete osobama koje su im izazivale strah dok su učili neki strani jezik. Osveta primjerice može biti glumljenje bivših nastavnika stranih jezika, ali tako da govore smiješnim naglaskom, pa im se svi smiju. Sve se osvete izvode, komentiraju i uspoređuju s vlastitim iskustvima učenika. U trećoj aktivnosti, nazvanoj žiri za pogreške (engl. mistakes panel), učenici se grupiraju po dvoje ili troje, a zatim svaka grupa na kartice napiše svoje stvarne ili izmišljene pogreške. Nakon što se kartice podijele drugim grupama, svaka grupa provodi bodovanje pogrešaka prema istim kriterijima (koliko su pogreške originalne i smiješne, koliko su logične i razumljive, koliko su komunikativno prihvatljive i slično). Na kraju se zbroje bodovi i proglasi pobjednik. Pristupajući pogreškama na opušten i duhovit način, učenici uviđaju da su pogreške sastavni dio procesa učenja jezika i da se iz njih može nešto korisno naučiti. U četvrtoj aktivnosti, fotografije straha (engl. anxious photos), nakon što učenici u grupama izaberu fotografije situacija koje kod njih izazivaju strah od stranoga jezika (npr. na željezničkom kolodvoru, na aerodromu, na satu stranoga jezika u školi i slično), grupe međusobno komentiraju zašto baš te situacije kod njih izazivaju strah te kako ga prevladati. Na kraju se sve navedene situacije i savjeti za prevladavanje straha napišu na školsku ploču. Peta aktivnost, obrnuti naglasak (engl. reversed accent), pomaže učenicima da se oslobode straha od pogrešnoga naglaska. Učenici razgovaraju na materinskome jeziku, ${ }^{8}$ oponašajući naglas zamišljenu osobu koja je izvorni govornik stranoga jezika koji sami uče. Ovom aktivnošću nastoji se smanjiti strah od pogrešnoga izgovora u stranome jeziku.

Za sve navedene aktivnosti nužna je prisutnost nastavnika koji usmjerava aktivnosti kako bi se one provele na pravi način i do zadnjega koraka. Međutim, postoji i aktivnost u kojoj sudjeluju samo nastavnici, a koju Crookall i Oxford (1991) nazivaju odluke o pogreškama (engl. correction decisions). Naime, svaki nastavnik ispuni tablicu u kojoj navede pogreške,

\footnotetext{
${ }^{8}$ Uz naziv prvi jezik ili umjesto njega često se rabi naziv materinski jezik (engl. mother tongue).
} 
opiše njihovu važnost, objasni zašto misli da tu pogrešku treba ispraviti, navede način ispravljanja pogreške i moguće strahove koje navedeni način ispravljanja pogreške može izazvati kod učenika. Nakon toga svi nastavnici zajedno uspoređuju i komentiraju podatke navedene u tablicama. Nastavnici bi trebali obratiti pozornost na način na koji ispravljaju pogreške, na učestalost ispravljanja pogreški i odabir pravoga trenutka (Omaggio Hadley, 1986) te biti manje strogi pri ispravljanju pogreški (Young, 1990). Pod utjecajem recentnijih istraživanja razvija se nov stav prema učeničkim pogreškama - počinje ih se promatrati kao nezaobilaznu i sasvim prirodnu pojavu tijekom ovladavanja jezikom (Medved Krajnović, 2009) te ih smatrati sastavnim dijelom učenja stranoga jezika (Young, 1990).

Budući da je strah od jezika prepoznat kao problem koji mnogim učenicima otežava uspješno učenje jezika, u nekim socioedukacijskim sredinama pokušala se organizirati i institucionalna pomoć. Tako različiti oblici dopunske nastave i grupe za podršku ili jednokratna predavanja na temu ovladavanja strahom od komunikacije i strahom od stranoga jezika, te poučavanje strategija učenja i tehnika relaksacije mogu biti vrlo korisni u ovladavanju strahom od stranoga jezika i njegovom neutraliziranju.

\subsection{Istraživanja straha od stranoga jezika}

\subsubsection{Istraživanja strukture straha od stranoga jezika}

Prva istraživanja straha od stranoga jezika koja su imala cilj opisati i objasniti pojam straha od stranoga jezika počela su se provoditi 1980-ih godina u SAD-u. Na osnovi opisa poteškoća u učenju stranoga jezika, prikupljenih među studentima na jednome sveučilištu u Teksasu, Horwitz i suradnici (1986) konstruirali su upitnik za mjerenje straha od stranoga jezika u razrednoj situaciji FLCAS i s pomoću njega proveli istraživanje straha od stranoga jezika na kolegijima početnoga španjolskoga i francuskoga jezika $(N=75)$. Upitnik $\operatorname{FLCAS}(\alpha=, 93)$ sadržava 33 tvrdnje i objedinjuje strah od komunikacije, strah od ocjenjivanja i strah od negativne društvene evaluacije u razrednoj situaciji. Istraživanjem se utvrdilo da studenti koji imaju visoki strah osjećaju neugodu kada govore pred drugim ljudima i boje se govoriti na stranome jeziku jer se brinu da će pogriješiti i da će ih ostali studenti negativno procijeniti. Također se brinu da će nastavnik svaku njihovu pogrešku procijeniti kao neuspjeh i loše ih ocijeniti. Korelacijskim analizama utvrđena je negativna povezanost straha od jezika i 
zaključnih ocjena iz jezika. Glavni je zaključak istraživanja da strah od stranoga jezika treba sagledati kao složen fenomen koji karakteriziraju doživljaji, vjerovanja, osjećaji i oblici ponašanja pojedinca koji su specifični za razrednu situaciju učenja stranoga jezika i proces učenja stranoga jezika (Horwitz i sur., 1986: 128).

Upitnik FLCAS od 1980-ih do danas često je korišten mjerni instrument u istraživanjima straha od stranoga jezika. Za potrebe nekih istraživanja provodile su se i faktorske analize koje su ukazale na različite strukture straha od jezika s obzirom na različite socioedukacijske kontekste istraživanja i s obzirom na različite ispitivane jezike, a među njima su istraživanja koja su proveli Aida (1994), Cheng i suradnici (1999), Matsuda i Gobel (2001, 2004) i Tóth (2008).

\subsubsection{Istraživanja povezanosti straha od stranoga jezika i uspjeha u učenju stranoga jezika}

Veći broj istraživanja straha od stranoga jezika koja su se provodila tijekom 1980-ih i 1990-ih u SAD-u i Kanadi pokazala su negativnu povezanost straha od stranoga jezika i uspjeha u učenju jezika (Horwitz i sur., 1986; MacIntyre i Gardner, 1989, 1991, 1994a, 1994b; MacIntyre, 1995). Negativnu povezanost straha od stranoga jezika i uspjeha u učenju jezika utvrdili su i Young (1986) u SAD-u, Abu-Rabia (2004) u Izraelu, Piechurska-Kuciel (2008, 2011) u Poljskoj, Liu i Huang (2011) u Kini i Ödemis i Uslu (2014) u Turskoj.

Međutim, u nekim istraživanjima utvrđena je pozitivna povezanost straha i uspjeha. Među američkim studentima takvu su povezanost utvrdile Kitano (2001) za japanski, MarcosLlinás i Garau (2009) za španjolski jezik te Joo i Damron (2015) za korejski. Za engleski jezik takva je povezanost utvrđena u istraživanju koje su proveli Park i French (2013) u Koreji te Koul i suradnici (2009) na Tajlandu. Nalazi o pozitivnoj povezanosti straha i uspjeha uputili su na tumačenje o postojanju pozitivnoga straha koji, ako nije previsok, može biti poticaj učenju (Alpert i Haber, 1960; Scovel, 1978; MacIntyre, 1995). Pri tumačenju nalaza o navedenoj pozitivnoj povezanosti straha i uspjeha treba uzeti u obzir i specifičnosti ciljnoga jezika, osobito specifičnosti jezika koji ne koriste alfabetsko pismo (japanski i korejski), te specifičnosti uzorka i nastavnoga konteksta. 
U mnogim istraživanjima straha od stranoga jezika učenici izvještavaju o različitim iskustvima negativnoga djelovanja straha na uspjeh u učenju jezika. Neki navode izbjegavanje nastave ili odgađanje izrade domaćega rada zbog straha (Horwitz i sur., 1986), drugi navode da im je potrebno više vremena za učenje vokabulara ili se teže prisjećaju naučenoga vokabulara zbog straha (MacIntyre i Gardner, 1989; Sellers, 2000; Rai i sur., 2011).

Sukladno dobivenim nalazima došlo se do spoznaje da je strah od stranoga jezika ometajući čimbenik u postizanju uspjeha u stranome jeziku.

\subsubsection{Istraživanja odnosa straha od stranoga jezika i ostalih čimbenika}

U većem broju istraživanja koja su se bavila ispitivanjem motivacije kao važnoga čimbenika u učenju stranoga jezika utvrdilo se da su motivacija i uspjeh pozitivno povezani (Gardner, 1985; Gardner i sur., 1992, 1997; Mihaljević Djigunović, 2002; Noels i sur., 1999; MacIntyre i sur., 2002; Csizér i Dörnyei, 2005; Ushioda, 2008; Liu i Huang, 2011; Jósza, 2014; Ödemis i Uslu, 2014).

Opsežnije istraživanje povezanosti motivacije i straha od stranoga jezika proveo je Papi (2010) u Iranu, utvrdivši da oni pojedinci koji imaju razvijeniju pozitivnu sliku o sebi, odnosno motivacijski aspekt idealnoga ja, imaju nižu razinu straha od jezika, kao i oni koji imaju bolju procjenu iskustva učenja engleskoga jezika. Dva opsežna istraživanja straha od engleskoga jezika u Kini ukazala su na negativnu povezanost straha i motivacije (Liu i Huang, 2011; Liu i Zhang, 2013), što je sukladno rezultatima nekih istraživanja u drugim socioedukacijskim kontekstima (Gardner, 1985; Csizér i Dörnyei, 2005; Wei, 2007; Ushioda, 2008).

Istraživanja koja su se bavila ispitivanjem razlika u intenzitetu straha od stranoga jezika s obzirom na spol provodila su se u različitim socioedukacijskim kontekstima, ukazavši na nekonzistentnost rezultata. Među mnogobrojnim istraživanjima koja su utvrdila da žene imaju višu razinu straha od muškaraca jesu i istraživanja koja su proveli među srednjoškolcima Abu-Rabia (2004) u Izraelu i Piechurska-Kuciel (2008) u Poljskoj, te među studentima Elkhafaifi (2005) u SAD-u, Koul i suradnici (2009) na Tajlandu, Arnaiz i Guillén (2012) u Španjolskoj i Park i French (2013) u Koreji. Viša razina straha od jezika utvrđena je kod žena 
u istraživanjima provedenima u Turskoj (Aydin, 2008; Balemir, 2009; Karabiyik i Özkan, 2017). Međutim, postoje istraživanja u kojima je utvrđeno da višu razinu straha od jezika imaju muškarci. Takve su nalaze dobili Kitano (2001) u istraživanju straha od japanskoga jezika među američkim studentima i Zhang (2000) u istraživanju straha od engleskoga jezika među kineskim studentima.

Treću skupinu istraživanja razlika s obzirom na spol čine istraživanja u kojima je utvrđeno da ne postoje razlike u visini straha od stranoga jezika između žena i muškaraca. To su utvrdili MacIntyre i suradnici (2002) među srednjoškolcima koji su učili francuski jezik, Dewaele (2007) među studentima koji su učili prvi, drugi i treći strani jezik u Velikoj Britaniji, Zhao (2009) i Zhao i suradnici (2013), ispitujući strah od kineskoga jezika među američkim studentima, i Wu (2011), ispitujući strah od engleskoga jezika među studentima na Tajvanu.

Neke od varijabli koje mogu biti povezane s razinom straha od stranoga jezika jesu duljina učenja jezika i postignuta razina znanja jezika. Često su se pretpostavke o povezanosti straha od jezika i razine znanja jezika temeljile na istraživanju koje su proveli Gardner i suradnici (1977) u kojemu se utvrdilo da strah od francuskoga opada s napredovanjem u učenju jezika. Tendencija opadanja razine straha od jezika s napredovanjem u učenju utvrdila se i u nekim drugim istraživanjima (Elkhafaifi, 2005; Liu, 2006; Piechurska-Kuciel, 2008; Arnaiz i Guillén, 2012). Istraživanja kojima se ispitalo kako strah od jezika može biti povezan s jezičnim procesiranjem proveli su MacIntyre i Gardner (1989) u Kanadi, utvrdivši da strah može ometati kognitivne procese pri učenju jezika i da može biti negativno povezan s uspjehom u jezičnome umijeću.

Na važnost uloge nastavnika u procesu učenja stranoga jezika ukazalo je više istraživača, među kojima su Abu-Rabia (2004) i Piechurska-Kuciel (2011) koji su utvrdili da postoji negativna povezanost straha i učeničkih percepcija nastavnika, te da je nastavnikova podrška u učenju stranoga jezika važan čimbenik koji može biti povezan sa smanjivanjem straha od stranoga jezika i napredovanjem u učenju jezika, što je u skladu s nalazima koje su u svojim istraživanjima dobili Wentzel (1997) i Roeser, Eccles i Sameroff (2000).

Opsežno longitudinalno istraživanje straha od engleskoga jezika, vjerovanja o učenju jezika i procjene obilježja rada nastavnika provela je Piechurska-Kuciel (2008) među srednjoškolcima u Poljskoj $(N=393)$. Utvrđeno je da se strah smanjuje s napredovanjem u 
učenju te da učenici kojima se sviđa engleski jezik imaju niži strah od onih kojima se engleski ne sviđa. Pokazalo se da učenice imaju viši strah od učenika, što je osobito izraženo kod čitanja na engleskome jeziku. Viši strah od stranoga jezika povezan je s višim strahom od komunikacije, višim strahom od ocjenjivanja i lošijim općim uspjehom. Učenje vokabulara smatra se teškim zbog grafofonemske netransparentnosti. Govorenje je procijenjeno kao najteža, a čitanje kao najlakša jezična djelatnost. Piechurska-Kuciel (2011) utvrdila je da je nastavnikova podrška u učenju stranoga jezika važan čimbenik koji može biti povezan sa smanjivanjem straha od stranoga jezika i napredovanjem u učenju jezika.

Mnoga poredbena istraživanja ukazala su da postoje razlike u strahu od jezika s obzirom na različite strane jezike (Saito i sur., 1999; Piniel, 2006; Puškar, 2010; Božinović i Didović Baranac, 2011; Mardešić i Stanković, 2013). Poredbena istraživanja omogućavaju usporedbu dobivenih rezultata i pružaju uvid u sličnosti i razlike u strahu od stranoga jezika s obzirom na više varijabli, među kojima su različit status i percepcija težine ciljnih jezika, razlike u nastavnim kontekstima poučavanja i izvannastavnoj izloženosti stranim jezicima.

\subsubsection{Istraživanja straha od stranoga jezika u Hrvatskoj}

Istraživanja straha od stranoga jezika u Hrvatskoj svoje začetke nalaze u istraživanjima Jelene Mihaljević Djigunović, koja je tijekom proteklih triju desetljeća provela i sudjelovala u mnogobrojnim istraživanjima i projektima u kojima se nastojalo produbiti razumijevanje ovoga složenoga fenomena i njegova povezanost s drugim relevantnim varijablama u učenju stranoga jezika.

Mihaljević Djigunović (2000) je u istraživanju straha od engleskoga jezika među gimnazijalcima utvrdila negativnu povezanost straha i uspjeha u učenju jezika izmjerenoga zaključnom ocjenom na polugodištu. Visoka razina straha bila je povezana s niskim pojmom o sebi i niskom razinom motivacije, a kod učenica je utvrđena viša razina straha nego kod učenika. Opsežno kvalitativno istraživanje provedeno među hrvatskim učenicima različitih dobnih skupina ukazalo je na izvore straha od jezika (Mihaljević Djigunović, 2002). Kao najčešći izvor straha utvrđena je uporaba engleskoga jezika na nastavi, a na drugom i trećem mjestu po učestalosti našli su se ocjenjivanje i negativna samopercepcija. Nastava i negativna 
samopercepcija najčešći su izvori straha kod adolescenata koji su u razvojnoj dobi u kojoj učenici i sebe i nastavnike kritički procjenjuju.

Kostić Bobanović (2009) istražila je strah od stranoga jezika kod austrijskih i hrvatskih studenata, utvrdivši da je četvrtina studenata zabrinuta zbog velikoga broja pravila kojima treba ovladati, a trećina se nerado dobrovoljno javlja usmeno odgovarati i uznemiri se kada ne razumije svaku nastavnikovu riječ. Čiček (2014) je ispitala strah od engleskoga jezika među osnovnoškolcima i utvrdila negativnu povezanost straha i motivacije, kao i straha i uspjeha u engleskome jeziku. Kao važan izvor straha pokazao se strah od ocjenjivanja, strah od pismenih testova i čitanja naglas. Maturanec (2015) je utvrdila umjereni strah od engleskoga jezika među studentima anglistike. Pokazalo se da postoji negativna povezanost visine straha i samoprocjene četiriju jezičnih djelatnosti te straha i ocjene iz jezičnih vježbi. Buben (2018) je istražila strah od stranoga jezika među studentima Filozofskoga fakulteta koji ne studiraju anglistiku. Studenti koji su procijenili da su na nižoj razini znanja imali su viši strah od slušanja i govorenja.

Tijekom posljednjih desetak godina u Hrvatskoj je provedeno i nekoliko poredbenih istraživanja straha od stranoga jezika. U poredbenom istraživanju koje je proveo Puškar (2010) na Filozofskome fakultetu u Zagrebu utvrđeno je da studenti germanistike imaju viši strah od studenata anglistike. Dva glavna izvora straha su zabrinutost studenata da neće položiti ispit iz jezičnih vježbi i zabrinutost zbog pogrešaka na satu jezičnih vježbi. Duljina učenja i razina znanja negativno su povezane sa strahom od jezika. Pozitivna percepcija profesora povezana je s nižim strahom. Za studente germanistike utvrđena je negativna povezanost straha i motivacije, a za studente anglistike utvrđeno je da studentice imaju višu razinu straha od studenata.

Božinović i Didović Baranac (2011) provele su poredbeno istraživanje straha od jezika među studentima Američke visoke škole za management i tehnologiju i među studentima Sveučilišta u Dubrovniku, utvrdivši umjereni strah od stranoga jezika. Nisu utvrđene statistički značajne razlike s obzirom na spol, ni s obzirom na strani jezik (engleski, francuski, njemački, španjolski i talijanski). Posebnom skalom procjene studenti su procijenili francuski i njemački jezik kao najteže, a engleski kao najlakši jezik.

Mardešić i Stanković (2013) ispitale su strah od stranoga jezika među studentima francuskoga, španjolskoga i talijanskoga jezika na Filozofskome fakultetu u Zagrebu. Najniža razina straha utvrđena je za španjolski jezik. Neki od nalaza koje su dobile Mardešić i Stanković 
sukladni su nalazima koje je dobio Puškar (2010). Pozitivna percepcija profesora i viša razina motivacije utvrđene su kod studenata s nižom razinom straha. Nisu utvrđene razlike u strahu od jezika s obzirom na duljinu učenja. Studenti su izrazili prijedloge za poboljšanje nastavnoga rada u smislu postavljanja jasnih kriterija ocjenjivanja, razvijanja pozitivnoga stava nastavnika prema studentima, kvalitetnije interakcije studenata i nastavnika te revidiranja izvedbenih planova.

Istraživanjima straha od stranoga jezika utvrdilo se da je strah od stranoga jezika složen fenomen specifičan za situaciju učenja stranoga jezika i proces učenja stranoga jezika. Veći broj istraživanja ukazao je na negativnu povezanost straha od stranoga jezika i uspjeha u učenju jezika te negativnu povezanost straha od stranoga jezika i motivacije za učenje jezika. Rezultati istraživanja razlika u strahu od stranoga jezika s obzirom na spol ukazali su na nekonzistentnost, što bi se moglo tumačiti različitostima u socioedukacijskim kontekstima u kojima su se istraživanja provodila. Nalazi nekih istraživanja straha od jezika ukazali su i na odnos straha od stranoga jezika i ostalih čimbenika koji mogu biti važni u procesu učenja stranoga jezika kao što su vjerovanja o učenju jezika, pojam o sebi, percepcija i djelovanje nastavnika, te izvannastavna izloženost stranome jeziku. 


\section{STRAH OD ČITANJA NA STRANOME JEZIKU}

Saito, Horwitz i Garza su razmatrajući strah od čitanja na stranome jeziku pretpostavili da je strah od čitanja na stranome jeziku zaseban fenomen i da bi se razina te vrste straha mogla razlikovati s obzirom na specifični ciljni jezik (engl. specific target language) (Saito i sur., 1999: 203). Ukazali su na činjenicu da se u standardnome upitniku za mjerenje straha od stranoga jezika FLCAS (Horwitz i sur., 1986) čak 20 od 33 čestice odnose na govorenje i slušanje te da taj upitnik nije prikladan mjerni instrument za ispitivanje straha od čitanja na stranome jeziku. Stoga su za potrebe istraživanja straha od čitanja u američkome socioedukacijskome kontekstu Saito i suradnici (1999) konstruirali poseban mjerni instrument. Riječ je o upitniku FLRAS (Upitnik za mjerenje straha od čitanja na stranome jeziku). Budući da se utvrdilo da upitnici FLCAS i FLRAS dijele 49\% varijance, potvrđena je pretpostavka da je strah od čitanja zaseban fenomen, odvojen od općega straha od stranoga jezika (Saito i sur., 1999). Subaş1 (2014) je na jednome sveučilištu u Turskoj također provela istraživanje straha od stranoga jezika i straha od čitanja na stranome jeziku koristeći upitnike FLCAS i FLRAS te utvrdila da upitnici FLCAS i FLRAS dijele 37\% varijance. Njezinim istraživanjem potvrđeno je da je strah od čitanja zaseban fenomen u okviru OVIJ-a.

Među teorijskim modelima čitanja na stranome jeziku u kojima se ukazuje na važnost afektivnih faktora jest i interaktivni model koji je razvila Bernhardt $(2000,2005)$, navevši da je uloga afektivnih faktora u procesu ovladavanja čitanjem na stranome jeziku nedovoljno razjašnjena i da se ta uloga tek treba istražiti (Bernhardt, 2005). Horwitz (2001) je upozorila da bi se strah od jezika kao specifičan fenomen u okviru OVIJ-a trebao ispitivati s obzirom na različite jezične vještine i korištenjem specifičnih mjernih instrumenata. Ove preporuke postale su smjernice za recentnija istraživanja straha od čitanja na stranome jeziku. Tijekom posljednjih dvaju desetljeća provedeno je nekoliko istraživanja kojima se ispitala struktura straha od čitanja na stranome jeziku, te su među njima Matsuda i Gobel (2001), Zoghi (2012) i Zoghi i Alivandivafa (2014) utvrdili trodimenzionalnu strukturu straha od čitanja na engleskome jeziku, a Al-Shboul i suradnici (2013) ponudili model straha od čitanja na engleskome jeziku koji se sastoji od dviju komponenata: čitatelja i teksta.

Nalazima uvodno navedenih znanstvenoistraživačkih radova utvrđeno je da je strah od čitanja na stranome jeziku zaseban fenomen u OVIJ-u. Pokušajima konceptualizacije straha od čitanja pridonijeli su više radovi na empirijskoj nego na teorijskoj razini, te će se detaljniji 
pregled nalaza empirijskih istraživanja o strahu od čitanja na stranome jeziku izložiti u sljedećemu potpoglavlju.

\subsection{Istraživanja strukture i izvora straha od čitanja na stranome jeziku}

Početci istraživanja straha od čitanja na stranome jeziku kao posebnoj vrsti straha u okviru OVIJ-a sežu u 1990-e godine. Cilj istraživanja koje su proveli Saito, Horwitz i Garza (1999) bio je ispitati postoji li strah od čitanja na stranome jeziku kao posebna vrsta straha odvojena od općega straha od stranoga jezika. Kao mogući izvori straha od čitanja na stranome jeziku navedeni su nepoznato i novo pismo, specifična pravila pisanja te nepoznati kulturološki koncepti. Prvi izvor straha bila bi grafofonemska nepodudarnost, na kojoj se temelji pretpostavka: što je manja grafofonemska podudarnost između prvoga jezika i stranoga jezika, to je dekodiranje teže, što može izazvati višu razinu straha od čitanja. Budući da se jezici razlikuju prema fonološkim, sintaktičkim i leksičkim osobitostima, različiti jezici mogu biti izvor različitih razina straha od čitanja, pa će se strah od čitanja na stranome jeziku razlikovati s obzirom na ciljni jezik. Sudionici istraživanja koje su proveli Saito i suradnici (1999) bili su studenti $(N=383)$ prvoga semestra jednoga američkoga sveučilišta koji su pohađali kolegije iz francuskoga, japanskoga i ruskoga jezika. U istraživanju su korištena dva mjerna instrumenta: upitnik FLCAS i posebno konstruirani mjerni instrument za ispitivanje straha od čitanja upitnik FLRAS. Upitnik FLRAS obuhvaća 20 čestica koje odražavaju učenička zapažanja vezana uz različite aspekte čitanja, njihovu percepciju o poteškoćama pri čitanju na ciljnom jeziku i njihovu percepciju relativne težine čitanja u usporedbi s procjenom težine ostalih jezičnih vještina (Saito i sur., 1999: 204). Studenti su stupnjeve slaganja za oba upitnika izražavali na petstupanjskoj Likertovoj skali. Utvrđena je pouzdanost i srednja vrijednost aritmetičkih sredina za upitnik FLCAS $(\alpha=, 94 ; A S=2,88)$ i za upitnik FLRAS $(\alpha=, 86 ; A S=$ 2,64). Nalazi su ukazali na pozitivnu povezanost straha od jezika i straha od čitanja na stranome jeziku te negativnu povezanost straha od čitanja i zaključnih ocjena iz kolegija stranoga jezika. Nije utvrđeno da postoje razlike u općemu strahu od stranoga jezika s obzirom na ciljni jezik, što je u skladu s nalazom koji su dobili Horwitz i suradnici (1986). Međutim, za strah od čitanja na stranome jeziku pokazale su se statistički značajne razlike u intenzitetu straha s obzirom na ciljni jezik. Najviši strah od čitanja zabilježen je za japanski jezik, niži za francuski, a najniži za ruski. S obzirom da japanski nije alfabetski jezik i studenti moraju ovladati novim pismom i pravilima čitanja, rezultat nije iznenađujuć. Međutim, pomalo neočekivano niži strah od čitanja 
zabilježen je za ruski nego za francuski jezik, iako su studenti, da bi čitali na ruskome, morali ovladati novim pismom (ćirilicom), za razliku od francuskoga, kod kojega su se služili već poznatim pismom. Budući da je grafofonemska korespondencija veća u ruskome nego u francuskome jeziku, moguće je da je za početnike dekodiranje lakše i brže u ruskome nego u francuskome jeziku. Utvrđena je pozitivna povezanost između procjene težine jezika i visine straha od čitanja, a japanski je procijenjen kao najteži jezik. Saito i suradnici (1999) ukazali su na nužnost provedbe daljnjih istraživanja u kojima bi se ispitao strah od čitanja na višim razinama učenja stranoga jezika, te odnos straha od čitanja i drugih važnih varijabli kao što su motivacija, strategije čitanja, prethodno iskustvo učenja stranih jezika i uloga nastavnika u procesu učenja jezika.

U istraživanju koje su proveli Matsuda i Gobel (2001) među studentima prve, druge i treće godine jednoga sveučilišta u Kyotu $(N=252)$ ispitan je strah od engleskoga jezika upitnikom FLCAS (Horwitz i sur., 1986) i strah od čitanja na engleskome jeziku upitnikom FLRAS (Saito i sur., 1999). Faktorska analiza upitnika FLRAS $(\alpha=, 71)$ ukazala je na trokomponentnu strukturu straha od čitanja na engleskome jeziku u japanskome socioedukacijskome kontekstu. Prva komponenta odnosi se na poznavanje gramatike i vokabulara engleskoga jezika, druga komponenta na užitak i samopouzdanje pri čitanju, a treća komponenta na kulturu engleskoga govornoga područja i sistem pisanja na engleskome jeziku, a nazvana je jezična udaljenost. Kao glavni zaključak istraživanja istaknuto je da je strah od čitanja zaseban fenomen koji je multidimenzionalan, te se njegova struktura razlikuje ovisno o različitim ciljnim jezicima i nastavnom kontekstu (Matsuda i Gobel, 2001: 241).

Polazeći od upitnika FLRAS koji su konstruirali Saito i suradnici (1999) Zoghi (2012) je za potrebe provođenja istraživanja straha od čitanja na engleskome jeziku u Iranu izradio i validirao novi mjerni instrument English as a Foreign Language Reading Anxiety Inventory (EFLRAI). Sudionici istraživanja bili su studenti jednoga velikoga iranskoga sveučilišta $(N=251)$ koji uče engleski jezik kao obvezan kolegij u različitim studijskim programima. Nakon kvalitativnoga dijela istraživanja u kojemu su studenti opisali situacije koje izazivaju strah od čitanja, naveli razloge zbog kojih se to događa i probleme na koje nailaze na nastavi engleskoga jezika, konstruirana je konačna inačica upitnika EFLRAI s 27 čestica ( $\alpha=$ ,89). Faktorskom analizom upitnika ELFRAI utvrđena je trodimenzionalna struktura straha od čitanja na engleskome jeziku: prvi faktor $(\alpha=, 77)$ strah od čitanja odozgo-prema-dolje (engl. Top-down Reading Anxiety - TRA), drugi faktor $(\alpha=, 84)$ strah od čitanja odozdo-prema-gore 
(engl. Bottom-up Reading Anxiety - BRA) i treći faktor $(\alpha=, 75)$ strah od čitanja u razredu (engl. Classroom Reading Anxiety - CRA). Prvi faktor Zoghijeva konstrukta odnosi se na čitatelja, drugi faktor na tekst i specifičnosti teksta, a treći se faktor odnosi na kontekst poučavanja jezika. Analizom je utvrđeno da upitnik FLCAS (Horwitz i sur., 1986) i upitnik EFLRAI dijele 39\% varijance, što je ukazalo na to da se upitnikom EFLRAI mjeri zaseban fenomen straha od čitanja na stranome jeziku, odvojen od straha od stranoga jezika.

Istraživanjem koje su proveli Zoghi i Alivandivafa (2014) na istome iranskome sveučilištu na većem broju sudionika $(N=939)$ dokazana su dobra psihometrijska svojstva upitnika ELFRAI $(\alpha=0,90)$ te je potvrđena trodimenzionalna struktura straha od čitanja na engleskome jeziku.

Nalazi istraživanja koje su proveli Zoghi (2012) i Zoghi i Alivandivafa (2014) usporedivi su s nalazima kvalitativnoga istraživanja koje je provela Kuru-Gonen (2009) među studentima engleskoga jezika jednoga turskoga sveučilišta $(N=50)$. Autorica je utvrdila da postoje tri izvora straha od čitanja na engleskome kao stranome jeziku: (1) osobni faktori (neprikladno korištenje strategija, nedostatak motivacije, nedostatak samopouzdanja), (2) osobitosti teksta (tema teksta, nepoznat vokabular, nepoznavanje kulturnoga konteksta teksta) i (3) nastava (udžbenici, razredno ozračje, nastavnik, ocjenjivanje).

Kvalitativno istraživanje o mogućim izvorima straha od čitanja na engleskome jeziku proveli su Al-Shboul i njegovi suradnici na sveučilištu Yarmouk u Jordanu (Al-Shboul i sur., 2013). Analiza polustrukturiranih intervjua i dnevnika ukazala je na dva aspekta straha od čitanja: aspekt straha koji se odnosi na čitatelja i aspekt straha koji se odnosi na tekst. Model straha od čitanja na engleskome jeziku koji su autori predložili prikazan je na slici 2.1 . 


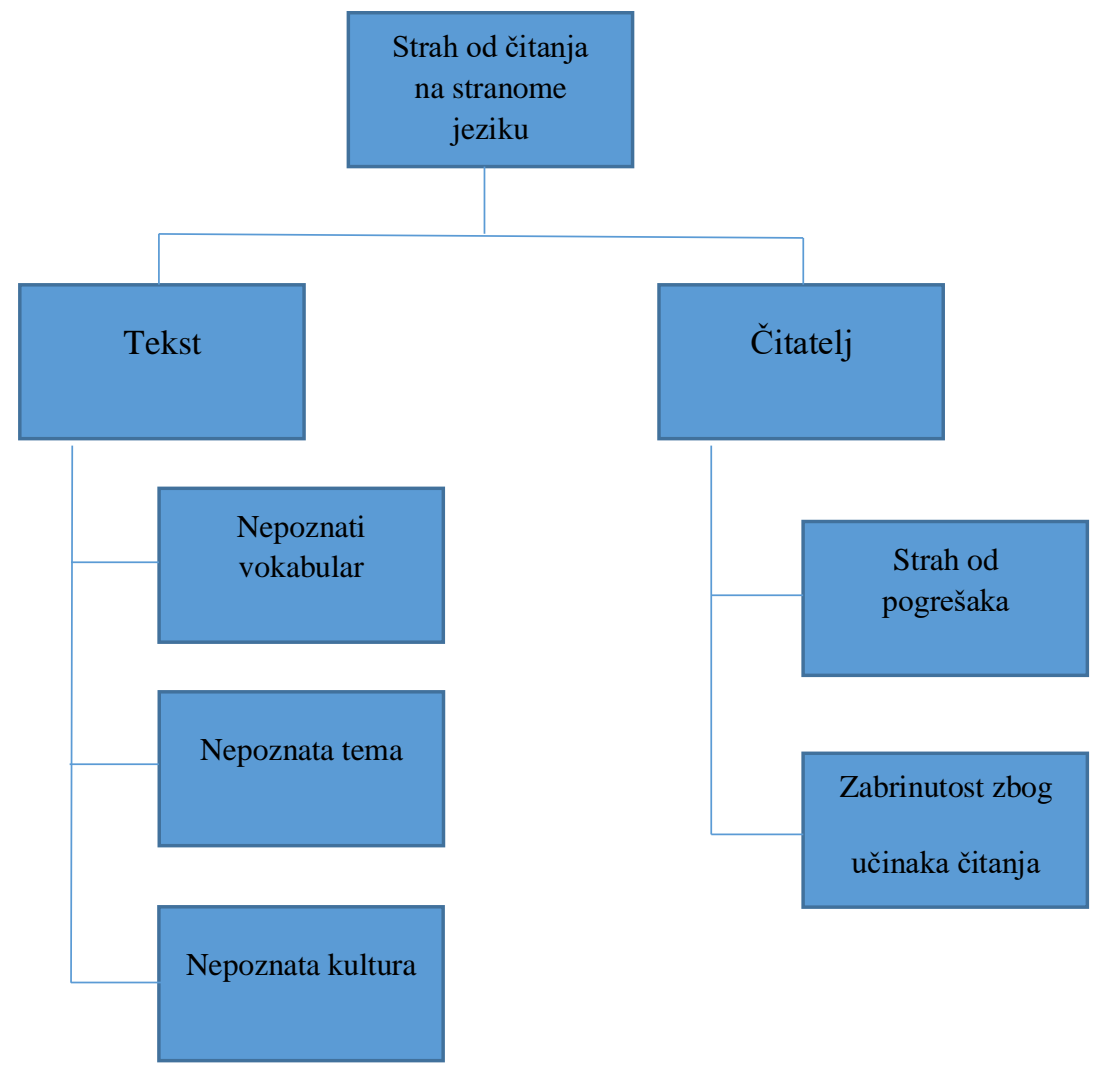

Slika 2.1. Generirani model koji predstavlja faktore u strukturi straha od čitanja na engleskome jeziku (Al-Shboul i suradnici, 2013: 51)

U istraživanju koje su proveli Ahmad i suradnici (2013) na istome sveučilištu korišten je upitnik konstruiran na temelju modela straha od čitanja koji su predložili Al-Shboul i suradnici (2013). Nalazima istraživanja potvrđen je model straha od čitanja na engleskome jeziku koji su predložili Al-Shboul i suradnici (2013).

Nalazi istraživanja koje su proveli Kuru-Gonen (2009), Zoghi (2012), Ahmad i suradnici (2013), Al-Shboul i suradnici (2013) te Zoghi i Alivandivafa (2014) ukazali su na multidimenzionalnu strukturu straha od čitanja na engleskome kao stranome jeziku, te dali poticaj za daljnja istraživanja koja bi se provodila u drugim društvenokulturnim okruženjima i uz korištenje novih mjernih instrumenata.

Istražujući strah od čitanja, neki su se istraživači usmjerili na ispitivanje izvora straha od čitanja na stranome jeziku. Tako je Alsaleh (2017) među studentima u Saudijskoj Arabiji utvrdio da su najčešći izvori straha od čitanja na engleskome jeziku nepoznate riječi, nesigurnost u izgovoru riječi, dugi tekstovi, poteškoće povezane s engleskom ortografijom, 
strah od pogrešaka i sramežljivost. Hassaskhah i Joghataeian (2016) su u istraživanju provedenome među studentima u Iranu kao izvore straha od čitanja utvrdili nepoznati sadržaj teksta, nepoznavanje kulture engleskoga govornoga područja i negativnu evaluaciju od strane nastavnika i ostalih učenika. Aisyah (2017) je među srednjoškolcima u Indoneziji utvrdila da je nepoznati vokabular jedan od najčešćih izvora straha od čitanja na engleskome jeziku. Zhang (2000) je ispitujući strah od čitanja među kineskim studentima u Singapuru utvrdio da su izvori straha loše znanje engleskoga jezika i nepoznavanje kulture engleskoga govornoga područja. Zhao i suradnici (2013) su utvrdili da su izvori straha od čitanja na kineskome jeziku među američkim studentima nepoznata ortografija, nepoznate teme i zabrinutost studenata da neće razumjeti napisani tekst. Marzec-Stawiarska (2013) je među studentima anglistike u Poljskoj utvrdila da više od polovice studenata brine evaluacija nastavnika i loša ocjena, a trećinu zabrinjava negativna društvena procjena. Najčešći izvor straha je zabrinutost studenata hoće li razumjeti tekst i hoće li moći uspješno riješiti zadatke razumijevanja pročitanoga. Oko trećinu studenata brine nepoznata gramatika i nepoznata tema teksta, a samo se manji broj slaže da nepoznavanje kulture engleskoga govornoga područja može izazvati strah od čitanja. Subaş1 (2014) je među studentima u Turskoj utvrdila šest izvora straha od čitanja na engleskome jeziku: osobni razlozi, djelovanje nastavnika u razredu, metode poučavanja, osobitosti teksta (vokabular, dužina teksta, vrsta teksta, poznavanje teme teksta), strah od ocjenjivanja razumijevanja čitanjem i prethodno iskustvo čitanja na engleskome jeziku.

Pri kraju ovoga dijela pregleda istraživanja kratko ćemo sa osvrnuti na kritiku upitnika FLRAS (Saito i sur., 1999) koju su izrazili Sparks, Ganschow i Javorsky (2000), američki znanstvenici iz područja obrazovanja i obrazovne psihologije koji smatraju upitnim mjeri li navedeni upitnik samoprocjenu jezičnih vještina ili strah. U istraživanju koje su proveli Saito i suradnici (1999) nije ispitana motivacija za učenje niti razina ovladanosti čitanjem na trima ispitivanim jezicima, što predstavlja nedostatak istraživanja jer istraživači nužno trebaju uzeti u obzir ulogu jezičnih vještina u istraživanjima afektivnih razlika pri čitanju i razumijevanju stranoga jezika (Sparks i sur., 2000: 253). Predlaže se da bi trebalo sagledati i ulogu prvoga jezika i nekih drugih varijabli koje su bitne u učenju stranoga jezika kao što su jezični talent $i$ motivacija (Sparks i Ganschow 1991, 1995; Sparks i sur., 2008, 2009, 2018). 


\subsection{Istraživanja povezanosti straha od čitanja i uspjeha u čitanju na stranome jeziku}

Istraživanja odnosa straha od čitanja i uspjeha u čitanju na stranome jeziku pretežno ukazuju na negativnu povezanost. U nekim je istraživanjima kao mjera uspjeha korišten uspjeh na testu razumijevanja teksta čitanjem, dok je u drugim istraživanjima mjera uspjeha bila zaključna ocjena iz stranoga jezika.

Zhao (2009) je utvrdila među američkim studentima koji uče kineski jezik negativnu povezanost straha od čitanja na engleskome jeziku i uspjeha na testu razumijevanja teksta čitanjem. U istraživanju koje su proveli Zhao i suradnici (2013) ispitao se strah od kineskoga jezika i strah od čitanja na kineskome među studentima jednoga američkoga sveučilišta. Utvrđeno je da studenti koji imaju viši strah od jezika imaju i viši strah od čitanja na stranome jeziku, te se utvrdilo da su strah od čitanja i uspjeh na testu čitanja negativno povezani. Rajab i suradnici (2012) su među malezijskim studentima utvrdili da oni studenti koji imaju viši strah od čitanja imaju niže zaključne ocjene iz engleskoga jezika. Huang je među studentima jednoga kineskoga sveučilišta utvrdila pozitivnu povezanost straha od engleskoga jezika i straha od čitanja na engleskome te negativnu povezanost straha od čitanja i uspjeha na testu razumijevanja teksta čitanjem, što ukazuje na negativan utjecaj straha na ovladavanje vještinom čitanja na stranome jeziku (Huang, 2012). Sličan nalaz dobio je Cabansag (2013) za strah od čitanja na engleskome jeziku u istraživanju na jednome filipinskome sveučilištu. U Iranu su Hayati i Ghassemi (2008), Jafarigohar i Behrooznia (2012) i Mohammadpur i Ghafournia (2015) utvrdili negativnu povezanost straha od čitanja na engleskome jeziku i uspjeha na testu razumijevanja teksta čitanjem.

Fokus nekih istraživača bio je usmjeren ispitivanju odnosa straha od čitanja i uspjeha u zadatcima koji slijede nakon čitanja. Nekoliko takvih istraživanja provedeno je među američkim studentima koji uče španjolski jezik. Sellers je utvrdila da studenti s višom razinom straha lošije rješavaju zadatke dosjećanja teksta i imaju više ometajućih misli pri obradi teksta nego studenti s nižom razinom straha (Sellers, 2000). Sličan nalaz istraživanja nalazimo kod Rai i suradnika (2011), koji su utvrdili da studenti s višim strahom od čitanja zbog kognitivne interferencije trebaju više vremena pri obradi teksta i odgovaranju na pitanja o pročitanome tekstu, što je usporedivo s nalazima koje su dobili MacIntyre i Gardner (1994b). Brantmeier je provela istraživanje odnosa straha od čitanja i uspjeha u zadatcima razumijevanja pročitanoga 
teksta među američkim studentima na naprednoj razini učenja španjolskoga i utvrdila da studenti imaju višu razinu straha od usmenih zadataka razumijevanja pročitanoga koji slijede nakon čitanja nego razinu straha od čitanja (Brantmeier, 2005).

Nalazi većega broja istraživanja u kojima se utvrdila negativna povezanost straha od čitanja na stranome jeziku i uspjeha u čitanju upućuju na zaključak da je strah od čitanja na stranome jeziku ometajući čimbenik u postizanju uspjeha u čitanju na stranome jeziku.

\subsection{Istraživanja odnosa straha od čitanja i ostalih čimbenika}

\section{U potpoglavlju 1.6.3. Istraživanja odnosa straha od stranoga jezika i ostalih čimbenika} navedeno je da su istraživanja koja su se bavila ispitivanjem razlika u intenzitetu straha od stranoga jezika i s obzirom na spol ukazala na nekonzistentnost rezultata. Na sličan bismo se način mogli osvrnuti i na nalaze istraživanja koja su se bavila ispitivanjem razlika u intenzitetu straha od čitanja na stranome jeziku s obzirom na spol.

U istraživanju koje su provele Lu i Liu među studentima na pet sveučilišta u Kini utvrdilo se da muškarci imaju višu razinu straha od čitanja na engleskome jeziku nego žene (Lu i Liu, 2015). Međutim, u nekoliko drugih istraživanja u drugačijim socioedukacijskim kontekstima utvrđeno je da ne postoje razlike u visini straha od stranoga jezika i straha od čitanja na stranome jeziku između žena i muškaraca. To su utvrdili Hayati i Ghassemi (2008) istražujući strah od čitanja na engleskome jeziku među studentima u Iranu, Wu (2011) istražujući strah od čitanja na engleskome jeziku među studentima na Tajvanu, Zhao (2009) i Zhao i suradnici (2013) ispitujući strah od čitanja na kineskome jeziku među američkim studentima, Capan i Karaca (2013) istražujući strah od čitanja na engleskome jeziku među studentima u Turskoj i Al-Sohbani (2018) ispitujući strah od čitanja na engleskome jeziku među srednjoškolcima u Jemenu.

Nekonzistentnost rezultata istraživanja straha od čitanja na stranome jeziku s obzirom na spol mogla bi se tumačiti različitim socioedukacijskim i kulturološkim kontekstima, kao i različitim nastavnim kontekstom poučavanja. Osvrt na nekonzistentnost rezultata ispitivanja razlika u komunikaciji s obzirom na spol nalazimo kod Canary i Hause (1993), koji su zaključili da su dosadašnja istraživanja pokazala nekonzistentnost rezultata ili da su razlike bile male. 
Navedeni autori sugeriraju da u budućim istraživanjima pažnju treba više usmjeriti ispitivanju ostalih čimbenika, a manje razmatranjima razlika u komunikaciji s obzirom na spol.

Među ostalim varijablama koje mogu biti povezane sa strahom od čitanja na stranome jeziku u nekim istraživanjima ispitala se povezanost straha od čitanja i razine učenja jezika. Među njima su istraživanja koja su proveli Zhao (2009) i Zhao i suradnici (2013), ispitujući strah od čitanja na kineskome jeziku među američkim studentima, u kojima se utvrdilo da višu razinu straha od čitanja osjećaju studenti na višoj razini učenja. Na višem stupnju učenja obrađuju se zahtjevniji tekstovi i češće koriste autentični pisani materijali, pa čitanje postaje teže, što Zhao i suradnici (2013) navode kao moguće tumačenje zašto strah od čitanja na kineskome jeziku raste s napredovanjem u učenju. Kada učenici osjećaju viši strah na višim razinama učenja, to bi moglo biti povezano i njihovim višim očekivanjima i većom samokritičnošću koja se razvija s napredovanjem u učenju. Nalazi istraživanja koje su proveli Zhao (2009) i Zhao i suranici (2013) u skladu su s utvrđenom pozitivnom povezanošću straha od jezika i razine učenja jezika u nekim ranije spomenutim istraživanjima straha od stranoga jezika (Saito i Samimy, 1996; Kitano, 2001; Marcos-Llinás i Garau, 2009).

U nekim istraživanjima čitanja na stranome jeziku ispitala se uloga straha od čitanja kao prediktora uspjeha u čitanju. Jedno od takvih istraživanja proveli su Mill, Pajares i Herron (2006) među američkim studentima koji su učili francuski u trećem i četvrtome semestru. Istraživanjem se utvrdilo da strah od čitanja nije prediktor uspjeha u čitanju, ali da je vlastita procjena učinkovitosti u čitanju na francuskome jeziku značajan prediktor uspjeha u čitanju. Nalazi toga istraživanja ukazali su na nužnost jačanja osjećaja vlastite učinkovitosti u učenju stranoga jezika kao načina smanjenja straha od čitanja i povećanja uspješnosti u čitanju na stranome jeziku.

\subsection{Istraživanja straha od čitanja na stranome jeziku u Hrvatskoj}

Provodeći mnogobrojna istraživanja straha od stranoga jezika, Mihaljević Djigunović (2002) je među zagrebačkim srednjoškolcima ispitala odnos straha od čitanja prema općem strahu od jezika, prema uspjehu u učenju engleskoga jezika, pojmu o sebi, spremnosti na rizik i motivaciji (Mihaljević Djigunović, 2002). Svi koeficijenti korelacije bili su statistički su značajni, što je uputilo na zaključak da postoji povezanost straha od čitanja i svih ispitanih varijabli. Kao mjera 
uspjeha uzeta je zaključna ocjena iz engleskoga jezika, a strah od jezika ispitan je upitnikom FLRAS (Saito i sur., 1999). Utvrđena je srednja vrijednost straha od čitanja $A S=2,19$, što je usporedivo s nalazom koji su dobili Saito i suradnici (1999) $(A S=2,64)$. Nalazi istraživanja upućuju da su strah od jezika i strah od čitanja pozitivno povezani. Za strah od čitanja i uspjeh utvrđena je negativna povezanost. Na osnovi tih nalaza zaključeno je da čitanje predstavlja važnu komponentu uspjeha u učenju engleskoga jezika. Utvrđeno je da učenici koji imaju pozitivan pojam o sebi i viši intenzitet motivacije imaju nižu razinu straha, a to je povezano i s njihovom spremnošću na rizik u upotrebi engleskoga jezika.

U istraživanju straha od pisanja Mihaljević Djigunović (2002) je među zagrebačkim srednjoškolcima ispitala povezanosti općega straha od jezika, straha od pisanja, straha od čitanja i uspjeha u učenju engleskoga jezika. Nalazi toga istraživanja ukazali su na pozitivnu povezanost straha od pisanja i općega straha od jezika, dok za strah od pisanja i strah od čitanja nije utvrđena povezanost.

Matić (2015) je provela ispitivanje straha od čitanja na njemačkome kao stranome jeziku, koristeći preoblikovani upitnik FLRAS (Saito i sur., 1999) i upitnik FRAM (engl. Foreign language Reading Anxiety Matić) koji je autorica oblikovala polazeći od upitnika FLRAS. Istraživanje je provedeno među učenicima petoga i osmoga razreda osnovne škole koji uče njemački jezik kao obvezan predmet od prvoga razreda $(N=37)$. Rezultati su pokazali da kod učenika obiju dobnih skupina postoji srednja razina straha od čitanja mjereno upitnikom FLRAS i upitnikom FRAM. Učenici koji su dulje učili jezik (osmi razred) osjećali su niže razine straha. Učenici koji su imali bolji uspjeh u učenju njemačkoga jezika imali su nižu razinu straha od čitanja od učenika s lošijim uspjehom. U istraživanju su razmatrani mogući čimbenici utvrđenoga straha od čitanja, te je glasno čitanje prepoznato kao čimbenik straha. Kao dodatni čimbenici straha od čitanja izdvojili su se nepoznate riječi, nepoznata gramatika, nerazumijevanje sadržaja, dužina teksta i čitanje kao djelatnost koja je sastavni dio nastave njemačkoga jezika. Autorica je ukazala da nije dovoljno tek utvrditi postojanje straha i njegove razine, nego je potrebno detaljnije razmotriti moguće čimbenike otkrivenoga straha. U budućim istraživanjima straha od čitanja trebalo bi kombinirati kvantitativne i kvalitativne metode istraživanja straha te ispitati i uspjeh u čitanju na stranome jeziku.

Matić (2018) je provela ispitivanje straha od čitanja na njemačkome kao stranome jeziku te istražila moguće čimbenike toga straha među učenicima petoga i osmoga razreda osnovne 
škole, koristeći preoblikovani upitnik FLRAS (Saito i sur., 1999). Svi sudionici istraživanja bili su učenici koji uče njemački jezik kao obvezan predmet od prvoga razreda $(N=37)$. Nalazi istraživanja pokazali su da učenici osjećaju srednju razinu straha i da ne postoji statistički značajnija razlika u strahu s obzirom na godine učenja. Utvrdila se negativna povezanost straha od čitanja na njemačkome jeziku i zaključne ocjene iz njemačkoga jezika. Ispitavši moguće čimbenike straha od čitanja utvrdilo se da osobni stav učenika i nepoznata kulturna obilježja zemalja njemačkoga govornoga područja nisu čimbenici straha. Učenici smatraju da čitanje nije jezična vještina kojom je teško ovladati i da uvježbavanjem čitanje postaje lakše. Značajke teksta poput dužine ili teme teksta nisu prepoznati kao čimbenici povezani sa strahom od čitanja. Međutim, kao mogući čimbenik straha od čitanja na njemačkome jeziku izdvojio se način čitanja teksta. Učenici često prevode riječi za vrijeme čitanja, pa čak i kada razumiju gotovo sve riječi ne razumiju pročitani tekst. Razlozi ovakvoga nalaza čimbenika straha od čitanja nisu bili utvrđeni ovim istraživanjem. Stoga autorica zaključuje da bi opisani rezultati trebali potaknuti dodatna istraživanja načina čitanja kao čimbenika straha od čitanja na njemačkome jeziku ili kao čimbenika nerazumijevanja pročitanih tekstova te istražiti što je u pozadini te pojave (Matić, 2018: 261).

Istraživanjima straha od čitanja koja su se provodila od kraja 1990-ih utvrdilo se da je strah od čitanja na stranome jeziku zaseban i specifičan fenomen u okviru OVIJ-a. Nalazi istraživanja ukazali su na multidimenzionalnost strukture straha od čitanja, uzevši u obzir domenu čitatelja i domenu teksta. U mnogim istraživanjima utvrđeno je da se strah od čitanja razlikuje s obzirom na ciljni jezik i nastavni kontekst poučavanja. Nalazi mnogih istraživanja ukazuju na negativnu povezanost straha od čitanja i uspjeha u čitanju na stranome jeziku, te negativnu povezanost straha od čitanja i motivacije za učenje jezika. Strah od pogrešaka, te strah od ocjenjivanja i lošega uspjeha utvrđeni su kao najčešći izvori straha od jezika. Među čimbenicima straha od čitanja izdvojili su se nepoznate riječi, nepoznata gramatika, dužina teksta i način čitanja. Dosadašnja istraživanja pridonijela su rasvjetljavanju pojma straha od čitanja na stranome jeziku. Kako bismo stekli detaljniji uvid u strukturu i čimbenike ove složene afektivne varijable potrebna su daljnja istraživanja u kojima će se koristiti mjerni instrumenti specifični za određene socioedukacijske kontekste i upotrebljavati kvantitativne i kvalitativne istraživačke metode. 


\section{3. ČITANJE - OD DEKODIRANJA DO RAZUMIJEVANJA}

\subsection{Pregled teorijskih modela čitanja}

Čitanje je jedna od temeljnih jezičnih vještina koja se analizira i kao perceptivni i kao kognitivni proces, a tumačenja toga procesa svoja polazišta nalaze u različitim disciplinama: od psihologije, lingvistike i psiholingvistike do kognitivnih znanosti. Čitanje kao vještina, psihološki proces i najnovija evolucijska prilagodba živčanoga sustava potrebama komunikacije i kulture proučava se odavno (Čudina-Obradović, 2014). Stoga ne čudi da teorijska razmatranja i razmatranja o modelima čitanja zaokupljaju znanstvenoistraživačku pozornost desetljećima. U radovima psihologa s kraja devetnaestoga i početka dvadesetoga stoljeća u SAD-u nailazimo na razmatranja o čitanju (Bernhardt, 2011). Huey (1908) je početkom dvadesetoga stoljeća čitanje opisao kao psihofiziološki proces koji je čudesan i zahtijeva proučavanje dubina ljudskoga uma. Ukazao je na važnost čitateljeva znanja i konteksta pri razumijevanja procesa čitanja te na fizikalnu stranu procesa čitanja. Proučavajući pokretanje očiju pri čitanju, dao znatno je pridonio prvim spoznajama o čitanju u empirijskome smislu. Provođenjem daljnjih istraživanja došlo se do saznanja da čitanje na različitim jezicima može biti povezano s različitim fizikalnim obrascima čitanja te da postoji povezanost pokretanja očiju i razumijevanja teksta čitanjem (Carpenter i Just, 1977).

Prvi teorijski model čitanja pojavljuje se 1970-ih godina, a prema njemu čitanje se promatra kao aktivnost mehaničkoga dekodiranja. Čitatelj prepoznaje slova, riječi i njihova sintaktička obilježja te im zatim određuje značenje. Taj se model naziva vanjski (dolje-gore ili odozdo-prema-gore) model (engl. bottom-up; inside-in model) (Šamo, 2014: 6) i svoje začetke nalazi 1970-ih godina u istraživanjima koje je proveo Gough (1972). Shemu modela „odozdoprema-gore“ Davies (1995, str. 58, prema Jelić, 2004) prikazuje ovako:

pokreti očiju $\Rightarrow$ identifikacija slova $\Rightarrow$ prepoznavanje riječi $\Rightarrow$ uklapanje riječi u gramatičke kategorije i strukturu rečenice $\Rightarrow$ rečenice dobivaju značenje $\Rightarrow$ značenje vodi razmišljanju

Gough i Tunmer (1986) usavršavaju model i daju mu naziv jednostavni prikaz čitanja. Prema tome modelu čitanje je proizvod dekodiranja i razumijevanja (Gough i Tunmer, 1986: 7). Nastavši u duhu bihevioralnih promišljanja prema kojima su slova podražaji koji izazivaju reakcije, model je bio kritiziran jer je prevelika pozornost bila usmjerena na izvore obavijesti 
na nižim razinama. Model pruža sliku donekle pasivnoga čitatelja koji dekodira grafofonemsku, a zatim sintaktičko-semantičku razinu teksta izvan određenoga konteksta. Danas se taj model smatra glavnim teorijskim polazištem razmatranja o čitanju, ali nepotpunim teorijskim opisom čitanja. Pozornost je više usmjerena na varijable koje se odnose na tekst, a manje na varijable koje se odnose na čitatelja (Lally, 1998). Jednostavni prikaz čitanja predstavljao je teorijsku osnovu za razvoj audiolingvalnih metoda poučavanja stranoga jezika 1960-ih i 1970-ih godina, a kojima je temelj poučavanja predstavljalo dekodiranje odnosa glasova i simbola.

Goodman je 1960-ih i 1970-ih godina svojim radom na području proučavanja čitanja s psiholingvističkoga stajališta označio prekretnicu, ukazavši na specifičnosti čitanja na stranome jeziku. U okruženju u kojem su u SAD pristizali mnogi imigranti pojavila se nužna potreba školovanja i zapošljavanja ljudi koji nisu vladali engleskim jezikom. U takvome društvenome okruženju i u psiholingvističkome znanstvenoistraživačkome ozračju djelovali su Kenneth Goodman i njegova supruga Yetta. Prema njima, čitanje je aktivan proces koji je teško proučiti, ali analiza pogrešaka omogućava nam uvid u taj proces te predstavlja prozor u razumijevanje čitanja i razumijevanje ostalih jezičnih procesa (Goodman i Goodman, 1977: 317). Pri čitanju naglas i strukturiranju značenja čitatelj sam sebe ispravlja, zamjenjuje jednu riječ nekom drugom riječju, mijenja gramatički oblik. Analiza pogrešaka može nam pomoći u razumijevanju procesa čitanja.

Razvoj kognitivne psihologije doveo je do promjena u razmatranju psihičkih temelja ponašanja, pa se tako i u području čitanja počinju razmatrati kognitivni procesi. U razmatranjima o jeziku vodeću polazišnu poziciju zauzima psiholingvistika koja se bavi jezičnim ponašanjem i psihološkim procesima koji leže u osnovi toga ponašanja (Crystal, 2008: 396). U psiholingvistici proučavaju se umni procesi koji se nalaze u osnovi planiranja, proizvodnje, opažanja i razumijevanja govora (Jelaska, 2007). U takvome znanstvenoistraživačkome okruženju ubrzo se pojavljuje drugi teorijski model čitanja koji je poznat kao unutarnji (gore-dolje ili odozgo-prema-dolje) model (engl. top-down; inside-out model) (Šamo, 2014: 8). Prema tome modelu čitanje započinje u svijesti čitatelja, a zatim se usmjerava slovima i glasovima, pri čemu pogađanje i predviđanje imaju osobito značenje. Ističe se iskustveno znanje kao važna komponenta čitanja. Goodman (1967) se smatra glavnim zagovornikom unutarnjega modela u kojem se čitanje opisuje kao psiholingvistička igra pogađanja. Čitanje je psiholingvistički proces koji započinje kada pisac jezično kodira značenje, a završava kada čitatelj dekodiranjem konstruira značenje (Goodman, 1998: 12). To 
je selektivan proces pri kojem čitatelj odabire grafeme, zadržava ih u kratkoročnome pamćenju i pokušava prepoznati pročitanu riječ. Informacija se prenosi u srednjoročno pamćenje, provjerava se značenje, a ako sintaktički i semantički odgovara čitateljevima predviđanjima, prenosi se u dugoročno pamćenje. Dekodiranje značenja ili potraga za značenjem smisao je čitanja, a čitanje je najprirodnija aktivnost na svijetu (Smith, 2004: 2).

U fokusu razmatranja je čitatelj koji aktivno sudjeluje u stvaranju značenja ili, kao što Lally (1998) naglašava, u ovome modelu pozornost je usmjerena varijablama koje se odnose na čitatelja. Shemu modela „odozgo-prema-dole“ Davies (1995, str. 58, prema Jelić, 2004) prikazuje ovako:

pokreti očiju $\Rightarrow$ razmišljanje - oblikovanje pretpostavki o značenju $\Rightarrow$ promatranje rečenice u cjelini kako bi se provjerilo značenje $\Rightarrow$ za provjeru daljnjega značenja treba se usredotočiti na riječi $\rightarrow$ ako i dalje postoji nesigurnost, provjeriti slova $\Rightarrow$ ponovno oblikovanje pretpostavki o značenju

I taj je model bio izložen kritici jer je prevelika pozornost usmjerena oblikovanju pretpostavki, a druge sastavnice su zanemarene. Tako su zanemareni vizualno percipiranje i dekodiranje s kojim se često susrećemo u učenju stranoga jezika, a osobito na početku učenja.

Krajem 1970-ih i tijekom 1980-ih godina pojavljuje se nekoliko interaktivnih modela čitanja koji čitanje promatraju kao multidimenzionalan fenomen. Interaktivnim modelima nastoje se pomiriti dotadašnji vanjski i unutarnji model, uz isticanje da postoji interakcija procesa više i niže razine pri čitanju i razumijevanju, te da je pri čitanju važna uloga društvenih i kontekstualnih čimbenika. Među interaktivnim modelima ističe se model Stanovicha (1980) koji čitanje opisuje kao interaktivno-kompenzacijski proces, te isti naziv koristi i za naziv modela (engl. Interactive-Compensatory Model). Procesori (ortografski, leksički, sintaktički, semantički) sudjeluju u obradi teksta interaktivno i nelinerano, ali im ujedno pripisuje sposobnost kompenzacije u slučaju da bilo koji od njih ne funkcionira dobro ili ne raspolaže potrebnim podatcima (Šamo, 2014: 13).

Među mnogim modelima čitanja ističe se „odozdo-prema-gore“ interaktivni model (engl. bottom-up interactive model) koji najbolje opisuje ponašanje čitatelja na stranome jeziku (Davies, 1995, prema Jelić 2004). Čitanje se promatra kao proces koji počinje od automatskoga identificiranja riječi i procesiranja grafemskih obavijesti. Upravo to automatsko identificiranje 
riječi potrebno je da bi čitatelj mogao imati dovoljno vremena da se posveti ostalim izvorima obavijesti i interakcijama raznih izvora obavijesti na višim razinama, a u skladu s leksičkim, sintaktičkim i semantičkim znanjem, shemama ili čitateljevim znanjem. Čitanje je, dakle, aktivan proces građenja smisla teksta, a čitatelj je pritom suočen s mnogim znakovima koje treba ispravno iščitati (Jelić, 2004: 25).

Mathewsonov model znatno je promijenio dotadašnja stajališta jer je pozornost usmjerio afektivnim faktorima u procesu čitanja (stavu, motivaciji, raspoloženju i osjećajima). Mathewson (1976) je ukazao na važnost osobne odluke i osobnoga stava. Čitanje započinje odlukom, a odluka se uvelike temelji na motivaciji za čitanje. Čitatelj može biti motiviran željom za pripadnošću, za napredovanjem, za dokazivanjem ili nekom drugom željom. Mathewson je potvrdio važnost uloge stava jer stav određuje namjeru, a namjera određuje ponašanje tijekom čitanja. Prema Mathewsonovu modelu pozitivan stav, zajedno $\mathrm{s}$ motivacijom, čini preduvjet uspješnoga čitanja (Šamo, 2014: 18.)

$\mathrm{Na}$ ulogu društvenokulturnoga konteksta u proučavanju čitanja upozorio je Bloome (1993), koji čitanje promatra kao društveni proces, u kojem je prva dimenzija interakcija autorčitatelj koja ovisi o čitateljevim interpretacijama pročitanoga. Druga dimenzija odnosi se na društvene odnose među ljudima koji se stvaraju tijekom čitanja. Ta se dimenzija osobito dobro može promatrati u nastavi stranoga jezika, gdje su u interakciji učenici i nastavnici. Tijekom njihove društvene interakcije i interakcije s tekstom, oni se definiraju kao nastavnik i kao učenik, raspodjeljuju prava i obveze koji određuju kako će se oni ponašati, tumačiti tekst i pridavati značenje svojem djelovanju (Bloome, 1993: 101). Udaljavanjem od psiholingvističkoga pristupa čitanju i definiranjem čitanja kao društvenoga procesa pojavio se nov metodološki pristup proučavanju čitanja koji Bloome (1993) naziva mikroetnografskim pristupom. Prema tome pristupu čitanje se proučava kao društveni proces u kojemu se pozornost usmjerava na djelovanje ljudi i njihovo reagiranje tijekom čitanja. Pritom važnu ulogu imaju društveno i kulturno okruženje, te se istraživanja čitanja mogu provoditi i tumačiti samo s obzirom na određeni društveni i kulturni kontekst.

U recentnim znanstvenoistraživačkim razmatranjima o čitanju, uz čitanje kao proces, čitalačke vještine i podvještine, posebno se u posljednje vrijeme ističe i koncept čitalačke pismenosti. Čitalačka se pismenost odnosi na razumijevanje, korištenje i promišljanje o pisanim tekstovima radi osobnih ciljeva, stjecanja i razvijanja znanja i cjeloživotnoga učenja (Visinko, 
2014: 265). Da bi se pojedinci danas uspješno obrazovali i radili u društvu znanja, trebaju biti sposobni doći do informacija, razumjeti te informacije, promišljati o njima i zauzeti kritički stav. Stoga je čitalačka pismenost jedno od triju ključnih područja procjene u Međunarodnome programu za procjenu znanja i vještina učenika (engl. Programme for International Student Assessment - PISA), u Organizaciji za ekonomsku suradnju i razvoj (engl. Organization for Economic Cooperation and Development-OECD). Danas se smatra da je čitalačka pismenost, osim što predstavlja temelj za uspjeh u svim drugim predmetnim područjima, preduvjet aktivnom sudjelovanju u većini područja života odrasle osobe (PISA 2009 Čitalačke kompetencije za život, 2010: 34). Bez nje nema napretka u drugim pismenostima (Peti-Stantić, 2019: 75), a brojna istraživanja pokazuju da su za njezin razvoj važni i čitalački stavovi, interesi, navike i ponašanja, kao i strategije učenja. U ciklusu PISA 2009 definicija čitalačke pismenosti glasi:

Čitalačka pismenost je razumijevanje, korištenje, promišljanje $i$ angažman u pisanim tekstovima radi postizanja osobnih ciljeva, razvoja vlastita znanja i potencijala te aktivnog sudjelovanja u društvu.

(PISA 2009 Čitalačke kompetencije za život, 2010: 36)

Pojam čitanje često se povezuje samo s dekodiranjem, a za razliku od toga pojam čitalačka pismenost uključuje skupinu kognitivnih kompetencija: od osnovnoga dekodiranja, poznavanja riječi, gramatičkih pravila i jezičnih i tekstualnih struktura i obilježja, do znanja o svijetu (PISA 2009 Čitalačke kompetencije za život, 2010: 36). Ona uključuje i metakognitivne kompetencije koje se koriste prilikom promišljanja, praćenja i reguliranja čitalačke aktivnosti. Razumijevanje se odnosi na koncept čitanja s razumijevanjem, odnosno na konstruiranje značenja teksta od osnovnoga razumijevanja riječi u tekstu do kompleksnoga razumijevanja teme teksta. Čitalački angažman u definiciji podrazumijeva motivaciju za čitanje i sadržava skupinu afektivnih karakteristika i ponašanja koje obuhvaćaju interes i zadovoljstvo čitanjem, osjećaj kontrole nad onime što se čita, uključenost u socijalnu dimenziju čitanja te različite i učestale navike čitanja (PISA 2009 Čitalačke kompetencije za život, 2010).

U hrvatskome znanstvenoistraživačkome kontekstu osvrnut ćemo se na definiciju u kojoj je Visinko (2014) čitanje definirala kao složenu jezičnu djelatnost te se osvrnula na pojmove dekodiranja i razumijevanja. U praksi o čitanju govorimo kao o složenoj vještini i sposobnosti, a psihologija objašnjava i tumači dekodiranje i razumijevanje teksta koji se čita 
(Visinko, 2014: 118). Fonološka svjesnost predstavlja preduvjet dekodiranju, a dekodiranju se pridružuje razumijevanje. Razumijevanje se proteže od razumijevanja riječi, rečenice, dijelova teksta do razumijevanja teksta u cjelini. Međutim, razumijevanje pročitanoga ne temelji se samo na jezičnim elementima. Razumijevanje pročitanoga, kojemu težimo, rezultat je trointerakcijskoga komunikacijskoga čina u kojemu sudjeluju autor teksta, tekst i čitatelj, opremljen svim svojim čitateljskim, jezičnim i životnim iskustvima i stečenim znanjem iz različitih područja (Visinko, 2014: 120).

Suvremeno teorijsko razmatranje o čitanju u hrvatskoj znanstvenoj literaturi nalazimo i kod Čudine-Obradović (2014), koja upozorava na unutarnje i vanjske preduvjete za razvoj čitanja, utjecaj pravopisne jasnoće jezika i fonemske svjesnosti, tečnost čitanja, razumijevanje pri čitanju i motivaciju za čitanje. Svrha vještine čitanja jest postizanje razumijevanja, ali sam pojam razumijevanja nije jednostavan. Razumijevanje cjelovitoga teksta nastaje na temelju prepoznavanja značenja riječi, potom rečenice i zatim cjeline teksta. Te tri razine prepoznavanja međusobno su povezane, a na učinkovitost svake od njih djeluju mnogi čimbenici (ČudinaObradović, 2014: 189). Slika 3.1. prikazuje čimbenike prema njihovu utjecaju i najvjerojatnijem vremenu utjecaja na razumijevanje pri čitanju. 


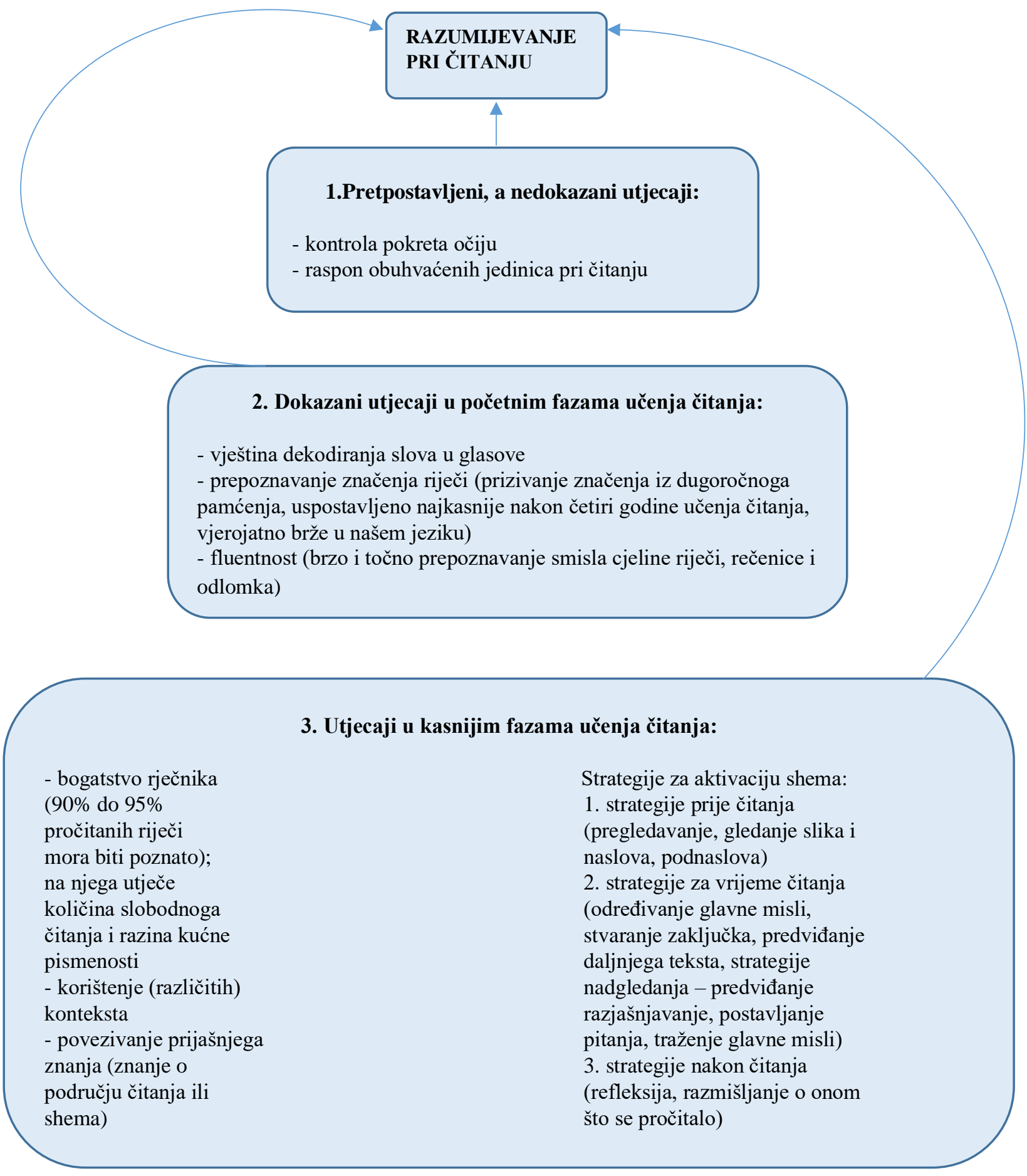

Slika 3.1. Pretpostavljeni i dokazani utjecaji na razumijevanje pri čitanju (prema Rončević, 2005) (preuzeto iz Čudina-Obradović, 2014: 190)

Rončević (2005) navodi da je čitanje vrlo kompleksna kognitivna vještina, koja zahtijeva koordinaciju niza okulomotornih i perceptivnih procesa, te procesa razumijevanja, a 
svaki od tih procesa predstavlja potencijalno uzrok individualnih razlika u vještini čitanja i razumijevanja pri čitanju.

Peti-Stantić (2019) čitanje smatra jednom od osnovnih kompetencija koja svakome pismenome pojedincu omogućuje kvalitetan život. Pojedinac od nižih razina čitalačke pismenosti može napredovati prema ostvarivanju viših kognitivnih i čitateljskih sposobnosti. Tako postoji razlika između čitača i čitatelja. Čitač je onaj koji čita zato što je prekoračio prag bespismene kulture i zakoračio u pismenu, dakle onaj koji može čitati. Čitatelj je, s druge strane, onaj koji uživa čitajući, koji uživa u spoznaji i svakim novim čitanjem nadograđuje svoju sposobnost, pretvarajući je u sredstvo izgradnje svojega svijeta i sebe kao intelektualnoga bića (Peti-Stantić, 2019: 271-272).

Definirajući čitanje kao proces, Grabe (1999) je naveo elemente tečnoga čitanja:

1. Čitanje je brz proces.

2. Čitanje podrazumijeva učinkovito procesuiranje.

3. Čitanje podrazumijeva strategije.

4. Čitanje je interaktivno.

5. Čitanje je svrhovito.

6. Čitanje podrazumijeva čitateljevo jezično znanje.

7. Čitanje podrazumijeva čitateljevo znanje o svijetu i zadanoj temi

(Grabe, 1999: 12).

Međutim, za tečno čitanje nisu važni samo kognitivni elementi, nego i socijalni kontekst i individualna motivacija koja podržava proces razumijevanja pročitanoga. Raznovrsni društveni čimbenici utječu na to kako i koliko čitamo te time pridonose čitalačkim navikama, stavu prema čitanju i motivaciji (Geld i Stanojević, 2007: 149). Uz društveni kontekst važnu ulogu u procesu čitanja imaju kognitivni i afektivni faktori koji djeluju u složenoj interakciji. Kod čitanja na stranome jeziku pojavljuje se i kognitivni i afektivni transfer iz prvoga jezika te time interakcija postaje još složenija.

Ovo potpoglavlje teorijskoga osvrta zaključit ćemo promišljanjem Aldersona (2000) o podvojenosti prirode čitanja. S jedne strane čitanje podrazumijeva proces, odnosno interakciju čitatelja i teksta, a s druge strane čitanje podrazumijeva rezultat toga procesa, odnosno razumijevanje pročitanoga. U mnogim istraživanjima čitanja korišten je pristup kojim se proučavao rezultat, dakle proučavalo se razumijevanje teksta kao rezultata čitanja. Ta istraživanja temeljila su se na analizi rezultata čitanja i za potrebe takvih istraživanja sudionici 
su ispunjali testove razumijevanja pročitanoga ili pisali sažetke pročitanoga teksta. Rezultati takvih ispitivanja su mjerljivi i usporedivi, ali njima se ne stječe uvid u proces čitanja. U novijim istraživanjima proučava se čitanje kao proces jer značenje nastaje u interakciji čitatelja i teksta. Tekst sadrži značenjski potencijal, a taj se potencijal ostvaruje - u rezultatu razumijevanja - tek kada čitatelj čita (Alderson, 2000).

\section{2. Čitanje na stranome jeziku}

Opisani modeli i definicije čitanja većim su se dijelom odnosili na čitanje na prvome jeziku, ali su svakako utjecali na razumijevanje čitanja na inome jeziku. Jednu od recentnijih definicija čitanja na prvome i inome jeziku u hrvatskome znanstvenoistraživačkome kontekstu nalazimo kod Jelić (2009), prema kojoj je čitanje - i na materinskom i na stranom jeziku - složen kognitivni proces, tijekom kojega dolazi do interakcije znanja čitatelja i obavijesti u tekstu. Čitatelj konstruira i integrira značenje poruke te tako ispunjava temeljnu svrhu čitanja, a to je razumijevanje pročitanoga. Na čitanje utječu mnogi čimbenici i ono ovisi, primjerice, o zadatku postavljenom pred čitatelja, njegovoj motivaciji, ciljevima i jezičnome znanju (Jelić, 2009: 897).

Istraživanja čitanja na materinskome jeziku uglavnom su se do sada bavila leksičkim i metalingvističkim znanjem čitatelja, a istraživanja čitanja na stranome jeziku pretežito isticala važnost sintaktičkoga i leksičkoga znanja čitatelja, tek u novije vrijeme i njegova retoričkoga i metalingvističkoga znanja (Šamo, 2006).

Posljednjih se dvadesetak godina istražuje čitanje na stranome jeziku, a nalazi istraživanja potvrđuju da je riječ o složenome konstruktu koji možemo razmatrati s dvaju polazišta: ili se čitanju na stranome jeziku pristupa kao problemu čitanja ili se čitanju na stranome jeziku pristupa kao jezičnom problemu (Alderson, 1984). Dva su važna aspekta u razumijevanju čitanja na stranome jeziku: čitalačka sposobnost ${ }^{9}$ na prvome jeziku (engl. L1 reading ability) i jezična vrsnoća u inome jezikom (engl. L2 linguistic proficiency). U skladu s nastojanjima da se sagledaju oba aspekta, razvile su se dvije pretpostavke: pretpostavka o jezičnoj međuovisnosti (engl. the linguistic interdependence hypothesis) i pretpostavka o

\footnotetext{
${ }^{9}$ Za uvriježeni opći termin čitalački Peti-Stantić predlaže termin čitateljski, koji se najizravnije odnosi na pojedinoga čitatelja (Peti-Stantić, 2019: 88).
} 
jezičnome pragu (engl. the linguistic treshold hypothesis). Prema prvoj pretpostavci, čitanje podrazumijeva mehanizme koji su zajednički procesu usvajanja prvoga jezika i ovladavanja inim jezikom. To su mehanizmi prepoznavanja riječi, mehanizmi na fonološkoj razini obrade, sintaktički mehanizmi određivanja značenja i razumijevanja teksta. U pojašnjenju pretpostavke o jezičnoj međuovisnosti Cummins $(1986,2005)$ navodi da, unatoč razlikama u površinskim osobinama prvoga i inoga jezika, postoje određena obilježja koja čine zajedničku inherentnu vrsnoć $u^{10}$ u obama jezicima (Mikulec, 2016). Prema pretpostavki o jezičnome pragu (Cummins, 1991), oni koji nastoje ovladati nekim nematerinskim jezikom najprije trebaju dostići određenu razinu znanja toga jezika da bi doista imali koristi od potencijalno pozitivnih učinaka dvojezičnosti na svoj kognitivni razvoj, a time i na uspjeh u učenju (Šamo, 2014: 21). Istraživanja čitanja na stranome jeziku ukazala su da i znanje stranoga jezika i sposobnost čitanja na prvome jeziku pridonose uspješnosti čitanja na stranome jeziku, ali je pritom znanje stranoga jezika važnije (Carrell, 1991; Bernhardt i Kamil, 1995). Široko je prihvaćeno viđenje da je određena razina jezičnoga znanja osnovni preduvjet za uspješno čitanje na inome jeziku (Koda, 2007: 22).

Razmatrajući čitanje na prvome i čitanje na inome jeziku, primjećuju se univerzalije i različitosti. Za sve jezike univerzalna je kognitivna arhitektura, zajednička svim jezicima, ali i prevođenje napisanoga u izgovoreno. Univerzalna značajka svih jezika jest kodiranje. U pojedinim jezicima kodiraju se glasovi u slova, u nekima se slogovi kodiraju u simbole, a u nekima morfemi u simbole. Ortografija je prva osobitost prema kojoj se jezici razlikuju, a zatim slijede fonologija, morfologija, te vokabular i gramatika. Stoga različita pisma mogu utjecati na čitanje i razumijevanje pročitanoga.

Kako bi opisao proces razumijevanja pročitanoga, Grabe (2009) opisuje vještine procesiranja niže razine (engl. lower-level processing skills) kao što su ortografski, morfološki, leksički i sintaktički obrasci, te vještine procesiranja više razine (engl. higher-level processing skills) pri kojima razumijevanje proizlazi iz kognitivnih procesa. Najvažnije je odrediti što je univerzalno svim jezicima, a što je specifično za čitanje i ovladavanje čitanjem u svakom jeziku (Grabe, 2009).

\footnotetext{
${ }^{10}$ Engl. common underlying proficiency: zajednička inherentna vrsnoća (Mikulec, 2016)
} 
Jezike možemo podijeliti na jezike ortografskoga (abecednoga) pisma i jezike logografskoga (slikovnoga) pisma (Čudina-Obradović, 2014: 71). Logografska pisma nastala su povijesno prije ortografskih i tipična su za neeuropske jezike, a europski su jezici jezici abecednoga pisma i za njih se dugo smatralo da se ne razlikuju znatnije po načinu i težini čitanja. Međutim, rezultati međunarodne usporedbe koju su proveli Seymour i suradnici (2003) pokazali su da se europski jezici razlikuju po lakoći učenja čitanja. U istraživanju su uspoređeni rezultati u točnosti i brzini čitanja na kraju prvoga razreda osnovne škole u trinaest različitih europskih jezika. U većini jezika učenici u potpunosti ovladaju čitanjem do kraja prvoga razreda, ali u nekima ne, kao u francuskom, portugalskom, danskom i osobito u engleskom. Istraživanje je pokazalo da su razlike u brzini i točnosti usvajanja čitanja posljedica razlika u pravopisnoj jasnoći. Pravopisna dosljednost (često nazivana transparentnost, prozirnost, jasnoća i plitkost, nasuprot nedosljednosti, gustoći, dubini) izražena je u dosljednoj povezanosti jednoga slova i jednoga glasa (Čudina-Obradović, 2014: 73). U nekim je jezicima ta dosljednost velika (hrvatski), a u nekima vrlo mala (engleski). Slogovna struktura jezika odnosi se na zastupljenost i redoslijed samoglasnika i suglasnika u riječi, te ona može biti jednostavna ili složena. S obzirom na kombinaciju dosljednosti glas-slovo i složenost slogovne strukture, nastala je sljedeća podjela europskih jezika na skupine pravopisne jasnoće (v. sliku 3.2.).

\begin{tabular}{|l|l|l|}
\hline & \multicolumn{2}{|c|}{ PRAVOPISNA DOSLJEDNOST } \\
\hline SLOGOVNA SLOŽENOST & \multicolumn{1}{|c|}{ VELIKA } & \multicolumn{1}{c|}{ MALA } \\
\hline mala & $\begin{array}{l}\text { (1) grčki, finski, talijanski, } \\
\text { španjolski, albanski, turski, } \\
\text { hrvatski, srpski }\end{array}$ & $\begin{array}{l}\text { (3) portugalski, francuski, } \\
\text { češki, ruski }\end{array}$ \\
\hline velika & $\begin{array}{l}\text { (2) njemački, švedski, } \\
\text { holandski, norveški }\end{array}$ & $\begin{array}{l}\text { (4) engleski, danski, } \\
\text { poljski }\end{array}$ \\
\hline
\end{tabular}

Slika 3.2. Podjela europskih jezika prema pravopisnoj dosljednosti i slogovnoj složenosti (prema Seymour, 2007., Hoxhillari i sur., 2004., Oney i Goldman, 1984., Caravolas i sur., 2005., Turvey i sur., 1984) (preuzeto iz Čudina-Obradović, 2014: 73)

Prema slici 2.2. moguće je podijeliti europske jezike na: 1. pravopisno potpuno jasne, 2. jasne, 3. osrednje jasne i 4. pravopisno nejasne jezike. Ziegler i Goswami (2005) ukazali su na to da se pri učenju čitanja čitatelji različitih jezika služe leksičkim jedinicama različitih veličina, među kojima je najveća riječ, a najmanja glas (fonem). Što je veća pravopisna jasnoća nekoga jezika, to će manja leksička jedinica biti prikladna za dekodiranje riječi. Stoga je za 
dekodiranje u jezicima velike pravopisne jasnoće potrebno kraće vrijeme i jednostavnija strategija dekodiranja, dok je za dekodiranje u jezicima male pravopisne jasnoće potrebno dulje vrijeme i više različitih strategija dekodiranja (Čudina-Obradović, 2014).

Postoje transparentni alfabetski jezici u kojima jedan grafem odgovara jednome fonemu (hrvatski). No postoje i jezici u kojima grafofonemska korespondencija nije pravilna, pa je povezanost grafema i fonema nejasna (engleski). Jezici koji ne koriste alfabetsko pismo, koji su logografski, kao što su japanski i kineski, još su manje transparentni. Ove osobitosti jezika povezane su s fizikalnim obrascima čitanja. Pomicanje oka i praćenje teksta, kao i širina vidnoga polja i fiksiranost pogleda na određene riječi ili skupine riječi razlikuje se kod različitih jezika. Budući da je prepoznavanje riječi ključan preduvjet za razumijevanje čitanjem, ortografske, fonološke i morfološke razlike mogu biti povezane s uspješnošću u čitanju na stranome jeziku, što se posebno manifestira onda kada su sposobnost čitanja i jezično znanje na nižoj razini. Što su jezici tipološki udaljeniji jedan od drugoga, slabija je interferencija u njihovu procesiranju, pa čimbenik jezične udaljenosti (engl. linguistic distance) itekako treba uzeti u obzir pri istraživanju usvajanja vještine čitanja na stranom jeziku (Šamo, 2014: 23).

Čitanje je interaktivan proces, a tu interakciju može se sagledati najmanje s dvaju polazišta. Najprije, dok čitatelj prepoznaje riječi i zadržava ih u radnome pamćenju, istovremeno analizira strukturu rečenice i razaznaje značenje pročitanoga. Nadalje, interakcija se uspostavlja kada to jezično znanje čitatelj povezuje sa znanjem koje ima pohranjeno u dugoročnome pamćenju. Na osnovi dvaju izvora znanja - jezičnoga i pozadinskoga ${ }^{11}$ - nastaje interpretacija pročitanoga (Grabe i Stoller, 2011: 12). U hrvatskome socioedukacijskome kontekstu Šamo (2006) je provela istraživanje čitanja na engleskome jeziku kojim je utvrdila da su čimbenici koji se tiču čitatelja i čimbenici koji se tiču teksta neminovno povezani. Autorica je pritom upozorila na važnost uloge znanja o jeziku (morfosintaktičke i leksičkosemantičke značajke) i uloge znanja o svijetu kojim čitatelj raspolaže (Šamo, 2006).

Interaktivni model čitanja na stranome jeziku koji je razvila Bernhardt (2000, 2003, 2005) svoje polazište nalazi u interaktivno-kompenzacijskome modelu Stanovicha (1980), prema kojemu se nedostatci u jednom području procesiranja mogu kompenzirati iz nekoga drugoga područja procesiranja. Tako se čitatelj može osloniti na svoje kontekstualno

\footnotetext{
${ }^{11}$ Engl. background knowledge: pozadinsko znanje (Geld i Stanojević: 2007).
} 
razumijevanje ako nije siguran razumije li pojedine riječi u tekstu koji čita. Bernhardt (2003, 2005) predlaže model prema kojemu čitalačka pismenost ${ }^{12}$ na prvome jeziku (engl. Ll literacy) i znanje stranoga jezika (engl. L2 language knowledge) određuju 50\% varijance čitanja na stranome jeziku. Pritom se $20 \%$ odnosi na čitalačku pismenost na prvome jeziku (abeceda, vokabular, struktura teksta, vjerovanja o svijetu, struktura rečenice itd.), a 30\% odnosi se na znanje stranoga jezika (gramatika, vokabular, udaljenost J1 i J2 itd.). Čitanje na stranome jeziku moglo bi se opisati kao žongliranje ili prebacivanje u kognitivnome procesu (Bernhardt, 2005: 140), pri kojemu se korištenjem čitalačke pismenosti na prvome jeziku po potrebi mogu kompenzirati nedostatci u čitanju na stranome jeziku. Bernhardt također ukazuje na potrebu da se detaljnije istraži uloga afektivnih faktora u procesu ovladavanja čitanjem na stranome jeziku. Različiti izvori znanja u ovome modelu djeluju sinkrono, odnosno u sinergiji. Prema Bernhardt, nije više pitanje postoji li transfer jezičnih vještina i znanja, pravo je pitanje koliki je taj transfer, u kojim se uvjetima događa i u kojemu kontekstu (Bernhardt, 2005: 138).

Prema interaktivnim modelima čitanja, niža i viša razina procesiranja istovremeno su aktivne, stoga bez vještina procesiranja više razine nema ni razumijevanja. Te vještine vode od čitanja i razumijevanja rečenica do razumijevanja teksta, odnosno teksta u kontekstu. Pri tome čitatelj stvara predodžbe o tekstu i značenju teksta. Procesiranje na nižoj i višoj razini isprepleće se. Dok čitamo neki tekst na osnovi svojega znanja i iskustva zaključujemo, pretpostavljamo i povezujemo. Grabe (2009) taj model smatra mentalnim modelom. Budući da se odnosi na našu mentalnu predodžbu o situaciji opisanoj u tekstu, taj nam model omogućuje razmatrati tekst ne samo na osnovi onoga što autor želi da u njemu razumijemo, već podrazumijeva i naše osjećaje potaknute tekstom (i autorom, to jest njegovim stajalištima) (Šamo, 2014: 32).

Čitanje na stranome jeziku ,za razliku od čitanja na prvome jeziku, uključuje dva jezika i interakciju između dvaju (ili više) jezika. Čitanje na stranome jeziku je složen, multidimenzionalan konstrukt koji obuhvaća više podvještina (engl. subskills) (Koda, 2007). Iako je Goodman (1967) zastupao holistički pristup čitanju ili unitarni pristup, prema kojemu je čitanje jedna nedjeljiva cjelina, prevladao je pristup prema kojemu se čitanju pristupa kao konstruktu s više komponenti, koje se mogu ciljano proučavati. Komponente koje se proučavaju kognitivne su vještine u osnovi čitanja koje pridonose izvedbi čitanja (Carr i Levy, 1990), one su mentalni procesi, teorijski su razdvojene i svaka od njih zahtijeva specifičan empirijski

\footnotetext{
${ }^{12}$ Engl. literacy: čitalačka pismenost (Peti-Stantić, 2019; Visinko, 2014).
} 
pristup. Koda (2007) razlikuje tri komponente čitanja. Prva se odnosi na dekodiranje, odnosno ekstrahiranje jezične informacije iz napisanoga. Za proces dekodiranja potrebno je jezično znanje koje obuhvaća ortografiju, fonologiju, vokabular i morfologiju. Jezici mogu biti ortografski bliski ili udaljeni, manje ili više transparentni, što je povezano s uspjehom i brzinom čitanja. Druga komponenta odnosi se na integraciju informacije u tekst i obuhvaća znanja iz jezične sintakse, strukture teksta i diskursa. Treća komponenta odnosi se na integriranje informacija iz teksta s čitateljevim znanjem i predstavlja konceptualno procesiranje kako bi se ostvario krajnji cilj. A krajnji je cilj čitanja konstrukcija značenja iz teksta (Koda, 2007: 30). Takav teorijski pristup čitanju traži i specifičan empirijski pristup i metodologiju istraživanja kako bi se detaljnije istražile pojedine komponente čitanja.

Čitanje na stranome jeziku podrazumijeva dva jezika, od kojih je jedan usvojen ranije, te dva načina procesiranja, stoga je neizbježna interakcija dvaju sustava pri razvoju čitalačkih sposobnosti na stranome jeziku. No prijenos čitalačkih sposobnosti treba promatrati u širemu kontekstu jezičnoga prijenosa koji zanimanje istraživača zaokuplja još od 1950-ih i 1960-ih godina, kada je u ozračju bihevioralnih promišljanja pažnja bila usmjerena na proučavanje negativnoga jezičnoga prijenosa. Pretpostavljalo se da znanje prvoga jezika ometa ovladavanje inim jezikom zbog negativnoga prijenosa. Danas se ovladavanje inim jezikom shvaća kao neprekidno postavljanje i provjeravanje pretpostavki koje se temelji na dostupnome jezičnome unosu. Prethodno jezično iskustvo promatra se kao osnova na kojoj se gradi dodatni jezični sustav (Koda, 2004). Budući da je materinski jezik uvijek prisutan u poučavanju inoga jezika, usporedba i međusobni utjecaj dvaju jezičnih sustava neizbježni su i ne smiju se zanemariti (Mikulec, 2016: 53).

Pristup čitanju koji predlažu Carr i Levy (1990) podrazumijeva da čitanje obuhvaća više komponenti odnosno vještina (engl. component skills approach). Ovaj pristup omogućuje istraživanje individualnih varijacija i razvojnih razlika u čitanju na prvome jeziku te bolje razumijevanje jezičnoga transfera pri ovladavanju inim jezikom. Uz pojam jezičnoga prijenosa vezan je i pojam međujezika, koji se pripisuje Selinkeru (1972). Međujezik se razvija od početne točke na kojoj pojedinac još ne posjeduje znanja ciljnoga jezika, ali posjeduje znanja prvoga ili nekoga inoga jezika do krajnje točke, odnosno one točke na kojoj je pojedinac odlučio da je stekao dovoljno znanja u ciljnome jeziku. Riječ je o jeziku koji se sustavno razvija kako korisnik napreduje u ovladavanju inim jezikom (Medved Krajnović, 2010: 24). Međujezik pokazuje i određenu nepredvidljivu promjenjivost, koju bi moglo uzrokovati međujezično 
djelovanje jezičnih sustava koje određeni pojedinac posjeduje, neka druga učenikova obilježja ili kontekst ovladavanja jezikom. U današnje vrijeme naziv međujezik (engl. interlanguage) sve se više zamjenjuje nazivom učenikov jezik (engl. learner language), a mogao bi se uskoro zamijeniti i nazivom korisnikov jezik, sukladno tendenciji da se naziv učenik inoga jezika (engl. second langauge learner) zamijeni nazivom korisnik inoga jezika (engl. second language user) (Medved Krajnović, 2009). Cook smatra da se produženim korištenjem riječi učenik zapravo nedovoljno ističe da je osoba koja nastoji ovladati inim jezikom tim jezikom već djelomično ovladala i da se njime u određenoj mjeri može koristiti u komunikacijske svrhe (Cook, 2002, prema Medved Krajnović, 2009).

Istraživanja međujezičnih utjecaja bave se analizom pozitivnih i negativnih utjecaja prvoga jezika na ini jezik i inoga jezika na prvi jezik, odnosno međusobnim višesmjernim utjecajima svih jezičnih sustava. U tome kontekstu potrebno je spomenuti i jezično nazadovanje (engl. language attrition), pod kojim podrazumijevamo smanjenje lingvističke i komunikacijske kompetencije u jeziku kojim je pojedinac već ovladao (bilo da je riječ o prvome ili inome jeziku) (Medved Krajnović, 2010: 111). U novijim istraživanjima čitanja na stranome jeziku pozornost istraživača usmjerila se s utjecaja materinskoga jezika (pozitivni, negativni, neutralni) na resurse novoga jezika koji se usvaja. U tome kontekstu prijenos se ne shvaća apsolutno nego u suodnosu. Prijenos se definira kao automatska aktivacija dobro usvojenih kompetencija, potaknuta novim unosom. Prema takvome shvaćanju, prijenos ne prestaje ni u jednom trenutku, a prenesene kompetencije nastavljaju se razvijati s pomoću unosa novih jezičnih podataka jezika koji pojedinac uči.

Mihaljević Djigunović (2006) provela je u Hrvatskoj poredbeno istraživanje kojim se nastojala otkriti povezanost komunikacijske kompetencije na prvome i stranome jeziku. Ispitana je kompetencija za slušanje, čitanje i pisanje u prvome (hrvatskome) i stranome (engleskome) jeziku. Utvrđeno je da postoji povezanost između čitanja na hrvatskome i svih ostalih vještina na hrvatskome i engleskome jeziku te da je povezanost između čitanja na hrvatskome i engleskome visoka. Utvrđeno je da postoji povezanost čitanja na engleskome i svih vještina na hrvatskome i engleskome jeziku, osim pisanja na hrvatskome. Najveće međujezično djelovanje utvrđeno je za čitanje. Nalazi ovoga istraživanja upozoravaju da jezično međudjelovanje treba sagledati u širem kontekstu, uzevši u obzir da prelaženje jezičnoga praga (Cummins, 1979, 1991) možda nije dovoljan preduvjet za jezični prijenos. Autorica ukazuje na razmišljanje da sve jezične vještine imaju jezičnu osnovu koja im je 
zajednička i na kojoj počiva jezična uporaba bez obzira koristi li pojedinac prvi ili ini jezik. Ne samo da se u različitim jezicima mogu naći zajednički aspekti jezičnoga znanja, već bismo mogli pretpostaviti da i u različitim jezicima postoje slične podvještine i sposobnosti. Moguće je da ih spretan jezični korisnik prenosi iz prvoga u ini jezik i obratno (Mihaljević Djigunović, 2006: 272).

Ispitujući razlike između čitanja na prvome i na inome jeziku Grabe i Stoller (2011) utvrdili su da se one mogu podijeliti u tri kategorije:

1. Jezične razlike i razlike procesiranja

2. Individualne i iskustvene razlike

3. Društvenokulturalne i institucionalne razlike

(Grabe i Stoller, 2011: 34).

Prva kategorija razlika obuhvaća razlike u količini leksičkoga, gramatičkoga i diskursnoga znanja koje su rezultat različitih okolnosti u početku usvajanja prvoga jezika i ovladavanja inim jezikom. Znanje vokabulara i jezičnih struktura kojima čitatelj raspolaže kada počinje čitati na prvome jeziku veće je od znanja vokabulara i jezičnih struktura istoga čitatelja koji tek počinje ovladavati inim jezikom. Inojezični čitatelji imaju izraženiju metajezičnu i metakognitivnu svjesnost, što se može objasniti većom izloženošću eksplicitnom poučavanju inoga jezika. Sljedeća je važna činjenica da se jezici razlikuju i mogu biti lingvistički više ili manje udaljeni, počevši od ortografskih razlika, zatim morfoloških i sintaktičkih. Jezična vrsnoća čitatelja pokazala se kao važna pretpostavka pri ovladavanju čitanjem na inome jeziku, kao i jezična međuovisnost i jezični prijenos.

Druga kategorija razlika odnosi se na čitalačke sposobnosti koje čitatelj može prenijeti iz prvoga u ini jezik. Ako čitatelj nema razvijene čitalačke sposobnosti na prvome jeziku, neće ih moći prenijeti u ini jezik, odnosno moći će ih prenijeti najviše do one razine na kojoj su te sposobnosti razvijene u prvome jeziku. Postoje i razlike u motivaciji za čitanje, pa se motivacija za čitanje na inome jeziku mijenja ovisno o dobi, cilju i kontekstu učenja i mnogim drugim varijablama. Iskustvene razlike podrazumijevaju razlike u izloženosti čitanju na prvome $\mathrm{i}$ inome jeziku, razlike u vrstama tekstova koji se čitaju, kao i izvorima i sredstvima kojima se inojezični čitatelji koriste pri čitanju (dvojezični i jednojezični rječnici, izvorni tekstovi o određenim temama, pomoć nastavnika). 
Čitatelji različitoga društvenokulturnoga podrijetla ovladavaju različitim inim jezicima. No, u različitim društvenokulturnim okruženjima pismenost se shvaća različito. U nekim kulturama velika pozornost pridaje se opismenjavanju, pa i čitanju, a u nekima se čitanje i pisanje koriste tek povremeno, pa je u tim društvima uloga pismenosti sasvim drugačija. $\mathrm{Na}$ inojezične čitatelje velik utjecaj mogu imati i društvenokulturni i obrazovni kontekst.

Iako ne postoji jedinstven model čitanja, modeli koji postoje potrebni su nam jer određuju okvir unutar kojega možemo promatrati relevantne slojeve procesa čitanja i procesa usvajanja čitanja te nam pružaju kriterije prema kojima vrednujemo rezultate istraživanja (Šamo, 2014). 


\section{MOTIVACIJA U OVLADAVANJU INIM JEZIKOM}

\subsection{Uvodna razmatranja o motivaciji u OVIJ-u}

U teorijama i istraživanjima OVIJ-a motivaciji se pridaje velika pozornost, no unatoč tome danas još nema jedinstvene definicije motivacije. Mnogi ju opisuju kao pokretačku snagu za određeno djelovanje ili stupanj truda koji pojedinac ulaže u djelovanje. Moglo bi se reći da je to skup motiva (engl. motive), odnosno psiholoških stanja koji pokreću i usmjeravaju ljudsko ponašanje te određuju intenzitet toga ponašanja (Medved Krajnović, 2010: 77).

Što to pokreće pojedinca da napravi izbor, da sudjeluje u nekoj aktivnosti, da uloži napor i ustraje u nekoj aktivnosti - osnovna su pitanja teorije i istraživanja motivacije (Dörnyei i Ushioda, 2011: 3). Iako su se teorije motivacije tijekom vremena mijenjale, istraživači se slažu da je motivacija jedan od najvažnijih faktora u učenju inoga jezika (Gardner i Lambert, 1972; Gardner, 1985; Mihaljević Djigunović, 1998, 2002; Dörnyei, 1998, 2001, 2005; Csizér i Dörnyei, 2005; Medved Krajnović, 2010, Dörnyei i Ushioda, 2011; Dörnyei i Ryan, 2015), da je povezana s ishodima učenja (Gardner, 1985; Mihaljević Djigunović, 1998, 2002; Dörnyei, 2005), te da se može poticati, razvijati i mijenjati (Dörnyei, 2001).

Kada govorimo o učenju jezika kao procesu koji se odvija u određenome vremenskome periodu, moramo imati na umu da motivacija nije uvijek ista, da se mijenja ne samo tijekom godina, tjedana ili tijekom dana, nego se može mijenjati, jačati ili slabiti čak i tijekom jednoga nastavnoga sata (Dörnyei i Ushioda, 2011). U općem smislu, motivaciju bi se moglo definirati kao dinamično kumulativno poticanje koje u pojedincu pokreće, usmjerava, koordinira, pojačava, prekida i vrednuje kognitivne i motoričke procese, pri kojima se između početnih želja i čežnji obavlja izbor, određuju prioriteti te se one operacionaliziraju i (uspješno ili neuspješno) izvršavaju (Dörnyei i Otto, 1998: 65).

Kako bismo dali kraći osvrt na razvoj teorija motivacije u OVIJ-u, slijedit ćemo podjelu na tri razdoblja koju je ponudio Dörnyei:

1. Sociopsihološko razdoblje (1959-1990) - obilježeno je radovima Gardnera i njegovih suradnika u Kanadi

2. Kognitivno-situacijsko razdoblje (tijekom 1990-ih) - obilježeno je radovima koji polazište nalaze u kognitivnim teorijama psihologije obrazovanja 
3. Procesno usmjereno razdoblje (na prijelazu stoljeća) - obilježeno je interesom za promjene u motivaciji

(Dörnyei, 2005: 38 i 39).

\subsection{Sociopsihološko razdoblje teorije motivacije}

Autor koji se smatra začetnikom motivacijskoga koncepta i motivacijskih istraživanja u sklopu OVIJ-a kanadski je socijalni psiholog Robert Gardner. Gardner i Lambert (1972), Gardner (1985), te zatim Gardner i MacIntyre (1992, 1993a) ispitivali su stavove i motivaciju u procesu usvajanja drugoga jezika te radili na razvoju socioedukacijskoga modela usvajanja drugoga jezika ${ }^{13}$. Gardner (1985) je ukazao na ulogu stavova i motivacije i upozorio da stavovi učenika prema društvenoj zajednici drugoga jezika mogu biti povezani s uspjehom $u$ ovladavanju jezikom. Prema Gardneru, krajnji cilj učenja drugoga jezika može biti integrativno ili instrumentalno orijentiran. Koncept integrativnoga motiva sastoji se od triju dijelova: motivacije, koja predstavlja trud, želju i pozitivan stav prema učenju jezika, integrativnosti, koja predstavlja interes za jezik i stav prema društvenoj zajednici inoga jezika i stavova prema kontekstu učenja, koji obuhvaćaju stavove prema nastavniku i nastavnim materijalima.

Prema Gardnerovu modelu integrativnost i stavovi prema kontekstu učenja utječu na motivaciju, a motivacija utječe na jezično postignuće (v. sliku 4.1.) Integrativnost u ovome kontekstu trebamo razumjeti u smislu identifikacije. Identifikaciju, odnosno integrativnost pri učenju drugoga jezika možemo usporediti s usvajanjem prvoga jezika kada dijete usvaja prvi jezik i pritom integrira obilježja drugih iz svoje okoline, pa tako i jezična obilježja. Gardner upozorava da strah može olakšati i otežati učenje drugoga jezika i naglašava negativnu ulogu straha u procesu OVIJ-a.

\footnotetext{
${ }^{13}$ Socioedukacijski model usvajanja drugoga jezika (Gardnera i Macintyrea, 1993a) opisan je detaljnije u potpoglavlju 1.1 .
} 


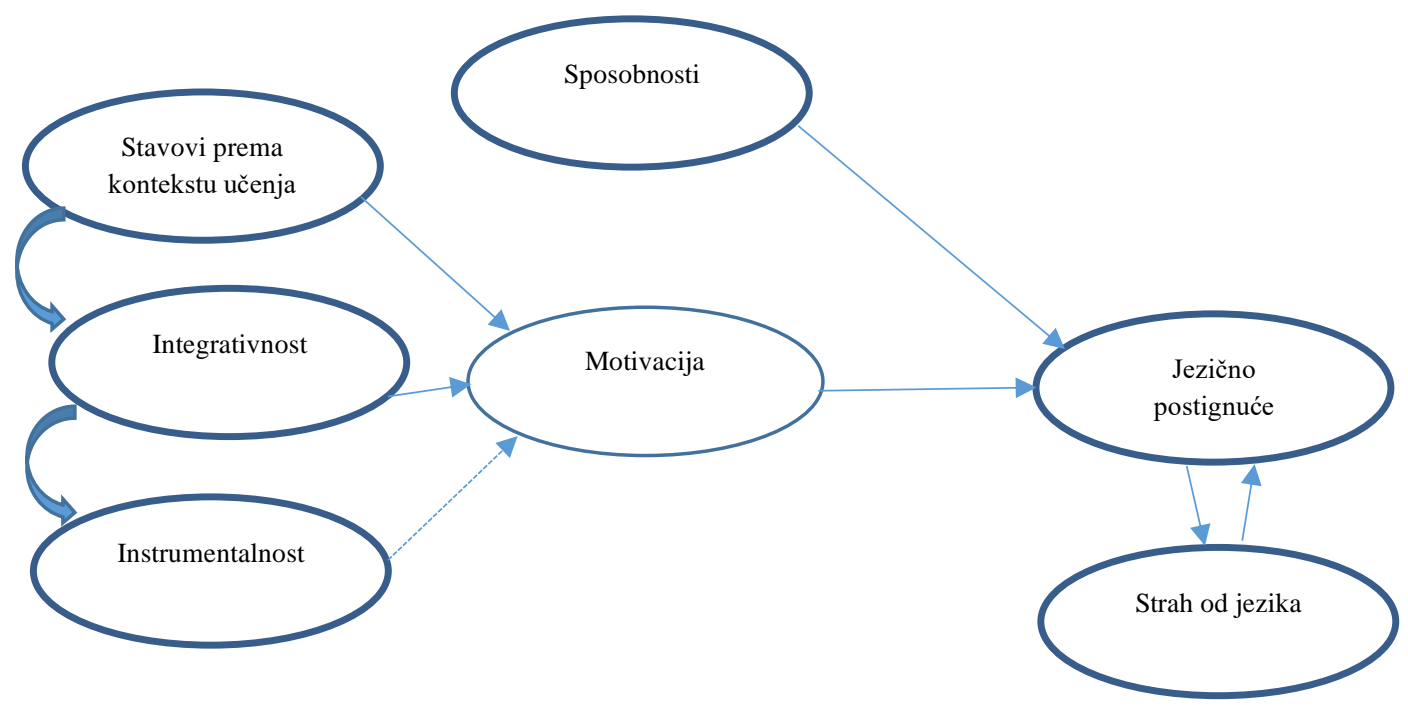

Slika 4.1. Socioedukacijski model (Gardner, 2005: 6)

\subsection{Kognitivno-situacijsko razdoblje teorije motivacije}

$\mathrm{U}$ ovome razdoblju istraživanja motivacije nalaze svoje polazište u kognitivnim teorijama psihologije obrazovanja, a makroperspektiva zamjenjuje se mikroperspektivom istraživanja (Dörnyei i Ushioda, 2011). Crookes i Schmidt definiraju motivaciju kao izbor aktivnosti i ciljeva koje pojedinac bira ili izbjegava, te stupanj truda koji će u njih uložiti (Crookes i Schmidt, 1991). Ističe se mikroperspektiva istraživanja, ispituju se povezanosti nastavnikova djelovanja i učeničke motivacije za učenje, važnost nastavnih aktivnosti i ocjenjivanja. Proučavanju motivacije kao dinamičnoga konstrukta u kojemu situacijski čimbenici (nastavnik, metode poučavanja i ocjenjivanja, grupna dinamika) imaju važnu ulogu pridonijeli su 1990-ih mnogi istraživači, a među njima Mihaljević (1990, 1991/1992), Dörnyei (1994) i Mihaljević Djigunović (1994, 1998).

Kognitivno-situacijsko razdoblje istraživanja motivacije uvelike obilježava djelovanje Zoltana Dörnyeija, koji je predložio trodijelni model motivacije za učenje inoga jezika (Dörnyei, 1994). Prva razina modela je jezična razina. Druga razina je razina učenika i ona podrazumijeva skup kognitivnih i afektivnih individualnih faktora, među kojima je i strah od upotrebe jezika. Motivacijski procesi na ovoj razini mogu se podijeliti u dvije kategorije: potreba za postignućem i samopouzdanje. Treća razina modela je razina konteksta učenja i obuhvaća skup intrinzičnih i ekstrinzičnih motiva koji se odnose na tri područja: nastavu, nastavnika i razred kao grupu. 
Društvenokonstruktivistički motivacijski model predložili su Williams i Burden (1997), navevši mnogobrojne unutarnje i vanjske motivacijske čimbenike: sliku o sebi, usmjerenost na učenje, strah te kontekst učenja i širi društvenokulturni kontekst.

U kognitivno-situacijskom razdoblju neki istraživači za empirijska istraživanja motivacije polazište nalaze u teoriji samoodređenja (Deci i Ryan, 1985; Ryan i Deci, 2000), koja polazi od temeljne pretpostavke o ljudskim potrebama samoodređenja i razvoja kompetencija. Prema toj teoriji ekstrinzična motivacija odnosi se na izvođenje određene aktivnosti u cilju da se postigne neki cilj koji je odvojen od te aktivnosti, a intrinzična motivacija odnosi se na obavljanje određene aktivnosti u cilju inherentnoga zadovoljavanja same aktivnosti (Ryan i Deci, 2000: 71). Empirijska ispitivanja primjene teorije samoodređenja proveli su Noels i njezini suradnici (1999, 2000), utvrdivši povezanost intrinzične motivacije s pozitivnim ishodom učenja, većom motivacijom i manjim strahom. Uloga nastavnika pokazala se važnom. Učenici koji percipiraju nastavnika kao osobu sklonu kontroli i njegovo poučavanje kao nedovoljno kvalitetno, manje su intrinzično motivirani.

\subsection{Procesno usmjereno razdoblje teorije motivacije}

Procesno usmjereno razdoblje obilježeno je promatranjem motivacije u njezinoj dinamičnosti i vremenskim fluktuacijama. Berliner (1989) ukazuje na dinamičnost motivacije na dnevnoj razini u razredu i uvodi pojmove mijena (engl. ebb and flow), odnosno niže i više razine motivacije. Mijene se mogu promatrati na dnevnoj razini, a pri njihovim izmjenama veliku ulogu igraju nastavnici. Williams i Burden (1997), Ushioda (1998) i Dörnyei i Otto (1998) među prvima su motivaciju sagledali polazeći od procesno-usmjerenoga pristupa. Ushioda ukazuje da je institucionaliziranom okruženju učenja stranoga jezika svojstvena fluktuacija motivacije. Vremenski okvir u kojem se oblikuje motivacija podrazumijeva evoluciju tijekom toga perioda, što se čini centralnim za učeničko iskustvo, a time i za koncepciju motivacije za učenje jezika (Ushioda, 1998). Dörnyei i Otto (1998) i Dörnyei (2000) predlažu dinamičniji prikaz motivacije i predstavljaju procesni model motivacije za učenje inoga jezika, koji obuhvaća tri vremenske etape, faze: fazu prije aktivnosti, tijekom koje se odabire cilj djelovanja, fazu aktivnosti, u kojoj se aktivnost obavlja, i fazu poslije aktivnosti, u kojoj se aktivnost kritički procjenjuje. U zadnjoj fazi dolazi do uspoređivanja početnih očekivanja i krajnjih postignuća, 
te se iz nje može generirati motiviranost za buduće aktivnosti. Iako je model Dörnyei i Otta (1998) dinamičan model motivacije, ni taj model nije obuhvatio svu složenost i dinamičnost motivacije u OVIJ-u (Dörnyei, 2005), pa se nadalje promatranju fenomena motivacije pristupilo iz sociodinamične perspektive.

\subsection{Od procesno usmjerenoga prema sociodinamičnome razdoblju teorije motivacije}

U suvremenome svijetu globalizacije ne mijenjaju se samo identiteti pojedinaca i identiteti zajednica nego i identitet engleskoga jezika koji je postao jezik međunarodne komunikacije, te se uz matematičku pismenost i čitalačku pismenost danas smatra jednom od temeljnih vještina (Dörnyei i Ushioda, 2011). Engleski jezik više nema status stranoga jezika nego postaje lingua franca suvremenoga svijeta. Jedna od posljedica toga razvoja jest da se i motivacija za učenje engleskoga jezika ne može proučavati na isti način i s istih polazišta kao motivacija za učenje ostalih jezika. Dörnyei i Csizér (2002) utvrđuju da motivacijski obrasci za učenje engleskoga kao svjetskoga jezika (engl. world language) nisu isti kao motivacijski obrasci za učenje ostalih stranih jezika (engl. other foreign languages).

Kako bi se mogla proučiti motivacija za učenje inoga jezika, uzevši u obzir specifičnu motivaciju za učenje engleskoga kao internacionalnoga jezika, a ne jezika neke određene društvenokulturne zajednice, treba preispitati Gardnerov koncept integrativnosti (Dörnyei, 2005). Integrativnost se može sagledati kao neka vrsta psihološke i emocionalne identifikacije sa sociokulturnim obilježjima zajednice koju čine izvorni govornici inoga jezika. Budući da je engleski svjetski jezik, ta bi se identifikacija odnosila na identifikaciju s građaninom svijeta koji vlada globalnim engleskim jezikom (engl. Global English). Globalni engleski ne možemo povezati sa specifičnom jezičnom zajednicom na specifičnome geografskome području jer se koristi na globalnoj razini u komunikaciji kako izvornih govornika engleskoga jezika tako i onih kojima engleski nije prvi usvojeni jezik (Dörnyei, 2005; Dörnyei i Ushioda, 2011). Govoreći o integrativnosti i identifikaciji, Norton (2000) uvodi pojam zamišljenoga pojedinčeva identiteta koji se ostvaruje u zamišljenoj zajednici, koja može biti uža ili šira pojedinčeva zajednica, dok je neposredna zajednica u procesu učenja stranoga jezika razredna zajednica koju sačinjavaju nastavnik i svi učenici. 
Dörnyei (2005) je, polazeći od Higginsove (1987) teorijske podjele na stvarno ja ${ }^{14}$ (engl. the actual self), idealno ja ${ }^{15}$ (engl. the ideal self) i traženo ja ${ }^{16}$ (engl. the ought-to-self), razradio nov motivacijski konstrukt. Stvarno ja odnosi se na one atribute za koje pojedinac vjeruje da ih ima, idealno ja na one atribute koje bi pojedinac idealno želio imati (predstavlja pojedinčeve nade i želje), a traženo ja odnosi se na one atribute za koje pojedinac vjeruje da bi ih trebao imati (povezani su s osjećajem dužnosti, obveze ili odgovornosti) (Higgins, 1987). Pojedinac nastoji smanjiti neusklađenost između trenutačnoga stanja, odnosno njegova predočavanja trenutačnoga stanja i ciljnih stanja za kojima taj pojedinac čezne (Higgins, 1987, 1998). Motivacija, u ovome smislu, uključuje želju da se smanje razlike između stvarnoga ja i idealnoga i traženoga ja (Dörnyei, 2005: 100).

Polazeći od Higginsove konceptualizacije, te potaknut rezultatima provedenoga istraživanja stavova i motivacije među mađarskim učenicima (Dörnyei i Csizér, 2002) Dörnyei (2005) provodi rekonceptualizaciju Gardnerova pojma integrativnosti i predlaže nov motivacijski konstrukt, koji naziva inojezični motivacijski sustav pojmova o sebi (engl. L2 Motivational Self-System - L2MSS).

Tri dimenzije Dörnyeijeva konstrukta su:

1. Idealno inojezično ja (engl. Ideal L2 self) - odnosi se na osobu koja bismo željeli postati.

2. Traženo inojezično ja (engl. Ought-to L2 self) - odnosi se na atribute koje bi netko trebao imati (razne obveze, dužnosti i odgovornosti) kako bi izbjegao moguće negativne ishode.

3. Iskustvo učenja inoga jezika (engl. L2 learning experience) - obuhvaća situacijski specifične motive koji se odnose na neposredno okruženje učenja i iskustvo.

Dörnyeieva rekonceptualizacija Gardnerovoga koncepta integrativnosti dovela je do novih pristupa razmatranju motivacije (Dörnyei, Csizér i Neméth, 2006; Dörnyei i Ushioda, 2009). Krajem 1990-ih pojavljuju se kvalitativni istraživački pristupi koji se primjenjuju kako bi se proučio dinamični razvoj motivacije za učenje inoga jezika. Ushioda $(1998,2001)$ je utvrdila da se motivacija mijenja i evoluira s vremenom. Motivaciju treba proučavati uzimajući

\footnotetext{
${ }^{14}$ Engl. the actual self: stvarno ja (Vidak, 2019)

${ }^{15}$ Engl. the ideal self: idealno ja (Vidak, 2019)

${ }^{16}$ Engl. the ought-to-self: traženo ja (Vidak, 2019)
} 
u obzir sve osobitosti određenoga pojedinca (osobine, prethodna iskustva, namjere, ciljevi) koji se nalazi u određenome kontekstu te razmatrajući sve socijalne aktivnosti i iskustva toga pojedinca. Sve kontekstualne elemente treba ispitivati u njihovim složenim odnosima relacijskim pristupom te motivaciju promatrati kao organički proces koji nastaje u tim složenim interakcijama (Ushioda, 2009: 220).

Motivacija se tradicionalno proučavala u okviru proučavanja individualnih razlika. Međutim, Dörnyei (2009) i Dörnyei i Ushioda (2011) upozoravaju da individualne razlike nisu stabilne i nepromjenjive karakteristike i da se mijenjaju s vremenom i u određenim situacijama. Prihvaćanjem dinamičkih i holističkih pristupa otvara se nova stranica u konceptualizaciji motivacije.

Norton (2000) promatra motivaciju, identitet i jezik u sociokulturnome i sociopovijesnome kontekstu. Identitet se stvara u odnosu pojedinca i svijeta, a taj se odnos razvija u određenome vremenu i društvenome okruženju. De Costa i Norton (2017) upozoravaju da trend globalizacije dovodi do porasta višejezičnosti u školama i društvima i do nastajanja novih identiteta. Higgins (2015) nove identitete naziva milenijskim identitetima, koji nastaju u protoku ljudi, medija, novca, tehnologija i ideologija u suvremenome globalnome društvu.

Teorija dinamičkih sustava u OVIJ-u (Larsen-Freeman, 1997; De Bot i sur., 2007) ogleda se u razumijevanju jezika kao dinamičnoga skupa varijabli koji sadržava neke značajke dinamičkih sustava, kao što su osjetljivost na početne uvjete razvoja, potpuna povezanost i isprepletenost svih podsustava, sposobnost unutarnje reorganizacije i osjetljivost na male promjene u okolinskim uvjetima. Da bi došlo do razvoja, postoji jezična sposobnost ili općenito sposobnost učenja, a da bi se razvoj nastavio, postoje stalni izvori energije koji su unutarnji i vanjski. Ti se izvori mogu kompenzirati, pa tako motivacija može nadoknaditi nedostatke u nekim vanjskim izvorima energije, kao što su loši uvjeti učenja. Jezični razvoj je kreativan i individualan, a u nekim aspektima može biti i kaotičan, ali nije nasumičan (Medved Krajnović, 2010). Teorija dinamičkih sustava u OVIJ-u teorija je u nastajanju koja ističe dinamiku i individualnost u jezičnome razvoju, te taj razvoj sagledava holistički, uzimajući u obzir interakciju unutarnjih (individualnih) i vanjskih (društvenih) čimbenika. Prinos razvoju teorija OVIJ-a kao teorije dinamičkih sustava nalazimo u radovima Larsen-Freeman (1997, 2006), Ellis i Larsen-Freeman (2006), De Bot i suradnika (2007) i Dörnyeija (2009). Ta teorija 
uspijeva, ako ne još uvijek objasniti, ali barem objediniti i ukazati na potrebu uvažavanja svih brojnih čimbenika u teorijskome pristupu OVIJ-u (Medved Krajnović, 2010). 


\section{ISTRAŽIVANJE STRAHA OD ČITANJA I RAZMIJEVANJE ČITANJEM NA ENGLESKOME I NJEMAČKOME JEZIKU}

\subsection{Uvod}

Dosadašnja istraživanja straha od čitanja na stranome jeziku ukazala su na zanimljive spoznaje o strahu od čitanja na stranome jeziku kao zasebnome fenomenu u okviru OVIJ-a. Novija istraživanja uključila su različite metodološke pristupe i ukazala na povezanost straha od čitanja i razumijevanja čitanjem. Utvrdilo se da povezanost straha od čitanja na stranome jeziku i uspjeha u razumijevanju teksta čitanjem na stranome jeziku nije lako pouzdano odrediti jer je taj odnos složen, te se stoga pri proučavanju ove povezanosti u obzir trebaju uzeti i ostali važni individualni faktori, među kojima se ističe uloga motivacije koja je jedan od ključnih afektivnih faktora u procesu ovladavanja inim jezikom. No, odnos straha od čitanja na stranome jeziku, uspjeha u čitanju i motivacije nedovoljno je istražen kod nas i u svijetu. Većina je istraživanja poučavanja inih jezika i ovladavanja njima provedena u SAD-u, Kanadi i Australiji i istraživani je jezik u većini slučajeva engleski kao drugi jezik. Vrlo je mali broj istraživanja iz drugih zemalja, onih koja istražuju druge strane jezike ili koja uzimaju u obzir više stranih jezika (Bagarić Medve i Pavičić Takač, 2015: 99). Komparativna istraživanja koja se bave proučavanjem straha od čitanja na više stranih jezika nisu brojna, kao ni komparativna istraživanja koja se bave motivacijom za učenje više stranih jezika.

U hrvatskome socioedukacijskome kontekstu poučava se više stranih jezika, te se u većini osnovnih i srednjih škola engleski poučava kao prvi strani jezik, dok ostali jezici imaju status drugoga i trećega stranoga jezika. Engleski jezik na globalnoj razini poprima status svjetskoga jezika, te se utvrdilo da motivacijski obrasci za učenje engleskoga kao svjetskoga jezika i ostalih stranih jezika ne mogu biti isti (Dörnyei i Csizér, 2002). Tako bi se moglo pretpostaviti da ni struktura straha od čitanja na engleskome kao međunarodnome jeziku i nekome drugome stranome jeziku ne bi bila ista. Od 2013. godine, od kada je Republika Hrvatska članica EU-a, značenje učenja engleskoga kao prvoga stranoga jezika i učenje još jednoga stranoga jezika kao drugoga stranoga jezika još više se naglašava. U hrvatskome formalnome obrazovnome kontekstu postoji duga tradicija poučavanja njemačkoga jezika, ali njegov status, nastavni i izvannastavni kontekst učenja i usvajanja drugačiji je od statusa $i$ konteksta učenja i usvajanja engleskoga jezika. 
Navedene činjenice predstavljale su polazište za provedbu poredbenoga istraživanja kojim bi se stekao uvid u strukturu straha od čitanja na engleskome i njemačkome jeziku u specifičnome hrvatskome socioedukacijskome kontekstu te ispitao odnos straha od čitanja i razumijevanja teksta čitanjem na engleskome i njemačkome jeziku uzevši u obzir ulogu motivacije za učenje engleskoga i njemačkoga jezika.

U sljedećem se potpoglavlju detaljno opisuju ciljevi, problemi i hipoteze istraživanja.

\subsection{Ciljevi, problemi i hipoteze}

Osnovni je cilj ovoga rada ispitati odnos straha od čitanja i uspjeha u čitanju na engleskome kao stranome jeziku i njemačkome kao stranome jeziku, uzimajući u obzir motivaciju za učenje oba jezika. Ispitivanja straha od čitanja na stranome jeziku u svijetu i u Hrvatskoj ukazala su na činjenicu da je strah od čitanja na stranome jeziku zaseban fenomen i da postoji potreba za provođenjem dodatnih empirijskih istraživanja ovoga fenomena kako bi se stekao bolji uvid u njegovu strukturu. Na osnovi rezultata ranijih istraživanja i iz praktičnoga iskustva može se zaključiti da su strah od čitanja i uspjeh u čitanju na stranome jeziku povezani, a motivacija za učenje stranoga jezika ističe se kao važan faktor u razjašnjavanju ove povezanosti. S obzirom na činjenicu da je strah od stranoga jezika fenomen koji je kulturno i društveno specifičan, te da mjerni instrument kojim se provodi mjerenje straha treba biti utemeljen na kulturnim i društvenim specifičnostima populacije u kojoj će se istraživanje provesti (Mihaljević Djigunović i sur., 2004), jedan od ciljeva ovoga rada bila je konstrukcija valjanoga i pouzdanoga mjernoga instrumenta za mjerenje straha od čitanja na engleskome i njemačkome jeziku u hrvatskome formalnome obrazovnome kontekstu.

Polazeći od empirijskih istraživanja i teorijskih spoznaja, mogli bismo pretpostaviti da će struktura straha od čitanja biti složena te da će postojati razlike u strukturi straha od čitanja s obzirom na ciljni jezik (engleski i njemački). Također bi se moglo pretpostaviti da će postojati povezanost između straha od čitanja na engleskome i njemačkome jeziku i postignutoga uspjeha u razumijevanju teksta čitanjem na engleskome i njemačkome jeziku i uspjeha u učenju jezika. Moglo bi se pretpostaviti da će se strah od čitanja razlikovati s obzirom na određene individualne varijable, te da će motivacija imati važnu ulogu u povezanosti straha od čitanja i razumijevanju teksta čitanjem na engleskome i njemačkome jeziku. 
Kako bi se ostvario cilj ovoga istraživanja, definirani su sljedeći problemi i hipoteze (oznaka $\mathrm{H}$ ).

1. problem: Kako su strah od čitanja na engleskome i njemačkome jeziku povezani s uspjehom u čitanju na engleskome i njemačkome jeziku?

H1 - strah od čitanja na engleskome i njemačkome jeziku povezan je s uspjehom u čitanju na engleskome i njemačkome jeziku. Može se očekivati da će viša razina straha od čitanja na engleskome i njemačkome jeziku biti povezana s lošijim uspjehom u razumijevanju čitanjem na engleskome i njemačkome jeziku.

2. problem: Razlikuje li se strah od čitanja s obzirom na strani jezik koji se uči?

H2a - očekuje se da će se struktura straha od čitanja razlikovati u engleskome i njemačkome jeziku. Pretpostavlja se da bi razlike mogle biti povezane s razlikama među jezicima (ortografskim, leksičkim, sintaktičkim, semantičkim), različitim statusom jezika i različitim nastavnim i izvannastavnim kontekstom.

H2b - očekuje se da će se visina straha od čitanja razlikovati u engleskome i njemačkome jeziku. Pretpostavlja se da će intenzitet straha za engleski i njemački jezik razlikovati zbog razlika među jezicima (ortografskim, leksičkim, sintaktičkim, semantičkim), različitoga statusa jezika i različitoga nastavnoga i izvannastavnoga konteksta.

3. problem: Razlikuje li se strah od čitanja na engleskome i njemačkome jeziku s obzirom na spol?

H3 - ne postoje razlike u strahu od čitanja na engleskome i njemačkome jeziku s obzirom na spol. Pretpostavljamo da neće postojati razlike u strahu od čitanja na engleskome i njemačkome jeziku između učenica i učenika. 
4. problem: Razlikuje li se strah od čitanja na engleskome i njemačkome jeziku s obzirom na srednjoškolsko usmjerenje?

H4 - ne postoje razlike u strahu od čitanja na engleskome i njemačkome jeziku s obzirom na srednjoškolsko usmjerenje. S obzirom na to da među srednjoškolskim usmjerenjima koja su obuhvaćena našim istraživanjem ne postoje veće razlike između statusa prvoga stranoga jezika (engleskoga) i drugoga stranoga jezika (njemačkoga), kao ni u broju nastavnih sati, ne očekujemo da će se utvrditi razlika u visini strah od čitanja na engleskome i njemačkome jeziku s obzirom na srednjoškolsko usmjerenje.

5. problem: Postoji li medijacijski utjecaj motivacije na povezanost straha od čitanja i razumijevanja teksta čitanjem?

H5 - motivacija ima medijacijski utjecaj na povezanost straha od čitanja i razumijevanja teksta čitanjem. Medijacijski je utjecaj motivacije za učenje engleskoga i njemačkoga jezika na povezanost straha od čitanja na engleskome i njemačkome jeziku i razumijevanja teksta čitanjem značajan.

U sljedećim potpoglavljima detaljno se opisuju metodologija istraživanja i metode obrade i analize podataka, prikazuju se rezultati istraživanja i izlažu njihova tumačenja. Zatim se izlažu zaključci, prednosti i nedostatci istraživanja, te razmatraju implikacije i smjernice za buduća istraživanja. 


\subsection{Metodologija istraživanja}

U ovom se potpoglavlju opisuje uzorak na kojemu je istraživanje provedeno, postupak prikupljanja podataka, izrada instrumenata i metode obrade podataka. U istraživanju je korištena triangulacija, i to:

- triangulacija podataka, odnosno prikupljanje podataka iz različitih izvora (različitih srednjoškolskih obrazovnih ustanova)

- lokacijska triangulacija, provođenje istraživanja u različitim gradovima

\subsubsection{Sudionici}

Svi sudionici ${ }^{17}$ fokus grupa, u preliminarnome i u glavnome istraživanju izvorni su govornici hrvatskoga jezika i svi uče engleski kao prvi strani jezik, a njemački kao drugi strani jezik. Objašnjenje kratica korištenih za označavanje uzorka sudionika fokus grupa, u preliminarnome i u glavnome istraživanju nalazi se u prilogu 3.

\subsubsection{Sudionici u fokus grupama i preliminarnome istraživanju}

Metoda fokus grupe provedena je među učenicima ${ }^{18}$ Turističke i ugostiteljske škole Dubrovnik u preliminarnoj fazi istraživanja. U fokus grupi o strahu od čitanja na engleskome jeziku sudjelovalo je osam sudionika $\left(N_{e_{-} f_{-} p}=8\right)$, četiri učenika i četiri učenice iz 3.a i 3.b razreda, koji uče engleski i njemački jezik. Iz svakoga razreda sudjelovalo je dva učenika i dvije učenice. Transkript diskusije fokus grupe za engleski jezik nalazi se u prilogu 1. U fokus grupi o strahu od čitanja na njemačkome jeziku sudjelovalo je deset sudionika $\left(N_{n j_{-} f_{-} p}=10\right)$, pet učenika i pet učenica iz 3.a i 3.b razreda, koji uče engleski i njemački jezik. Iz 3.a razreda sudjelovalo je tri učenika i dvije učenice, a iz 3.b razreda dva učenika i tri učenice. Transkript diskusije fokus grupe za njemački jezik nalazi se u prilogu 2.

U preliminarnome istraživanju sudjelovali su učenici iz sljedećih srednjih škola na području Dubrovačko-neretvanske županije: Ekonomska i trgovačka škola Dubrovnik,

\footnotetext{
${ }^{17} \mathrm{U}$ ovome radu izraz sudionik odnosi se na sudionika i sudionicu, a izraz sudionici na sudionike i sudionice, osim ako se izričito ne navodi razlika s obzirom na spol.

${ }^{18}$ U ovome radu izraz učenik odnosi se na učenika i učenicu, a izraz učenici na učenike i učenice, osim ako se izričito ne navodi razlika s obzirom na spol.
} 
Gimnazija Dubrovnik, Gimnazija Metković i Turistička i ugostiteljska škola Dubrovnik. Obuhvaćeno je ukupno 233 učenika, od kojih 150 učenika drugih razreda i 83 učenika četvrtih razreda. Uklonjen je 31 nevažeći upitnik. Nakon uklanjanja nevažećih upitnika, obrađena su 202 važeća upitnika za engleski jezik $\left(N_{e_{-} p}=202\right)$ i 202 upitnika za njemački jezik $\left(N_{n j \_} p=\right.$ 202).

\subsubsection{Sudionici glavnoga istraživanja}

U glavnome istraživanju sudjelovali su učenici četvrtih razreda iz četiriju srednjih škola s područja Dubrovačko-neretvanske županije: iz Gimnazije Dubrovnik, Turističke i ugostiteljske škole Dubrovnik, Gimnazije Metković i Srednje škole fra Andrije Kačića Miošića Ploče. Isti su učenici sudjelovali u ispitivanju za engleski i za njemački jezik. U ispitivanju straha od čitanja na engleskome jeziku i motivacije za učenje engleskoga jezika sudjelovalo je 157 učenika $\left(N_{e_{-} s_{-} m}=157\right)$, a u ispitivanju razumijevanja teksta čitanjem za engleski jezik njih $160\left(N_{e_{-} t e s t}=160\right)$. Broj učenika koji su sudjelovali i u ispitivanju straha od čitanja na engleskome jeziku, motivaciji za učenje engleskoga jezika i razumijevanja teksta čitanjem na engleskome jeziku iznosio je $149\left(N_{\text {eng }}=149\right)$. U ispitivanju straha od čitanja na njemačkome jeziku i motivacije za učenje njemačkoga jezika sudjelovalo je 155 učenika $\left(N_{n j \_s \_m}=155\right)$, a u ispitivanju razumijevanja teksta čitanjem za njemački jezik sudjelovalo ih je $154\left(N_{n j}\right.$ test $\left.=154\right)$. Broj sudionika u ispitivanju straha od čitanja na njemačkome jeziku, motivaciji za učenje njemačkoga jezika i razumijevanja teksta čitanjem na njemačkome jeziku iznosio je $153\left(N_{\text {njem }}\right.$ = 153). Ukupan broj sudionika obuhvaćenih svim mjernim instrumentima koji su korišteni u ovom istraživanju, te je time sudjelovao i u ispitivanju straha od čitanja na engleskome $\mathrm{i}$ njemačkome jeziku, motivaciji za učenje engleskoga i njemačkoga jezika i razumijevanja teksta čitanjem na engleskome i njemačkome jeziku iznosio je $139\left(N_{e+n j}=139\right)$.

U nastavku teksta izlažu se detaljniji podatci o sudionicima onoga dijela ispitivanja kojim se ispitao strah od čitanja na engleskome i njemačkome jeziku. Tablica 5.1. prikazuje sastav uzorka po školama. 
Tablica 5.1. Pregled broja sudionika istraživanja za engleski jezik $\left(N_{e_{-} s_{-} m}\right)$ i njemački jezik $\left(N_{n j \_s \_}\right)$po školama

\begin{tabular}{lll}
\hline Škola & \multicolumn{2}{c}{ Broj sudionika (\%) } \\
& engleski & njemački \\
\hline Gimnazija Dubrovnik & $20(12,7 \%)$ & $22(14,2 \%)$ \\
Turistička i ugostiteljska škola (TUŠ) & $31(19,7 \%)$ & $33(21,3 \%)$ \\
$\begin{array}{l}\text { Dubrovnik } \\
\text { Gimnazija Metković }\end{array}$ & $91(58 \%)$ & $83(53,5 \%)$ \\
$\begin{array}{l}\text { Srednja škola fra Andrije Kačića Miošića } \\
\text { Ploče }\end{array}$ & $15(9,6 \%)$ & $17(11 \%)$ \\
Ukupno (\%) & & \\
\hline
\end{tabular}

Tablica 5.2. prikazuje sastav uzorka po razredima za engleski i njemački jezik. U razredima Gimnazije Metković, Gimnazije Dubrovnik i Srednje škole fra Andrije Kačića Miošića Ploče istraživanjem su bili obuhvaćeni svi učenici koji uče engleski i njemački jezik, a to su svi učenici navedenih razreda. Iz tri razreda Turističke i ugostiteljske škole Dubrovnik $\mathrm{u}$ istraživanje su bili uključeni oni učenici koji uče engleski jezik kao prvi strani jezik, a njemački su izabrali u prvome razredu srednje škole kao drugi strani jezik.

Tablica 5.2. Pregled broja sudionika istraživanja za engleski jezik $\left(N_{e_{-} s_{-} m}\right)$ i njemački jezik $\left(N_{n j \_s} m\right)$ po razredima

\begin{tabular}{lll}
\hline \multicolumn{1}{c}{ Razred i škola } & \multicolumn{2}{c}{ Broj sudionika (\%) } \\
& engleski & njemački \\
\hline 4A Gimnazija Dubrovnik & $20(12,7 \%)$ & $22(14,2 \%)$ \\
4B TUŠ Dubrovnik & $10(6,4 \%)$ & $10(6,5 \%)$ \\
4C TUŠ Dubrovnik & $11(7 \%)$ & $13(8,4 \%)$ \\
4D TUŠ Dubrovnik & $10(6,4 \%)$ & $10(6,5 \%)$ \\
4A Gimnazija Metković & $22(14 \%)$ & $17(11 \%)$ \\
4B Gimnazija Metković & $26(16,6 \%)$ & $23(14,8 \%)$ \\
4C Gimnazija Metković & $21(13,4 \%)$ & $21(13,5 \%)$ \\
4D Gimnazija Metković & $22(14 \%)$ & $22(14,2 \%)$ \\
4B Srednja škola fra Andrije Kačića Miošića & $15(9,5 \%)$ & $17(11 \%)$ \\
Ploče & & \\
Ukupno (\%) & $\mathbf{1 5 7}(\mathbf{1 0 0 \% )}$ & $\mathbf{1 5 5}(\mathbf{1 0 0 \% )}$ \\
\hline
\end{tabular}

Sastav uzorka u odnosu na spol prikazan je u tablici 5.3. iz koje je vidljivo da je za engleski i za njemački jezik ujednačena zastupljenost sudionika istraživanja muškoga i ženskoga spola. 
Tablica 5.3. Pregled broja sudionika istraživanja za engleski jezik $\left(N_{e_{-} s_{-} m}\right)$ i njemački jezik $\left(N_{n j \_s} s_{-}\right)$u odnosu na spol

\begin{tabular}{lll}
\hline Spol & \multicolumn{2}{c}{ Broj sudionika (\%) } \\
& engleski & njemački \\
\hline muški & $56(35,7 \%)$ & $52(33,5 \%)$ \\
ženski & $101(64,3 \%)$ & $103(66,5 \%)$ \\
Ukupno (\%) & $\mathbf{1 5 7 ( 1 0 0 \% )}$ & $\mathbf{1 5 5 ( 1 0 0 \% )}$ \\
\hline
\end{tabular}

Za sudionike istraživanja za engleski jezik prosječna duljina učenja engleskoga jezika iznosi oko 12 godina (v. tablicu 5.4.), te gotovo svi sudionici engleski jezik uče 12 godina, dakle od prvoga razreda osnovne škole (v. tablicu 5.5.).

Tablica 5.4. Duljina učenja engleskoga jezika

\begin{tabular}{ll}
\hline $\begin{array}{l}\text { Statistički } \\
\text { pokazatelj } \\
\left(\boldsymbol{N}_{e_{\_} \_m=157}\right)\end{array}$ & Vrijednost \\
\hline $\begin{array}{l}\text { Aritmetička } \\
\text { sredina }(A S)\end{array}$ & 11,87 \\
Medijan & 12,00 \\
Minimum & 9 \\
Maksimum & 12 \\
\hline
\end{tabular}

Tablica 5.5. Broj godina učenja engleskoga jezika

\begin{tabular}{lcc}
\hline $\begin{array}{l}\text { Broj godina } \\
\text { učenja } \\
\text { engleskoga jezika }\end{array}$ & Frekvencija & $\%$ \\
\hline 9 & 6 & 3,8 \\
10 & 1 & 0,6 \\
12 & 150 & 95,5 \\
Ukupno & $\mathbf{1 5 7}$ & $\mathbf{1 0 0 , 0}$ \\
\hline
\end{tabular}

Za sudionike istraživanja za njemački jezik prosječna duljina učenja njemačkoga jezika je skoro sedam godina (v. tablicu 5.6.). Iz tablice 5.7. vidljivo je da gotovo polovica sudionika uči njemački devet godina, dakle od četvrtoga razreda osnovne škole, a nešto manje od polovice sudionika uči njemački ukupno četiri godine, dakle od prvoga razreda srednje škole. Svi sudionici su u prvome razredu srednje škole počeli učiti njemački jezik od početne razine. 
Tablica 5.6. Duljina učenja njemačkoga jezika

\begin{tabular}{ll}
\hline $\begin{array}{l}\text { Statistički } \\
\text { pokazatelj } \\
\left(\boldsymbol{N}_{\left.\boldsymbol{n}{ }_{j} \_\boldsymbol{m}=\mathbf{1 5 5}\right)}\right.\end{array}$ & Vrijednost \\
\hline $\begin{array}{l}\text { Aritmetička } \\
\text { sredina }(A S)\end{array}$ & 6,94 \\
Medijan & 9,00 \\
Minimum & 3 \\
Maksimum & 12 \\
\hline
\end{tabular}

Tablica 5.7. Broj godina učenja njemačkoga jezika

\begin{tabular}{lcc}
\hline $\begin{array}{l}\text { Broj godina } \\
\text { učenja } \\
\text { njemačkoga } \\
\text { jezika }\end{array}$ & Frekvencija & \% \\
\hline 3 & & \\
4 & 1 & 0,6 \\
7 & 61 & 39,4 \\
8 & 1 & 0,6 \\
9 & 9 & 5,8 \\
12 & 82 & 52,9 \\
Ukupno & 1 & 0,6 \\
\hline
\end{tabular}

\subsubsection{Postupak}

Autorica je najprije zatražila od voditeljice PDS Glotodidaktike Filozofskoga fakulteta u Zagrebu izdavanje potvrde o znanstvenoj svrsi rada i istraživanja, koja je sadržavala i preporuku voditeljice za provođenje istraživanja u ciljanoj populaciji. Nakon toga autorica je na osnovi dobivene potvrde, a s cilju provođenja istraživanja stupila u kontakt sa stručnim službama i ravnateljima Ekonomske i trgovačke škole Dubrovnik, Gimnazije Dubrovnik, Gimnazije Metković, Srednje škole fra Andrije Kačića Miošića Ploče i Turističke i ugostiteljske škole Dubrovnik. Nakon dobivenih suglasnosti ravnatelja, pedagoga, razrednika i nastavnika u spomenutim školama, autorica je u suradnji s njima napravila plan provedbe istraživanja.

Diskusija u fokus grupi za engleski jezik obavljena je 25. svibnja 2016. godine tijekom redovite nastave 4. i 5. sat u poslijepodnevnoj smjeni, a diskusija u fokus grupi za njemački jezik 26. svibnja 2016. godine tijekom redovite nastave 4. i 5. sat u poslijepodnevnoj smjeni. 
Za potrebe provođenja ovoga dijela istraživanja Turistička i ugostiteljska škola Dubrovnik ljubazno je ustupila korištenje školske knjižnice gdje su učenici sjedali polukružno prema vlastitome izboru mjesta. Takav raspored sjedanja omogućio je učenicima i moderatorici uravnoteženu interakciju, pri kojoj je svaki učenik mogao jasno čuti i vidjeti drugoga sudionika i u prikladnome trenutku izraziti svoje stavove, osjećaje, vjerovanja i iskustva. Diskusija se vodila prema unaprijed pripremljenome nizu pitanja koja su sudionicima omogućila fleksibilnost pri davanju odgovora.

Moderatorica (autorica ovoga rada) mogla je vidjeti sve sudionike istraživanja i s podjednakom pažnjom pratiti izlaganje svih sudionika, potičući njihovu interakciju. Uz moderatoricu i sudionike fokus grupe, diskusiji je prisustvovala još jedna profesorica stranih jezika, kolegica moderatorice, koja je bila je upućena u cilj istraživanja. Njezin je zadatak bio detaljno vođenje bilješki kako bi se moderatorica mogla posvetiti vođenju diskusije. Sudionici su dobili upute u kojima su upozoreni da s pažnjom slušaju ostale sudionike, te da se bez nametanja i ne prekidajući drugoga sudionika uključuju u diskusiju. Interakcija među sudionicima fokus grupe potiče diskusiju pri kojoj jedan sudionik reagira na komentare drugoga sudionika. Takva grupna dinamika opisuje se kao sinergija grupnoga efekta te omogućuje da se u određene teme razgovora dobije dublji uvid s različitih gledišta koji ne bi bio moguć pri vođenju pojedinačnih razgovora sa sudionicima (Berg, 2001). Ugodna i mirna atmosfera školske knjižnice s pogledom na more pridonijela je opuštenome ozračju u kojemu su diskusije u fokus grupama obavljene.

Preliminarno istraživanje provedeno je tijekom redovite nastave engleskoga i njemačkoga jezika u razdoblju od ukupno šest tjedana tijekom travnja i svibnja 2017. godine u Ekonomskoj i trgovačkoj školi Dubrovnik, Gimnaziji Dubrovnik, Gimnaziji Metković i Turističkoj i ugostiteljskoj školi Dubrovnik. Svaki je učenik popunio Upitnik za ispitivanje straha od čitanja na engleskome jeziku i Upitnik za ispitivanje straha od čitanja na njemačkome jeziku. Sudionici su bili upoznati s ciljem istraživanja. Sudjelovanje u istraživanju bilo je dobrovoljno, a identitet svih sudionika zaštićen.

Glavno istraživanje provedeno je u periodu od veljače do travnja 2018. godine. Sudionici su najprije bili upoznati s ciljem istraživanja i zamoljeni da odgovorno pristupe sudjelovanju u istraživanju. Autorica ih je uputila na to da je ispitivanje dobrovoljno i anonimno. Budući da je svaki sudionik trebao ispuniti više dijelova upitnika (Opći dio upitnika, 
Upitnik za ispitivanje straha od čitanja na engleskome jeziku, Upitnik za ispitivanje straha od čitanja na njemačkome jeziku, Upitnik o motivaciji za učenje engleskoga jezika i Upitnik o motivaciji za učenje njemačkoga jezika) i dva testa (Razumijevanje teksta čitanjem - engleski jezik i Razumijevanje teksta čitanjem - njemački jezik), ispunjavanje upitnika i rješavanje testova organiziralo se u dvama terminima, od kojih je svaki trajao dva školska sata. Jedan termin od 90 minuta organizirao se za ispitivanje za engleski jezik, drugi termin za ispitivanje za njemački jezik. Pri ispunjavanju upitnika i rješavanju testova sudionici su koristili šesteroznamenkaste šifre. Svaki je sudionik šest praznih mjesta šifre popunio tako da su prva dva mjesta sadržavala četiri broja, a preostala dva po jedno veliko tiskano slovo. Na prvo i drugo prazno mjesto sudionik je upisao brojkom dan u mjesecu za majčin datum rođenja (za datume prije desetoga dana u mjesecu upisuje se 0 na prvo prazno mjesto), a na treće i četvrto i prazno mjesto upisao je brojkom mjesec za majčin datum rođenja (za mjesece prije listopada upisuje se 0 na treće prazno mjesto). Na peto prazno mjesto upisao je inicijal imena majke, na šesto prazno mjesto inicijal djevojačkoga prezimena majke. Primjer: za datum rođenja 2. travnja, ime majke Ana, djevojačko prezime Horvat, upisuje se 0204AH. Sudionici su dobili usmenu i pismenu uputu za rješavanje upitnika i testova. Zamoljeni su da pažljivo pročitaju svaku tvrdnju upitnika, te da na kraju provjere jesu li izostavili neku tvrdnju. Kod rješavanja testova upućeni su na to da pažljivo čitaju i rješavaju zadatke. Sudionici koji su sjedili u istoj klupi dobili su dvije različite verzije testova (A verzija i B verzija) kako ne bi surađivali pri rješavanju testa. Sudionicima je objašnjeno da će rezultati testova biti poznati samo autorici i da neće imati utjecaja na njihovu ocjenu iz engleskoga i njemačkoga jezika. Bilo je potrebno oko 20 minuta da sudionici ispune upitnike i oko 60 minuta da riješe test razumijevanja teksta čitanjem. Deset upitnika i testova nije bilo valjano ispunjeno, pa su uklonjeni iz obrade. 


\subsubsection{Instrumenti}

U istraživanju je upotrijebljeno više mjernih instrumenata kako bi se ispitao strah od čitanja, motivacija za učenje i razumijevanje teksta čitanjem na engleskome i njemačkome jeziku. Glavni instrumenti za prikupljanje podataka u ovom istraživanju bili su upitnici. Upitnik je često korišten instrument $\mathrm{u}$ istraživanjima straha od stranoga jezika, straha od čitanja na stranome jeziku i istraživanjima motivacije. U ovom potpoglavlju iznijet će se pregled svih korištenih mjernih instrumenta, a u poglavlju 5.4. Rezultati detaljnije će se opisati konstrukcija Upitnika o strahu od čitanja na engleskome/njemačkome jeziku za provođenje preliminarnoga istraživanja te konstrukcija Upitnika o strahu od čitanja na engleskome/njemačkome jeziku za provođenje glavnoga istraživanja.

Upitnik za mjerenje straha od čitanja na engleskome/njemačkome jeziku koji je korišten u preliminarnome istraživanju sadržavao je dva dijela, a upitnik za mjerenje straha od čitanja na engleskome/njemačkome jeziku koji je korišten u glavnome istraživanju sadržavao je tri dijela.

Prvi dio upitnika koji su sudionici popunjavali u preliminarnome istraživanju bio je Opći dio upitnika i sadržavao je podatke o spolu, o materinskome jeziku, o zaključnim ocjenama iz engleskoga/njemačkoga jezika, podatke o općem uspjehu u prethodnome razredu, o duljini učenja engleskoga/njemačkoga jezika, o iskustvu učenja ostalih stranih jezika, o učenju engleskoga/njemačkoga jezika izvan škole te podatke o boravku u zemlji/zemljama engleskoga/njemačkoga govornoga područja (v. prilog 4 prvi dio i prilog 5 prvi dio).

Drugi dio upitnika u preliminarnome istraživanju bio je Upitnik o strahu od čitanja na engleskome/njemačkome jeziku koji je sadržavao 40 čestica (v. prilog 4 drugi dio i prilog 5 drugi dio). Čestice upitnika sudionici su vrednovali na Likertovoj skali od 1 do 5 (1-uopće se ne odnosi na mene, 2-uglavnom se ne odnosi na mene, 3-niti se odnosi niti se ne odnosi na mene, 4-uglavnom se odnosi na mene, 5 -u potpunosti se odnosi na mene).

Prvi dio upitnika koji su sudionici popunjali u glavnome istraživanju bio je Opći dio upitnika i sadržavao je podatke o spolu, o materinskome jeziku, o općem uspjehu u prvome, drugome i trećemu razredu srednje škole, podatke o zaključnim ocjenama iz engleskoga/njemačkoga jezika u prvome, drugome i trećemu razredu srednje škole, podatke o 
iskustvu učenja ostalih stranih jezika, o duljini učenja engleskoga/njemačkoga jezika, o učenju engleskoga/njemačkoga jezika izvan škole te podatke o boravku u zemlji/zemljama engleskoga/njemačkoga govornoga područja (v. prilog 6 prvi dio i prilog 7 prvi dio).

Drugi dio upitnika u glavnome istraživanju bio je Upitnik o strahu od čitanja na engleskome/njemačkome jeziku koji je sadržavao 25 čestica (v. prilog 6 drugi dio i prilog 7 drugi dio). Čestice upitnika sudionici su vrednovali na Likertovoj skali od 1 do 5 (1-uopće se ne odnosi na mene, 2-uglavnom se ne odnosi na mene, 3-niti se odnosi niti se ne odnosi na mene, 4-uglavnom se odnosi na mene, 5 -u potpunosti se odnosi na mene).

Upitnik o strahu od čitanja na engleskome/njemačkome jeziku koji je korišten u preliminarnome istraživanju i Upitnik o strahu od čitanja na engleskome/njemačkome jeziku koji je korišten u glavnome istraživanju konstruirani su za potrebe ovoga rada, a njihove deskriptivne i metrijske karakteristike opisane su u poglavlju 5.4. Rezultati.

Treći dio upitnika u glavnome istraživanju bio je Upitnik o motivaciji za učenje engleskoga/njemačkoga jezika. Sudionici su riješili Test razumijevanja teksta čitanjem za engleski jezik i Test razumijevanja teksta čitanjem za njemački jezik.

Inačica mjernoga instrumenta za mjerenje straha od čitanja na engleskome jeziku u preliminarnome istraživanju prikazana je u prilogu 4, a inačica mjernoga instrumenta za mjerenje straha od čitanja na njemačkome jeziku u preliminarnome istraživanju prikazana je u prilogu 5.

Inačica mjernoga instrumenta za mjerenje straha od čitanja na engleskome jeziku i mjerni instrument za ispitivanje motivacije za učenje engleskoga jezika koji su korišteni u glavnome istraživanju prikazani su u prilogu 6 , dok su inačica mjernoga instrumenta za mjerenje straha od čitanja na njemačkome jeziku i mjerni instrument za ispitivanje motivacije za učenje njemačkoga jezika prikazani u prilogu 7. 


\subsubsection{Upitnik o motivaciji za učenje engleskoga/njemačkoga jezika}

Za ispitivanje motivacije za učenje engleskoga i njemačkoga jezika korišten je Upitnik o motivaciji za učenje engleskoga/njemačkoga jezika koji je konstruiran i validiran u Mađarskoj (Fekete i sur., 1999), a zatim validiran u istraživanju u Hrvatskoj (Projekt MZOŠ-a br. 130793: Engleski jezik u Hrvatskoj). Upitnik je dio instrumenta za mjerenje afektivnih karakteristika sudionika koji je korišten u Mađarskoj i Hrvatskoj i sastoji se od triju dijelova. Prvi dio toga instrumenta je Upitnik za ispitivanje stavova i motivacije za učenje engleskoga/njemačkoga jezika, koji se sastoji od 14 tvrdnji kojima se ispituju stavovi i motivacija za učenje engleskoga, odnosno njemačkoga jezika. Čestice upitnika sudionici su vrednovali na Likertovoj skali od 1 do 5 (1-neistinito, uopće nije tako, 2-uglavnom neistinito, često nije tako, 3-nisam siguran, ne mogu se odlučiti, 4-uglavnom istinito, često je tako, 5-istinito, uvijek je tako). Čestice u engleskoj i njemačkoj inačici upitnika izražavaju isti sadržaj tvrdnji, ali se u engleskoj inačici tvrdnja odnosi na engleski jezik, a u njemačkoj inačici na njemački jezik. Za Upitnik o motivaciji za učenje engleskoga jezika (Cronbachov $\alpha=, 872)$ vidi prilog 6 treći dio, za Upitnik o motivaciji za učenje njemačkoga jezika (Cronbachov $\alpha=, 794)$ vidi prilog 7 treći dio.

\subsubsection{Test razumijevanja teksta čitanjem za engleski jezik $i$ Test razumijevanja teksta čitanjem za njemački jezik}

Pri ispitivanju uspjeha u čitanju na engleskome/njemačkome jeziku korišteni su testovi razumijevanja teksta čitanjem za engleski jezik i za njemački jezik. Testove je izradio i validirao mađarski tim znanstvenika u sklopu projekta reformiranja završnih ispita (Fekete i sur., 1999; Alderson i sur., 2000). Budući da su ti testovi validirani i korišteni u Hrvatskoj u sklopu projekta Engleski jezik u Hrvatskoj (Projekt MZOŠ-a br. 130793), te budući da se tim testovima ispituje komunikacijska kompetencija koja je propisana i hrvatskim nacionalnim kurikulumom, smatralo se da su testovi koji su korišteni za srednjoškolski uzorak u navedenome projektu u Hrvatskoj primjereni i za ovo istraživanje. Mađarski testovi uključuju mjerenje svih četiriju jezičnih vještina, a njima se testiraju kontekstualna znanja i sposobnosti potrebne za uspješnu jezičnu uporabu pri izvođenju komunikacijskih zadataka (Bachman i Palmer, 1996, prema Mihajljević Djigunović i Bagarić, 2007a). Za potrebe ovoga istraživanja korišteni su samo testovi razumijevanja teksta čitanjem jer je cilj bio testirati vještinu čitanja s razumijevanjem, a testove je ocijenila autorica. 
Test kojim je mjereno razumijevanje teksta čitanjem na engleskome jeziku sastoji se od ukupno pet zadataka koji pojedinačno imaju deset ili jedanaest pitanja. U svakome zadatku riješeno je prvo pitanje, označeno slovom A, kako bi učenicima bilo jasno kako treba upisivati rješenja. U A verziji testa prvi zadatak sadržava devet pitanja (B-J), kojima učenici trebaju pridružiti točne odgovore. Pitanja su kratka i sastoje se od jedne rečenice, a odgovori su duži i svaki predstavlja jedan odlomak teksta. Jedan odgovor je višak. Pitanja i odgovori predstavljaju autentičan intervju koji novinar vodi s televizijskim snimateljem o njegovu poslu. Drugi zadatak sastoji se od devet pitanja (B-J). Za svako pitanje ponuđeno je tri, četiri ili pet odgovora, od kojih učenik treba izabrati jedan točan. Pitanja su vezana uz novinski tekst o jednome poznatome američkome filmu. Treći zadatak sadržava deset pitanja (B-K). Za svako pitanje ponuđeno je četiri odgovora, od kojih je samo jedan točan. Odgovori na pitanja nalaze se u novinskome tekstu o temi vezanoj uz jedan važan događaj iz moderne američke i svjetske povijesti. Četvrti zadatak sadržava devet oglasa. Svakome oglasu nedostaje jedan dio teksta. Dijelovi teksta koji nedostaju ponuđeni su u isječcima teksta od B do J. Učenici trebaju pridružiti svakome oglasu odgovarajući dio teksta koji nedostaje. Peti zadatak sadržava deset opisa knjiga kojima treba pridružiti odgovarajuće naslove navedene od B do K. Jedan opis knjige je višak. B verzija testa sadržava iste zadatke, ali su posloženi drugačijim redoslijedom. Prvi zadatak iz A verzije je drugi u B verziji, drugi zadatak je treći, treći zadatak je prvi, četvrti zadatak je peti, a peti zadatak je četvrti zadatak u B verziji.

Test kojim je mjereno razumijevanje teksta čitanjem na njemačkome jeziku sastoji se od ukupno pet zadataka, koji pojedinačno imaju šest, osam ili deset pitanja. U svakome zadatku je riješeno prvo pitanje, označeno slovom A, kako bi sudionicima bilo jasno kako treba upisivati rješenja. U A verziji testa prvi zadatak sadržava osam rečenica (B-I), koje su preuzete iz autentičnoga novinskoga teksta koji predstavlja kratak životopis austrijske carice Sisi. Rečenice nisu napisane kronološkim redoslijedom te sudionici trebaju označiti kronološki slijed životopisa. U drugom zadatku učenici trebaju povezati šest ponuđenih pitanja (B-G) $\mathrm{S}$ odgovarajućim odgovorima. Pitanja su kratka i sastoje se od jedne rečenice, a odgovori su duži i svaki predstavlja odlomak teksta. Jedno pitanje je višak. Pitanja i odgovori predstavljaju autentičan novinski tekst o bolesti koja se može prenijeti s životinja na čovjeka. Treći zadatak sadržava osam pitanja (B-I). Za svako pitanje ponuđeno je tri ili četiri odgovora, od kojih sudionik treba izabrati jedan točan. Odgovori na pitanja nalaze se u novinskome tekstu koji opisuje borbu protiv iskorištavanja tuljanova krzna i ugrožavanja tuljana za proizvodnju odjeće. 
Četvrti zadatak sadržava deset tvrdnji (B-K), uz koje je autentičan novinski tekst. Svakoj tvrdnji treba pridružiti ime jedne ili više osoba koje su izrazile mišljenje izraženo tvrdnjom. U tekstu se nalaze mišljenja šest srednjoškolaca o korištenju mobitela. Peti zadatak sastoji se od osam oglasa. Svakome oglasu nedostaje jedan dio teksta. Dijelovi teksta koji nedostaju ponuđeni su od B do I. Sudionici trebaju pridružiti svakome oglasu odgovarajući dio teksta koji nedostaje. Jedan dio teksta je višak. B verzija testa sadržava iste zadatke, ali su posloženi drugačijim redoslijedom. Prvi zadatak iz A verzije drugi je u B verziji, drugi zadatak je peti, treći zadatak je treći, četvrti zadatak je četvrti, a peti zadatak je prvi zadatak u B verziji.

Opisani testovi standardizirani su testovi komunikacijske kompetencije u engleskome i njemačkome jeziku i usporedivi su za engleski i njemački jezik jer se formalno i sadržajno podudaraju (Bagarić, 2007).

$\mathrm{Za}$ ispitivanje razumijevanja teksta čitanjem za engleski jezik korišten je test u A verziji (v. prilog 8) i test u B verziji (v. prilog 9). Za ispitivanje razumijevanja teksta čitanjem za njemački jezik korišten je test u A verziji (v. prilog 10) i test u B verziji (v. prilog 11).

\subsubsection{Metode obrade $\mathrm{i}$ analize podataka}

Podatci prikupljeni u preliminarnome istraživanju i u glavnome istraživanju uneseni su u statistički programski paket SPSS. Metode obrade i analize podataka u svrhu postizanja odgovora na pojedina istraživačka pitanja, odnosno testiranja hipoteza opisane su u nastavku teksta.

Provedene su deskriptivne analize svih čestica i utvrđivanje pouzdanosti mjernih instrumenta korištenih u preliminarnome istraživanju, pri čemu je korištena metoda interne konzistencije (Cronbachov $\alpha$ ).

Na podatcima prikupljenim u glavnome istraživanju provedene su i deskriptivne analize varijabli koje su predstavljale mjere ključnih koncepata u ovome radu, odnosno ukupnih rezultata na upitniku o strahu od čitanja i upitniku o motivaciji, te testu razumijevanja teksta čitanjem. Deskriptivna analiza uključivala je i analizu frekvencija za nominalne varijable (spol, škola), a za ordinalne i kvaziintervalne varijable analiza je uključivala statističke pokazatelje 
aritmetičke sredine, medijana, standardne devijacije, asimetričnosti i zaobljenosti distribucija ukupnih rezultata sudionika na upitniku o strahu od čitanja, upitniku o motivaciji, testu razumijevanja teksta čitanjem, te varijabli povezanih uz uspjeh iz engleskoga i njemačkoga jezika (zaključne ocjene iz engleskoga, odnosno njemačkoga jezika u prva tri razreda srednje škole i prosjeka tih triju ocjena).

U svrhu testiranja hipoteze 1 (H1) provedena je korelacijska analiza. Najprije je odabran odgovarajući pokazatelj povezanosti među konstruktima. Stoga je provedeno testiranje normaliteta distribucija Kolmogorov-Smirnovljevim testom. Ukoliko je jedna od varijabli pokazala statistički značajno odstupanje od normalne distribucije, kao odgovarajuća mjera povezanosti s bilo kojom drugom varijablom korišten je Spearmanov koeficijent korelacije. Ako obje varijable, povezanost kojih je od interesa u ovom radu, nisu pokazale statistički značajno odstupanje od normalne distribucije, odgovarajuća mjera povezanosti je Pearsonov koeficijent korelacije. Svi koeficijenti interpretirani su kao značajni ako je $p$-vrijednost bila jednaka ili manja od ,05. U ovome radu izvještavamo obje vrste korelacija, parametrijsku (Pearsonov koeficijent korelacije) i neparametrijsku (Spearmanov koeficijent korelacije) za sve parove varijabli, čak i u slučaju kad su obje varijable normalno distribuirane. Odabrali smo ovaj pristup zbog triju razloga. Prvo, čak ako je testiranje normaliteta distribucije pokazalo da ne postoji statistički značajno odstupanje od normalne distribucije, za većinu korištenih mjera vidljivo je da postoji asimetričnost. Dobivanje značajne razlike ovisi i o veličini uzorka (manji uzorak, manja vjerojatnost detektiranja razlike), a mi smo uglavnom raspolagali relativno malim uzorcima. Drugo, neke od varijabli su ordinalne (npr. školske ocjene) te je stoga primjerenije korištenje Spearmanova koeficijenta korelacije koji se temelji na rangiranju vrijednosti u svakoj varijabli. Naposljetku, Spearmanov koeficijent korelacije može biti prikladnija mjera povezanosti kod nekih nelinearnih oblika povezanosti među varijablama.

Testiranje hipoteze 2a (H2a) provedeno je faktorskom analizom (komponentnom analizom, tj. analizom glavnih komponenti) čestica upitnika o strahu od čitanja. Faktorska analiza omogućuje utvrđivanje latentnih varijabli koje leže u osnovi međusobne povezanosti manifestnih varijabli. Stoga ovaj postupak, uz omogućavanje redukcije dimenzionalnosti i odgovarajućega odabira čestica, omogućuje i usporedbu sličnosti dvaju srodnih koncepata u latentnome prostoru. 
Kao prvi korak, provjereno je jesu li matrice pogodne za faktorizaciju s pomoću Bartettova testa sfericiteta i provedeno je testiranje adekvatnosti uzorka pomoću KeyserMeyer-Olkinove mjere. Potom je broj značajnih glavnih komponenti određen GuttmanKaisserovim kriterijem (koji se temelji na karakterističnom korijenu većem od 1).

Koristili smo Oblimin rotaciju za utvrđivanje odnosa među latentnim varijablama, koja ne pretpostavlja ortogonalnost među faktorima. Kod neortogonalnih faktorskih analiza kod kojih se dozvoljava da faktori međusobno koreliraju zasićenja su prikazana u matrici obrazaca dok su korelacije između varijabli i faktora prikazane u strukturnoj matrici. O razlikama $\mathrm{u}$ strukturi straha od čitanja na engleskome i njemačkome jeziku zaključivali smo na temelju usporedbi faktorskih rješenja mjernoga instrumenta za oba jezika.

Budući da je svaki sudionik imao rezultat za dva upitnika straha s identičnim tvrdnjama, jedan za engleski, a drugi za njemački jezik, testiranje hipoteze $2 \mathrm{~b}(\mathrm{H} 2 \mathrm{~b})$ provedeno je dvosmjernim t-testom za zavisni uzorak, uključujući testiranje pretpostavke o jednakosti varijance među dvjema distribucijama, ali i neparametrijskim testom (Wilcoxon Rank testom za zavisne uzorke).

Za testiranje hipoteze $3(\mathrm{H} 3)$ i hipoteze $4(\mathrm{H} 4)$ provedeni su dvosmjerni t-testovi za dva nezavisna uzorka s obzirom na spol, odnosno s obzirom na srednjoškolsko usmjerenje. U slučaju kad je zavisna varijabla statistički odstupala od normalne distribucije, dodatno je provedeno testiranje neparametrijskim testom (Medijan test za nezavisne uzorke).

Zbog ponovljenoga testiranja razlika na istom uzorku i posljedične inflacije pogreške tipa 1 u statističkom zaključivanju, koristili smo Bonferroni korekciju za određivanje kriterija (razine $\mathrm{p}$ vrijednosti) za odbacivanje nul hipoteze. Budući da je provedeno ukupno pet testiranja statističke značajnosti razlika $(m)$, odabranu razinu značajnosti $p=.05(\propto)$ potrebno je korigirati koristeći sljedeću formulu: $\propto / m$. Stoga kod svake od pet hipoteza, nakon Bonferronijeve korekcije zbog multitestiranja, nul-hipoteza je odbačena ako je $p$ vrijednost manja od 0,01 .

Hipoteza 5 (H5) testirana je prema postupku predloženom od strane Barona i Kennyja (1986). Taj postupak se temelji na seriji regresijskih analiza i detaljnije je opisan u poglavlju o rezultatima testiranja hipoteze 5 . 
Naposljetku, provedene su dodatne višestruke regresijske analize u svrhu predviđanja straha od čitanja na temelju relevantnih čimbenika obuhvaćenih u ovom istraživanju. Analize su napravljene odvojeno za engleski jezik i za njemački jezik.

Statistička analiza rezultata provedena je s pomoću programskoga paketa SPSS za Windows 11.0., a neke od vizualizacija su napravljene u $\mathrm{R}$ programu. 


\subsection{Rezultati}

\subsubsection{Deskriptivni pokazatelji}

U sljedećih šest potpoglavlja prikazani su temeljni deskriptivni pokazatelji za Upitnik o strahu od čitanja na engleskome jeziku, Upitnik o strahu od čitanja na njemačkome jeziku, Upitnik o motivaciji za učenje engleskoga jezika, Upitnik o motivaciji za učenje njemačkoga jezika, test Razumijevanje teksta čitanjem-engleski jezik i test Razumijevanje teksta čitanjemnjemački jezik koji su korišteni u glavnome istraživanju.

\subsubsection{Deskriptivni pokazatelji za strah od čitanja na engleskome jeziku}

Tablica 5.8. pokazuje temeljne deskriptivne pokazatelje Upitnik o strahu od čitanja na engleskome jeziku koji je korišten u glavnome istraživanju.

Tablica 5.8. Deskriptivna statistika za čestice Upitnika o strahu od čitanja na engleskome jeziku

\begin{tabular}{lcccc}
\hline \multicolumn{1}{c}{ Čestice } & Min. & Maks. & $\boldsymbol{A S}$ & \multicolumn{1}{c}{$\boldsymbol{S D}$} \\
\hline $\begin{array}{l}\text { 1. Osjećam se nervozno dok čitam naglas na } \\
\text { engleskome pred drugima. }\end{array}$ & 1 & 5 & 1,93 & 1,220 \\
$\begin{array}{l}\text { 2. Kad čitam naglas na engleskome pred drugima, } \\
\text { uznemirim se i glas mi se promijeni i drhti. }\end{array}$ & 1 & 5 & 1,84 & 1,212 \\
$\begin{array}{l}\text { 3. Uznemiruje me kad pri čitanju u sebi nađem na } \\
\text { riječ ili izraz koji ne razumijem. }\end{array}$ & 1 & 5 & 2,27 & 1,283 \\
$\begin{array}{l}\text { 4. Ako trebam odabrati između čitanja, pisanja, } \\
\text { slušanja i govora na engleskome jeziku, najteže mi }\end{array}$ & $\mathbf{1}$ & $\mathbf{5}$ & $\mathbf{1 , 5 5}$ & $\mathbf{1 , 0 0 3}$ \\
$\begin{array}{l}\text { je čitanje. } \\
\text { 5. Osjećam se ugodno dok čitam naglas na } \\
\text { engleskome jeziku. }\end{array}$ & $\mathbf{1}$ & $\mathbf{5}$ & $\mathbf{2 , 6 1}$ & $\mathbf{1 , 2 9 9}$ \\
$\begin{array}{l}\text { 6. Brinem se kako ću u sebi pročitati duge tekstove na } \\
\text { engleskome. }\end{array}$ & 1 & 5 & 1,82 & 1,112 \\
$\begin{array}{l}\text { 7. Zbunjuje me nepodudarnost između načina } \\
\text { pisanja i čitanja na engleskome jeziku. }\end{array}$ & $\mathbf{1}$ & $\mathbf{5}$ & $\mathbf{1 , 6 1}$ & $\mathbf{9 7 2}$ \\
$\begin{array}{l}\text { 8. Čini me nervoznim/om kad čitam u sebi i razumijem } \\
\text { gotovo sve riječi u rečenici, ali ne razumijem značenje } \\
\text { rečenice. }\end{array}$ & 1 & 5 & 2,04 & 1,270 \\
$\begin{array}{l}\text { 9. Strah me da nikada neću dobro naučiti čitati } \\
\text { engleski jer je čitanje na engleskome teško. }\end{array}$ & $\mathbf{1}$ & $\mathbf{5}$ & $\mathbf{1 , 4 5}$ & $\mathbf{9 7 7}$ \\
$\begin{array}{l}\text { 10. Postajem nervozan/na kad pri čitanju u sebi naiđem } \\
\text { na nepoznatu gramatičku konstrukciju. }\end{array}$ & 1 & 5 & 1,91 & 1,179 \\
$\begin{array}{l}\text { 11. Kad čitam naglas na engleskome jeziku, osjećam } \\
\text { se opušteno i siguran/na u sebe. }\end{array}$ & 1 & 5 & 2,54 & 1,389 \\
$\begin{array}{l}\text { 12. Dok čitam naglas na engleskome pred drugima, } \\
\text { srce mi jače lupa. }\end{array}$ & 1 & 5 & 2,02 & 1,201 \\
\end{tabular}


13. Postupci nastavnika/ce ometaju me i zbunjuju dok čitam naglas na engleskome.

14. Ako pri čitanju u sebi naiđem na riječ ili riječi koje ne razumijem, nastavljam čitati a da se nisam uznemirio/la.

15. Smeta me kad me nastavnik/ca prekida i ispravlja dok čitam naglas.

16. Dok čitam naglas na engleskome, brinem se kako ću izgovoriti pojedine riječi.

17. Nervozan/na sam kad čitam tekst koji nije zanimljiv.

18. Dok čitam naglas na engleskome pred drugima, osjećam da mi se znoje dlanovi.

19. Nervozniji/ja sam kad čitam naglas na engleskome nego kad pišem, slušam ili govorim.

20. Ako čitam tekst na engleskome o nepoznatoj temi, postajem nervozan/na.

21. Smeta me kad u tekstu naiđem na neki pojam iz britanske, američke ili druge kulture engleskoga govornoga područja koji mi nije poznat.

22. Uznemiruje me kad čitam u sebi tekst na engleskome, a nastavnik/ca nakon toga ocjenjuje zadatke razumijevanja pročitanoga.

23. Strah me da će me ostali učenici ismijavati jer ne čitam dobro.

24. Pri čitanju u sebi na engleskome zbunjuju me duge riječi koje je teško pročitati.

25. Osjećam se nesigurno kad čitam naglas na engleskome jer nemam dara za čitanje na engleskome.

\begin{tabular}{llll}
$\mathbf{1}$ & $\mathbf{5}$ & $\mathbf{1 , 6 2}$ & $\mathbf{1 , 0 4 1}$ \\
$\mathbf{1}$ & $\mathbf{5}$ & $\mathbf{2 , 7 3}$ & $\mathbf{1 , 4 6 6}$ \\
& & & \\
1 & 5 & 2,09 & 1,263 \\
$\mathbf{1}$ & $\mathbf{5}$ & $\mathbf{2 , 5 7}$ & $\mathbf{1 , 3 5 1}$ \\
1 & 5 & 2,13 & 1,265 \\
1 & 5 & 1,67 & 1,088 \\
1 & 5 & 2,04 & 1,221 \\
1 & 5 & 1,80 & 1,100 \\
1 & 5 & 1,92 & 1,107 \\
& & & \\
1 & 5 & 1,90 & 1,215 \\
& & & 1,278 \\
1 & 5 & 1,88 & 1,157 \\
1 & 5 & 2,04 & \\
1 & 5 & 1,80 & \\
\hline & & &
\end{tabular}

Min. =minimum, Maks. = maksimum, AS=aritmetička sredina, $S D=$ standardna devijacija

Rekodirane su sljedeće tvrdnje: 5. „Osjećam se ugodno dok čitam naglas na engleskome jeziku. “, 11. „Kad čitam naglas na engleskome jeziku, osjećam se opušteno i siguran/na u sebe. “ i 14. „Ako pri čitanju u sebi naiđem na riječ ili riječi koje ne razumijem, nastavljam čitati a da se nisam uznemirio/la.".

Najveće vrijednosti aritmetičkih sredina (tablica 5.8.) dobivene su za tvrdnje: 14. „Ako pri čitanju u sebi naiđem na riječ ili riječi koje ne razumijem, nastavljam čitati a da se nisam uznemirio/la. “ (rekodirano), 5. „Osjećam se ugodno dok čitam naglas na engleskome jeziku. “ (rekodirano) i 16. „Dok čitam naglas na engleskome, brinem se kako ću izgovoriti pojedine riječi. “. Najmanje vrijednosti aritmetičkih sredina zabilježene su za tvrdnje: 9. „Strah me da nikada neću dobro naučiti čitati engleski jer je čitanje na engleskome teško. “, 7. „Zbunjuje me nepodudarnost između načina pisanja i čitanja na engleskome jeziku. “ i 13. „Postupci nastavnika/ce ometaju me i zbunjuju dok čitam naglas na engleskome. “. 
Iz tablice 5.9. vidljivo je da je aritmetička sredina na razini upitnika 1,99, što ukazuje na nisku razinu straha od čitanja na engleskome jeziku. Najniža zabilježena vrijednost je 1,00, a najviša vrijednost $4,44 .{ }^{19}$

Tablica 5.9. Deskriptivna analiza

\begin{tabular}{ll}
\hline $\begin{array}{l}\text { Statistički } \\
\text { pokazatelj } \\
\left(\boldsymbol{N}_{\boldsymbol{e}_{\_}=\mathbf{1 5 7}}\right)\end{array}$ & Vrijednost \\
\hline $\mathrm{AS}$ & 1,9911 \\
Medijan & 1,8000 \\
$\mathrm{SD}$ & 0,74333 \\
Asimetričnost & 0,999 \\
Zaobljenost & 0,627 \\
Minimum & 1,00 \\
Maksimum & 4,44 \\
\hline AS=aritmetička sredina, SD=standardna devijacija
\end{tabular}

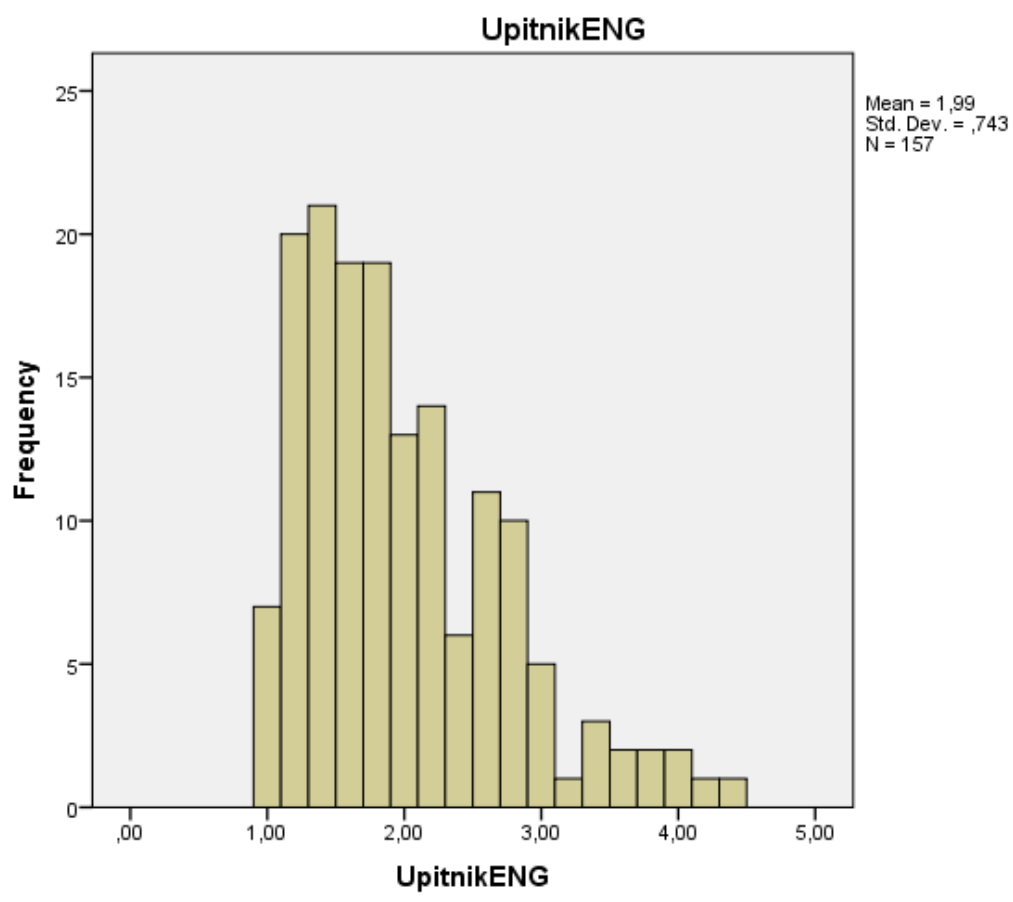

Slika 5.1. Distribucija ukupnoga rezultata za strah od čitanja na engleskome jeziku

\footnotetext{
${ }^{19}$ Napomena: Ukupan rezultat jednak je sumi svih tvrdnji podijeljen s ukupnim brojem tvrdnji izražen brojkom s dvije decimale. To je matematički ekvivalentno jednostavnoj sumi svih tvrdnji, jer su obje vrste određivanja kompozitnoga rezultata jednostavne linearne kombinacije. Međutim, korištenje prosjeka slaganja sa svim tvrdnjama umjesto jednostavnim zbrojem slaganja olakšava interpretaciju rezultata. Važno je napomenuti da ukoliko je za sudionika nedostajao odgovor u jednoj od čestica, ova metoda je ekvivalentna zamjeni nedostajućih vrijednosti s prosjekom odgovora pojedinoga sudionika na svim česticama (nakon rekodiranja).
} 
Histogram na slici 5.1. prikazuje distribuciju ukupnoga rezultata za strah od čitanja na engleskome jeziku. Primjenom Kolmogorov-Smirnovljeva testa normaliteta distribucije dobivena $p$ vrijednost iznosila je 0,026 , što ukazuje da postoji značajno odstupanje od normalne distribucije. Inspekcijom slike 5.1. i vrijednost asimetričnosti u tablici 5.9. vidimo da se radi o pozitivnoj asimetričnosti. Pozitivno asimetrična distribucija opisuje distribuciju koja ima više nižih vrijednosti i kod koje je desni dio „razvučen“. Potonje je rezultat manje frekvencije viših vrijednosti. Bez obzira na uzrok asimetričnosti, njezina značajnost uvjetuje da se u daljnjim analizama varijable straha od čitanja na engleskome jeziku preferiraju neparametrijski postupci koji ne počivaju na pretpostavci o normalnoj distribuciji.

\subsubsection{Deskriptivni pokazatelji za strah od čitanja na njemačkome jeziku}

Tablica 5.10. pokazuje temeljne deskriptivne pokazatelje za Upitnik o strahu od čitanja na njemačkome jeziku koji je korišten u glavnome istraživanju.

Tablica 5.10. Deskriptivna statistika za čestice Upitnika o strahu od čitanja na njemačkome jeziku

\begin{tabular}{|c|c|c|c|c|}
\hline Čestice & Min. & Maks. & $\mathbf{A S}$ & SD \\
\hline $\begin{array}{l}\text { 1. Osjećam se nervozno dok čitam naglas na } \\
\text { njemačkome pred drugima. }\end{array}$ & 1 & 5 & 2,36 & 1,289 \\
\hline $\begin{array}{l}\text { 2. Kad čitam naglas na njemačkome pred drugima, } \\
\text { uznemirim se i glas mi se promijeni i drhti. }\end{array}$ & 1 & 5 & 1,99 & 1,203 \\
\hline $\begin{array}{l}\text { 3. Uznemiruje me kad pri čitanju u sebi naiđem na riječ } \\
\text { ili izraz koji ne razumijem. }\end{array}$ & 1 & 5 & 2,54 & 1,325 \\
\hline $\begin{array}{l}\text { 4. Ako trebam odabrati između čitanja, pisanja, } \\
\text { slušanja i govora na njemačkome jeziku, najteže mi } \\
\text { je čitanje. }\end{array}$ & 1 & 5 & 1,94 & 1,327 \\
\hline $\begin{array}{l}\text { 5. Osjećam se ugodno dok čitam naglas na njemačkome } \\
\text { jeziku. }\end{array}$ & 1 & 5 & 3,34 & 1,170 \\
\hline $\begin{array}{l}\text { 6. Brinem se kako ću u sebi pročitati duge tekstove na } \\
\text { njemačkome. }\end{array}$ & 1 & 5 & 2,23 & 1,220 \\
\hline $\begin{array}{l}\text { 7. Zbunjuje me nepodudarnost između načina pisanja i } \\
\text { čitanja na njemačkome jeziku. }\end{array}$ & 1 & 5 & 2,48 & 1,369 \\
\hline $\begin{array}{l}\text { 8. Čini me nervoznim/om kad čitam u sebi i razumijem } \\
\text { gotovo sve riječi u rečenici, ali ne razumijem značenje } \\
\text { rečenice. }\end{array}$ & 1 & 5 & 2,68 & 1,283 \\
\hline $\begin{array}{l}\text { 9. Strah me da nikada neću dobro naučiti čitati njemački } \\
\text { jer je čitanje na njemačkome teško. }\end{array}$ & 1 & 5 & 2,29 & 1,391 \\
\hline $\begin{array}{l}\text { 10. Postajem nervozan/na kad pri čitanju u sebi naiđem } \\
\text { na nepoznatu gramatičku konstrukciju. }\end{array}$ & 1 & 5 & 2,33 & 1,254 \\
\hline $\begin{array}{l}\text { 11. Kad čitam naglas na njemačkome jeziku, osjećam se } \\
\text { opušteno i siguran/na u sebe. }\end{array}$ & 1 & 5 & 3,34 & 1,229 \\
\hline
\end{tabular}


12. Dok čitam naglas na njemačkome pred drugima, srce mi jače lupa.

\begin{tabular}{|c|c|c|c|c|}
\hline $\begin{array}{l}\text { 13. Postupci nastavnika/ce ometaju me i zbunjuju } \\
\text { dok čitam naglas na njemačkome. }\end{array}$ & 1 & 5 & 1,74 & 1,140 \\
\hline $\begin{array}{l}\text { 14. Ako pri čitanju u sebi naiđem na riječ ili riječi } \\
\text { koje ne razumijem, nastavljam čitati a da se nisam } \\
\text { uznemirio/la. }\end{array}$ & 1 & 5 & 2,70 & 1,305 \\
\hline $\begin{array}{l}\text { 15. Smeta me kad me nastavnik/ca prekida i ispravlja } \\
\text { dok čitam naglas. }\end{array}$ & 1 & 5 & 2,10 & 1,328 \\
\hline $\begin{array}{l}\text { 16. Dok čitam naglas na njemačkom, brinem se kako } \\
\text { ću izgovoriti pojedine riječi. }\end{array}$ & 1 & 5 & 2,77 & 1,283 \\
\hline 17. Nervozan/na sam kad čitam tekst koji nije zanimljiv. & 1 & 5 & 2,28 & 1,273 \\
\hline $\begin{array}{l}\text { 18. Dok čitam naglas na njemačkome pred drugima, } \\
\text { osjećam da mi se znoje dlanovi. }\end{array}$ & 1 & 5 & 1,77 & 1,139 \\
\hline $\begin{array}{l}\text { 19. Nervozniji/ja sam kad čitam naglas na njemačkome } \\
\text { nego kad pišem, slušam ili govorim. }\end{array}$ & 1 & 5 & 2,10 & 1,226 \\
\hline $\begin{array}{l}\text { 20. Ako čitam tekst na njemačkome o nepoznatoj temi, } \\
\text { postajem nervozan/na. }\end{array}$ & 1 & 5 & 2,05 & 1,159 \\
\hline $\begin{array}{l}\text { 21. Smeta me kad u tekstu naiđem na neki pojam iz } \\
\text { njemačke, austrijske ili druge kulture njemačkoga } \\
\text { govornoga područja koji mi nije poznat. }\end{array}$ & 1 & 5 & 2,15 & 1,152 \\
\hline $\begin{array}{l}\text { 22. Uznemiruje me kad čitam u sebi tekst na } \\
\text { njemačkome, a nastavnik/ca nakon toga ocjenjuje } \\
\text { zadatke razumijevanja pročitanoga. }\end{array}$ & 1 & 5 & 2,61 & 1,355 \\
\hline $\begin{array}{l}\text { 23. Strah me da će me ostali učenici ismijavati jer ne } \\
\text { čitam dobro. }\end{array}$ & 1 & 5 & 1,96 & 1,268 \\
\hline $\begin{array}{l}\text { 24. Pri čitanju u sebi na njemačkome zbunjuju me } \\
\text { duge riječi koje je teško pročitati. }\end{array}$ & 1 & 5 & 2,70 & 1,379 \\
\hline $\begin{array}{l}\text { 25. Osjećam se nesigurno kad čitam naglas na } \\
\text { njemačkome jer nemam dara za čitanje na njemačkome. }\end{array}$ & 1 & 5 & 2,24 & 1,344 \\
\hline
\end{tabular}

Min.=minimum, Maks. =maksimum, AS=aritmetička sredina, $S D=$ standardna devijacija

Rekodirane su sljedeće tvrdnje: 5. „Osjećam se ugodno dok čitam naglas na njemačkome jeziku.“, 11. „Kad čitam naglas na njemačkome jeziku, osjećam se opušteno $i$ siguran/na u sebe.“ i 14. „Ako pri čitanju u sebi naiđem na riječ ili riječi koje ne razumijem, nastavljam čitati a da se nisam uznemirio/la. “.

Najveće vrijednosti aritmetičkih sredina (tablica 5.10.) dobivene su za sljedeće tvrdnje: 16. „Dok čitam naglas na njemačkom, brinem se kako ću izgovoriti pojedine riječi.“, 14. „,Ako pri čitanju u sebi naiđem na riječ ili riječi koje ne razumijem, nastavljam čitati a da se nisam uznemirio/la. “ (rekodirano) i 24. „Pri čitanju u sebi na njemačkome zbunjuju me duge riječi koje je teško pročitati. “. Najmanje vrijednosti aritmetičkih sredina zabilježene su za tvrdnje: 13. „Postupci nastavnika/ce ometaju me i zbunjuju dok čitam naglas na njemačkome. “, 18. „Dok čitam naglas na njemačkome pred drugima, osjećam da mi se znoje dlanovi. “ i 4. „Ako 
trebam odabrati između čitanja, pisanja, slušanja i govora na njemačkome jeziku, najteže mi je čitanje. “.

Iz tablice 5.11. vidljivo je da je aritmetička sredina na razini upitnika 2,35, što ukazuje na nisku razinu straha od čitanja na njemačkome jeziku. Najniža zabilježena vrijednost je 1,04, a najviša 4,56 .

Tablica 5.11. Deskriptivna analiza

\begin{tabular}{ll}
\hline $\begin{array}{l}\text { Statistički } \\
\text { pokazatelj } \\
\left(\boldsymbol{N}_{n j \_s=155}\right)\end{array}$ & Vrijednost \\
\hline AS & 2,3488 \\
Medijan & 2,2400 \\
SD &, 73638 \\
Asimetričnost &, 481 \\
Zaobljenost &,- 154 \\
Minimum & 1,04 \\
Maksimum & 4,56 \\
\hline AS=aritmetička sredina, SD=standardna devijacija
\end{tabular}

Slika 5.2. prikazuje histogram ukupnoga rezultata za strah od čitanja na njemačkome jeziku. Za razliku od engleskoga jezika, iako je distribucija također pomaknuta prema nižim vrijednostima (ulijevo), to odstupanje nije statistički značajno, budući da je KolmogorovSmirnovljev test rezultirao $p$ vrijednošću 0,396 . Posljedično, pri analizi ove varijable možemo koristiti parametrijske postupke jer pretpostavka o normalnosti distribucije nije narušena. Međutim, budući da je detektiranje značajnoga odstupanja djelomično ovisno o veličini uzorka (veći uzorak dopušta detektiranje manjega odstupanja) i da vizualnom inspekcijom histograma na slici 5.2., te uvidom u tablicu 5.11. vidimo da je asimetričnost veća od nule, uz Pearsonove koeficijente korelacije, navodimo i vrijednosti Spearmanova koeficijenata korelacije. 


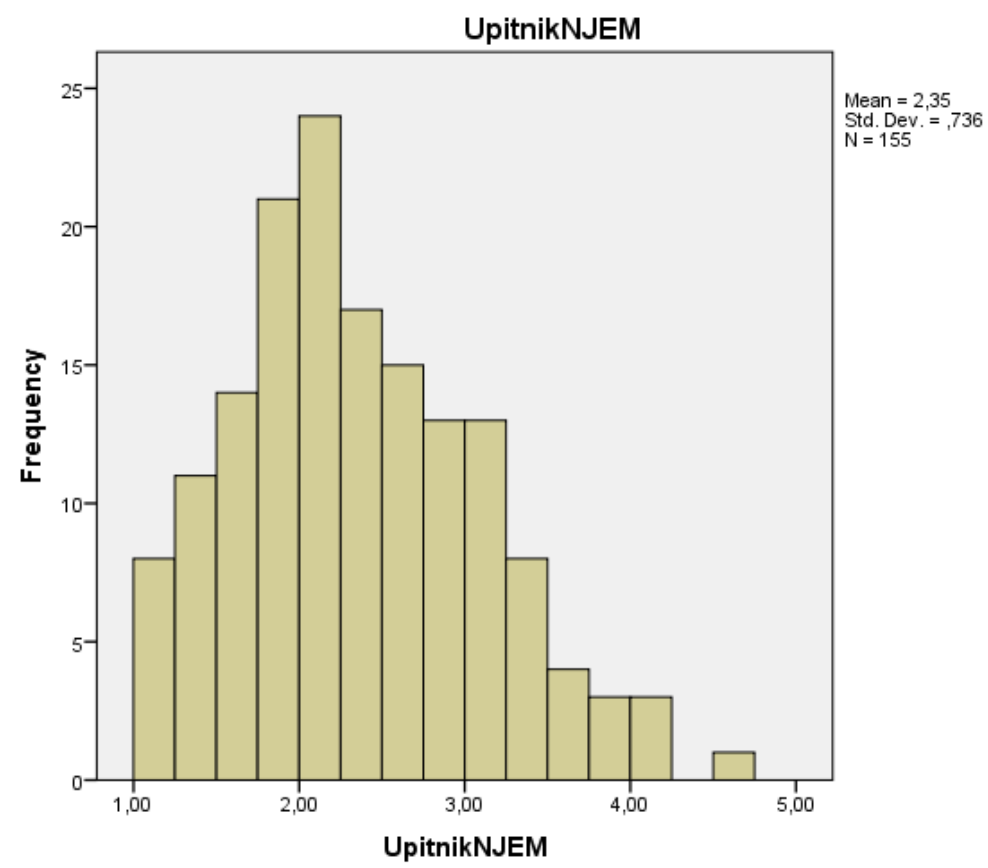

Slika 5.2. Distribucija ukupnoga rezultata za strah od čitanja na njemačkome jeziku

\subsubsection{Deskriptivni pokazatelji za motivaciju za učenje engleskoga jezika}

Tablica 5.12. pokazuje temeljne deskriptivne pokazatelje za Upitnik o motivaciji za učenje engleskoga jezika.

Tablica 5.12. Deskriptivna statistika za čestice Upitnika o motivaciji za učenje engleskoga jezika

\begin{tabular}{|c|c|c|c|c|}
\hline Čestice & Min. & Maks. & AS & SD \\
\hline 1. Jako mi se sviđa engleski jezik. & 1 & 5 & 4,18 & 1,37 \\
\hline 2. Znanje engleskoga jezika za mene je beskorisno. & 1 & 5 & 4,75 & ,775 \\
\hline $\begin{array}{l}\text { 3. Moji roditelji smatraju važnim da znam engleski } \\
\text { jezik. }\end{array}$ & 1 & 5 & 4,46 & ,805 \\
\hline 4. Zanimaju me ljudi koji govore engleski jezik. & 1 & 5 & 4,21 & 1,007 \\
\hline $\begin{array}{l}\text { 5. Zanimaju me filmovi i glazba na engleskome } \\
\text { jeziku. }\end{array}$ & 1 & 5 & 4,39 & ,958 \\
\hline 6. Sati engleskoga jezika neizmjerno su mi dosadni. & 1 & 5 & 3,48 & 1,233 \\
\hline $\begin{array}{l}\text { 7. Nemam osjećaj za jezik, beznadni sam slučaj za } \\
\text { učenje jezika. }\end{array}$ & 1 & 5 & 4,37 & 1,076 \\
\hline 8. Lako učim engleski jezik. & 1 & 5 & 3,98 & 1,157 \\
\hline $\begin{array}{l}\text { 9. Trebalo bi mi više truda i volje da budem } \\
\text { uspješniji/uspješnija. }\end{array}$ & 1 & 5 & 2,85 & 1,300 \\
\hline
\end{tabular}


10. Kolikogod učio/učila, ne mogu postići bolje rezultate.

11. U svoje slobodno vrijeme rado se bavim engleskim jezikom.

12. Tijekom učenja engleskoga jezika često doživim $\quad \begin{array}{llll}1 & 5 & 4,06 & 1,084\end{array}$ neuspjeh.

$\begin{array}{lllll}\text { 13. Na satima engleskoga jezika bojim se usmenog } & 1 & 5 & 3,79 & 1,378\end{array}$ odgovaranja.

14. Udžbenici po kojima učimo engleski loši su.

1

Min.=minimum, Maks. $=$ maksimum, $A S=$ aritmetička sredina, $S D=$ standardna devijacija

Rekodirane su sljedeće tvrdnje: 2. „Znanje engleskoga jezika za mene je beskorisno. “, 6. „Sati engleskoga jezika neizmjerno su mi dosadni. “, 7. „,Nemam osjećaj za jezik, beznadni sam slučaj za učenje jezika.“, 9. „Trebalo bi mi više truda i volje da budem uspješniji/uspješnija. “, 10. „Kolikogod učio/učila, ne mogu postići bolje rezultate. “, 12. „,Tijekom učenja engleskoga jezika često doživim neuspjeh. “, 13. „, Na satima engleskoga jezika bojim se usmenog odgovaranja. “i 14. „Udžbenici po kojima učimo engleski loši su. “.

U tablici 5.12. vidljivo je da su najveće vrijednosti aritmetičkih sredina dobivene za sljedeće tvrdnje: 2. „Znanje engleskoga jezika za mene je beskorisno. “ (rekodirano), 3. „Moji roditelji smatraju važnim da znam engleski jezik. “ i tvrdnje 5. „Zanimaju me filmovi i glazba na engleskome jeziku.“ i 10. „Kolikogod učio/učila, ne mogu postići bolje rezultate.“ (rekodirano). Najniže aritmetičke sredine zabilježene su za tvrdnje: 9. „Trebalo bi mi više truda i volje da budem uspješniji/uspješnija.“, 11. „U svoje slobodno vrijeme rado se bavim engleskim jezikom. “ i 6. „Sati engleskoga jezika neizmjerno su mi dosadni. “ (rekodirano).

Iz tablice 5.13. vidljivo je da je aritmetička sredina 3,99, što ukazuje na visoku razinu motivacije za učenje engleskoga jezika. Najniža zabilježena vrijednost je 2,29, a najviša 5. 
Tablica 5.13. Deskriptivna analiza

\begin{tabular}{ll}
\hline $\begin{array}{l}\text { Statistički } \\
\text { pokazatelj } \\
\left(\boldsymbol{N}_{\left.e_{\boldsymbol{}} \boldsymbol{m}=\mathbf{1 5 7}\right)}\right.\end{array}$ & Vrijednost \\
\hline AS & 3,9873 \\
Medijan & 4,1429 \\
$\mathrm{SD}$ &, 68385 \\
Asimetričnost &,- 446 \\
Zaobljenost &,- 839 \\
Minimum & 2,29 \\
Maksimum & 5,00 \\
\hline AS=aritmetička sredina, SD=standardna devijacija
\end{tabular}

Slika 5.3. prikazuje histogram ukupnoga rezultata motivacije za učenje engleskoga jezika. Premda je distribucija također pomaknuta prema višim vrijednostima (udesno), što ukazuje na blagu negativnu asimetričnost, to odstupanje nije statistički značajno, budući da je Kolmogorov-Smirnovljev test rezultirao $p$ vrijednošću 0,071 .

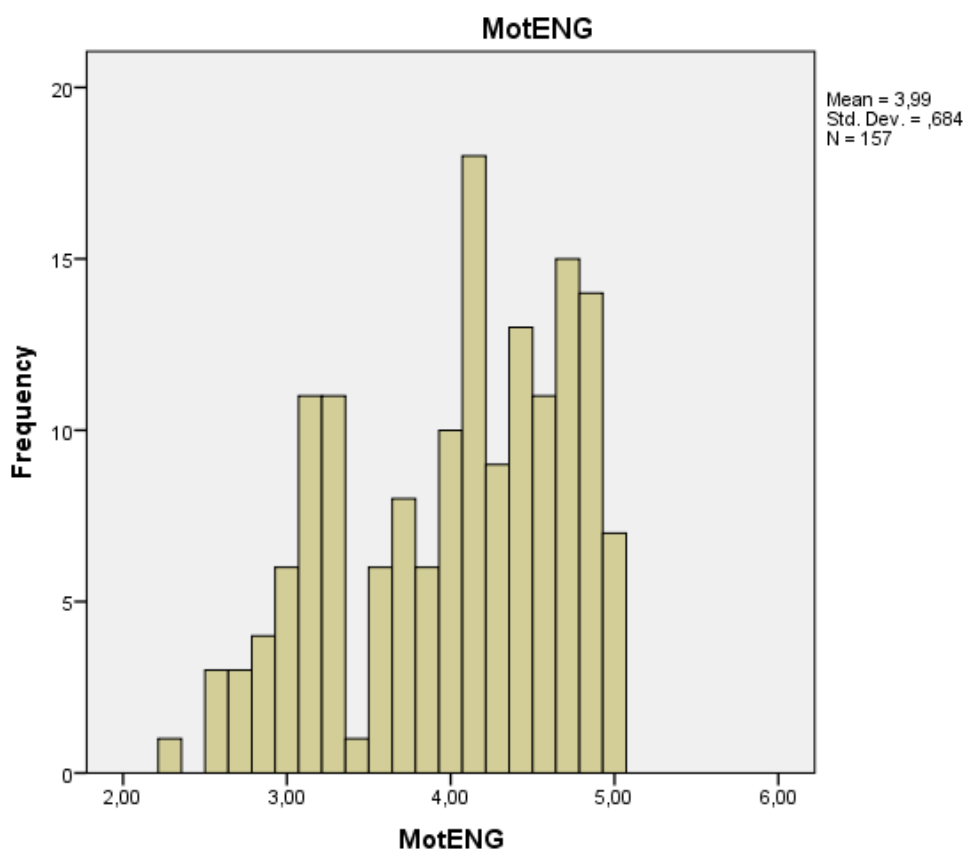

Slika 5.3. Distribucija ukupnoga rezultata za motivaciju za učenje engleskoga jezika 


\subsubsection{Deskriptivni pokazatelji za motivaciju za učenje njemačkoga jezika}

Tablica 5.14. pokazuje temeljne deskriptivne pokazatelje za Upitnik o motivaciji za učenje njemačkoga jezika.

Tablica 5.14. Deskriptivna statistika za sve čestice Upitnika o motivaciji za učenje njemačkoga jezika

\begin{tabular}{|c|c|c|c|c|}
\hline Čestice & Min. & Maks. & $\mathbf{A S}$ & SD \\
\hline 1. Jako mi se sviđa njemački jezik. & 1 & 5 & 2,70 & 1,249 \\
\hline 2. Znanje njemačkoga jezika za mene je beskorisno. & 1 & 5 & 3,87 & 1,215 \\
\hline $\begin{array}{l}\text { 3. Moji roditelji smatraju važnim da znam njemački } \\
\text { jezik. }\end{array}$ & 1 & 5 & 3,24 & 1,344 \\
\hline 4. Zanimaju me ljudi koji govore njemački jezik. & 1 & 5 & 2,95 & 1,229 \\
\hline $\begin{array}{l}\text { 5. Zanimaju me filmovi i glazba na njemačkome } \\
\text { jeziku. }\end{array}$ & 1 & 5 & 2,11 & 1,182 \\
\hline 6. Sati njemačkoga jezika neizmjerno su mi dosadni. & 1 & 5 & 2,76 & 1,320 \\
\hline $\begin{array}{l}\text { 7. Nemam osjećaj za jezik, beznadni sam slučaj za } \\
\text { učenje jezika. }\end{array}$ & 1 & 5 & 3,83 & 1,330 \\
\hline 8. Lako učim njemački jezik. & 1 & 5 & 2,90 & 1,178 \\
\hline $\begin{array}{l}\text { 9. Trebalo bi mi više truda i volje da budem } \\
\text { uspješniji/uspješnija. }\end{array}$ & 1 & 5 & 2,09 & 1,047 \\
\hline $\begin{array}{l}\text { 10. Kolikogod učio/učila, ne mogu postići bolje } \\
\text { rezultate. }\end{array}$ & 1 & 5 & 3,86 & 1,111 \\
\hline $\begin{array}{l}\text { 11. U svoje slobodno vrijeme rado se bavim } \\
\text { njemačkim jezikom. }\end{array}$ & 1 & 5 & 1,64 & ,969 \\
\hline $\begin{array}{l}\text { 12. Tijekom učenja njemačkoga jezika često doživim } \\
\text { neuspjeh. }\end{array}$ & 1 & 5 & 3,44 & 1,338 \\
\hline $\begin{array}{l}\text { 13. Na satima njemačkoga jezika bojim se usmenog } \\
\text { odgovaranja. }\end{array}$ & 1 & 5 & 3,74 & 1,323 \\
\hline 14. Udžbenici po kojima učimo njemački loši su. & 1 & 5 & 2,96 & 1,304 \\
\hline
\end{tabular}

Rekodirane su sljedeće tvrdnje: 2. „Znanje njemačkoga jezika za mene je beskorisno. “, 6. „Sati njemačkoga jezika neizmjerno su mi dosadni. “, 7. „, Nemam osjećaj za jezik, beznadni sam slučaj za učenje jezika.“, 9. „Trebalo bi mi više truda i volje da budem uspješniji/uspješnija. “, 10. „Kolikogod učio/učila, ne mogu postići bolje rezultate. “, 12. „,Tijekom učenja njemačkoga jezika često doživim neuspjeh.“, 13. „Na satima njemačkoga jezika bojim se usmenog odgovaranja. “ i 14. „,Udžbenici po kojima učimo njemački loši su. “.

U tablici 5.14. vidljivo je da su najveće vrijednosti aritmetičkih sredina dobivene za sljedeće tvrdnje: 2. „Znanje njemačkoga jezika za mene je beskorisno. “ (rekodirano), 10. „,Kolikogod učio/učila, ne mogu postići bolje rezultate. “ (rekodirano) i 7. „,Nemam osjećaj za jezik, beznadni sam slučaj za učenje jezika." (rekodirano). Najniže aritmetičke sredine 
zabilježene su za tvrdnje: 11. „U svoje slobodno vrijeme rado se bavim njemačkim jezikom. “, 9. „Trebalo bi mi više truda $i$ volje da budem uspješniji/uspješnija." (rekodirano) i 5. „Zanimaju me filmovi i glazba na njemačkome jeziku. “.

Iz tablice 5.15. vidljivo je da je aritmetička sredina na razini upitnika 3,00, što ukazuje na umjerenu razinu motivacije za učenje njemačkoga jezika. Najniža zabilježena vrijednost je 1,64 , a najviša 4,93 .

Tablica 5.15. Deskriptivna analiza

\begin{tabular}{ll}
\hline $\begin{array}{l}\text { Statistički } \\
\text { pokazatelj } \\
\left(\boldsymbol{N}_{\boldsymbol{n j} \mathbf{m}=\mathbf{m}=\mathbf{1 5 5})}\right.\end{array}$ & Vrijednost \\
\hline $\mathrm{AS}$ & 3,0075 \\
Medijan & 3,0000 \\
$\mathrm{SD}$ &, 63888 \\
Asimetričnost &, 296 \\
Zaobljenost &,- 327 \\
Minimum & 1,64 \\
Maksimum & 4,93 \\
\hline AS=aritmetička sredina, SD=standardna devijacija
\end{tabular}

Histogram na slici 5.4. prikazuje distribuciju ukupnoga rezultata. Vidimo da je motivacija za učenje njemačkoga jezika približno normalno distribuirana. To je potvrđeno Kolmogorov-Smirnovljev testom koji je rezultirao $p$ vrijednošću 0,253 što ukazuje da ne postoji odstupanje od normalne distribucije. 


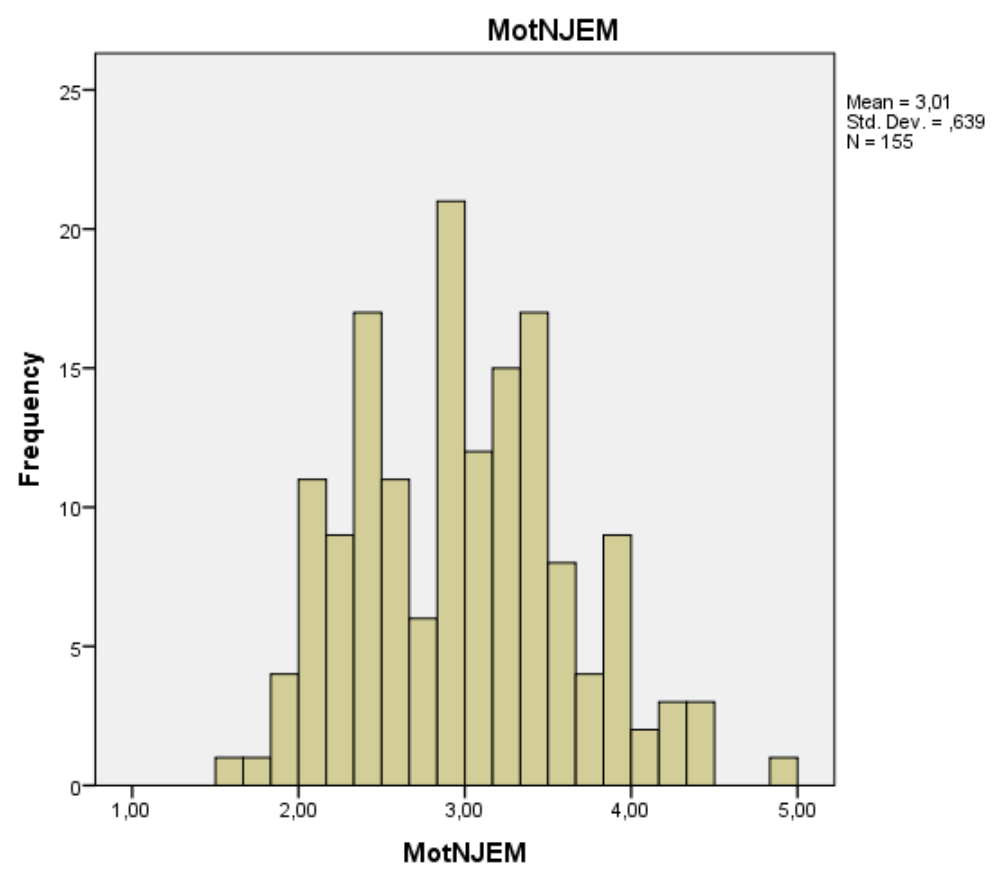

Slika 5.4. Distribucija ukupnoga rezultata za motivaciju za učenje njemačkoga jezika

\subsubsection{Deskriptivni pokazatelji za razumijevanje teksta čitanjem - engleski jezik}

Kao mjera uspjeha u čitanju na engleskome jeziku korišten je test Razumijevanje teksta čitanjem na engleskome jeziku. Maksimalni broj bodova na testu iznosi 47. Prosječna srednja vrijednost iznosi 35,79, što čini 76,1\% točnosti za ukupan broj bodova na testu. Distribucija uspjeha kreće se od najnižega rezultata 10 do najvišega rezultata 47 (tablica 5.16). Histogram distribucije uspjeha na testu prikazan je na slici 5.5. Vidljivo je da je distribucija pomaknuta u desnome smjeru (negativna asimetričnost), odnosno da su visoki rezultati frekventniji od niskih rezultata. Kolmogorov-Smirnovljev test je pokazao da distribucija značajno odstupa od normalne distribucije $(p=, 004)$. Neovisno o uzroku asimetričnosti, u daljnjim analizama ove varijable preferiraju se neparametrijski postupci koji ne počivaju na pretpostavci o normalnoj distribuciji. Detaljni prikaz deskriptive statistike za sve zadatke testa nalazi se u prilogu 12. 


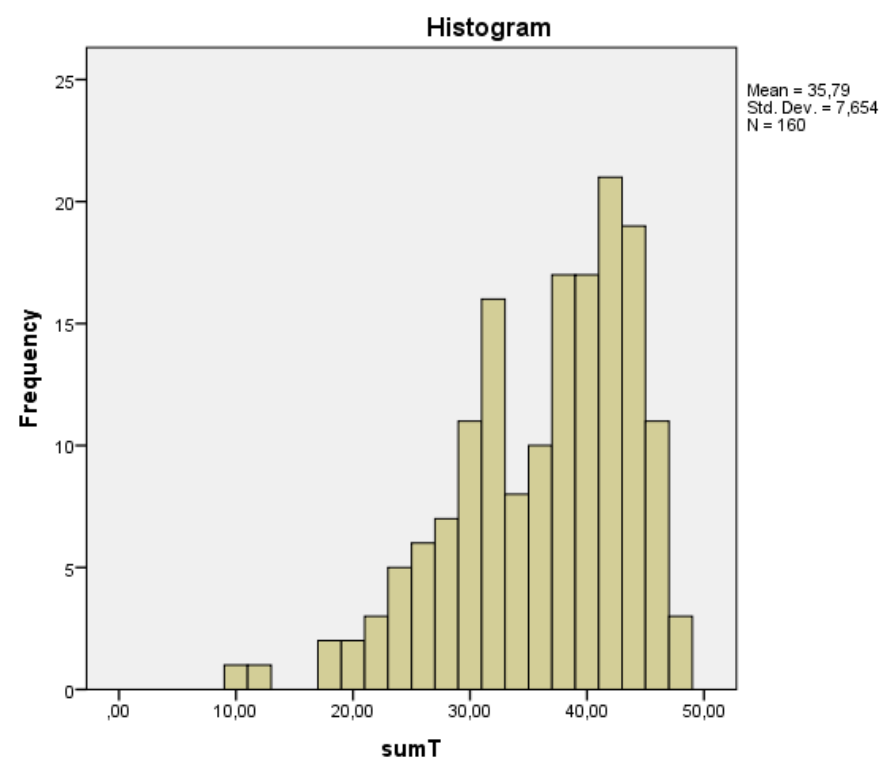

Slika 5.5. Distribucija ukupnoga rezultata za test Razumijevanje teksta čitanjem - engleski jezik

Tablica 5.16. Deskriptivna analiza

\begin{tabular}{ll}
\hline $\begin{array}{l}\text { Statistički } \\
\text { pokazatelj } \\
\left(\boldsymbol{N}_{\left.\boldsymbol{e}_{\boldsymbol{t}}=\mathbf{1 6 0}\right)}\right)\end{array}$ & Vrijednost \\
\hline $\mathrm{AS}$ & 35,7875 \\
Medijan & 38,0000 \\
$\mathrm{SD}$ & 7,65399 \\
Asimetričnost &,- 780 \\
Zaobljenost &, 227 \\
Minimum & 10,00 \\
Maksimum & 47,00 \\
\hline AS=aritmetička sredina, SD=standardna devijacija
\end{tabular}




\subsubsection{Deskriptivni pokazatelji za razumijevanje teksta čitanjem - njemački jezik}

Kao mjera uspjeha u čitanju na njemačkome jeziku korišten je test Razumijevanje teksta čitanjem na njemačkome jeziku. Maksimalan broj bodova na testu iznosi 42. Distribucija uspjeha kreće se od najnižega rezultata 7 do najvišega rezultata 40 (tablica 5.17). Histogram distribucije uspjeha na testu prikazan je na slici 5.6. Kolmogorov-Smirnovljev test pokazao je da distribucija značajno ne odstupa od normalne distribucije $(p=, 231)$. Prosječna srednja vrijednost je 23,32, što čini 58,2 \% točnosti za ukupan broj bodova na testu. Detaljni prikaz deskriptive statistike za sve zadatke testa nalazi se u prilogu 13.

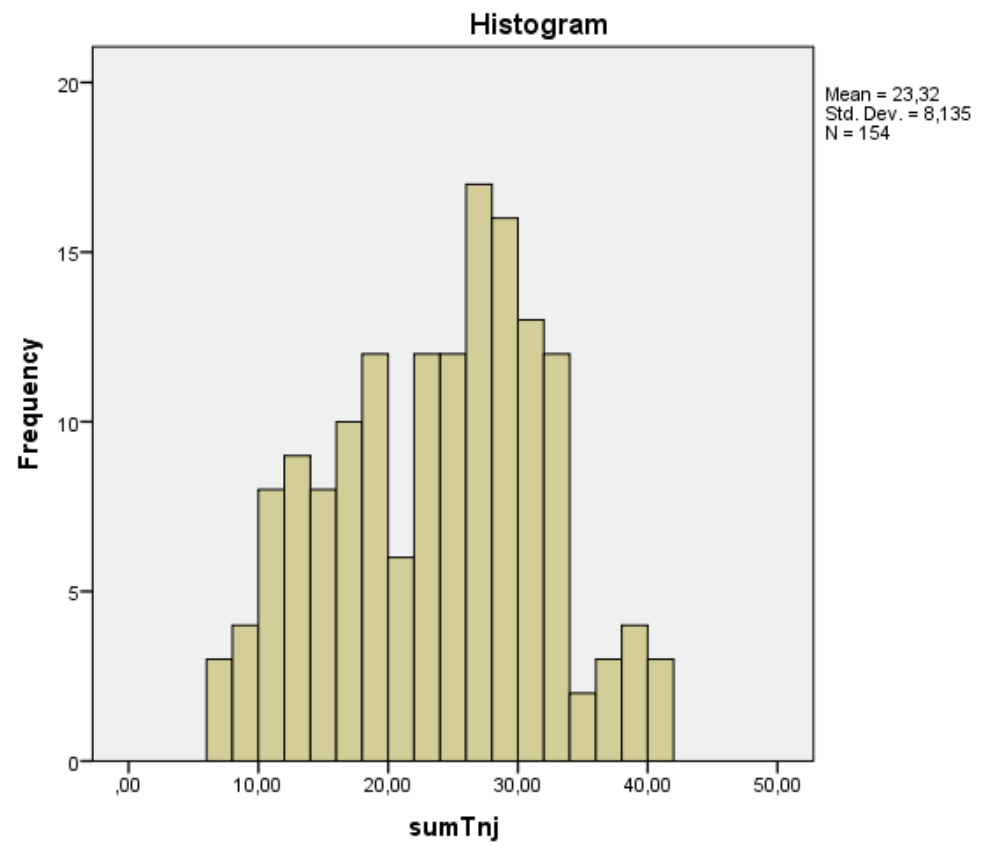

Slika 5.6. Distribucija ukupnoga rezultata za test Razumijevanje teksta čitanjem - njemački jezik 
Tablica 5.17. Deskriptivna analiza

\begin{tabular}{ll}
\hline $\begin{array}{l}\text { Statistički } \\
\text { pokazatelj } \\
\left(\boldsymbol{N}_{\text {nj_t } t=154}\right)\end{array}$ & Vrijednost \\
\hline AS & 23,3182 \\
Medijan & 24,0000 \\
SD & 8,13506 \\
Asimetričnost &,- 105 \\
Zaobljenost &, 741 \\
Minimum & 7,00 \\
Maksimum & 40,00 \\
\hline AS=aritmetička sredina, SD=standardna devijacija
\end{tabular}

\subsubsection{Normalnost distribucija ključnih varijabli}

Tablica 5.18. Sažeti prikaz nalaza o normalnosti distribucija straha od čitanja, uspjeha na testu razumijevanja teksta čitanjem, te motivacije za učenje s obzirom na jezik

\begin{tabular}{lll}
\hline Varijabla & \multicolumn{2}{c}{ Normalnost distribucije } \\
\hline Strah od čitanja & Engleski jezik & Njemački jezik \\
& Značajno odstupanje & $\begin{array}{l}\text { Odstupanje nije statistički } \\
\text { značajno }\end{array}$ \\
$\begin{array}{l}\text { Uspjeh na testu razumijevanja teksta } \\
\text { čitanjem }\end{array}$ & Značajno odstupanje & $\begin{array}{l}\text { Odstupanje nije statistički } \\
\text { značajno }\end{array}$ \\
Motivacija za učenje & & \\
& Odstupanje nije statistički & Odstupanje nije statistički \\
& značajno & značajno \\
\hline
\end{tabular}

U tablici 5.18. sažeto su prikazani rezultati testiranja normalnosti distribucija triju ključnih varijabli u ovom istraživanju. Posljedično, testiranje razlika s obzirom na spol i srednjoškolsko usmjerenje za strah od čitanja i uspjeh na testu razumijevanja teksta čitanjem za engleski jezik dodatno će biti provedeno i neparametrijskim testovima. 


\subsubsection{Konstrukcija Upitnika o strahu od čitanja na engleskome jeziku i Upitnika o strahu od čitanja na njemačkome jeziku u preliminarnome istraživanju}

Za potrebe provođenja preliminarnoga istraživanja konstruiran je upitnik za mjerenje straha od čitanja na engleskome/njemačkome kao stranome jeziku. U usporedbi s postojećim upitnicima, naš mjerni instrument mjeri strah od čitanja na stranome jeziku tijekom formalnoga učenja stranoga jezika u specifičnome hrvatskome socioedukacijskome kontekstu i omogućuje provedbu poredbenoga istraživanja dvaju stranih jezika (engleskoga i njemačkoga jezika).

Kao polazište za konstrukciju upitnika poslužili su Upitnik za mjerenje straha od stranoga jezika u razrednoj situaciji FLCAS (engl. Foreign Language Classroom Anxiety Scale) (Horwitz i sur., 1986) (v. prilog 14), Upitnik o strahu od čitanja na stranome jeziku FLRAS (engl. Foreign Language Reading Anxiety Scale) (Saito i sur., 1999) (v. prilog 15), te nalazi diskusija fokus grupa za engleski i njemački jezik o strahu od čitanja na engleskome, odnosno njemačkome jeziku.

Upitnik o strahu od čitanja na engleskome/njemačkome jeziku za preliminarno istraživanje izrađen je u dvije inačice: Upitnik o strahu od čitanja na engleskome jeziku (v. prilog 4 drugi dio) i Upitnik o strahu od čitanja na njemačkome jeziku (v. prilog 5 drugi dio). Upitnik se sastoji od dvaju dijelova, a prvi dio je Opći dio upitnika. Općim dijelom upitnika prikupili su se podatci o spolu, materinskome jeziku, posljednjoj zaključnoj ocjeni iz engleskoga, odnosno njemačkoga jezika, općem uspjehu u prethodno završenome razredu, početku učenja engleskoga, odnosno njemačkoga jezika, ostalim stranim jezicima koje učenici uče, iskustvu učenja engleskoga, odnosno njemačkoga jezika izvan škole, iskustvu boravka u zemlji engleskoga, odnosno njemačkoga govornoga područja. Drugi dio upitnika sadržava 40 čestica koje su tvrdnje kojima se ispituje strah od čitanja na engleskome, odnosno njemačkome jeziku. Čestice u engleskoj i njemačkoj inačici upitnika izražavaju iste tvrdnje, ali se u engleskoj inačici navodi da se tvrdnja odnosi na engleski jezik, a u njemačkoj inačici da se tvrdnja odnosi na njemački jezik. Čestice upitnika o strahu učenici su vrednovali na Likertovoj skali od 1 do 5 (1-uopće se ne odnosi na mene, 2-uglavnom se ne odnosi na mene, 3-niti se odnosi niti se ne odnosi na mene, 4-uglavnom se odnosi na mene, 5-u potpunosti se odnosi na mene).

Svrha preliminarnoga istraživanja bila je, prije svega, provjeriti razumljivost tvrdnji, vrijeme koje je potrebno sudionicima za popunjavanje upitnika te utvrditi njegova 
psihometrijska svojstva. U preliminarnome istraživanju demografski podatci nisu razmatrani kao relevantan faktor.

\subsubsection{Psihometrijska svojstva Upitnika o strahu od čitanja na engleskome jeziku u preliminarnome istraživanju}

Najprije je izvršena analiza drugoga dijela upitnika s 40 tvrdnji. Deskriptivna analiza provedena je nakon rekodiranja na ukupnom rezultatu na svim tvrdnjama, koji je linearni zbroj vrijednosti svih tvrdnji.

Rekodirane su sljedeće čestice:

4. Kad svi u razredu mirno slušaju i opušteni su ne osjećam napetost kad čitam naglas na engleskom.

6. Osjećam se ugodno dok čitam naglas na engleskom jeziku.

9. Lijepo mi je čuti sebe kad čitam engleski naglas pred drugima.

15. Kad čitam naglas na engleskom jeziku osjećam se opušteno i siguran/na u sebe.

18. Osjećam se sigurnije kad čitam poluglasno tekst na engleskom jeziku prije čitanja naglas.

19. Kad čitam naglas na engleskom pred drugima nisam uznemiren/a i glas mi se ne mijenja i ne drhti.

20. Ako pri čitanju u sebi naiđem na riječ ili riječi koje ne razumijem, nastavljam čitati bez uznemiravanja.

40. Ne uznemiruje me što postoji nepodudarnost između načina pisanja i čitanja na engleskom jeziku.

Statistički pokazatelji upućuju na to da su ukupni rezultati bazirani na svih 40 čestica u upitniku za engleski jezik (tablica 5.19. i slika 5.7.) blago asimetrični. KolmogorovSmirnovljev test normaliteta distribucije pokazao je da se distribucija značajno razlikuje od normalne $(p=, 022)$. 
Tablica 5.19. Deskriptivna analiza

\begin{tabular}{lc}
\hline Statistički pokazatelj $\left(\boldsymbol{N}_{\text {eng } \boldsymbol{p}} \mathbf{~ = ~ 2 0 2}\right)$ & Vrijednost \\
\hline Aritmetička sredina $(A S)$ & 81,376 \\
Medijan & 77 \\
Standardna devijacija $(S D)$ & 23,472 \\
Asimetričnost (skewness) &, 517 \\
Zaobljenost (kurtosis) &,- 646 \\
Minimum & 44 \\
Maksimum & 144 \\
\hline
\end{tabular}

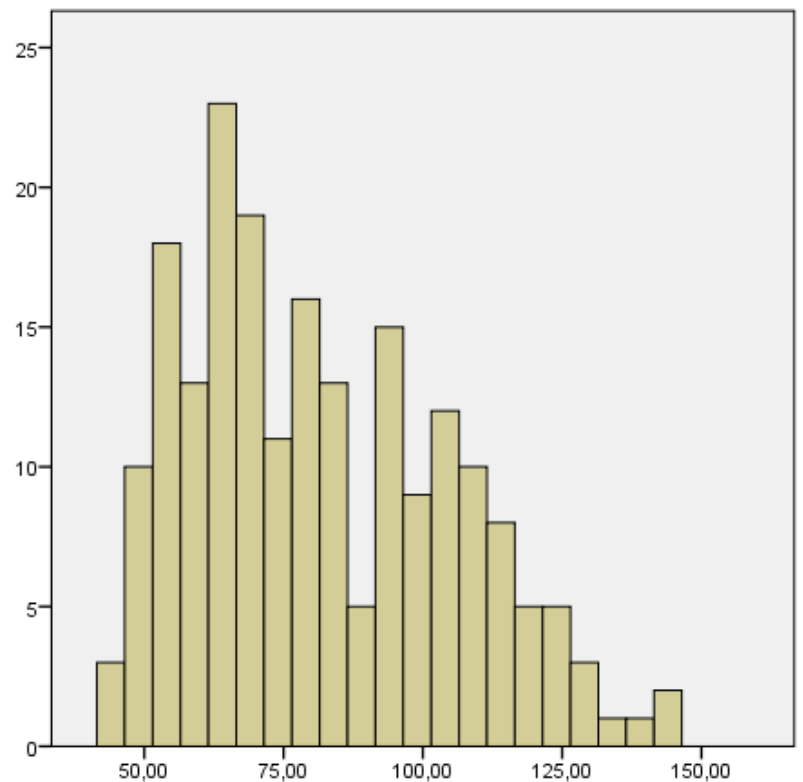

Slika 5.7. Distribucija ukupnoga rezultata za strah od čitanja na engleskome jeziku

U svrhu analize distribucije i prosječnih vrijednosti tvrdnji, vizualizirani su kutijasti dijagrami (engl. box-plot) za svaku tvrdnju u upitniku, prikazani na slici 5.8. 

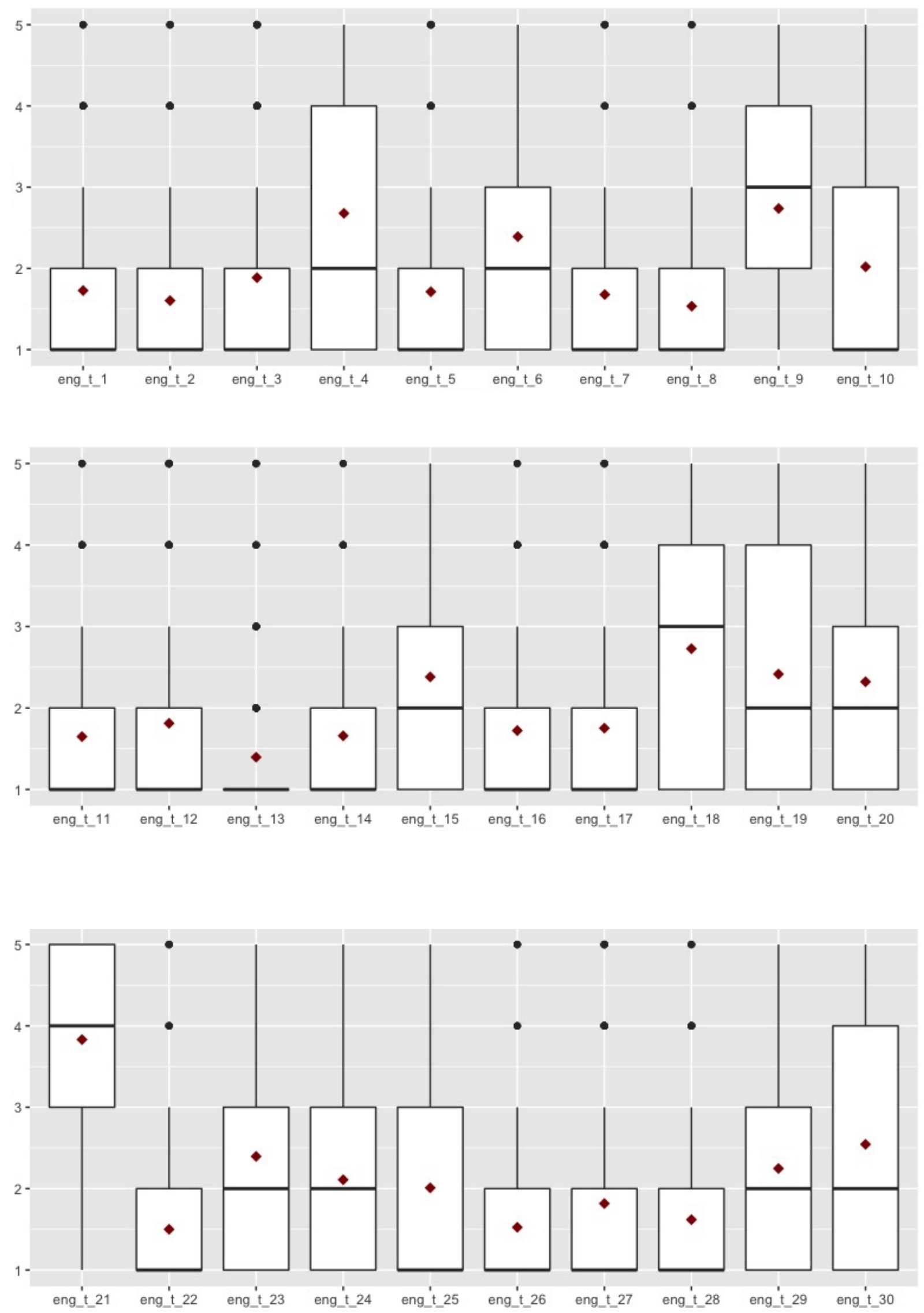


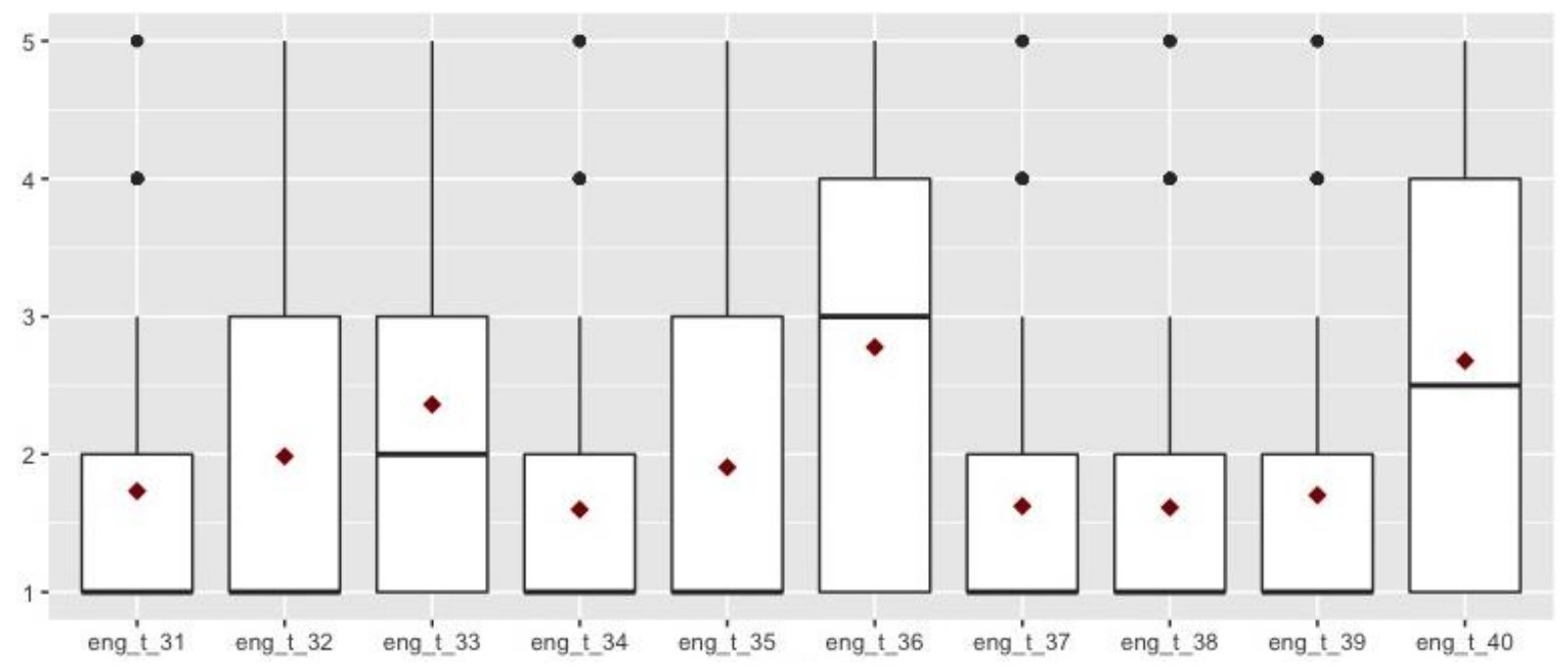

Slika 5.8. Kutijasti dijagrami stupnja slaganja za svaku tvrdnju (crveni romb prikazuje aritmetičku sredinu, horizontalna linija u svakom kvadratu prikazuje medijan, a crne točke izvan kutijastih dijagrama prikazuju ekstremne vrijednosti (engl. outlier)

\subsubsection{Psihometrijska svojstva Upitnika o strahu od čitanja na njemačkome jeziku u preliminarnome istraživanju}

Izvršena je najprije analiza drugoga dijela upitnika s 40 tvrdnji. Deskriptivna analiza provedena je nakon rekodiranja na ukupnom rezultatu na svim tvrdnjama, koji predstavlja linearni zbroj vrijednosti svih tvrdnji.

Rekodirane su sljedeće čestice:

4. Kad svi u razredu mirno slušaju i opušteni su ne osjećam napetost kad čitam naglas na njemačkom.

6. Osjećam se ugodno dok čitam naglas na njemačkom jeziku.

9. Lijepo mi je čuti sebe kad čitam njemački naglas pred drugima.

15. Kad čitam naglas na njemačkom jeziku osjećam se opušteno i siguran/na u sebe.

18. Osjećam se sigurnije kad čitam poluglasno tekst na njemačkom jeziku prije čitanja naglas.

19. Kad čitam naglas na njemačkom pred drugima nisam uznemiren/a i glas mi se ne mijenja i ne drhti. 
20. Ako pri čitanju u sebi naiđem na riječ ili riječi koje ne razumijem, nastavljam čitati bez uznemiravanja.

40. Ne uznemiruje me što postoji nepodudarnost između načina pisanja i čitanja na njemačkom jeziku.

Statistički pokazatelji upućuju na to da su ukupni rezultati bazirani na svih 40 čestica normalno distribuirani za tvrdnje u upitniku o njemačkom jeziku (tablica 5.20. i slika 5.9.). To je potvrđeno Kolmogorov-Smirnovljevim testom normaliteta distribucije $(p=, 372)$.

Tablica 5.20. Deskriptivna analiza

\begin{tabular}{lc}
\hline Statistički pokazatelj $\left(\boldsymbol{N}_{\text {njem_p }} \mathbf{~ = 2 0 2}\right)$ & Vrijednost \\
\hline Aritmetička sredina $(A S)$ & 95,272 \\
Medijan & 93 \\
Standardna devijacija $(S D)$ & 25,013 \\
Asimetričnost (skewness) &, 349 \\
Zaobljenost ( kurtosis) &,- 428 \\
Minimum & 50 \\
Maksimum & 168 \\
\hline
\end{tabular}

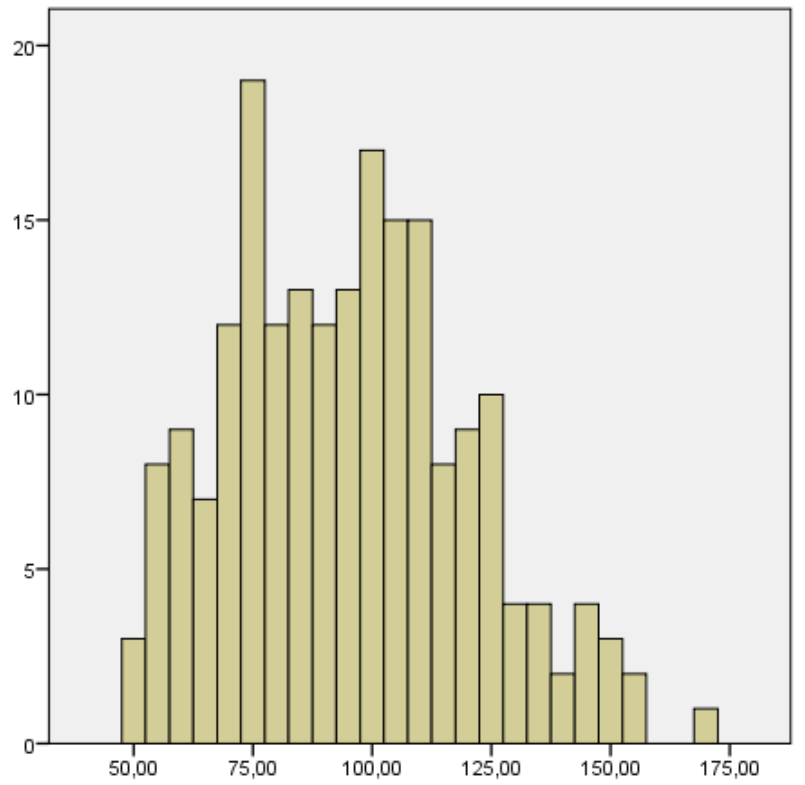

Slika 5.9. Distribucija ukupnoga rezultata za strah od čitanja na njemačkome jeziku 
U svrhu analize distribucije i prosječnih vrijednosti tvrdnji, vizualizirani su kutijasti dijagrami za svaku tvrdnju u upitniku, prikazani na slici 5.10.
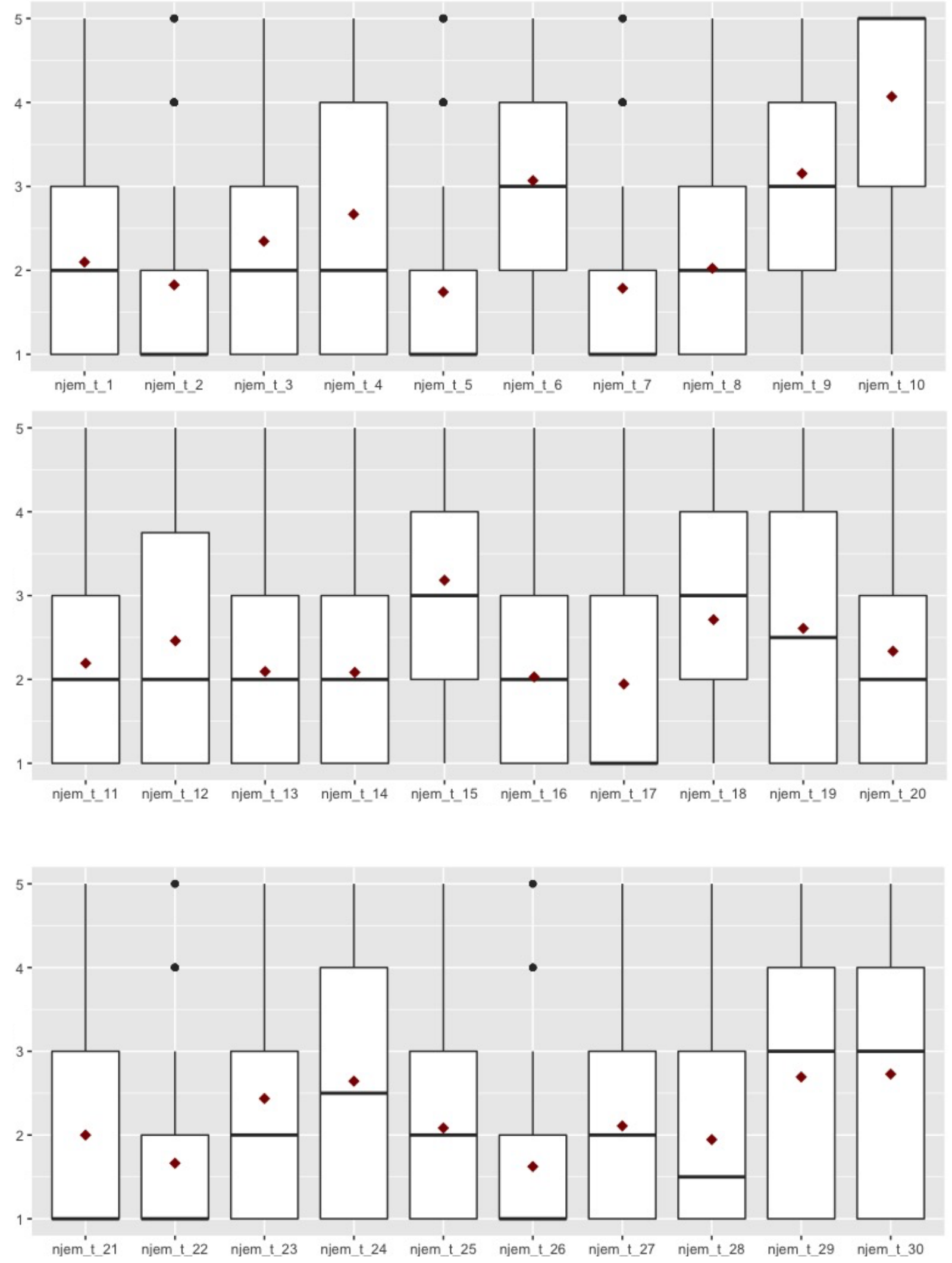


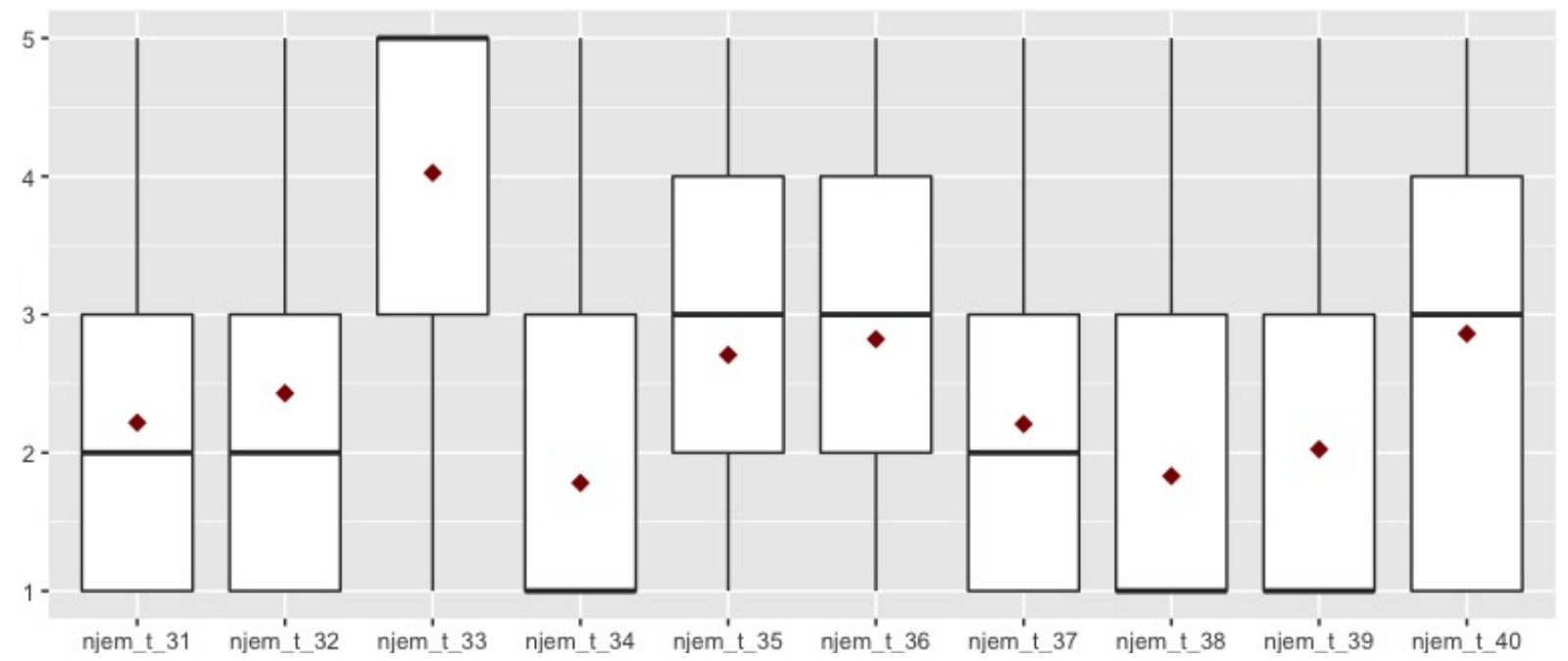

Slika 5.10. Kutijasti dijagrami stupnja slaganja za svaku tvrdnju (crveni romb prikazuje aritmetičku sredinu, horizontalna linija u svakom kvadratu prikazuje medijan, a crne točke izvan kutijastih dijagrama prikazuju ekstremne vrijednosti)

\subsubsection{Proces selekcije tvrdnji Upitnika o strahu od čitanja na engleskome jeziku s pomoću Cronbachova $\alpha$}

Krajnji odabir tvrdnji obavljen je s ciljem da obje završne verzije upitnika, za njemački i za engleski jezik, budu usporedive, odnosno da sadržavaju koliko je maksimalno moguće što više istih tvrdnji.

Usporedbom promjene u veličini Cronbachova $\alpha$ na razini svih 40 čestica do koje dolazi nakon izbacivanja pojedine čestice, ustanovljeno je koje čestice umanjuju koeficijent unutarnje pouzdanosti. Drugim riječima, ukoliko je takva čestica izbačena, koeficijent se na razini čitavoga upitnika povećava. Budući da te čestice umanjuju unutarnju konzistentnost upitnika, prema tom kriteriju one su bile najizgledniji kandidati za izbacivanje iz upitnika prilikom konstrukcije završne verzije upitnika. Uzeli su se u obzir i komentari učenika nakon ispunjavanja upitnika u kojima su oni procijenili neke tvrdnje kao nedovoljno jasne, dvoznačne, zbunjujuće ili nepripadajuće u upitnik o strahu od čitanja na engleskome/njemačkome jeziku, te je tako strukturirana cjelovita završna verzija upitnika.

Za engleski jezik, upitnik s početnih 40 čestica je imao Cronbachov $\alpha$,913. S obzirom na vrijednosti istoga nakon izbacivanja pojedine čestice, odlučeno je da se sljedeće čestice izbace iz upitnika: 4. „Kad svi u razredu mirno slušaju i opušteni su ne osjećam napetost kad čitam 
naglas na engleskom.“, 7. „Osjećam se nervozno dok čitam naglas i na hrvatskom i na engleskom jeziku. “, 9. „Lijepo mi je čuti sebe kad čitam engleski naglas pred drugima. “, 10. „,Draže mi je čitati naglas na engleskom nego na njemačkom. “, 18. „, Osjećam se sigurnije kad čitam poluglasno tekst na engleskom jeziku prije čitanja naglas. “, 19. „Kad čitam naglas ne engleskom pred drugima nisam uznemiren/a i glas mi se ne mijenja i ne drhti. “, 21. „Osjećam se sigurnije kad čitam naglas na engleskom nego kad čitam naglas na njemačkom. “, 22. „Loše mi ide čitanje na hrvatskom i na engleskom jeziku. “, 29. „,Nervozniji/ja sam kad čitam naglas na engleskom nego kad čitam u sebi. “, 30. „,Smeta mi kad čitam naglas na engleskom, a ostali učenici me ne slušaju i stvaraju žamor. “, 33. „,Manje sam uznemiren/na kad čitam naglas na engleskom nego na njemačkom. “, 36. „, Ne osjećam nesigurnost kad čitam u sebi na engleskom nego kad čitam naglas.“, 38. „Uznemiren/a sam kad čitam naglas i na hrvatskom $i$ na engleskom jeziku. “, 39. „, Uhvati me panika kad čitam naglas na engleskom jer znam da i o tome ovisi ocjena koju će mi zaključiti nastavnik/ca.“ i 40. „Ne uznemiruje me što postoji nepodudarnost između načina pisanja i čitanja na engleskom jeziku. “.

U prilogu 16 prikazan je Cronbachov $\alpha$ za čitav upitnik, te Cronbachov $\alpha$ u slučaju eliminacije pojedine čestice.

\subsubsection{Proces selekcije tvrdnji Upitnika o strahu od čitanja na njemačkome jeziku s pomoću Cronbachova a}

Za njemački jezik, upitnik s početnih 40 čestica je imao Cronbachov $\alpha$,92. S obzirom na vrijednosti istoga nakon izbacivanja pojedine čestice izbačene su čestice 4. „Kad svi u razredu mirno slušaju i opušteni su ne osjećam napetost kad čitam naglas na njemačkom. “, 7. „, Osjećam se nervozno dok čitam naglas i na hrvatskom i na njemačkom jeziku. “, 9. „Lijepo mi je čuti sebe kad čitam njemački naglas pred drugima. “, 10. „Draže mi je čitati naglas na njemačkom nego na engleskom.“, 18. „Osjećam se sigurnije kad čitam poluglasno tekst na njemačkom jeziku prije čitanja naglas.“, 19. „Kad čitam naglas na njemačkom pred drugima nisam uznemiren/a i glas mi se ne mijenja i ne drhti. “, 21. „, Osjećam se sigurnije kad čitam naglas na njemačkom nego kad čitam naglas na engleskom. “, 22. „Loše mi ide čitanje na hrvatskom i na njemačkom jeziku. “, 29. „Nervozniji/ja sam kad čitam naglas na engleskom nego kad čitam u sebi. “, 30. „, Smeta mi kad čitam naglas na njemačkom, a ostali učenici me ne slušaju i stvaraju žamor. “, 33. „,Manje sam uznemiren/na kad čitam naglas na njemačkom nego na engleskom. “, 
36. „Ne osjećam nesigurnost kad čitam u sebi na njemačkom nego kad čitam naglas. “, 38. „,Uznemiren/a sam kad čitam naglas i na hrvatskom i na njemačkom jeziku. “, 39. „, Uhvati me panika kad čitam naglas na njemačkom jer znam da i o tome ovisi ocjena koju će mi zaključiti nastavnik/ca.“ i 40. „Ne uznemiruje me što postoji nepodudarnost između načina pisanja $i$ čitanja na njemačkom jeziku. “.

U prilogu 17 prikazan je Cronbachov $\alpha$ za čitav upitnik, te Cronbachov $\alpha$ u slučaju eliminacije pojedine čestice.

\subsubsection{Faktorska struktura Upitnika za mjerenje straha od čitanja na engleskome jeziku i Upitnika za mjerenje straha od čitanja na njemačkome jeziku u glavnome istraživanju}

Vrijednost Cronbachova $\alpha$ s 25 tvrdnji koje su se izdvojile za upitnik za engleski jezik je ,92, a za upitnik za njemački jezik ,914. Neznatan pad potonje vrijednosti u odnosu na prvu verziju upitnika ne treba interpretirati kao pad interne konzistentnosti, budući da je ukupan broj čestica znatno manji u drugoj verziji. Općenito, obje su vrijednosti vrlo blizu Cronbachovu $\alpha$ prve verzije upitnika, što upućuje na to da izbacivanje čak 15 čestica nije rezultiralo značajnom promjenom u unutarnjoj konzistentnosti kod oba upitnika.

Da bi se provjerila pouzdanost preostalih 25 čestica, provedena je analiza glavnih komponenti gdje su faktori bili nezavisni, te Oblimin rotacija, koja dozvoljava korelaciju među faktorima. Iako su faktorska rješenja upućivala na veći broj faktora (šest), struktura od triju faktora čini se zadovoljavajućom za objašnjenje većine preostalih 25 čestica u upitnicima za engleski jezik, te za njemački jezik. Razlozi za odabir tri faktora su: prvo, trodimenzionalna struktura straha od čitanja utvrđena je u modelu koji su ponudili Zoghi (2012) i Zoghi i Alivandivafa (2014), drugo, gotovo sve čestice imaju veća zasićenja na prva tri, nego na preostala tri ekstrahirana faktora. Najprije je proveden Bartlettov test u svrhu provjere opisuje li korelacijska matrica odnos među varijablama koje nisu povezane, te su stoga pogodne za faktorsku analizu. $p$-vrijednosti manje od ,05 upućuju da je provedba analize komponenti prikladna (za oba testa $p=, 000)$. 


\subsubsection{Analiza glavnih komponenti i faktorska analiza Upitnika o strahu od čitanja na engleskome jeziku}

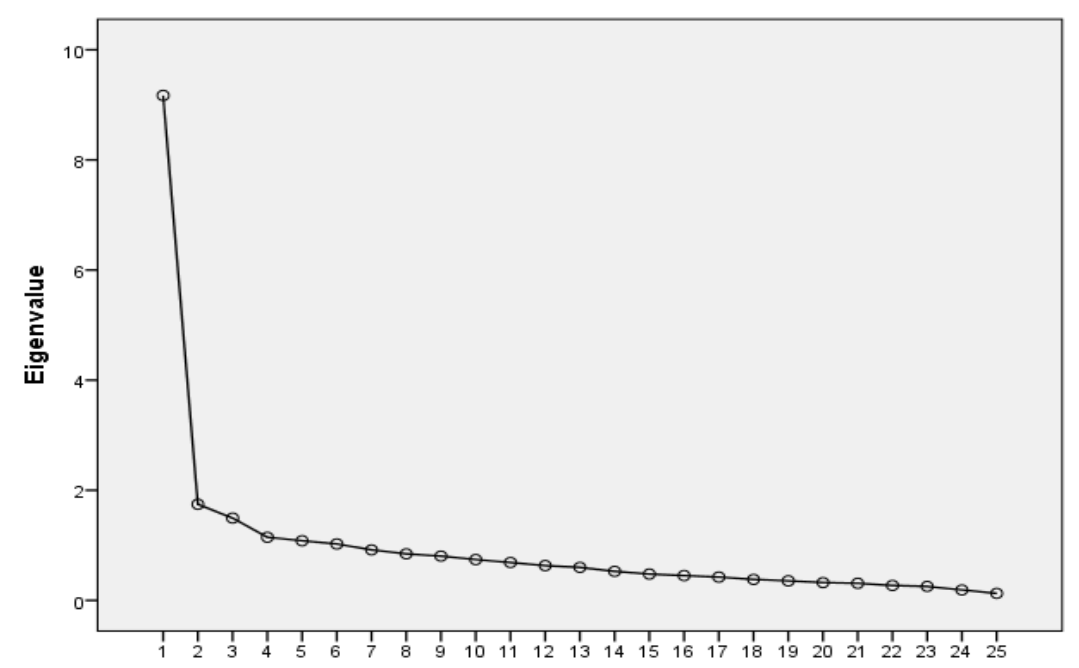

Slika 5.11. Grafički prikaz vrijednosti karakterističnih korijena (Eigen vrijednosti) za 25 faktora

Analiza glavnih komponenti (engl. Principal component analysis-PCA) rezultirala je ekstrakcijom šest komponenti, odnosno šest komponenti je imalo Eigen vrijednosti veće od 1. Zasićenje svake tvrdnje s pojedinim komponentama je prikazano u tablici 5.21., gdje zasićenja manja od ,30 apsolutne vrijednosti nisu prikazana.

Tablica 5.21. Matrica obrazaca

\begin{tabular}{lcccccc}
\hline & \multicolumn{7}{c}{ Komponenta } \\
Tvrdnja & $\mathbf{1}$ & $\mathbf{2}$ & $\mathbf{3}$ & $\mathbf{4}$ & $\mathbf{5}$ & $\mathbf{6}$ \\
\hline eng_t_1 &, 708 & &,- 409 & & & \\
eng_t_2 &, 701 & &,- 434 & & & \\
eng_t_3 &, 703 & & & &, 362 & \\
eng_t_5 &, 594 & & & & & \\
eng_t_6 &, 537 &,- 527 & & & & \\
eng_t_8 &, 534 & & &,- 423 &,- 330 &, 322 \\
eng_t_11 &, 566 & & & &,- 335 & \\
eng_t_12 &, 629 & &, 319 & & & \\
eng_t_13 &, 656 & &, 374 & & & \\
eng_t_14 &, 558 &, 337 &, 321 &,- 313 & & \\
eng_t_15 &, 506 &,- 491 & & & &, 363 \\
eng_t_16 &, 611 & &,- 372 & & & \\
eng_t_17 &, 420 &, 504 & & & & \\
eng_t_20 &, 325 & &, 369 & &, 463 &
\end{tabular}




\begin{tabular}{lllll} 
eng_t_23 & &, 562 &, 389 & \\
eng_t_24 &, 726 & & & \\
eng_t_25 &, 612 &, 380 & & \\
eng_t_26 &, 645 & & & \\
eng_t_27 &, 708 & & & \\
eng_t_28 &, 688 & & & \\
eng_t_31 &, 500 & & &,- 330 \\
eng_t_32 &, 607 & & & \\
eng_t_34 &, 578 & &,- 314 & \\
eng_t_35 &, 693 & & & \\
eng_t_37 &, 760 & & & \\
\hline
\end{tabular}

Inspekcija tablice 5.21. ukazuje da se bar jedna od prve dvije komponente manifestira u svakoj od 25 tvrdnji. Usto, najviša zasićenja u četvrtoj, petoj ili šestoj komponenti niža su nego najviše zasićenje u prvoj, drugoj ili trećoj komponenti, uz iznimku tvrdnje 20. Takav obrazac sugerira da fokusiranjem na interpretaciju prve tri komponente ne dolazi do većega gubitka informacija.

Tablica 5.22. Ekstrahirane komponente $u$ analizi

\begin{tabular}{|c|c|c|c|c|}
\hline Komponenta & $\begin{array}{l}\text { Ekstrak } \\
\text { Ukupno }\end{array}$ & $\begin{array}{l}\text { ija sume kvad } \\
\% \text { Varijance }\end{array}$ & $\begin{array}{l}\text { iranih zasićenja } \\
\text { Kumulativni \% }\end{array}$ & $\begin{array}{c}\text { Rotacija sume } \\
\text { kvadriranih zasićenja } \\
\text { Ukupno }\end{array}$ \\
\hline 1 & 9,171 & 36,682 & 36,682 & 6,992 \\
\hline 2 & 1,747 & 6,986 & 43,669 & 3,055 \\
\hline 3 & 1,495 & 5,979 & 49,648 & 6,267 \\
\hline 4 & 1,147 & 4,590 & 54,237 & 1,108 \\
\hline 5 & 1,084 & 4,335 & 58,572 & 3,967 \\
\hline 6 & 1,026 & 4,104 & 62,676 & 2,842 \\
\hline
\end{tabular}

Prve tri komponente objašnjavaju gotovo 50\% ukupne varijance (49,6\%, tablica 5.22.), dok preostale tri komponente objašnjavaju zajedno oko 13\% varijance. Rotirana solucija pokazuje malo složeniji obrazac, budući da je Eigen vrijednost malo viši za petu komponentu nego za drugu. Provedena je Oblimin rotacija, koja dopušta korelaciju među komponentama. Strukturna matrica je prikazana u tablici 5.23. 
Tablica 5.23. Strukturna matrica (Oblimin rotacija, 6 komponenti)

\begin{tabular}{lcccccc}
\hline \multirow{2}{*}{ Tvrdnja } & \multicolumn{5}{c}{ Komponenta } \\
& $\mathbf{1}$ & $\mathbf{2}$ & $\mathbf{3}$ & $\mathbf{4}$ & $\mathbf{5}$ & $\mathbf{6}$ \\
\hline eng_t_1 &, 841 & &, 373 & & & \\
eng_t_2 &, 849 & &, 408 & & & \\
eng_t_3 &, 740 & &, 338 &, 569 & \\
eng_t_5 &, 584 & &, 422 & & & \\
eng_t_6 &, 415 & &, 428 & & &, 815 \\
eng_t_8 &, 435 & &, 441 &,- 612 &, 376 & \\
eng_t_11 &, 422 & &, 644 &,- 322 & & \\
eng_t_12 &, 389 & &, 434 & &, 793 & \\
eng_t_13 &, 368 & &, 741 & &, 459 & \\
eng_t_14 &, 306 &, 308 &, 368 & &, 811 & \\
eng_t_15 &, 402 & &, 369 & & &, 790 \\
eng_t_16 &, 701 &, 350 &, 356 & & & \\
eng_t_17 & &, 797 & & & & \\
eng_t_20 & & & & &, 430 &, 652 \\
eng_t_23 & &, 862 & & & & \\
eng_t_24 &, 620 &, 367 &, 509 & &, 537 & \\
eng_t_25 &, 417 &, 531 &, 533 & &, 470 & \\
eng_t_26 &, 704 & &, 488 & & & \\
eng_t_27 &, 743 & &, 535 & & &, 345 \\
eng_t_28 &, 620 & &, 528 & &, 527 & \\
eng_t_31 &, 352 & &, 428 &, 435 &, 481 & \\
eng_t_32 &, 405 &, 428 &, 652 & & & \\
eng_t_34 &, 362 & &, 701 & & & \\
eng_t_35 &, 450 & &, 790 & &, 328 &, 347 \\
eng_t_37 &, 602 & &, 751 & &, 319 &, 379 \\
\hline & & & & &
\end{tabular}

Korelacija među zavisnim komponentama je prikazana u tablici 5.24.

Tablica 5.24. Korelacijska matrica komponenti

\begin{tabular}{crrrrrr}
\hline Komponenta & \multicolumn{1}{c}{$\mathbf{1}$} & \multicolumn{1}{c}{$\mathbf{2}$} & \multicolumn{1}{c}{$\mathbf{3}$} & \multicolumn{1}{c}{} & \multicolumn{1}{c}{$\mathbf{5}$} & \multicolumn{1}{c}{$\mathbf{6}$} \\
\hline 1 & 1,000 &, 297 &, 505 &,- 018 &, 301 &, 263 \\
2 &, 297 & 1,000 &, 258 &, 055 &, 242 &, 036 \\
3 &, 505 &, 258 & 1,000 &,- 012 &, 341 &, 261 \\
4 &,- 018 &, 055 &,- 012 & 1,000 &, 028 &,- 007 \\
5 &, 301 &, 242 &, 341 &, 028 & 1,000 &, 150 \\
6 &, 263 &, 036 &, 261 &,- 007 &, 150 & 1,000 \\
\hline
\end{tabular}


Tablica 5.24. pokazuje najvišu korelaciju između treće i prve komponente, koja je pozitivnoga smjera i umjereno visoka ( ,505). Također, četvrta komponenta ne korelira ni s jednom od ostalih četiriju komponenata, dok je peta najviše povezana s trećom, a šesta s prvom komponentom.

\subsubsection{Analiza glavnih komponenti i faktorska analiza Upitnika o strahu od čitanja na njemačkome jeziku}

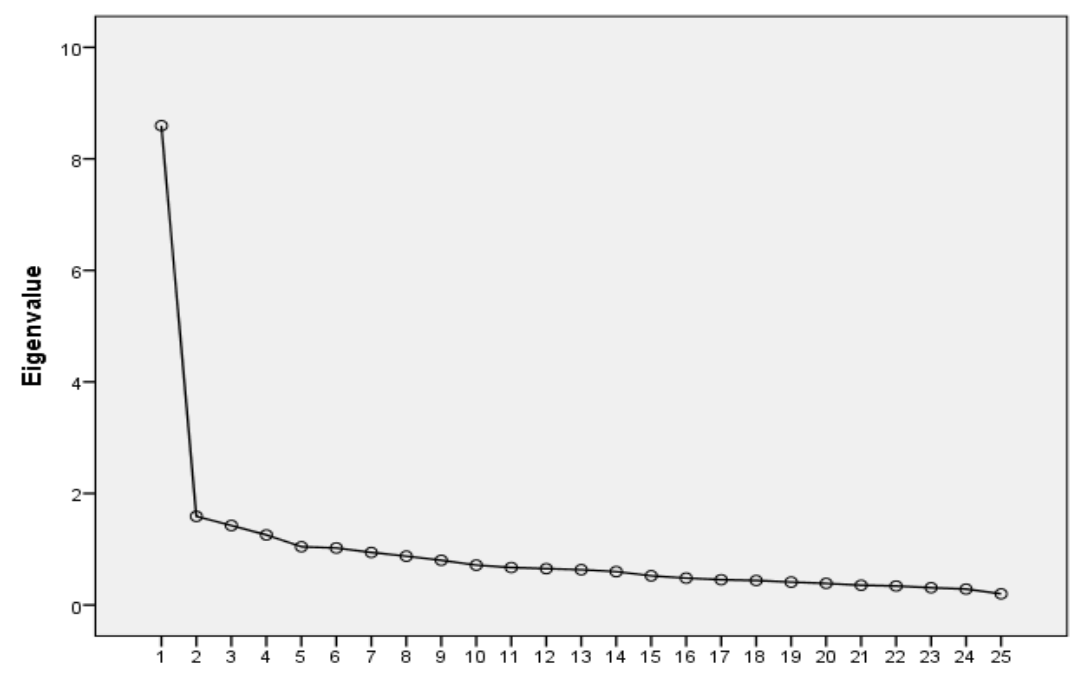

Slika 5.12. Grafički prikaz vrijednosti karakterističnih korijena (Eigen vrijednosti) za 25 faktora

Analiza glavnih komponenti rezultirala je ekstrakcijom šest komponenti, odnosno šest komponenti je imalo Eigen vrijednosti veće od 1. Zasićenje svake tvrdnje s pojedinim komponentama je prikazano u tablici 5.25., gdje zasićenja manja od ,30 apsolutne vrijednosti nisu prikazana. 
Tablica 5.25. Matrica obrazaca

\begin{tabular}{lcccccc}
\hline \multirow{2}{*}{ Tvrdnja } & \multicolumn{7}{c}{ Komponenta } \\
& $\mathbf{1}$ & $\mathbf{2}$ & $\mathbf{3}$ & $\mathbf{4}$ & $\mathbf{5}$ & $\mathbf{6}$ \\
\hline njem_t_1 &, 706 &,- 428 & & & & \\
njem_t_2 &, 696 &,- 346 & & & & \\
njem_t_3 &, 678 & & & & & \\
njem_t_5 &, 455 & & & &, 458 &,- 499 \\
njem_t_6 &, 570 &,- 370 & &, 345 & & \\
njem_t_8 &, 548 & & & &,- 351 & \\
njem_t_11 &, 405 & & &, 465 & &,- 336 \\
njem_t_12 &, 454 &, 412 &,- 381 & & & \\
njem_t_13 &, 632 & & & & & \\
njem_t_14 &, 528 & &,- 418 & & & \\
njem_t_15 &, 519 &,- 340 & &, 385 & &, 324 \\
njem_t_16 &, 544 & &, 328 & &,- 351 & \\
njem_t_17 &, 411 &, 398 &, 507 & & & \\
njem_t_20 &, 586 & & & & &, 481 \\
njem_t_23 & &, 369 &, 479 &, 480 &, 322 & \\
njem_t_24 &, 700 & & & & & \\
njem_t_25 &, 598 & & & &, 322 & \\
njem_t_26 &, 636 & & & & & \\
njem_t_27 &, 694 & & & & & \\
njem_t_28 &, 651 & & & & & \\
njem_t_31 &, 568 & & &,- 308 & & \\
njem_t_32 &, 624 & & & & & \\
njem_t_34 &, 592 & &, 356 & & & \\
njem_t_35 &, 675 & & & & & \\
njem_t_37 &, 715 & & & & & \\
\hline
\end{tabular}

Kao i u upitniku za engleski jezik, inspekcija tablice 5.25. ukazuje na to da se bar jedna od prvih dviju komponenata manifestira u svakoj od 25 tvrdnji. Usto, najviša zasićenja u četvrtoj, petoj ili šestoj komponenti manja su nego najviše zasićenje u prvoj, drugoj ili trećoj komponenti, uz iznimku tvrdnje 5., 11. i 23. Takav obrazac sugerira da fokusiranjem na interpretaciju prvih triju komponenata ne dolazi do većega gubitka informacija. 
Tablica 5.26. Ekstrahirane komponente u analizi

\begin{tabular}{ccccc}
\hline & \multicolumn{3}{c}{ Ekstrakcija sume kvadriranih zasićenja } & $\begin{array}{c}\text { Rotacija sume } \\
\text { kvadriranih zasićenja }\end{array}$ \\
Komponenta & Ukupno & \% Varijance & Kumulativni \% & Ukupno \\
\hline 1 & 8,595 & 34,379 & 34,379 & 5,163 \\
2 & 1,589 & 6,357 & 40,736 & 5,041 \\
3 & 1,425 & 5,702 & 46,438 & 1,470 \\
4 & 1,256 & 5,026 & 51,464 & 2,505 \\
5 & 1,045 & 4,180 & 55,644 & 4,141 \\
6 & 1,022 & 4,087 & 59,730 & 4,881 \\
\hline
\end{tabular}

Prve tri komponente objašnjavaju gotovo 50\% ukupne varijance (46,4\%, tablica 5.26.), dok je ukupan prinos preostalih triju komponenata oko 13\% varijance. Rotirana verzija ukazuje na to da četvrta, peta, i šesta komponenta objašnjavaju više varijance nego treća komponenta. Ovaj nalaz upućuje na to da je struktura faktora za njemački jezik nešto složenija nego za engleski jezik, i da odabir samo triju faktora koji su rotirani, dovodi do većega gubitka informacije. Ipak, u svrhu dosljednosti i usporedivosti upitnika za oba jezika, trofaktorsko rješenje bit će korišteno i za tvrdnje o njemačkom jeziku. Provedena rotacija dopušta korelaciju među komponentama (Oblimin rotacija). Strukturna matrica prikazana je u tablici 5.27.

Tablica 5.27. Strukturna matrica (Oblimin rotacija, 6 komponenti)

\begin{tabular}{lcccccc}
\hline \multirow{2}{*}{ Tvrdnja } & \multicolumn{5}{c}{ Komponenta } \\
& $\mathbf{1}$ & $\mathbf{2}$ & $\mathbf{3}$ & $\mathbf{4}$ & $\mathbf{5}$ & $\mathbf{6}$ \\
\hline njem_t_1 &, 582 & & & &, 623 &, 630 \\
njem_t_2 &, 557 & & & &, 677 &, 550 \\
njem_t_3 &, 523 &, 382 & & &, 441 &, 535 \\
njem_t_5 & & & & &, 866 & \\
njem_t_6 & & & &, 309 &, 430 &, 743 \\
njem_t_8 &, 416 & & &, 623 & &, 390 \\
njem_t_11 & & & &, 751 & & \\
njem_t_12 & &, 620 & &, 516 & & \\
njem_t_13 & &, 592 & &, 333 &, 391 &, 535 \\
njem_t_14 & &, 690 & &, 393 & & \\
njem_t_15 & & & & & &, 820 \\
njem_t_16 &, 767 & & & & & \\
njem_t_17 &, 442 & &, 673 &, 311 & & \\
njem_t_20 &, 395 &, 440 & & & &, 712 \\
njem_t_23 & & &, 872 & & & \\
njem_t_24 &, 589 &, 506 & & &, 390 &, 488 \\
njem_t_25 & &, 697 & & &, 390 &, 325
\end{tabular}




\begin{tabular}{llllll} 
njem_t_26 &, 522 &, 627 & &, 303 &, 383 \\
njem_t_27 &, 531 &, 507 & &, 655 &, 334 \\
njem_t_28 &, 513 &, 679 & &, 356 & \\
njem_t_31 &, 421 &, 674 & & & \\
njem_t_32 &, 583 &, 477 &, 342 & &, 382 \\
njem_t_34 &, 708 &, 324 & &, 389 & \\
njem_t_35 &, 597 &, 363 &, 380 &, 425 &, 462 \\
njem_t_37 &, 513 &, 395 &, 303 &, 564 &, 539 \\
\hline
\end{tabular}

Korelacija među zavisnim komponentama prikazana je u tablici 5.28.

Tablica 5.28. Korelacijska matrica komponenti

\begin{tabular}{crrrrrr}
\hline Komponenta & $\mathbf{1}$ & \multicolumn{1}{c}{$\mathbf{2}$} & \multicolumn{1}{c}{$\mathbf{3}$} & $\mathbf{4}$ & \multicolumn{1}{c}{$\mathbf{5}$} & $\mathbf{6}$ \\
\hline 1 & 1,000 &, 360 &, 083 &, 165 &, 335 &, 335 \\
2 &, 360 & 1,000 &, 071 &, 238 &, 262 &, 325 \\
3 &, 083 &, 071 & 1,000 &, 061 &, 066 &,- 007 \\
4 &, 165 &, 238 &, 061 & 1,000 &, 151 &, 221 \\
5 &, 335 &, 262 &, 066 &, 151 & 1,000 &, 343 \\
6 &, 335 &, 325 &,- 007 &, 221 &, 343 & 1,000 \\
\hline
\end{tabular}

Tablica 5.28. prikazuje najvišu korelaciju između pete i šeste komponente, koja je pozitivnoga smjera $(, 343)$. Usporedbom s korelacijom među rotiranim komponentama dobivenom za engleski jezik (tablica 5.24.), korelacijska struktura tvrdnji o njemačkom jeziku pokazuje manje koeficijente - manju zavisnost među faktorima. 


\subsubsection{Formiranje subskala na temelju faktorske analize Upitnika o strahu od}

čitanja na engleskome jeziku i faktorske analize Upitnika o strahu od čitanja na njemačkome jeziku u glavnome istraživanju

\subsubsection{Formiranje subskala na temelju faktorske analize Upitnika o strahu od} čitanja na engleskome jeziku

Najprije je pomoću Keyser-Meyer-Olkinove mjere i Bartlettova testa sfericiteta utvrđeno da je matrica rezultata pogodna za faktorizaciju $\left(K M O=, 918, \chi^{2}=2225,718 ; p=, 000\right)$, a potom je provedena analiza glavnih komponenti s Oblimin rotacijom.

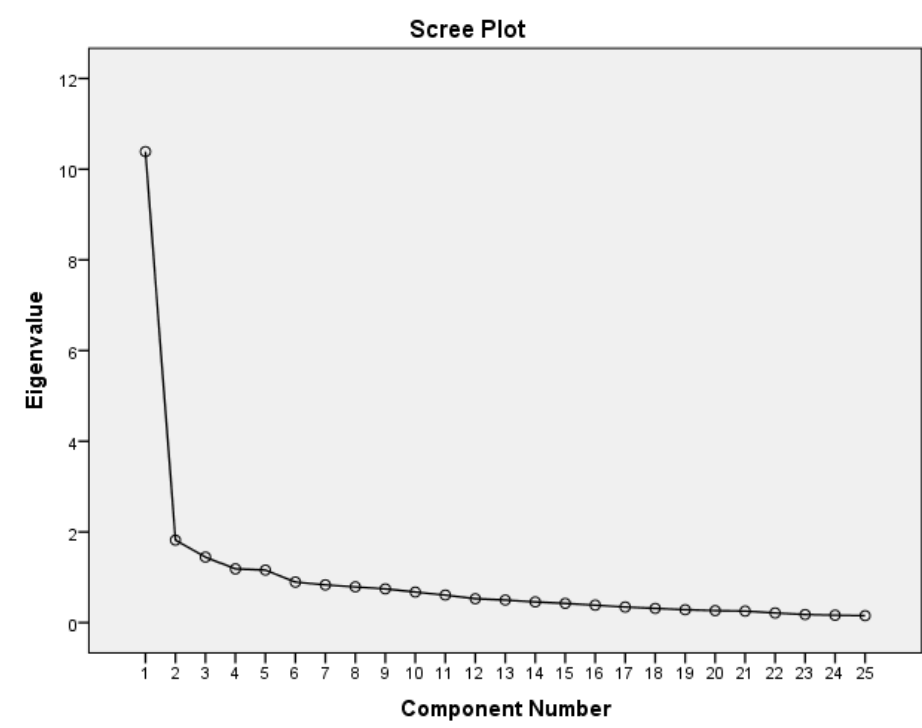

Slika 5.13. Grafički prikaz vrijednosti karakterističnih korijena (Eigen vrijednosti) za 25 varijabli

Iz grafičkoga prikaza vrijednosti karakterističnih korijena vidljivo je da pet faktora ima Eigen vrijednosti veće od 1.

Analiza glavnih komponenti rezultirala je ekstrakcijom pet komponenti, odnosno pet komponenti imalo je Eigen vrijednosti veće od 1. Zasićenje svake tvrdnje s pojedinim 
komponentama prikazano je u tablicama 5.29. i 5.30., gdje zasićenja manja od 0,30 apsolutne vrijednosti nisu prikazana.

U tablici 5.29. vidljivo je da prvih pet komponenti objašnjava preko 60\% (64\%) ukupne varijance. Prva komponenta objašnjava 41,5 \% varijance, druga 7,3\%, treća 5,8\%, četvrta 4,7\%, a peta komponenta $4,6 \%$ varijance.

Tablica 5.29. Ekstrahirane komponente u analizi

\begin{tabular}{|c|c|c|c|c|}
\hline \multirow[t]{2}{*}{ Komponenta } & \multicolumn{3}{|c|}{ Vrijednost karakterističnoga korijena } & \multirow{2}{*}{ 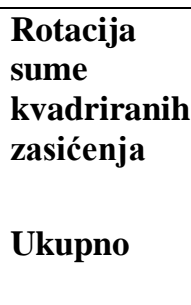 } \\
\hline & Ukupno & $\begin{array}{c}\% \\
\text { varijance }\end{array}$ & $\begin{array}{c}\text { Kumulativni } \\
\%\end{array}$ & \\
\hline 1 & 10,387 & 41,549 & 41,549 & 8,389 \\
\hline 2 & 1,819 & 7,277 & 48,826 & 6,658 \\
\hline 3 & 1,445 & 5,781 & 54,606 & 6,167 \\
\hline 4 & 1,185 & 4,741 & 59,347 & 1,273 \\
\hline 5 & 1,159 & 4,636 & 63,983 & 1,254 \\
\hline 6 & ,894 & 3,577 & 67,560 & \\
\hline 7 & 832 & 3,329 & 70,889 & \\
\hline 8 & ,788 & 3,153 & 74,042 & \\
\hline 9 & ,745 & 2,980 & 77,022 & \\
\hline 10 & 674 & 2,695 & 79,717 & \\
\hline 11 & 608 & 2,431 & 82,148 & \\
\hline 12 &, 527 & 2,108 & 84,256 & \\
\hline 13 & ,498 & 1,992 & 86,248 & \\
\hline 14 & ,456 & 1,825 & 88,073 & \\
\hline 15 & ,425 & 1,701 & 89,774 & \\
\hline 16 & ,385 & 1,541 & 91,315 & \\
\hline 17 & ,345 & 1,378 & 92,693 & \\
\hline 18 & ,314 & 1,258 & 93,951 & \\
\hline 19 & ,285 & 1,139 & 95,090 & \\
\hline 20 & ,265 & 1,061 & 96,151 & \\
\hline 21 & ,254 & 1,014 & 97,165 & \\
\hline 22 & ,213 &, 851 & 98,016 & \\
\hline 23 & 179 & ,716 & 98,731 & \\
\hline 24 &, 164 & ,654 & 99,386 & \\
\hline 25 & 154 & 614 & 100,000 & \\
\hline
\end{tabular}


Najviša zasićenja su: za komponentu 1 na čestici 13. „Postupci nastavnika/ce ometaju me i zbunjuju dok čitam naglas na engleskome.“, za komponentu 2 na čestici 8. „Čini me nervoznim/om kad čitam u sebi i razumijem gotovo sve riječi u rečenici, ali ne razumijem značenje rečenice.“ za komponentu 3 na čestici 11. „Kad čitam naglas na engleskome jeziku, osjećam se opušteno i siguran/na u sebe. “, za komponentu 4 na čestici 14. „Ako pri čitanju u sebi naiđem na riječ ili riječi koje ne razumijem, nastavljam čitati a da se nisam uznemirio/la. “ i za komponentu 5 na čestici 15. „Smeta me kad me nastavnik/ca prekida $i$ ispravlja dok čitam naglas. "(tablica 5.30.).

Tablica 5.30. Matrica obrazaca (Oblimin rotacija, 5 komponenti)

\begin{tabular}{|c|c|c|c|c|c|}
\hline \multirow[t]{2}{*}{ Čestica } & \multicolumn{5}{|c|}{ Komponenta } \\
\hline & 1 & 2 & 3 & 4 & 5 \\
\hline eng_t_1 & & & ,726 & & \\
\hline eng_t_2 & & & ,686 & & \\
\hline eng_t_3 & & ,623 & & & \\
\hline eng_t_4 & ,383 & & &, 377 & \\
\hline eng_t_5 & & &, 740 & & \\
\hline eng_t_6 & &, 324 &, 317 &, 325 & \\
\hline eng_t_7 & & ,409 & & & \\
\hline eng_t_8 & & ,851 & & & \\
\hline eng_t_9 & & ,486 & & & \\
\hline eng_t_10 & &, 737 & & & \\
\hline eng_t_11 & & & ,865 & & \\
\hline eng_t_12 & 648 & & & & \\
\hline eng_t_13 &, 830 & & & & \\
\hline eng_t_14 & & & &,- 723 & \\
\hline eng_t_15 & & & & & ,887 \\
\hline eng_t_16 & &, 501 & & & \\
\hline eng_t_17 & &, 721 & & & \\
\hline eng_t_18 & ,733 & & & & \\
\hline eng_t_19 & ,759 & & & & \\
\hline eng_t_20 & ,741 & & & & \\
\hline eng_t_21 & , 455 &, 548 &,- 409 & & \\
\hline eng_t_22 & ,589 & & & & \\
\hline eng_t_23 & 669 & & & & \\
\hline eng_t_24 & ,472 &, 327 & & & \\
\hline eng_t_25 &, 540 & & ,338 & & \\
\hline
\end{tabular}


Tablica 5.31. Strukturna matrica

\begin{tabular}{|c|c|c|c|c|c|}
\hline \multirow[t]{2}{*}{ Čestica } & \multirow[b]{2}{*}{1} & \multicolumn{2}{|c|}{ Komponenta } & \multirow[b]{2}{*}{4} & \multirow[b]{2}{*}{5} \\
\hline & & 2 & 3 & & \\
\hline eng_t_1 & ,593 & ,452 & ,843 & & \\
\hline eng_t_2 &, 561 & ,394 & 800 & & \\
\hline eng_t_3 &, 504 & ,747 & ,506 & & \\
\hline eng_t_4 &, 528 & 360 & ,362 & ,408 & \\
\hline eng_t_5 & ,477 & ,376 & ,809 & & \\
\hline eng_t_6 &, 500 & ,508 &, 526 &, 343 & \\
\hline eng_t_7 & ,509 &, 570 & ,454 & ,306 & \\
\hline eng_t_8 & ,362 & ,823 & ,314 & & \\
\hline eng_t_9 &, 570 & 654 & ,450 & & \\
\hline eng_t_10 &, 380 & ,743 & & & \\
\hline eng_t_11 & ,402 & &, 857 & & \\
\hline eng_t_12 &, 713 & ,312 & ,499 & & \\
\hline eng_t_13 &, 751 & 305 & & & \\
\hline eng_t_14 & & & &,- 709 & \\
\hline eng_t_15 & & & & & ,861 \\
\hline eng_t_16 & ,459 & ,625 & ,367 & & \\
\hline eng_t_17 & & ,663 & & & \\
\hline eng_t_18 &, 759 & ,379 & ,408 & & \\
\hline eng_t_19 &, 777 &, 325 & ,497 & & \\
\hline eng_t_20 & ,807 &, 543 & ,377 & & \\
\hline eng_t_21 &, 527 & ,649 & & & \\
\hline eng_t_22 & 669 & ,447 & ,378 & & \\
\hline eng_t_23 &, 757 & ,477 & ,441 & & \\
\hline eng_t_24 &, 740 & ,638 & ,559 & & \\
\hline eng_t_25 &, 788 &, 555 & ,658 & & \\
\hline
\end{tabular}

Korelacijska analiza provedena je kako bi se pojasnila struktura straha od čitanja na engleskome jeziku utvrđivanjem povezanosti među komponentama. Korelacija među zavisnim komponentama ${ }^{20}$ prikazana je u tablici 5.32. Najviša i pozitivna korelacija je između prve i druge komponente $(r=, 508)$, dok je najniži, i ujedno negativni koeficijent korelacije između druge i pete komponente $(r=-, 002)$.

\footnotetext{
${ }^{20}$ Vrijednosti Pearsonova koeficijenta korelacije tumačit će se u ovome radu na sljedeći način: $\mathrm{r}=+/-0,10$ do $+/-0,29$ niska korelacija, $\mathrm{r}=+/-0,30$ do $+/-0,49$ umjerena korelacija, $\mathrm{r}=+/-0,50$ do $+/-0,69$ visoka korelacija $\mathrm{i}$ $\mathrm{r}=+/-0,70$ do $+/-1,00$ vrlo visoka korelacija
} 
Tablica 5.32. Korelacijska matrica komponenti - subskala straha od čitanja na engleskome jeziku

\begin{tabular}{llllll}
\hline Komponente & $\mathbf{1}$ & $\mathbf{2}$ & $\mathbf{3}$ & $\mathbf{4}$ & $\mathbf{5}$ \\
$\mathbf{1}$ & 1,000 &, 508 &, 471 &, 063 &,- 011 \\
$\mathbf{2}$ & $\mathbf{5 0 8}$ & 1,000 &, 319 &,- 003 &,- 002 \\
$\mathbf{3}$ &, 471 &, 319 & 1,000 &, 004 &,- 123 \\
$\mathbf{4}$ &, 063 &,- 003 &, 004 & 1,000 &,- 032 \\
$\mathbf{5}$ &,- 011 & $\mathbf{- , 0 0 2}$ &,- 123 &,- 032 & 1,000 \\
\hline
\end{tabular}

Provedena je analiza Cronbachova $\alpha$ na ukupnom upitniku i subskalama definiranim faktorskom analizom. Izračunata je mjera pouzdanosti za Upitnik o strahu od čitanja na engleskome jeziku s ukupno 25 čestica te je utvrđeno da Cronbachov $\alpha$ za cijeli upitnik iznosi 0,933, ukazujući na visoku pouzdanost mjernoga instrumenta. Nakon toga pristupilo se izračunavanju pouzdanosti subskala upitnika koje su definirane faktorskom analizom.

\section{Subskala 1 Upitnika o strahu od čitanja na engleskome jeziku}

Subskala 1 Upitnika o strahu od čitanja na engleskome jeziku sadržava deset čestica (v. tablicu 5.33.), a Cronbachov $\alpha$ za ovu subskalu iznosi ,911, što ukazuje na visoku pouzdanost. Iz tablice 5.33. vidljivo je da se u ovoj subskali najviša aritmetička sredina bilježi za čestice 19. „, Nervozniji/ja sam kad čitam naglas na engleskome nego kad pišem, slušam ili govorim. “ i 24. „Pri čitanju u sebi na engleskome zbunjuju me duge riječi koje je teško pročitati. “, koje se odnose na osjećaj uznemirenosti i zbunjenosti i kod čitanja naglas i kod čitanja u sebi na engleskome. Najnižu aritmetičku sredinu bilježi čestica 4. „Ako trebam odabrati između čitanja, pisanja, slušanja i govora na engleskome jeziku, najteže mi je čitanje. ", koja se odnosi na rangiranje težine čitanja u odnosu na težinu pisanja, slušanja i govora. U ovoj subskali objedinjene su čestice koje se mogu povezati s kognitivnom komponentom straha od čitanja na engleskome jeziku. Sadržaj čestica ove subskale odnosi se na negativno samovrednovanje učenika (čestica 4. i 25.), preokupiranost mislima o sebi i zabrinutost o kvaliteti obavljanja zadatka (čestice 19., 20. i 24.), zabrinutost zbog prijetećih ili predosjećanih događaja, odnosno strah od evaluacije (čestice 22. i 23.), osjećaj da djelovanje okoline (nastavnik) može ometati 
izvršavanje zadatka (čestica 13.). U ovoj subskali nalaze se dvije čestice (čestice 12. i 18.) u kojima se odražava tjelesna komponenta straha od čitanja na engleskome jeziku, koja se pojavljuje kao manifestacija straha u situaciji kada učenik čita pred drugima što se također može povezati s kognitivnom komponentom učenikove zabrinutosti o slici koju drugi imaju o njemu.

Tablica 5.33. Čestice subskale 1 Upitnika o strahu od čitanja na engleskome jeziku

\begin{tabular}{|c|c|c|}
\hline Čestica & AS & SD \\
\hline $\begin{array}{l}\text { 4. Ako trebam odabrati između čitanja, pisanja, slušanja i govora na } \\
\text { engleskome jeziku, najteže mi je čitanje. }\end{array}$ & 1,55 & 1,003 \\
\hline 12. Dok čitam naglas na engleskome pred drugima, srce mi jače lupa. & 2,02 & 1,201 \\
\hline $\begin{array}{l}\text { 13. Postupci nastavnika/ce ometaju me i zbunjuju dok čitam naglas na } \\
\text { engleskome. }\end{array}$ & 1,62 & 1,041 \\
\hline $\begin{array}{l}\text { 18. Dok čitam naglas na engleskome pred drugima, osjećam da mi se } \\
\text { znoje dlanovi. }\end{array}$ & 1,67 & 1,088 \\
\hline $\begin{array}{l}\text { 19. Nervozniji/ja sam kad čitam naglas na engleskome nego kad } \\
\text { pišem, slušam ili govorim. }\end{array}$ & 2,04 & 1,221 \\
\hline $\begin{array}{l}\text { 20. Ako čitam tekst na engleskome o nepoznatoj temi, postajem } \\
\text { nervozan/na. }\end{array}$ & 1,80 & 1,100 \\
\hline $\begin{array}{l}\text { 22. Uznemiruje me kad čitam u sebi tekst na engleskome, a } \\
\text { nastavnik/ca nakon toga ocjenjuje zadatke razumijevanja pročitanoga. }\end{array}$ & 1,90 & 1,215 \\
\hline $\begin{array}{l}\text { 23. Uznemiruje me kad čitam u sebi tekst na engleskome, a } \\
\text { nastavnik/ca nakon toga ocjenjuje zadatke razumijevanja pročitanoga. }\end{array}$ & 1,88 & 1,278 \\
\hline $\begin{array}{l}\text { 24. Pri čitanju u sebi na engleskome zbunjuju me duge riječi koje je } \\
\text { teško pročitati. }\end{array}$ & 2,04 & 1,157 \\
\hline $\begin{array}{l}\text { 25. Osjećam se nesigurno kad čitam naglas na engleskome jer nemam } \\
\text { dara za čitanje na engleskome. }\end{array}$ & 1,80 & 1,232 \\
\hline
\end{tabular}

\section{Subskala 2 Upitnika o strahu od čitanja na engleskom jeziku}

Subskala 2 Upitnika o strahu od čitanja na engleskome jeziku sadrži osam čestica (v. tablicu 5.34.), a Cronbachov $\alpha$ za ovu subskalu iznosi ,850 što ukazuje na visoku pouzdanost. Iz tablice 5.34. vidljivo je da se u ovoj subskali najviša aritmetička sredina bilježi za česticu 16. „Dok čitam naglas na engleskome, brinem se kako ću izgovoriti pojedine riječi. ", koja se odnosi na zabrinutost vezanu uz izgovor riječi na engleskome jeziku. Najnižu aritmetičku sredinu bilježi čestica 9. „Strah me da nikada neću dobro naučiti čitati engleski jer je čitanje na engleskome teško. “, koja izražava zabrinutost zbog ovladavanja čitanjem, ali i uvjerenje da je čitanje na engleskome jeziku teško. Za sve čestice ove subskale moglo bi se reći da odražavaju jezičnu komponentu straha od čitanja na engleskome jeziku. Sadržaj čestica odnosi se na uznemirenost koja se pojavljuje kada učenik naiđe na nepoznati izraz ili riječ (čestica 3.), nepoznatu gramatiku (čestica 10.), nepoznati pojam iz kulture engleskoga govornoga područja 
(čestica 21.), nerazumljivu rečeničnu sintaksu (čestica 8.), nepodudarnost između načina pisanja i čitanja (čestica 7.), teškoće u izgovoru pojedinih riječi (čestica 16.) i vjerovanje da je čitanje na engleskome jeziku teško savladiva jezična vještina (čestica 9.).

Tablica 5.34. Čestice subskale 2 Upitnika o strahu od čitanja na engleskome jeziku

\begin{tabular}{lcc}
\hline \multicolumn{1}{c}{ Čestica } & AS & SD \\
\hline $\begin{array}{l}\text { 3. Uznemiruje me kad pri čitanju u sebi naiđem na riječ ili izraz koji } \\
\text { ne razumijem. }\end{array}$ & 2,27 & 1,283 \\
$\begin{array}{l}\text { 7. Zbunjuje me nepodudarnost između načina pisanja i čitanja na } \\
\text { engleskome jeziku. }\end{array}$ & 1,61 &, 972 \\
$\begin{array}{l}\text { 8. Čini me nervoznim/om kad čitam u sebi i razumijem gotovo sve } \\
\text { riječi u rečenici, ali ne razumijem značenje rečenice. }\end{array}$ & 2,04 & 1,270 \\
$\begin{array}{l}\text { 9. Strah me da nikada neću dobro naučiti čitati engleski jer je čitanje } \\
\text { na engleskome teško. }\end{array}$ & $\mathbf{1 , 4 5}$ &, 977 \\
$\begin{array}{l}\text { 10. Postajem nervozan/na kad pri čitanju u sebi naiđem na nepoznatu } \\
\text { gramatičku konstrukciju. }\end{array}$ & 1,91 & 1,179 \\
$\begin{array}{l}\text { 16. Dok čitam naglas na engleskome, brinem se kako ću izgovoriti } \\
\text { pojedine riječi. }\end{array}$ & $\mathbf{2 , 5 7}$ & 1,351 \\
$\begin{array}{l}\text { 17. Nervozan/na sam kad čitam tekst koji nije zanimljiv. } \\
\text { 21. Smeta me kad u tekstu naiđem na neki pojam iz britanske, } \\
\text { američke ili druge kulture engleskoga govornoga područja koji mi } \\
\text { nije poznat. }\end{array}$ & $\begin{array}{l}2,13 \\
\text { AS=aritmetička sredina, SD=standardna devijacija }\end{array}$ & 1,265 \\
\end{tabular}

\section{Subskala 3 Upitnika o strahu od čitanja na engleskom jeziku}

Subskala 3 Upitnika o strahu od čitanja na engleskome jeziku sadrži pet čestica (v. tablicu 5.34.), a Cronbachov $\alpha$ za ovu subskalu iznosi ,868, što ukazuje na visoku pouzdanost. Iz tablice 5.34. vidljivo je da se u ovoj subskali najviša aritmetička sredina bilježi za česticu 5 . „Osjećam se ugodno dok čitam naglas na engleskome.“ (rekodirano), u kojoj se izražava osjećaj neugode pri čitanju naglas. Najnižu aritmetičku sredinu bilježi čestica 6 . „,Brinem se kako ću u sebi pročitati duge tekstove na engleskome. “, koja izražava zabrinutost o uspješnosti čitanja dugih tekstova na engleskome jeziku u sebi. Ova subskala objedinjuje čestice koje odražavaju emocionalnu komponentu straha od čitanja na engleskome jeziku. Emocionalna komponenta u ovoj subskali ukazuje na negativne emocije - uznemirenost i neugodu, a to se odražava u sadržaju čestica ove subskale. Uznemirenost je povezana i s tjelesnom manifestacijom straha koju opisuje čestica 2. (drhtanje glasa), a uznemirenost može biti 
potaknuta zabrinutošću koja se pojavljuje kada učenik treba pročitati tekst koji je dug (čestica $6)$.

Tablica 5.35. Čestice subskale 3 Upitnika o strahu od čitanja na engleskome jeziku

\begin{tabular}{|c|c|c|}
\hline Čestica & AS & SD \\
\hline $\begin{array}{l}\text { 1. Osjećam se nervozno dok čitam naglas na engleskome pred } \\
\text { drugima. }\end{array}$ & 1,93 & 1,220 \\
\hline $\begin{array}{l}\text { 2. Kad čitam naglas na engleskome pred drugima, uznemirim se i } \\
\text { glas mi se promijeni i drhti. }\end{array}$ & 1,84 & 1,212 \\
\hline 5. Osjećam se ugodno dok čitam naglas na engleskome. & 2,61 & 1,299 \\
\hline 6. Brinem se kako ću u sebi pročitati duge tekstove na engleskome. & 1,82 & 1,112 \\
\hline $\begin{array}{l}\text { 11. Kad čitam naglas na engleskome jeziku, osjećam se opušteno i } \\
\text { siguran/na u sebe. }\end{array}$ & 2,54 & 1,389 \\
\hline
\end{tabular}

Prilikom obrade utvrđeno je da subskala 4 Upitnika o strahu od čitanja na engleskome jeziku sadržava samo jednu česticu 14. „Ako pri čitanju u sebi naiđem na riječ ili riječi koje ne razumijem, nastavljam čitati a da se nisam uznemirio/la. “ (rekodirano) i da subskala 5 Upitnika o strahu od čitanja na engleskome jeziku također sadržavav samo jednu česticu 15. „Smeta me kad me nastavnik/ca prekida i ispravlja dok čitam naglas. “. Budući da su ta dva faktora bila manifestirana u po jednoj čestici, oni nisu tretirani kao subskale, već su izostavljeni iz daljnje obrade. 


\subsubsection{Formiranje subskala na temelju faktorske analize Upitnika o strahu od čitanja na njemačkome jeziku}

Najprije je pomoću Keyser-Meyer-Olkinove mjere i Bartlettova testa sfericiteta utvrđeno da je matrica rezultata pogodna za faktorizaciju $\left(K M O=, 898 ; \chi^{2}=1696,474 ; p=, 000\right)$, a potom je provedena analiza glavnih komponenti s Oblimin rotacijom.

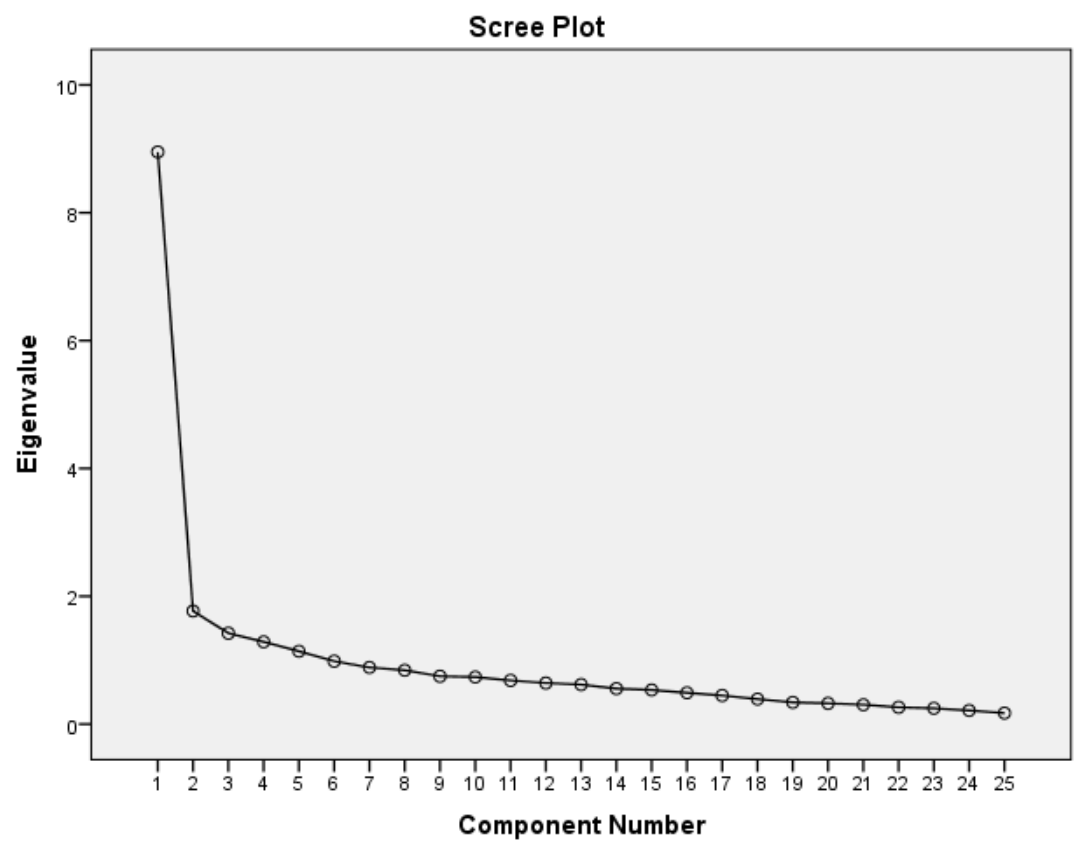

Slika 5.14. Grafički prikaz vrijednosti karakterističnih korijena (Eigen vrijednosti) za 25 varijabli

Iz grafičkoga prikaza vrijednosti karakterističnih korijena vidljivo je da pet faktora ima Eigen vrijednosti veće od 1.

Analiza glavnih komponenti rezultirala je ekstrakcijom pet komponenti, odnosno pet komponenti imalo je Eigen vrijednosti veće od 1. Zasićenje svake tvrdnje s pojedinim komponentama prikazano je u tablicama 5.37. i 5.38., gdje zasićenja manja od ,30 apsolutne vrijednosti nisu prikazana. 
U tablici 5.36. vidljivo je da prvih pet komponenti objašnjavaju preko 50\% $(58,3 \%)$ ukupne varijance. Prva komponenta objašnjava 35,8\% varijance, druga 7,1\%, treća 5,7\%, četvrta $5,1 \%$, a peta komponenta $4,5 \%$ varijance.

Tablica 5.36. Ekstrahirane komponente u analizi

\begin{tabular}{|c|c|c|c|c|}
\hline \multirow[t]{2}{*}{ Komponenta } & \multicolumn{3}{|c|}{ Vrijednost karakterističnoga korijena } & \multirow{2}{*}{$\begin{array}{l}\text { Rotacija } \\
\text { sume } \\
\text { kvadriranih } \\
\text { zasićenja } \\
\text { Ukupno }\end{array}$} \\
\hline & Ukupno & $\begin{array}{c}\% \\
\text { varijance }\end{array}$ & $\begin{array}{c}\text { Kumulativni } \\
\%\end{array}$ & \\
\hline 1 & 8,951 & 35,803 & 35,803 & 4,842 \\
\hline 2 & 1,769 & 7,078 & 42,881 & 4,525 \\
\hline 3 & 1,422 & 5,689 & 48,570 & 4,376 \\
\hline 4 & 1,287 & 5,147 & 53,717 & 2,607 \\
\hline 5 & 1,140 & 4,558 & 58,275 & 5,797 \\
\hline 6 & ,984 & 3,937 & 62,212 & \\
\hline 7 & ,886 & 3,545 & 65,756 & \\
\hline 8 & ,843 & 3,374 & 69,130 & \\
\hline 9 &, 749 & 2,995 & 72,125 & \\
\hline 10 &, 736 & 2,944 & 75,070 & \\
\hline 11 & 683 & 2,733 & 77,802 & \\
\hline 12 & 643 & 2,572 & 80,374 & \\
\hline 13 & 619 & 2,475 & 82,849 & \\
\hline 14 &, 556 & 2,223 & 85,072 & \\
\hline 15 &, 534 & 2,137 & 87,209 & \\
\hline 16 & ,491 & 1,966 & 89,175 & \\
\hline 17 & ,448 & 1,793 & 90,968 & \\
\hline 18 & ,391 & 1,565 & 92,534 & \\
\hline 19 &, 340 & 1,362 & 93,896 & \\
\hline 20 &, 325 & 1,299 & 95,195 & \\
\hline 21 & ,304 & 1,214 & 96,409 & \\
\hline 22 &, 263 & 1,053 & 97,462 & \\
\hline 23 & ,248 & ,991 & 98,453 & \\
\hline 24 &, 214 & ,855 & 99,308 & \\
\hline 25 & , 173 & ,692 & 100,000 & \\
\hline
\end{tabular}

Najviša zasićenja su za komponentu 1 na čestici 25. „Osjećam se nesigurno kad čitam naglas na njemačkome jer nemam dara za čitanje na njemačkome. “, za komponentu 2 na čestici 8. „Čini me nervoznim/om kad čitam u sebi i razumijem gotovo sve riječi u rečenici, ali ne razumijem značenje rečenice. “, za komponentu 3 na čestici 5. „Osjećam se ugodno dok čitam 
naglas na njemačkome.“, za komponentu 4 na čestici 15. „Smeta me kad me nastavnik/ca prekida i ispravlja dok čitam naglas. “, a za komponentu 5 na čestici 18. „,Dok čitam naglas na njemačkome pred drugima, osjećam da mi se znoje dlanovi. “(v. tablicu 5.37.).

Tablica 5.37. Matrica obrazaca (Oblimin rotacija, 5 komponenti)

\begin{tabular}{|c|c|c|c|c|c|}
\hline \multirow[t]{2}{*}{ Čestica } & \multirow[b]{2}{*}{1} & \multicolumn{3}{|c|}{ Komponenta } & \multirow[b]{2}{*}{5} \\
\hline & & 2 & 3 & 4 & \\
\hline njem_t_1 & & & ,561 & & ,364 \\
\hline njem_t_2 & & & ,420 & &, 554 \\
\hline njem_t_3 &, 317 & ,432 & & & \\
\hline njem_t_4 & & & &, 580 & \\
\hline njem_t_5 & & & ,809 & & \\
\hline njem_t_6 &, 530 & & & & \\
\hline njem_t_7 &, 351 & & & & \\
\hline njem_t_8 & & ,714 & & & \\
\hline njem_t_9 & ,304 & & & & \\
\hline njem_t_10 & &, 514 & & & ,348 \\
\hline njem_t_11 & & & ,724 & & \\
\hline njem_t_12 & & & & & ,696 \\
\hline njem_t_13 & & & & ,648 & \\
\hline njem_t_14 &,- 444 & & ,683 & & \\
\hline njem_t_15 & & & & ,753 & \\
\hline njem_t_16 &, 522 & ,343 & & & \\
\hline njem_t_17 & & & & & ,434 \\
\hline njem_t_18 & & & & & ,786 \\
\hline njem_t_19 & ,460 & & & & ,424 \\
\hline njem_t_20 & & & & & ,608 \\
\hline njem_t_21 & & ,610 & & & \\
\hline njem_t_22 & & ,658 & & & \\
\hline njem_t_23 &, 421 & & & & ,397 \\
\hline njem_t_24 & ,491 & ,356 & & & \\
\hline njem_t_25 & ,692 & & & & \\
\hline
\end{tabular}


Tablica 5.38. Strukturna matrica

\begin{tabular}{|c|c|c|c|c|c|}
\hline \multirow[t]{2}{*}{ Čestica } & \multicolumn{4}{|c|}{ Komponenta } & \multirow[b]{2}{*}{5} \\
\hline & 1 & 2 & 3 & 4 & \\
\hline njem_t_1 & ,529 & ,306 & ,729 & & ,608 \\
\hline njem_t_2 & ,404 &, 319 & ,605 & & ,707 \\
\hline njem_t_3 & ,483 &, 549 & ,353 & & ,450 \\
\hline njem_t_4 & ,392 & & ,388 & ,627 & \\
\hline njem_t_5 & ,313 & & ,789 & & \\
\hline njem_t_6 & 659 & ,466 & & &, 510 \\
\hline njem_t_7 & ,479 &, 425 & ,433 &, 363 & \\
\hline njem_t_8 & &, 703 & & & \\
\hline njem_t_9 &, 521 & ,411 & ,457 & ,329 & ,507 \\
\hline njem_t_10 & & ,656 & & &, 549 \\
\hline njem_t_11 & & & ,760 & & ,343 \\
\hline njem_t_12 & ,438 & & & & ,748 \\
\hline njem_t_13 & & ,309 & & ,711 &, 412 \\
\hline njem_t_14 & & ,319 & ,641 & & \\
\hline njem_t_15 & & & & ,721 & \\
\hline njem_t_16 & ,662 &, 515 & ,329 & & ,463 \\
\hline njem_t_17 & & ,443 & & &, 530 \\
\hline njem_t_18 & ,351 & & & &, 813 \\
\hline njem_t_19 & ,611 & & & &, 582 \\
\hline njem_t_20 & &, 514 & ,358 & &, 727 \\
\hline njem_t_21 & & ,681 & & ,357 & ,414 \\
\hline njem_t_22 & & 681 & & ,312 & \\
\hline njem_t_23 & ,598 &, 307 & & &, 588 \\
\hline njem_t_24 & 623 &, 529 & ,322 & ,365 &, 351 \\
\hline njem_t_25 & 804 & & ,448 & & ,416 \\
\hline
\end{tabular}

Korelacijska analiza provedena je kako bi se pojasnila struktura straha od čitanja na njemačkome jeziku utvrđivanjem povezanosti među komponentama. Korelacija među zavisnim komponentama prikazana je u tablici 5.39. Prevladavaju niske korelacije. Najviša korelacija je između prve i pete komponente, koja je umjerena korelacija pozitivnoga smjera $(r=, 353)$. Najniža korelacija je između četvrte i treće komponente, također pozitivnoga smjera $(r=, 162)$. 
Tablica 5.39. Korelacijska matrica komponenti - subskala straha od čitanja na njemačkome jeziku

\begin{tabular}{llllll}
\hline Komponente & $\mathbf{1}$ & $\mathbf{2}$ & $\mathbf{3}$ & $\mathbf{4}$ & $\mathbf{5}$ \\
$\mathbf{1}$ & 1,000 &, 227 &, 285 &, 169 & $\mathbf{3 5 3}$ \\
$\mathbf{2}$ &, 227 & 1,000 &, 246 &, 238 &, 338 \\
$\mathbf{3}$ &, 285 &, 246 & 1,000 &, $\mathbf{1 6 2}$ &, 297 \\
$\mathbf{4}$ &, 169 &, 238 &, 162 & 1,000 &, 179 \\
$\mathbf{5}$ &, 353 &, 338 &, 297 &, 179 & 1,000 \\
\hline
\end{tabular}

Provedena je analiza Cronbachova $\alpha$ na ukupnom testu i subskalama definiranim faktorskom analizom. Izračunata je mjera pouzdanosti za Upitnik o strahu od čitanja na njemačkome jeziku s ukupno 25 čestica te je utvrđeno da Cronbachov $\alpha$ za cijeli upitnik iznosi ,919, što znači da upitnik posjeduje visoku pouzdanost. Nakon toga se pristupilo izračunavanju pouzdanosti subskala upitnika koje su definirane faktorskom analizom.

\section{Subskala 1 Upitnika o strahu od čitanja na njemačkome jeziku}

Subskala 1 Upitnika o strahu od čitanja na njemačkome jeziku sadržava osam čestica, a Cronbachov $\alpha$ za ovu subskalu iznosi ,869, što ukazuje na visoku pouzdanost. Iz tablice 5.40. vidljivo je da se u ovoj subskali najviša aritmetička sredina bilježi za česticu 16. „Dok čitam naglas na njemačkom, brinem se kako ću izgovoriti pojedine riječi. ", koja se odnosi na zabrinutost zbog točnosti izgovora pojedinih riječi na njemačkome. Najnižu aritmetičku sredinu bilježi čestica 23. „Uznemiruje me kad čitam u sebi tekst na njemačkome, a nastavnik/ca nakon toga ocjenjuje zadatke razumijevanja pročitanoga. “, koja se odnosi na evaluaciju zadataka razumijevanja pročitanoga teksta koji slijede nakon čitanja. Četiri čestice ove subskale odnose se na kognitivnu komponentu straha od čitanja na njemačkome jeziku. To su čestice 19., 23., 24 i 25 . Te iste čestice nalaze se u subskali 1 Upitnika o strahu od čitanja na engleskome jeziku. Sadržaj čestica ove subskale odnosi se na negativno samovrednovanje učenika (čestica 25. i 9.), preokupiranost mislima o sebi i zabrinutost o kvaliteti obavljanja zadatka (čestice 19.,6. i 24.), zabrinutost zbog prijetećih ili predosjećanih događaja, odnosno strah od evaluacije (čestica 23.). U ovoj subsklali su dvije čestice koje se odnose na jezičnu komponentu straha od čitanja zabrinutost zbog nepodudarnosti načina pisanja i čitanja i zbog izgovora (čestice 7. i 16.). 
Tablica 5.40. Čestice subskale 1 Upitnika o strahu od čitanja na njemačkome jeziku

\begin{tabular}{|c|c|c|}
\hline Čestica & AS & SD \\
\hline 6. Brinem se kako ću u sebi pročitati duge tekstove na njemačkome. & 2,23 & 1,220 \\
\hline $\begin{array}{l}\text { 7. Zbunjuje me nepodudarnost između načina pisanja i čitanja na } \\
\text { njemačkome jeziku. }\end{array}$ & 2,48 & 1,369 \\
\hline $\begin{array}{l}\text { 9. Strah me da nikada neću dobro naučiti čitati njemački jer je čitanje } \\
\text { na njemačkome teško. }\end{array}$ & 2,29 & 1,391 \\
\hline $\begin{array}{l}\text { 16. Dok čitam naglas na njemačkom, brinem se kako ću izgovoriti } \\
\text { pojedine riječi. }\end{array}$ & 2,77 & 1,283 \\
\hline $\begin{array}{l}\text { 19. Nervozniji/ja sam kad čitam naglas na njemačkome nego kad } \\
\text { pišem, slušam ili govorim. }\end{array}$ & 2,10 & 1,226 \\
\hline $\begin{array}{l}\text { 23. Uznemiruje me kad čitam u sebi tekst na njemačkome, a } \\
\text { nastavnik/ca nakog toga ocjenjuje zadatke razumijevanja pročitanoga. }\end{array}$ & 1,96 & 1,268 \\
\hline $\begin{array}{l}\text { 24. Pri čitanju u sebi na njemačkome zbunjuju me duge riječi koje je } \\
\text { teško pročitati. }\end{array}$ & 2,70 & 1,379 \\
\hline $\begin{array}{l}\text { 25. Osjećam se nesigurno kad čitam naglas na njemačkome jer nemam } \\
\text { dara za čitanje na njemačkome. }\end{array}$ & 2,24 & 1,344 \\
\hline
\end{tabular}

\section{Subskala 2 Upitnika o strahu od čitanja na njemačkom jeziku}

Subskala 2 Upitnika o strahu od čitanja na njemačkome jeziku sadrži pet čestica, a Cronbachov $\alpha$ za ovu subskalu iznosi ,736. Pouzdanost se smatra prihvatljivom s obzirom da ova subskala sadržava samo pet čestica. Iz tablice 5.41. vidljivo je da se u ovoj subskali najviša aritmetička sredina bilježi za česticu 8. „Čini me nervoznim/om kad čitam u sebi i razumijem gotovo sve riječi u rečenici, ali ne razumijem značenje rečenice.”, koja izražava uznemirenost zbog nerazumijevanja rečenične sintakse na njemačkome jeziku. Najnižu aritmetičku sredinu bilježi čestica 21. „Smeta me kad u tekstu naiđem na neki pojam iz njemačke, austrijske ili druge kulture njemačkoga govornoga područja koji mi nije poznat.", koja izražava uznemirenost koja može biti povezana s nedovoljnim poznavanjem pojmova iz kulture njemačkoga govornoga područja. U ovoj subskali objedinjene su čestice sadržaj kojih se povezuje s jezičnom komponentom straha od čitanja na engleskome jeziku (čestice 3., 8., 10. i 21.). Za česticu 22., koja izražava zabrinutost zbog ocjenjivanja zadataka razumijevanja pročitanoga također možemo reći da odražava jezičnu komponentu straha jer odražava zabrinutost zbog rješavanja zadatka koji se odnose na razumijevanje pročitanoga teksta. 
Tablica 5.41. Čestice subskale 2 Upitnika o strahu od čitanja na njemačkome jeziku

\begin{tabular}{lll}
\hline \multicolumn{1}{c}{ Čestica } & AS & SD \\
\hline $\begin{array}{l}\text { 3. Uznemiruje me kad pri čitanju u sebi naiđem na riječ ili izraz koji } \\
\text { ne razumijem. }\end{array}$ & 1,325 \\
$\begin{array}{l}\text { 8. Čini me nervoznim/om kad čitam u sebi i razumijem gotovo sve } \\
\text { riječi u rečenici, ali ne razumijem značenje rečenice. }\end{array}$ & $\mathbf{2 , 6 8}$ & 1,283 \\
$\begin{array}{l}\text { 10. Postajem nervozan/na kad pri čitanju u sebi naiđem na nepoznatu } \\
\text { gramatičku konstrukciju. }\end{array}$ & 1,254 \\
$\begin{array}{l}\text { 21. Smeta me kad u tekstu naiđem na neki pojam iz njemačke, } \\
\text { austrijske ili druge kulture njemačkoga govornoga područja koji mi } \\
\text { nije poznat. }\end{array}$ & 1,152 \\
$\begin{array}{l}\text { 22. Uznemiruje me kad čitam u sebi tekst na njemačkome, a } \\
\text { nastavnik/ca nakon toga ocjenjuje zadatke razumijevanja pročitanoga. }\end{array}$ & 1,355 \\
\hline
\end{tabular}

\section{Subskala 3 Upitnika o strahu od čitanja na njemačkom jeziku}

Subskala 3 Upitnika o strahu od čitanja na njemačkome jeziku sadrži četiri čestice, a Cronbachov $\alpha$ za ovu subskalu iznosi ,740. Pouzdanost se može smatrati prihvatljivom s obzirom da ova subskala sadržava samo četiri čestice. Iz tablice 5.42. vidljivo je da se u ovoj subskali najviša aritmetička sredina bilježi za dvije čestice 5. „Osjećam se ugodno dok čitam naglas na njemačkome. “ (rekodirano) u kojoj se izražava osjećaj neugode pri čitanju naglas i 11. „Kad čitam naglas na njemačkome jeziku, osjećam se opušteno i siguran/na u sebe.” (rekodirano) koja se odnosi na izostanak osjećaj opuštenosti i samopouzdanja pri čitanju naglas na njemačkome. Najnižu aritmetičku sredinu bilježi čestica 1. „Osjećam se nervozno dok čitam naglas na njemačkome pred drugima." koja izražava uznemirenost koju učenik osjeća pri čitanju naglas na njemačkome pred drugima. Ova subskala objedinjuje čestice koje odražavaju emocionalnu komponentu straha od čitanja na njemačkome jeziku. Emocionalna komponenta u ovoj subskali ukazuje na negativne emocije - nervozu i neugodu, a to se odražava u sadržaju čestica ove subskale. Tri od četiri čestice ove subskale nalaze se u subskali 3 Upitnika o strahu od čitanja na engleskome jeziku (čestice 1., 5. i 11.). Emocionalna uznemirenost može biti potaknuta i situacijom kada učenik naiđe na neku riječ koju ne zna pročitati (čestica 14. ) 
Tablica 5.42. Čestice subskale 3 Upitnika o strahu od čitanja na njemačkome jeziku

\begin{tabular}{|c|c|c|}
\hline Čestica & $\mathbf{A S}$ & SD \\
\hline $\begin{array}{l}\text { 1. Osjećam se nervozno dok čitam naglas na njemačkome pred } \\
\text { drugima. }\end{array}$ & 2,36 & 1,289 \\
\hline 5. Osjećam se ugodno dok čitam naglas na njemačkome. & 3,34 & 1,170 \\
\hline $\begin{array}{l}\text { 11. Kad čitam naglas na njemačkome jeziku, osjećam se opušteno i } \\
\text { siguran/na u sebe. }\end{array}$ & 3,34 & 1,229 \\
\hline $\begin{array}{l}\text { 14. Ako pri čitanju u sebi naiđem na riječ ili riječi koje ne razumijem, } \\
\text { nastavljam čitati a da se nisam uznemirio/la. }\end{array}$ & 2,70 & 1,305 \\
\hline
\end{tabular}

\section{Subskala 4 Upitnika o strahu od čitanja na njemačkom jeziku}

Subskala 4 Upitnika o strahu od čitanja na njemačkome jeziku sadrži tri čestice, a Cronbachov $\alpha$ za ovu subskalu iznosi ,541. Ova subskala sadržava samo tri čestice i ima najmanju pouzdanost od svih pet subskala za njemački jezik. Unutarnja konzistencija ove subskale je niska, ali će se ona ipak uzeti u obzir za daljnje razmatranje. Vrijednost Cronbachova $\alpha$ za ovu subskalu nije indikator loše pouzdanosti nego maloga broja čestica.

Iz tablice 5.43. vidljivo je da se u ovoj subskali najviša aritmetička sredina bilježi za česticu 15. „Smeta me kad me nastavnik/ca prekida i ispravlja dok čitam naglas.”, koja izražava percepciju uloge nastavnika i ukazuje na to da učenika ometa kada ga nastavnik prekida pri čitanju naglas. Najnižu aritmetičku sredinu bilježi čestica 13. „Postupci nastavnika/ce ometaju me i zbunjuju dok čitam naglas na njemačkome. ”, koja se također odnosi na percepciju djelovanja nastavnika pri čitanju naglas na njemačkome. Dvije od tri čestice ove subskale odnose se na djelovanje nastavnika koje kod učenika može potaknuti osjećaj uznemirenosti pri čitanju na njemačkome jeziku (čestice 13. i 15.). Čestica 4. odražava procjenu težine čitanja kao vještine koja može biti povezana i s djelovanjem nastavnika u formalnome okruženju učenja njemačkoga jezika.

Tablica 5.43. Čestice subskale 4 Upitnika o strahu od čitanja na njemačkome jeziku

\begin{tabular}{lll}
\hline \multicolumn{1}{c}{ Čestica } & AS & SD \\
\hline $\begin{array}{l}\text { 4. Ako trebam odabrati između čitanja, pisanja, slušanja i govora na } \\
\text { njemačkome jeziku, najteže mi je čitanje. }\end{array}$ & 1,327 \\
$\begin{array}{l}\text { 13. Postupci nastavnika/ce ometaju me i zbunjuju dok čitam naglas na } \\
\text { njemačkome. }\end{array}$ & $\mathbf{1 , 7 4}$ & 1,140 \\
$\begin{array}{l}\text { 15. Smeta me kad me nastavnik/ca prekida i ispravlja dok čitam } \\
\text { naglas. }\end{array}$ & $\mathbf{2 , 1 0}$ & 1,328 \\
\hline
\end{tabular}




\section{Subskala 5 Upitnika o strahu od čitanja na njemačkom jeziku}

Subskala 5 Upitnika o strahu od čitanja na engleskome jeziku sadrži pet čestica, a Cronbachov $\alpha$ za ovu subskalu iznosi ,802 što ukazuje na visoku pouzdanost. Iz tablice 5.44. vidljivo je da se u ovoj subskali najviša aritmetička sredina bilježi za česticu 12. „Dok čitam naglas na njemačkome pred drugima, srce mi jače lupa.", u kojoj se opisuje ubrzano lupanje srca kao tjelesna manifestacija koja se pojavljuje pri čitanju naglas na njemačkome pred drugima. Najnižu aritmetičku sredinu bilježi čestica 18. „Dok čitam naglas na njemačkome pred drugima, osjećam da mi se znoje dlanovi.", koja se također odnosi na tjelesnu manifestaciju znojenje dlanova koje prati čitanje naglas na njemačkome pred drugima. U ovoj subskali nalaze se tri čestice koje se odnose na tjelesnu komponentu straha od čitanja na njemačkome jeziku (čestice 2., 12. i 18.). Ostale dvije čestice izražavaju uznemirenost koja može biti potaknuta nezanimljivošću teksta ili nepoznavanjem teme koja se u tekstu obrađuje (čestice 17. i 20.) te se za te dvije čestice može utvrditi da odražavaju jezičnu komponentu straha od čitanja na njemačkome jeziku.

Tablica 5.44. Čestice subskale 5 Upitnika o strahu od čitanja na njemačkome jeziku

\begin{tabular}{|c|c|c|}
\hline Čestica & AS & SD \\
\hline $\begin{array}{l}\text { 2. Kad čitam naglas na njemačkome pred drugima, uznemirim se i glas } \\
\text { mi se promijeni i drhti. }\end{array}$ & 2,00 & 1,205 \\
\hline 12. Dok čitam naglas na njemačkome pred drugima, srce mi jače lupa. & 2,03 & 1,201 \\
\hline 17. Nervozan/na sam kad čitam tekst koji nije zanimljiv. & 2,29 & 1,273 \\
\hline $\begin{array}{l}\text { 18. Dok čitam naglas na njemačkome pred drugima, osjećam da mi } \\
\text { se znoje dlanovi. }\end{array}$ & 1,76 & 1,138 \\
\hline $\begin{array}{l}\text { 20. Ako čitam tekst na njemačkome o nepoznatoj temi, postajem } \\
\text { nervozan/na. }\end{array}$ & 2,05 & 1,159 \\
\hline
\end{tabular}




\subsubsection{Usporedba subskala na temelju faktorske analize analiza Upitnika o strahu od čitanja na engleskome jeziku i Upitnika o strahu od čitanja na njemačkome jeziku}

Rezultati analiza pokazuju da postoje strukturne razlike u strahu od čitanja na engleskome i njemačkome jeziku. Za engleski jezik utvrđene su tri subskale Upitnika o strahu od čitanja na engleskome jeziku, a za njemački jezik utvrđeno je pet subskala Upitnika o strahu od čitanja na njemačkome jeziku. Pregledom sastava subskala uvidjelo se da postoje određene sličnosti, ali i razlike. Subskala 1 za engleski jezik objedinjuje deset čestica, a subskala 1 za njemački jezik osam čestica. Čestice u subskali 1 za engleski jezik odnose se na kognitivnu i tjelesnu komponentu straha od čitanja na engleskome jeziku. Subskala 1 za njemački jezik sadržava čestice koje se odnose na kognitivnu i jezičnu komponentu straha od čitanja na njemačkome jeziku, a među tim česticama četiri su iste kao u subskali 1 za engleski jezik. Subskala 2 za engleski jezik sadržava osam čestica koje sadržajno odražavaju jezičnu komponentu straha od čitanja na engleskome jeziku. Subskala 2 za njemački jezik sadržava pet čestica, od kojih su četiri iste kao i za engleski jezik. Subskala 2 za njemački jezik također odražava jezičnu komponentu straha od čitanja. Subskala 3 za engleski jezik objedinjuje pet čestica koje odražavaju emocionalnu komponentu straha od čitanja na engleskome jeziku. Subskala 3 za njemački jezik sadržava četiri čestice, od kojih se tri nalaze u subskali 3 za engleski jezik. Subskala 3 za njemački jezik također odražava emocionalnu komponentu straha od čitanja. Za njemački jezik utvrđena je subskala 4 koja sadržava tri čestice, od kojih se dvije odnose na djelovanje nastavnika. Čestice koje se odnose na djelovanje nastavnika nisu se odvojile u posebnu subskalu za engleski jezik. Subskala 5 za njemački jezik objedinjuje pet čestica, od kojih tri odražavaju tjelesnu komponentu, a dvije jezičnu komponentu straha od čitanja na njemačkome jeziku. 


\subsubsection{Razlike u strahu od čitanja na engleskome i njemačkome jeziku s obzirom na spol}

\subsubsection{Razlike u strahu od čitanja na engleskome jeziku s obzirom na spol}

Kao što je vidljivo u tablici 5.45., vrijednost aritmetičke sredine za sudionike istraživanja muškoga spola iznosi 1,98, a za sudionice ženskoga spola 1,2. Obje vrijednosti su niske, ali je nešto viša aritmetička sredina za ženski spol. Da bi se utvrdilo postoji li statistički značajna razlika u strahu od engleskoga jezika s obzirom na spol (muški i ženski), korišten je t-test za nezavisne uzorke. Za provedbu t-testa treba biti zadovoljen osnovni preduvjet o homogenosti varijance. Stoga je najprije testirana homogenost varijance Levenovim testom i utvrđeno je da ne postoji statistički značajna razlika u varijancama između dva poduzorka $(p=, 072)$ što ukazuje na to da se može provesti t-test. Prema rezultatima t-testa $(p=, 925)$ zaključujemo da nema statistički značajne razlike u strahu od čitanja na engleskome jeziku s obzirom na spol (v. tablicu 5.46.). Zbog značajnoga odstupanja zavisne varijable od normaliteta, provedeno je testiranje i neparametrijskim testom - Medijan testom za nezavisne uzorke. Njime je također zadržana nul-hipoteza $(p=, 730)$.

Tablica 5.45. Statistički pokazatelji za straha od čitanja na engleskome jeziku s obzirom na spol sudionika

\begin{tabular}{lllll}
\hline Spol & N & AS & SD & $\begin{array}{l}\text { Std. pogreška } \\
\text { aritmetičke } \\
\text { sredine }\end{array}$ \\
\hline muški & 56 & 1,9836 &, 61121 &, 08162 \\
ženski & 101 & 1,9952 &, 81022 &, 08062 \\
\hline$N=$ ukupno, $A S=$ aritmetička sredina, $S D=$ standardna devijacija & &
\end{tabular}


Tablica 5.46. Rezultati t-testa za nezavisne uzorke

\begin{tabular}{|c|c|c|c|c|c|c|c|c|c|}
\hline & \multicolumn{2}{|c|}{$\begin{array}{l}\text { Levenov test } \\
\text { jednakosti } \\
\text { varijanci }\end{array}$} & \multicolumn{7}{|c|}{ T-test jednakosti aritmetičkih sredina } \\
\hline & \multirow[t]{2}{*}{$F$} & \multirow[t]{2}{*}{$p$} & \multirow[t]{2}{*}{$t$} & \multirow[t]{2}{*}{$d f$} & \multirow[t]{2}{*}{$\begin{array}{l}t \\
(2-\text { smjerno })\end{array}$} & \multirow[t]{2}{*}{$\begin{array}{l}\text { Prosječna } \\
\text { razlika }\end{array}$} & \multirow{2}{*}{$\begin{array}{l}\text { Standardna } \\
\text { pogreška } \\
\text { razlike }\end{array}$} & \multicolumn{2}{|c|}{$\begin{array}{l}95 \% \text { intervali } \\
\text { pouzdanosti }\end{array}$} \\
\hline & & & & & & & & $\begin{array}{l}\text { Donja } \\
\text { granica }\end{array}$ & $\begin{array}{l}\text { Gornja } \\
\text { granica }\end{array}$ \\
\hline $\begin{array}{l}\text { Pretpostavljena } \\
\text { jednakost } \\
\text { varijance }\end{array}$ & 3,281 & 072 &,- 094 & 155 & ,925 &,- 01168 & ,12424 &,- 25710 &, 23375 \\
\hline $\begin{array}{l}\text { Jednakost } \\
\text { varijance nije } \\
\text { pretpostavljena }\end{array}$ & & &,- 102 & 140,848 & ,919 &,- 01168 &, 11476 &,- 23856 &, 21520 \\
\hline
\end{tabular}

\subsubsection{Razlike u strahu od čitanja na njemačkome jeziku s obzirom na spol}

U tablici 5.47.vidljivo je da je vrijednost aritmetičke sredine za sudionike istraživanja muškoga spola 2,33, a za sudionice ženskoga spola 2,36. Obje su vrijednosti niske, ali je vrijednost aritmetičke sredine za ženski spol nešto viša. Da bi se utvrdilo postoji li statistički značajna razlika u strahu od njemačkoga jezika s obzirom na spol (muški i ženski), korišten je t-test za nezavisne uzorke. Najprije je testirana homogenost varijance kako bi se utvrdilo može li se provesti t-test. Levenovim testom utvrđeno je da nije narušena pretpostavka o homogenosti varijance $(p=, 338)$, te se pristupilo t-testu kojim je utvrđeno da nema statistički značajne razlike u strahu od čitanja na njemačkome jeziku s obzirom na spol $(p=, 790)$ (v. tablicu 5.48.).

Tablica 5.47. Statistički pokazatelji za straha od čitanja na njemačkome jeziku s obzirom na spol sudionika

\begin{tabular}{lllll}
\hline Spol & N & AS & SD & $\begin{array}{l}\text { Std. pogreška } \\
\text { aritmetičke } \\
\text { sredine }\end{array}$ \\
\hline muški & 52 & &, 09146 \\
ženski & 103 & 2,3265 &, 65954 &, 07638 \\
\hline$N=$ ukupno, $A S=$ aritmetička sredina, $S D=$ standardna devijacija &, 77512 &
\end{tabular}


Tablica 5.48. Rezultati t-testa za nezavisne uzorke

\begin{tabular}{|c|c|c|c|c|c|c|c|c|c|}
\hline & \multicolumn{2}{|c|}{$\begin{array}{l}\text { Levenov test } \\
\text { jednakosti } \\
\text { varijanci }\end{array}$} & \multicolumn{7}{|c|}{ T-test jednakosti aritmetičkih sredina } \\
\hline & \multirow[t]{2}{*}{$F$} & \multirow[t]{2}{*}{$p$} & \multirow[t]{2}{*}{$t$} & \multirow[t]{2}{*}{$d f$} & \multirow[t]{2}{*}{$\begin{array}{l}t \\
(2-\text { smjerno })\end{array}$} & \multirow[t]{2}{*}{$\begin{array}{l}\text { Prosječna } \\
\text { razlika }\end{array}$} & \multirow{2}{*}{$\begin{array}{l}\text { Standardna } \\
\text { pogreška } \\
\text { razlike }\end{array}$} & \multicolumn{2}{|c|}{$\begin{array}{l}95 \% \text { intervali } \\
\text { pouzdanosti }\end{array}$} \\
\hline & & & & & & & & $\begin{array}{l}\text { Donja } \\
\text { granica }\end{array}$ & $\begin{array}{l}\text { Gornja } \\
\text { granica }\end{array}$ \\
\hline $\begin{array}{l}\text { Pretpostavljena } \\
\text { jednakost } \\
\text { varijance }\end{array}$ & ,922 & ,338 &,- 267 & 153 & ,790 &,- 03349 & ,12565 &,- 28173 & ,21474 \\
\hline $\begin{array}{l}\text { Jednakost } \\
\text { varijance nije } \\
\text { pretpostavljena }\end{array}$ & & &,- 281 & 118,189 & ,779 &,- 03349 & ,11916 &,- 26945 & ,20247 \\
\hline
\end{tabular}

\subsubsection{Razlike u strahu od čitanja na engleskome i njemačkome jeziku s obzirom na srednjoškolski smjer}

\subsubsection{Razlike u strahu od čitanja na engleskome jeziku s obzirom na srednjoškolski smjer}

Kao što je vidljivo u tablici 5.49. vrijednost aritmetičke sredine za učenike koji pohađaju gimnazijski smjer je 2,05, a za učenike koji pohađaju turistički i ugostiteljski smjer 1,85. Obje vrijednosti su niske, ali je nešto viša vrijednost zabilježena za učenike iz gimnazijskih usmjerenja. Da bi se utvrdilo postoji li statistički značajna razlika u strahu od engleskoga jezika s obzirom na srednjoškolski smjer, korišten je t-test za nezavisne uzorke. Ponovno je najprije testirana homogenost varijance Levenovim testom i utvrđeno je da se može provesti t-test ( $p=$ ,186). T-test je pokazao da nema statistički značajne razlike u strahu od čitanja na engleskome jeziku s obzirom na srednjoškolski smjer ( $p=, 133$, v. tablicu 5.50.). Radi značajnoga odstupanja zavisne varijable od normaliteta, provedeno je testiranje i Medijan testom za nezavisne uzorke. Njime je također zadržana nul-hipoteza $(p=, 216)$. 
Tablica 5.49. Statistički pokazatelji za strah od čitanja na engleskome jeziku s obzirom na srednjoškolski smjer

\begin{tabular}{lllll}
\hline Srednjoškolski smjer & N & AS & SD & $\begin{array}{l}\text { Std. } \\
\text { pogreška } \\
\text { aritmetičke } \\
\text { sredine }\end{array}$ \\
\hline Gimnazijski & & & &, 07109 \\
Turističko ugostiteljski & 47 & 2,0495 &, 74556 &, 10614 \\
\hline$N=$ ukupno, $A S=$ aritmetička sredina, $S D=$ standardna devijacija & & & &
\end{tabular}

Tablica 5.50. Rezultati t-testa za nezavisne uzorke

\begin{tabular}{|c|c|c|c|c|c|c|c|c|c|}
\hline & \multirow{3}{*}{$\begin{array}{l}\text { Levenov tes } \\
\text { jednakosti } \\
\text { varijanci } \\
F\end{array}$} & \multirow{3}{*}{$S p$} & \multicolumn{7}{|c|}{ T-test jednakosti aritmetičkih sredina } \\
\hline & & & \multirow[t]{2}{*}{$t$} & \multirow[t]{2}{*}{$d f$} & \multirow[t]{2}{*}{$\begin{array}{l}t \\
(2 \text {-smjerno })\end{array}$} & \multirow[t]{2}{*}{$\begin{array}{l}\text { Prosječna } \\
\text { razlika }\end{array}$} & \multirow{2}{*}{$\begin{array}{l}\text { Standardna } \\
\text { pogreška } \\
\text { razlike }\end{array}$} & \multicolumn{2}{|c|}{$\begin{array}{l}95 \% \text { intervali } \\
\text { pouzdanosti }\end{array}$} \\
\hline & & & & & & & & $\begin{array}{l}\text { Donja } \\
\text { granica }\end{array}$ & $\begin{array}{l}\text { Gornja } \\
\text { granica }\end{array}$ \\
\hline $\begin{array}{l}\text { Pretpostavljena } \\
\text { jednakost } \\
\text { varijance }\end{array}$ & 1,762 & ,186 & 1,511 & 155 & 133 & , 19499 & 12901 &,- 05985 & ,44982 \\
\hline $\begin{array}{l}\text { Jednakost } \\
\text { varijance nije } \\
\text { pretpostavljena }\end{array}$ & & & 1,526 & 88,968 &, 130 & 19499 &, 12775 &,- 05884 & ,44882 \\
\hline
\end{tabular}

\subsubsection{Razlike u strahu od čitanja na njemačkome jeziku s obzirom na srednjoškolski smjer}

U tablici 5.51. vidljivo je da je vrijednost aritmetičke sredine za učenike gimnazijskih usmjerenja 2,35, a za učenike turističkih i ugostiteljskih usmjerenja 2,34. Obje vrijednosti su niske i gotovo jednake, ali je vrijednost aritmetičke sredine za učenike gimnazijskih usmjerenja viša. Da bi se utvrdilo postoji li statistički značajna razlika u strahu od njemačkoga jezika s obzirom na srednjoškolsko usmjerenje, korišten je t-test za nezavisne uzorke. Najprije je testirana homogenost varijance kako bi se utvrdilo može li se provesti t-test. Nakon Levenova testa $(p=, 202)$, t-testom je utvrđeno da ne postoji statistički značajna razlika u strahu od čitanja na njemačkome jeziku među grupama s obzirom na srednjoškolsko usmjerenje ( $p=$ ,930, v. tablicu 5.52.) . 
Tablica 5.51. Statistički pokazatelji za strah od čitanja na njemačkome jeziku s obzirom na srednjoškolski smjer

\begin{tabular}{lllll}
\hline Srednjoškolski smjer & $\mathbf{N}$ & AS & SD & $\begin{array}{l}\text { Std. } \\
\text { pogreška } \\
\text { aritmetičke } \\
\text { sredine }\end{array}$ \\
\hline Gimnazijski & 105 & & &, 06893 \\
Turističko ugostiteljski & 50 & 2,3524 &, 70635 &, 11359 \\
\hline$N=$ ukupno, $A S=$ aritmetička sredina, $S D=$ standardna devijacija & 2,3412 &, 80324 &
\end{tabular}

Tablica 5.52. Rezultati t-testa za nezavisne uzorke

\begin{tabular}{|c|c|c|c|c|c|c|c|c|c|}
\hline & \multirow{3}{*}{$\begin{array}{l}\text { Levenov tes } \\
\text { jednakosti } \\
\text { varijanci } \\
F\end{array}$} & \multirow{3}{*}{ Sig. } & \multicolumn{7}{|c|}{ T-test jednakosti aritmetičkih sredina } \\
\hline & & & \multirow[t]{2}{*}{$t$} & \multirow[t]{2}{*}{$d f$} & \multirow[t]{2}{*}{$\begin{array}{l}t \\
\text { (dvosmjerno) }\end{array}$} & \multirow[t]{2}{*}{$\begin{array}{l}\text { Prosječna } \\
\text { razlika }\end{array}$} & \multirow{2}{*}{$\begin{array}{l}\text { Standardna } \\
\text { pogreška } \\
\text { razlike }\end{array}$} & \multicolumn{2}{|c|}{$\begin{array}{l}95 \% \text { intervali } \\
\text { pouzdanosti }\end{array}$} \\
\hline & & & & & & & & $\begin{array}{l}\text { Donja } \\
\text { granica }\end{array}$ & $\begin{array}{l}\text { Gornja } \\
\text { granica }\end{array}$ \\
\hline $\begin{array}{l}\text { Pretpostavljena } \\
\text { jednakost } \\
\text { variiance }\end{array}$ & 1,640 & ,202 & ,088 & 153 & ,930 & ,01121 & ,12694 &,- 23956 & 26199 \\
\hline $\begin{array}{l}\text { Jednakost } \\
\text { varijance nije } \\
\text { pretpostavljena }\end{array}$ & & & ,084 & 86,223 & ,933 & ,01121 & ,13287 &,- 25292 & 27535 \\
\hline
\end{tabular}

\subsubsection{Razlike u intenzitetu straha od čitanja na engleskome i njemačkome jeziku s obzirom na jezik}

Kao što je vidljivo u tablici 5.53. u istraživanju je sudjelovalo je 139 sudionika koji su ispunili oba upitnika o strahu od čitanja: Upitnik o strahu od čitanja na engleskome jeziku i Upitnik o strahu od čitanja na njemačkome jeziku. Rezultati tih dvaju upitnika su nisko, ali značajno i pozitivno povezani $(r=, 247 ; p=, 003)$. Dakle, učenici koji imaju visoki strah od čitanja u jednome jeziku, imaju tendenciju imati visoki strah od čitanja i u drugome jeziku. Iz tablice 5.53. vidljivo je da vrijednost aritmetičke sredine za upitnik za engleski jezik iznosi 1,92, a za upitnik za njemački jezik 2,31. Dakle, zabilježena je veća aritmetička sredina za strah od čitanja na njemačkome jeziku nego za strah od čitanja na engleskome jeziku. Da bi se utvrdilo postoji li statistički značajna razlika u strahu od čitanja s obzirom na jezik (engleski i njemački) korišten je t-test za zavisne uzorke. Rezultati testiranja su prikazani u tablici 5.54 . 
Utvrđuje se da postoji statistički značajna razlika u strahu od čitanja na stranome jeziku s obzirom na jezik koji se uči $(p=, 000)$. Neparametrijskim testom - Wilcoxonovim testom rangova zavisnih uzoraka - nul-hipoteza o jednakosti straha od čitanja za engleski i njemački jezik je također odbačena $(p=, 000)$. Drugim riječima, rezultati analiza ukazuju da je viši strah od čitanja za njemački jezik nego za engleski jezik.

Tablica 5.53. Statistički pokazatelji za strah od čitanja na engleskome i njemačkome jeziku na čitavom uzorku $\left(N_{e+n j}=139\right)$

\begin{tabular}{lcccl}
\hline & N & AS & SD & $\begin{array}{l}\text { Std. } \\
\text { pogreška } \\
\text { aritmetičke } \\
\text { sredine }\end{array}$ \\
\hline Engleski jezik & 139 & & &, 0617670 \\
Njemački jezik & 139 & 1,919712 &, 7282219 &, 0635877 \\
\hline$N=$ ukupno, $A S=$ aritmetička sredina, $S D=$ standardna devijacija & & &
\end{tabular}

$N=$ ukupno, $A S=$ aritmetička sredina, $S D=$ standardna devijacija

Tablica 5.54. Rezultati t-testa za zavisne uzorke

\begin{tabular}{|c|c|c|c|c|c|c|c|c|}
\hline & \multirow{3}{*}{$\begin{array}{l}\text { Aritmetička } \\
\text { sredina }\end{array}$} & \multirow{3}{*}{$S D$} & \multirow{3}{*}{$\begin{array}{c}\text { Razlike } \\
\text { Std. } \\
\text { pogreška } \\
\text { AS-e }\end{array}$} & & & \multirow{3}{*}{$t$} & \multirow{3}{*}{$d f$} & \multirow{3}{*}{$\begin{array}{c}p(2- \\
\text { smjerno })\end{array}$} \\
\hline & & & & \multicolumn{2}{|c|}{$\begin{array}{c}95 \% \text { intervali } \\
\text { pouzdanosti razlike }\end{array}$} & & & \\
\hline & & & & $\begin{array}{l}\text { Donja } \\
\text { granica }\end{array}$ & $\begin{array}{l}\text { Gornja } \\
\text { granica }\end{array}$ & & & \\
\hline $\begin{array}{l}\text { Strah od } \\
\text { čitanja ENG } \\
\text { - Strah od } \\
\text { čitanja } \\
\text { NJEM }\end{array}$ &,- 3877578 & ,9067409 & ,0769088 &,- 5398298 &,- 2356858 & $-5,042$ & 138 & ,000 \\
\hline
\end{tabular}




\subsubsection{Povezanost straha od čitanja na engleskome i njemačkome jeziku i uspjeha na testu razumijevanja teksta čitanjem na engleskome i njemačkome jeziku}

\subsubsection{Povezanost straha od čitanja na engleskome jeziku i uspjeha na testu razumijevanja teksta čitanjem na engleskome jeziku}

Kako bi se odgovorilo na istraživački problem 1 i testirala hipoteza 1 (H1) testirana je povezanost straha od čitanja na engleskome jeziku i uspjeha na testu razumijevanja teksta čitanjem za engleski jezik. Kao što je vidljivo iz dijagrama raspršenja (eng. scatterplot) na slici 5.15. postoji statistički značajna niska (granično umjerena) negativna povezanost između dviju varijabli. Viša razina straha od čitanja povezana je s lošijim uspjehom na testu $\left(r_{P}=\right.$ ,$\left.- 295 ; r_{S}=-, 305 ; p=, 000\right)$.

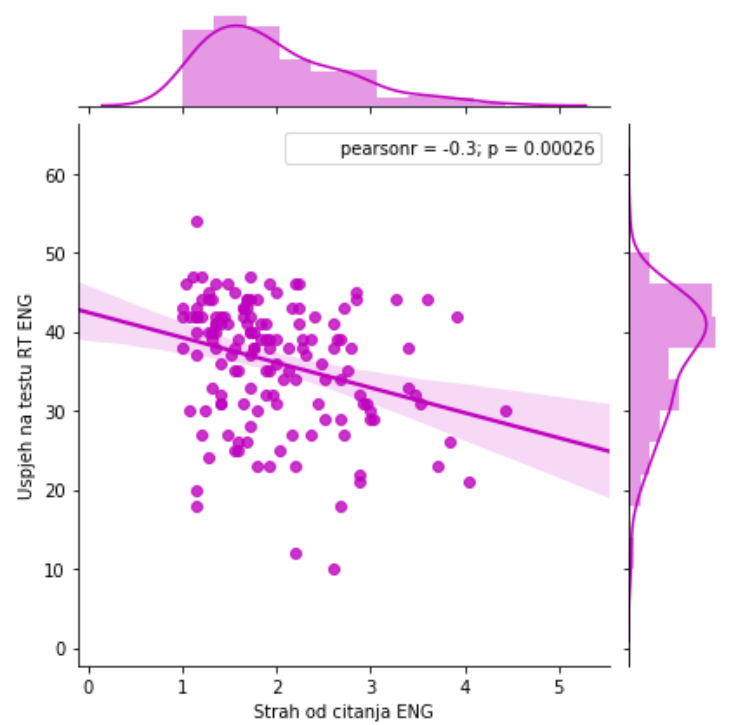

Slika 5.15. Dijagram raspršenja, crta regresije i distribucije za strah od čitanja i uspjeh na testu razumijevanja teksta čitanjem za engleski jezik

U tablicama 5.55. i 5.56. prikazane su korelacijski koeficijenti, Pearsonovi i Spearmanovi, između straha od čitanja na engleskome jeziku i uspjeha na testu razumijevanja teksta čitanjem na engleskome jeziku. 
Tablica 5.55. Korelacijska matrica $\left(N_{\text {eng }}=149\right)$ Pearsonovih koeficijenata korelacije straha od čitanja i uspjeha na testu razumijevanja teksta čitanjem na engleskome jeziku

\begin{tabular}{|l|l|l|l|}
\hline \multicolumn{2}{|l|}{} & Strah eng & Test eng \\
\hline Strah eng & & 1 &,$- 295^{* *}$ \\
& $p$ (dvosmjerno) & &, 000 \\
\hline Test eng & &,$- 295^{* *}$ & 1 \\
& $p$ (dvosmjerno) &, 000 & \\
\hline$* *$ Korelacija je značajna na razini 0,01 (dvosmjerno)
\end{tabular}

Iz tablice 5.55. vidljivo je da postoji statistički značajna niska (granično umjerena) negativna povezanost straha od čitanja i uspjeh na testu razumijevanja teksta čitanjem na engleskome jeziku

$(r=-, 295)$.

Tablica 5.56. Korelacijska matrica $\left(N_{\text {eng }}=149\right)$ Spermanovih koeficijenata korelacije straha od čitanja i uspjeha na testu razumijevanja teksta čitanjem na engleskome jeziku

\begin{tabular}{|c|c|c|c|c|}
\hline & & & Strah eng & Test eng \\
\hline \multirow{4}{*}{$\begin{array}{l}\text { Spearmanov } \\
\text { koeficijent }\end{array}$} & \multirow[t]{2}{*}{ Strah eng } & & 1,000 &,$- 305^{* *}$ \\
\hline & & $p$ (dvosmjerno) & & ,000 \\
\hline & \multirow[t]{2}{*}{ Test eng } & &,$- 305^{* *}$ & 1,000 \\
\hline & & $p$ (dvosmjerno) & ,000 & \\
\hline
\end{tabular}

** Korelacija je značajna na razini 0,01 (dvosmjerno)

Iz tablice 5.56. vidljivo je da postoji umjerena negativna povezanost straha od čitanja i uspjeh na testu razumijevanja teksta čitanjem na engleskome jeziku $(r=-, 305)$. 


\subsubsection{Povezanost straha od čitanja na njemačkome jeziku $i$ uspjeha na testu razumijevanja teksta čitanjem na njemačkome jeziku}

Kako bi se odgovorilo na istraživački problem 1 i testirala hipotezu 1 (H1) testirana je povezanost straha od čitanja na njemačkome jeziku i uspjeha na testu razumijevanja teksta čitanjem za njemački jezik. Dijagram raspršenja na slici 5.16. pokazuje da postoji statistički značajna niska negativna povezanost dviju varijabli. Viša razina straha od čitanja povezana je s lošijim uspjehom na testu $\left(r_{P}=-, 159 ; p=, 049 ; r_{S}=-, 144 ; p=, 076\right)$.

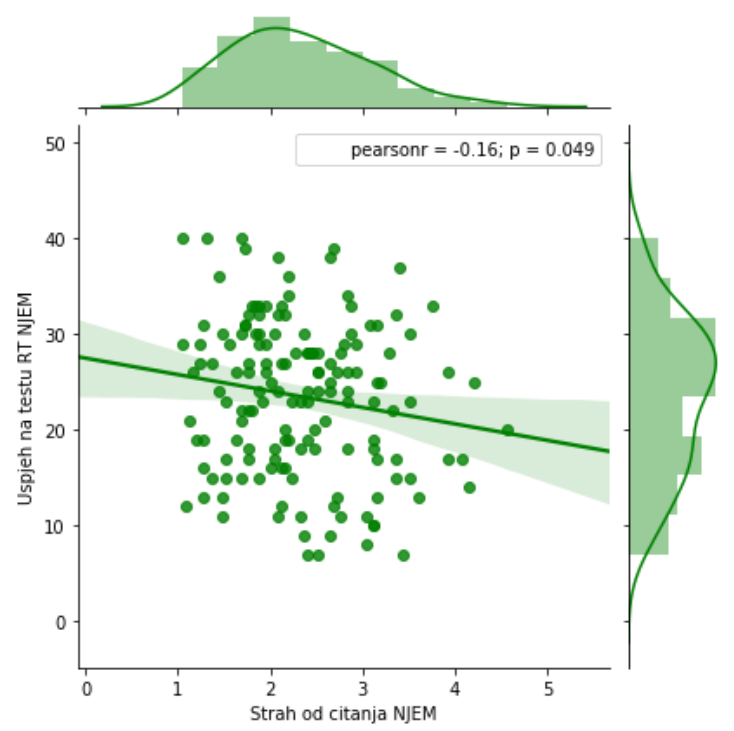

Slika 5.16. Dijagram raspršenja, crta regresije i distribucije za strah od čitanja i uspjeh na testu razumijevanja teksta čitanjem za njemački jezik

U tablicama 5.57. i 5.58. prikazane su korelacijski koeficijenti, Pearsovi i Spearmanovi, straha od čitanja na njemačkome jeziku i uspjeha na testu razumijevanja teksta čitanjem na njemačkome jeziku.

Tablica 5.57. Korelacijska matrica $\left(N_{n j e m}=153\right)$ Pearsonovih koeficijenata korelacije straha od čitanja i uspjeha na testu razumijevanja teksta čitanjem na njemačkome jeziku

\begin{tabular}{|l|l|l|l|}
\hline \multicolumn{2}{|c|}{} & Strah njem & Test njem \\
\hline \multirow{2}{*}{ Strah njem } & & 1 &,$- 159^{*}$ \\
\cline { 2 - 4 } & $p$ (dvosmjerno) & &, 049 \\
\hline \multirow{2}{*}{ Test njem } & &,$- 159^{*}$ & 1 \\
\cline { 2 - 4 } & $p$ (dvosmjerno) &, 049 & \\
\hline
\end{tabular}

* Korelacija je značajna na razini 0,05 (dvosmjerno) 
Iz tablice 5.57. je vidljivo da postoji statistički značajna niska negativna povezanost straha od čitanja i uspjeh na testu razumijevanja teksta čitanjem na njemačkome jeziku $(r=-$ ,159).

Tablica 5.58. Korelacijska matrica $\left(N_{n j e m}=153\right)$ Spermanovih koeficijenata korelacije straha od čitanja i uspjeha na testu razumijevanja teksta čitanjem na njemačkome jeziku

\begin{tabular}{|l|l|l|l|l|}
\hline \multirow{2}{*}{} & \multicolumn{2}{|c|}{} & $\begin{array}{l}\text { Strah } \\
\text { njem }\end{array}$ & $\begin{array}{l}\text { Test } \\
\text { njem }\end{array}$ \\
\hline $\begin{array}{l}\text { Spearmanov } \\
\text { Koeficijent }\end{array}$ & Strah njem & & 1,000 &,- 144 \\
\cline { 3 - 5 } & & $p$ (dvosmjerno) & &, 076 \\
\cline { 2 - 5 } & Test njem & &,- 144 & 1,000 \\
\cline { 3 - 5 } & & $p$ (dvosmjerno) &, 076 & \\
\hline
\end{tabular}

Neparametrijska mjera korelacije ne pokazuje statistički značajnu povezanost straha od čitanja i uspjeha na testu razumijevanja teksta čitanjem za njemački jezik, dok parametrijske ukazuju na nisku negativnu, ali statistički značajnu povezanost. Do nedosljednosti u utvrđenoj značajnosti dolazi zbog niske povezanosti, za koju je potreban veći uzorak za detekciju značajnosti i zbog manje snage neparametrijskih testova. 
5.4.11. Povezanost straha od čitanja na engleskome i njemačkome jeziku i zaključnih ocjena iz engleskoga i njemačkoga jezika

\subsubsection{Povezanost straha od čitanja na engleskome jeziku i zaključnih ocjena} iz engleskoga jezika

U tablicama 5.59. i 5.60. prikazane su korelacijski koeficijenti, Pearsonovi i Spearmanovi, zaključnih ocjena iz engleskoga jezika u prva tri razreda srednje škole i straha od čitanja na engleskome jeziku.

Tablica 5.59. Korelacijska matrica $\left(N_{e_{-} s}=157\right)$ Pearsonovih koeficijenata korelacije zaključnih ocjena iz engleskoga u prva tri razreda srednje škole i straha od čitanja na engleskome jeziku

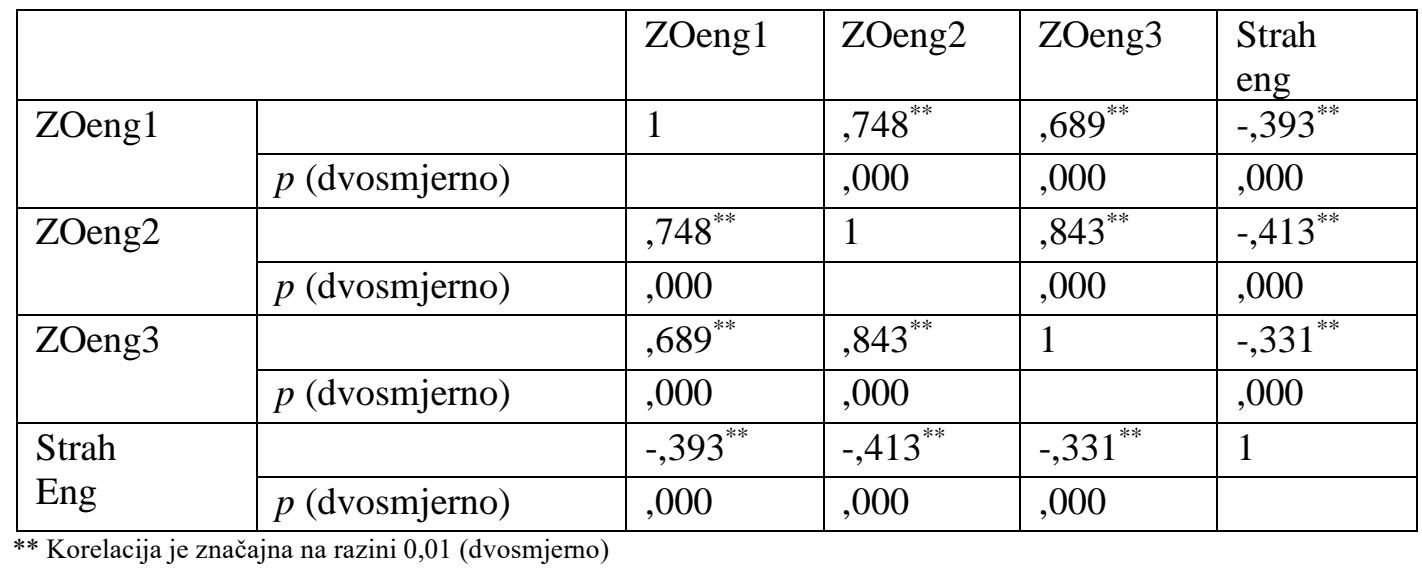

Iz tablice 5.59. vidljivo je da postoji statistički značajna negativna umjerena povezanost straha od čitanja i zaključne ocjene iz engleskoga jezika u prvome $(r=-, 393)$, drugome $(r=-$ ,413) i trećemu $(r=-, 331)$ razredu. 
Tablica 5.60. Korelacijska matrica $\left(N_{e_{-}}=157\right)$ Spearmanovih koeficijenata korelacije zaključnih ocjena iz engleskoga u prva tri razreda srednje škole i straha od čitanja na engleskome jeziku

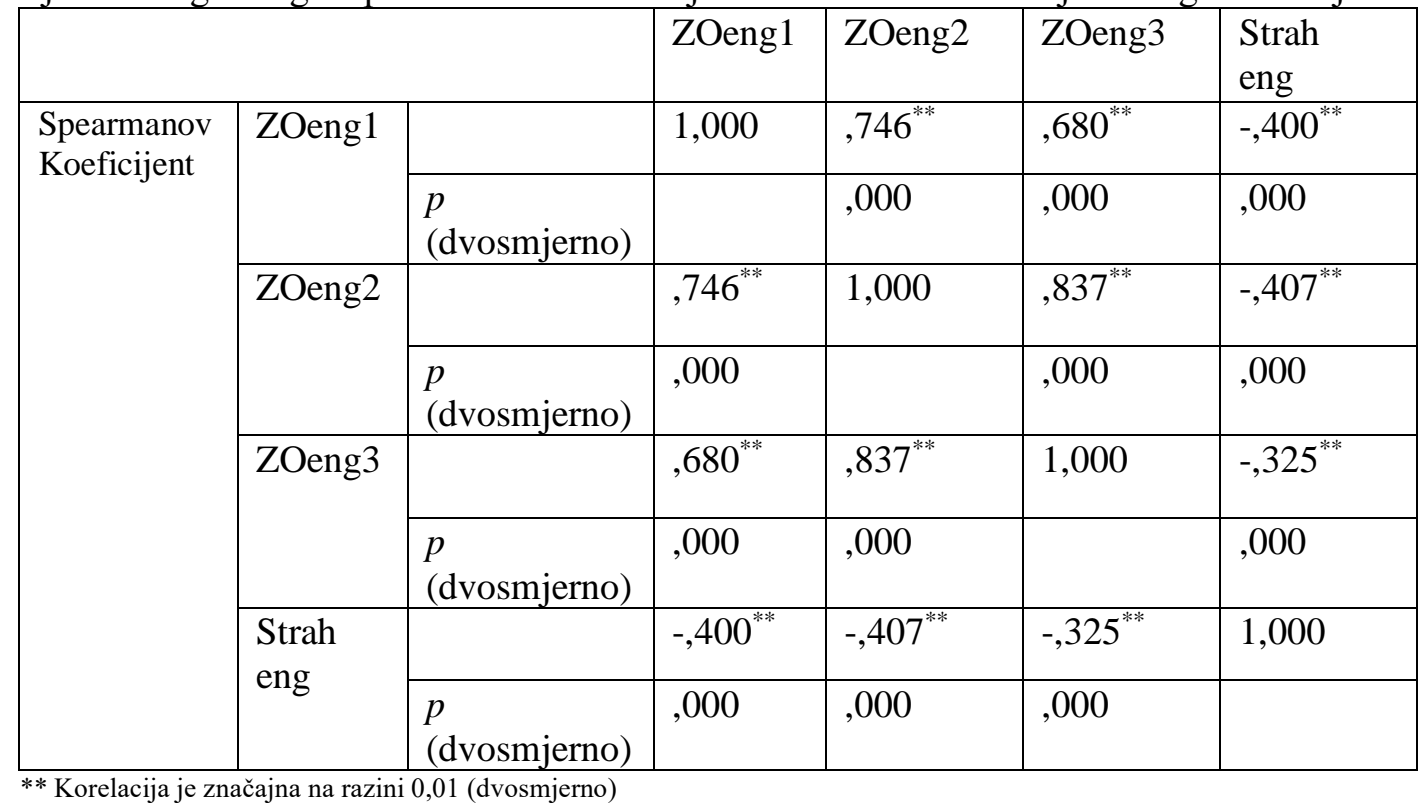

Iz tablice 5.60. vidljivo je da postoji statistički značajna negativna umjerena povezanost straha od čitanja i zaključne ocjene iz engleskoga jezika u prvome $(r=-, 400)$, drugome $(r=-$ ,407) i trećemu $(r=-, 325)$ razredu. 


\subsubsection{Povezanost straha od čitanja na njemačkome jeziku i zaključnih ocjena iz njemačkoga jezika}

U tablicama 5.61. i 5.62. prikazane su korelacijski koeficijenti, Pearsonovi i Spearmanovi, zaključnih ocjena iz njemačkoga jezika u prva tri razreda srednje škole i straha od čitanja na njemačkome jeziku.

Tablica 5.61. Korelacijska matrica $\left(N_{n j \_}=155\right)$ Pearsonovih koeficijenata korelacije zaključnih ocjena iz njemačkoga u prva tri razreda srednje škole i straha od čitanja na njemačkome jeziku

\begin{tabular}{|l|l|l|l|l|l|l|}
\hline \multicolumn{2}{|c|}{} & ZOnjem1 & ZOnjem2 & ZOnjem3 & $\begin{array}{l}\text { Strah } \\
\text { njem }\end{array}$ & \\
\hline \multirow{2}{*}{ ZOnjem1 } & 1 &, $668^{* *}$ &, $602^{* *}$ &,$- 283^{* *}$ & \\
\cline { 2 - 7 } & $p$ (dvosmjerno) & &, 000 &, 000 &, 000 & \\
\hline \multirow{2}{*}{ ZOnjem2 } & &, $668^{* *}$ & 1 &, $786^{* *}$ &,$- 210^{* *}$ & \\
\cline { 2 - 7 } & $p$ (dvosmjerno) &, 000 & &, 000 &, 009 & \\
\hline \multirow{2}{*}{ ZOnjem3 } &, $602^{* *}$ &, $786^{* *}$ & 1 &,$- 205^{*}$ & \\
\cline { 2 - 7 } & $p$ (dvosmjerno) &, 000 &, 000 & &, 011 & \\
\hline $\begin{array}{l}\text { Strah } \\
\text { njem }\end{array}$ &,$- 283^{* *}$ &,$- 210^{* *}$ &,$- 205^{*}$ & 1 & \\
\cline { 2 - 7 } \\
$\begin{array}{l}* \text { Korelacija je značana na razini 0,05 (dvosmjerno) } \\
* * \text { Korelacija je značajna na razini 0,01 (dvosmjerno), }\end{array}$ &, 000 &, 009 &, 011 & & \\
\end{tabular}

Iz tablice 5.61. vidljivo je da postoji statistički značajna negativna niska povezanost straha od čitanja i zaključne ocjene iz njemačkoga jezika u prvome $(r=-, 283)$, drugome $(r=-, 210) \mathrm{i}$ trećemu $(r=-, 205)$ razredu. 
Tablica 5.62. Korelacijska matrica $\left(N_{n j \_}=155\right)$ Spearmanovih koeficijenata korelacije zaključnih ocjena iz njemačkoga u prva tri razreda srednje škole i straha od čitanja na njemačkome jeziku

\begin{tabular}{|c|c|c|c|c|c|c|}
\hline \multicolumn{3}{|c|}{ 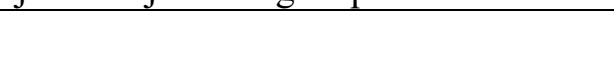 } & \multirow{2}{*}{$\begin{array}{l}\begin{array}{l}\mathrm{ZO} \\
\text { njem1 }\end{array} \\
1,000\end{array}$} & \multirow{2}{*}{$\begin{array}{l}\mathrm{ZO} \\
\text { njem2 } \\
, 679^{* *}\end{array}$} & \multirow{2}{*}{$\begin{array}{l}\text { ZO } \\
\text { njem3 } \\
, 582^{* *}\end{array}$} & \multirow{2}{*}{$\begin{array}{l}\begin{array}{l}\text { Strah } \\
\text { njem }\end{array} \\
-, 271^{\text {*** }}\end{array}$} \\
\hline \multirow{8}{*}{$\begin{array}{l}\text { Spearmanov } \\
\text { koeficijent }\end{array}$} & \multirow{2}{*}{$\begin{array}{l}\mathrm{ZO} \\
\text { njem1 }\end{array}$} & & & & & \\
\hline & & $\begin{array}{l}p \\
\text { (dvosmjerno) }\end{array}$ & &, 000 & ,000 & ,001 \\
\hline & \multirow{2}{*}{$\begin{array}{l}\mathrm{ZO} \\
\text { njem2 }\end{array}$} & &, $679^{* *}$ & 1,000 &, $784^{* *}$ &,$- 207^{* *}$ \\
\hline & & $\begin{array}{l}p \\
\text { (dvosmjerno) }\end{array}$ &, 000 & & 000 &, 010 \\
\hline & \multirow{2}{*}{$\begin{array}{l}\mathrm{ZO} \\
\text { njem3 }\end{array}$} & &, $582^{* *}$ &, $784^{* *}$ & 1,000 &,$- 213^{* *}$ \\
\hline & & $\begin{array}{l}p \\
\text { (dvosmjerno) }\end{array}$ & ,000 &, 000 & &, 008 \\
\hline & \multirow{2}{*}{$\begin{array}{l}\text { Strah } \\
\text { njem }\end{array}$} & &,$- 271^{* *}$ &,$- 207^{* *}$ &,$- 213^{* *}$ & 1,000 \\
\hline & & $\begin{array}{l}p \\
\text { (dvosmierno) }\end{array}$ & ,001 &, 010 & ,008 & \\
\hline
\end{tabular}

** Korelacija je značajna na razini 0,01 (dvosmjerno)

Iz tablice 5.62. vidljivo je da postoji statistički značajna negativna niska povezanost straha od čitanja i zaključne ocjene iz njemačkoga jezika u prvome $(r=-, 271)$, drugome $(r=-$ ,207) i trećemu $(r=-, 213)$ razredu. 


\subsubsection{Povezanost motivacije za učenje engleskoga i njemačkoga jeziku i zaključnih}

ocjena iz engleskoga i njemačkoga jezika

\subsubsection{Povezanost motivacije za učenje engleskoga jezika i zaključnih ocjena iz engleskoga jezika}

U tablicama 5.63. i 5.64. prikazani su korelacijski koeficijenti, Pearsonovi i Spearmanovi, zaključnih ocjena iz engleskoga $u$ prva tri razreda srednje škole i motivacije za učenje engleskoga jezika.

Tablica 5.63. Korelacijska matrica $\left(N_{e \_m=157}\right)$ Pearsonovih koeficijenata korelacije zaključnih ocjena iz engleskoga u prva tri razreda srednje škole i motivacije za učenje engleskoga jezika

\begin{tabular}{|l|l|l|l|l|l|}
\hline \multicolumn{2}{|c|}{} & ZOeng1 & ZOeng2 & ZOeng3 & $\begin{array}{l}\text { Mot } \\
\text { eng }\end{array}$ \\
\hline \multirow{2}{*}{ ZOeng1 } & 1 &, $748^{* *}$ &, $689^{* *}$ &, $532^{* *}$ \\
\cline { 2 - 6 } & $p$ (dvosmjerno) & &, 000 &, 000 &, 000 \\
\hline ZOeng2 & $p$ (dvosmjerno) &, $748^{* *}$ & 1 &, $843^{* *}$ &, $599^{* *}$ \\
\cline { 2 - 6 } & &, 000 & &, 000 &, 000 \\
\cline { 2 - 6 } ZOeng3 &, $689^{* *}$ &, $843^{* *}$ & 1 &, $535^{* *}$ \\
\hline \multirow{2}{*}{$\begin{array}{l}\text { Mot } \\
\text { eng }\end{array}$} & $p$ (dvosmjerno) &, 000 &, 000 & &, 000 \\
\cline { 2 - 6 } & &, $532^{* *}$ &, $599^{* *}$ &, $535^{* *}$ & 1 \\
\hline
\end{tabular}

** Korelacija je značajna na razini 0,01 (dvosmjerno), $p$ vrijednost za sve parove korelacije je jednaka 0,000

Iz tablice 5.63. vidljivo je da postoji statistički značajna pozitivna visoka povezanost zaključne ocjene i motivacije za učenje engleskoga jezika u u prvome $(r=, 532)$, drugome $(r=$ ,599) i trećemu $(r=, 535)$ razredu. 
Tablica 5.64. Korelacijska matrica $(N=157)$ Spearmanovih koeficijenata korelacije zaključnih ocjena iz engleskoga u prva tri razreda srednje škole i motivacije za učenje engleskoga jezika

\begin{tabular}{|c|c|c|c|c|c|c|}
\hline & & & ZOeng1 & ZOeng2 & ZOeng3 & $\begin{array}{l}\text { Mot } \\
\text { eng }\end{array}$ \\
\hline \multirow{8}{*}{$\begin{array}{l}\text { Spearmanov } \\
\text { koeficijent }\end{array}$} & \multirow[t]{2}{*}{ ZOeng1 } & & 1,000 &, $746^{* *}$ &, $680^{* * *}$ &, $512^{* *}$ \\
\hline & & $\begin{array}{l}p \\
\text { (dvosmierno) }\end{array}$ & & ,000 & ,000 & ,000 \\
\hline & \multirow[t]{2}{*}{ ZOeng2 } & &, $746^{* *}$ & 1,000 &, $837^{* *}$ &, $563^{* *}$ \\
\hline & & $\begin{array}{l}p \\
\text { (dvosmjerno) }\end{array}$ & ,000 & & ,000 & ,000 \\
\hline & \multirow[t]{2}{*}{ ZOeng3 } & &, $680^{* *}$ &, $837^{* *}$ & 1,000 &, $518^{* *}$ \\
\hline & & $\begin{array}{l}p \\
\text { (dvosmjerno) }\end{array}$ & ,000 & ,000 & & ,000 \\
\hline & \multirow{2}{*}{$\begin{array}{l}\text { Mot } \\
\text { eng }\end{array}$} & &, $512^{* *}$ &, $563^{* *}$ &, $518^{* *}$ & 1,000 \\
\hline & & $\begin{array}{l}p \\
\text { (dvosmjerno) }\end{array}$ & ,000 & ,000 & ,000 & \\
\hline
\end{tabular}

** Korelacija je značajna na razini 0,01 (dvosmjerno), $p$ vrijednost za sve parove korelacije je jednaka 0,000

Iz tablice 5.64. vidljivo je da postoji statistički značajna pozitivna visoka povezanost zaključne ocjene i motivacije za učenje engleskoga jezika u u prvome $(r=, 512)$, drugome $(r=$ $, 563)$ i trećemu $(r=, 518)$ razredu. 


\subsubsection{Povezanost motivacije za učenje njemačkoga jezika i zaključnih ocjena iz njemačkoga jezika}

U tablicama 5.65. i 5.66. prikazane su korelacijski koeficijenti, Pearsonovi i Spearmanovi, zaključnih ocjena iz njemačkoga jezika u prva tri razreda srednje škole i motivacije za učenje njemačkoga jezika.

Tablica 5.65. Korelacijska matrica $\left(N_{n j} m=155\right)$ Pearsonovih koeficijenata korelacije zaključnih ocjena iz njemačkoga jezika u prva tri razreda srednje škole i motivacije za učenje njemačkoga jezika

\begin{tabular}{|l|l|l|l|l|l|}
\hline \multicolumn{2}{|c|}{} & ZOnjem1 & ZOnjem2 & ZOnjem3 & $\begin{array}{l}\text { Mot } \\
\text { njem }\end{array}$ \\
\hline ZOnjem1 & & 1 &, $668^{* *}$ &, $602^{* *}$ &, $322^{* *}$ \\
\cline { 2 - 6 } & $p$ (dvosmjerno) & &, 000 &, 000 &, 000 \\
\hline \multirow{3}{*}{ ZOnjem2 } & &, $668^{* *}$ & 1 &, $786^{* *}$ &, $403^{* *}$ \\
\cline { 2 - 6 } & &, 000 & &, 000 &, 000 \\
\hline ZOnjem3 &, $602^{* *}$ &, $786^{* *}$ & 1 &, $450^{* *}$ \\
\cline { 2 - 6 } & $p$ (dvosmjerno) &, 000 &, 000 & &, 000 \\
\hline \multirow{2}{*}{$\begin{array}{l}\text { Mot } \\
\text { njem }\end{array}$} &, $322^{* *}$ &, $403^{* *}$ &, $450^{* *}$ & 1 \\
\cline { 2 - 6 } & $p$ (dvosmjerno) &, 000 &, 000 &, 000 & \\
\hline \multirow{2}{*}{ Korelacija je značajna na razini 0,01 (dvosmjerno) } & & & &
\end{tabular}

Iz tablice 5.65. vidljivo je da postoji statistički značajna pozitivna umjerena povezanost zaključne ocjene i motivacije za učenje njemačkoga jezika u u prvome $(r=, 322)$, drugome $(r=, 402)$ i trećemu $(r=, 450)$ razredu. 
Tablica 5.66. Korelacijska matrica $\left(N_{n j \_}=155\right)$ Spearmanovih koeficijenata korelacije zaključnih ocjena iz njemačkoga jezika u prva tri razreda srednje škole i motivacije za učenje njemačkoga jezika

\begin{tabular}{|c|c|c|c|c|c|c|}
\hline & & & $\begin{array}{l}\mathrm{ZO} \\
\text { njem1 }\end{array}$ & $\begin{array}{l}\mathrm{ZO} \\
\text { njem2 }\end{array}$ & $\begin{array}{l}\mathrm{ZO} \\
\text { njem3 }\end{array}$ & $\begin{array}{l}\text { Mot } \\
\text { NJEM }\end{array}$ \\
\hline \multirow{8}{*}{$\begin{array}{l}\text { Spearmanov } \\
\text { koeficijent }\end{array}$} & \multirow{2}{*}{$\begin{array}{l}\mathrm{ZO} \\
\text { njem1 }\end{array}$} & & 1,000 &, $679^{* *}$ &, $582^{* * *}$ &, $316^{* *}$ \\
\hline & & $\begin{array}{l}p \\
\text { (dvosmjerno) }\end{array}$ & & ,000 & ,000 & ,000 \\
\hline & \multirow{2}{*}{$\begin{array}{l}\mathrm{ZO} \\
\text { njem2 }\end{array}$} & & ,679** & 1,000 &, $784^{* *}$ &, $403^{* *}$ \\
\hline & & $\begin{array}{l}p \\
\text { (dvosmjerno) }\end{array}$ & ,000 & & ,000 & ,000 \\
\hline & \multirow{2}{*}{$\begin{array}{l}\mathrm{ZO} \\
\text { njem3 }\end{array}$} & &, $582^{* *}$ &, $784^{* *}$ & 1,000 & ,446 \\
\hline & & $\begin{array}{l}p \\
\text { (dvosmjerno) }\end{array}$ & ,000 & , 000 & & ,000 \\
\hline & \multirow{2}{*}{$\begin{array}{l}\text { Mot } \\
\text { NJEM }\end{array}$} & &, $316^{* *}$ &, $403^{* *}$ & , $446^{* *}$ & 1,000 \\
\hline & & $\begin{array}{l}p \\
\text { (dvosmjerno) }\end{array}$ & ,000 & ,000 & ,000 & \\
\hline
\end{tabular}

** Korelacija je značajna na razini 0,01 (dvosmjerno)

Iz tablice 5.66. vidljivo je da postoji statistički značajna pozitivna umjerena povezanost zaključne ocjene i motivacije za učenje njemačkoga jezika u prvome $(r=, 316)$, drugome $(r=, 403)$ i trećemu $(r=, 446)$ razredu. 


\subsubsection{Povezanost uspjeha na testu razumijevanja teksta čitanjem i zaključne ocjene iz trećega razreda}

\subsubsection{Povezanost uspjeha na testu razumijevanja teksta čitanjem $i$ zaključne ocjene iz trećega razreda za engleski jezik}

Povezanost rezultata na testu razumijevanja teksta čitanjem - engleski jezik i zaključne ocjene iz engleskoga jezika u trećem razredu srednje škole prikazana je u tablicama 5.67. i 5.684.

Tablica 5.67. Korelacijska matrica $\left(N_{e_{\_} t=160}\right)$ Pearsonova koeficijenta korelacije za zaključnu ocjenu u trećem razredu srednje škole i ukupni rezultat na testu razumijevanja teksta čitanjem - engleski jezik

\begin{tabular}{|l|c|l|c|}
\hline \multicolumn{2}{|c|}{} & $\begin{array}{l}\text { ocjena } \\
\text { 3. raz }\end{array}$ & $\begin{array}{l}\text { test } \\
\text { eng }\end{array}$ \\
\hline $\begin{array}{l}\text { ocjena } \\
3 . \text { raz }\end{array}$ & $p$ (dvosmjerno) & 1 &, $546^{* *}$ \\
\cline { 2 - 4 } $\begin{array}{l}\text { test } \\
\text { eng }\end{array}$ &, $546^{* *}$ &, 000 \\
\cline { 2 - 4 } & $p$ (dvosmjerno) &, 000 & 1 \\
\hline \multirow{2}{*}{ ** Korelacija je značajna na razini 0,01 (dvosmjerno) }
\end{tabular}

Iz tablice 5.67. je vidljivo da postoji statistički značajna visoka pozitivna povezanost uspjeha na testu razumijevanja teksta čitanjem na engleskome jeziku i zaključne ocjene iz engleskoga jezika u trećemu razredu $(r=, 546)$. 
Tablica 5.68. Korelacijska matrica $\left(N_{e_{-} t=160}\right)$ Spearmanova koeficijenta korelacije za zaključnu ocjenu u trećem razredu srednje škole i ukupni rezultat na testu razumijevanja teksta čitanjem - engleski jezik

\begin{tabular}{|l|l|l|l|l|}
\hline \multicolumn{2}{|c|}{} & $\begin{array}{l}\text { ocjena } \\
\text { 3. raz }\end{array}$ & $\begin{array}{l}\text { test } \\
\text { eng }\end{array}$ \\
\hline $\begin{array}{l}\text { Spearmanov } \\
\text { koeficijent }\end{array}$ & $\begin{array}{l}\text { ocjena } \\
\text { 3. raz }\end{array}$ & $\begin{array}{l}p \\
(\text { dvosmjerno })\end{array}$ & 1,000 &, $536^{* *}$ \\
\cline { 2 - 5 } & $\begin{array}{l}\text { test } \\
\text { eng }\end{array}$ & $\begin{array}{l}p \\
(\text { dvosmjerno })\end{array}$ &, 000 \\
\cline { 3 - 5 } & &, $536^{* *}$ & 1,000 \\
\hline
\end{tabular}

** Korelacija je značajna na razini 0,01 (dvosmjerno)

Iz tablice 5.68. je vidljivo da postoji statistički značajna visoka pozitivna povezanost uspjeha na testu razumijevanja teksta čitanjem na engleskome jeziku i zaključne ocjene iz engleskoga jezika u trećemu razredu $(r=, 536)$. 


\subsubsection{Povezanost uspjeha na testu razumijevanja teksta čitanjem $i$}

\section{zaključne ocjene iz trećega razreda za njemački jezik}

Povezanost rezultata na testu razumijevanja teksta čitanjem - njemački jezik i zaključne ocjene iz njemačkoga jezika u trećem razredu srednje škole prikazana je u tablicama 5.69. i 5.70.

Tablica 5.69. Korelacijska matrica $\left(N_{n j \_} \_=154\right)$ Pearsonova koeficijenta korelacije za zaključnu ocjenu u trećem razredu srednje škole i ukupni rezultat na testu razumijevanja teksta čitanjem - njemački jezik

\begin{tabular}{|l|l|l|l|}
\hline \multicolumn{2}{|c|}{} & $\begin{array}{l}\text { ocjena } \\
\text { 3. raz }\end{array}$ & $\begin{array}{l}\text { test } \\
\text { njem }\end{array}$ \\
\hline $\begin{array}{l}\text { ocjena } \\
\text { 3. raz }\end{array}$ & $p$ (dvosmjerno) & 1 &, $766^{* *}$ \\
\hline $\begin{array}{l}\text { test } \\
\text { njem }\end{array}$ & $p$ (dvosmjerno) &, $766^{* *}$ &, 000 \\
\cline { 2 - 4 } &, 000 & 1 \\
\hline \multirow{*}{*}{ Korelacija je značajna na razini 0,01 (dvosmjerno) } &
\end{tabular}

Iz tablice 5.69. vidljivo je da postoji statistički značajna vrlo visoka pozitivna povezanost uspjeha na testu razumijevanja teksta čitanjem na njemačkome jeziku i zaključne ocjene iz njemačkoga jezika u trećemu razredu $(r=, 766)$.

Tablica 5.70. Korelacijska matrica $\left(N_{n j}{ }_{-}=154\right)$ Spearmanova koeficijenta korelacije za zaključnu ocjenu u trećem razredu srednje škole i ukupni rezultat na testu razumijevanja teksta čitanjem - njemački jezik

\begin{tabular}{|l|l|l|l|l|}
\hline \multicolumn{2}{|c|}{} & $\begin{array}{l}\text { ocjena } \\
\text { 3. raz }\end{array}$ & $\begin{array}{l}\text { test } \\
\text { njem }\end{array}$ \\
\hline $\begin{array}{l}\text { Spearmanov } \\
\text { koeficijent }\end{array}$ & \multirow{2}{*}{$\begin{array}{l}\text { ocjena } \\
\text { 3. raz }\end{array}$} & $\begin{array}{l}p \\
(\text { dvosmjerno })\end{array}$ & 1,000 &, $766^{* *}$ \\
\cline { 2 - 5 } & $\begin{array}{l}\text { test } \\
\text { njem }\end{array}$ & $\begin{array}{l}p \\
(\text { dvosmjerno) }\end{array}$ &, $766^{* *}$ & 1,000 \\
\cline { 2 - 5 } & &, 000 & \\
\hline
\end{tabular}

** Korelacija je značajna na razini 0,01 (dvosmjerno)

Iz tablice 5.70. vidljivo je da postoji statistički značajna vrlo visoka pozitivna povezanost uspjeha na testu razumijevanja teksta čitanjem na njemačkome jeziku i zaključne ocjene iz njemačkoga jezika u trećemu razredu $(r=, 766)$. 


\subsubsection{Medijacijske analize}

U svrhu testiranja hipoteze 5 (H5) provedeno je testiranje medijacije regresijskim analizama između varijabli definiranih u hipotezi.

Medijacija je hipotetski uzročni lanac u kojem varijabla $X$ utječe na varijablu $M$, koja opet utječe na varijablu $Y$. Pritom je $M$ intervenirajući varijabla, odnosno medijator odnosa između varijabli $X$ (prediktora) i $Y$ (ishoda).

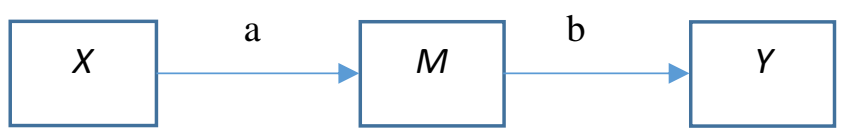

Slika 5.17. Intervenirajuća varijabla $M$ u odnosu između varijable $X$ i $Y$

Putevi $a$ i $b$ nazivaju se direktnim efektima, a medijacijski efekt kojim $X$ utječe na $Y$ kroz $M$ naziva se indirektnim efektom. Indirektni efekt odnosi se na dio odnosa između $X$ i $Y$ koji je posredovan varijablom $M$.

Testiranje medijacije često se provodi postupkom koji su predložili Baron i Kenny (1986). Postupak se sastoji od četiriju koraka (v. tablicu 5.71.) u kojima se provode regresijske analize i provjerava značajnost koeficijenata.

Tablica 5.71. Koraci u medijacijskoj analizi (Baron i Kenny, 1986)

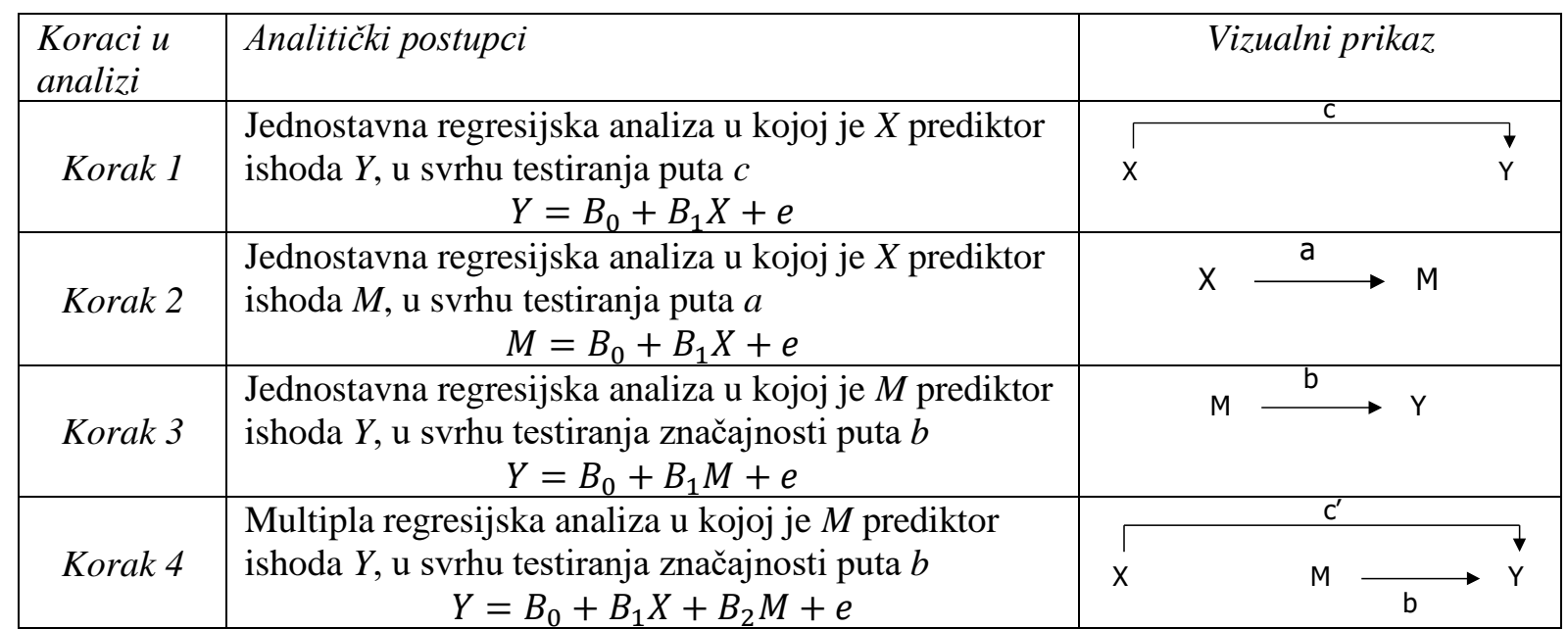


$\mathrm{Na}$ dijagramu prikazanom na slici 5.18. prikazani su svi testirani odnosi, gdje $c^{\prime}$ označava direktni efekt. Slika prikazuje takozvani jednostavni medijacijski model s jednom medijacijskom varijablom $M$ uzročno smještenom između varijabli $X$ i $Y$.

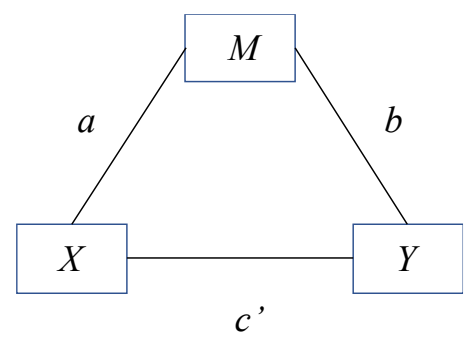

Slika 5.18. Jednostavni medijacijski model

U našem istraživanju varijabla $X$ je strah od čitanja, varijabla $Y$ je rezultat na testu razumijevanja teksta čitanjem (razumijevanje tekstom), a varijabla $M$ je motivacija za učenje jezika (v. sliku 5.19.).

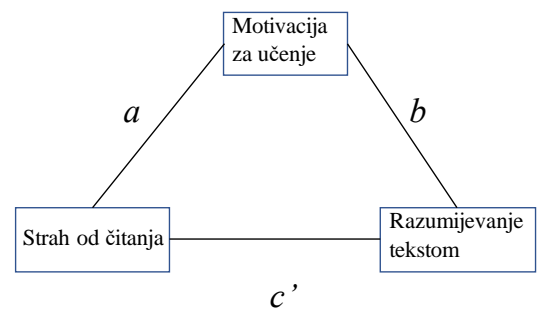

Slika 5.19. Jednostavni medijacijski model varijabli u ovom istraživanju

Sobel (1982) je predložio pristup u izračunavanju indirektnoga efekta u kojem se pomnože dva regresijska koeficijenta koja se dobiju iz dvaju regresijskih modela, opisanih u tablici 5.72.

Tablica 5.72. Prikaz Sobelova testa

\begin{tabular}{|l|c|c|}
\hline \multicolumn{3}{|c|}{ Sobelov test: Produkt koeficijenata } \\
\hline & Analiza & Vizualni prikaz \\
\hline Model 1 & $Y=B_{0}+B_{1} X+B_{2} M+e$ & $\mathrm{c}^{\prime}$ \\
& $M=B_{0}+B X+e$ & $\mathrm{x} \longrightarrow \mathrm{\textrm {b }}$ \\
\hline Model 2 & $\mathrm{y} \stackrel{\mathrm{a}}{\longrightarrow} \mathrm{M}$ \\
\hline
\end{tabular}

Parcijalni regresijski koeficijent dobiven je u modelu 1, a modelom 2 dobiva se odnos između varijabli $X$ i $M$. Kad se pomnože dva nestandardizirana koeficijenta, parcijalni 
regresijski efekt gdje $M$ predviđa $Y-B_{2}$, te jednostavni koeficijent gdje $X$ predviđa $M-B$, dolazi se do indirektnog efekta. Odnosno, prikazano formulom: $B_{\text {indirektni }}=\left(B_{2}\right) \times(B)$

Nakon izračunavanja regresijskoga koeficijenta za indirektni efekt potrebno je testiranje statističke značajnosti.

Postupak opisan u ovom poglavlju proveden je za engleski i za njemački jezik, a rezultati su opisani u sljedećim poglavljima.

\subsubsection{Testiranje medijacije regresijskim analizama-engleski jezik}

Rezultati regresijske analize opisane u koraku 1 (tablica 5.71.) prikazani su u tablicama 5.73. i 5.74 .

Tablica 5.73. Koeficijenti regresijske analize (korak 1)

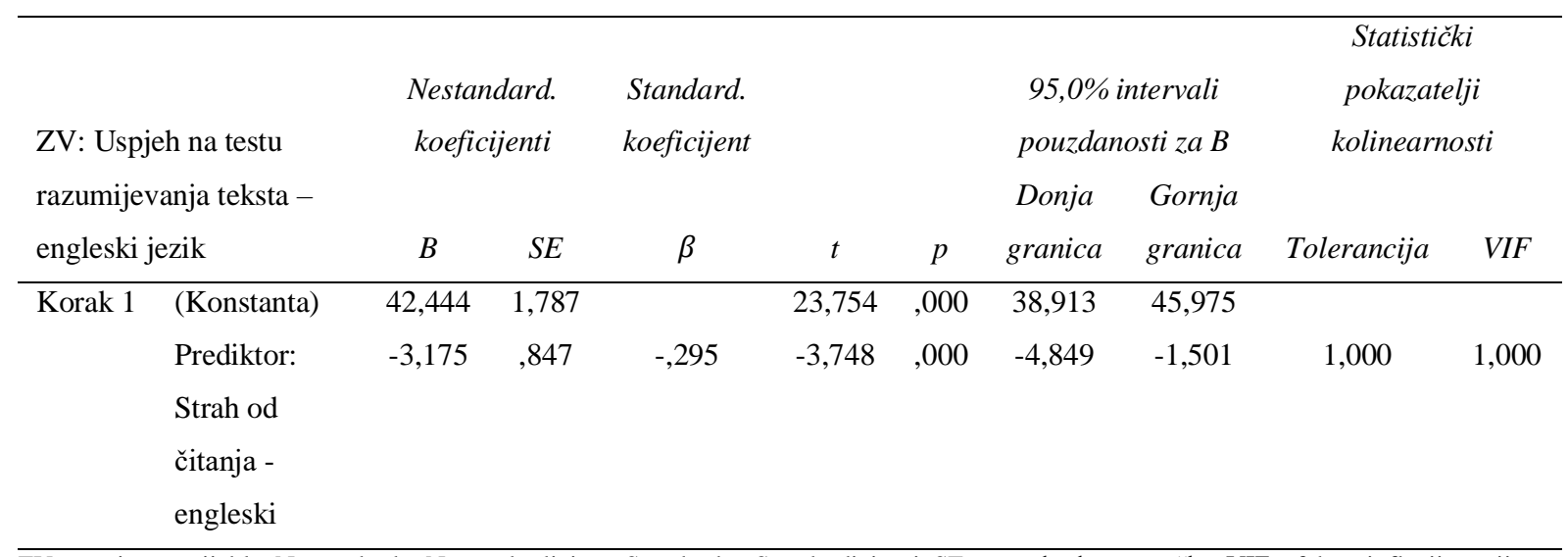

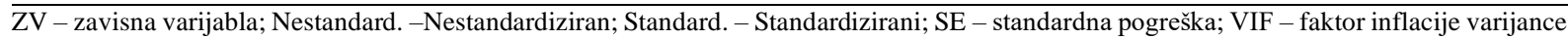
(engl. variance inflation factor)

Tablica 5.74. Sažetak modela (korak 1)

\begin{tabular}{lcclcc}
\hline \multicolumn{6}{c}{ ZV: Uspjeh na testu razumijevanja teksta - engleski jezik $(N=149)$} \\
\hline Prediktor & $R$ & $R^{2}$ & Korigirani $R^{2}$ & $r$ & $S E$ \\
\hline Strah od čitanja - engleski & 0,295 & 0,087 & 0,081 &,- 295 & 7,493 \\
\hline$F(1 / 147)=$ & $14,049, p=, 000$ \\
\hline ZV - zavisna varijabla; $r$ - Pearsonov koeficijent korelacije; $S E$ - standardna pogreška procjene
\end{tabular}

Strah od čitanja za engleski jezik ukupno objašnjava $8,7 \%(\mathrm{p}<, 001)$ varijance uspjeha na testu razumijevanja teksta čitanjem za engleski jezik.

Rezultati regresijske analize opisane u koraku 2 (tablica 5.71.) prikazani su u tablicama 5.75. i 5.76 . 
Tablica 5.75. Koeficijenti regresijske analize (korak 2)

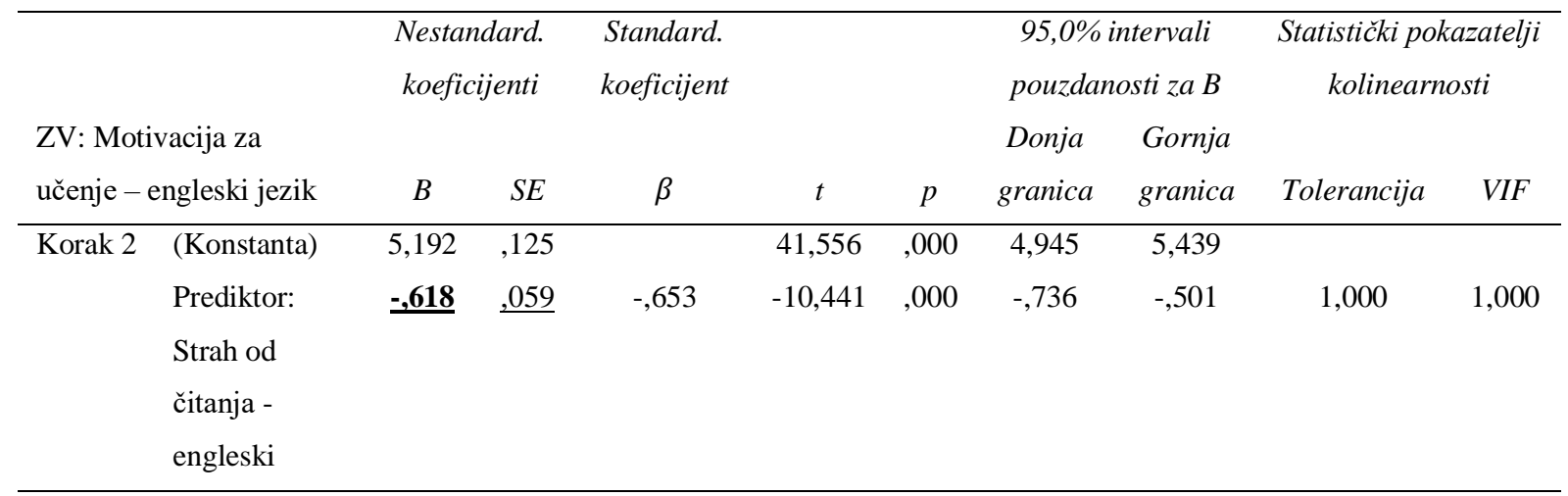

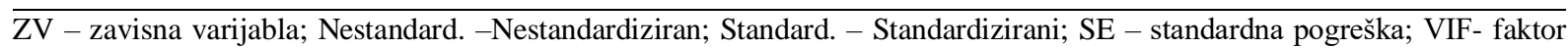
inflacije varijance

Tablica 5.76. Sažetak modela (korak 2)

\begin{tabular}{llllll}
\hline \multicolumn{6}{c}{ ZV: Motivacija za učenje - engleski jezik $(N=149)$} \\
\hline Prediktor & $R$ & $R^{2}$ & Korigirani $R^{2}$ & $r$ & $S E$ \\
\hline Strah od čitanja - engleski &, 653 &, 426 &, 422 &,- 653 & 0,5239 \\
\hline$F(1 / 147)=109,013, p=0,000$ \\
ZV - zavisna varijabla; $r$ - Pearsonov koeficijent korelacije; $S E$ - standardna pogreška procjene
\end{tabular}

Strah od čitanja za engleski jezik ukupno objašnjava $42,6 \%(p<, 001)$ varijance motivacije za učenje engleskoga jezika.

Rezultati regresijske analize opisane u koraku 3 (tablica 5.67) prikazani su u tablicama 5.77. i 5.78 .

Tablica 5.77. Koeficijenti regresijske analize (korak 3)

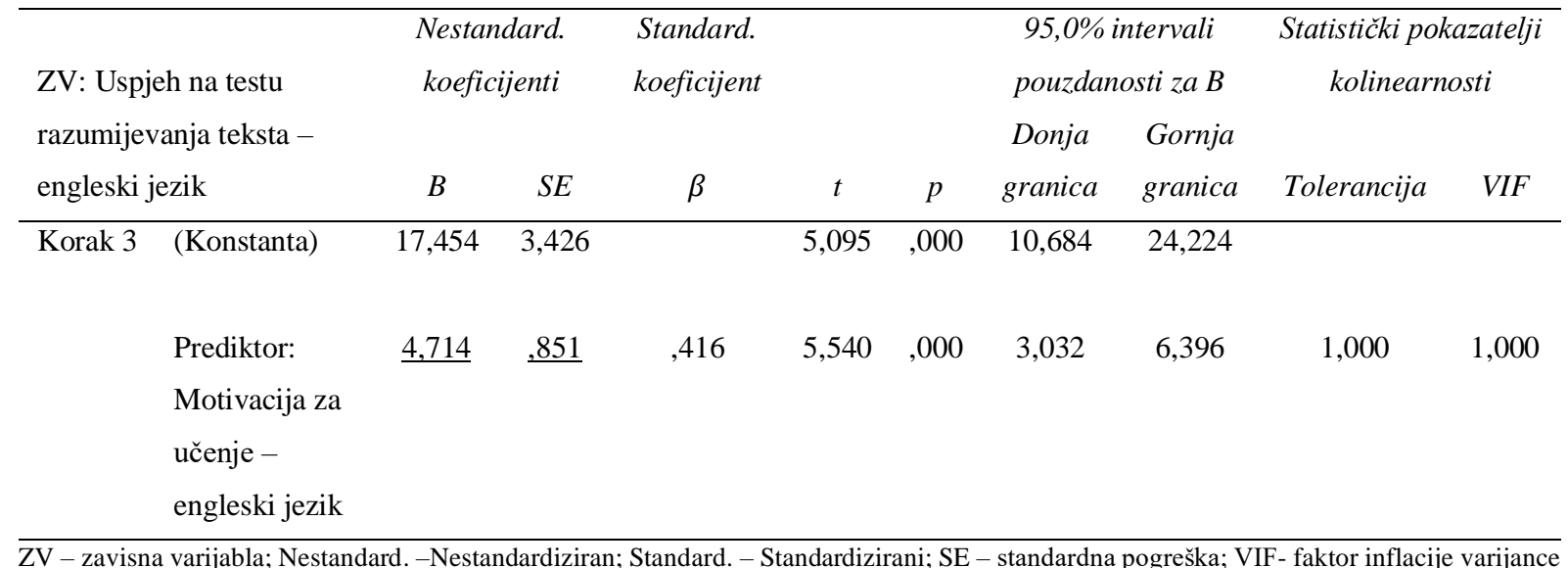


Tablica 5.78. Sažetak modela (korak 3 )

\begin{tabular}{|c|c|c|c|c|c|}
\hline Prediktor & $R$ & $R^{2}$ & Korigirani $R^{2}$ & $r$ & $S E$ \\
\hline Motivacija za učenje - engleski & 416 &, 173 & 167 & ,416 & 7,133 \\
\hline$F(1 / 147)=30,689, p=, 000$ & & & & & \\
\hline
\end{tabular}

Motivacija za učenje engleskog jezika ukupno objašnjava $17,3 \%(p<, 001)$ varijance uspjeha na testu razumijevanja teksta čitanjem za engleski jezik.

Rezultati multiple regresijske analize opisane u koraku 4 (tablica 5.71.) prikazani su u tablicama 5.79. i 5.80 .

Tablica 5.79. Koeficijenti regresijske analize (korak 4)

\begin{tabular}{|c|c|c|c|c|c|c|c|c|c|c|}
\hline \multirow{2}{*}{\multicolumn{2}{|c|}{$\begin{array}{l}\text { ZV: Uspjeh na testu } \\
\text { razumijevanja teksta - } \\
\text { engleski jezik }\end{array}$}} & \multirow{2}{*}{\multicolumn{2}{|c|}{$\begin{array}{l}\text { Nestandard. } \\
\text { koeficijenti } \\
\text { B SE }\end{array}$}} & \multirow{2}{*}{$\begin{array}{c}\text { Standard. } \\
\text { koeficijent } \\
\quad \beta\end{array}$} & \multirow[b]{2}{*}{$t$} & \multirow[b]{2}{*}{$p$} & \multicolumn{2}{|c|}{$\begin{array}{c}95,0 \% \text { intervali } \\
\text { pouzdanosti za } B\end{array}$} & \multicolumn{2}{|c|}{$\begin{array}{c}\text { Statistički pokazatelji } \\
\text { kolinearnosti }\end{array}$} \\
\hline & & & & & & & $\begin{array}{l}\text { Donja } \\
\text { granica }\end{array}$ & $\begin{array}{l}\text { Gornja } \\
\text { granica }\end{array}$ & Tolerancija & $V I F$ \\
\hline \multirow[t]{2}{*}{ Blok 1} & (Konstanta) & 42,444 & 1,787 & & 23,754 & ,000 & 38,913 & 45,975 & & \\
\hline & $\begin{array}{l}\text { Strah od } \\
\text { čitanja - } \\
\text { engleski jezik }\end{array}$ & $-3,175$ & ,847 &,- 295 & $-3,748$ &, 000 & $-4,849$ & $-1,501$ & 1,000 & 1,000 \\
\hline \multirow[t]{3}{*}{ Blok 2} & (Konstanta) & 19,586 & 6,091 & & 3,216 & ,002 & 7,549 & 31,623 & & \\
\hline & $\begin{array}{l}\text { Strah od } \\
\text { čitanja - } \\
\text { engleski jezik }\end{array}$ &,- 452 & 1,067 &,- 042 &,- 424 & ,672 & $-2,562$ & 1,657 & ,574 & 1,742 \\
\hline & $\begin{array}{l}\text { Motivacija za } \\
\text { učenje - } \\
\text { engleski jezik }\end{array}$ & 4,403 & 1,126 & ,388 & 3,909 & ,000 & 2,177 & 6,628 & ,574 & 1,742 \\
\hline
\end{tabular}

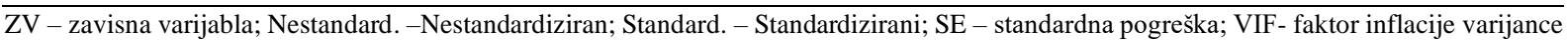


Tablica 5.80. Sažetak modela (korak 4)

\begin{tabular}{|c|c|c|c|c|c|c|c|c|c|}
\hline \multicolumn{10}{|c|}{ ZV: Uspjeh na testu razumijevanja teksta - engleski jezik $(N=149)$} \\
\hline & Prediktor & $R$ & $R^{2}$ & $\begin{array}{c}\text { Korigirani } \\
R^{2}\end{array}$ & $S E$ & $\Delta R$ & $\Delta F$ & $d f 1 / d f 2$ & $\Delta p$ \\
\hline Blok 1 & $\begin{array}{c}\text { Strah od } \\
\text { čitanja - } \\
\text { engleski } \\
\text { jezik }\end{array}$ & ,295 & ,087 & ,081 & 7,493 & ,087 & 14,049 & $1 / 147$ & 000 \\
\hline Blok 2 & $\begin{array}{l}\text { Motivacija za } \\
\text { učenje- } \\
\text { engleski } \\
\text { jezik }\end{array}$ & ,417 &, 174 &, 162 & 7,153 & ,086 & 15,284 & $1 / 146$ & 000 \\
\hline
\end{tabular}

Sveukupno je s pomoću straha od čitanja i motivacije za učenje jezika objašnjeno 17,4\% $(\mathrm{p}<, 001)$ varijance uspjeha na testu razumijevanja teksta čitanjem za engleski jezik. Motivacija za učenje dodana u drugom koraku ima statistički značajan doprinos objašnjenju varijance uspjeha na testu $-8,6 \%$. U toj zadnjoj regresijskoj analizi u koraku 4, zanimljivo je primijetiti da kad se i strah od čitanja i motivacija za učenje jezika uvrste zajedno kao prediktori uspjeha na testu, strah od čitanja više nije značajan prediktor, dok motivacija ostaje značajan prediktor. Detaljniji uvid u važnost pojedinih varijabli mogu nam dati rezultati beta pondera pojedinih prediktora i njihove značajnosti u tablici 5.79.

Parcijalni regresijski koeficijent dobiven je u koraku 4 (u tablici 5.79), a u koraku 2 (u tablici 5.75) utvrđuje se odnos između varijabli straha od čitanja i motivacije. Indirektni efekt dobiva se umnoškom parcijalnoga regresijskoga efekta, gdje je motivacija prediktor uspjeha $u$ testu razumijevanja teksta čitanjem 4,403 $\left(B_{2}\right)$, te jednostavnoga koeficijenta, gdje je strah od čitanja prediktor motivacije -,618 (B), prikazano formulom: $B_{\text {indirektni }}=4,403 \times$ $(-0,618)=-2.721$. Testiranje statističke značajnosti indirektnoga efekta (v. prilog 18 tablica 1), pokazalo je da se radi o značajnom efektu $(p<, 001)$. Drugim riječima, motivacija je značajan medijator u odnosu straha od čitanja i uspjeha u testu razumijevanja teksta čitanjem za engleski jezik. 


\subsubsection{Testiranje medijacije regresijskim analizama-njemački jezik}

Rezultati regresijske analize opisane u koraku 1 (tablica 5.71) prikazani su u tablicama 5.81. i 5.82 .

Tablica 5.81. Koeficijenti regresijske analize (korak 1)

\begin{tabular}{|c|c|c|c|c|c|c|c|c|c|c|}
\hline \multirow{2}{*}{\multicolumn{2}{|c|}{$\begin{array}{l}\mathrm{ZV} \text { : Uspjeh na testu } \\
\text { razumijevanja teksta - } \\
\text { njemački jezik }\end{array}$}} & \multicolumn{2}{|c|}{$\begin{array}{l}\text { Nestandard. } \\
\text { koeficijenti }\end{array}$} & \multirow{2}{*}{$\begin{array}{c}\text { Standard. } \\
\text { koeficijent } \\
\beta \\
\beta\end{array}$} & \multirow[b]{2}{*}{$t$} & \multirow[b]{2}{*}{$p$} & \multicolumn{2}{|c|}{$\begin{array}{c}95,0 \% \text { intervali } \\
\text { pouzdanosti za B }\end{array}$} & \multicolumn{2}{|c|}{$\begin{array}{c}\text { Statistički } \\
\text { pokazatelji } \\
\text { kolinearnosti }\end{array}$} \\
\hline & & B & $S E$ & & & & granica & granica & Tolerancija & VIF \\
\hline \multirow[t]{2}{*}{ Korak 1} & (Konstanta) & 27,508 & 2,120 & & 12,977 & ,000 & 23,320 & 31,697 & & \\
\hline & $\begin{array}{l}\text { Prediktor: } \\
\text { Strah od } \\
\text { čitanja - } \\
\text { njemački }\end{array}$ & $-1,719$ & ,866 &,- 159 & $-1,985$ & ,049 & $-3,430$ &,- 008 & 1,000 & 1,000 \\
\hline
\end{tabular}

Tablica 5.82. Sažetak modela (korak 1)

\begin{tabular}{|c|c|c|c|c|c|}
\hline \multicolumn{6}{|c|}{ ZV: Uspjeh na testu razumijevanja teksta - njemački jezik $(N=153)$} \\
\hline Prediktor & $R$ & $R^{2}$ & Korigirani $R^{2}$ & $r$ & $S E$ \\
\hline Strah od čitanja - njemački &, 159 &, 025 & ,019 &,- 159 & 7,903 \\
\hline \multicolumn{6}{|c|}{$F(1 / 151)=3,940, p=, 049$} \\
\hline
\end{tabular}

Strah od čitanja za njemački jezik ukupno objašnjava 2,5\% $(p<, 05)$ varijance uspjeha na testu razumijevanja teksta čitanjem za njemački jezik.

Rezultati regresijske analize opisane u koraku 2 (tablica 5.71.) prikazani su u tablicama 5.83. i 5.84 .

Tablica 5.83. Koeficijenti regresijske analize (korak 2)

\begin{tabular}{|c|c|c|c|c|c|c|c|c|c|c|}
\hline \multirow{2}{*}{\multicolumn{2}{|c|}{$\begin{array}{l}\text { ZV: Motivacija za učenje } \\
\text { - njemački jezik }\end{array}$}} & \multicolumn{2}{|c|}{$\begin{array}{c}\text { Nestandard. } \\
\text { koeficijenti }\end{array}$} & \multirow{2}{*}{$\begin{array}{c}\text { Standard. } \\
\text { koeficijent } \\
\beta\end{array}$} & \multirow[b]{2}{*}{$t$} & \multirow[b]{2}{*}{$p$} & \multicolumn{2}{|c|}{$\begin{array}{l}\text { 95,0\% intervali } \\
\text { pouzdanosti za B }\end{array}$} & \multicolumn{2}{|c|}{$\begin{array}{c}\text { Statistički pokazatelji } \\
\text { kolinearnosti }\end{array}$} \\
\hline & & $B$ & $S E$ & & & & $\begin{array}{l}\text { Donja } \\
\text { granica }\end{array}$ & $\begin{array}{l}\text { Gornja } \\
\text { granica }\end{array}$ & Tolerancija & $V I F$ \\
\hline \multirow[t]{2}{*}{ Korak 2} & (Konstanta) & 3,821 & , 158 & & 24,220 &, 000 & 3,509 & 4,133 & & \\
\hline & $\begin{array}{l}\text { Prediktor: } \\
\text { Strah od } \\
\text { čitanja - } \\
\text { njemački }\end{array}$ & $\underline{-, 350}$ &, 064 &,- 404 & $-5,426$ & ,000 &,- 477 &,- 222 & 1,000 & 1,000 \\
\hline
\end{tabular}


Tablica 5.84. Sažetak modela (korak 2)

\begin{tabular}{lcclcc}
\hline \multicolumn{5}{c}{ ZV: Motivacija za učenje - njemački jezik $(N=153)$} \\
\hline Prediktor & $R$ & $R^{2}$ & Korigirani $R^{2}$ & $r$ & $S E$ \\
\hline Strah od čitanja - njemački &, 404 &, 163 &, 158 &,- 404 & 0,588 \\
\hline$F(1 / 151)=29,437, p=, 000$ \\
\hline ZV - zavisna varijabla; $r$ - Pearsonov koeficijent korelacije; $S E$ - standardna pogreška procjene
\end{tabular}

Strah od čitanja za njemački jezik ukupno objašnjava $16,3 \%(\mathrm{p}<, 001)$ varijance motivacije za učenje njemačkoga jezika.

Rezultati regresijske analize opisane u koraku 3 prikazani su u tablicama 5.85. i 5.86.

Tablica 5.85. Koeficijenti regresijske analize (korak 3)

\begin{tabular}{|c|c|c|c|c|c|c|c|c|c|c|}
\hline \multirow{2}{*}{\multicolumn{2}{|c|}{$\begin{array}{l}\mathrm{ZV} \text { : Uspjeh na testu } \\
\text { razumijevanja teksta - } \\
\text { njemački jezik }\end{array}$}} & \multicolumn{2}{|c|}{$\begin{array}{l}\text { Nestandard. } \\
\text { koeficijenti }\end{array}$} & \multirow{2}{*}{$\begin{array}{l}\text { Standard. } \\
\text { koeficijent } \\
\quad \beta\end{array}$} & \multirow[b]{2}{*}{$t$} & \multirow[b]{2}{*}{$p$} & \multicolumn{2}{|c|}{$\begin{array}{c}\text { 95,0\% intervali } \\
\text { pouzdanosti za B }\end{array}$} & \multicolumn{2}{|c|}{$\begin{array}{c}\text { Statistički pokazatelji } \\
\text { kolinearnosti }\end{array}$} \\
\hline & & B & $S E$ & & & & $\begin{array}{l}\text { Donja } \\
\text { granica }\end{array}$ & $\begin{array}{l}\text { Gornja } \\
\text { granica }\end{array}$ & Tolerancija & $V I F$ \\
\hline \multirow[t]{2}{*}{ Korak 3} & (Konstanta) & 6,051 & 2,754 & & 2,198 &, 030 & ,611 & 11,492 & & \\
\hline & $\begin{array}{l}\text { Prediktor: } \\
\text { Motivacija za } \\
\text { učenje- } \\
\text { njemački jezik }\end{array}$ & $\underline{5,806}$ &, 896 & ,466 & 6,477 & ,000 & 4,035 & 7,577 & 1,000 & 1,000 \\
\hline
\end{tabular}

Tablica 5.86. Sažetak modela (korak 3)

\begin{tabular}{lccccc}
\hline \multicolumn{6}{c}{ ZV: Uspjeh na testu razumijevanja teksta - njemački jezik $(N=153)$} \\
\hline Prediktor & $R$ & $R^{2}$ & Korigirani $R^{2}$ & $r$ & $S E$ \\
\hline Motivacija za učenje - njemački &, 466 &, 217 &, 212 &, 466 & 7,082 \\
\hline$F(1 / 147)=41,950, p=, 000$ \\
\hline ZV - zavisna varijabla; $r$ - Pearsonov koeficijent korelacije; $S E$ - standardna pogreška procjene
\end{tabular}

Motivacija za učenje njemačkoga jezika ukupno objašnjava 21,7 \% $(\mathrm{p}<, 001)$ varijance uspjeha na testu razumijevanja teksta čitanjem za njemački jezik. 
Rezultati multiple regresijske analize opisane u koraku 4 (tablica 5.71.) prikazani su u tablicama 5.87. i 5.88 .

Tablica 5.87. Koeficijenti regresijske analize (korak 4)

\begin{tabular}{|c|c|c|c|c|c|c|c|c|c|c|}
\hline \multirow{2}{*}{\multicolumn{2}{|c|}{$\begin{array}{l}\text { ZV: Uspjeh na testu } \\
\text { razumijevanja teksta - } \\
\text { njemački jezik }\end{array}$}} & \multicolumn{2}{|c|}{$\begin{array}{l}\text { Nestandard. } \\
\text { koeficijenti }\end{array}$} & \multirow{2}{*}{$\begin{array}{c}\text { Standard. } \\
\text { koeficijent } \\
\quad \beta\end{array}$} & \multirow[b]{2}{*}{$t$} & \multirow[b]{2}{*}{$p$} & \multicolumn{2}{|c|}{$\begin{array}{c}95,0 \% \text { intervali } \\
\text { pouzdanosti za B }\end{array}$} & \multicolumn{2}{|c|}{$\begin{array}{c}\text { Statistički pokazatelji } \\
\text { kolinearnosti }\end{array}$} \\
\hline & & $B$ & $S E$ & & & & $\begin{array}{l}\text { Donja } \\
\text { granica }\end{array}$ & $\begin{array}{l}\text { Gornja } \\
\text { granica }\end{array}$ & Tolerancija & $V I F$ \\
\hline \multirow[t]{2}{*}{ Blok 1} & (Konstanta) & 27,508 & 2,120 & & 12,977 & ,000 & 23,320 & 31,697 & & \\
\hline & $\begin{array}{l}\text { Strah od } \\
\text { čitanja - } \\
\text { njemački jezik }\end{array}$ & $-1,719$ & ,866 &,- 159 & $-1,985$ & ,049 & $-3,430$ &,- 008 & 1,000 & 1,000 \\
\hline \multirow[t]{3}{*}{ Blok 2} & (Konstanta) & 4,662 & 4,210 & & 1,107 & ,270 & $-3,656$ & 12,980 & & \\
\hline & $\begin{array}{l}\text { Strah od } \\
\text { čitanja - } \\
\text { njemački jezik }\end{array}$ & ,372 &, 851 & ,035 & ,437 & ,663 & $-1,309$ & 2,053 &, 837 & 1,195 \\
\hline & $\begin{array}{l}\text { Motivacija za } \\
\text { učenje - } \\
\text { njemački jezik }\end{array}$ & 5,979 & ,983 & ,480 & 6,086 & ,000 & 2,177 & 6,628 & ,837 & 1,195 \\
\hline
\end{tabular}

Tablica 5.88. Sažetak modela (korak 4)

\begin{tabular}{|c|c|c|c|c|c|c|c|c|c|}
\hline \multicolumn{10}{|c|}{ ZV: Uspjeh na testu razumijevanja teksta - njemački jezik $(N=153)$} \\
\hline & Prediktor & $R$ & $R^{2}$ & $\begin{array}{c}\text { Korigirani } \\
R^{2}\end{array}$ & $S E$ & $\Delta R$ & $\Delta F$ & $d f 1 / d f 2$ & $\Delta p$ \\
\hline Blok 1 & $\begin{array}{l}\text { Strah od } \\
\text { čitanja- } \\
\text { njemački } \\
\text { jezik }\end{array}$ & ,159 &, 025 & 019 & 7,903 & ,025 & 3,940 & $1 / 151$ & ,049 \\
\hline Blok 2 & $\begin{array}{l}\text { Motivacija } \\
\text { za učenje } \\
\text { - njemački } \\
\text { jezik }\end{array}$ & ,467 & ,218 & ,208 & 7,101 & ,193 & 37,036 & $1 / 150$ & ,000 \\
\hline
\end{tabular}

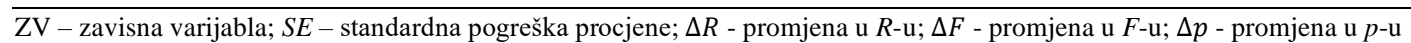

Strah od čitanja i motivacija za učenje zajedno objašnjavaju $21,8 \%(\mathrm{p}<, 001)$ varijance uspjeha na testu razumijevanja teksta čitanjem za njemački jezik. Motivacija za učenje dodana u drugom koraku ima statistički značajan doprinos objašnjenju varijance uspjeha na testu 19,3\%. Kao što je bio slučaj i kod engleskoga jezika, kada se i strah od čitanja i motivacija za 
učenje jezika uvrste zajedno kao prediktori uspjeha na testu, strah od čitanja više nije značajan prediktor, dok motivacija jest. Detaljniji uvid u važnost pojedinih varijabli mogu nam dati rezultati beta pondera pojedinih prediktora i njihove značajnosti u tablici 5.87 .

Parcijalni regresijski koeficijent dobiven je u koraku 4 (u tablici 5.87.), a koraku 2 (u tablici 5.83.) utvrđuje se odnos između varijabli straha od citanja i motivacije. Indirektni efekt dobiva se umnoškom parcijalnog regresijskoga efekta, gdje je motivacija prediktor uspjeha $u$ testu razumijevanja teksta čitanjem 5,979 $\left(B_{2}\right)$, te jednostavnoga koeficijenta, gdje je strah od čitanja prediktor motivacije -,350 (B), prikazano formulom: $B_{\text {indirektni }}=5,979 \times$ $(-0,350)=-2.093$. Nakon izračunavanja regresijskoga koeficijenta za indirektni efekt izvršeno je testiranje statističke značajnosti toga efekta (v. prilog 18 tablica 2). Indirektni efekt pokazao se statistički značajnim ( $p<, 001)$. Drugim riječima, motivacija je značajan medijator u odnosu straha od čitanja i uspjeha u testu razumijevanja teksta čitanjem za njemački jezik.

\subsubsection{Sažetak analiza medijacije za engleski i njemački jezik}

Da bi pospješili zaključak medijacijskih analiza i usporedbu između engleskoga i njemačkoga jezika rezultati su sumirani u tablici 5.89 .

Tablica 5.89. Sažeti prikaz rezultata medijacijske analize za engleski i njemački jezik

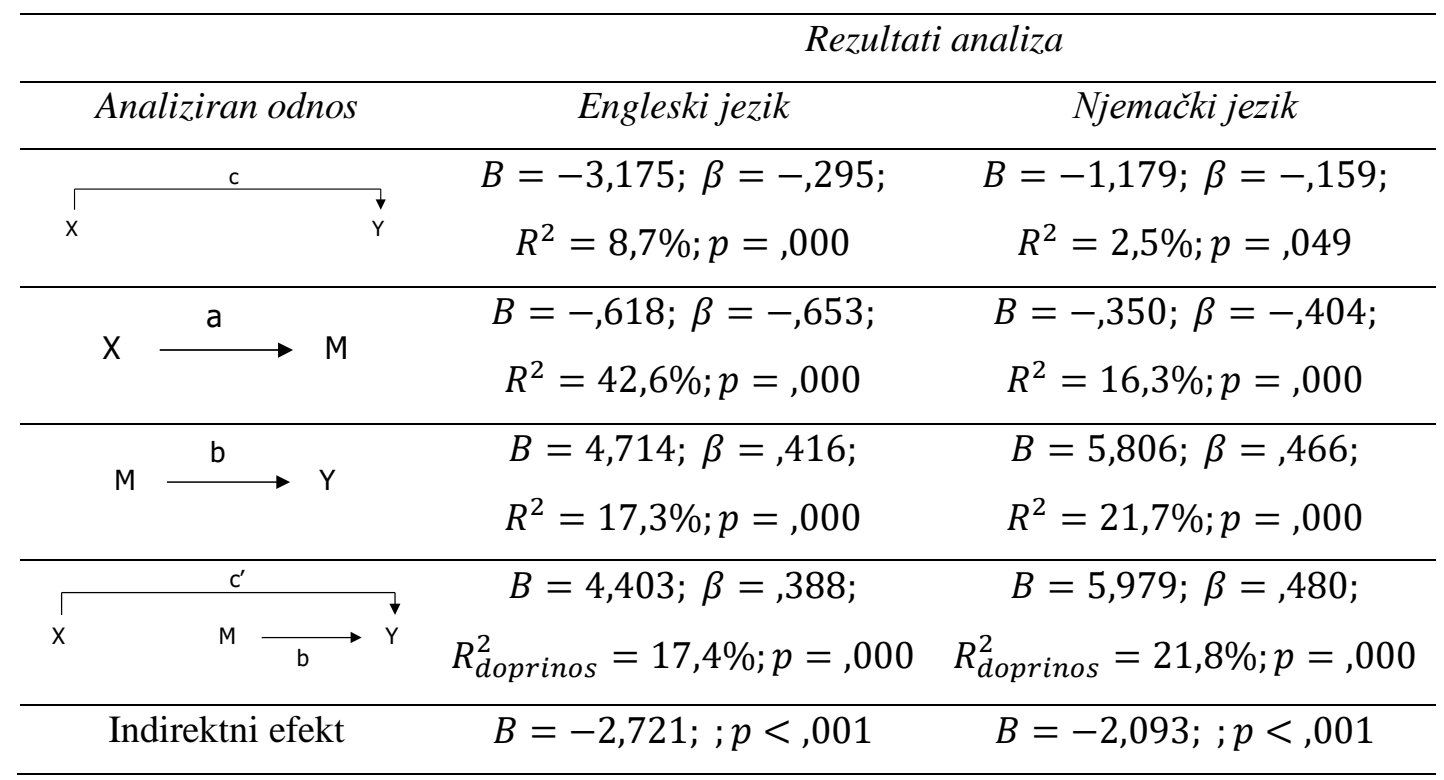

Iz tablice 5.89. vidljivo je da je opći obrazac rezultata za oba jezika vrlo sličan. Jedine razlike mogu se primijetiti u apsolutnim veličinama pojedinih efekata, ali ne i u njihovu smjeru ili značajnosti. Strah od čitanja je bolji negativni prediktor uspjeha u testu za engleski nego za njemački jezik. Također, strah od čitanja je bolji negativni prediktor motivacije za učenje jezika 
kod engleskoga nego kod njemačkoga jezika. Međutim, motivacija je pozitivni i bolji prediktor uspjeha u testu za njemački nego za engleski jezik. U skladu s time, jedinstven prinos motivacije objašnjenju uspjeha u testu, nakon kontroliranja straha od čitanja, veći je za njemački nego za engleski jezik. Indirektni efekt, odnosno medijacijski utjecaj motivacije na povezanost straha od čitanja i uspjeha u testu ( $\mathrm{tj}$. dio povezanosti koji se može pripisati razlikama u motivaciji) negativan je i značajan za oba jezika, iako je nestandardizirani koeficijent $B$ nešto veći (u apsolutnoj vrijednosti) za engleski jezik. Značajnost ovoga efekta znači da je odnos straha od čitanja i razumijevanja teksta čitanjem značajno reduciran nakon uključivanja motivacije kao medijacijske varijable.

\subsubsection{Dodatne analize}

S obzirom na cilj ovoga rada i u svrhu boljega i dodatnoga razumijevanja istraživačkih problema, te u skladu s mogućnostima s obzirom na ulazne podatke, provedene su određene dodatne analize.

\subsubsection{Regresijski modeli straha od čitanja za engleski i njemački jezik}

Kako bi smo bolje razumjeli ključni koncept u ovom istraživanju - strah od čitanja - proveli smo regresijske analize sa strahom od čitanja kao zavisnom varijablom, za engleski jezik i za njemački jezik zasebno. Najprije smo odredili koje varijable uvrstiti u prediktorski skup. Pri tome smo slijedili nekoliko kriterija. Željeli smo uključiti kao prediktore varijable koje nisu u previsokoj međusobnoj korelaciji, da izbjegnemo problem multikolinearnosti (kolinearnosti). Također, izabrali smo varijable za koje smo za većinu sudionika imali podatke, da ne umanjimo statističku snagu (mogućnost detektiranja statistički značajnih efekata). Takvim procesom selekcije, kao finalni skup prediktorskih varijabli izdvojili smo pet prediktora: spol, vrsta škole (srednjoškolsko usmjerenje), prosjek zaključnih ocjena u jeziku (engleskome ili njemačkome) u prva tri razreda srednje škole, motivacija za učenje jezika (engleskoga ili njemačkoga), te uspjeh na testu razumijevanja teksta čitanjem.

Iako se za neke varijable uključene u regresijskom modelu za engleski jezik pokazalo da značajno odstupaju od normalnih distribucija (zavisna varijabla - strah od čitanja i jedan od 
prediktora - uspjeh u testu razumijevanja teksta čitanjem), pokazatelji kolinearnosti varijabli (VIF i tolerancija) bili su u prihvatljivom rasponu i distribucija rezidualnih vrijednosti bila je nalik normalnoj distribuciji, što opravdava korištenje regresijskih analiza.

U tablici 5.90. prikazani su rezultati regresijske analize za objašnjenje straha od čitanja za engleski jezik.

Tablica 5.90. Rezultati višestruke regresijske analize sa strahom od čitanja za engleski jezik kao zavisnom varijablom i sa šest prediktora

\begin{tabular}{|c|c|c|c|c|c|c|c|c|c|}
\hline \multirow{2}{*}{$\begin{array}{l}\text { Model } \\
(N=149)\end{array}$} & \multicolumn{2}{|c|}{$\begin{array}{l}\text { Nestandard. } \\
\text { koeficijenti }\end{array}$} & \multirow{2}{*}{$\begin{array}{c}\text { Standard. } \\
\text { koeficijenti } \\
\text { Beta }\end{array}$} & \multirow[b]{2}{*}{$t$} & \multirow[b]{2}{*}{$p$} & \multicolumn{2}{|c|}{$\begin{array}{c}95,0 \% \text { intervali } \\
\text { pouzdanosti za } B\end{array}$} & \multicolumn{2}{|c|}{$\begin{array}{c}\text { Stat. pokazatelji } \\
\text { kolinearnosti }\end{array}$} \\
\hline & $B$ & $S E$ & & & & $\begin{array}{c}\text { Donja } \\
\text { granica }\end{array}$ & $\begin{array}{l}\text { Gornja } \\
\text { granica }\end{array}$ & Tolerancija & $V I F$ \\
\hline (Konstanta) & 4,782 & ,321 & & 14,884 & ,000 & 4,147 & 5,417 & & \\
\hline Spol & ,209 & ,098 & ,139 & 2,136 & ,034 & ,016 & ,403 & ,902 & 1,108 \\
\hline Vrsta škole &,- 092 & ,103 &,- 058 &,- 894 & ,373 &,- 294 & ,111 & ,922 & 1,085 \\
\hline $\begin{array}{l}\text { Prosjek zaključnih } \\
\text { ocjena - } 3 \text { god. SŠ }\end{array}$ &,- 087 & ,072 &,- 104 & $-1,211$ & ,228 &,- 229 & ,055 &, 517 & 1,934 \\
\hline $\begin{array}{l}\text { Motivacija za } \\
\text { učenje }\end{array}$ &,- 655 & ,084 &,- 621 & $-7,779$ & ,000 &,- 821 &,- 489 & ,604 & 1,656 \\
\hline $\begin{array}{l}\text { Uspjeh na testu } \\
\text { razumijevanja } \\
\text { tekstom }\end{array}$ & ,003 & ,008 &, 031 & ,385 & ,701 &,- 012 & ,018 & ,591 & 1,692 \\
\hline
\end{tabular}

Nestandard. -Nestandardiziran; Standard. - Standardizirani; SE - standardna pogreška; VIF- faktor inflacije varijance (eng. variance inflation factor), Spol:0- muški; 1- ženski; Vrsta škole (srednjoškolsko usmjerenje):1- Gimnazija; 2-Ugostiteljsko tursitička škola

Sveukupno je s pomoću pet varijabli objašnjeno 45,0\% (korigirani $R=42,1 \% ; S E=, 584$; $F(5 / 143)=23,415 ; p=, 000)$ varijance straha od čitanja. Dakle, gotovo pola varijance u zavisnoj varijabli objašnjeno je regresijskim modelom.

Kod regresijskoga modela za engleski jezik treba uzeti u obzir da značajno odstupanje od normalne distribucije utječe na interpretaciju beta pondera (Nathans, Frederick i Nimon, 2012). Standardizirani beta ponder pokazuje koliko će se vrijednost u zavisnoj varijabli promijeniti (u standardnim devijacijama) ako dođe do promjene od jedne SD u vrijednostima nezavisne varijable. Kako su u modelu za strah od čitanja za engleski jezik neke varijable 
značajno asimetrične, apsolutna veličina tih pondera ne može se smatrati preciznom mjerom nezavisnoga doprinosa prediktora. Stoga interpretacije koje slijede treba sagledavati u kontekstu navedenih ograničenja.

U skupu prediktora najveći doprinos ima motivacija za učenje $(\beta=-, 621, p<, 001)$. Veća motivacija za učenje engleskoga jezika povezana je s manjim strahom, čak kad se statistički uzmu u obzir četiri dodatne varijable. Uz motivaciju za učenje jezika, jedini značajni prediktor je spol $(\beta=, 139, p<, 05)$. Pozitivna vrijednost ovoga prediktora $(0=$ muški; $1=$ ženski) ukazuje da učenice imaju višu razinu straha od čitanja od učenika, kad se kontroliraju (istovremeno uzimaju statistički u obzir) ostale četiri prediktorske varijable. Ostali prediktori: vrsta škole (srednjoškolsko usmjerenje), prosjek zaključnih ocjena u engleskome jeziku u tri razreda srednje škole, te objektivna mjera uspjeha u čitanju nemaju značajan doprinos u predviđanju straha od čitanja.

U tablici 5.91. prikazani su rezultati regresijske analize za objašnjenje straha od čitanja za njemački jezik.

Tablica 5.91. Rezultati višestruke regresijske analize sa Strahom od čitanja za njemački jezik kao zavisnom varijablom i sa šest prediktora

\begin{tabular}{|c|c|c|c|c|c|c|c|c|c|}
\hline \multirow{2}{*}{$\begin{array}{l}\text { Model } \\
(N=153)\end{array}$} & \multicolumn{2}{|c|}{$\begin{array}{l}\text { Nestandard. } \\
\text { koeficijenti }\end{array}$} & \multirow{2}{*}{$\begin{array}{c}\text { Standard. } \\
\text { koeficijenti } \\
\text { Beta }\end{array}$} & \multirow[b]{2}{*}{$t$} & \multirow[b]{2}{*}{$p$} & \multicolumn{2}{|c|}{$\begin{array}{c}95,0 \% \text { intervali } \\
\text { pouzdanosti za } B\end{array}$} & \multicolumn{2}{|c|}{$\begin{array}{l}\text { Stat. pokazatelji } \\
\text { kolinearnosti }\end{array}$} \\
\hline & $B$ & $S E$ & & & & $\begin{array}{l}\text { Donja } \\
\text { granica }\end{array}$ & $\begin{array}{l}\text { Gornja } \\
\text { granica }\end{array}$ & Tolerancija & $V I F$ \\
\hline (Konstanta) & 3,898 & ,342 & & 11,381 & ,000 & 3,221 & 4,574 & & \\
\hline Spol &, 073 & , 118 & ,047 & ,615 & ,539 &,- 161 & ,307 & ,954 & 1,048 \\
\hline Vrsta škole & ,062 &, 124 & ,039 &, 500 & ,617 &,- 182 & ,306 & ,921 & 1,085 \\
\hline $\begin{array}{l}\text { Prosjek zaključnih } \\
\text { ocjena - } 3 \text { god. SS }\end{array}$ &,- 138 & ,093 &,- 160 & $-1,490$ & , 138 &,- 322 & ,045 & , 480 & 2,081 \\
\hline $\begin{array}{l}\text { Motivacija za } \\
\text { učenje }\end{array}$ & -,464 &, 100 &,- 402 & $-4,655$ & ,000 &,- 661 &,- 267 & ,747 & 1,338 \\
\hline $\begin{array}{l}\text { Uspjeh na testu } \\
\text { razumijevanja } \\
\text { tekstom }\end{array}$ & ,011 & ,010 & , 122 & 1,091 & ,277 &,- 009 & ,032 & , 446 & 2,241 \\
\hline
\end{tabular}

Nestandard. -Nestandardiziran; Standard. - Standardizirani; SE - standardna pogreška; VIF- faktor inflacije varijance; Spol:0- muški; 1ženski; Vrsta škole (srednjoškolsko usmjerenje): 1- Gimnazija; 2- Ugostiteljsko tursitička škola 
Sveukupno je s pomoću pet varijabli objašnjeno $18,1 \%$ (korigirani $R=15,3 \% ; S E=$ $, 681 ; F(5 / 147)=6,512 ; p=, 000)$ varijance straha od čitanja. Dakle, u usporedbi s modelom za engleski jezik, isti prediktori objašnjavaju zamjetno manji postotak zavisne varijable za njemački jezik. Jedini značajan prediktor je motivacija za učenje $(\beta=-, 402, p<, 001)$. Veća motivacija je povezana s manjim strahom od čitanja, čak kad se kontroliraju ostale četiri varijable uključene kao prediktori u modelu. Spol se nije pokazao značajnim prediktorom straha od čitanja na njemačkome jeziku. 


\subsubsection{Sažetak rezultata prema hipotezama}

Tablica 5.92. Sažeti prikaz odgovora na istraživačka pitanja i rezultata testiranja hipoteza

\begin{tabular}{|c|c|}
\hline ki problem i hipoteza & Odgovor na hipotezu \\
\hline $\begin{array}{l}\text { 1. problem: Kako su strah od čitanja na } \\
\text { engleskome i njemačkome jeziku povezani s } \\
\text { uspjehom u čitanju na engleskome i } \\
\text { njemačkome jeziku? } \\
\text { H1 - strah od čitanja na engleskome i } \\
\text { njemačkome jeziku povezan je s uspjehom u } \\
\text { čitanju na engleskome i njemačkome jeziku. } \\
\text { Može se očekivati da će viša razina straha od } \\
\text { čitanja na engleskome i njemačkome jeziku } \\
\text { biti povezana s lošijim uspjehom u } \\
\text { razumijevanju čitanjem na engleskome i } \\
\text { njemačkome jeziku. }\end{array}$ & $\begin{array}{l}\text { Utvrđeno je da postoji statistički značajna } \\
\text { umjerena negativna povezanost između } \\
\text { straha od čitanja i uspjeha na testu } \\
\text { razumijevanja teksta čitanjem za engleski } \\
\text { jezik. } \\
\text { Utvrđeno je da postoji statistički značajna } \\
\text { niska negativna povezanost između straha od } \\
\text { čitanja i uspjeha na testu razumijevanja teksta } \\
\text { čitanjem za njemački jezik. }\end{array}$ \\
\hline $\begin{array}{l}\text { 2. problem: Razlikuje li se strah od čitanja s } \\
\text { obzirom na strani jezik koji se uči? } \\
\text { H2a - očekuje se da će se struktura straha od } \\
\text { čitanja razlikovati u engleskome i njemačkome } \\
\text { jeziku. Pretpostavlja se da bi razlike mogle biti } \\
\text { povezane s razlikama među jezicima } \\
\text { (ortografskim, leksičkim, sintaktičkim, } \\
\text { semantičkim), različitim statusom jezika i } \\
\text { različitim nastavnim i izvannastavnim } \\
\text { kontekstom. }\end{array}$ & $\begin{array}{l}\text { Struktura straha od čitanja na engleskome } \\
\text { njemačkome jeziku se razlikuje. Za strah od } \\
\text { čitanja na engleskome jeziku utvrđena je } \\
\text { trokomponentna struktura. Za strah od čitanja } \\
\text { na njemačkome jeziku utvrđena je } \\
\text { peterokomponentna struktura. }\end{array}$ \\
\hline $\begin{array}{l}\text { 2. problem: Razlikuje li se strah od čitanja s } \\
\text { obzirom na strani jezik koji se uči? }\end{array}$ & $\begin{array}{l}\text { Razina straha od čitanja na engleskome i } \\
\text { njemačkome jeziku se razlikuje. }\end{array}$ \\
\hline
\end{tabular}




\begin{tabular}{|c|c|}
\hline $\begin{array}{l}\text { H2b - očekuje se da će se visina straha od } \\
\text { čitanja razlikovati u engleskome i njemačkome } \\
\text { jeziku. Pretpostavlja se da će intenzitet straha } \\
\text { za engleski i njemački jezik razlikovati zbog } \\
\text { razlika među jezicima (ortografskim, } \\
\text { leksičkim, sintaktičkim, semantičkim), } \\
\text { različitoga statusa jezika i različitoga } \\
\text { nastavnoga i izvannastavnoga konteksta. }\end{array}$ & $\begin{array}{l}\text { Razina straha od čitanja na engleskome } \\
\text { jeziku je niža }(A S=1,92) \text { nego razina straha } \\
\text { od čitanja na njemačkome jeziku }(A S=2,31) \text {. }\end{array}$ \\
\hline $\begin{array}{l}\text { 3. problem: Razlikuje li se strah od čitanja na } \\
\text { engleskome i njemačkome jeziku s obzirom na } \\
\text { spol? }\end{array}$ & $\begin{array}{l}\text { Razina straha od čitanja na engleskome i na } \\
\text { njemačkome jeziku ne razlikuje se s obzirom } \\
\text { na spol. }\end{array}$ \\
\hline $\begin{array}{l}\text { H3 - ne postoje razlike u strahu od čitanja na } \\
\text { engleskome i njemačkome jeziku s obzirom na } \\
\text { spol. }\end{array}$ & H3 je potvrđena. \\
\hline $\begin{array}{l}\text { 4. problem: Razlikuje li se strah od čitanja na } \\
\text { engleskome i njemačkome jeziku s obzirom na } \\
\text { srednjoškolsko usmjerenje? }\end{array}$ & $\begin{array}{l}\text { Razina straha od čitanja na engleskome i na } \\
\text { njemačkome jeziku ne razlikuje se s obzirom } \\
\text { na srednjoškolsko usmjerenje. }\end{array}$ \\
\hline $\begin{array}{l}\text { H4 - ne postoje razlike u strahu od čitanja na } \\
\text { engleskome i njemačkome jeziku s obzirom na } \\
\text { srednjoškolsko usmjerenje. }\end{array}$ & H4 je potvrđena. \\
\hline $\begin{array}{l}\text { H5 - motivacija ima medijacijski utjecaj na } \\
\text { povezanost straha od čitanja i razumijevanja } \\
\text { teksta čitanjem. Medijacijski utjecaj } \\
\text { motivacije na povezanost straha od čitanja na } \\
\text { engleskome i njemačkome jeziku i } \\
\text { razumijevanja teksta čitanjem je značajan. }\end{array}$ & $\begin{array}{l}\text { Utvrđeno je da je motivacija značajan } \\
\text { medijator } \mathrm{u} \text { odnosu straha od čitanja i } \\
\text { razumijevanja teksta čitanjem za engleski i za } \\
\text { njemački jezik. Odnos straha od čitanja i } \\
\text { razumijevanja teksta čitanjem manje je } \\
\text { izražen nakon uključivanja motivacije kao } \\
\text { medijacijske varijable. }\end{array}$ \\
\hline
\end{tabular}




\subsection{Rasprava}

Glavni cilj ovoga istraživanja bio je istražiti odnos straha od čitanja i uspjeha u čitanju na engleskome i njemačkome kao stranome jeziku u hrvatskome socioedukacijskome kontekstu, uzimajući u obzir motivaciju za učenje engleskoga i njemačkoga jezika.

Prije utvrđivanja glavnoga cilja istraživanja bilo je potrebno:

- utvrditi razinu straha od čitanja na engleskome i njemačkome jeziku

- utvrditi uspjeh na testu razumijevanja teksta čitanjem za engleski i njemački jezik

- utvrditi intenzitet motivacije za učenje engleskoga i njemačkoga jezika.

Ostale varijable koje su se uvrstile u analize kojima su se pokušale rasvijetliti istražene pojave i njihovi odnosi su: spol, tip škole (srednjoškolsko usmjerenje), zaključne ocjene iz prvoga, drugoga i trećega razreda iz engleskoga i njemačkoga jezika.

\subsubsection{Tumačenje deskriptivnih pokazatelja straha od čitanja na engleskome $i$ njemačkome jeziku}

Za potrebe ovoga rada konstruiran je upitnik kojim se izmjerio strah od čitanja na stranome jeziku. Za ispitivanje straha od čitanja na engleskome jeziku korišten je Upitnik o strahu od čitanja na engleskome jeziku, a za ispitivanje straha od čitanja na njemačkome jeziku korišten je Upitnik o strahu od čitanja na njemačkome jeziku. Izračunata su deskriptivna obilježja za čestice obaju upitnika, odnosno utvrđene su prosječne vrijednosti i obilježja distribucije rezultata koje učenici postižu na korištenim mjernim instrumentima.

Izračunavanjem srednjih vrijednosti utvrdili smo da je razina straha od čitanja za oba jezika niska, te da je za engleski jezik srednja vrijednost 1,99, a za njemački jezik nešto viša, 2,35. Naš nalaz usporediv je s nalazom istraživanja straha od čitanja na engleskome jeziku koje je provela Mihaljević Djigunović (2002) među srednjoškolcima, utvrdivši da je srednja vrijednost straha od čitanja 2,19, što također ukazuje na nisku razinu straha od čitanja. Istraživanje straha od jezika koje je proveo Puškar (2010) ukazalo je na razinu straha od engleskoga jezika $A S=2,61$ i njemačkoga jezika $A S=2,83$ među studentima anglistike i germanistike. Sukladno nalazima ranijih istraživanja straha od jezika u Hrvatskoj, očekivali 
smo da bi nalaz našega istraživanja mogao ukazivati na slične vrijednosti nižih razina straha od čitanja.

Nadalje, uvidom u rezultate istraživanja straha od čitanja koja su provedena u svijetu možemo primijetiti da je razina straha od čitanja na engleskome jeziku u našem istraživanju slična ili niža od razine straha od čitanja utvrđene u tim istraživanjima. Tako su Saito i suradnici (1999) ispitujući strah od čitanja na francuskome, japanskome i ruskome izračunom srednjih vrijednosti utvrdili razinu straha od čitanja na stranome jeziku $A S=2,64$, s najvišom vrijednošću zabilježenom za japanski, a najnižom za ruski jezik. Za kineski jezik Zhao (2009) je utvrdila razinu straha od čitanja $A S=2,66$, a zatim su Zhao i suradnici (2013) utvrdili razinu straha od čitanja $A S=2,68$ među američkim studentima koji su učili kineski. Razine straha od čitanja na engleskome jeziku utvrdili su u svojim istraživanjima Jafarigohar i Behrooznia (2012) u Iranu $(A S=1,96)$ i Al-Sohbani (2018) u Jemenu $(A S=3,10)$. Iako se radi o istraživanjima straha od čitanja različitih jezika, koja su provedena u različitim kulturnodruštvenim okruženjima i među sudionicima istraživanja koji su na različitim obrazovnim razinama, primjećujemo da navedeni rezultati pretežno ukazuju na niske razine straha od čitanja na stranome jeziku.

Najveće vrijednosti aritmetičkih sredina za strah od čitanja na engleskome jeziku zabilježene su za tvrdnje: 14. „,Ako pri čitanju u sebi naiđem na riječ ili riječi koje ne razumijem, nastavljam čitati a da se nisam uznemirio/la. “ (rekodirano), 5. „Osjećam se ugodno dok čitam naglas na engleskome jeziku. “ (rekodirano) i 16. „Dok čitam naglas na engleskome, brinem se kako ću izgovoriti pojedine riječi. “. Za strah od čitanja na njemačkome jeziku zabilježene su najviše aritmetičke sredine za tvrdnje: 16. „Dok čitam naglas na njemačkom, brinem se kako ću izgovoriti pojedine riječi. “, 14. „Ako pri čitanju u sebi naiđem na riječ ili riječi koje ne razumijem, nastavljam čitati a da se nisam uznemirio/la. “(rekodirano) i 24. „,Pri čitanju u sebi na njemačkome zbunjuju me duge riječi koje je teško pročitati. “. Vidljivo je da su naši sudionici istraživanja izrazili najviši stupanj slaganja s tvrdnjama 14. i 16. za oba ispitivana jezika. Možemo zaključiti da naše sudionike uznemirava ako pri čitanju u sebi naiđu na neku riječ koju ne razumiju. Uznemirava ih i ako nisu sigurni u izgovor pojedinih riječi, pa i to može ometati čitanje. Taj nalaz u skladu je s nalazom koje je dobila Horwitz (1988), utvrdivši da američki studenti vjeruju da je u učenju stranoga jezika važna točnost, a osobito točan naglasak. Sadržaj tvrdnji 14. i 16. odražava karakteristike koje su u suprotnosti s afektivnim strategijama uspješnoga učenika koje je navela Oxford (1990), a odnose se na kontrolu negativnih osjećaja. 
Za naše sudionike moglo bi se zaključiti da ne kontroliraju uznemirenost koja se pojavljuje zbog nerazumijevanja pojedinih riječi ili nesigurnosti u izgovor pojedinih riječi. Poznato je da učenici u stanju uznemirenosti zbog nervoze teško razlikuju određene glasove i teško kontroliraju njihovu proizvodnju pa dolazi do izobličenoga izgovora ili intonacije (Horwitz i sur., 1986; Young, 1991). Izgovor je, dakako, veći izvor nevolja odraslijima jer djeca lakše usvajaju glasove i intonaciju stranoga jezika nego odrasli (Mihaljević Djigunović, 2002). Crookall i Oxford (1991) su, prepoznavši ovu vrstu straha, naveli posebnu strategiju oslobađanja straha od pogrešnoga naglaska koju su nazvali „obrnuti naglasak“. Moguće je da naši sudionici imaju i nizak stupanj tolerancije nejasnoće (Ely, 1989), pa nejasnoće na koje nailaze ometaju čitanje. Još jedno moguće objašnjenje je da naši sudionici imaju visoke kriterije prema sebi i visoka očekivanja, pa su više zabrinuti zbog svojih pogrešaka kao što su to u svom istraživanju utvrdile Gregersen i Horwitz (2002). Ova zabrinutost povezana je sa zabrinutošću o prihvaćanju i evaluaciji okoline, što je prema Horwitz i suradnicima (1986), jedan od elemenata općega straha od stranoga jezika.

Za skupinu sudionika istraživanja za engleski jezik utvrđena je visoka aritmetička sredina stupnja slaganja s tvrdnjom 5. „Osjećam se ugodno dok čitam naglas na engleskome jeziku. “ (rekodirano), kojom se mjeri opći osjećaj neugode pri čitanju na engleskome jeziku pred drugima. Tumačenje ovoga negativnoga osjećaja moglo bi biti povezano sa strahom od negativne evaluacije okoline (Horwitz i sur., 1986). Na nastavi stranoga jezika učenik je gotovo neprestano izložen evaluaciji okoline. Kada učenik čita naglas, slušaju ga ne samo nastavnik nego i svi ostali učenici u razredu, što može predstavljati izvor straha. Treba uzeti u obzir da su na kritike vršnjaka osobito osjetljivi učenici adolescenti (Mihaljević Djigunović 2002), pa oni u nastojanju da se ne izlože takvoj kritici ponekad izbjegavaju sudjelovanje u nastavnim aktivnostima ili se povlače. U mnogim se istraživanjima utvrdilo da nastavnik može biti jedan od izvora straha od jezika (Mihaljević Djigunović, 2002; Abu-Rabia, 2004; Turula, 2006; Liu, 2006; Piechurska-Kuciel, 2008, 2011; Marzec-Stawiarska, 2013; Zoghi, 2012 i Zoghi i Alivandivafa, 2014; Hassaskhah i Joghataeian, 2016). Pokazalo se da nastavnici poklanjaju manje pažnje manje komunikativnim učenicima (McCroskey i Daly, 1976; Mihaljević, 1991/1992), pa onda takav odnos nastavnika prema manje komunikativnim učenicima još više potiče njihovo povlačenje iz komunikacije. Moguće je da nastavnik manje komunikativne učenike rjeđe proziva da čitaju naglas, pa bi rjeđe izlaganje čitanju naglas kod tih učenika moglo biti povezano i s osjećajem neugode koji prati tu aktivnost. Stoga se ovoj pojavi treba osobito 
pažljivo pristupiti kako bi se stvaranjem ugodne radne atmosfere izbjegli negativni osjećaji i ponašanje koje negativni osjećaji potiču.

Za skupinu sudionika istraživanja za njemački jezik utvrđena je visoka aritmetička sredina stupnja slaganja s tvrdnjom 24, „Pri čitanju u sebi na njemačkome zbunjuju me duge riječi koje je teško pročitati. “, odražava osjećaj zbunjenosti pri čitanju na njemačkome koji može proizaći iz morfoloških obilježja specifičnih za njemački jezik u kojemu riječi (najčešće složene imenice) mogu biti duge i znatno duže nego riječi u engleskome jeziku. S obzirom na to da se složene imenice mogu sastojati od dvije ili više imenica, pridjeva i imenice ili glagola i imenice ili složenijih kombinacija, primjerice od pridjeva, glagola i imenice, učenicima je ponekad teško razaznati od kojih se riječi sastoji složena imenica i koje je njezino značenje. Njemački jezik odlikuje se brojnim složenicama, pa se tako do prije nekoliko godina koristila riječ koja se sastojala od 63 slova, a to je bio zakon o nadzoru obilježavanja i označavanja goveđega mesa. Iako se ta riječ više ne koristi, u njemačkome jeziku se i nadalje svakodnevno stvaraju nove složenice. Za izvorne govornike hrvatskoga jezika, koji u materinskom jeziku nisu izloženi čitanju tako dugih riječi na svome materinskom jeziku, čitanje dugih složenica na njemačkome jeziku može biti jedan od izvora straha od čitanja.

Najmanje prosječne vrijednosti aritmetičkih sredina za strah od čitanja na engleskome jeziku zabilježene su za tvrdnje: 9. „Strah me da nikada neću dobro naučiti čitati engleski jer je čitanje na engleskome teško. “, 7. „Zbunjuje me nepodudarnost između načina pisanja $i$ čitanja na engleskome jeziku. “ i 13. „Postupci nastavnika/ce ometaju me i zbunjuju dok čitam naglas na engleskome. “. Za strah od čitanja na njemačkome jeziku zabilježene su najmanje prosječne vrijednosti aritmetičkih sredina za tvrdnje: 13. „Postupci nastavnika/ce ometaju me i zbunjuju dok čitam naglas na njemačkome. “, 18. „Dok čitam naglas na njemačkome pred drugima, osjećam da mi se znoje dlanovi. “ i 4. „Ako trebam odabrati između čitanja, pisanja, slušanja i govora na njemačkome jeziku, najteže mi je čitanje. " Uvidom u navedene rezultate mogli bismo zaključiti da postupci nastavnika/ce ne predstavljaju izvor straha od čitanja niti na engleskome niti na njemačkome jeziku, odnosno da postupci nastavnika ne ometaju učenike pri čitanju. Taj nalaz upućuje na obilježja poticajnoga i ugodnoga nastavnoga konteksta. Kao što smo ranije u tekstu naveli, poznato je da nastavnik i njegovo djelovanje mogu biti jedan od izvora straha od stranoga jezika. Jedna od nastavnikovih uloga je uloga evaluatora učeničkih postignuća, što može biti povezano sa strahom od ocjenjivanja i strahom od negativne društvene evaluacije kao što su to naveli i Horwitz i suradnici (1986), a zatim utvrdili i mnogi drugi 
istraživači. Nizak stupanj slaganja za ove tvrdnje kod naših učenika ukazuje na to da naši učenici ne doživljavaju da nastavnik/ca svojim djelovanjem pridonosi strahu od čitanja. Tvrdnja 9. „Strah me da nikada neću dobro naučiti čitati engleski jer je čitanje na engleskome teško.“ odražavaju vjerovanje da čitanje na engleskome jeziku nije teško. Tvrdnja 4. „Ako trebam odabrati između čitanja, pisanja, slušanja i govora na njemačkome jeziku, najteže mi je čitanje. “ odražavaju vjerovanje da čitanje na njemačkome jeziku nije vještina kojom je teško ovladati, što je sukladno nalazu koje je dobila Matić (2018) u istraživanju straha od čitanja na njemačkome jeziku. Strah od jezika specifična je kombinacija samopercepcija, vjerovanja, osjećaja i ponašanja (Horwitz i sur., 1986: 128), pa negativna i nerealna vjerovanja kao i vjerovanja o težini ovladavanja određenim jezikom mogu biti izvori straha od jezika (Rubin, 1975; Horwitz, 1988; Young, 1991). Budući da se naši sudionici istraživanja u niskome stupnju slažu s vjerovanjem da je čitanje na engleskome i njemačkome jeziku teško, možemo utvrditi da za naše sudionike vjerovanje da je teško čitati ne predstavlja izvor straha od čitanja na engleskome i njemačkome jeziku.

Sudionici istraživanja za engleski jezik u niskome su se stupnju složili s tvrdnjom 7. „Zbunjuje me nepodudarnost između načina pisanja i čitanja na engleskome jeziku. “. Ovaj je nalaz zanimljiv jer pokazuje da unatoč činjenici da u engleskome jeziku grafofonemska korespondencija nije pravilna i unatoč činjenici da engleski pripada u skupinu jezika male pravopisne dosljednosti i velike slogovne složenosti (Čudina-Obradović, 2014), to ne predstavlja izvor straha od čitanja za naše sudionike. Moguće objašnjenje je da naši sudionici zbog dugogodišnjega učenja jezika (dvanaest godina), postignute visoke razine znanja (pretpostavljena B1 razina ili viša) i velike izloženosti engleskome jeziku i u izvannastavnome kontekstu grafofonemsku nepodudarnost engleskoga jezika ne doživljavaju kao izvor uznemirenosti i straha od čitanja na engleskome jeziku za razliku od sudionika s manje iskustva učenja i na nižoj razini znanja koji su učili neke druge jezike i u drugačijim nastavnim i izvannastavnim kontekstima (Saito i sur., 1999; Piechurska-Kuciel, 2008; Alsaleh, 2017).

Za skupinu sudionika istraživanja za njemački jezik utvrđen je nizak stupanj slaganja s tvrdnjom 18. „Dok čitam naglas na njemačkome pred drugima, osjećam da mi se znoje dlanovi. ", koja pokazuje da navedena tjelesna manifestacija straha od čitanja na njemačkome jeziku nije učestala kod naših sudionika. 


\subsubsection{Tumačenje deskriptivnih pokazatelja motivacije za učenje engleskoga $i$ njemačkoga jezika}

Izračunavanjem srednjih vrijednosti za motivaciju za učenje engleskoga jezika utvrdilo se da je razina motivacije za engleski $(A S=3,99)$ viša od razine motivacije za njemački jezik $(A S=$ $3,0)$.

Deskriptivni pokazatelji za motivaciju za učenje engleskoga jezika ukazuju na najveće prosječne vrijednosti aritmetičkih sredina u tvrdnjama: 2. „Znanje engleskoga jezika za mene je beskorisno. “ (rekodirano), 3. „,Moji roditelji smatraju važnim da znam engleski jezik. “, 5. „Zanimaju me filmovi i glazba na engleskome jeziku. “ i 10. „,Kolikogod učio/učila, ne mogu postići bolje rezultate. " (rekodirano).

Uvidom u deskriptivnu statistiku za motivaciju za učenje njemačkoga jezika uočavamo da su najveće prosječne vrijednosti aritmetičkih sredina dobivene u tvrdnjama: 2. „Znanje njemačkoga jezika za mene je beskorisno. “ (rekodirano), 10. „Kolikogod učio/učila, ne mogu postići bolje rezultate. “ (rekodirano) i 7. „Nemam osjećaj za jezik, beznadni sam slučaj za učenje jezika. "(rekodirano).

$\mathrm{Na}$ temelju vrijednosti aritmetičkih sredina za tvrdnju 2. „Znanje engleskoga/njemačkoga jezika za mene je beskorisno. “ (rekodirano) može se zaključiti da sudionici u našem istraživanju smatraju da im i engleski i njemački jezik mogu biti korisni. Dörnyei i Csizér (2002) i Dörnyei (2005) upozoravaju da se danas motivacija za učenje engleskoga jezika treba promatrati kao motivacija za učenje međunarodnoga jezika, pa motivacijski obrasci za učenje engleskoga nisu isti kao za učenje ostalih stranih jezika. No, bez obzira na takav različit status engleskoga i njemačkoga jezika, naši sudionici prepoznaju korist poznavanja ovih obaju stranih jezika. Naš nalaz u skladu je i s nalazom koji su dobile Mihaljević Djigunović i Bagarić (2007a) pri ispitivanju motivacije za učenje engleskoga i njemačkoga jezika u Hrvatskoj. Pri sagledavanju ovoga rezultata treba uzeti u obzir da je Hrvatska članica Europske unije i zemlja koja gospodarske i kulturne kontakte ostvaruje ne samo s mnogim europskim zemljama, nego i šire na globalnoj razini. Sukladno preporuci Vijeća Europe o sveobuhvatnom pristupu poučavanju i učenju jezikâ, mladi bi ljudi prije završetka višega sekundarnoga obrazovanja trebali - uz jezik na kojemu se školuju - u barem još jednome 
europskome jeziku steći razinu kompetencije, koja im omogućuje da se tim jezikom učinkovito koriste $\mathrm{u}$ društvene i profesionalne svrhe te u svrhe učenja, a trebalo bi poticati i stjecanje znanja dodatnoga (trećega) jezika do razine koja im omogućuje dovoljno tečnu interakciju (Službeni list Europske unije, 2019/C 189/03). Recentna preporuka nadovezuje se na zaključak koji je usvojen u Barceloni 2002. kada je Europsko vijeće pozvalo na daljnje djelovanje u području obrazovanja u svrhu poboljšanja ovladavanja temeljnim vještinama, posebice poučavanjem najmanje dvaju stranih jezika od vrlo rane dobi (Presidency Conclusions, Barcelona European Council, 2002: 19). Stoga znanje dvaju stranih jezika uz materinski jezik predstavlja u današnjem hrvatskom društvenoobrazovnom kontekstu kako prednost tako i nužnost pri obrazovanju i zapošljavanju. Treba uzeti u obzir da je naše istraživanje provedeno među adolescentima Dubrovačko-neretvanske županije, koja je izrazito orijentirana turizmu i pomorstvu, a to su gospodarske grane u kojima je za zapošljavanje i rad nužno poznavanje stranih jezika. Mnogi maturanti s toga područja već imaju iskustvo povremenoga rada u turizmu i susreli su se s nužnošću upotrebe stranih jezika za potrebe posla. To vjerovanje naših sudionika istraživanja može odražavati i vjerovanje o korisnome znanju stranih jezika njihove šire društvene zajednice.

Sudionici obiju skupina izrazili su visoko slaganje s tvrdnjom 10. „Kolikogod učio/učila, ne mogu postići bolje rezultate. “ (rekodirano), koja odražava njihovo zadovoljstvo uloženim trudom i postignutim rezultatima učenja obaju stranih jezika. Ovu tvrdnju bismo mogli sagledati iz perspektive atribucijske teorije koja nam daje mogućnost dodatnoga uvida u razumijevanje motivacije. Osoba koja svoj uspjeh pripisuje internalnim uzrocima, kao što su uloženi trud ili sposobnost, ima pozitivno motivacijsko razmišljanje (Ushioda, 1998; Weiner, 2010). Nadalje, osobe koje imaju visoku potrebu za postignućem imaju tendenciju pripisivati uspjeh osobnim faktorima (sposobnost i marljivost), što potiče osjećaj ponosa, a što je ponos veći, to je broj budućih pokušaja da se postigne uspjeh veći (Mihaljević Djigunović, 1998). Zadovoljstvo uloženim trudom za naše sudionike mogao bi biti poticaj za daljnje ulaganje truda u učenje engleskoga i njemačkoga jezika.

U visokom stupnju slaganja s tvrdnjom 3. „Moji roditelji smatraju važnim da znam engleski jezik. “ prepoznajemo da motivacija za učenje engleskoga jezika odražava pozitivan stav roditelja prema važnosti učenja engleskoga jezika. Naš nalaz za ovu tvrdnju $(A S=4,46)$ je sličan nalazu koji su dobile Mihaljević Djigunović i Bagarić (2007a) za istu tvrdnju $(A S=4,41)$. Iako su naši učenici adolescenti, visok stupanj slaganja s ovom tvrdnjom ukazuje na to da se u 
motivaciji naših učenika za učenje engleskoga može prepoznati utjecaj pozitivnoga stava njihovih roditelja. Učenici su za engleski jezik izrazili visok stupanj slaganja s tvrdnjom 5. „Zanimaju me filmovi i glazba na engleskome jeziku.“, koja izražava interes za kulturnoumjetničkim ostvarenjima koja su ostvarena na engleskome jeziku, a time i pozitivne stavove. Gardner (1985) je utvrdio da pojedinci koji imaju pozitivne stavove prema zajednici inoga jezika imaju integrativnu orijentiranost, a Gardner i MacIntyre (1993b) integrativnu motivacijsku orijentaciju promatraju kao pozitivnu usmjerenost pojedinca prema inojezičnoj zajednici. No razumijevanje ove tvrdnje trebali bismo sagledati i šire. Budući da je engleski jezik danas postao jezik sporazumijevanja globaliziranoga svijeta, ova tvrdnja ne izražava samo interes prema ostvarenjima onih zajednica koje sačinjavaju izvorni govornici engleskoga jezika, nego prema filmskim i glazbenim ostvarenjima na engleskome jeziku na globalnoj razini. Ovo tumačenje u skladu je s razumijevanjem koncepta integrativnosti u motivaciji i stavova prema govornicima i korisnicima engleskoga jezika koji se danas definiraju na globalnoj razini (Dörnyei i Ushioda, 2011), te je u skladu i s konceptom o zamišljenom pojedinčevu identitetu koji se ostvaruje u zamišljenoj zajednici (Norton, 2000). Mogli bismo također reći da se interes izražen u ovoj tvrdnji ne bi morao samo odnositi na film i glazbu u užem, nego u širem smislu. Pod pojmom filma mogu se podrazumijevati ne samo dugometražni igrani filmovi, nego i kraći videoklipovi različitoga sadržaja (sportski, informativni, edukativni) od kojih se mnogi mogu naći na internetu i društvenim mrežama (YouTube, Instagram), a koje mnogi adolescenti koriste.

Učenici su za njemački jezik izrazili visok stupanj slaganja s tvrdnjom 7. „Nemam osjećaj za jezik, beznadni sam slučaj za učenje jezika." (rekodirano), koja odražava da naši učenici ne vjeruju u nedostatak talenta za jezik i vjeruju u vlastitu uspješnost učenja njemačkoga jezika. Jedna od varijabli koja ima važnu ulogu u motivaciji za učenje jezika je jezično samopouzdanje (Clément i sur., 1977; Clément i Kruidenier, 1985), koje se odnosi na učenikovo vjerovanje da je sposoban steći jezičnu kompetenciju i uspješno ostvariti ciljeve učenja. Pri učenju stranih jezika faktor koji je izvan kontrole učenika, a kojemu se najčešće pripisuje uspjeh ili neuspjeh u učenju, jest talent za učenje stranih jezika. Neuspješni učenici tako često svoj neuspjeh pripisuju nedostatku talenta, dok nastavnici njihov neuspjeh pripisuju nedovoljno uloženome trudu (Mihaljević Djigunović, 1998). Rezultati pokazuju da naši učenici imaju jezično samopouzdanje, odnosno vjeruju u sebe i svoj uspjeh u učenju jezika, što može pridonijeti motivaciji i uspjehu u učenju njemačkoga jezika. 
Najmanje prosječne vrijednosti aritmetičkih sredina za motivaciju za učenje engleskoga jezika zabilježene su za tvrdnje: 9. „Trebalo bi mi više truda $i$ volje da budem uspješniji/uspješnija. “ (rekodirano), 11. „U svoje slobodno vrijeme rado se bavim engleskim jezikom. “i 6. „, Sati engleskoga jezika neizmjerno su mi dosadni. “ (rekodirano).

Za njemački jezik utvrđene su najmanje prosječne vrijednosti aritmetičkih sredina za tvrdnje: 11. „U svoje slobodno vrijeme rado se bavim njemačkim jezikom. “, 9. „Trebalo bi mi više truda $i$ volje da budem uspješniji/uspješnija.“ (rekodirano) i 5. „Zanimaju me filmovi $i$ glazba na njemačkome jeziku. “.

Za tvrdnju 9. „Trebalo bi mi više truda $i$ volje da budem uspješniji/uspješnija. “ (rekodirano) zabilježen je niski stupanj slaganja i za engleski i za njemački jezik. Možemo zaključiti da su naši sudionici istraživanja za engleski i za njemački jezik zadovoljni uloženim trudom i svojim uspjehom u učenju engleskoga i njemačkoga jezika, što ukazuje na to da imaju i pozitivan pojam o sebi. Mihaljević Djigunović (2002) je utvrdila da učenici koji imaju pozitivan pojam o sebi i viši intenzitet motivacije imaju niži strah.

Nizak stupanj slaganja za tvrdnju 11. „U svoje slobodno vrijeme rado se bavim engleskim/njemačkim jezikom. " pokazuje da se naši sudionici istraživanja ne bave engleskim i njemačkim jezikom u onome dijelu vremena koji se ne odnosi na školu i školske obveze. Moguće je da se u slobodno vrijeme radije bave nekim drugim aktivnostima, kao što su sportske i glazbene, a ne bave se učenjem stranih jezika. Ovu tvrdnju su učenici možda zbog izraza bavim se razumjeli kao učim jezik, pa je njihovo nisko slaganje s ovom tvrdnjom moguće tumačiti i u tome smislu.

Nizak stupanj slaganja za tvrdnju 6. „,Sati engleskoga jezika neizmjerno su mi dosadni. “ (rekodirano) ukazuje na percepciju zanimljivosti nastave engleskoga jezika. Naši sudionici su se u niskome stupnju složili s pozitivnim doživljajem nastave engleskoga, što ukazuje na tendenciju njihova negativnoga doživljaja nastavnoga konteksta. U istraživanju Mihaljević Djigunović i Bagarić (2007a) nailazimo na percepciju učenika koji ističu da su im nastavni sadržaji nedovoljno zanimljivi, da nastavnici nedovoljno koriste inovativne pristupe učenju, da im je gramatički sadržaj nejasan i dosadan, a tekstovi u udžbenicima nezanimljivi. O neaktualnim i nezanimljivim tekstovima izvijestili su i studenti anglistike u Puškarovu (2010) istraživanju. Takač i Berka (2014) su, istražujući motivaciju za učenje kod gimnazijalaca, 
utvrdile da učenici smatraju da nastavna situacija djeluje demotivirajuće te da djelovanje nastavnika, izbor nastavnoga materijala i razredno ozračje nisu zadovoljavajući za njihovo napredovanje u učenju engleskoga jezika. Današnji srednjoškolci žive u vremenu velikih i brzih promjena u komunikacijskim i elektroničkim medijima, a izvan škole izloženi su intenzivno korištenju pametnih telefona $i$ računala na kojima pronalaze različite interaktivne multimedijske materijale. Trebalo bi razmotriti koliko i kako se u nastavnu situaciju integriraju multimedijski sadržaji i interaktivni pristupi učenju koji potiču rad. Osuvremenjivanjem nastave stranih jezika i uvođenjem inovativnih i dinamičnih pristupa u radu mogao bi se umanjiti njezin demotivirajući utjecaj na učenje stranih jezika.

Tvrdnja 5. „Zanimaju me filmovi i glazba na njemačkome jeziku.“ za njemački jezik našla se u skupini tvrdnji s niskim stupnjem slaganja, za razliku od te iste tvrdnje koja za engleski jezik bilježi visok stupanj slaganja. Za razliku od engleskoga jezika, koji je svjetski jezik i kojemu su učenici svakodnevno izloženi, učenike ne privlači gledanje filmova i slušanje glazbe na njemačkome jeziku. Učenici u Hrvatskoj vrlo su rijetko izloženi filmskim i glazbenim ili nekim drugim kulturnoumjetničkim sadržajima na njemačkome jeziku pa je teže i razvijati interes prema takvim sadržajima, kao što je to utvrdila i Bagarić (2007). Ovaj različit rezultat za istu tvrdnju za dva ispitivana jezika može biti povezan i s različitim statusom engleskoga kao svjetskoga jezika i njemačkoga kao stranoga jezika te s različitom percepcijom koristi upotrebe ovih dvaju jezika. Korist upotrebe njemačkoga jezika sagledava se u kontekstu traženja i obavljanja posla (pragmatična upotreba), dok se korist upotrebe engleskoga kao svjetskoga jezika sagledava u općem smislu i u svim domenama svakodnevnice (Mihaljević Djigunović i Bagarić, 2007a; Karlak, 2014).

\subsubsection{Tumačenje deskriptivnih pokazatelja razumijevanja teksta čitanjem za engleski i njemački jezik}

Izračunavanjem srednjih vrijednosti utvrdili smo da prosječna srednja vrijednost bodova na testu razumijevanje teksta čitanjem za engleski jezik iznosi 35,79, što čini 76,1\% točnosti za ukupan broj bodova na testu. Histogram distribucije ukazuje na to da su visoki rezultati frekventniji od niskih rezultata. Moguće je utvrditi da je primjetna tendencija uspješnosti i da su sudionici našega istraživanja uspješni u razumijevanju tekstova na engleskome jeziku. U istraživanju koje su proveli Geld i Stanojević (2007) u kojem je korišten isti test razumijevanja 
teksta čitanjem za srednjoškolski uzorak zabilježena je prosječna srednja vrijednost bodova 23,17 , što je niže od prosječne srednje vrijednosti u našem istraživanju. No, treba uzeti u obzir da usporedbe nisu moguće samo na osnovi navedenih prosječnih vrijednosti, te da veličina $\mathrm{i}$ sastav uzorka u tim istraživanjima nisu usporedivi. Naši sudionici istraživanja su maturanti na području Dubrovačko-neretvanske županije koji su gotovo svakodnevno izloženi engleskome jeziku i u školskome i u izvanškolskome okruženju, možemo pretpostaviti da često koriste internet, kao što 85\% srednjoškolaca u Hrvatskoj koristi internet (Mihaljević Djigunović i Bagarić, 2007b), gledaju filmove i slušaju glazbu na engleskome jeziku, te žive u okruženju koje je orijentirano turizmu i pomorstvu, dakle upotrebi engleskoga kao prvoga stranoga jezika. Prosječna srednja vrijednost bodova za test iz engleskoga jezika može se usporediti s nalazima za engleski jezik koje je navela Bagarić (2007) u istraživanju komunikacijske kompetencije učenika engleskoga i njemačkoga jezika u pisanju i govorenju. Autorica je na osnovi visokih rezultata za engleski jezik u raspravi postavila zanimljivo pitanje o tome koju razinu ili podrazinu komunikacijske kompetencije na engleskome jeziku maturanti u Hrvatskoj dostižu pitajući se je li to razina B1 ili je možda već B2. Buduća istraživanja komunikacijske kompetencije iz engleskoga jezika među hrvatskim učenicima mogla bi dati odgovor na ovo pitanje.

Prosječna srednja vrijednost bodova na testu razumijevanje teksta čitanjem za njemački jezik je 23,32, što čini 58,2\% točnosti za ukupan broj bodova na testu. Činjenica da je prosječna srednja vrijednost bodova na testu za njemački jezik niža od one na testu za engleski jezik ne iznenađuje. Osim što su učenici izloženiji engleskome nego njemačkome jeziku u izvannastavnome kontekstu, značajke nastavnoga konteksta poučavanja engleskoga i njemačkoga jezika mogle bi se razmotriti pri tumačenju razlika u uspješnosti vještine čitanja. U našem istraživanju nije ispitana percepcija nastavnoga konteksta, no potrebno je naglasiti da je polovica naših učenika završavala četverogodišnji nastavni plan učenja njemačkoga jezika za srednje škole, a učenju engleskoga jezika gotovo su svi bili izloženi od početka prvoga razreda osnovne škole. Nadalje, u obzir bi trebalo uzeti i činjenicu da je njemački jezik našim učenicima složeniji u pogledu derivacijske morfologije i sintakse, te to uz manju izvannastavnu izloženost jeziku također može biti dio tumačenja lošijega rezultata na testu čitanja na njemačkome, kako je to upozorila i Bagarić (2007), utvrdivši da su u njemačkome jeziku učenici postigli statistički značajnu nižu razinu komunikacijske kompetencije nego u engleskome jeziku, te da učenici koji uče osam do devet godina engleski i njemački jezik u 
istome socioedukacijskome okruženju ne dostižu istu razinu komunikacijske kompetencije u pisanju i govorenju u engleskome i njemačkome jeziku.

\subsubsection{Tumačenje metrijskih obilježja i subskala Upitnika o strahu od čitanja na engleskome i Upitnika o strahu od čitanja na njemačkome jeziku u glavnome istraživanju}

$\mathrm{S}$ metrijskoga aspekta pouzdanost Upitnika o strahu od čitanja na engleskome jeziku u glavnome istraživanju zadovoljena je na razini cijeloga upitnika (Cronbachov $\alpha=, 933$ ), kao i za sve subskale upitnika. Za subskalu 1 (deset čestica) alfa koeficijent unutarnje konzistencije iznosi ,911, za subskalu 2 (osam čestica) ,850, dok za subskalu 3 (pet čestica) iznosi ,868. Navedeni pokazatelji unutarnje konzistencije ukazuju na visoku pouzdanost korištenoga mjernoga instrumenta. Analiza glavnih komponenti rezultirala je ekstrakcijom pet komponenti koje objašnjavaju preko $60 \%$ ukupne varijance. Međutim, budući da su subskala četiri i subskala pet bile manifestirane u po jednoj čestici, one su izostavljene iz daljnje obrade. Rezultati faktorske analize Upitnika o strahu od čitanja na engleskome jeziku ukazali su na trokomponentnu strukturu straha od čitanja na engleskome jeziku.

Na subskali 1 upitnika za engleski jezik oblikovalo se osam čestica, koje se odnose na kognitivnu komponentu straha od čitanja na engleskome jeziku, i dvije čestice koje odražavaju tjelesnu komponentu straha od čitanja. Subskala 2 sadržava čestice koje se odnose na jezičnu komponentu straha od čitanja na engleskome jeziku. Subskala 3 sadržava četiri čestice koje se odnose na emocionalnu komponentu straha od čitanja na engleskome jeziku i jednu česticu koja odražava tjelesnu komponentu straha od čitanja.

Između prve i druge subskale postoji visoka povezanost, a između prve i treće subskale umjerena povezanost. Utvrđene pozitivne korelacije upućuju na povezanost triju komponenata na temelju kojih su subskale formirane.

Pouzdanost Upitnika o strahu od čitanja na njemačkome jeziku u glavnome istraživanju zadovoljena je na razini cijeloga upitnika (Cronbachov $\alpha=, 919)$, kao i za sve subskale upitnika. Za subskalu 1 (osam čestica) alfa koeficijent unutarnje konzistencije iznosi ,869, za subskalu 2 (pet čestica) ,736, za subskalu 3 (četiri čestice) ,740, za četvrtu subskalu (tri čestice) alfa 
koeficijent iznosi ,541 i za petu subskalu (pet čestica) ,802. Navedeni pokazatelji unutarnje konzistencije ukazuju na zadovoljavajuću pouzdanost korištenoga mjernoga instrumenta. Analiza glavnih komponenti rezultirala je ekstrakcijom pet komponenti koje objašnjavaju gotovo 60\% ukupne varijance. Rezultati faktorske analize Upitnika o strahu od čitanja na njemačkome jeziku ukazali su na peterokomponentnu strukturu straha od čitanja na njemačkome jeziku.

Na subskali 1 upitnika za njemački jezik formiralo se šest čestica koje se odnose na kognitivnu komponentu straha od čitanja na njemačkome jeziku i dvije čestice koje odražavaju jezičnu komponentu straha od čitanja. Subskala 2 sadržava čestice koje se odnose na jezičnu komponentu straha od čitanja na njemačkome jeziku. Subskala 3 sadržava čestice koje se odnose na emocionalnu komponentu straha od čitanja na njemačkome jeziku. Na subskali 4 formirale su se čestice koje se odnose na djelovanje nastavnika koje kod učenika može potaknuti osjećaj uznemirenosti pri čitanju na njemačkome jeziku. Subskala 5 sadržava tri čestice koje se odnose na tjelesnu komponentu straha od čitanja na njemačkome jeziku i dvije čestice koje se odnose na jezičnu komponentu straha od čitanja na njemačkome jeziku.

Između subskala prevladavaju niske povezanosti, a najviša povezanost umjerena je povezanost između prve i pete subskale. Sve su povezanosti među subskalama pozitivne. Vrijednosti koeficijenta korelacije niže su za njemački nego za engleski jezik, ali možemo zaključiti da utvrđene pozitivne korelacije ukazuju na nisku do umjerenu povezanost između pet subskala definiranih na temelju analize glavnih komponenti.

Provedene faktorske analize Upitnika o strahu od čitanja na engleskome jeziku i Upitnika o strahu od čitanja na njemačkome jeziku ukazale su na multidimenzionalnost ispitivanoga konstrukta, što je usporedivo s nalazima nekih ranijih istraživanja straha od čitanja na stranome jeziku. Matsuda i Gobel (2004) su faktorskom analizom upitnika FLRAS (Saito i sur., 1999) utvrdili trokomponentnu strukturu straha od čitanja na engleskome jeziku u Japanu. Zoghi (2012) je konstruirao upitnik EFLRAI i utvrdio trokomponentnu strukturu straha od čitanja na engleskome jeziku u iranskome socioedukacijskome kontekstu. Ahmad i suradnici (2013) su koristeći upitnik koji je nastao na temelju rezultata kvalitativnoga istraživanja koje su proveli Al-Shboul i suradnici (2013), utvrdivši dvokomponentnu strukturu straha od čitanja na engleskome jeziku u Jordanu. 
U tumačenju rezultata faktorskih analiza Upitnika o strahu od čitanja na engleskome jeziku i Upitnika o strahu od čitanja na njemačkome jeziku najprije ćemo se osvrnuti na sličnosti subskala za engleski i njemački jezik, a zatim na različitosti. Na kraju ćemo dati tumačenja za subskalu 4 i subskalu 5 upitnika za njemački jezik.

Subskala 1 Upitnika o strahu od čitanja na engleskom jeziku sadržava osam tvrdnji koje se mogu povezati s kognitivnom komponentom straha od čitanja na engleskome jeziku. Subskala 1 Upitnika o strahu od čitanja na njemačkom jeziku sadržava četiri tvrdnje koje se mogu povezati s kognitivnom komponentom straha od čitanja na njemačkome jeziku. Četiri tvrdnje koje su se formirale u subskali 1 za oba jezika su: 19. „Nervozniji/ja sam kad čitam naglas na engleskome/njemačkome nego kad pišem, slušam ili govorim. “, 23. „Uznemiruje me kad čitam u sebi tekst na engleskome/njemačkome, a nastavnik/ca nakon toga ocjenjuje zadatke razumijevanja pročitanoga.“, 24. „Pri čitanju u sebi na engleskome/njemačkome zbunjuju me duge riječi koje je teško pročitati. “ i 25. „Osjećam se nesigurno kad čitam naglas na engleskome/njemačkome jer nemam dara za čitanje na engleskome. “

Negativna samopercepcija, koju odražavaju tvrdnje 4. „Ako trebam odabrati između čitanja, pisanja, slušanja i govora na engleskome jeziku, najteže mi je čitanje. “ i 25. „Osjećam se nesigurno kad čitam naglas na engleskome/njemačkome jer nemam dara za čitanje na engleskome.", jedan je od često navođenih izvora straha od stranoga jezika (Mihaljević Djigunović, 2002; Mak, 2011). S odrastanjem se pozitivno mišljenje koje učenici imaju o sebi mijenja, njihova samoprocjena postaje realnija i pojavljuje se negativna samopercepcija vlastitih osobina i sposobnosti. Kod učenja stranih jezika to može biti popraćeno i povećanim očekivanjima koje učenik s napredovanjem u učenju sam sebi postavlja. Tvrdnja 19. „,Nervozniji/ja sam kad čitam naglas na engleskome/njemačkome nego kad pišem, slušam ili govorim. " upućuje na razmišljanje o razlozima zbog kojih učenici čitanje izdvajaju kao vještinu koja izaziva najviše uznemirenosti. Treba naglasiti da čitanje nije, suprotno raširenom mišljenju, pasivna receptivna vještina, nego vrlo kompleksna kognitivna vještina, koja zahtijeva koordinaciju niza procesa, od okulomotornih i perceptivnih procesa do procesa razumijevanja (Rončević, 2005; Visinko, 2014) i složen aktivan proces građenja smisla pročitanoga teksta (Jelić, 2004). Složenost čitanja kao procesa osobito su naglašene u čitanju na stranome jeziku zbog suočavanja čitatelja s novim i do tada nepoznatim ortografskim, morfološkim, sintaktičkim i semantičkim obilježjima jezika koji uči. Čitanje na stranome jeziku integrira dekodiranje, integraciju informacija u tekst i integraciju informacije iz teksta s prethodnim 
znanjem. Tako se postiže konceptualno procesuiranje i konstrukcija značenja iz pročitanoga teksta (Koda, 2007). Čestice 22. „Uznemiruje me kad čitam u sebi tekst na engleskome, a nastavnik/ca nakon toga ocjenjuje zadatke razumijevanja pročitanoga. “ i 23. „,Uznemiruje me kad čitam u sebi tekst na engleskome, a nastavnik/ca nakon toga ocjenjuje zadatke razumijevanja pročitanoga. “ za engleski jezik i čestica 23. „Uznemiruje me kad čitam u sebi tekst na njemačkome, a nastavnik/ca nakon toga ocjenjuje zadatke razumijevanja pročitanoga. " za njemački jezik ukazuju na to da je ocjenjivanje jedan od izvora straha od čitanja na stranome jeziku. Strah od ocjenjivanja jedan je od tri straha koje su Horwitz i suradnici (1986) naveli kao konceptualno polazište za razmatranje općega straha od stranoga jezika u razrednoj situaciji. U mnogim istraživanjima utvrdilo se da je to jedan od izvora straha od stranoga jezika i straha od čitanja na stranome jeziku (Daly, 1991; Madsen i sur., 1991; MacIntyre i Gardner, 1991; Phillips, 1992; Gregersen i Horwitz, 2002; Mihaljević Djigunović, 2002; Abu-Rabia, 2004; Piechurska-Kuciel, 2008; Kuru-Gonen, 2009; Marzec-Stawiarska, 2013). Jedan od najvažnijih okidača stresa u adolescentskoj dobi mogu biti prijelazna razdoblja, kao što je prijelaz iz osnovne u srednju školu, kada se učenici suočavaju s novim društvenoobrazovnim okruženjem, novim vlastitim očekivanjima i očekivanjima okoline (PiechurskaKuciel, 2008), no i prijelazno razdoblje kada adolescenti završavaju srednjoškolsko obrazovanje. Koliko je ocjena bitna za adolescente pokazalo se i u istraživanju motivacije za učenje engleskoga jezika među različitim dobnim skupinama u kojemu je Mihaljević (1990) utvrdila da je motiv da se zadovolji polaganje testa i postigne zadovoljavajuća ocjena u najvećoj mjeri bio zabilježen među adolescentima. S obzirom na to da su naši sudionici istraživanja maturanti, kojima predstoji zaključivanje ocjena iz engleskoga i njemačkoga jezika, a koje mogu biti važne pri upisu na fakultet, ne čudi da ocjenjivanje može potaknuti strah od čitanja. Testiranje vještine čitanja dio je ispita iz engleskoga jezika na državnoj maturi, pa je stoga strah od čitanja na engleskome jeziku moguće povezan i s tim predstojećim testiranjem znanja. Strah koji učenik osjeća zbog,,javnoga nastupa“ potiče i tjelesne manifestacije straha, što se odražava u tvrdnjama 12. „Dok čitam naglas na engleskome pred drugima, srce mi jače lupa.“ i 18. „Dok čitam naglas na engleskome pred drugima, osjećam da mi se znoje dlanovi.“. Taj strah povezan je sa strahom od negativne reakcije drugih učenika i nastavnika, a kod adolescenata je povezan i s osjećajem „reducirane ličnosti“ koje učenje stranoga jezika nameće dok se ne postigne visoka kompetencija (Mihaljević Djigunović, 2002). Tjelesne manifestacije prate osjećaj uznemirenosti i često ih je teško sakriti. Stoga se uznemirenost tada još više primjećuje i može izazvati dodatni osjećaj neugode ili odustajanje od aktivnosti. 
U subskali 1 upitnika za njemački jezik našle su se i dvije tvrdnje koje odražavaju jezičnu komponentu straha od stranoga jezika. To su tvrdnje 7. „Zbunjuje me nepodudarnost između načina pisanja i čitanja na njemačkome jeziku. “i 16. „,Dok čitam naglas na njemačkom, brinem se kako ću izgovoriti pojedine riječi. “No, budući da je jezična komponenta obuhvaćena subskalom 2 za oba ispitana jezika, tumačenje slijedi u nastavku teksta.

Subskala 2 Upitnika o strahu od čitanja na engleskom jeziku sadržava osam tvrdnji koje se mogu povezati s jezičnom komponentom straha od čitanja na engleskome jeziku. Subskala 2 Upitnika o strahu od čitanja na njemačkom jeziku sadržava pet tvrdnji koje se mogu povezati s jezičnom komponentom straha od čitanja na engleskome jeziku. Iako subskala 2 za engleski jezik sadržava veći broj tvrdnji nego subskala 2 za njemački jezik, ove dvije subskale sadržajno su usporedive. Četiri tvrdnje koje su se formirale u subskali 2 za oba jezika su: 3. „,Uznemiruje me kad pri čitanju u sebi naiđem na riječ ili izraz koji ne razumijem.“, 8. „Čini me nervoznim/om kad čitam u sebi i razumijem gotovo sve riječi u rečenici, ali ne razumijem značenje rečenice. “, 10. „Postajem nervozan/na kad pri čitanju u sebi naiđem na nepoznatu gramatičku konstrukciju. “ i 21. „Smeta me kad u tekstu naiđem na neki pojam iz britanske, američke ili druge kulture engleskoga govornoga područja / njemačke, austrijske ili druge kulture njemačkoga govornoga područja koji mi nije poznat. “. Prema Saito i suradnicima (1999) čitanje na stranome jeziku može uzrokovati strah iz najmanje dvaju razloga. Prvi je to što pri učenju stranoga jezika učenik treba ovladati novom ortografijom i novim sustavom dekodiranja, što ukazuje na osobitosti jezika kao izvora straha od čitanja. To je osobito izraženo kod jezika kod kojih grafofonemska korespondencija nije pravilna, kao kod engleskoga jezika. Drugi se razlog odnosi na kulturološke koncepte jer učenik nakon uspješnoga dekodiranja zbog nedovoljnoga znanja o kulturološkome aspektu sadržaja ne može postići razumijevanje pročitanoga teksta. Čitanje je interaktivan proces, a ta se interakcija uspostavlja kada se jezične informacije povezuju s dostupnim znanjem (Grabe i Stoller, 2011). Tijekom čitanja odvijaju se procesi niže i više razine i ti procesi vode do razumijevanja teksta. Dok čitamo, mi dekodiramo, povezujemo i pretpostavljamo, te na osnovu tih procesa i svojega znanja i iskustva stvaramo značenje (Grabe, 2009; Grabe i Stoller, 2011). Ako se ne postigne razina razumijevanja teksta, to izaziva uznemirenost, a osobito $\mathrm{u}$ formalnome razrednome okruženju gdje su učenici izloženi provjerama i ocjenjivanju pročitanoga teksta, što se odražava u tvrdnji 22. „,Uznemiruje me kad čitam u sebi tekst na njemačkome, a nastavnik/ca nakon toga ocjenjuje zadatke razumijevanja pročitanoga. “ koja se za njemački jezik nalazi u subskali 2. 
Aspekt straha od čitanja koji se odnosi na tekst (vokabular, tema teksta i kultura) utvrđen je u nekoliko istraživanja straha od čitanja (Kuru-Gonen, 2009, Al-Shboul i suradnici, 2013; Ahmad i sur., 2013), a Zoghi (2012) i Zoghi i Alivandivafa (2014) utvrdili su osobitosti teksta (vokabular i gramatika) kao jednu od triju komponenata straha od čitanja na engleskome jeziku. Prema Saito i suradnicima (1999) to bi bio prvi izvor straha od čitanja. Zabrinutost zbog izgovora može se tumačiti kao zabrinutost zbog pogreške ili mogućega ismijavanja. Tu zabrinutost odražava tvrdnja 16. „Dok čitam naglas na engleskome, brinem se kako ću izgovoriti pojedine riječi. ". Usprkos činjenici da naši sudionici u prosjeku već 12 godina uče engleski jezik, zabrinutost zbog pogrešnoga izgovora još uvijek je prisutna. Moguće je da postavljaju sebi velika očekivanja i baš zbog visoke razine znanja koju su dostigli i dugoga perioda učenja teže „opraštaju“ sebi pogrešan izgovor. Ovaj nalaz bi se mogao tumačiti u kontekstu njihovih viših i strožih očekivanja, kao što su to utvrdili Onwuegbuzie i suradnici (1999) i Gregersen i Horwitz (2002) u istraživanju među studentima u Americi i Tóth (2009) u istraživanju među studentima u Mađarskoj. Moguće je da je ovaj strah povezan sa strahom od pogreške općenito, kao što je to utvrđeno u mnogim istraživanjima straha od jezika i straha od čitanja na stranome jeziku kod srednjoškolaca i studenata (Gregersen i Horwitz, 2002; Mihaljević Djigunović, 2002; Kostić-Bobanović, 2009; Puškar, 2010; Al-Shboul i suradnici, 2013; Pavičević, 2013; Čiček, 2014; Alsaleh, 2017). Tvrdnje u ovoj subskali koje se odnose na strah koji može nastati zbog nepoznatih izraza ili riječi, nepoznate gramatike, nepoznatih pojmova iz kulture engleskoga govornoga područja, nerazumljive rečenične sintakse i nepodudarnost između načina pisanja i čitanja sačinjavaju komponentu straha od čitanja na engleskome jeziku koja je utvrđena u nekoliko prethodnih istraživanja. Matsuda i Gobel (2001, 2004) utvrdili su da se prva komponenta upitnika FLRAS (Saito i sur., 1999) odnosi na poznavanje gramatike i vokabulara engleskoga jezika, a treća na kulturu engleskoga govornoga područja i sustav pisanja na engleskome jeziku. Zoghi (2012) je utvrdio drugi faktor straha od čitanja koji je nazvao strah od čitanja odozdo-prema-gore, a obuhvaća vokabular i gramatiku. Kuru-Gonen (2009) je drugi izvor straha od čitanja nazvala osobitosti teksta, a obuhvaća temu teksta, nepoznat vokabular i nepoznavanje kulturnoga konteksta teksta. Al-Shboul i suradnici (2013) i Ahmad i suradnici (2013) utvrdili su jedan od dvaju aspekata straha od čitanja koji je nazvan aspekt teksta, a obuhvaća nepoznati vokabular, nepoznatu temu i nepoznatu kulturu.

Subskala 3 Upitnika o strahu od čitanja na engleskom jeziku sadržava pet tvrdnji koje se mogu povezati s emocionalnom komponentom straha od čitanja na engleskome jeziku. 
Subskala 3 Upitnika o strahu od čitanja na njemačkom jeziku sadržava četiri tvrdnje koje se mogu povezati s emocionalnom komponentom straha od čitanja na njemačkome jeziku. Tri tvrdnje koje su se formirale u subskali 3 za oba jezika su: 1. „Osjećam se nervozno dok čitam naglas na engleskome/njemačkome pred drugima. “, 5. „, Osjećam se ugodno dok čitam naglas na engleskome/njemačkome.“ (rekodirano) i 11. „Kad čitam naglas na engleskome/njemačkome jeziku, osjećam se opušteno i siguran/na u sebe. “(rekodirano).

Ove tri tvrdnje jasno opisuju unutarnji osjećaj neugode. Glavni je efekt straha od komunikacije, općenito, unutarnji osjećaj neugode koji je prisutan u svakoj osobi i pri svim vrstama straha od komunikacije (Mihaljević Djigunović, 2002: 36). Uz ovaj osjećaj vezuju se različite fiziološke i bihevioralne manifestacije koje se razlikuju kod različitih pojedinaca $\mathrm{u}$ različitim situacijama, a koje uključuju izbjegavanje i povlačenje iz komunikacije ili poremećaje u komunikaciji, kao što su zamuckivanja, izobličeni govor i intonacija i slično (Horwitz i sur., 1986; Rardin, prema Young, 1992; Mihaljević Djigunović, 2002). Tvrdnja 2. „, Kad čitam naglas na engleskome pred drugima, uznemirim se i glas mi se promijeni i drhti. “ opisuje takvu manifestaciju. Horwitz i suradnici (1986) navode strah od komunikacije kao jedno od konceptualnih polazišta za razmatranje straha od jezika, a time i straha od čitanja na stranome jeziku. Stoga se ova subskala našega upitnika o strahu od čitanja na engleskom jeziku može usporediti sa sličnim česticama u upitniku FLCAS (Horwitz i suradnici, 1986). Ova emocionalna komponenta opisuje prijelazno emocionalno stanje koje prema Spielbergeru (1966, 1972) karakteriziraju subjektivni osjećaji napetosti, nervoze i zabrinutosti. To je stanje koje pojedinac osjeća kao stanje ličnosti i pojavljuje se u situaciji učenja stranoga jezika. Pretjerana zabrinutost može dovesti do poremećaja koncentracije i ometajućih misli, a time i do lošijega uspjeha (Tobias, 1986; MacIntyre i Gardner, 1989; Sellers, 2000; Gregersen, 2003). Stoga je ta komponenta straha od jezika jedna od onih protiv koje se u borbi protiv straha od čitanja na stranome jeziku treba ciljano boriti. U toj borbi mogu pomoći različiti postupci fizičke relaksacije tijela, tehnike dubokoga disanja, pa čak i slušanje glazbe ili humor, čime bi se umirile i smanjile fizičke manifestacije straha, te pažnja usmjerila nastavnomu sadržaju.

Faktorskom analizom upitnika za njemački jezik utvrđena je subskala $\mathbf{4}$ koja sadržava dvije tvrdnje koje se odnose na djelovanje nastavnika koje kod učenika može potaknuti osjećaj uznemirenosti pri čitanju na njemačkome jeziku i jednu tvrdnju koja odražava vjerovanje da je čitanje na njemačkome jeziku teško. Za razliku od njemačkoga jezika, za engleski se jezik faktorskom analizom nije formirala subskala koja se odnosi na nastavnika. Ovaj nalaz bismo 
mogli tumačiti u kontekstu različitoga razumijevanja uloge nastavnika $\mathrm{u}$ formalnome obrazovnome kontekstu za dva ispitivana jezika. S obzirom na status engleskoga kao svjetskoga jezika, te jezika koji je sveprisutan u našoj svakodnevnici, a osobito u svakodnevnici adolescenata koji prate filmove, glazbu i društvene mreže na engleskome jeziku percepcija engleskoga kao globalnoga jezika nije ista kao percepcija njemačkoga kao stranoga jezika. Osim toga, i formalni status prvoga stranoga jezika (engleski) i drugoga stranoga jezika (njemački) ukazuje na tu različitost. Time se i uloga nastavnika kao organizatora i prenositelja znanja u formalnome kontekstu učenja stranoga jezika drugačije doživljava za engleski nego za njemački jezik. U nastavi njemačkoga jezika nastavnik i nastavna situacija primarno su okruženje i izvori učenja jezika. Stoga je moguće da je uloga nastavnika naglašenija u nastavi njemačkoga nego u nastavi engleskoga jezika, pa se to odrazilo u rezultatu faktorske analize za njemački jezik, gdje se djelovanje nastavnika izdvojilo kao posebna komponenta. Na ulogu nastavnika u interakciji učenik-nastavnik u razrednome okruženju i njegovu zadaću stvaranja ugodne i poticajne radne atmosfere upozorili su mnogi znanstvenici iz područja pedagogije i psihologije, kao i istraživači i teoretičari OVIJ-a (Finnocchiaro, 1974; Vilke, 1977; Krashen, 1982; Oxford, 1990; Bratanić, 1991; Young, 1991; Wentzel, 1997; Roeser i sur., 2000; Mihaljević Djigunović, 2002; Pivac, 2009; Puškar, 2010; Didović Baranac, 2012). Nastavnik se u takvome složenome interakcijsko-komunikacijskom odnosu promatra kao poticatelj i moderator aktivnosti u kojima je naglasak na sadržajnoj komponenti jezične uporabe $u$ pozitivnome emocionalnome ozračju (Mihaljević Djigunović, 2002; Dörnyei i Murphy, 2004; Didović Baranac, 2012). A kako bi se postigla takva poticajna radna atmosfera, vrlo su važni način i učestalost ispravljanja pogreški jer i to mogu biti izvori straha od stranoga jezika (Omaggio Hadley, 1986; Crookall i Oxford, 1991). Bloome (1993) je pak, promatrajući čitanje kao društveni proces, također upozorio da se nastavnik i učenik nalaze u uzajamnoj interakciji i interakciji s tekstom, te da razumijevanje i tumačenje teksta počivaju na njihovoj uzajamnoj raspodjeli uloga u tome odnosu.

Na važnost uloge nastavnika u procesu učenja stranoga jezika i povezanost nastavnikova djelovanja i straha od jezika ukazala su mnoga istraživanja provedena u različitim socioedukacijskim kontekstima. U američkome obrazovnome kontekstu Horwitz i suradnici (1986) upozorili su da nastavnik i nastavne metode mogu izazvati strah od stranoga jezika, Vogely (1998) je utvrdila da su nastavnik, nastavno ozračje i nastavne metode jedan od izvora straha od slušanja, a Saito i suradnici (1999) upozorili su da bi u budućim istraživanjima trebalo ispitati i ulogu nastavnika u procesu učenja stranoga jezika. Faktorskom analizom Zoghijeva 
upitnika (Zoghi, 2012) utvrđeno je da je treća komponenta straha od čitanja strah od čitanja u razredu i da se pod ovom komponentom podrazumijevaju nastavnik i nastavne metode. To je potvrđeno u istraživanju koje su proveli Zoghi i Alivandivafa (2014) u Iranu. Kuru-Gonen (2009) u Turskoj, Piniel (2006) i Tóth (2009) u Mađarskoj, te Marzec-Stawiarska (2013) u Poljskoj utvrdile su da su nastava, nastavnik, način ispravljanja pogreški i nastavno ozračje izvori straha od stranoga jezika. Piechurska-Kuciel (2008, 2011) je u Poljskoj utvrdila da je nastavnikova podrška u učenju stranoga jezika važan čimbenik koji može biti povezan sa smanjivanjem straha i napredovanjem u učenju jezika. Istraživanje koje je proveo Abu-Rabia (2004) pokazalo je da su učeničke procjene nastavnika jedan od prediktora straha kod učenika u Izraelu. U Hrvatskoj su na ulogu nastavnika u procesu učenja stranoga jezika ukazala istraživanja koja je provela Mihaljević (1990, 1991/1992), a kasnije je ista autorica utvrdila da je nastavnik jedan od izvora straha od engleskoga jezika (Mihaljević Djigunović, 2002). Puškarovo istraživanje među studentima anglistike i germanistike ukazalo je na percipiranu ulogu nastavnika (lektora). Komentari studenata odnosili su se na preveliku strogoću lektora, primjenu određenih nastavnih metoda i poboljšanje kvalitete nastave (Puškar, 2010). Utvrđeno je da studenti koji imaju negativno iskustvo s lektorima (negativnu percepciju) imaju viši strah od jezika, što je potvrđeno $u$ istraživanju straha od stranoga jezika među studentima romanistike, a koje su provele Mardešić i Stanković (2013).

Faktorskom analizom upitnika za njemački jezik utvrđena je subskala 5 koja sadržava pet čestica, od kojih se tri odnose na tjelesnu komponentu straha od čitanja na njemačkome jeziku, a dvije na jezičnu komponentu straha od čitanja na engleskome jeziku. Tumačenje jezične komponente straha od čitanja naveli smo u tumačenju subskale 2, stoga ćemo ovdje izložiti tumačenje za tjelesnu komponentu. Dakle, za njemački jezik posebno se izdvojila subskala u kojoj su se formirale sve tri čestice upitnika koje se odnose na tjelesnu komponentu straha od čitanja, a za engleski jezik su se dvije čestice koje izražavaju tjelesnu komponentu formirale na subskali 1, a jedna na subskali 3. Moguće je da je manifestacija tjelesne komponente straha od čitanja doista i prisutnija na nastavi njemačkoga nego engleskoga jezika zbog različite percepcije, različitih vjerovanja i različitih razina ovladanosti komunikacijskim kompetencijama u ova dva jezika. Učenici u Hrvatskoj doživljavaju njemački jezik težim od engleskoga, nakon istoga broja godina učenja obaju jezika postižu nižu razinu komunikacijske kompetencije u njemačkom jeziku, izloženi su drugačijim značajkama kako nastavnoga tako i izvannastavnoga konteksta učenja i usvajanja jezika (Bagarić, 2007; Božinović i Didović Baranac, 2011; Vidak i sur., 2015). Ta vjerovanja mogu biti izvori straha i neugode, pa stoga i 
fizičke manifestacije straha od čitanja mogu biti izraženije na nastavi njemačkoga nego engleskoga jezika. Ovakve fizičke manifestacije promatraju se kao manifestacije, odnosno posljedice straha i neugode, ali kada se pojave, oni postaju izvori neugode i srama. Time se efekt negativnih osjećaja samo još više pojačava.

Na fiziološke manifestacije straha upozorili u svojim radovima Horwitz i suradnici (1986) i Young (1991), a Oxford (1990) govori o strategijama smanjenja straha kojima se postiže fizička relaksacija tijela. Na upotrebu kinestetičkih strategija u nastavi ukazao je Oflaz (2019) u Turskoj, utvrdivši da primjenom metode potpunoga fizičkoga odgovora (engl. total physical response method) nastavnici mogu smanjiti strah i stres kod studenata i time pridonijeti uspješnijem učenju.

Provedene faktorske analize Upitnika o strahu od čitanja na engleskome jeziku i Upitnika o strahu od čitanja na njemačkome jeziku ukazale su na multidimenzionalnost ispitivanoga konstrukta, što je usporedivo s nalazima nekih ranijih istraživanja straha od čitanja na stranome jeziku (Matsuda i Gobel, 2001, 2004; Kuru-Gonen, 2009; Zoghi, 2012; Ahmad i sur., 2013; Al-Shboul i sur., 2013; Zoghi i Alivandivafa, 2014).

Provedene faktorske analize Upitnika o strahu od čitanja na engleskome jeziku i Upitnika o strahu od čitanja na njemačkome jeziku ukazale su na postojanje strukturalnih razlika u strahu od čitanja na engleskome i njemačkome kao stranome jeziku. Dok je za engleski jezik utvrđena trokomponentna struktura straha od čitanja, za njemački jezik utvrđena je složenija peterokomponentna struktura straha od čitanja. Ekstrahiranje kognitivne, emocionalne i jezične komponente straha od čitanja za oba ispitivana jezika upućuje na sličnosti u strukturama straha od čitanja na engleskome i njemačkome jeziku. Iako sastav triju komponenti nije za oba jezika isti, primjetne su sličnosti u sastavu, te su te tri komponente ukupno gledano sadržajno usporedive. Ono što je usporedivo moglo bi se promatrati kao ono što je zajedničko, odnosno univerzalno za strukturu straha od čitanja za oba ispitivana jezika. Ono što je različito moglo bi se promatrati kao jezično i sociokulturno specifično u kontekstu u kojemu je istraživanje provedeno. Pri tome mislimo na različit status dvaju ispitivanih jezika, različit nastavni kontekst učenja i različit izvannastavni kontekst usvajanja ovih dvaju jezika. 
Polazeći od teorijskih polazišta o čitanju koja ističu dva elementa: čitatelja i tekst, a čitanje opisuju kao interakciju znanja čitatelja i obavijesti u tekstu koji vodi razumijevanju pročitanoga teksta (Alderson, 2000; Jelić, 2009) moglo bi se reći da kognitivna i emocionalna komponenta straha od čitanja odražavaju osobitosti pojedinca (čitatelja), a jezična komponenta odražava osobitosti jezika (teksta).

Polazeći od teorijskih polazišta o strahu od stranoga jezika koje su konceptualizirali Horwitz i suradnici (1986) možemo primijetiti da su strah od komunikacije, strah od ocjenjivanja i negativne društvene evaluacije u razrednoj sredini zastupljeni $u$ utvrđenim komponentama straha od čitanja na engleskome i njemačkome jeziku.

Polazeći od teorijskih polazišta o strahu od čitanja na stranome jezik koje su konceptualizirali Saito i suradnici (1999) možemo primijetiti da su aspekt ortografije i kulturološki aspekt zastupljeni u utvrđenim komponentama straha od čitanja na njemačkome i engleskome jeziku.

U mnogim istraživanjima straha od stranoga jezika i straha od čitanja na stranome jeziku faktorske analize nisu uvijek ukazale na istu strukturu ispitivanih pojava (Aida, 1994; Cheng i sur., 1999; Matsuda i Gobel 2001, 2004; Mak, 2011; Park, 2014). Matsuda i Gobel ističu da se ti rezultati razlikuju s obzirom na ispitivane jezike i s obzirom na različitosti nastavnoga konteksta te se tako trebaju i tumačiti (Matsuda i Gobel, 2001: 241). Takvim pristupom su tumačeni i navedeni rezultati našega istraživanja.

\subsubsection{Tumačenje razlika u strahu od čitanja na engleskome i njemačkome jeziku s obzirom na spol}

U skladu s očekivanjima nisu utvrđene statistički značajne razlike u strahu od čitanja na engleskome i njemačkome jeziku s obzirom na spol. U tumačenju ovoga rezultata krenut ćemo od osvrta na istraživanja straha od stranoga jezika.

Istraživanja straha od stranoga jezika ukazala su na nekonzistentnost rezultata koji su ukazivali na razlike u strahu od stranoga jezika s obzirom na spol. Tako se u nekim istraživanjima utvrdilo da žene imaju višu razinu straha od stranoga jezika nego muškarci, a 
među njima su istraživanja koja su proveli Abu-Rabia (2004) u Izraelu, Elkhafaifi (2005) u SAD-u, Aydin (2008) i Balemir (2009) u Turskoj, Koul i suradnici (2009) na Tajlandu, Arnaiz i Guillén (2012) u Španjolskoj, Jafarigohar i Behrooznia (2012) u Iranu, Park i French (2013) u Koreji, Čiček (2014) i Maturanec (2015) u Hrvatskoj, te Karabiyik i Özkan (2017) u Turskoj. Međutim, u nekim je istraživanjima utvrđeno da muškarci imaju višu razinu straha od stranoga jezika nego žene, npr. u istraživanjima koje su proveli Kitano (2001) u SAD-u i Zhang (2000) u Kini. Istraživanja u kojima rezultati ukazuju da nema razlike u strahu od stranoga jezika s obzirom na spol proveli su: Aida (1994) i Zhao i suradnici (2013) u SAD-u, MacIntyre i suradnici (2002) u Kanadi, Dewaele (2007) u Velikoj Britaniji, Božinović i Didović Baranac (2011) u Hrvatskoj, Wu (2011) na Tajvanu i Marzec-Stawiarska (2014) u Poljskoj. Nekonzistentnost rezultata istraživanja straha s obzirom na spol ukazuje da postoji utjecaj moderator varijable ili varijabli koje nisu sistematski kontrolirane u prethodnim istraživanjima, a mogle bi utjecati na manifestaciju razlika s obzirom na spol u ispitivanom strahu. Primjerice, neki od mogućih moderatora različiti su ispitivani jezici ili/i različiti socioedukacijski i kulturološki konteksti.

Međutim, $u$ istraživanjima straha od čitanja na stranome jeziku prevladavaju rezultati koji ukazuju da nema razlika u strahu od čitanja s obzirom na spol, kao što su to utvrdili Hayati i Ghassemi (2008) u Iranu, Zhao (2009), Wu (2011) na Tajvanu, Zhao i suradnici (2013) u SAD-u, Capan i Karaca (2013) u Turskoj i Al-Sohbani (2018) u Jemenu. Iako su i ova istraživanja provedena u različitim socioedukacijskim i kulturnim kontekstima, rezultati su konzistentniji nego za ispitivanje općega straha od stranoga jezika. Stoga je pretpostavka našega istraživanja bila u skladu s ovim nalazima. Potencijalno tumačenje ovakvoga rezultata može biti priroda ispitivane pojave. Naime, pri ispitivanju straha od čitanja istraživački fokus usmjeren je ispitivanju čitanja kao kompleksne kognitivne i jezične vještine i afektivnoga faktora straha koji se može pojaviti u procesu ovladavanja ovom vještinom. Krenimo najprije od razumijevanja čitanja kao jezične djelatnosti u kojoj je interakcija s nastavnikom i ostalim učenicima manja nego kod nekih drugih jezičnih djelatnosti, a osobito primjerice kod govorenja koji predstavlja javni nastup na stranome jeziku pred razredom. S obzirom da je interakcija s ostalim sudionicima nastavnoga procesa manja, odnosno manje vidljiva, moglo bi se pretpostavili da različitosti koje bi mogle biti spolno uvjetovane moguće neće doći do izražaja pri čitanju, odnosno da se neće niti utvrditi postojanje takvih razlika. Moguće objašnjenje je da je ovaj nalaz povezan i s dobi sudionika istraživanja, te se možda u adolescentskoj dobi u suvremenome društvu razlike s obzirom na spol brišu i uloge muškarca i žene u društvu 
izjednačuju. No, daljnje elaboriranje ovakvoga tumačenja zahtijevalo bi temeljitiju znanstvenoistraživačku podlogu.

\subsubsection{Tumačenje razlika u strahu od čitanja na engleskome i njemačkome jeziku s obzirom na srednjoškolski smjer}

U našem istraživanju nisu utvrđene statistički značajne razlike u intenzitetu straha od čitanja na engleskome i njemačkome jeziku s obzirom na srednjoškolski smjer. Ovakav nalaz bio je očekivan s obzirom da su u istraživanju sudjelovali učenici onih srednjoškolskih smjerova koji se usporedivi s obzirom na status prvoga i drugoga stranoga jezika u nastavnim programima i sličan broj sati nastave tjedno. Nadalje, za oba srednjoškolska usmjerenja postoji pretpostavljena slična pozitivna usmjerenost učenika prema učenju stranih jezika, a sličnost u pozitivnim stavovima koji odražavaju motivaciju bi mogla biti polazište za pretpostavku o sličnosti u intenzitetu straha. Takvu pretpostavku temeljimo na rezultatima istraživanja stavova učenika prema učenju stranih jezika, a koja su ranije provedena u sličnome socioedukacijskome kontekstu na području Dubrovačko-neretvanske županije (Vidak i sur., 2015; Didović Baranac i sur., 2016; Falkoni-Mjehović i sur., 2016).

\subsubsection{Tumačenje razlika $u$ intenzitetu straha od čitanja na engleskome $i$ njemačkome jeziku s obzirom na jezik}

Rezultati istraživanja ukazuju na to da postoje statistički značajne razlike u intenzitetu straha od čitanja na engleskome i njemačkome jeziku s obzirom na jezik, te da je utvrđen viši intenzitet straha za njemački $(A S=2,31)$ nego za engleski jezik $(A S=1,92)$. Ovakav nalaz bio je očekivan s obzirom na već ranije opisan različit status engleskoga kao jezika za međunarodnu komunikaciju i njemačkoga kao stranoga jezika (Dörnyei i Csizér, 2002). Globalni status engleskoga jezika koji je postao lingua franca može se odraziti i na druge afektivne faktore pri učenju engleskoga jezika u formalnome okruženju osim na motivaciju. Tako se može odraziti i na strah od čitanja u smislu da se za engleski kao međunarodni jezik utvrdi niža razina straha od čitanja nego za njemački kao strani jezik. 
Kada se govori o širenju engleskoga jezika i njegova značaja u globalnim razmjerima možemo razlikovati tri koncentrična kruga širenja. Unutarnji krug predstavljaju zemlje u kojima je engleski materinski jezik (Velika, Britanija, SAD, Australija, Kanada i Novi Zeland), vanjski krug (bivše britanske kolonije gdje se engleski jezik upotrebljava u institucionaliziranome društvenome okviru, kao što su vlada, obrazovanje, gospodarstvo), a ostatak svijeta pripada koncentričnome krugu koji se širi, a koji obuhvaća zemlje u kojima engleski ima status stranoga jezika (Kachru, 1982, prema Mihaljević Djigunović i Geld, 2003). Tako se danas govori o engleskome kao stranome jeziku (engl. English as a foreign language) u kontekstima onih zemalja gdje se engleski poučava, a nije materinski jezik, te engleskome kao drugome jeziku (engl. English as a second language) u kontekstima zemalja kao što su Kanada i Singapur. Možemo govoriti o engleskome kao o međunarodnome jeziku (engl. English as an international language) i engleskome kao lingua franca (engl. English as a lingua franca) kada se upotrebljava za komunikaciju među različitim grupama ljudi koji nisu izvorni govornici engleskoga jezika (Mihaljević Djigunović i Geld, 2003).

U Republici Hrvatskoj je u osnovnoškolskome i srednjoškolskome obrazovanju obvezno učenje najmanje jednoga stranoga jezika (Zakon o odgoju i obrazovanju u osnovnoj i srednjoj školi), a najviše učenika uči engleski jezik. Nadalje, Hrvatska je 2013. godine postala punopravna članica Europske unije pa od tada značenje učenja engleskoga jezika u Hrvatskoj još više raste jer se za učenike, studente i građane Republike Hrvatske otvaraju mogućnosti mobilnosti unutar EU-a. Na činjenicu da su sudionici našega istraživanja maturanti koji 12 godina uče engleski jezik i koji su upravo pred polaganjem državne mature također treba obratiti pozornost pri tumačenju. Državna matura u Republici Hrvatskoj prema Pravilniku o polaganju državne mature sadržava tri obvezna ispita, od kojih je jedan ispit iz stranoga jezika. ${ }^{21}$

Najveći postotak maturanta odlučuje se upravo za polaganje engleskoga jezika, jer im pri upisu na neki od fakulteta u Hrvatskoj postignut uspjeh na maturi iz stranoga jezika donosi bodove. Oni maturanti koji se odluče na studij izvan Hrvatske najčešće pri postupku prijave i upisa na fakultet trebaju priložiti potvrdu o znanju engleskoga jezika. Sve ovo ukazuje na visoku razinu važnosti engleskoga jezika $\mathrm{u}$ hrvatskome formalnome obrazovanju, a osobito $\mathrm{u}$ srednjoškolskome.

\footnotetext{
21 (https://narodnenovine.nn.hr/clanci/sluzbeni/2013_01_1_35.html; https://narodnenovine.nn.hr/clanci/sluzbeni/2019_04_41_845.html).
} 
Za razliku od engleskoga jezika, njemački jezik nema globalnu važnost za učenike u Hrvatskoj. Učenici percipiraju njemački jezik kao strani jezik, u smislu da im je nepoznat i dalek. To je jezik koji se koristi izvan zemlje i okruženja u kojemu se učenici školuju i žive, jezik kojemu su hrvatski učenici vrlo rijetko izloženi u izvannastavnome okruženju i jezik koji se uči gotovo isključivo u formalnome obrazovnome kontekstu, pa taj kontekst može biti jedan od izvora straha od jezika. Naš je nalaz u skladu je s nalazima nekih ranijih istraživanja straha od stranoga jezika u Hrvatskoj u kojima se utvrdilo da učenici percipiraju njemački kao težak jezik (Mihaljević Djigunović i Bagarić, 2007a; Didović Baranac i sur., 2016) te da imaju višu razinu straha od njemačkoga nego od engleskoga jezika (Puškar, 2010). Karlak (2014) je utvrdila da u strukturi motivacije za učenje engleskoga i njemačkoga jezika postoji razlika u sastavu komponente osobina učenika. Za njemački jezik utvrđeno je da komponenta osobine učenika obuhvaća, uz roditeljsku podršku, i strah od njemačkoga jezika, a za engleski jezik u istoj komponenti nije utvrđen strah od engleskoga jezika. Međutim, osim razlika u percepciji težine jezika i razlika u statusu engleskoga i njemačkoga jezika, pri razmatranju ovoga nalaza trebalo bi razmotriti i razlike u nastavnome kontekstu poučavanja ovih dvaju jezika. Na te razlike ukazali su nalazi istraživanja koje su proveli Mihaljević Djigunović i Bagarić (2007a) i Puškar (2010). U oba istraživanja učenici i studenti lošije su procijenili nastavnika i nastavni kontekst za njemački jezik. Inovativniji pristup poučavanju, zanimljiv i autentičan nastavni materijal, jačanje komunikacijske kompetencije, a manje uvježbavanja gramatičke kompetencije, prema mišljenju učenika i studenata, unaprijedilo bi nastavu njemačkoga jezika (Mihaljević Djigunović i Bagarić, 2007a; Puškar, 2010). Mogli bismo pretpostaviti da bi to djelovalo i na smanjenje razine straha od čitanja na njemačkome jeziku. Dakle, još jedno moguće objašnjenje zašto je viši strah od čitanja na njemačkome jeziku moglo bi se temeljiti u osobitostima nastavnoga konteksta poučavanja njemačkoga jezika u našim školama.

Osvrnemo li se na neka ranije provedena poredbena istraživanja straha od stranoga jezika i straha od čitanja na stranome jeziku, naići ćemo na nekonzistentnost rezultata o razlikama u strahu s obzirom na ciljni jezik. Neka od poredbenih istraživanja straha od stranoga jezika u kojima je korišten upitnik FLCAS (Horwitz i sur., 1986) u kojima nisu utvrđene razlike u strahu s obzirom na ciljni jezik proveli su: Bailey i suradnici (1998), Saito i suradnici (1999), Rodríguez i Abreu (2003) te Božinović i Didović Baranac (2011). Međutim, Piniel (2006) je u Mađarskoj utvrdila različite razine straha za engleski i francuski jezik. U Hrvatskoj je Puškar (2010) proveo poredbeno istraživanja straha od jezika i utvrdio viši strah kod studenata 
germanistike nego kod studenata anglistike, a Mardešić i Stanković (2013) su utvrdile niži strah od jezika kod studenata španjolskoga, nego kod studenata francuskoga i talijanskoga jezika.

Saito i suradnici (1999) utvrdili su da nema razlika u općem strahu od stranoga jezika s obzirom na ciljni jezik. Međutim, za strah od čitanja na stranome jeziku izmjeren upitnikom FLRAS (Saito i sur., 1999) među sudionicima koji su izvorni govornici engleskoga jezika utvrđene su razlike između triju ispitanih jezika, što je potvrdilo pretpostavku toga istraživanja. Najviša razina straha od čitanja utvrđena je za japanski, nešto niža za francuski, a najniža za ruski jezik. Rezultati našega istraživanja također su potvrdili našu pretpostavku o postojanju razlika u strahu od čitanja s obzirom na ciljni jezik.

\subsubsection{Tumačenje povezanosti straha od čitanja i razumijevanja teksta čitanjem na engleskome i njemačkome jeziku}

Kao mjera uspjeha u čitanju na engleskome i njemačkome jeziku korišteni su rezultati testova Razumijevanje teksta čitanjem na engleskome jeziku i Razumijevanje teksta čitanjem na njemačkome jeziku. Rezultati analize za engleski jezik pokazali su da postoji statistički značajna negativna umjerena povezanost straha od čitanja i uspjeha na testu razumijevanja teksta čitanjem. Rezultati analize za njemački jezik pokazali su da postoji statistički značajna negativna niska povezanost straha od čitanja i uspjeha na testu razumijevanja teksta čitanjem. Iz navedenoga zaključujemo da je povezanost straha od čitanja i razumijevanja teksta čitanjem manje izražena za njemački nego za engleski jezik. Moguće je da bi se za njemački jezik pokazalo da su neke druge varijable (motivacija ili strategije čitanja) više povezane s razumijevanjem teksta čitanjem nego strah, što bi bilo potrebno posebno ispitati. Povezanost straha od čitanja i razumijevanja čitanjem izraženija je za engleski jezik, što bi moglo uputiti na razmišljanje da bi povezanost nekih drugih varijabli (motivacije ili strategija čitanja) moguće bila manje izražena nego povezanost straha i razumijevanja čitanjem. No, takvo bi razmišljanje trebalo također posebno ispitati. 


\subsubsection{Tumačenje povezanosti straha od čitanja i zaključnih ocjena iz engleskoga i njemačkoga jezika}

Podatci o zaključnim ocjenama iz engleskoga i njemačkoga jezika u prvome, drugome i trećemu razredu srednje škole korišteni su kao mjera uspjeha u učenju engleskoga i njemačkoga jezika. Rezultati analize za engleski jezik pokazali su da postoji statistički značajna negativna umjerena povezanost straha od čitanja i zaključnih ocjena iz engleskoga jezika u prvome, drugome i trećemu razredu srednje škole. Rezultati analize za njemački jezik pokazali su da postoji statistički značajna negativna niska povezanost straha od čitanja i zaključnih ocjena iz njemačkoga jezika prvome, drugome i trećemu razredu srednje škole.

Iako se testom razumijevanja teksta čitanjem mjeri uspjeh u specifičnoj jezičnoj djelatnosti - čitanju, a ocjena obuhvaća sveukupnu procjenu jezičnoga znanja, možemo utvrditi da postoji konzistentnost $u$ navedenim rezultatima. Utvrđene statistički značajne povezanosti straha i dvaju mjera uspjeha negativne su za obje mjere uspjeha i za oba ispitivana jezika. Dobiveni nalaz o negativnoj povezanosti straha i uspjeha nije iznenadio. Polazeći od stajališta da je strah vjerojatno afektivni faktor koji najintenzivnije ometa proces učenja (Arnold i Brown, 1999) i da afektivna strana učenika ima vjerojatno najveći utjecaj na uspjeh ili neuspjeh u učenju jezika (Oxford, 1990), te uzevši u obzir rezultate dosadašnjih istraživanja, očekivali smo ovakav rezultat.

Veći broj istraživanja provedenih u različitim socioedukacijskim kontekstima u svijetu ukazala su na negativnu povezanost straha od stranoga jezika i uspjeha (Horwitz i sur., 1986; MacIntyre i Gardner, 1989, 1991; Phillips, 1992; Gardner i MacIntyre, 1993b; Gardner i sur., 1997; MacIntyre i sur., 1997; Bailey i sur., 1998; Abu-Rabia, 2004; Liu i Huang, 2011; Piechurska-Kuciel, 2011; Liu, 2012; Liu i Cheng, 2014), a na takvu povezanost ukazala su i istraživanja straha od stranoga jezika u Hrvatskoj (Mihaljević Djigunović, 2002; Mihaljević Djigunović i Legac, 2008; Puškar, 2010; Čiček, 2014; Karlak, 2014; Maturanec, 2015).

U mnogim istraživanjima straha od čitanja na stranome jeziku također je utvrđena negativna povezanost straha od čitanja i uspjeha na testu čitanja ili uspjeha u učenju jezika izraženoga zaključnom ocjenom (Saito i sur., 1999; Sellers, 2000; Argaman i Abu-Rabia, 2002; Mihaljević Djigunović, 2002; Hayati i Ghassemi, 2008; Zhao, 2009; Huang, 2012; Rajab i sur., 2012; Cabansag, 2013; Zhao i sur. 2013; Bensalem, 2017). 
Možemo zaključiti da su nalazi našega istraživanja u skladu s ovdje navedenima nalazima istraživanja odnosa straha od stranoga jezika, odnosno straha od čitanja na stranome jeziku i uspjeha u učenju jezika i uspjeha u čitanju na stranome jeziku.

Budući da strah izaziva slabljenje koncentracije i smanjenje kapaciteta procesuiranja pri čitanju, pojavljuju se ometajuće misli, pa će osoba koja osjeća strah vrlo vjerojatno postići lošiji uspjeh (Eysenck, 1979; Sellers, 2000; Gregersen, 2003). Takva situacija može izazvati i ulaganje pojačanoga napora u obavljanje zadatka i produljenje vremena obavljanja zadataka, pa možda učenik zbog straha i usporenosti neće ni obaviti zadatak u predviđenome vremenu, pa i tako ugroziti postizanje uspjeha (MacIntyre i Gardner, 1989). Čitanje je selektivan proces pri kojem čitatelj najprije dekodira na grafofonemskoj, a zatim na sintaktičko-semantičkoj razini. Procesuiranje se odvija u kratkoročnome i srednjoročnome pamćenju, a zatim se značenje prenosi u dugoročno pamćenje (Smith, 2004). Kao što se strah može pojaviti u svakoj od triju faza učenja jezika: u fazi ulaza informacije, fazi obrade i fazi izlaza (Tobias, 1979; 1986), te kao što je utvrđeno da oni sudionici istraživanja koji imaju strah od jezika u jednoj fazi imaju strah i u drugim dvjema fazama (MacIntyre i Gardner, 1994b), tako bismo mogli pretpostaviti da se strah može pojaviti i na svakoj spomenutoj razini procesuiranja pri čitanju i ometati čitanje. Strah može ometati kontrolu pokreta očiju i raspon obuhvaćenih jedinica pri čitanju, brzinu i točnost prepoznavanja riječi, razumijevanje rečenice i konteksta i povezivanje prijašnjega znanja s pročitanim tekstom. Budući da nakon čitanja često slijede i zadatci provjere razumijevanja pročitanoga teksta, strah može biti prisutan i u toj fazi. Upravo je to faza u kojoj se provodi ocjenjivanje, pa viši strah u toj fazi može biti povezan s lošijom ocjenom. Brantmeier (2005) i Rai i suradnici (2011) utvrdili su da sudionici istraživanja imaju višu razinu straha od usmenih i pismenih zadataka koji slijede nakon čitanja, nego razinu straha od čitanja za vrijeme čitanja teksta.

\subsubsection{Tumačenje povezanosti motivacije za učenje engleskoga i njemačkoga jezika i zaključnih ocjena iz engleskoga i njemačkoga jezika}

Kako bismo dobili uvid u povezanost motivacije za učenje engleskoga i njemačkoga jezika i uspjeha u učenju engleskoga i njemačkoga jezika provedene su korelacijske analize. Zaključne ocjene iz prvoga, drugoga i trećega razreda srednje škole uzete su kao mjera uspjeha u učenju 
jezika. Za engleski jezik utvrđena je statistički značajna pozitivna visoka povezanost motivacije za učenje engleskoga jezika i uspjeha u svim trima razredima srednje škole. Za njemački jezik utvrđena je statistički značajna pozitivna umjerena povezanost motivacije za učenje njemačkoga jezika i uspjeha u svim trima razredima srednje škole.

Naš nalaz o pozitivnoj povezanosti motivacije i uspjeha u skladu je s nalazima mnogih istraživanja koja su također ukazala su na pozitivnu povezanost ovoga važnoga afektivnoga faktora i uspjeha u učenju stranoga jezika (Gardner i Lambert, 1972; Gardner i sur., 1992, 1997; MacIntyre i sur., 1997; Noels i sur., 1999; Mihaljević Djigunović, 2002; Liu i Huang, 2011; Jósza, 2014; Ödemis i Uslu, 2014; Vidak, 2019). Polazeći od teorijskih razmatranja i empirijskih istraživanja, došlo se do zaključka da je među afektivnim faktorima u procesu učenja stranoga jezika motivacija faktor koji je relevantan za uspjeh u učenju. Na povezanost integrativne motivacije s uspjehom u učenju jezika upozorili su Gardner i Lambert (1972), a Rubin (1975) je motivaciju navela kao jednu od triju varijabli povezanih s uspješnim učenjem. Nalazi našega istraživanja mogli bi se tumačiti u tome smislu. Ako je učenik motiviran za učenje drugoga jezika, trudi se naučiti jezik zbog želje da ga nauči i zadovoljstva koje pritom osjeća. No, učenik je doista motiviran kada su njegova želja da postigne cilj učenja i pozitivni stavovi prema tome cilju povezani. Integrativnost i stavovi prema kontekstu učenja utječu na motivaciju, a motivacija utječe na jezično postignuće (Gardner, 1985, 2005). Na temelju dobivenih rezultata zaključujemo da je kod naših učenika motivacija za jezično postignuće povezana s uspjehom u jezičnome postignuću. Moguće je da integrativnost koja odražava interes za ovladavanje jezikom i pozitivni stavovi prema jeziku i učenju jezika podržavaju motivaciju za učenje. Ako podsjetimo da su sudionici našega istraživanja maturanti srednjoškolskih usmjerenja u kojima se poučavanju stranih jezika poklanja velika pozornost (gimnazijska i turističko-hotelijersko usmjerenja), te da ova usmjerenja obično izabiru učenici koji imaju interes za učenje stranih jezika, moglo se očekivati da će motivacija za učenje i uspjeh u učenju biti povezani. Djelovanje nastavnika i konteksta učenja na motivaciju jest važno (Gardner, 2005), no za regulaciju motivacije ključan je učenik. Motivaciju moraju pokretati učenikove osobne potrebe, ciljevi i interesi (Ushioda, 2008: 27). Hrvatska je članica Europske unije, ali i članica globalnoga modernoga društva koje karakterizira globalna komunikacija i mobilnost. Za školovanje, rad i usavršavanje u radu neophodno je poznavanje najmanje jednoga stranoga jezika, odnosno engleskoga kao međunarodnoga jezika, a poznavanje još jednoga stranoga jezika predstavlja dodatnu kompetenciju. Naši sudionici istraživanja su adolescenti koji odrastaju i školuju se u takvome sociocioedukacijskome kontekstu. Stoga bismo mogli 
pretpostaviti da oni prepoznaju važnost znanja stranih jezika, kao što je utvrđeno u istraživanju koje su provele Falkoni-Mjehović i suradnice (2016), te da se to odražava u njihovoj motivaciji za učenje jezika koja je povezana s postignućem u učenju.

\subsubsection{Tumačenje povezanosti razumijevanja teksta čitanjem i zaključne ocjene iz trećega razreda za engleski i njemački jezik}

Pri analizi povezanosti razumijevanja teksta čitanjem i uspjeha u učenju engleskoga i njemačkoga jezika željeli smo posebno analizirati zaključne ocjene iz trećega razreda srednje škole. Razlog tome jest da je zaključna ocjena iz trećega razreda vremenski najbliža terminu provođenju našega istraživanja. Stoga smo pri ispitivanju povezanosti razumijevanja teksta čitanjem odlučili uzeti u obzir najrecentniju mjeru školskoga uspjeha u učenju jezika posljednju zaključnu ocjenu.

Korelacijskim analizama utvrđeno je da postoji statistički značajna visoka pozitivna povezanost uspjeha na testu razumijevanja teksta čitanjem i zaključne ocjene za engleski i njemački jezik. Ti nalazi upućuju na zaključak da s porastom školske ocjene raste i uspjeh na testu čitanja. To bi značilo da oni učenici koji imaju visoke ocjene iz engleskoga i njemačkoga jezika ostvaruju i velik uspjeh u razumijevanju čitanjem na oba ispitivana jezika. Naš je nalaz u skladu s nalazom istraživanja uspjeha u razumijevanju čitanjem na engleskome jeziku među hrvatskim maturantima koje su proveli Geld i Stanojević (2007) i u kojemu su utvrdili da između školske ocjene i uspjeha na testu čitanja postoji blaga značajna povezanost.

Dobiveni nalazi upućuju na zaključak da je važno razvijati vještinu čitanja jer je to složena vještina i kognitivni proces koji je povezan s uspjehom u učenju stranoga jezika. No, nije samo važno razvijati vještinu čitanja, nego i čitalačku pismenost koja predstavlja temelj za uspjeh u mnogim drugim predmetnim područjima (PISA 2009 Čitalačke kompetencije za život, 2010). Da bi se pojedinci uspješno obrazovali i radili u suvremenome društvu znanja moraju biti sposobni razumjeti i promišljati o pisanim tekstovima. S obzirom na to da je engleski međunarodni jezik, to se osobito odnosi na razvijanje vještine čitanja i čitalačke pismenosti na engleskome jeziku. Budući da čitalačka pismenost uključuje skupinu kognitivnih kompetencija koje obuhvaćaju dekodiranje, poznavanje riječi, gramatičkih pravila, jezičnih i tekstualnih struktura, pa i metakognitivne kompetencije, za očekivati je bilo da uspješnost u čitanju na 
stranome jeziku može biti pozitivno povezana s uspješnošću u ovladavanju stranim jezikom u širem smislu.

\subsubsection{Tumačenje rezultata regresijskih analiza za engleski i njemački jezik}

Rezultati regresijske analize za engleski jezik pokazali su da strah od čitanja ukupno objašnjava $8,7 \%$ varijance uspjeha na testu razumijevanja teksta čitanjem, a motivacija za učenje engleskoga jezika ukupno objašnjava 17,3\% varijance uspjeha na testu razumijevanja teksta čitanjem. Sveukupno je s pomoću straha od čitanja i motivacije objašnjeno $17,4 \%$ varijance uspjeha na testu za engleski jezik, što čini gotovo jednu petinu varijance. Kad se strah od čitanja i motivacija uvrste zajedno kao prediktori uspjeha na testu, strah više nije značajan prediktor, dok motivacija za učenje engleskoga jezika ostaje značajan prediktor uspjeha na testu razumijevanja teksta čitanjem.

Izračunavanjem regresijskoga koeficijenta za indirektni efekt utvrđeno je da je motivacija za učenje engleskoga jezika značajan medijator u odnosu između straha od čitanja i uspjeha u testu razumijevanja teksta čitanjem za engleski jezik. Utvrđeno je da je odnos straha i uspjeha značajno posredovan motivacijom. Dakle, odnos straha od čitanja i uspjeha na testu razumijevanja teksta čitanjem manje je izražen ako se statistički uzme u obzir motivacija za učenje engleskoga jezika.

Regresijskom analizom utvrđeno je da strah od čitanja ukupno objašnjava 42,6\% varijance motivacije za učenje engleskoga jezika. Strah od čitanja objašnjava gotovo polovicu varijance motivacije za učenje engleskoga jezika i to upućuje na potencijalno preklapanje ovih dvaju konstrukata. Gardner, Day i MacIntyre (1992) su razmatrajući odnos straha i motivacije naveli da bi strah i motivacija mogli biti dva suprotna kraja jedne iste dimenzije (Gardner i sur., 1992: 212). Tim slijedom razmišljanja mogli bismo pretpostaviti da postoje učenici koji su motivirani i nemaju strah od čitanja i učenici koji nisu motivirani i imaju strah od čitanja na engleskome jeziku. No, Gardner, Day i MacIntyre u svojemu zaključnome razmatranju upućuju na to da bi se u budućim istraživanjima i faktorskim analizama motivaciju i strah moglo promatrati kao dva odvojena konstrukta među kojima postoji povezanost. Treba imati na umu da su se istraživanja Gardnera i njegovih suradnika provodila u Kanadi, dakle unutar specifične sociokulturne sredine. U Kanadi je 1969. donesen zakon o službenim jezicima koji je 
osiguravao jednak status engleskom i francuskom jeziku u svim institucijama Parlamenta i federalne vlade, a 1971. federalna vlada usvojila je politiku multikulturalizma u dvojezičnom okviru (Čičak-Chand, 1991: 2). U našem istraživanju ispituje se odnos straha od čitanja i motivacije za učenje engleskoga jezika, koji u hrvatskoj sociokulturnoj sredini ima status međunarodnoga jezika ili lingua franca. Sudionici našega istraživanja, kao i mnogi učenici u Hrvatskoj, engleski jezik uče od prvoga razreda osnovne škole, te su engleskome jeziku izloženi gotovo neprestano putem elektroničkih medija i u izvanškolskome okruženju. Na hrvatskim visokoškolskim ustanovama dio propisane ispitne literature moguće je naći samo na engleskome jeziku. S povećanim brojem studenata koji putem razmjene Erasmus programa dolaze na hrvatska sveučilišta nužno se uvode stručni kolegiji koji se izvode na engleskome jeziku. S obzirom na sve navedeno engleski jezik razlikuje se od njemačkoga i ostalih stranih jezika koji se poučavanju u hrvatskome socioedukacijskome kontekstu.

Rezultati regresijske analize za njemački jezik pokazali su da strah od čitanja ukupno objašnjava 2,5\% varijance uspjeha na testu razumijevanja teksta čitanjem, a motivacija za učenje njemačkoga jezika ukupno objašnjava 21,7\% varijance uspjeha na testu razumijevanja teksta čitanjem. Sveukupno je s pomoću straha od čitanja i motivacije objašnjeno 21,8\% varijance uspjeha na testu razumijevanja teksta čitanjem, što čini jednu petinu varijance. Kad se strah od čitanja i motivacija uvrste zajedno kao prediktori uspjeha na testu, strah više nije značajan prediktor, dok motivacija za učenje njemačkoga jezika ostaje značajan prediktor uspjeha na testu čitanjem teksta s razumijevanjem.

Izračunavanjem regresijskoga koeficijenta za indirektni efekt utvrđeno je da je motivacija za učenje njemačkoga jezika značajan medijator u odnosu između straha od čitanja i uspjeha u testu razumijevanja teksta čitanjem za njemački jezik. Kao i kod engleskoga jezika, pokazalo se da je odnos straha i uspjeha značajno posredovan motivacijom. Dakle, isto kao kod engleskoga jezika, odnos straha od čitanja i uspjeha na testu razumijevanja teksta čitanjem manje je izražen ako se statistički uzme u obzir motivacija za učenje njemačkoga jezika.

Regresijskom analizom utvrđeno je da strah od čitanja ukupno objašnjava $16,3 \%$ varijance motivacije za učenje njemačkoga jezika. Kada ovaj nalaz usporedimo s nalazom koji smo dobili za udio straha od čitanja u objašnjenju varijance motivacije za učenje engleskoga jezika možemo primijetiti da strah od čitanja na njemačkome jeziku objašnjava gotovo tri puta 
manje varijance motivacije za učenje njemačkoga jezika. Moglo bi se reći da ovaj nalaz upućuje na zaključak da su motivacija za učenje njemačkoga jezika i strah od čitanja na njemačkome jeziku uistinu dva odvojena konstrukta. Pri tumačenju usporedbe ovih nalaza treba imati na umu da se engleski i njemački jezik u hrvatskome socioedukacijskome kontekstu razlikuju s obzirom na status jezika i kontekst učenja. Utvrđene razlike u prirodi konstrukta motivacije za učenje jezika mogle bi se tumačiti s obzirom na te razlike. Moguće je da se priroda konstrukta mijenja ako se promatraju različiti jezici, te bi se regresijskim analizama u budućim istraživanjima drugih stranih jezika koji se poučavaju u hrvatskome socioedukacijskome kontekstu (francuski, španjolski, talijanski) moglo dodatno ispitati ovakvo tumačenje.

Regresijskim analizama utvrđeno je da je strah od čitanja negativni prediktor uspjeha u testu razumijevanja teksta čitanjem i za engleski i za njemački jezik. Nadalje, usporedbom regresijskih modela za oba jezika, može se primijetiti da je strah od čitanja bolji negativni prediktor uspjeha za engleski nego za njemački jezik. Međutim, s obzirom na razlike u distribuciji zavisnih varijabli dvaju modela, dobivene razlike možemo tretirati samo kao indikativne o tome da je strah od čitanja potencijalno snažniji ometajući čimbenik postizanja uspjeha u čitanju za engleski nego za njemački jezik.

Nalaz naše regresijske analize u skladu je s nalazom višestruke regresijske analize koju su provele Liu i Huang (2011) u Kini u kojoj je utvrđeno da je strah od engleskoga jezika najbolji negativni prediktor uspjeha u završnome semestralnome testu iz engleskoga jezika. Kao što su autorice navele za rezultate svojega istraživanja, slično bismo tumačenje mogli navesti i za rezultate našega istraživanja; za studente koji imaju viši strah od jezika moglo bi se pretpostaviti da postižu lošiji uspjeh u jeziku. U našem istraživanju strah od čitanja na engleskome jeziku predstavlja snažniji čimbenik koji ometa uspjeh u čitanju nego što je to slučaj za njemački jezik. Iako ne možemo tvrditi da je ta razlika statistički značajna budući da vrijednosti regresijskih koeficijenta dvaju modela nisu direktno usporediva, među ostalim i zbog razlika u distribuciji zavisne varijable, takav rezultat u skladu je s nalazima koje su dobili Liu (2012) na Tajvanu, Khodadady i Khajavy (2013) u Iranu i Ödemis i Uslu (2014) u Turskoj, koji su također utvrdili da je strah od jezika značajan negativan prediktor uspjeha u učenju engleskoga jezika. 
Moguće je da naši sudionici istraživanja nakon 12 godina učenja engleskoga jezika imaju visoka očekivanja koja sebi postavljaju, pa bi strah koji bi se mogao kod njih pojaviti trebalo tumačiti u kontekstu tih visokih očekivanja. Iako su naši sudionici na visokoj razini učenja (B1 ili više), strah može postojati i na naprednoj razini učenja (Saito i Samimy, 1996; Onwuegbuzie i sur. 1999; Kitano, 2001; Ewald 2007; Marscos-Llinás i Garau 2009; Tóth, 2009; Zhao, 2009; Puškar, 2010; Marzec-Stawiarska, 2014), te je moguće njegovo ometajuće djelovanje.

Regresijskim analizama utvrđeno je da je strah od čitanja negativni prediktor motivacije za učenje engleskoga i njemačkoga jezika. Nadalje, usporedbom vrijednosti regresijskih koeficijenta primjetno je da je strah bolji negativni prediktor motivacije za engleski nego za njemački jezik. Kao što je spomenuto ranije, takav obrazac rezultata sugerira da je strah od čitanja potencijalno snažniji ometajući čimbenik motivacije za engleski nego za njemački jezik.

Motivacija je pozitivni prediktor uspjeha u testu razumijevanja teksta čitanjem i na engleskome i na njemačkome jeziku. Nadalje, utvrđeno je da je motivacija bolji pozitivni prediktor uspjeha na testu za njemački nego za engleski jezik, što sugerira da motivacija ima važniju ulogu za uspjeh u čitanju kod njemačkoga nego kod engleskoga jezika.

Naš je nalaz u skladu s nalazima višestruke regresijske analize koju su provele Liu i Huang (2011), u kojoj je utvrđeno da je intrinzična motivacija pozitivan prediktor uspjeha na testu engleskoga jezika. Autorice su zaključile da bi se moglo se reći da bi učenici koji imaju višu razinu motivacije mogli imati tendenciju ostvarivanja boljega uspjeha. Rezultati regresijskih analiza koje su proveli Khodadady i Khajavy (2013) u Iranu i Ödemis i Uslu (2014) u Turskoj također su pokazali da je motivacija značajan pozitivan prediktor uspjeha u učenju engleskoga jezika.

Rezultati sugeriraju da je motivacija važniji čimbenik uspjeha u čitanju za njemački nego za engleski jezik. Ovaj nalaz upućuje na to da bi se pri učenju njemačkoga jezika jačanjem motivacije moglo pridonijeti povećanju uspjeha u učenju. Za engleski jezik je to manje izraženo. Učenici od početka svojega školovanja do mature uče engleski jezik i svjesni su nužne potrebe njegova poznavanja. Engleskom jeziku neprestano su izloženi i u formalnome 
obrazovnome kontekstu i izvan njega, te se za engleski jezik motivacija pokazuje kao manje izražen čimbenik uspjeha u čitanju nego za njemački jezik, za koji je, čini se, upravo motivacija za učenje jezika važan čimbenik uspjeha u čitanju. Učenici su čitanju na njemačkome jeziku izloženi gotovo isključivo u nastavnome kontekstu, te se tu može djelovati i na jačanje motivacije. Ako uzmemo u obzir da je kod hrvatskih srednjoškolaca motivacija za učenje njemačkoga niža od motivacije za učenje engleskoga (Mihaljević Djigunović i Bagarić, 2007a) i da je postignuta komunikacijska kompetencija za njemački jezik niža nego za engleski (Bagarić, 2007), još se više nameće zaključak o nužnome jačanju motivacije za učenje njemačkoga jezika kod hrvatskih srednjoškolaca.

Medijacijski je utjecaj, odnosno indirektni efekt motivacije na povezanost straha od čitanja i uspjeha u testu negativan i značajan i za engleski i za njemački jezik. Strah i uspjeh na testu negativno su povezani, a motivacija ima značajnu ulogu u toj povezanosti. Drugim riječima, odnos straha i uspjeha u testu manje je izražen ako se kontrolira motivacija kao medijacijska varijabla.

\subsubsection{Tumačenje rezultata dodatnih analiza}

Kako bismo dobili detaljniji uvid u ključni koncept našega istraživanja - strah od čitanja na engleskome i njemačkome jeziku - proveli smo regresijske analize za svaki jezik posebno, s pet varijabli koje smo uvrstili u prediktorski skup. Kao što je Tóth (2009) upozorila, pri istraživanjima straha od stranoga jezika potrebno je ispitati ne samo jednu varijablu, jedan prediktor, nego je potrebno sagledati i analizirati više relevantnih varijabli. Prediktorske varijable koje su uvrštene u našu analizu su: spol, vrsta srednje škole (srednjoškolsko usmjerenje), prosjek zaključnih ocjena iz engleskoga/njemačkoga jezika u trima razredima srednje škole, motivacija za učenje engleskoga/njemačkoga jezika i uspjeh na testu razumijevanja teksta čitanjem na engleskome/njemačkome jeziku.

\section{Rezultati višestruke regresijske analize sa strahom od čitanja na engleskome jeziku} kao zavisnom varijablom i navedenim prediktorima pokazali su da je sveukupno s pomoću pet varijabli objašnjeno 45,0\% varijance straha od čitanja, što čini gotovo pola varijance. Među svim prediktorskim varijablama najveći prinos strahu od čitanja na engleskome jeziku ima motivacija za učenje engleskoga jezika $(\beta=-, 621, p<, 001)$. Ovaj nalaz u skladu je s ranije 
spomenutim nalazom regresijske analize, kojom je utvrđeno da strah od čitanja ukupno objašnjava 42,6\% varijance motivacije za učenje engleskoga jezika. Sukladno ovdje iznesenim nalazima, možemo zaključiti da je viša razina motivacije za učenje engleskoga jezika povezana s nižom razinom straha od čitanja na engleskome jeziku.

Osim motivacije, kao značajni prediktor straha od čitanja na engleskome jeziku pokazao se i spol $(\beta=, 139, p<, 05)$. Pozitivna vrijednost regresijskoga koeficijenta $(0=$ muški; $1=$ ženski) pokazuje da učenice imaju višu razinu straha od čitanja od učenika.

\section{Rezultati višestruke regresijske analize sa strahom od čitanja na njemačkome}

jeziku kao zavisnom varijablom i navedenim prediktorima pokazali su da je sveukupno s pomoću pet varijabli objašnjeno $18,1 \%$ varijance straha od čitanja, što čini nešto manje od petine varijance. Možemo zaključiti da u usporedbi s modelom za engleski jezik isti prediktori objašnjavaju zamjetno manji postotak zavisne varijable za njemački jezik. Jedini značajan prediktor je motivacija za učenje njemačkoga jezika $(\beta=-, 402, p<, 001)$. Usporedbom s ranije spomenutim nalazom regresijske analize, u kojoj je utvrđeno da strah od čitanja ukupno objašnjava 16,3\% varijance motivacije za učenje njemačkoga jezika, vidimo da se radi o sličnom postotku objašnjene varijance. Sukladno nalazima, možemo zaključiti da je viša razina motivacije za učenje njemačkoga jezika povezana s nižom razinom straha od čitanja na njemačkome jeziku, a spol se nije pokazao značajnim prediktorom straha od čitanja na njemačkome jeziku.

Nalazi našega istraživanja, koji ukazuju da je spol jedan od prediktora straha od čitanja na engleskome jeziku, u skladu su s nalazima nekih ranijih istraživanja straha od engleskoga kao stranoga jezika. Abu-Rabia (2004) je u Izraelu utvrdio da je spol najbolji prediktor straha od engleskoga jezika. U istraživanju koje su proveli Arnaiz i Guillén (2012) u Španjolskoj spol se, uz ocjenu, dob i razinu učenja, pokazao kao jedan od prediktora straha. Piechurska-Kuciel (2008) je u Poljskoj utvrdila da je spol, uz mjesto stanovanja i stav prema nastavniku engleskoga jezika, jedan od prediktora straha od jezika.

Nalazi regresijske analize našega istraživanja upućuju na zaključak da učenice imaju višu razinu straha nego učenici kad se kontroliraju ostale četiri prediktorske varijable. Ovaj nalaz u skladu je s mnogim istraživanjima straha od stranoga jezika u kojima se utvrdila viša razina straha za učenice (Abu-Rabia, 2004; Elkhafaifi, 2005; Aydin, 2008; Piechurska-Kuciel, 
2008; Balemir, 2009; Koul i suradnici, 2009; Arnaiz i Guillén, 2012; Jafarigohar i Behrooznia, 2012; Park i French, 2013; Karabiyik i Özkan, 2017), te u skladu s nalazima istraživanja koje su proveli Benson i suradnici (1994). Naime, ispitujući strah od ocjenjivanja, autori su utvrdili da žene imaju tendenciju izvještavati o višoj razini zabrinutosti i negativnim osjećajima više nego muškarci. Ovo bi moglo biti jedno polazište za tumačenje našega rezultata. Ovdje bismo se mogli osvrnuti i na nalaze koje je dobila Piechurska-Kuciel (2012) u Poljskoj. Nalazi njezina istraživanja ukazuju na to da su učenice više posvećene učenju jezika, ozbiljnije pristupaju izvršavanju zadataka i osjećaju višu razinu straha od engleskoga jezika. Učenici osjećaju nižu razinu straha i nastavu stranoga jezika ne doživljavaju kao kontekst koji bi im izazvao strah i stres, za razliku od učenica koje to doživljavaju kao više ,žensko“ područje učenja, imaju viša vlastita očekivanja i izraženiju zabrinutost i strah. No, Clark i Trafford (1996) u svojem su kvalitativnome istraživanju ukazali na tumačenje da su učenice iskrenije i otvorenije kada odgovaraju na pitanja o sebi i svojim osjećajima, pa razlike s obzirom na spol možda možemo razmatrati i s takva polazišta. Tako bismo mogli pretpostaviti da su učenice iskrenije odgovarale na pitanja i u našem istraživanju. To bi nas navelo na razmišljanja da učenici nisu jednako iskreno odgovarali, što bi značilo da utvrđena razlika u razini straha s obzirom na spol moguće i ne postoji, iako je utvrđena u samoizvještavanju. Dosadašnja ispitivanja razlika u razini straha od stranoga jezika s obzirom na spol ukazala su na nekonzistentnost rezultata, a dobiveni rezultati tumačili su se u kontekstu specifičnosti sociokulturne sredine.

Kada su se spol i strah od čitanja analizirali zasebno, nije se pokazala statistički značajna razlika u strahu od čitanja između učenica i učenika ni za engleski ni za njemački jezik. Samo kada se uzmu u obzir druge varijable, uvrštene među prediktore straha (srednjoškolsko usmjerenje, prosjek zaključnih ocjena, motivacija za učenje jezika i uspjeh na testu razumijevanja teksta čitanjem), spol se pokazuje kao značajan prediktor, i to samo za engleski jezik. Takav obrazac rezultata sugerira mogućnost da su razlike između učenica i učenika u samoizvještenome strahu od čitanja posredovane drugim čimbenicima. Budući da nalazi ranijih istraživanja i naši rezultati ne daju podršku hipotezi o visokom i direktnom utjecaju spola na strah od čitanja, u zaključnome dijelu tumačenja fokusirat ćemo se na nalaz koji ukazuje na to da je motivacija značajan negativan prediktor straha od čitanja za oba jezika. 
Kada se veći broj varijabli koje zajedno djeluju u procesu učenja stranoga jezika analizira istovremeno višestrukom regresijskom analizom, nalazi upućuju na to da je i za engleski i za njemački jezik motivacija za učenje jezika značajan prediktor straha od čitanja. Nalazi pokazuju da u skupu prediktora motivacija ima veći prinos strahu od čitanja za engleski $(\beta=-, 621, p<, 001)$ nego za njemački jezik $(\beta=-, 402, p<, 001)$. Ovaj nalaz ukazuje na razlike u strukturi konstrukta straha od čitanja na engleskome i njemačkome jeziku, što bismo mogli tumačiti značenjem engleskoga kao prvoga stranoga jezika i njemačkoga kao drugoga stranoga jezika, te različitim nastavnim kontekstom ovih dvaju jezika.

Možemo zaključiti da je, sukladno nalazima regresijske analize, niža razina motivacije za učenje jezika povezna s višom razinom straha od čitanja. Na negativnu povezanost motivacije za učenje jezika i strah od jezika ukazali su Gardner i MacIntyre (1992), Gardner i suradnici (1997), Wei (2007), Papi (2010), Liu i Huang (2011) i Liu i Zhang (2013). U hrvatskome socioedukacijskome kontekstu utvrđena je negativna povezanost motivacije i straha u istraživanjima koje su proveli Mihaljević Djigunović (2000, 2002), Puškar (2010), Mardešić i Stanković (2013) i Čiček (2014).

S obzirom na to da je za oba ispitivana jezika utvrđeno da je motivacija za učenje jezika značajan prediktor straha od čitanja, mogli bismo zaključno reći da jačanjem motivacije možemo pridonijeti smanjenju straha od čitanja kod obaju jezika. 


\section{ZAKLJUČCI}

Na temelju provedenoga istraživanja stečen je uvid u odnos straha od čitanja i razumijevanja teksta čitanjem na engleskome i njemačkome kao stranome jeziku, uzimajući u obzir motivaciju za učenje engleskoga i njemačkoga jezika. Istraživanje je provedeno na uzorku specifične skupine učenika koji uče i engleski i njemački jezik, te se takvim izborom sudionika omogućilo ispitivanje istih učenika poredbenim istraživanjem koje je ukazalo na sličnosti i razlike $s$ obzirom na dva ispitivana jezika. Ovakvo poredbeno istraživanje odnosa straha od čitanja na stranome jeziku i uspjeha u čitanju na stranome jeziku omogućilo je uvid u rasvjetljavanje navedenoga odnosa u hrvatskome socioedukacijskome kontekstu učenja engleskoga i njemačkoga jezika. Kako bi se produbile spoznaje o strahu od čitanja na stranome jeziku ispitala se i uloga određenoga broja prediktorskih varijabli straha od čitanja na engleskome i njemačkome jeziku. Rezultati ovoga istraživanja upućuju na sljedeće zaključke:

1. Mjerni instrument koji je konstruiran za mjerenje straha od čitanja na engleskome jeziku i straha od čitanja na njemačkome jeziku za potrebe ovoga istraživanja je pouzdan i valjan. Time je ostvaren jedan od ciljeva istraživanja. Korištenjem ovoga mjernoga instrumenta u nekim budućim istraživanjima uslijedile bi provjere njegove konstruktne valjanosti na drugome uzorku i u drugome sociokulturnome kontekstu. Ovaj mjerni instrument mogao bi poslužiti i kao polazište za konstrukciju novoga mjernoga instrumenta za ispitivanje straha od čitanja na engleskome i njemačkome jeziku za neka buduća istraživanja u nekim drugim specifičnim socioedukacijskim kontekstima.

2. Razine straha od čitanja na engleskome jeziku $\left(A S=1,99 ; N_{e_{-} s}=157\right)$ i straha od čitanja na njemačkome jeziku $\left(A S=2,35 ; N_{n j \_}=155\right)$ su niske. Iako naši sudionici imaju nisku razinu straha, smatramo da i ovoj razini straha treba posvetiti pozornost $u$ nastavi engleskoga i njemačkoga jezika. Strah od čitanja negativno je povezan s uspjehom u čitanju na stranome jeziku, te stoga smanjivanje straha može pridonijeti postizanju boljega uspjeha u čitanju na stranome jeziku.

3. Strah od čitanja na engleskome i njemačkome jeziku je multidimenzionalan konstrukt. Postoje sličnosti i razlike u strukturi straha od čitanja s obzirom na strani jezik. Za engleski jezik utvrđena je trokomponentna struktura, a za njemački jezik peterokomponentna struktura straha od čitanja. Time je potvrđena hipoteza 2a. Unatoč 
utvrđenim razlikama u strukturi straha postoje sličnosti ekstrahiranih subskala koje predstavljaju kognitivnu, emocionalnu i jezičnu komponentu straha od čitanja na engleskome i njemačkome jeziku. Za njemački jezik utvrđene su tjelesna komponenta i komponenta djelovanja nastavnika. Kao što ni strah od stranoga jezika nije jednodimenzionalan konstrukt, tako ni strah od čitanja na stranome jeziku nije jednodimenzionalan. U konceptualizaciji straha od jezika govori se o njegovoj emocionalnoj, kognitivnoj i tjelesnoj komponenti koje su se u ovome istraživanju pokazale kao latentne dimenzije straha od čitanja na engleskome i njemačkome jeziku. Korelacijske analize ukazale su na povezanost među komponentama, što upućuje da se ekstrahirane komponente istraženoga fenomena ne manifestiraju zasebno jer su $\mathrm{u}$ interakciji. U borbi protiv straha od čitanja potrebno je djelovati imajući na umu komponente straha, ali ne zaboravljajući njihovu povezanost. Ta borba može obuhvatiti ovladavanje afektivnim strategijama i strategijama za smanjenje straha, jačanje samopouzdanja i motivacije za učenje, kontrolu negativnih osjećaja i promjenu negativnih stavova prema učenju, ovladavanje strategijama učenja, podršku nastavnika, te stvaranje poticajne i ugodne razredne atmosfere.

4. Ne postoje razlike u razinama straha od čitanja na engleskome i njemačkome jeziku s obzirom na spol. Tim nalazom potvrđena je hipoteza 3. U našem istraživanju spol se nije pokazao kao varijabla koja je povezana s razlikama u intenzitetu straha od čitanja.

5. Ne postoje razlike u razinama straha od čitanja na engleskome i njemačkome jeziku s obzirom na srednjoškolski smjer. Tim nalazom potvrđena je hipoteza 4. Našim istraživanjem bili su obuhvaćeni učenici srednjoškolskih smjerova koji se ne razlikuju s obzirom na status ispitivanih stranih jezika (engleski je prvi, a njemački drugi strani jezik), a ne razlikuju se znatnije ni s obzirom na broj nastavnih sati. Svi nastavnici koji poučavaju učenike našega istraživanja sudjeluju u radu istoga županijskoga stručnoga vijeća, a učenici žive i školuju se u socioedukacijskome kontekstu hrvatske najjužnije županije koja je gospodarski orijentirana turizmu i pomorstvu i u kojoj poučavanje ovih dvaju stranih jezika ima dugu tradiciju.

6. Postoje statistički značajne razlike u razinama straha od čitanja na engleskome i njemačkome jeziku s obzirom na jezik. Za njemački jezik utvrđena je viša razina straha $\left(A S=2,31 ; N_{e+n j}=139\right)$ nego za engleski jezik $\left(A S=1,92 ; N_{e+n j}=139\right)$. Tim nalazom 
potvrđena je hipoteza 2b. Razlike u intenzitetu straha od čitanja utvrđene za engleski i njemački jezik mogle bi se promatrati u kontekstu razlika u statusu engleskoga kao međunarodnoga jezika i njemačkoga kao stranoga jezika. Engleski kao jezik za međunarodnu komunikaciju gubi status stranoga jezika u Hrvatskoj, te se usvaja često i u širem izvannastavnome kontekstu. Njemački jezik percipira se kao strani jezik, a izloženost učenika njemačkome jeziku u izvannastavnome kontekstu puno je manja nego izloženost engleskome jeziku, što bi moglo biti povezano s višom razinom straha od čitanja na njemačkome jeziku. Moguće je da razlike u utvrđenim razinama straha odražavaju razlike u nastavnim kontekstima poučavanja ovih dvaju jezika, te razlike koje postoje na morfološkoj i sintaktičkoj razini između dvaju ispitivanih jezika.

7. Strah od čitanja na engleskome i njemačkome jeziku i uspjeh u čitanju na engleskome i njemačkome jeziku negativno su povezani, kada je test razumijevanja teksta čitanjem uzet kao mjera uspjeha u čitanju. Tim nalazom potvrđena je hipoteza 1 .

8. Strah od čitanja na engleskome i njemačkome jeziku i uspjeh u učenju engleskoga i njemačkoga jezika negativno su povezani, kada je zaključna ocjena na kraju prvoga, drugoga i trećega razreda srednje škole uzeta kao mjera uspjeha u učenju jezika.

Može se, dakle, zaključiti da su strah od čitanja na engleskome i njemačkome jeziku i uspjeh u čitanju, kao i strah od čitanja na engleskome i njemačkome jeziku i uspjeh u učenju jezika negativno povezani. Stoga svaka redukcija straha od čitanja potencijalno stvara mogućnost postizanja više razine čitanja, ali i mogućnost postizanja većega uspjeha u učenju jezika.

9. Motivacija za učenje engleskoga i njemačkoga jezika i uspjeh u učenju engleskoga i njemačkoga jezika pozitivno su povezani. Stoga zaključujemo da bi jačanje motivacije za učenje jezika moglo biti povezano s postizanjem boljega uspjeha u učenju jezika.

10. Uspjeh na testu razumijevanja teksta čitanjem i zadnja zaključna ocjena za engleski i njemački jezik pozitivno su povezani. Taj nalaz upozorava na važnost razvijanja vještine čitanja i čitalačke pismenosti koja predstavlja temelj za uspjeh ne samo u učenju stranoga jezika nego i temelj za uspjeh u mnogim drugim obrazovnim i profesionalnim područjima. 
11. Strah od čitanja na engleskome i njemačkome jeziku negativan je prediktor uspjeha u čitanju na engleskome i njemačkome jeziku, što ukazuje na ulogu straha kao ometajućega čimbenika u postizanju uspjeha u čitanju na engleskome i njemačkome jeziku. Nalaz upućuje na zaključak da smanjivanje straha od čitanja može pridonijeti povećanju uspjeha u čitanju na engleskome i njemačkome jeziku.

12. Strah od čitanja na engleskome i njemačkome jeziku negativan je prediktor motivacije za učenje engleskoga i njemačkoga jezika. S obzirom na to da je strah ometajući čimbenik za motivaciju, a motivacija pridonosi uspjehu, ovaj nalaz upućuje na nužnost borbe protiv straha od čitanja u cilju postizanja boljega uspjeha u čitanju na engleskome i njemačkome jeziku.

13. Motivacija za učenje engleskoga i njemačkoga jezika pozitivan je prediktor uspjeha u čitanju na engleskome i njemačkome jeziku. Pridonosi postizanju uspjeha, te je svako nastojanje koje je usmjereno poticanju motivacije usmjereno i poticanju uspjeha. $\mathrm{S}$ obzirom na to da su sudionici našega istraživanja adolescenti koji su već veći broj godina izloženi učenju engleskoga i njemačkoga jezika, te s obzirom da je motivacija podložna fluktuaciji kod ovakve dobne skupine, pozornost bi trebalo usmjeriti održavanju motivacije i sprječavanju smanjenja motivacije. To se osobito odnosi na njemački jezik za koji je već zabilježena tendencija smanjenja motivacije za učenje kod hrvatskih srednjoškolaca.

14. Motivacija za učenje engleskoga i njemačkoga jezika ima medijacijski utjecaj na povezanost straha i uspjeha u čitanju na engleskome i njemačkome jeziku. Tim nalazom potvrđena je hipoteza 5. Odnos straha od čitanja i uspjeha na testu razumijevanja teksta čitanjem manje je izražen ako se statistički uzme u obzir motivacija za učenje jezika. U borbi protiv straha od čitanja na engleskome i njemačkom kao stranome jeziku jačanje motivacije metoda je koja može biti među najučinkovitijima.

15. Značajni prediktori straha od čitanja za engleski jezik jesu spol i motivacija, a za njemački samo motivacija. Učenice imaju viši strah od čitanja na engleskome jeziku nego učenici, kada se kontrolira više prediktorskih varijabli. Korištenjem različitih strategija upravljanja strahom i metoda borbe protiv straha od čitanja može se pridonijeti 
smanjenju straha od čitanja na engleskome jeziku kod učenica. Budući da je motivacija za učenje jezika značajan negativan prediktor straha od čitanja za oba ispitivana jezika, ključno je naglasiti važnost jačanja i održavanja motivacije kao čimbenika koji može pridonijeti smanjenju straha od čitanja. 


\section{PREDNOSTI I NEDOSTATCI ISTRAŽIVANJA}

Dvije su glavne prednosti istraživanja provedenoga u okviru ovoga doktorskoga rada: konstrukcija i prva primjena specifičnoga mjernoga instrumenta o strahu od čitanja na stranome jeziku te provedba poredbenoga istraživanja straha od čitanja na engleskome i njemačkome jeziku u hrvatskome obrazovnome kontekstu na uzorku koji obuhvaća iste sudionike za oba ispitivana jezika.

Ovo istraživanje predstavlja pokušaj da se ispita odnos straha od čitanja i razumijevanja čitanjem na engleskome i njemačkome jeziku koji (prema našim saznanjima) nije ispitan u Hrvatskoj do sada. S tim ciljem konstruiran je novi mjerni instrument za mjerenje straha od čitanja na engleskome/njemačkome jeziku, a koji je prilagođen za mjerenje navedenoga konstrukta u ciljanoj populaciji. Ovo istraživanje omogućilo je stjecanje uvida u strukturu straha od čitanja na engleskome i njemačkome jeziku, ukazalo je na multidimenzionalnost ispitivanoga konstrukta, te na razlike u strukturama straha od čitanja između dva ispitivana jezika.

Jedna od prednosti ovoga istraživanja očituje se u konstrukciji i primjeni upitnika kao instrumenta za mjerenje straha od čitanja na engleskome/njemačkome jeziku. Korištenje upitnika omogućilo je prikupljanje podataka u relativno kratkom vremenu koje je za glavno istraživanje obuhvatilo period od dva mjeseca u tri grada Dubrovačko-neretvanske županije. Rezultati deskriptivne statistike $\mathrm{i}$ faktorskih analiza upitnika omogućili su detaljniji uvid u intenzitet ispitivanoga konstrukta i njegovu strukturu. U ovome istraživanju konstruiran je pouzdan mjerni instrument za mjerenje straha od čitanja na engleskome/njemačkome jeziku.

Izbor mjernih instrumenata za provođenje ovoga istraživanja predstavlja jednu od prednosti istraživanja. Korištenjem dvaju upitnika (upitnik o strahu od čitanja i upitnik o motivaciji) prikupljeni su subjektivni iskazi učenika o ispitivanim pojavama. Upitnik za ispitivanje motivacije već je bio validiran i prethodno korišten u opsežnijem istraživanju u hrvatskome socioedukacijskome kontekstu. Budući je tim upitnikom ispitana motivacija za učenje engleskoga i njemačkoga jezika, njime je omogućen širi uvid u koncept motivacije za učenje dvaju ispitivanih jezika. Korištenjem validiranoga testa znanja (testa za ispitivanje razumijevanja teksta čitanjem) primijenjen je objektivni test kojim se stekao uvid u uspjeh u razumijevanju teksta čitanjem na stranome jeziku. 
Specifična struktura uzorka predstavlja jednu od bitnih prednosti ovoga istraživanja. Sudionici istraživanja za oba ispitivana jezika su isti učenici koji uče engleski i njemački jezik. Mnoge ključne varijable su iste za pojedinoga učenika kada ga ispitujemo kao učenika engleskoga i kao učenika njemačkoga jezika. Provedba poredbenoga istraživanja omogućila je da se ispita postojanje razlika u strahu od čitanja za iste sudionike s obzirom na dva strana jezika, te da se stekne uvid u povezanost straha od čitanja i razumijevanja teksta čitanjem za oba ispitivana jezika, kao i povezanost straha od čitanja i zaključnih ocjena iz oba ispitivana jezika za iste sudionike istraživanja.

Prednost ovoga istraživanja očituje se i u činjenici da su se provele analize razlika u strahu od čitanja s obzirom na spol i srednjoškolsko usmjerenje, te se utvrdilo da ne postoje razlike u visini straha od čitanja s obzirom na spol i srednjoškolski smjer. Analizom razlika s obzirom na jezik utvrdilo se da je razina straha od čitanja viša za njemački nego za engleski jezik. Korelacijskim analizama utvrdilo se da postoji negativna povezanost straha od čitanja na engleskome i njemačkome jeziku s uspjehom na testu i zaključnim ocjenama iz engleskoga i njemačkoga jezika.

Prednost ovoga istraživanja pokazala se u mogućnosti provođenja regresijskih analiza koje su omogućile ispitivanje važnosti prediktora straha od čitanja i prediktora uspjeha u čitanju na engleskome i njemačkome jeziku, te utvrđivanje medijacijske uloge motivacije $u$ povezanosti straha od čitanja i uspjeha u čitanju na engleskome i njemačkome jeziku. Regresijske analize omogućile su uvid u važnost određenih prediktora straha od čitanja za dva ispitivana jezika, gdje se motivacija izdvojila kao značajan negativni prediktor straha od čitanja i na engleskome i na njemačkome jeziku. Višestruka regresijska analiza omogućila je da se simultano analizira veći broj varijabli koje su potencijalno bitne u procesu čitanja na stranome jeziku te se time stekao uvid u važnost individualnih čimbenika čitanja na stranome jeziku kada se zajednički uzmu u obzir.

Nedostatci ovoga istraživanja odnose se na metodološke aspekte. Iako su upitnici glavna metoda istraživanja u Hrvatskoj (Bagarić Medve i Pavičić Takač, 2015), strukturiranje upitnika za ispitivanje određenoga konstrukta sadržajno ograničava. U našem istraživanju upitnik je sadržavao 25 čestica koje moguće nisu obuhvatile ispitivani konstrukt u njegovoj cjelini. Kako bi se taj nedostatak nadišao u budućim istraživanjima, mogle bi se, uz upitnik, koristiti i druge 
istraživačke metode, osobito kvalitativne istraživačke metode jet kombiniranje metoda pridonosi povećanome stupnju valjanosti istraživanja i mogućnosti da se kompleksne pojave istraže s pomoću više vrsta analiza (Dörnyei, 2007). Jedno od ograničenja istraživanja proizlazi iz karakteristika uzorka koji su sačinjavali srednjoškolci koji uče ispitivane jezike gotovo isti broj godina, prema sličnim nastavnim planovima, te zbog toga nije bilo moguće ispitati razlike s obzirom na veći varijabilitet u nastavnim sadržajima, duljini učenja i broju nastavnih sati. Iako je to mogući nedostatak našega istraživanja, takav homogen uzorak omogućio nam je da ispitamo odnos straha od čitanja s ostalim varijablama (spol, motivacija i uspjeh u čitanju) među učenicima koji dijele slična obilježja s obzirom na nastavni sadržaj i broj nastavnih sati. Iako je veličina uzorka u našem istraživanju bila primjerena za korištene statističke postupke, replikacija na većem uzorku srednjoškolaca omogućila bi detaljniji uvid u ispitivanu pojavu. 


\section{IMPLIKACIJE I SMJERNICE ZA BUDUĆA ISTRAŽIVANJA}

Glavni rezultati ovoga istraživanja upućuju na zaključak da je strah od čitanja afektivna varijabla, koja može ometati čitanje na stranome jeziku i biti povezana s lošijim uspjehom u razumijevanju čitanjem na engleskome i njemačkome jeziku. Stoga bi bilo važno da učenici i nastavnici engleskoga i njemačkoga jezika budu upoznati s ovakvim nalazom kako bi mogli lakše prepoznati strah od čitanja te pronaći učinkovite metode borbe sa strahom od čitanja u nastavi engleskoga i njemačkoga jezika. Time bi se pridonijelo ostvarivanju boljega uspjeha u čitanju, kako u razrednome vrednovanju (zaključne ocjene na kraju školske godine), tako i pri standardiziranome vrednovanju na kraju srednje škole (polaganju ispita državne mature) ili nekome drugome standardiziranome vrednovanju jezičnoga znanja (polaganje međunarodno priznatih standardiziranih ispita poznavanja engleskoga i njemačkoga jezika). Osim toga, čitanje, uz pisanje, predstavlja pismenost, koju ovdje razumijevamo kao krovni termin koji obuhvaća ukupnost aktivnosti pismenih ljudi, od elementarnoga čitanja i pisanja do tih istih aktivnosti na najvišem mogućem stupnju kognitivne složenosti (Peti-Stantić, 2019). Čitanje je, uz pisanje, najsloženija od svih jezičnih djelatnosti. No, budući da nam čitanje nije urođeno, posebno se ističe važnost poučavanja čitanja, pa tako i poučavanje čitanja na stranome jeziku i ovladavanje čitanjem na stranome jeziku.

Rezultati faktorske analize pokazali su da struktura straha od čitanja nije ista za dva ispitivana jezika, što upućuje na zaključak da nastavnici trebaju pristupiti sagledavanju straha od čitanja na stranome jeziku polazeći od osobitosti jezika koji poučavaju i nastavnoga konteksta u kojemu se poučavanje odvija.

Nakon što učenici i nastavnici osvijeste da postoji strah od čitanja, mogu različitim metodama umanjiti ili ukloniti strah, počevši od metoda borbe protiv straha kao što su crtanje i analiza dijagrama straha (Foss i Reitzel, 1991), primjene afektivnih strategija opuštanja i samoohrabrivanja (Oxford, 1990), različitih metoda oslobađanja od straha (Crookall i Oxford, 1991) do njegovanja pozitivnoga pojma o sebi (Mihaljević Djigunović, 2002) te razvijanja učinkovitih strategija učenja (Oxford, 1990), čime se učenike osposobljava da se samostalno bore protiv straha i unaprjeđuju svoje učenje. Učinkovita borba protiv straha od stranoga jezika i uspješno učenje mogu se ostvariti samo u ugodnome i poticajnome razrednome ozračju (Bratanić, 1991; Hentig, 1997; Mihaljević Djigunović, 2002; Dörnyei i Murphy, 2004; Pivac, 2009; Didović Baranac, 2012). 
Nadalje, važan nalaz ovoga istraživanja uputio je na ulogu motivacije kao bitnoga afektivnoga faktora u učenju stranoga jezika za koji je utvrđeno da je pozitivan prediktor uspjeha u čitanju i negativan prediktor straha od čitanja na engleskome i njemačkome jeziku. Ovim istraživanjem utvrđeno je da je motivacija medijator u povezanosti straha od čitanja i uspjeha u čitanju na engleskome i njemačkome jeziku, te da je odnos straha od čitanja i uspjeha u razumijevanju teksta čitanjem manje izražen ako se statistički uzme u obzir motivacija. Danas znamo da je motivacija jedan od važnih faktora učenja pa isto tako znamo koliko je korisno razbiti uvriježene metode poučavanja naizgled malim pomacima, posebno u mogućnostima istinskoga individualnoga odabira (Peti-Stantić, 2019: 99).

Kada govorimo o metodama poučavanja, tada govorimo i o nastavnicima, koji se u suvremenome školskome kurikulumu promatraju kao organizatori i poticatelji stjecanja znanja. Njihova uloga postala je uloga pomagača (Dörnyei i Murphy, 2004) koji empatijom, prihvaćanjem i svojim integritetom stvaraju uvjete za poticajnu i opuštenu atmosferu učenja stranoga jezika (Vilke, 1977). Takva atmosfera, uz korištenje suvremenih i zanimljivih tekstova pri poučavanju čitanja, mogu pridonijeti motivaciji za učenje jezika, a time i smanjenju straha i povećanju uspjeha u čitanju i učenju stranoga jezika. Uz današnju dostupnu modernu tehnologiju i mogućnost korištenja interneta i tableta u nastavi, uz tekstove koji se nalaze u udžbenicima, nastavnici mogu s lakoćom u nastavi koristiti i autentične tekstove. Nastavnik bira tekstove s obzirom na njihovu metodičku funkciju, određuje metode obrade i način provjere razumijevanja pročitanoga. No, nastavnik može ponekad i učenicima prepustiti da sami odaberu tekst, te ih potaknuti da sami osmisle metode obrade teksta i vježbe razumijevanja teksta (PetiStantić, 2019). Time se potiče motivacija za čitanje i rad na tekstu. Evaluacija čitanja i provjera razumijevanja čitanjem može uslijediti tek nakon što su učenici tijekom priprema bili izloženi zadatcima kojima će se evaluirati njihova sposobnost razumijevanja pročitanoga teksta. Ako nastavnik nije poučavao čitanje s razumijevanjem, nije opravdano ni očekivati da učenici budu sposobni riješiti testove u kojima se upravo to traži. Dakle, jasnoća i dosljednost u poučavanju i provođenju kriterija ocjenjivanja može pridonijeti smanjenju straha, jačanju motivacije i uspjehu u ovladavanju čitanjem na stranome jeziku.

Unaprjeđivanjem čitanja unaprjeđuje se čitalačka pismenost, a ona je jedna od najvažnijih kompetencija koju učenici stječu tijekom svojega obrazovanja. Čitalačka pismenost predstavlja pretpostavku uspjeha u svim predmetnim područjima, temelj je nadogradnje našega 
iskustva, te preduvjet našega svjesnog, kritičkog i aktivnog sudjelovanja u mnogim segmentima svakodnevnoga života. Ako važnost čitalačke pismenosti sagledamo u širemu društvenome kontekstu, mnoga istraživanja pokazuju da je čitalačka pismenost bolji prediktor gospodarskoga rasta od obrazovnoga postignuća (Peti-Stantić, 2019). Sve to ukazuje na važnost unaprjeđenja čitanja kako na materinskome tako i na stranome jeziku.

Nastavnici u školama imaju mnogo prilika za razmjenu iskustava iz nastavnoga rada pa tako i iskustava vezanih uz prepoznavanje straha od čitanja i borbe protiv toga straha. Školski aktiv nastavnika stranih jezika predstavlja jednu mogućnost za takvu komunikaciju, kao i županijska stručna vijeća i regionalna vijeća nastavnika stranih jezika. Stručni skupovi nastavnika stranih jezika na državnoj razini predstavljaju najsveobuhvatniju platformu na kojoj se nalazi ovakvih i sličnih istraživanja i njihove pedagoške implikacije mogu prezentirati nastavnicima stranih jezika kako bi se ukazalo na važnost uloge straha i motivacije u procesu učenja stranoga jezika.

\section{$* * *$}

Kako bi se stekao detaljniji uvid u fenomen straha od čitanja na stranome jeziku, bilo bi nužno provoditi buduća istraživanja ove afektivne varijable učenja stranoga jezika. Smjernice za buduća istraživanja upućuju najprije na primjenu kvalitativnih metoda ispitivanja straha od čitanja, što bi uz primjenu kvantitativnih metoda omogućilo istraživačima triangulaciju podataka i bolje razumijevanje ispitivane pojave. Za ispitivanje straha od čitanja, uz upitnik bi se mogle koristiti metoda glasnoga navođenja misli i vođenje dnevnika. Kako bi se te metode mogle primijeniti, bilo bi potrebno sudionike istraživanja najprije poučiti načinu provođenja tih istraživačkih metoda i pripremiti ih na dulje trajanje provođenja takvih istraživanja.

U budućim istraživanjima moglo bi se provesti ispitivanje na većem i sveobuhvatnijem uzorku u Hrvatskoj, što bi omogućilo da se ispitaju razlike u strahu od čitanja na stranome jeziku s obzirom na različita srednjoškolska usmjerenja, različitu regionalnu pripadnost gradova i mjesta, razlike s obzirom na ostale strane jezike koji se uče u hrvatskim školama (francuski, španjolski i talijanski), te razlike s obzirom na dob (7-10 godina, 11-14 godina, 15-18 godina, odrasli). U budućnosti bi se mogla ispitati struktura straha od čitanja kod učenika koji su prvo počeli učiti njemački jezik, a potom engleski jezik. S obzirom da je moguće da iskustvo učenja prvoga stranoga jezika oblikuje iskustvo učenja drugoga stranoga jezika, bilo bi zanimljivo steći uvid u strukturu straha od čitanja i razlike u strahu od čitanja kod takvih učenika. 
Buduća istraživanja mogla bi ispitati odnos straha od čitanja na stranome jeziku prema općem strahu od stranoga jezika, pojmu o sebi, spremnosti na rizik i spremnosti na komunikaciju. Ispitivanje odnosa straha od čitanja i motivacije moglo bi se provesti koristeći specifičan mjerni instrument, upitnik o motivaciji za čitanje na stranome jeziku. Nadalje, moglo bi se provesti ispitivanja odnosa straha od čitanja, strategija čitanja i uspjeha u čitanju na stranome jeziku. Poredbena istraživanja više stranih jezika u kojima bi se ispitali ti odnosi omogućila bi uvid u razlike u strukturama straha od čitanja i strategija čitanja s obzirom na ciljni jezik. Ispitivanja odnosa straha od čitanja na materinskome jeziku i straha od čitanja na stranome jeziku u različitim socioedukacijskim kontekstima omogućila bi bolje razumijevanje jezične međuovisnosti i jezičnoga prijenosa.

U budućim istraživanjima straha od jezika mogao bi se ispitati odnos ove afektivne varijable učenja jezika s obzirom na druge jezične vještine: govorenje, pisanje i slušanje. Regresijskim analizama straha kao zavisne varijable i odabranih relevantnih varijabli stekao bi se detaljniji uvid u koncept i prediktore straha od stranoga jezika s obzirom na određenu jezičnu vještinu, a analiza i usporedba dobivenih nalaza omogućila bi bolje razumijevanje ove složene pojave. 


\section{LITERATURA}

Abu-Rabia, S. (2004). Teachers' Role, Learners' Gender Differences, and FL Anxiety Among Seventh-Grade Students Studying English as a FL. Educational Psychology, 24(5), 711-721.

Ahmad, I. S., Al-Shboul, M. M., Nordin, M. S. i Rahman, Z. A, Burhan, M. i Madarsha, K. B. (2013). The Potential Sources of Foreign Language Reading Anxiety in a Jordanian EFL Context: A Theoretical Framework. English Language Teaching, 6(11), 89-110.

Aida, Y. (1994). Examination of Horwitz, Horwitz, and Cope's construct of foreign language anxiety: The case of students of Japanese. The Modern Language Journal, 78, 155-168.

Aisyah, J. (2017). Students' Reading Anxiety in English Foreign Language Classroom. Journal of English and Education, 5(1), 56-63. Pristup 16. 6. 2019.

http://ejournal.upi.edu/index.php/L-E/article/view/9903/6317

Alderson, J. C. (1984). Reading in a foreign language: a reading problem or a language problem? U J. C. Alderson i A. H. Urquhart (ur.), Reading in a foreign language (str. 1-24). London: Longman.

Alderson, J. C. (2000). Assessing Reading. Cambridge: Cambridge University Press.

Alderson, J. C., Nagy, E. i Öveges, E. (ur.) (2000). English Language Education in Hungary. Part II. Examining Hungarian Learners' Achievements in English. Budapest: The British Council Hungary.

Alpert, R. i Haber, R. (1960). Anxiety in academic achievement situations. Journal of Abnormal and Social Psychology, 61, 207-215.

Alsaleh, A. K. (2017). Investigating Foreign Language Reading Anxiety among Imam Mohammad Ibn Saud Islamic University and Majma'ah University English Language Major Students. College of Languages and Translation, Al-Imam Muhammad Ibn Saud Islamic University, KSA (Master Thesis). Arab World English Journal (ID Number: 214 November 2018, 1-58. Pristup 1. 7. 2019. https://dx.doi.org/10.24093/awej/th.214 
Al-Shboul M. M, Ahmad, I. S., Nordin, M. S. i Rahman, Z. A. (2013). Foreign Language Reading Anxiety in a Jordanian EFL Context: A Qualitative Study. English Language Teaching, 6(6), 38-56.

Al-Sohbani, Y. (2018). Foreign Language Reading Anxiety among Yemeni Secondary School Students. International Journal of English Language and Translation Studies, 6(1), 57-65.

Argaman, O. i Abu-Rabia, S. (2002). The Influence of Language Anxiety on English Reading and Writing Tasks Among Native Hebrew Speakers. Language, Culture and Curriculum, 15(2), $143-160$.

Arnaiz, P. i Guillén, F. (2012). Foreign language anxiety in a Spanish university setting: the relation with gender, age and grade. Revista de Psicodidáctica, 17(1), 5-26.

Arnold, J. i Brown, H. D. (1999). A map of the terrain. U: J. Arnold (ur.), Affect in language learning (str. 1-24). Cambridge: Cambridge University Press.

Aydin, S. (2008). An investigation on the language anxiety and fear of negative evaluation among Turkish EFL Learners. Asian EFL Journal, 30(1), 421-444.

Bagarić, V. (2007). Razina komunikacijske kompetencije učenika engleskoga i njemačkoga jezika u pisanju i govorenju. Metodika, 8(1), 221-238.

Bagarić Medve, V. i Pavičić Takač, V. (2015). Istraživanja poučavanja inih jezika i ovladavanja njima. Strani jezici, 43(2), 81-103

Bailey, P., Onwuegbuzie, A. J. i Daley, C. E. (1998). Anxiety about Foreign Language among Students in French, Spanish, and German Classes. Psychological Reports, 82(3), 1007-1010.

Balemir, S. H. (2009). The sources of foreign language speaking anxiety and the relationship between proficiency level and degreee of foreign language speaking anxiety. (Unpublished Master's Thesis) Bilkent University, Turkey. Pristup 20. 6. 2019.

http://www.thesis.bilkent.edu.tr/0003883.pdf 
Baron, R. M. i Kenny, D. A. (1986). The Moderator-Mediator Variable Distinction in Social Psychological Research: Conceptual, Strategic, and Statistical Considerations. Journal of Personality and Social Psychology, 51(6), 1173-1182.

Bensalem, E. (2017). Exploring Foreign Language Anxiety among English-Major Undergraduate Students. Journal of the North for Humanities, Northern Border University, $2(1), 160-173$.

Benson, J., Bandalos, D., i Hutchinson, S. (1994). Modeling test anxiety among men and women. Anxiety, Stress \& Coping, 7(2), 131-148.

Berg, B. L. (2001). Qualitative Research Methods for the Social Sciences, $4^{\text {th }}$ Edition. Boston: Allyn and Bacon.

Berliner, D. C. (1989). Furthering our understanding of motivation and environments. U: C. Ames i R. Ames (ur.), Research on motivation in Education, Vol. 3: Goals and cognitions (str. 317-343). New York: Academic Press.

Bernhardt, E. B. (2000). Second language reading as a case study of reading scholarship in the twentieth century. U: M. Kamil, P. Mosenthal, P. D. Pearson i R. Barr (ur.), Handbook of reading research, Volume III (str. 793-811). Hillsdale, NJ: Erlbaum.

Bernhardt, E. B. (2003). New directions in reading research: Second language perspectives. Reading Research Quarterly, 37(4), 112-117.

Bernhardt, E. B. (2005). Progress and procrastination in second language reading. Annual Review of Applied Linguistics, 25, 133-150.

Bernhardt, E. B. (2011). Understanding Advanced Second-Language Reading. New York: Routledge. 
Bernhardt, E. B. i Kamil, M. L. (1995). Interpreting relationships between L1 and L2 reading: Consolidating the linguistic threshold and the linguistic interdependence hypotheses. Applied Linguistics, 16, 15-34.

Bloome, D. (1993). Necessary indeterminacy and the microethnographic study of reading as a social process. Journal of Research in Reading, 16(2), 98-111.

Božinović, N. i Didović Baranac, S. (2011). Strah od stranoga jezika u razrednom okruženju. U: J. Vučo i B. Milatović (ur.), Međunarodni tematski zbornik radova Stavovi promjena promjena stavova (str. 239-249). Nikšić: Filozofski fakultet Nikšić, Univerzitet Crne Gore.

Brantmeier, C. (2005). Anxiety about L2 reading or L2 reading tasks? A study with advanced language learners. The Reading Matrix, 5(2), 67-85.

Bratanić, M. (1991). Mikropedagogija: interakcijsko-komunikacijski aspekt odgoja. Priručnik za studente i nastavnike. Zagreb: Školska knjiga.

Brownell, W. W. i Katula, R. A. (1984). The communication anxiety graph: A classroom tool for managing speech anxiety. Communication Quarterly, 32, 243-249.

Buben, K. (2018). Listening and speaking anxiety in Croatian EFL learners. Diplomski rad. Sveučilište u Zagrebu. Pristup 12. 5. 2019.

http://darhiv.ffzg.unizg.hr/id/eprint/10529/1/Katarina\%20Buben Listening\%20and\%20speaki ng\%20anxiety\%20in\%20Croatian\%20EFL\%20learners.pdf

Buss, A. H. (1997). A dual conception of shyness. U: J. A. Daly i sur. (ur.), Avoiding Communication: Shyness, Reticence, and Communication Apprehension (str. 109-128). Cresskill, NJ: Hampton Press.

Cabansag, J. N. (2013). English language anxiety and reading comprehension. Performance of college students in a state university. Researchers World Journal of Arts, Science \& Commerce, 4(4), 20-31. 
Canary, D. J., i Hause, K. S. (1993). Is there any reason to research sex differences in communication? Communication Quarterly, 41(2), 129-144.

Capan, S. A. i Karaca, M. (2013). A comparative study of listening anxiety and reading anxiety. Akdeniz Language Studies Conference 2012. Procedia - Social and Behavioral Sciences 70, $1360-1373$.

Carpenter, P. A. i Just, M. A. (1977). Reading comprehension as eyes see it. U: M. A. Just i P. A. Carpenter (ur.), Cognitive processes in comprehension (str. 109-139). Hillsdale, NJ: Erlbaum.

Carr, T. H. i Levy, B. A. (ur.) (1990). Reading and its development: Component skills approaches. San Diego: Academic Press.

Carrell, P. (1991). Second Language Reading: Reading ability or language proficiency?. Applied Linguistics, 12, 159-179.

Chastain, K. (1975). Affective and ability factors in second language acquisition. Language Learning, 25, 153-161.

Cheng, Y.-S., Horwitz, E. K. i Schallert, D. L. (1999). Language anxiety: differentiating writing and speaking components. Language Learning, 49, 417-446.

Clark, A. i Trafford, J. (1996). Return to gender: boys' and girls' attitudes and achievements. The Language Learning Journal, 14(1), 40-49.

Clément, R. (1980). Ethnicity, Contact, and Communicative Competence in a Second Language. U: Giles, H. M., Robinson, W. P. and Smith, P. M. (ur.), Language: Social Psychological Perspectives (str. 147-159). Oxford: Pergamon Press.

Clément, R., Gardner, R. C. i Smythe, P. C. (1977). Motivational variables in second language acquisition: A study of Francophones learning English. Canadian Journal of Behavioural Science/Revue canadienne des sciences du comportement, 9(2), 123-133. 
Clément, R. i Kruidenier, B. G. (1985). Aptitude, attitude and motivation in second language proficiency: A test of Clément's model. Journal of Language and Social Psychology, 4, 21-37.

Clément, R., Smythe, P. C. i Gardner, R. C. (1978). Persistence in second language study: motivational considerations. Canadian Modern Language Review, 34, 688-694.

Crookall, D. (1983). Helping learners to deal with anxiety: An essential component in learner training. Simulation/Games for Learning, 20, 2.

Crookall, D. i Oxford, R. (1991). Dealing with anxiety: Some practical activities for language learners and teacher trainees. U: E. K. Horwitz i D. J. Young (ur.), Language Anxiety. From Theory and Research to Classroom Implications (str. 141-150). Englewood Cliffs, NJ: Prentice Hall.

Crookes, G. i Schmidt, R. W. (1991). Motivation: Reopening the research agenda. Language Learning, 41, 469-512.

Crystal, D. (2008). A Dictionary of Linguistics and Phonetics. (6. izdanje). Blackwell Publishing.

Csizér, K. i Dörnyei, Z. (2005). The Internal Structure of Language Learning Motivation and Its Relationship with language Choice and Learning Effort. The Modern Language Journal, 89(i), 19-36.

Cummins, J. (1979). Linguistic Interdependence and the Educational Development of Bilingual Children. Review of Educational Research, 49(2), 222-251.

Cummins, J. (1986). Empowering minority students: a framework for intervention. Harvard Educational Review, 56(1), 18-36.

Cummins, J. (1991). Conversational and academic language proficiency in bilingual contexts. AILA Review, 8, 75-89. 
Cummins, J. (2005). Teaching for Cross-Language Transfer in Dual Language Education: Possibilities and Pitfalls. TESOL Symposium on Dual Language Education: Teaching and Learning Two Languages in the EFL Setting at Boğaziçi University Istanbul, Turkey /online/. Preuzeto 9. 8. 2019. s https://www.tesol.org/docs/default-source/new-resourcelibrary/symposium-on-dual-language-education- 3 .pdf?sfvrsn $=0 \& \operatorname{sfvrsn}=0$

Čičak-Chand, R. (1991). Naznake o nekim etničkim manjinama u Kanadi. Migracijske i etničke teme, $7(1), 1-12$.

Čiček, L. (2014). Language anxiety - causes and consequences. Diplomski rad. Sveučilište u Zagrebu. Pristup 12. 5. 2019.

http://darhiv.ffzg.unizg.hr/id/eprint/5900/1/Language\%20learning\%20anxiety\%20\%20causes\%20and\%20conse.pdf

Čudina-Obradović, M. (2014). Psihologija čitanja-od motivacije do razumijevanja. Zagreb: Golden marketing-Tehnička knjiga, Učiteljski fakultet Sveučilišta u Zagrebu.

Daly, J. (1991). Understanding Communication Apprehension: An Introduction for Language Educators. U: E. K. Horwitz i D. J. Young (ur.), Language Anxiety: From Theory and Research to Classroom Implications (str. 3-13). Englewood Cliffs, NJ: Prentice Hall.

De Bot, K., Lowie, W. i Verspoor, M. (2007). A Dynamic Systems Theory approach to second language acquisition. Bilingualism: Language and Cognition, 10(1), 7-21.

De Costa, P. I. i Norton, B., (2017). Introduction: Identity, Transdisciplinarity, and the Good language Teacher. The Modern Language Journal, 101, 3-14.

Deci, E. L. i Ryan, R. M. (1985). Intrinsic Motivation and Self-Determination in Human Behavior, New York: Plenum.

Dewaele, J.-M. (2007). The effect of multilingualism, sociobiographical, and situational factors on communicative anxiety and foreign language anxiety of mature language learners. International Journal of Bilingualism, 11(4), 391-409. 
Didović Baranac, S. (2012). Razredno ozračje kao kurikulumska sastavnica u nastavi stranoga jezika. Magistarski rad. Filozofski fakultet Sveučilišta u Zagrebu.

Didović Baranac, S., Falkoni-Mjehović, D. i Vidak, N. (2016). Ispitivanje stavova prema učenju engleskoga, njemačkoga i španjolskog kao stranog jezika i jezika struke. U: V. Vrtiprah (ur.), 3. Zbornik Sveučilišta u Dubrovniku (str. 11-31). Dubrovnik: Sveučilište u Dubrovniku.

Dörnyei, Z. (1994). Motivation and Motivating in the foreign language classroom. Modern Language Journal, 78, 3, 273-284.

Dörnyei, Z. (1998). Motivation in second and foreign language learning. Language Teaching, $31,3,117-135$.

Dörnyei, Z. (2000). Motivation in action: towards a process-oriented conceptualisation of student motivation. British Journal of Educational Psychology, 70, 519-538.

Dörnyei, Z. (2001). Motivational Strategies in the Language Classroom. New York: Cambridge University Press.

Dörnyei, Z. (2005). The psychology of the language learner: Individual differences in second language acquisition. Mahwah, NJ: Lawrence Erlbaum.

Dörnyei, Z. (2007). Research Methods in Applied Linguistics. Oxford: Oxford University Press.

Dörnyei, Z. (2009). The Psychology of Second Language Acquisition. Oxford: Oxford University Press.

Dörnyei, Z. i Csizér, K. (2002). Motivational Dynamics in Second Language Acquisition: Results of a Longitudinal Nationwide Survey. Applied Linguistics, 23, 421-462.

Dörnyei, Z., Csizér, K. i Németh, N. (2006). Motivation, Language Attitudes and Globalisation: A Hungarina Perspective. Clevedon, Buffalo, Toronto: Multilingual Matters Ltd. 
Dörnyei, Z. i Murphey, T. (2004). Group Dynamics in the Language Classroom. Cambridge: Cambridge University Press.

Dörnyei, Z. i Otto, I. (1998). Motivation in action: A process model of L2 motivation. Working Papers in Applied Linguistics, 4, 43-69.

Dörnyei, Z. i Ryan, S. (2015). The Psychology of the Language Learner Revisited. New York, NY: Routledge.

Dörnyei, Z. i Ushioda, E. (2009). Motivation, language identities and the L2 self: Future research directions. U: Z. Dörnyei i E. Ushioda (ur.), Motivation, Language Identity and the L2 Self (str. 350-356). Bristol: Multilingual Matters.

Dörnyei, Z. i Ushioda, E. (2011). Teaching and Researching Motivation (Second Edition). Harlow; UK: Pearson Education Limited.

Elkhafaifi, H. (2005). Listening Comprehension and Anxiety in the Arabic Language Classroom. The Modern Language Journal, 89(2), 206-220.

Ellis, N. C. i Larsen-Freeman, D. (2006). Language Emergence: Implications for Applied Linguistics - Introduction to the Special Issue. Applied Linguistics, 27 (4), 558-589.

Ely, C. M. (1989). Tolerance of Ambiguity and Use of Second Language Strategies. Foreign Language Annals, 22, 437-446.

Ewald, J. D. (2007). Foreign Language Learning Anxiety in Upper-Level Classes: Involving Students as Researchers. Foreign Language Annals, 40(1), 122-142.

Eysenck, M. W. (1979). Anxiety, learning and memory: A reconceptualization. Journal of Research in Personality, 13, 363-385.

Falkoni-Mjehović, D., Vidak, N. i Didović Baranac, S. (2016). Povezanost stavova i uspjeha u učenju engleskoga, njemačkog i španjolskog kao stranog jezika. U: S. L. Udier i K. Cergol Kovačević (ur.), Metodologija i primjena lingvističkih istraživanja. Zbornik radova s 
međunarodnoga znastvenog skupa Hrvatskoga društva za primijenjenu lingvistiku (str. 377395). Zagreb: Srednja Europa, HDPL.

Fekete, H., Major, É. i Nikolov, M. (ur.) (1999). English Language Education in Hungary: A Baseline Study. Budapest: British Council Hungary.

Finocchiaro, M. (1974). English as a Second Language: From Theory to Practice. New York: Regents Publishing Company.

Foss, K. A. i Reitzel, A. C. (1991). A relational model for managing second language anxiety. U E. K. Horwitz i D. J. Young (ur.), Language Anxiety: From Theory and Research to Classroom Implications (str. 129-140). Englewood Cliffs, NJ: Prentice Hall.

Gardner, R. C. (1985). Social psychology and second language learning: The role of attitudes and motivation. London, United Kingdom: Edward Arnold.

Gardner, R. C. (2005). Integrative motivation and second language acquisition. Canadian Association of Applied Linguistics, Joint Plenary Talk, London. Pristup 15. 5. 2019. http://publish.uwo.ca/ gardner/docs/caaltalk5final.pdf

Gardner, R. C. (2006). Motivation and Second Language Acquisition. Manuscipt is the basis of an address by the author to the Seminario Sobre Plurilingüismo: Las Aportaciones Del Centro Europeo de Lenguas Modernas de Graz, on December 15, 2006 at the Universidad de Alcalá, Spain. Pristup 15. 5. 2019. http://publish.uwo.ca/ gardner/docs/SPAINTALK.pdf

Gardner, R. C., Day, J. B. i Maclntyre, P. D. (1992). Integrative Motivation, Induced Anxiety, and Language Learning in a Controlled Environment. Studies in Second Language Acquisition, 14(2), 192-214.

Gardner, R. C. i Lambert, W. E. (1972). Attitudes and Motivation in Second-Language Learning. Rowley, MA: Newbury House.

Gardner, R. C. i MacIntyre, P. D. (1992). A student's contribution to second language learning. Part I: Cognitive variables. Language Teaching, 25, 211-220. 
Gardner, R. C. i MacIntyre, P. D. (1993a). A student's contribution to second language learning. Part II: Affective variables. Language Teaching, 26, 1-11.

Gardner, R. C. i MacIntyre, P. D. (1993b). On the Measurement of Affective Variables in Second Language Learning. Language Learning, 43(2), 157-194.

Gardner, R. C., Smythe, P. C. i Brunet, G. R. (1977). Intensive Second Language Study: Effects on Attitudes, Motivation and French Achievement. Language Learning, 27(2), 243-261.

Gardner, R. C., Tremblay, P. F. i Masgoret, A.-M. (1997). Towards a Full Model of Second Language Learning: An Empirical Investigation. The Modern Language Journal, 81(3), 344362.

Geld, R. i Stanojević, M.-M. (2007). Razumijevanje teksta čitanjem: statistička analiza rezultata testova za osnovne i srednje škole. Metodika, 8(1), 148-159.

Goodman, K. S. (1967). Reading: A psycholinguistic guessing game. Journal of the Reading Specialist, 6, 126-135.

Goodman, K. S. (1998). The reading process. U: P. L. Carell i D. E. Eskey (ur.), Interactive approaches to second language reading (str. 11-21). Cambridge: Cambridge University Press.

Goodman, K. S. i Goodman, Y. M. (1977). Learning about Psycholinguistic Processes by Analyzing Oral Reading. Harvard Educational Review, 47(3), 317-333.

Gough, P. B. (1972). One second of reading. U F. J. Kavanagh i G. Mattingly (ur.) Language by Ear and by Eye. (str. 27-68). Cambridge, MA: MIT Press.

Gough, P. B. i Tunmer, W. E. (1986). Decoding, reading, and reading disability. Remedial and Special Education, 7, 6-10. 
Grabe, W. (1999). Developments in reading research and their implications for computeradaptive reading assessment. U: M. Chaloub-DeVille (ur.), Issues in Computer-adaptive Testing of Reading Proficiency (str. 11-47), Cambridge: Cambridge University Press.

Grabe, W. (2009). Reading in a Second Language: Moving from Theory to Practice. New York, NY: Cambridge University Press.

Grabe, W. i Stoller, F. L. (2011). Teaching and Researching Reading. London and New York: Routledge.

Gregersen, T. S. (2003). To Err is Human: A Reminder to Teachers of Language-Anxious Students. Foreign Language Annals, 36(1), 25-32.

Gregersen, T. i Horwitz, E. K. (2002). Language Learning and Perfectionism: Anxious and Non-Anxious Language Learners' Reactions to Their Own Oral Performance. The Modern Language Journal, 86(4), 562-570.

Hassaskhah, J. i Joghataeian, S. (2016). The Role of Foreign Language Reading Anxiety in Advanced Learners' Foreign Language Reading Comprehension. Journal of Applied Linguistics and Language Research, 3(6), 80-95.

Hayati, A. M. i Ghassemi, E. (2008). The Effect of Anxiety on Reading Comprehension Across Genders: A Case of Iranian EFL Learners. The Iranian EFL Journal, 2, 101-123.

Hentig, H. (1997). Humana škola. Zagreb: Educa.

Higgins, C. (2015). Intersecting scapes and new millennium identities in language learning. Language Teaching, 48, 373-389.

Higgins, E. T. (1987). Self-discrepancy: A theory relating self and affect. Psychological Review, 94, 319-340.

Horwitz, E. K. (1988). The Beliefs about Language Learning of Beginning University Foreign Language Students. Modern Language Journal, 72, 283-294. 
Horwitz, E. K. (2001). Language Anxiety and Achievement. Annual Review of Applied Linguistics, 21, 112-126.

Horwitz, E. K. (2016). Reflections on Horwitz (1986), "Preliminary Evidence for the Validity and Reliability of a Foreign Language Anxiety Scale." TESOL Quarterly, 50(4), 932-935.

Horwitz, E. K., Horwitz, M. B. i Cope, J. (1986). Foreign Language Classroom Anxiety. The Modern Language Journal, 70(2), 125-132.

Horwitz, E. K. i Young, D. J. (1991). Language Anxiety: From Theory and Research to Classroom Implications. Englewood Cliffs, NJ: Prentice Hall.

Huang, Q. (2012). Study on correlation of foreign language anxiety and English reading anxiety. TPLS Theory and Practice in Language Studies, 2(7), 1520-1525.

Huey, E.B. (1908). The psychology and pedagogy of reading. New York: Macmillan.

Jafarigohar, M. i Behrooznia, S. (2012). The Effect of Anxiety on Reading Comprehension among Distance EFL Learners. International Education Studies, 5(2), 159-174.

Jelaska, Z. (2007). Ovladavanje jezikom: izvornojezična i inojezična istraživanja. Lahor: časopis za hrvatski kao materinski, drugi i strani jezik, 1(3), 86-99.

Jelić, A.-B. (2004). Vještina čitanja na stranom jeziku: teorijska ishodišta. Strani jezici, 33(12), 19-33.

Jelić, A.-B. (2009). Čitanje, usvajanje vokabulara i strateško ponašanje učenika stranog jezika. Društvena istraživanja: časopis za opća društvena pitanja, 18, 4-5 (102-103), 895-911.

Joo, K. Y. i Damron, J. (2015). Foreign Language Reading Anxiety: Korean as a Foreign Language in the United States. National Council of Less Commonly Taught Languages, JNCOLCTL Volume 17, 23-55. Pristup 2. 5. 2019. http://www.ncolctl.org/files/ForeignLanguage.pdf 
Karabiyik, C. i Özkan, N. (2017). Foreign language anxiety: A study at Ufuk University Preparatory School. Journal of Language and Linguistic Studies, 13(2), 667-680.

Karlak. M. (2014). Odnos strategija učenja, motivacije i komunikacijske jezične kompetencije u stranom jeziku. Doktorski rad, Sveučilište Josipa Jurja Strossmayera u Osijeku. Pristup 1. 3. 2019.https://bib.irb.hr/datoteka/697342.MENTORuserprofilesmputnikDesktopDoktorski_rad _-_Manuela_Karlak___2014.pdf

Khodadady, E. i Khajavy, G. H. (2013). Exploring the Role of Anxiety and Motivation in Foreign Language Achievement: A Structural Equation Modeling Approach. Porta Linguarum, 20, 269-286.

Kim, Y. (2002). Construction of a theoretical model of foreign language anxiety and development of a measure of the construct: Korean university EFL learners' case. Unpublished doctoral dissertation. Indiana University.

Kitano, K. (2001). Anxiety in the College Japanese Language Classroom. The Modern Language Journal, 85(4), 549-566.

Koda, K. (2004). Insights into second language reading: A Cross-Linguistic Approach. Cambridge: Cambridge University Press.

Koda, K. (2007). Reading and Language Learning: Crosslinguistic Constraints on Second Language Reading Development. Language Learning, 57, 1-44.

Kostić-Bobanović, M. (2009). Foreign language anxiety of university students. Economic research - Ekonomska istraživanja, 22(3), 47-55.

Koul, R., Roy, L., Kaewkuekool, S., i Ploisawaschai, S. (2009). Multiple goal orientations and foreign language anxiety. System, 37(4), 676-688.

Krashen, S. D. (1981). Second language acquisition and second language learning. Oxford: Pergamon. 
Krashen, S. D. (1982). Principles and Practice in Second Language Acquisition. New York: Pergamon.

Kuru-Gonen, I. (2009). The sources of foreign language reading anxiety of students in a Turkish EFL context. Proceedings of the 5th WSEAS/IASME International Conference on EDUCATIONAL TECHNOLOGIES (EDUTE' $\quad$ 09) $\quad$ Pristup 19.4. 2019.https://pdfs.semanticscholar.org/665c/2ea3e365fc5f1f0a95ebfdec1fe5dcd2f022.pdf

Laine, E. (1987). Affective factors in foreign language learning and teaching: the study of the filter. Jyväskylä Cross-Language Studies, No. 13. University of Jyväskylä. Pristup 20. 2. 2019. https://files.eric.ed.gov/fulltext/ED292302.pdf

Lally, C. (1998). The Application of First Language Reading Models to Second Language Study: A Recent Historical Perspective, Reading Horizons: A Journal of Literacy and Language Arts, 38(4), 267-277.

Larsen-Freeman, D. (1997). Chaos/complexity science and second language acquisition. Applied Linguistics, 18, 141-165.

Larsen-Freeman, D. (2006). The Emergence of Complexity, Fluency, and Accuracy in the Oral and Written Production of Five Chinese Learners of English. Applied Linguistics, 27(4), 590619.

Liu, H.-J. (2012). Understanding EFL Undergraduate Anxiety in Relation to Motivation, Autonomy, and Language Proficiency. Electronic Journal of Foreign Language Teaching, 9(1),123-139. Pristup 20. 7. 2019. http://e-flt.nus.edu.sg/v9n12012/liu.pdf

Liu, H.-J. i Cheng, S.-H. (2014). Assessing Language Anxiety in EFL Students with Varying Degrees of Motivation. Electronic Journal of Foreign Language Teaching, 11(2), 285-299.

Liu, M. (2006). Anxiety in Chinese EFL students at different proficiency levels. System, 34(3), $301-316$. 
Liu, M. i Huang, W. (2011). An Exploration of Foreign Language Anxiety and English Learning Motivation. Education Research International, 1-8. Pristup 6. 7. 2019. http://dx.doi.org/10.1155/2011/493167

Liu, M. i Zhang, X. (2013). An Investigation of Chinese University Students' Foreign Language Anxiety and English Learning Motivation. English Linguistics Research, 2(1) Pristup 5. 7. 2019. http://www.sciedu.ca/journal/index.php/elr/article/view/2564

Lu, Z. i Liu, M. (2015). An investigation of Chinese university EFL learner's foreign language reading anxiety, reading strategy use and reading comprehension performance. Studies in Second Language Learning and Teaching, 5(1), 65-85.

Luo, H. (2011). Construction of a Chinese as a foreign language (CFL) anxiety scale: Towards a theoretical model of foreign language anxiety. Unpublished doctoral dissertation. University of Texas at Austin.

Luo, H. (2013). Foreign language anxiety: past and future. Chinese Journal of Applied Linguistics, 36(4), 442-464.

Macaro, E. (2007). Language learner strategies: adhering to aa theoretical framework. Language Learning Journal, 35(2), 239-243.

MacIntyre, P. D. (1995). How Does Anxiety Affect Second Language Learning? A Reply to Sparks and Ganschow. The Modern Language Journal, 79(i), 90-99.

MacIntyre, P. D., Baker, S. C., Clément, R., i Donovan, L. A. (2002). Sex and Age Effects on Willingness to Communicate, Anxiety, Perceived Competence, and L2 Motivation Among Junior High School French Immersion Students. Language Learning, 52(3), 537-564.

Maclntyre, P. D. i Gardner, R. C. (1988). The Measurement of Anxiety and Applications to Second Language Learning: An Annotated Bibliography. Department of Psychology Research Bulletin No. 672. London, Canada: The University of Western Ontario. Pristup 2. 04. 2019. https://files.eric.ed.gov/fulltext/ED301040.pdf 
MacIntyre, P. D. i Gardner, R. C. (1989). Anxiety and Second Language Learning: Toward a Theoretical Clarification. Language Learning, 39, 251-275.

MacIntyre, P. D. i Gardner, R. C. (1991). Language Anxiety: Its relationship to other anxieties and to processing in native and second languages. Language Learning, 41, 4, 513-534.

MacIntyre, P. D. i Gardner, R. C. (1994a). The effects of induced anxiety on three stages of cognitive processing in computerized vocabulary learning. SSLA, 16, 1-17.

MacIntyre, P. D. i Gardner, R. C. (1994b). The subtle effects of language anxiety on cognitive processing in the second language. Language Learning, 44, 283-305.

MacIntyre, P. D., Noels, K. A. i Clément, R. (1997). Biases in Self-Ratings of Second Language Proficiency: The Role of Language Anxiety. Language Learning, 47(2), 265-287.

Madsen, H. S., Brown, B. B. i Jones, R. L. (1991). Evaluating Student Attitudes toward Second Language Tests. U: E. K. Horwitz i D. J. Young (ur.), Language Anxiety: From Theory and Research to Classroom Implications (str. 65-86). Englewood Cliffs, NJ: Prentice Hall.

Mak, B. (2011). An exploration of speaking-in-class anxiety with Chinese ESL learners. System, 39, 201-214.

Marcos-Llinás, M., i Garau, M. J. (2009). Effects of Language Anxiety on Three ProficiencyLevel Courses of Spanish as a Foreign Language. Foreign Language Annals, 42(1), 94-111.

Mardešić, S. i Stanković, S. (2013). A Comparative Study of Foreign Language Anxiety among Students Majoring in French, Italian and Spanish. U: Dombi, J., Horváth, J. i Nikolov, M. (ur.), UZRT 2013 Empirical Studies in English Applied Linguistics (str. 68-79). Pecs: Lingua Franca Csoport.

Marzec-Stawiarska, M. (2013). Foreign language reading anxiety among advanced students of English - a pilot study. Acta Neophilologica, XV(1), 89-102. 
Marzec-Stawiarska, M. (2014). Gender differences in foreign language speaking-in-class anxiety. Linguistica Silesiana, 35, 417-434.

Mathewson, G. C. (1976). The function of attitude in the reading process. U H. Singer i R. B. Rudell (ur.), Theoretical Models and Processes of Reading (2. izd.) (str. 655-676). Newark, DE: International Reading Association.

Matić, I. (2015). Preoblikovanje i provjera instrumenta za mjerenje straha od čitanja na stranome jeziku. Strani jezici, 4(3), 162-191.

Matić, I. (2018). Strah od čitanja na njemačkome kao stranome jeziku. Strani jezici, 47(4), 243264.

Matsuda, S. i Gobel, P. (2001). Quiet apprehension: reading and classroom anxieties. JALT Journal, 23, 227-247.

Matsuda, S. i Gobel, P. (2004). Anxiety and predictors of performance in the foreign language classroom. System, 32, 21-36.

Maturanec, I. (2015). Foreign language anxiety: interaction with gender, length of study and selfperception of competence. Diplomski rad. Sveučilište u Zagrebu. Pristup 12. 5. 2019. http://darhiv.ffzg.unizg.hr/id/eprint/5721/1/Foreign\%20language\%20anxiety\%20\%20interaction $\% 20$ with $\% 20$ gender $\% 2 \mathrm{C} \% 20$ lenght $\% 20$ of $\% 20$ study $\% 20$ and $\% 20$ selfperception $\% 20 \mathrm{of} \% 20 \mathrm{competence.pdf}$

McCroskey, J. C. (1977). Classroom consequences of communication apprehension, Communication Education, 26, 27-33.

McCroskey, J. C. (1997). Willingness to Communicate, Communication Apprehension, and Self Perceived Communication Competence: Conceptualizations and Perspectives. U: J. A. Daly, J. C. McCroskey, J. Ayres, T. Hopf i D. M. Sonadre (ur.), Avoiding Communication: Shyness, Reticence, and Communication Apprehension (str. 75-108). Cresskill, NJ: Hampton. 
McCroskey, J. C. i Daly, J. A. (1976). Teachers' expectations of the communication apprehensive child in the elementary school. Human Communication Research, 1, 62-72.

McCroskey, J. C. i Richmond, V. P. (1976). The effects of communication apprehension on the perception of peers, Western Speech Communication, 1, 14-21.

McCroskey, J. C. i Richmond, V. P. (1982). The quiet ones: Communication apprehension and shyness, Gorsuch Scarisbrick, Dubuque, IA.

Medved Krajnović, M. (2009). SLA i OVIJ: što se krije iza skraćenice?, Lahor, IV/7, 95-109.

Medved Krajnović, M. (2010). Od jednojezičnosti do višejezičnosti: Uvod u istraživanja procesa ovladavanja inim jezikom. Zagreb: Leykam International d.o.o.

Mihaljević, J. (1990). Research on Motivation for Learning English as a Foreign Language - A project in Progress. SRAZ XXXV, 151-160.

Mihaljević, J. (1991/1992). Attitudes towards the teacher as a factor in foreign language learning. SRAZ XXXVI-XXXVII, 143-152.

Mihaljević Djigunović, J. (1994). Variation in Learner Effort-Effects of the Teaching Setting. SRAZ XXXIX, 53-57.

Mihaljević Djigunović, J. (1998). Uloga afektivnih faktora u učenju stranoga jezika. Zagreb: Filozofski fakultet Sveučilišta u Zagrebu.

Mihaljević Djigunović, J. (2000). Language Learning Strategies and Affect. CLCS, Occasional Paper No 59. Dublin: Trinity College.

Mihaljević Djigunović, J. (2000). Uloga straha od jezika u učenju stranog jezika. Strani jezici, $1-2,9-13$.

Mihaljević Djigunović, J. (2002). Strah od stranoga jezika. Kako nastaje, kako se očituje i kako ga se osloboditi. (1. izdanje). Zagreb: Naklada Ljevak. 
Mihaljević Djigunović, J. (2006). Interaction between L1 and L2 Communicative Language Competences. SRAZ LI, 261-277.

Mihaljević Djigunović, J. (2007). Afektivni profil, aspiracije i zadovoljstvo nastavom engleskoga jezika kod hrvatskih učenika. Metodika, 8(1), 104-114.

Mihaljević Djigunović, J., Andraka, I., Brajković, M., Cergol, K., Dombaj, K., Kacun, J., Kresojević, S., Rakoš, M. i Sviben, J. (2004). Foreign language anxiety of Croatian EFL learners: Construction of an anxiety scale. U: D. Kučanda, M. Brdar i B. Berić (ur.), Teaching English for Life: Studies to Honour Prof. Elvira Petrović on the Occasion of Her Seventieth Birthday (str. 115-126). Osijek: Faculty of Philosophy, Josip Juraj Strossmayer University.

Mihaljević Djigunović, J. i Bagarić, V. (2007a). A Comparative Study of Attitudes and Motivation of Croatian Learners of English and German. SRAZ LII, 259-281.

Mihaljević Djigunović, J. i Bagarić, V. (2007b). Engleski jezik u Hrvatskoj - od potreba do postignuća [English in Croatia - from needs to achievements]. Metodika, 8(1), 25-37. projekt Filozofskoga fakulteta u Zagrebu 'Engleski jezik u Hrvatskoj' 130514 (2001.-2006.)

Mihaljević Djigunović, J. i Geld, R. (2003). English in Croatia Today: Opportunities for Incidental Vocabulary Acquisition. SRAZ XLVII-XLVIII, 335-352.

Mihaljević Djigunović, J. i Legac, V. (2008). Foreign Language Anxiety and Listening Comprehension of Monolingual and Bilingual EFL Learners. SRAZ LIII, 327-347.

Mikulec, A. (2016). Strategije čitanja akademskih tekstova na hrvatskome i engleskome jeziku. Doktorski rad, Filozofski fakultet Sveučilišta u Zagrebu.

Mohammadpur, B. i Ghafournia, N. (2015). An Elaboration on the Effect of Reading Anxiety on Reading Achievement. English Language Teaching, 8(7), 206-215. 
Nathans, L.L., Frederick, L.O. i Nimon, K. (2012). Interpreting Multiple Linear Regression: A Guidebook of Variable Importance. Practical Assessment, Research \& Evaluation, 17(9), 119.

Noels, K. A., Clement, R. i Pelletier, L. G. (1999). Perceptions of Teachers' Communicative Style and Students' Intrinsic and Extrinsic Motivation. The Modern Language Journal, 83(1), 23-34.

Noels, K. A., Pelletier, L. G., Clemént, R. i Vallerand, R. J. (2000). Why are You Learning a Second language? Motivational Orientations and Self-Determination Theory. Language Learning, 50(1), 57-85.

Norton, B. (2000). Identity and Language Learning: Gender, Ethnicity and Educational Change. Harlow: Longman.

Oflaz, A. (2019). The foreign language anxiety in learning German and the effects of total physical response method on students' speaking skill. Journal of Language and Linguistic Studies, 15(1), 70-82.

Omaggio Hadley, A. (1986). Teaching Language in Context. Boston: Heinle and Heinle.

Onwuegbuzie, A. J., Bailey, P. i Daley, C. E. (1999). Factors associated with foreign language anxiety. Applied Psycholinguistics, 20(2), 217-239.

Ödemis, I. S. i Uslu, M. E. (2014). The Effect of Anxiety and Motivation on Foreign Language Achievement: A Studa of Structural Equation Modelling. Journal of Teaching and Education, 53-65. Pristup 14. 8. 2019.

file:///D:/Users/Korisnik/Downloads/The_effect_of_anxiety_and_motivation_on\%20(2).pdf

Oxford, R. L. (1990). Language Learning Strategies. What Every Teacher Should Know. Boston: Heinle and Heinle Publishers.

Papi, M. (2010.) The L2 motivational self system, L2 anxiety, and motivated behaviour: A structural equation modelling approach. System 38, 467-479. 
Peti-Stantić, A. (2019). Čitanjem do (spo)razumijevanja. Od čitalačke pismenosti do čitateljske sposobnosti. Zagreb: Naklada Ljevak.

Park, G.-P. (2014). Factor analysis of the Foreign Language Classroom Anxiety Scale in Korean learners of English as a foreign language. Psychological Reports, 115(1), 261-275.

Park, G.-P. i French, B. (2013). Gender differences in the Foreign Language Classroom Anxiety Scale. System, 41, 462-471.

Pavičević, N. (2013). A study of foreign language teaching anxiety among student teachers of english as a foreign language. Diplomski rad. Sveučilište u Zagrebu. Pristup 12. 5. 2019. http://darhiv.ffzg.unizg.hr/id/eprint/4100/1/Pavicevic\%20-\%20diplomski.pdf

Phillips, E. M. (1992). The Effects of Language Anxiety on Students' Oral Test Performance and Attitudes. The Modern Language Journal, 76(1), 14-26.

Piechurska-Kuciel, E. (2008). Language Anxiety in Secondary Grammar School Students. Opole: Wydawnictwo Uniwersytetu Opolskiego.

Piechurska-Kuciel, E. (2011). Perceived teacher support and language anxiety in Polish secondary school EFL learners. Studies in Second Language Learning and Teaching, 1(1), 83100.

Piechurska-Kuciel, E. (2012). Gender-dependent language anxiety in Polish communication apprehensives. Studies in Second Language Learning and Teaching, 2(2), 227-248.

Piniel, K. (2006). Foreign language classroom anxiety: A classroom perspective U Nikolov, M. i Horváth, J. (ur.), UPRT University of Pécs Roundtable: Empirical studies in English applied linguistics (str. 39-58). Pécs: Lingua Franca Csoport.

PISA 2009 Čitalačke kompetencije za život (2010). Zagreb: Nacionalni centar za vanjsko vrednovanje obrazovanja - PISA centar. Pristup: 16. 5. 2019. https://pisa.ncvvo.hr/wpcontent/uploads/2018/05/IZVJESTAJ_PISA2009_press.pdf 
Pivac, J. (2009). Izazovi školi. Zagreb: Školska knjiga. Odsjek za pedagogiju Filozofskog fakulteta u Zagrebu.

Projekt MZOŠ-a br. 130793: Engleski jezik u Hrvatskoj. Pristup 20.08.2019. http://zprojekti.mzos.hr/zProjektiold/arh zprojekata.asp?sort=4\&offset=750

Pravilnik o polaganju državne mature. Pristup 20. 6. 2019.

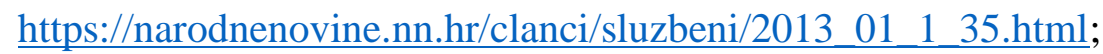

https://narodnenovine.nn.hr/clanci/sluzbeni/2019_04_41_845.html).

Presidency Conclusions, Barcelona European Council, 15 and 16 March 2002. Pristup 20.08.2019.

https://ec.europa.eu/invest-in-research/pdf/download_en/barcelona_european_council.pdf

Puškar, K. (2010). A comparative study of foreign language anxiety among majors of English and German. Faculty of Humanities and Social Sciences, University of Zagreb. Pristup 13. 5. 2019.https://www.academia.edu/4935608/A_comparative_study_of_FL_anxiety_among_maj ors_of_English_and_German

Rai, M. K., Loschky, L.C., Harris, R. J., Peck, N. R. i Cook, L. G. (2011). Effects of stress and working memory capacity on foreign language readers' inferential processing during comprehension. Language Learning, 61, 187-218.

Rajab, A., Zakaria, W. Z. W., Rahman, H. A., Hosni, A. D. i Hassani, S. (2012). Reading Anxiety among Second Language Learners. Procedia-Social and Behavioral Sciences, 66, 362-369. Pristup 3. 5. 2019.

file:///D:/Users/Korisnik/Downloads/Reading_Anxiety_among_Second_Language_Learners $\underline{\% 20(1) . p d f}$

Rodríguez, M., \& Abreu, O. (2003). The Stability of General Foreign Language Classroom Anxiety across English and French. The Modern Language Journal, 87(3), 365-374. 
Roeser, R. W., Eccles, J. S. i Sameroff, A. J. (2000). School as a Context of Early Adolescents' Academic and Social-Emotional Development: A Summary of Research Findings. The Elementary School Journal, 100(5), 443-471.

Rončević, B. (2005). Individualne razlike u razumijevanju pri čitanju. Psihologijske teme, $12(2), 55-77$.

Rubin, J. (1975). What the "good language learner" can teach us. TESOL Quarterly, 1, 41-51.

Ryan, R. M. i Deci, E.L. (2000). Self-Determination Theory and the facilitation of Intrinsic Motivation, Social Development, and Well-Being. American Psychologist, 55(1), 68-78.

Saito, Y., Horwitz, E. K. i Garza, T. J. (1999). Foreign language reading anxiety. Modern Language Journal, 83, 202-218.

Saito, Y. i Samimy, K. K. (1996). Foreign Language Anxiety and Language Performance: A Study of Learner Anxiety in Beginning, Intermediate, and Advanced-Level College Students of Japanese. Foreign Language Annals, 29(2), 239-249.

Sarason, I. G. (1986). Test anxiety, worry, and cognitive interference. U: R. Schwarzer (ur.), Self-related cognition in anxiety and motivation. Hillsdale: Erlbaum.

Sarason, I. G., Sarason, B. R. i Pierce, G. R. (1995). Anxiety, cognitive interference, and performance. U: D. Saklofske i M. Zeidner (ur.), International Handbook of Personality and Intelligence (str. 285-296). New York: Plenum Press.

Schumann, J. H. (1978). The Acculturation Model for Second Language Acquisition. U: R. C. Gingras (ur.), Second Language Acquisition and Foreign Language Teaching. Arlington, Virginia: Center for Applied Linguistics.

Schwarzer, R. (1986). Self-related cognition in anxiety and motivation. Hillsdale: Erlbaum.

Scovel, T. (1978). The Effect of Affect on Foreign Language Learning: A Review of the Anxiety Research. Language Learning, 28(1), 129-142. 
Selinker, L. (1972). Interlanguage. IRAL: International Review of Applied Linguistics in Language Teaching, 10/3, 209-241.

Sellers, V. D. (2000). Anxiety and Reading Comprehension in Spanish as a Foreign Language. Foreign Language Annals, 33(5), 512-520.

Seymour, P. H. K., Aro, M i Erskine, J. M. (2003). Foundation literacy acquisition in European orthographies. British Journal of Psychology, 94, 143-174.

Sinclair, K. E. (1987). Students' affective characteristics. U: M. J. Dunkin (ur.), The international encyclopedia of teaching and teacher education (str. 559-568). Oxford: Pergamon Press.

Službeni list Europske unije: Preporuka Vijeća od 22. svibnja 2019. o sveobuhvatnom pristupu poučavanju i učenju jezikâ (2019/C 189/03).

Pristup 20. 10. 2019.

https://eur-lex.europa.eu/legal-content/HR/TXT/PDF/?uri=OJ:C:2019:189:FULL\&from=EN

Smith, F. (2004). Understanding Reading. A Psycholinguistic Analysis of Reading and Learning to Read (6 ${ }^{\text {th }}$ ed.). Mahwah, NJ: Lawrence Erlbaum.

Sobel, M. E. (1982). Asymptotic confidence intervals for indirect effects in structural equation models. U S. Leinhardt (ur.), Sociological Methodology 1982 (str. 290-312). Washington DC: American Sociological Association.

Sparks, R. i Ganschow, L. (1991). Foreign Language Learning Differences: Affective or Native Language Aptitude Differences? The Modern Language Journal, 75(1), 3-16.

Sparks, R. i Ganschow, L. (1995). A strong inference approach to causal factors in foreign language learning: A response to MacIntyre. The Modern Language Journal, 79, 235-244.

Sparks, R., Ganschow, L. i Javorsky, J. (2000). Déjà vu all over again: A response to Saito, Horwitz and Garza. The Modern Language Journal, 84, 251-255. 
Sparks, R. L., Luebbers, J., Castaneda, M. i Patton, J. (2018). High School Spanish Students and Foreign Language Reading Anxiety: Déjà vu All Over Again All Over Again. The Modern Language Journal, 102(3), 533-556.

Sparks, R., Patton, J., Ganschow, L. i Humbach, N. (2009). Long-term cross-linguistic transfer of skills from L1 to L2. Language Learning, 59(1), 203-243.

Sparks, R. L., Patton, J., Ganschow, L., Humbach, N. i Javorsky, J. (2008). Early first-language reading and spelling skills predict later second-language reading and spelling skills. Journal of Educational Psychology, 100(1), 162-174.

Spielberger C. D. (1966). Anxiety and behaviour. New York: Academic Press.

Spielberger C. D. (1972). Anxiety: Current trends in research. London: Academic Press.

Spielberger, C. D. (1980). Test Anxiety Inventory: Preliminary Professional Manual. Palo Alto CA: Consulting Psychologists Press.

Spielberger C. D. (1983). Manual for the Stait-Trait Anxiety Inventory: STAI (Form Y), Palo Alto, CA: Consulting Psychologists Press.

Stanovich, K. E. (1980). Toward an interactive-compensatory model of individual differences in the development of reading fluency. Reading Research Quarterly, 16, 32-71.

Subaş1, G. (2014). Foreign Language Reading Anxiety: Does it really exist? Educational Research and Reviews, 9(24), 1360-1371.

Šamo, R. (2006). Jezično i iskustveno znanje učenika u zadacima čitanja na engleskom kao stranom jeziku. Metodički ogledi, 13(1), 31-48.

Šamo, R. (2014). Čitanjem do spoznaje, spoznajom do čitanja. Zagreb: Učiteljski fakultet u Zagrebu. 
Tobias, S. (1979). Anxiety and instruction. U: I. G. Sarason (ur.), Test anxiety: Theory, research and applications. Hillsdale, NJ: Erlbaum.

Tobias, S. (1986). Anxiety and cognitive processing of instruction. U R. Schwarzer (ur.), Selfrelated cognition in anxiety and motivation. Hillsdale, NJ: Erlbaum.

Tóth, Z. (2008). A foreign language anxiety scale for Hungarian learners of English. WoPaLP, 2, 55-78.

Tóth, Z. (2009). Foreign language anxiety: For beginners only? U: R. Lugossy, J. Horváth i M. Nikolov (ur.), UPRT 2008: Empirical studies in English applied linguistics (str. 225-246). Pécs: Lingua Franca Csoport.

Turula, A. (2006). Language anxiety and classroom dynamics. Bielsko-Biała: Wydawnictwo Naukowe ATH.

Ushioda, E. (1998). Effective motivational thinking: A cognitive theoretical approach to the study of language learning motivation. U E. A. Soler i V. C. Espurz (ur.), Current Issues in English Language Methodology (str. 77-89). Castellón de la Plana: Universitat Jaume I.

Ushioda, E. (2001). Language learning at university: Exploring the role of motivational thinking. U Z. Dörnyei i R. Schmidt (ur.), Motivation and second language acquisition (str. 91124). Honolulu, HI: University of Hawaii Press.

Ushioda, E. (2008). Motivation and good language learners. U: C. Griffiths (ur.), Lessons from Good Language Learners (str.19-34). Cambridge: Cambridge University Press.

Ushioda, E. (2009). A person-in-context relational view of emergent motivation, self and identity. U: Z. Dörnyei i E. Ushioda (ur.), Motivation, Language Identity and the L2 Self (str. 215-228). Bristol: Multilingual Matters.

Vidak, N. (2019). Provjera valjanosti konstrukta inojezičnoga motivacijskog sustava pojma o sebi. Doktorski rad, Filozofski fakultet Sveučilišta u Zagrebu. 
Vidak, N., Didović Baranac, S. i Falkoni-Mjehović, D. (2015). Attitudes of Croatian learners towards learning English, German and Spanish in a formal environment. U: A. Peti-Stantić, M.M. Stanojević i G. Antunović (ur.), Language Varieties Between Norms and Attitudes: south Slavic perspectives: Proceedings from the 2013 CALS conference (str.121-132). Frankfurt am Main: Peter Lang GmbH.

Vilke, M. (1977). Uvod u glotodidaktiku. Teorija nastave stranih jezika s posebnim obzirom na engleski jezik. Zagreb: Školska knjiga.

Visinko, K. (2014). Čitanje - poučavanje i učenje. Zagreb: Školska knjiga.

Vogely, A. J. (1998). Listening Comprehension Anxiety: Students' Reported Sources and Solutions. Foreign Language Annals, 31(1), 67-80.

Watson, D. i Friend, R. (1969). Measurement of Social-Evaluative Anxiety. Journal of Consulting and Clinical Psychology, 33, 448-451.

Wei, M. (2007). The Interrelatedness of Affective Factors in EFL Learning: An Examination of Motivational Patterns in Relation to Anxiety in China. TESL-EJ Top Volume, 11(1). Pristup 5. 7. 2019. http://www.tesl-ej.org/wordpress/issues/volume11/ej41/ej41a2/

Weiner, B. (2010). The Development of an Attribution-Based Theory of Motivation: A History of Ideas. Educational Psychologist, 45(1), 28-36.

Wentzel, K. R. (1997). Student Motivation in Middle School: The Role of Perceived Pedagogical Caring. Journal of Educational Psychology, 89(3), 411-419.

Williams, M. i Burden, R. L. (1997). Psychology for Language Teachers. Cambridge: Cambridge University Press.

Wu, H.-J. (2011). Anxiety and reading comprehension performance in English as a foreign language. Asian EFL Journal, 13(2), 273-307. 
Young, D. J. (1986). The Relationship Between Anxiety and Foreign Language Oral Proficiency Ratings. Foreign Language Annals, 19(5), 439-445.

Young, D. J. (1990). An Investigation of Students' Perspectives on Anxiety and Speaking. Foreign Language Annals, 23, 539-553.

Young, D. J. (1991). Creating a Low-Anxiety Classroom Environment: What Does Language Anxiety Research Suggest? Modern Language Journal, 75, 426-437.

Young, D. J. (1992). Language Anxiety from the Foreign Language Specialist's Perspective: Interviews with Krashen, Omaggio Hadley, Terrell, and Rardin. Foreign Language Annals, 25, $157-172$.

Zakon o odgoju i obrazovanju u osnovnoj i srednjoj školi. Pristup: 30. 8. 2019. https://mzo.gov.hr/o-ministarstvu/kutak-za-djelatnike-u-znanosti-i-obrazovanju-

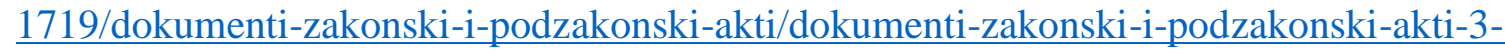
srednjoskolski-odgoj-i-obrazovanje/1699

Zeidner, M. i Matthews, G. (2003). Test anxiety. U: R. Fernández-Ballesteros (ur.), Encyclopedia of Psychological Assessment (str. 965-969). London: SAGE Publications Ltd.

Zhang, J. L. (2000). Uncovering Chinese ESL students' reading anxiety in a study-abroad context. Asia Pacific Journal of Language in Education, 3(2), 31-56.

Zhao, A. (2009). Foreign Language Reading Anxiety: Investigating English-Speaking University Students Learning Chinese as a Foreign Language in the United States. Unpublished doctoral dissertation. Florida State University, FSU Digital Library. Pristup 20. 4. 2019. file://D:/Users/Korisnik/Downloads/PDF\%20datastream\%20(1).pdf

Zhao, A., Dynia, J. i Guo, Y. (2013). Foreign Language Reading Anxiety: Chinese as a Foreign Language in the United States. The Modern Language Journal, 97(3), 764-778. 
Ziegler, J. C. i Goswami, U. (2005). Reading Acquisition, Developmental Dyslexia, and Skilled Reading Across Languages: A Psycholinguistic Grain Size Theory. Psychological Bulletin, 131(1), 3-29.

Zoghi, M. (2012). An instrument of EFL reading anxiety: Inventory construction and preliminary validation. Journal of Asia TEFL, 9(1), 31-56.

Zoghi, M. i Alivandivafa, M. (2014). EFL Reading Anxiety Inventory (ELFRAI): Factoral Validity and Reliability. Journal of Psychoeducational Assessment, 32(4), 318-329. 


\section{POPIS SLIKA}

Slika 1.1. Socioedukacijski model usvajanja drugoga jezika

(Gardner i MacIntyre, 1993a: 8)

Slika 1.2. Afektivni filtar (Krashen, 1982: 32) 8

Slika 1.3. Teorijski model straha od stranoga jezika (Kim, 2002: 106). 12

Slika 1.4. Model straha od stranoga jezika koji se sastoji od četiri komponente (Luo, 2011:60). 13

Slika 1.5. Model izvora straha od stranoga jezika koji se sastoji od četiriju dimenzija (Luo, 2011:59) 13

Slika 1.6. Dijagram afektivnih strategija (Oxford, 1990: 141). 19

Slika 2.1. Generirani model koji predstavlja faktore u strukturi straha od čitanja na engleskome jeziku (Al-Shboul i suradnici, 2013: 51).

Slika 3.1. Pretpostavljeni i dokazani utjecaji na razumijevanje pri čitanju (prema Rončević, 2005) (preuzeto iz Čudina-Obradović, 2014: 190).

Slika 3.2. Podjela europskih jezika prema pravopisnoj dosljednosti i slogovnoj složenosti (prema Seymour, 2007., Hoxhillari i sur., 2004., Oney i Goldman, 1984., Caravolas i sur., 2005., Turvey i sur., 1984) (preuzeto iz Čudina-Obradović, 2014: 73).

Slika 4.1. Socioedukacijski model (Gardner, 2005: 6) 60

Slika 5.1. Distribucija ukupnoga rezultata za strah od čitanja na engleskome jeziku 87

Slika 5.2. Distribucija ukupnoga rezultata za strah od čitanja na njemačkome jeziku. 91 
Slika 5.3. Distribucija ukupnoga rezultata za motivaciju za učenje engleskoga jezika.

Slika 5.4. Distribucija ukupnoga rezultata za motivaciju za učenje njemačkoga jezika

Slika 5.5. Distribucija ukupnoga rezultata za test Razumijevanje teksta čitanjem-engleski jezik

Slika 5.6. Distribucija ukupnoga rezultata za test Razumijevanje teksta čitanjem-njemački jezik 98

Slika 5.7. Distribucija ukupnoga rezultata za strah od čitanja na engleskome jeziku. 102

Slika 5.8. Kutijasti dijagrami stupnja slaganja za svaku tvrdnju (crveni romb prikazuje aritmetičku sredinu, horizontalna linija u svakom kvadratu prikazuje medijan, a crne točke izvan kutijastih dijagrama prikazuju ekstremne vrijednosti (engl. outlier).

Slika 5.9. Distribucija ukupnoga rezultata za strah od čitanja na njemačkome jeziku. 105

Slika 5.10. Kutijasti dijagrami stupnja slaganja za svaku tvrdnju (crveni romb prikazuje aritmetičku sredinu, horizontalna linija u svakom kvadratu prikazuje medijan, a crne točke izvan kutijastih dijagrama prikazuju ekstremne vrijednosti)

Slika 5.11. Grafički prikaz vrijednosti karakterističnih korijena (Eigen vrijednosti) za 25 faktora

Slika 5.12. Grafički prikaz vrijednosti karakterističnih korijena (Eigen vrijednosti) za 25 faktora.

Slika 5.13. Grafički prikaz vrijednosti karakterističnih korijena (Eigen vrijednosti) za 25 varijabli.

Slika 5.14. Grafički prikaz vrijednosti karakterističnih korijena (Eigen vrijednosti) za 25 varijabli 
Slika 5.15. Dijagram raspršenja, crta regresije i distribucije za strah od čitanja i uspjeh na testu razumijevanja teksta čitanjem za engleski jezik.

Slika 5.16. Dijagram raspršenja, crta regresije i distribucije za strah od čitanja i uspjeh na testu razumijevanja teksta čitanjem za njemački jezik.

Slika 5.17. Intervenirajuća varijabla $M$ u odnosu između varijable $X$ i $Y$. 156

Slika 5.18. Jednostavni medijacijski model 157

Slika 5.19. Jednostavni medijacijski model varijabli u ovom istraživanju. 157 


\section{POPIS TABLICA}

Tablica 5.1. Pregled broja sudionika istraživanja za engleski jezik $\left(N_{e_{-} s_{-} m}\right)$ i njemački jezik $\left(N_{n j \_} \_m\right)$ po školama.

Tablica 5.2. Pregled broja sudionika istraživanja za engleski jezik $\left(N_{e_{-} s_{-} m}\right)$ i njemački jezik $\left(N_{n j \_s \_}\right)$po razredima.

Tablica 5.3. Pregled broja sudionika istraživanja za engleski jezik $\left(N_{e_{-} s_{-} m}\right)$ i njemački jezik $\left(N_{n j \_} s_{-} m\right)$ u odnosu na spol.

Tablica 5.4. Duljina učenja engleskoga jezika.

Tablica 5.5. Broj godina učenja engleskoga jezika.

Tablica 5.6. Duljina učenja njemačkoga jezika

Tablica 5.7. Broj godina učenja njemačkoga jezika.

Tablica 5.8. Deskriptivna statistika za čestice Upitnika o strahu od čitanja na engleskome jeziku.

Tablica 5.9. Deskriptivna analiza. 87

Tablica 5.10. Deskriptivna statistika za čestice Upitnika o strahu od čitanja na njemačkome jeziku. 88

Tablica 5.11. Deskriptivna analiza. 90

Tablica 5.12. Deskriptivna statistika za čestice Upitnika o motivaciji za učenje engleskoga jezika.

Tablica 5.13. Deskriptivna analiza. 93 
Tablica 5.14. Deskriptivna statistika za sve čestice Upitnika o motivaciji za učenje njemačkoga jezika.

Tablica 5.15. Deskriptivna analiza...... 95

Tablica 5.16. Deskriptivna analiza. 97

Tablica 5.17. Deskriptivna analiza... 99

Tablica 5.18. Sažeti prikaz nalaza o normalnosti distribucija straha od čitanja, uspjeha na testu razumijevanja teksta čitanjem, te motivacije za učenje s obzirom na jezik. 99

Tablica 5.19. Deskriptivna analiza. 102

Tablica 5.20. Deskriptivna analiza 105

Tablica 5.21. Matrica obrazaca. 110

Tablica 5.22. Ekstrahirane komponente u analizi. 111

Tablica 5.23. Strukturna matrica (Oblimin rotacija, 6 komponenti)

Tablica 5.24. Korelacijska matrica komponenti. 112

Tablica 5.25. Matrica obrazaca. 114

Tablica 5.26. Ekstrahirane komponente u analizi. 115

Tablica 5.27. Strukturna matrica (Oblimin rotacija, 6 komponenti). 115

Tablica 5.28. Korelacijska matrica komponenti. 116

Tablica 5.29. Ekstrahirane komponente u analizi. 118 
Tablica 5.30. Matrica obrazaca (Oblimin rotacija, 5 komponenti).

Tablica 5.31. Strukturna matrica

Tablica 5.32. Korelacijska matrica komponenti-subskala straha od čitanja na engleskome jeziku.

Tablica 5.33. Čestice subskale 1 Upitnika o strahu od čitanja na engleskome jeziku.

Tablica 5.34. Čestice subskale 2 Upitnika o strahu od čitanja na engleskome jeziku.

Tablica 5.35. Čestice subskale 3 Upitnika o strahu od čitanja na engleskome jeziku.

Tablica 5.36. Ekstrahirane komponente u analizi.

Tablica 5.37 Matrica obrazaca (Oblimin rotacija, 5 komponenti) 127

Tablica 5.38. Strukturna matrica. 128

Tablica 5.39. Korelacijska matrica komponenti-subskala straha od čitanja na njemačkome jeziku

Tablica 5.40. Čestice subskale 1 Upitnika o strahu od čitanja na njemačkome jeziku 130

Tablica 5.41. Čestice subskale 2 Upitnika o strahu od čitanja na njemačkome. 131

Tablica 5.42. Čestice subskale 3 Upitnika o strahu od čitanja na njemačkome. 132

Tablica 5.43. Čestice subskale 4 Upitnika o strahu od čitanja na njemačkome jeziku 132

Tablica 5.44. Čestice subskale 5 Upitnika o strahu od čitanja na njemačkome jeziku 133

Tablica 5.45. Statistički pokazatelji za straha od čitanja na engleskome jeziku s obzirom na spol ispitanika 
Tablica 5.46. Rezultati t-testa za nezavisne uzorke

Tablica 5.47. Statistički pokazatelji za straha od čitanja na njemačkome jeziku s obzirom na spol ispitanika 136

Tablica 5.48. Rezultati t-testa za nezavisne uzorke. 137

Tablica 5.49. Statistički pokazatelji za strah od čitanja na engleskome jeziku s obzirom na srednjoškolski smjer. 138

Tablica 5.50. Rezultati t-testa za nezavisne uzorke. 138

Tablica 5.51. Statistički pokazatelji za strah od čitanja na njemačkome jeziku s obzirom na srednjoškolski smjer

Tablica 5.52. Rezultati t-testa za nezavisne uzorke.

Tablica 5.53. Statistički pokazatelji za strah od čitanja na engleskome i njemačkome jeziku na čitavom uzorku $\left(N_{e+n j}=139\right)$. 140

Tablica 5.54. Rezultati t-testa za zavisne uzorke

Tablica 5.55. Korelacijska matrica $\left(N_{\text {eng }}=149\right)$ Pearsonovih koeficijenata korelacije straha od čitanja i uspjeha na testu razumijevanja teksta čitanjem na engleskome.

Tablica 5.56. Korelacijska matrica $\left(N_{e n g}=149\right)$ Spermanovih koeficijenata korelacije straha od čitanja i uspjeha na testu razumijevanja teksta čitanjem na engleskome jeziku. 142

Tablica 5.57. Korelacijska matrica $\left(N_{n j e m}=153\right)$ Pearsonovih koeficijenata korelacije straha od čitanja i uspjeha na testu razumijevanja teksta čitanjem na njemačkome 143

Tablica 5.58. Korelacijska matrica $\left(N_{n j e m}=153\right)$ Spermanovih koeficijenata korelacije straha od čitanja i uspjeha na testu razumijevanja teksta čitanjem na njemačkome jeziku. 144 
Tablica 5.59. Korelacijska matrica $\left(N_{e_{-} s}=157\right)$ Pearsonovih koeficijenata korelacije zaključnih ocjena iz engleskoga u prva tri razreda srednje škole i straha od čitanja na engleskome jeziku.

Tablica 5.60. Korelacijska matrica $\left(N_{e_{-} s}=157\right)$ Spearmanovih koeficijenata korelacije zaključnih ocjena iz engleskoga u prva tri razreda srednje škole i straha od čitanja na engleskome jeziku.

Tablica 5.61. Korelacijska matrica $\left(N_{n j \_}=155\right)$ Pearsonovih koeficijenata korelacije zaključnih ocjena iz njemačkoga u prva tri razreda srednje škole i straha od čitanja na njemačkome jeziku.

Tablica 5.62. Korelacijska matrica $\left(N_{n j \_}=155\right)$ Spearmanovih koeficijenata korelacije zaključnih ocjena iz njemačkoga u prva tri razreda srednje škole i straha od čitanja na njemačkome jeziku.

Tablica 5.63. Korelacijska matrica $\left(N_{\ell_{-} m=157}\right)$ Pearsonovih koeficijenata korelacije zaključnih ocjena iz engleskoga u prva tri razreda srednje škole i motivacije za učenje.

Tablica 5.64. Korelacijska matrica $(\mathrm{N}=157)$ Spearmanovih koeficijenata korelacije zaključnih ocjena iz engleskoga u prva tri razreda srednje škole i motivacije za učenje engleskoga jezika.

Tablica 5.65. Korelacijska matrica $\left(N_{n j \_} m=155\right)$ Pearsonovih koeficijenata korelacije zaključnih ocjena iz njemačkoga jezika u prva tri razreda srednje škole i motivacije za učenje njemačkoga jezika. 151

Tablica 5.66. Korelacijska matrica $\left(N_{n j \_} m=155\right)$ Spearmanovih koeficijenata korelacije zaključnih ocjena iz njemačkoga jezika u prva tri razreda srednje škole i motivacije za učenje njemačkoga jezika. 152

Tablica 5.67. Korelacijska matrica $\left(N_{e_{-} t=160}\right)$ Pearsonovog koeficijenta korelacije za zaključnu ocjenu u trećem razredu srednje škole i ukupni rezultat na testu razumijevanja teksta čitanjem - engleski jezik. 


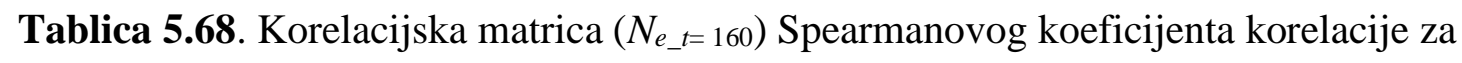
zaključnu ocjenu u trećem razredu srednje škole i ukupni rezultat na testu razumijevanja teksta čitanjem - engleski jezik.

Tablica 5.69. Korelacijska matrica $\left(N_{n j} t=154\right)$ Pearsonovog koeficijenta korelacije za zaključnu ocjenu u trećem razredu srednje škole i ukupni rezultat na testu razumijevanja teksta čitanjem - njemački jezik.

Tablica 5.70. Korelacijska matrica $\left(N_{n j \_} t=154\right)$ Spearmanovog koeficijenta korelacije za zaključnu ocjenu u trećem razredu srednje škole i ukupni rezultat na testu razumijevanja teksta čitanjem - njemački jezik.

Tablica 5.71. Koraci u medijacijskoj analizi (Baron i Kenny, 1986)

Tablica 5.72. Prikaz Sobelovog testa.

Tablica 5.73. Koeficijenti regresijske analize (korak 1)

Tablica 5.74. Sažetak modela (korak 1)

Tablica 5.75. Koeficijenti regresijske analize (korak 2).

Tablica 5.76. Sažetak modela (korak 2)

Tablica 5.77. Koeficijenti regresijske analize (korak 3)

Tablica 5.78. Sažetak modela (korak 3 )

Tablica 5.79. Koeficijenti regresijske analize (korak 4).

Tablica 5.80. Sažetak modela (korak 4)

Tablica 5.81. Koeficijenti regresijske analize (korak 1) 
Tablica 5.82. Sažetak modela (korak 1)

Tablica 5.83. Koeficijenti regresijske analize (korak 2) 162

Tablica 5.84. Sažetak modela (korak 2). 163

Tablica 5.85. Koeficijenti regresijske analize (korak 3) 163

Tablica 5.86. Sažetak modela (korak 3 ) 163

Tablica 5.87. Koeficijenti regresijske analize (korak 4). 164

Tablica 5.88. Sažetak modela (korak 4) 164

Tablica 5.89. Sažeti prikaz rezultata medijacijske analize za engleski i njemački jezik. 165

Tablica 5.90. Rezultati višestruke regresijske analize sa strahom od čitanja za engleski jezik kao zavisnom varijablom i sa šest prediktora. 167

Tablica 5.91. Rezultati višestruke regresijske analize sa strahom od čitanja za njemački jezik kao zavisnom varijablom i sa šest prediktora. 168

Tablica 5.92. Sažeti prikaz odgovora na istraživačka pitanja i rezultata testiranja hipoteza. 170 


\section{PRILOZI}

\section{Prilog 1}

\section{TRANSKRIPT RAZGOVORA S FOKUS GRUPOM ZA ENGLESKI JEZIK}

Vrijeme održavanja razgovora: 4. i 5. sat nastave poslijepodne, 25. svibnja 2016.

Mjesto održavanja razgovora: Turistička i ugostiteljska škola Dubrovnik, Dubrovnik

Sudionici razgovora: 4 učenice (UČ1, UČ2, UČ3, UČ4) i 4 učenika (UČ5, UČ6, UČ7, UČ8) 3.a i 3.b razreda Turističke i ugostiteljske škole Dubrovnik koji uče engleski jezik 11 godina i voditeljica razgovora (V)

V: Opišite kako se osjećate kada čitate tekst na engleskome jeziku. Opišite svoj opći osjećaj, ali i specifične fiziološkeltjelesne reakcije.

UČl: Kad čitam osjećam se uglavnom loše.

UČ3: I ja se ne osjećam dobro. Kad čitam u školi - kad čitamo svatko za sebe u sebi znam da slijede neki zadaci i to me brine. A tekst je često jako dosadan.

UČ1: Stvarno - nisu zanimljivi tekstovi. Kao da su za srednju školu.

UČ2, UČ4, UČ7, UČ 8: Ni meni.

UČ6: Nije mi problem to čitanje u sebi. Meni se čini da je dosadan način rada, a tekst nekad i nije dosadan.

UČ2, UČ4: Da, slažem se.

UČ4: Meni, na primjer, nije problem čitati naglas, ali nekima jest - čak i na hrvatskom. Meni je zapravo najdraže čitati na engleskom. A najbolje se skoncentriram kad čitam poluglasno. I lijepo se osjećam.

UČ1: Meni je problem jer me uznemirava što sam u razredu, svi me slušaju i gledaju, a još je nekad i buka dok čitam. To mi sve smeta. I onda samo tražim okom neke poznate riječi u tekstu. UČ5: Mene to uopće nije briga. Neka me slušaju, ja svoje čitam. Još mi je bolje da čitam u razredu nego pred totalno nepoznatim ljudima.

UČ6: Meni je ok kad čitam tekst iz udžbenika, ali kad čitam svoj tekst, neki svoj esej, to mi je grozno. Uvijek mislim da nekako nije dobro.

UČ1, UČ3, UČ7, UČ8: Meni je isto to najgore. 
V: Molim vas, da razjasnimo - danas razgovaramo o čitanju tekstova iz udžbenika, a ne o čitanju vlastitih radova.

UČ6: Onda je to iz udžbenika meni onako prilično ok.

UČ7: Meni isto, ali nekad mi se promijeni glas kad čitam na engleskom. I kao da mi oči lete, preskaču neke riječi.

UČ1: Da, tebi drhti glas čak. Kao meni na matematici.

UČ7: Znam, ali ne mogu to nikako kontrolirati. Čini mi se da mi je tako i na hrvatskom.

UČ4: Meni ne drhti glas, nemam taj problem, ali ja stalno pazim da mi ne drhti glas kad čitam naglas. Probaj i ti. I pazim kako zvučim, ono boja glasa.

UČ2: A ja baš nekad uživam kad čitam naglas na engleskom. Sebi zvučim super. Sve pazim na intonaciju. Baš sam nekako važna kad čitam na engleskom. Ali na kraju nemam pojma što sam pročitala. Kad samo pazim kako čitam, a ne mislim što čitam. Eto, tako meni. Ali barem uživam i ne drhti mi glas kao tebi.

UČ8: Ma, ja bih još i pazio kako čitam da me zanima tekst. Pa to su sve neki banalni tekstovi. Prepričavanje filma, kako preživjeti na pustom otoku, ma, baš ti to mene zanima. Zato mene i nije briga kako čitam. Što brže, to bolje do kraja. I ništa se ne opterećavam i ne uznemirujem. Još taman i da mi drhti glas. Ni slučajno.

UČ6: Ja bih baš uživao čitati u razredu neki super tekst o veganima, o GMO hrani, ono, to bih čitao s voljom i užitkom. I skroz bih se trudio da to lijepo pročitam. Baš su mi super te teme. Stalno se o tome govori, to je život, a ne prepričavanje radnje holivudskih filmova. Kao u osmom razredu.

UČ2: Ja bih najradije čitala nešto što je kao s interneta, pravi tekst, i prave riječi koje se koriste u pravom tekstu. Kao što na televiziji slušam pravi jezik.

UČ3: Meni je najgore kad vidim dugi tekst, ono cijela stranica ili skoro cijela, nekad je usko pisano, ali od vrha do dna nešto sve piše. Odmah mi se ne da čitati.

UČ8: Da, tako je i ja više imam motivacije da pročitam kad nije predug tekst. Čak i bez obzira ako je i zanimljiva tema, ne volim kad je predugo, nekako me odvraća od čitanja.

V: Ponekad u tekstu ne razumijete neke riječi ili rečenice. Prokomentirajte kako doživljavate takvu situaciju, ako ste bili u takvoj situaciji.

UČ5: Ništa se ja ne uznemiravan za tako nešto. Tu riječ koju nisam znao, poslije iz konteksta shvatim što je. A rečenice su mi sve jasne, pa ne dobijemo mi baš neke komplicirane rečenice. Više se dogodi neka nepoznata riječ. Ali je to izvučem nekako. I to su obično neke riječi iz struke. 


\section{$V$ : Što kažete vi ostali?}

UČ4, UČ6: Slažemo se s tim. Nepoznate riječi, ali nema velike nervoze zbog toga. U cjelini sve više-manje razumijemo. I samo ono što ne znamo iz struke jer nismo još učili, to je nekada problem.

UČ2: Ja pokušam uvijek uhvatiti malo vremena da pročitam tekst u sebi prvo i proletim sve riječi. To mi daje neku sigurnost. I onda isto ako naleti neka manje poznata riječ to iz konteksta shvatim. Ali treba mi to predčitanje.

UČ3: Meni to jako smeta, nekako mi djeluje negativno na ostatak teksta. Zbuni mi cijeli tekst i ne mogu zaboraviti tu riječ. Osjetim nesigurnost. Još ako mi dođe više takvih riječi u jednoj rečenici. Grozno.

UČ8: Ja samo nastavim čitati i do kraja nekako sve shvatim. I ne uznemiravam se oko toga.

V: Način pisanja na engleskom jeziku i način čitanja se ne podudaraju. Prokomentirajte kako to doživljavate.

UČ2: Ne uznemirava me to. Barem ne više. To mi je bilo zbunjujuće i ljutilo me dok sam bila mala. Na početku u osnovnoj školi. Ali sad to ni ne primjećujem. Znam da je tako.

UČ1, UČ3, UČ4: Ajme, isto tako. Ali u osnovnoj me je to baš nerviralo.

UČ5: To je meni kao neka navika. U stvari ja sam se navikao na to. A što se navikneš ne smeta ti više.

$V$ : Možete li vi ostali nešto dodati na ovu temu?

UČ6, UČ7, UČ8: Ma, nije to ništa uznemirujuće. Sve nam je to već obično.

V: Zamislimo sljedeću situaciju - dok čitate tekst na engleskome jeziku naišli ste na pojam iz kulture engleskoga govornoga područja, a taj pojam vam nije poznat. Prokomentirajte kako to doživljavate.

UČ5: Što, mislite je li se iznerviram nešto oko toga? Ma, ne, ili možda zato jer ne znam jesam li takvu situaciju uopće i doživio. Mislim da i nisam.

UČ7: To je ono kad smo imali nešto o kotrljanju sira. Ma, ja sam to nekako povezao, nije me baš nešto smetalo. 
UČ3: A ja to baš ne volim. Nije lako ni pročitati, a onda mi za čitanje daju neki čudan pojam, razumijem riječi, a ne znam što ti ljudi u stvari rade. Meni to baš sve poremeti, ne da mi se onda čitati kad ne razumijem bitan pojam. I sve mi lošije ide čitanje.

UČ4: Zato je meni totalno bilo super kad smo ono imali neke slikice uz tekstove. To bi mi uvijek uljepšalo čitanje. Možeš nešto shvatiti sa slike, a i živahnije je sve to što čitaš. Draže mi je onda čitati.

UČ5: Meni te slike ništa ne znače. Ja samo gledam tekst. A i ne smeta mi ako neki pojam ne razumijem. Neki neobičan pojam nastavnica objasni ili prije čitanja ili odmah poslije, tako da meni to ne smeta.

V: Kada se uči engleski jezik uvježbavaju se četiri jezične vještine (čitanje, pisanje, slušanje, govorenje). Kako doživljavate čitanje u usporedbi s ostalim jezičnim vještinama? Koja vještina vam je najdraža, koja draga, koja manje draga, a koja najmanje draga? Koje vještine su vam draže, a koje manje drage?

UČ2: Čitanje mi je na prvom mjestu. Osim ovo u razredu čitam ja puno i sama doma, tražim po internetu.

UČ4: Meni je čitanje draže od većine drugih aktivnost, a sigurno od pisanja. I ja čitam na internetu, nešto što me zanima.

UČ5: Čitanje mi je drago. Još mi je draže čitati na engleskom naglas nego na hrvatskom.

UČ7: Meni nije baš drago čitati.

UČ1: Ni meni. Najmanje mi je drago čitati.

UČ3: I meni. A najdraže mi je govoriti.

UČ6: Čitanje mi je svakako drago, onda govor, pa pisanje, a slušanje mi je najmanje drago.

Kad slušamo CD u razredu sve je tako zbrkano, a na televiziji bolje razumijem.

\section{$V$ : Kako doživljavate sebe u odnosu na druge kada čitate u razredu?}

UČ6: Većina se ni ne obazire na onoga tko čita. Barem ja tako mislim. Mislim da sam dobar kao i većina ostalih u čitanju i ne opterećavam se.

UČ4: Ja se osjećam sigurna dok čitam na engleskom i mislim da se to primijeti. A neki su baš nesigurni. Ne drhti mi glas kao nekima, ali i pazim na to.

UČ1: Ja srećom nisam jedina koja je nekako lošija, a i osjećam se loše dok čitam. Među lošijima u svakom pogledu. Vidim je da je nekima super, ali ja sam na onoj drugoj strani i ima nas još. Ne znam baš dobro, ne osjećam se lijepo i ne da mi se baš puno. A sve manje se i brinem, sve manje me je strah nešto kako ću ja to napraviti. 
UČ3: Ja sam tu negdje s tobom. Sve slično. Jedino ja sam još uvijek dosta nervozna kad moram u razredu čitati ili govoriti pred drugima. Ne mogu reći da sam sve manje nervozna, upravo suprotno.

\section{V: Kako bi opisali ulogu nastavnika/nastavnice pri ovladavanju vještinom čitanja?}

UČ4: Ona je nekako opuštena i čini mi se da se trudi da i mi budemo. Nije onako sve strogo kao što je bilo kad su nam roditelji išli u školu.

UČ7: Ma, mi smo dosta opušteni, nema tu nekog straha. I ona se trudi i nije nervozna. Svima nam je bolje.

UČ3: Meni smeta ako me nastavnica prekida dok čitam. Ruši mi samopouzdanje.

UČ5: I meni to smeta. Bilo bi mi draže da mi na kraju kaže što sam pogrešno pročitao. Jer me prekidanje dekoncentrira.

UČ2: Pa naravno, ja mislim da nam svima to smeta. Je li se slažete?

UČ4: Sad mi je malo čudno reći da je meni čak i drago da me nastavnica prekine i ispravi odmah. Onda to stvarno zapamtim da sam krivo pročitala. A i ako se ta ista riječ ponovi dalje znači može mi se dogoditi da je tri, četiri puta pogrešno pročitam. Pa bolje da me odmah upozori. Onda ću se potruditi to točno izgovoriti. I zapamtit ću to zauvijek.

UČ1: Ja ne volim prekidanje i ispravljanje. To me obeshrabri. Još ako je neki strogi ton glasa.

UČ7: Ni ja. To mi nekad bude kao neki prijekor.

UČ8: Bolje ne prekidati. I tako hoću što prije doći do kraja, pa me to usporava. Bolje da prije početka čitanja objasni neke teže riječi. To ona nekada i radi.

UČ3: Da, meni to isto odgovara. To mi olakšava, pa se manje nerviram.

UČ2: Objašnjenje na početku mi daje neku sigurnost. To volim.

UČ6: Meni se sviđa što neke teže tekstove nastavnica prva pročita, a ne traži nekoga od nas da prvi čitamo.

UČ2: To svakako. Ja onda od nje nešto pokupim i tako ponovim.

UČ4: Da, to je dobro. Ali onda kad mi trebamo čitati često pita dobrovoljce i uvijek se jave isti, oni koji dobro čitaju. A oni koji su slabiji se ni ne usude. Ja mislim da bi ona trebala nekako redom prozivati, pa da svi dobiju priliku za čitanje. Možda bi ti koji lošije čitaju postali onda nešto bolji.

UČ3: Da, ja se ovako i izvučem. Ali isto znam da me je i prozivala, nije baš da uvijek pita dobrovoljce.

UČ4: Ma ne, ne baš uvijek, ali često. 
UČ7: Da, možda bih i ja bolje čitao kad bih češće čitao naglas. Teško je znati ili bi mi glas onda uvijek drhtao.

\section{$V$ : Kako bi komentirali odnos (povezanost) doživljaja čitanja i uspješnosti u čitanju?}

UČ4: To je logično - kome je drago čitati, bolje će i čitati. I ako imamo pozitivan stav prema nečemu - prema čitanju, bit ćemo uspješniji. I rast će nam samopouzdanje.

UČl: Ja engleski općenito ne volim, pa ne volim ni čitati. I to je logično. A kako ne volim, onda to izbjegavam raditi. Sve logično. Ja to sve malo preko volje. Možda bih se bolje osjećala kad bih bila u grupi u kojoj svi onako malo lošije znaju kao i ja. Manje bi me bilo strah.

UČ5: Sve što dobro radim to nekako i volim. I obratno. I tako mi je otprilike i s čitanjem na engleskom. Dobro mi ide i drago mi je.

UČ4: Ako netko misli da zna čitati, vjeruje u sebe, bolje će i čitati. Ako netko misli da loše čita i čitat će loše.

UČ7: Ja baš ne volim čitati i ne ide mi baš. Eto, povezano je. Meni se čini kad mi glas ne bi drhtao, kad bih to riješio, onda bih i bio bolji i možda bih više volio čitati.

UČ4: Ja mislim da ti je to zbog razreda, zbog reakcije razreda, puno nas je na engleskom, a pola razreda je djetinjasto i smijulje se i zato je tebi tako. Kao malo si lošiji, ali nisi u stvari baš loš. To ti samo tako misliš o sebi.

UČ7: Da, sve je u glavi.

UČ8: Sve to ovisi o danu, o raspoloženju i koncentraciji. Nisam uvijek isto dobar. I o atmosferi u razredu. Ako je ugodna i opuštena atmosfera i donekle mirna, bit ću bolji.

UČ2: Meni se čini da oni koji manje znaju imaju više straha, a taj strah ih koči i onda su sporiji i manje se trude i lošije čitaju.

\section{$V$ : Usporedi svoj doživljaj čitanja na hrvatskome jeziku i na engleskome jeziku.}

UČ6: Teško je to usporediti kad nam je hrvatski materinski. Ali na primjer meni je uvijek bitna ta tema teksta. Bilo je lektira koje sam s voljom pročitao, ali većinom me nisu zanimale.

Sve što me zanima brže i bolje čitam, mislim više zapamtim. Bez obzira na jezik.

UČl: Meni je svako čitanje problem, ne volim. Pa kad ne volim na hrvatskom, ne volim ni na engleskom, još mi je i gore jer naravno manje razumijem. Hrvatski se barem isto čita i piše.

UČ4: Ja bih mogla reći da mi je čitanje jedna od dražih aktivnosti općenito. Ja stvarno puno čitam za nekoga mojih godina reklo bi se. Drugi više slušaju muziku, igraje nešto, a ja na tabletu 
i čitam. Svašta me zanima. Nešto o filmovima, glumcima, o parovima, nešto o modi, tako svašta. A što se tiče usporedbe, kad se navikneš malo, čitanje na engleskom i nije tako teško.

$V$ : Molim vas, iznesite svoj komentar za kraj. Navedite $i$ ono što nismo prokomentirali, a smatrate da je bitno.

UČ1: Ja mislim da neki ljudi imaju dar čitanja, dar učenja stranih jezika i da je to glavni razlog zašto netko bolje ili lošije čita ili uči neki jezik.

UČ4: Ja mislim da je čitanje na engleskom jedna ugodna aktivnost. Meni se sviđa i zato što uživam dobro mi i ide. I uvijek mi je dobro išlo. Imala sam sreću da sam uvijek imala i dobre nastavnike koji su me poticali. I volim sebe čuti - pa zato često poluglasno čitam.

UČ8: Meni je to čitanje kao i sve drugo. Ja gledam da to odradim, ali ne mogu reći da mi je nešto posebno drago. A ima tih ljudi koji baš vole jezike, dobro i ja donekle, zato sam u ovoj školi, ali ima ih koji su veći zaljubljenici od mene. To im puno pomaže.

UČ7: Ja znam da u ovoj struci moram imati strane jezike, a engleski učim od prvog osnovne. Ali meni je draže kad sam govorim, onda govorim što znam, a ovo s čitanjem mi nije baš lako nekad. Možda ja imam neki problem s gledanjem tih slova. Ne znam.

UČ2: Dajte nam zanimljivije tekstove ili nove udžbenike i rađe ćemo čitati i biti još sretniji s čitanjem.

UČ3: Zanimljiviji i kraći tekst i da me nitko ne prekida dok čitam i da mogu prvo dobiti malo vremena da pročitam barem na brzinu u sebi, pa tek me onda prozovi. Tako bih ja.

UČ6: Promijenite malo način rada s tim tekstovima. Nemojte da samo radimo gramatiku, pa čak i kad se čita neki tekst. Možemo li malo samo čitati i vježbati riječi. Pročitamo, a opet te riječi ne uvježbamo.

UČ5: Dobro je čitanje. Tek se tada skoncentriram na neke riječi. I nekih se sjetim koje sam zaboravio. Neke glavne fraze koje stalno koristim, zapamtio sam točno znam iz kojih tekstova. Meni je čitanje korisno. U stvari volim to čitanje. I lijepo mi je što čujem sebe kako govorim točno i ne zastajkujem. Samo čitam.

$V$ : Najprije bih se svima htjela iskreno zahvaliti što ste bili spremni odvojiti dio svoga vremena $i$ sudjelovati u ovom razgovoru. Hvala vam na iskrenim i tako detaljnim odgovorima. Doista ste kroz dio svojih zapažanja otvorili potpuno novi pogled na neke od teme koje su me zanimale. $V i$ ste svojim današnjim sudjelovanjem u velikoj mjeri pridonijeli ovome istraživanju $i$ bez vašega sudjelovanja ne bi se moglo nastaviti istraživanje. Svima vam želim sretan i uspješan završetak ove školske godine i da se lijepo odmorite kad krenu ljetni praznici. 


\section{Prilog 2}

\section{TRANSKRIPT RAZGOVORA S FOKUS GRUPOM ZA NJEMAČKI JEZIK}

Vrijeme održavanja razgovora: 4. i 5. sat nastave poslijepodne, 26. svibnja 2016.

Mjesto održavanja razgovora: Turistička i ugostiteljska škola Dubrovnik, Dubrovnik

Sudionici razgovora: 5 učenica (UČ1, UČ2, UČ3, UČ4, UČ5) i 5 učenika (UČ6, UČ7, UČ8, UČ9, UČ10) 3.a i 3.b razreda Turističke i ugostiteljske škole Dubrovnik koji uče njemački jezik 3 godine i voditeljica razgovora $(\mathrm{V})$

V: Opišite kako se osjećate kada čitate tekst na njemačkome jeziku. Opišite svoj opći osjećaj, ali i specifične fiziološke/tjelesne reakcije.

UČ6: Volim čitati na njemačkom naglas.

UČ7: Meni to nije baš ugodno.

UČ10: Ja sam opušten kad čitam na njemačkom.

UČ9: Ja nisam ni posebno opušten, ni ne opušten. Meni je to normalno.

UČ5: Čitati na njemačkom je teško. Ne mogu ja opušteno čitati. Sve one čudne točkice iznad slova i sve drugo.

UČ3: Ma, daj. Meni je sto puta lakše čitati njemački nego engleski. Baš mi je to ok.

UČ6: Meni je njemački dosta lako čitati, ali kao da ne razumijem sve što pročitam naglas na njemačkom. Pazim na čitanje. A na engleskom mogu i naglas čitati i znati što sam pročitao.

UČ1: I meni. Jedino gramatika mi je teža u njemačkom. I rodovi imenica. A čitanje mi je baš super. Volim čitati na njemačkom.

UČ3: Mislim da nam je svima više bilo opterećenje čitati naglas u razredu kad smo bili na početku u prvom razredu i još se nismo dobro poznavali. Pa sam mislila što će drugi misliti o meni. Znači - kako će me doživjeti drugi. Sad je sve opuštenije. Valjda svima. I dobro je što nismo cijeli razred na njemačkom nego samo manja grupa. To je razlika jer smo na engleskom svi skupa, a ogroman smo razred.

UČ4: Dobro, meni uvijek nekako malo srce jače lupa i malo mi se znoje dlanovi kad čitam ili govorim pred grupom. I na hrvatskom mi je tako. Još više nego na njemačkom. Ono cijeli smo razred i stvarno mi nije baš skroz ugodno.

$V$ : Jeste li ikada čitali poluglasno? 
UČ4: Jesam, kada čitam za test. U stvari kada trebam iza tog čitanja riješavati neke zadatke. To radim i na engleskom.

UČ3, UČ6, UČ8, UČ10: I ja. Tako sebe bolje čujem. Mislim da se tako bolje koncentriram.

\section{$V$ : Je li vam ikada drhato glas dok čitate na njemačkom?}

UČ2: Ja tiho čitam jer se ne osjećam sigurno.

UČ7: Meni nekako vibrira glas. A kad ne volim čitati. Ne volim ja čitati općenito. Ni na hrvatskom.

UČ5: Imam ja to s drhtanjem glasa. I onda me još i to dodatno uznemiri, pa još više griješim.

V: Ponekad u tekstu ne razumijete neke riječi ili rečenice. Prokomentirajte kako doživljavate takvu situaciju, ako ste bili u takvoj situaciji.

UČ1: Mene to ne uznemiruje. Zašto i bi? Ja mislim da imam dar za čitanje i ja to super odradim. UČ4: Mene isto ne previše. U stvari ne baš puno. Možda samo malo.

UČ7: Mene to grozi. Ja kad vidim one duge riječi, one imenice spojene od pet, šest riječi, strava. Ja ne znam gdje što počinje, a gdje završava.

UČ2: Jest, to je taj grozni dio u njemačkom. I kako ćeš onda mirno i opušteno čitati, kad ti dođe kupus od riječi. Sve mi se zamuti pred očima, sva slova se stope u kupus.

UČ8: Ma nije to tako strašno, samo polako čitaš i ide.

UČ3: Mene to ne uznemirava, ali ja inače sve rado čitam, pa i njemački.

UČ6: Meni tu pomaže kontekst. Navikao sam da se služim kontekstom da razjasnim sebi nešto što ne razumijem. Ali ako ne uspijem stvarno mi to smeta. Osjećam se nemoćno u tom trenutku i kvari mi sve drugo što trebam raditi dalje na satu.

UČ4: U engleskom nekako ne srećemo tako puno novih riječi tako često kao u njemačkom. I engleski nam je stalno u uhu, oko nas. A njemački mi je nekako dalek, totalno nepoznat, pa mi to bude teško. I, naravno, uznemirava me, mislim, čitam s manje sigurnosti. Iako sam ok u njemačkom, onako sve skupa.

UČ5: Tekstovi su u njemačkim udžbenicima preteški i predugi. U usporedbi s engleskim gdje su tekstovi predosadni. Trebalo bi obratno. One neke banalne teme iz engleskih udžbenika staviti u njemačke, a ove teške teme gdje ima puno struke iz njemačkih udžbenika napisati u engleske. Nama inače fali pojmova iz struke, a još su nam dali tekstove iz struke na njemačkom. E to je teško. I onda kako ću opušteno čitati takav tekst.

UČ9: Totalno se slažem. 
UČ 2: Da, i ja. Meni se taj jezik ne sviđa i sve mi je problem. Engleski se snađem, nađem i na internetu, a s njemačkim ne znam što bih.

UČ8: Jest, bude tih riječi dugih i iz struke, ali u stvari mi opet najviše radimo gramatiku na tim tekstovima. Pa ako baš i ne znaš te riječi, neće ti se baš puno to ni primijetiti. A ja s čitanjem nemam problema, pa valjda to ne primijetim jako.

UČ9: Da, puno je te gramatike. A meni ni gramatika ni čitanje ne ide. Ne volim ja to baš nešto. Ne voliš jedno, pa ne voliš ni drugo.

UČ3: Ja mislim da sam već stvorila neku bazu i oslanjam se na to i ne uznemirava me kada su riječi duge ili na prvi pogled skroz nepoznate. Često shvatim u sljedećoj minuti da nešto ipak razumijem od te duge riječi.Ali puno me više smeta kad naiđe rečenica koju ne razumijem jer je preduga ili previše složena.

UČ10: Tako i ja. S riječima nemam problema. To me neće iznervirati. Ali rečenica je drugo. I onda je pitanje je li nešto bitno moram dalje s tim tekstom raditi. Ako je dio testa stvarno se iznerviram. A ako je samo na satu tekst koji se obrađuje, onda ne baš puno.

V: Način pisanja na njemačkome jeziku i način čitanja se ne podudaraju. Prokomentirajte kako to doživljavate.

UČ4: To ni ne primjećujem puno. Na početku sam obraćala pažnju na to sada više ne, niti mi je to neko opterećenje.

UČ6: To se s vremenom uhodalo. I nije nikakav problem to više.

UČ1, UČ2, UČ3: Slažemo se.

UČ5, UČ7, UČ8, UČ9, UČ10: I mi.

$V$ : Zamislimo sljedeću situaciju - dok čitate tekst na njemačkome jeziku naišli ste na pojam iz kulture njemačkoga govornoga područja, a taj pojam vam nije poznat. Prokometirajte kako to doživljavate.

UČ8: Ima toga dosta. Jer su nam neki tekstovi stvarni. Iz života. Pa nam nastavnica razjasni što je to. To može malo smetati, ali ja to volim jer naučim nešto novo.

UČ3: Mene to ne uznemirava. Sve nam objasni nastavnica. Često i prije čitanja teksta. I onda nam nije više nepoznato.

UČ7: To nije problem i ne smeta mi to.

V: Kada se uči njemački jezik uvježbavaju se četiri jezične vještine (čitanje, pisanje, slušanje, govorenje). Kako doživljavate čitanje u usporedbi sostalim jezičnim vještinama? Koja vještina 
vam je najdraža, koja draga, koja manje draga, a koja najmanje draga?Koje vještine su vam draže, a koje manje drage?

UČ10: Meni je govor najdraži. A onda čitanje.

UČ1, UČ3: Meni je čitanje na prvom mjestu. Manje volim govoriti.

UČ6: Meni je najdraže govoriti. Pa čitati, pa pisati, pa slušati. Najlošije razumijem kad slušam, pa nisam baš zadovoljan i sretan.

UČ8: Meni je draže čitati od svega ostaloga.

UČ1: Čitanje mi je jako drago.

UČ2: Nije meni drago čitati na njemačkom. Najbolje mi je pisati. Bolje pišem testove nego usmeno.

UČ5: Ne volim čitati na njemačkom.

\section{V: Kako doživljavate sebe u odnosu na druge kada čitate u razredu?}

UČ6: Ja mislim da sam ja među onima koji su dobri, bolji. Iako mi je draže govoriti, dobro ja i čitam.

UČ10: Ja sam isto među onima koji nemaju problema. Ok se osjećam u razredu. Ali znam da ih ima kojima je valjda muka kad trebaju čitati.

UČ5: Ja stvarno ne volim čitati i ne osjećam se dobro i mislim da to svi i vide. Skoro svima nam tekstovi budu predugi, a meni se čini kao da su kilometar dugi.

UČ4: Ja ne znma gdje sam ja, negdje u sredini. Ali možda sam jedina kojoj se i dlanovi znoje dok čita. Ne znam da to drugi imaju.

UČ5: A ja sam definitivno na lošijoj strani. Ne snalazim se ja ni s onim točkicama, ni s onim kilometarskim riječima. Sve me to zbunjuje.

UČ3: Mene ne. Ja sam prihvatila da je to takav jezik i od početka tako učim. A i volim čitati, rekla sam na prvom mi je mjestu.

\section{V: Kako bi opisali ulogu nastavnika/nastavnice pri ovladavanju vještinom čitanja?}

UČ4: Meni dosta olakšava čitanje i daje mi osjećaj sigurnosti kada ona prva pročita tekst.

UČ9: To mi pomaže, ali ne previše. Meni smeta ako prestrogo ispravlja moje greške. To mi čini da se još lošije osjećam. Još ako ih je puno zaredom.

UČ1: Sviđa mi se što nam ona kaže da ne moramo sve razumjeti kad ono prvi put čitamo i traži da razumijemo samo o čemu je tekst. Pa onda idemo detaljnije.

UČ8: Ja volim da me ispravi i to odmah dok čitam. Onda ću skroz zapamtiti tu riječ, a ako me ispravi na kraju ja ću tu riječ zapamtiti onako pogrešno kako sam i pročitao prvi put sam. 
UČ6: Način kako ti nastavnik nešto ispravi ili te upozori, to ti je najbitnije. Jer te krivi način ili prestrogi odnos može i odvratiti od učenja.

UČ1, UČ2: Upravo tako.

\section{$V$ : Kako bi komentirali odnos (povezanost) doživljaja čitanja i uspješnosti u čitanju?}

UČ4: Kad se manje nerviram oko toga kako ću pročitati, bolje pročitam. Znači što se manje opterećavam time, to mi je bolji rezultat. Mislim treba mi biti stalo, ali se ne smijem previše opteretiti.

UČ10: Meni to ovisi o situaciji. Ali isto ako sam puno nervozan i nekako previše strahujem kako ću pročitati, lošije ću pročitati.

UČ6: Da, ali ja mislim da treba naglasiti - to je kao i s ostalim primjerima. Onaj tko voli čitati, a i nije previše opterećen time hoće li uspjeti, u stvari vjeruje da će uspjeti, stvarno će i bolje čitati. Znam po sebi. A ti ljudi i svoje greške ne shvaćaju previše tragično. Ne opterećavaju se time i idu dalje.

UČ2: Da, ali imaš i one ljude kojima je sve to teško. Na primjer, loše čitaju, stalno rade greške, nastavnica ih ispravlja, i tako stalno, na kraju više nemaju ni volje za čitati.

UČ6: To je onda vezano uz samopouzdanje. Oni ni ne vjeruju u sebe.

UČ2: Pa valjda da.

\section{V: Usporedi svoj doživljaj čitanja na hrvatskome jeziku i na njemačkome jeziku.}

UČ2: Ja mislim da se taj doživljaj prenosi iz jednog jezika u drugi. Ja nisam baš voljela čitati naglas ni na hrvatskom u osnovnoj školi, pa ni sad, ni na njemačkom, ni na engleskom. Sve je to povezano. Lektire sam bez problema čitala, ali naglas mi je problem. Tako da sam uvijek sve što je bilo naglas tiho čitala.

UČ7: Meni nije baš. Mislim da je meni teško na njemačkom čitati jer mi strani jezici nekako ne idu. A hrvatski mogu puno bolje i s manje opterećenja čitati.

UČ4: I mi imamo sreće da se naš jezik isto piše i čita, pa nam je valjda automatski svima lakše čitati hrvatski nego bilo koji drugi i još, naravno, strani jezik.

UČ5: Na hrvatskom mi je teško kad je stručni tekst pretežak. Drugo ništa. A to mi je i na njemačkom teško. Puno struke u nekim tekstovima, a struku još nismo svladali. Hrvatski znam da moram čitati lektiru, ali zašto su nam tekstovi u udžbeniku iz njemačkoga tako dugi, to ne razumijem. Tako da mi je i lakše i draže čitati ipak na hrvatskom. 
UČ8: Meni se čini da većinom svi koji dobro čitaju i dobro uče, i na hrvatskom i na njemačkom. Ja dobro čitam, sreća moja, i hrvatski i njemački i engleski. Pa sve i brže napravim. Čitanje čak i volim.

V: Molim vas, iznesite svoj komentar za kraj. Navedite $i$ ono što nismo prokomentirali, a smatrate da je bitno.

UČ2: Iako meni to ne ide baš najbolje ja mislim da kad više vježbaš to čitanje, to ćeš bolje i čitati. Znači možda bi i meni to nekako pomoglo.

UČ4: Više vježbe, bolji rezultat. Manje opterećenja, bolji rezultat.

UČ5: Prilagodite tekstove u udžbenicima nama. Lakše i kraće za njemački, zanimljivije za engleski.

UČ6: Možemo čitati u parovima; jedan koji lošije čita i jedan koji bolje čita, pa da bolji pomaže lošijemu. Možda se ovaj lošiji malo ohrabri.

UČ9: Ako hoćete da netko bolje čita i manje se brine oko toga, dajte mu kraći i zanimljiv tekst, a ne kobasice od cijele stranice teksta.

V: Ovim komentarima smo došli do kraja našeg razgovora. Svima vam se iskreno zahvaljujem što ste sudjelovali u razgovoru. Vaši komentari, dojmovi i prijedlozi za unaprjeđenje nastave bit će od izuzetne važnosti za nastavak istraživanja. Tijekom ovoga razgovora otvorili ste mi oči za razumijevanje nekih pojava pri učenju njemačkoga jezika kojih se sama ne bih niti sjetila i pojasnili puno tema koje su mi bile bitne. Od srca svima hvala i želim vam uspješan završetak školske godine. 


\section{Prilog 3}

\section{Kratice korištene pri označavanju uzorka}

Tablica 1. Kratice korištene u preliminarnome istraživanju

\begin{tabular}{|l|l|}
\hline \multicolumn{2}{|l|}{ Preliminarno istraživanje } \\
\hline$N_{e_{-} f_{-} p}$ sudionici u fokus grupi za engleski jezik \\
\hline$N_{n j_{-} f_{-} p}$ & sudionici u fokus grupi za njemački jezik \\
\hline$N_{e_{-} p}$ & sudionici u preliminarnome istraživanju za engleski jezik \\
\hline$N_{n j_{-} p}$ & sudionici u preliminarnome istraživanju za njemački jezik \\
\hline
\end{tabular}

Tablica 2. Kratice korištene u glavnome istraživanju

\begin{tabular}{|c|c|}
\hline \multicolumn{2}{|c|}{ Glavno istraživanje } \\
\hline$N_{e_{-} s_{-} m}$ & $\begin{array}{l}\text { sudionici koji su popunili upitnik o strahu od čitanja i upitnik o } \\
\text { motivaciji za engleski jezik }\end{array}$ \\
\hline$N_{e_{-} t e s t}$ & $\begin{array}{l}\text { sudionici koji su riješili test razmijevanja teksta čitanjem za } \\
\text { engleski jezik }\end{array}$ \\
\hline$N_{\text {eng }}$ & $\begin{array}{l}\text { sudionici koji su popunili upitnik o strahu od čitanja, upitnik o } \\
\text { motivaciji za engleski jezik i riješili test razmijevanja teksta } \\
\text { čitanjem za engleski jezik }\end{array}$ \\
\hline$\overline{N_{n j \_} s_{-} m}$ & $\begin{array}{l}\text { sudionici koji su popunili upitnik o strahu od čitanja i upitnik o } \\
\text { motivaciji za njemački jezik }\end{array}$ \\
\hline$N_{n j \_t e s t}$ & $\begin{array}{l}\text { sudionici koji su riješili test razmijevanja teksta čitanjem za } \\
\text { njemački jezik }\end{array}$ \\
\hline$N_{\text {njem }}$ & $\begin{array}{l}\text { sudionici koji su popunili upitnik o strahu od čitanja, upitnik o } \\
\text { motivaciji za njemački jezik jezik i riješili test razmijevanja teksta } \\
\text { čitanjem za njemački jezik }\end{array}$ \\
\hline$N_{e+n j}$ & $\begin{array}{l}\text { sudionici koji su popunili upitnik o strahu od čitanja, upitnik o } \\
\text { motivaciji za engleski jezik i riješili test razmijevanja teksta } \\
\text { čitanjem za engleski jezik i upitnik o strahu od čitanja, upitnik o } \\
\text { motivaciji za njemački jezik jezik i riješili test razmijevanja teksta } \\
\text { čitanjem za njemački jezik }\end{array}$ \\
\hline
\end{tabular}




\section{Prilog 4}

\section{UPITNIK O STRAHU OD ČITANJA NA ENGLESKOME JEZIKU}

\section{1. dio OPĆI PODATCI}

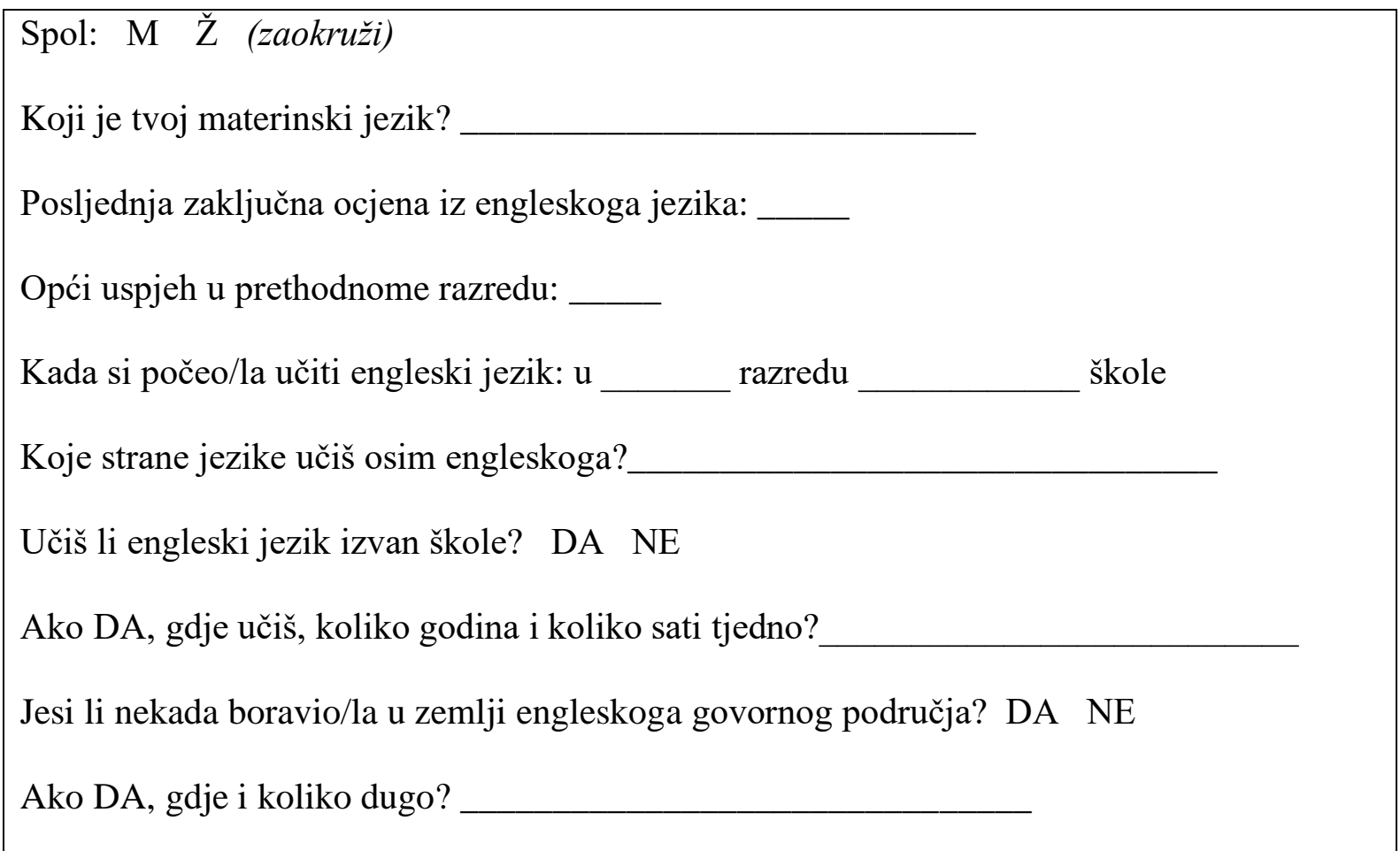

Sada te molimo da ispuniš priloženi upitnik.

Svaku tvrdnju pažljivo pročitaj i nemoj propustiti niti jednu tvrdnju.

Zaokruži jedan od brojeva uz svaku tvrdnju pri čemu pojedini broj ima sljedeće značenje:

$1=$ uopće se ne odnosi na mene

2 = uglavnom se ne odnosi na mene

$3=$ niti se odnosi niti se ne odnosi na mene

4 = uglavnom se odnosi na mene

$5=\mathrm{u}$ potpunosti se odnosi na mene

Nemoj žuriti i iskreno odgovori.

Nema točnih i netočnih odgovora, zanimaju nas tvoja zapažanja.

HVALA NA SURADNJI! :-; ;) ; +: ; 


\section{2. dio UPITNIK O STRAHU OD ČITANJA NA ENGLESKOME JEZIKU}

$1=$ uopće se ne odnosi na mene

2 = uglavnom se ne odnosi na mene

$3=$ niti se odnosi niti se ne odnosi na mene

4 = uglavnom se odnosi na mene

$5=u$ potpunosti se odnosi na mene

\begin{tabular}{|c|c|c|c|c|c|c|}
\hline 1. & $\begin{array}{l}\text { Osjećam se nervozno dok čitam naglas na engleskome pred } \\
\text { drugima. }\end{array}$ & 1 & 2 & 3 & 4 & 5 \\
\hline 2. & $\begin{array}{l}\text { Kad čitam naglas na engleskome pred drugima, uznemirim se i } \\
\text { glas mi se promijeni i drhti. }\end{array}$ & 1 & 2 & 3 & 4 & 5 \\
\hline 3. & $\begin{array}{l}\text { Uznemiruje me kad pri čitanju u sebi naiđem na riječ ili izraz } \\
\text { koji ne razumijem. }\end{array}$ & 1 & 2 & 3 & 4 & 5 \\
\hline 4. & $\begin{array}{l}\text { Kad svi u razredu mirno slušaju i opušteni su ne osjećam } \\
\text { napetost kad čitam naglas na engleskome. }\end{array}$ & 1 & 2 & 3 & 4 & 5 \\
\hline 5. & $\begin{array}{l}\text { Ako trebam odabrati između čitanja, pisanja, slušanja i govora } \\
\text { na engleskome jeziku najteže mi je čitanje. }\end{array}$ & 1 & 2 & 3 & 4 & 5 \\
\hline 6. & Osjećam se ugodno dok čitam naglas na engleskome jeziku. & 1 & 2 & 3 & 4 & 5 \\
\hline 7. & $\begin{array}{l}\text { Osjećam se nervozno dok čitam naglas i na hrvatskome i na } \\
\text { engleskome jeziku. }\end{array}$ & 1 & 2 & 3 & 4 & 5 \\
\hline 8. & Brine me kako ću pročitati duge tekstove u sebi na engleskome. & 1 & 2 & 3 & 4 & 5 \\
\hline 9. & Lijepo mi je čuti sebe kad čitam engleski naglas pred drugima. & 1 & 2 & 3 & 4 & 5 \\
\hline 10. & Draže mi je čitati naglas na engleskome nego na njemačkome. & 1 & 2 & 3 & 4 & 5 \\
\hline 11. & $\begin{array}{l}\text { Zbunjuje me nepodudarnost između načina pisanja i čitanja na } \\
\text { engleskome jeziku. }\end{array}$ & 1 & 2 & 3 & 4 & 5 \\
\hline 12. & $\begin{array}{l}\text { Čini me nervoznim/om kad čitam u sebi i razumijem gotovo sve } \\
\text { riječi u rečenici, ali ne razumijem značenje rečenice. }\end{array}$ & 1 & 2 & 3 & 4 & 5 \\
\hline 13. & $\begin{array}{l}\text { Strah me da nikada neću dobro naučiti čitati engleski jer je } \\
\text { čitanje na engleskome teško. }\end{array}$ & 1 & 2 & 3 & 4 & 5 \\
\hline 14. & $\begin{array}{l}\text { Postajem nervozan/na kad pri čitanju u sebi naiđem na } \\
\text { nepoznatu gramatiku. }\end{array}$ & 1 & 2 & 3 & 4 & 5 \\
\hline 15. & $\begin{array}{l}\text { Kad čitam naglas na engleskome jeziku osjećam se opušteno i } \\
\text { siguran/na u sebe. }\end{array}$ & 1 & 2 & 3 & 4 & 5 \\
\hline 16. & $\begin{array}{l}\text { Dok čitam naglas na engleskome pred drugima, srce mi jače } \\
\text { lupa. }\end{array}$ & 1 & 2 & 3 & 4 & 5 \\
\hline 17. & $\begin{array}{l}\text { Postupci nastavnika/ce me ometaju i zbunjuju dok čitam naglas } \\
\text { na engleskome. }\end{array}$ & 1 & 2 & 3 & 4 & 5 \\
\hline 18. & $\begin{array}{l}\text { Osjećam se sigurnije kad čitam poluglasno tekst na engleskome } \\
\text { jeziku prije čitanja naglas. }\end{array}$ & 1 & 2 & 3 & 4 & 5 \\
\hline 19. & $\begin{array}{l}\text { Kad čitam naglas ne engleskome pred drugima nisam } \\
\text { uznemiren/a i glas mi se ne mijenja i ne drhti. }\end{array}$ & 1 & 2 & 3 & 4 & 5 \\
\hline 20. & $\begin{array}{l}\text { Ako pri čitanju u sebi naiđem na riječ ili riječi koje ne } \\
\text { razumijem, nastavljam čitati bez uznemiravanja. }\end{array}$ & 1 & 2 & 3 & 4 & 5 \\
\hline 21. & $\begin{array}{l}\text { Osjećam se sigurnije kad čitam naglas na engleskome nego kad } \\
\text { čitam naglas na njemačkome. }\end{array}$ & 1 & 2 & 3 & 4 & 5 \\
\hline 22. & Loše mi ide čitanje na hrvatskome i na engleskome jeziku. & 1 & 2 & 3 & 4 & 5 \\
\hline 23. & $\begin{array}{l}\text { Smeta me kad me nastavnik/ca prekida i ispravlja dok čitam } \\
\text { naglas. }\end{array}$ & 1 & 2 & 3 & 4 & 5 \\
\hline
\end{tabular}




\begin{tabular}{|c|c|c|c|c|c|c|}
\hline 24. & $\begin{array}{l}\text { Dok čitam naglas na engleskome, brine me kako ću izgovoriti } \\
\text { pojedine riječi. }\end{array}$ & 1 & 2 & 3 & 4 & 5 \\
\hline 25. & Nervozan/na sam kad čitam tekst koji nije zanimljiv. & 1 & 2 & 3 & 4 & 5 \\
\hline 26. & $\begin{array}{l}\text { Dok čitam naglas na engleskome pred drugima osjećam da mi se } \\
\text { znoje dlanovi. }\end{array}$ & 1 & 2 & 3 & 4 & 5 \\
\hline 27. & $\begin{array}{l}\text { Nervozniji /ja sam kad čitam naglas na engleskome nego kad } \\
\text { pišem, slušam ili govorim. }\end{array}$ & 1 & 2 & 3 & 4 & 5 \\
\hline 28. & $\begin{array}{l}\text { Ako čitam tekst na engleskome o nepoznatoj temi postajem } \\
\text { nervozan/na. }\end{array}$ & 1 & 2 & 3 & 4 & 5 \\
\hline 29. & $\begin{array}{l}\text { Nervozniji/ja sam kad čitam naglas na engleskome nego kad } \\
\text { čitam u sebi. }\end{array}$ & 1 & 2 & 3 & 4 & 5 \\
\hline 30. & $\begin{array}{l}\text { Smeta mi kad čitam naglas na engleskome, a ostali učenici me } \\
\text { ne slušaju i stvaraju žamor. }\end{array}$ & 1 & 2 & 3 & 4 & 5 \\
\hline 31. & $\begin{array}{l}\text { Smeta me kad u tekstu naiđem na neki pojam iz britanske, } \\
\text { američke i dr. kultura koji mi nije poznat. }\end{array}$ & 1 & 2 & 3 & 4 & 5 \\
\hline 32. & $\begin{array}{l}\text { Uznemiruje me kad čitam u sebi tekst na engleskome, a } \\
\text { nastavnik/ca nakog toga ocjenjuje zadatke razumijevanja } \\
\text { pročitanoga. }\end{array}$ & 1 & 2 & 3 & 4 & 5 \\
\hline 33. & $\begin{array}{l}\text { Manje sam uznemiren/na kad čitam naglas na engleskome nego } \\
\text { na njemačkom. }\end{array}$ & 1 & 2 & 3 & 4 & 5 \\
\hline 34. & Strah me da će me ostali učenici ismijavati jer ne čitam dobro. & 1 & 2 & 3 & 4 & 5 \\
\hline 35. & $\begin{array}{l}\text { Pri čitanju na engleskome u sebi zbunjuju me duge riječi koje je } \\
\text { teško pročitati. }\end{array}$ & 1 & 2 & 3 & 4 & 5 \\
\hline 36. & $\begin{array}{l}\text { Ne osjećam nesigurnost kad čitam u sebi na engleskome nego } \\
\text { kad čitam naglas. }\end{array}$ & 1 & 2 & 3 & 4 & 5 \\
\hline 37. & $\begin{array}{l}\text { Osjećam se nesigurno kad čitam naglas na engleskome jer } \\
\text { nemam dar za čitanje na engleskome. }\end{array}$ & 1 & 2 & 3 & 4 & 5 \\
\hline 38. & $\begin{array}{l}\text { Uznemiren/a sam kad čitam naglas i na hrvatskom i na } \\
\text { engleskome jeziku. }\end{array}$ & 1 & 2 & 3 & 4 & 5 \\
\hline 39. & $\begin{array}{l}\text { Uhvati me panika kad čitam naglas na engleskome jer znam da i } \\
\text { o tome ovisi ocjena koju će mi zaključiti nastavnik/ca. }\end{array}$ & 1 & 2 & 3 & 4 & 5 \\
\hline 40. & $\begin{array}{l}\text { Ne uznemiruje me što postoji nepodudarnost između načina } \\
\text { pisanja i čitanja na engleskome jeziku. }\end{array}$ & 1 & 2 & 3 & 4 & 5 \\
\hline
\end{tabular}




\section{Prilog 5}

\section{UPITNIK O STRAHU OD ČITANJA NA NJEMAČKOME JEZIKU}

\section{1. dio OPĆI PODATCI}

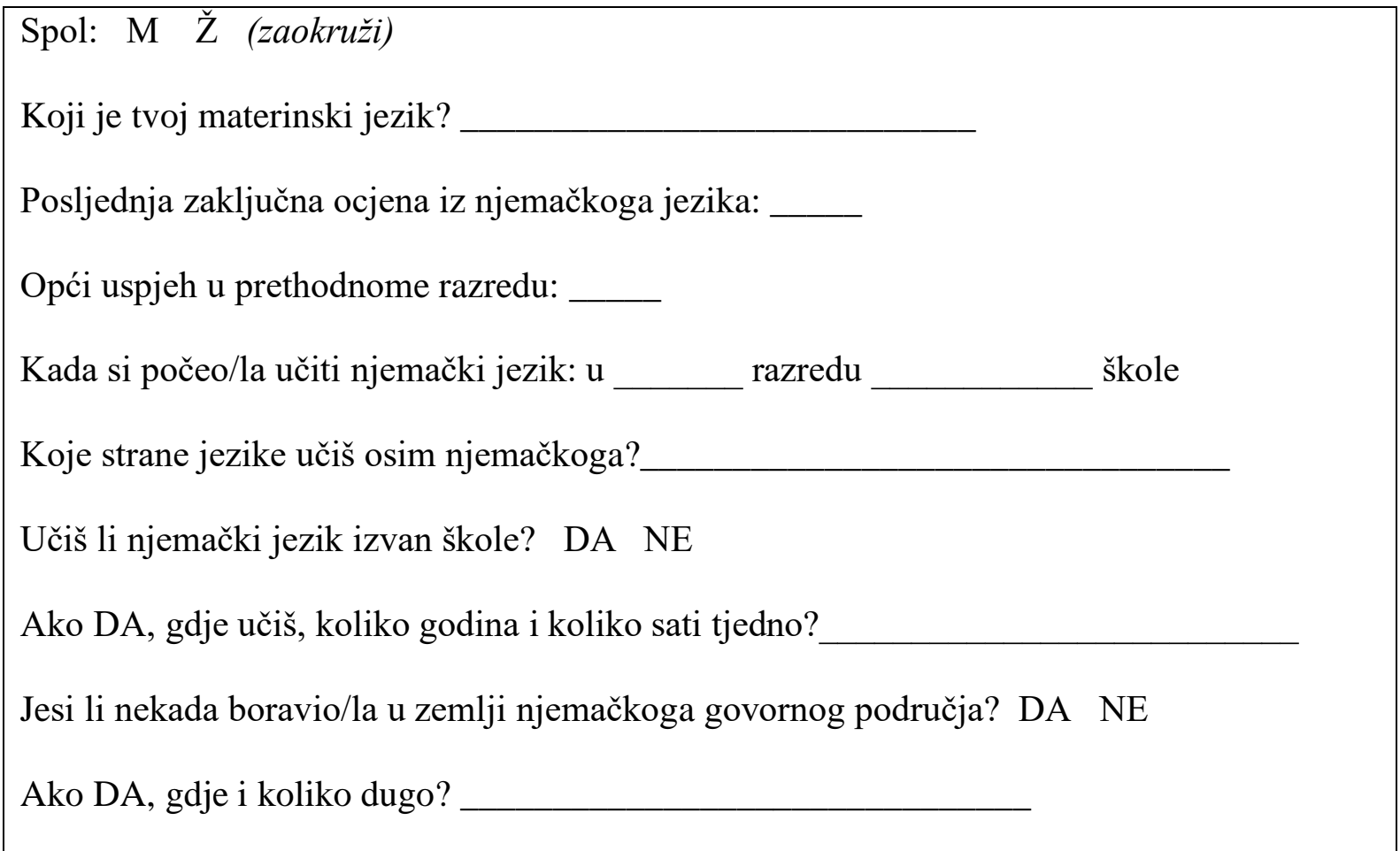

Sada te molimo da ispuniš priloženi upitnik.

Svaku tvrdnju pažljivo pročitaj i nemoj propustiti niti jednu tvrdnju.

Zaokruži jedan od brojeva uz svaku tvrdnju pri čemu pojedini broj ima sljedeće značenje:

$1=$ uopće se ne odnosi na mene

2 = uglavnom se ne odnosi na mene

$3=$ niti se odnosi niti se ne odnosi na mene

4 = uglavnom se odnosi na mene

$5=\mathrm{u}$ potpunosti se odnosi na mene

Nemoj žuriti i iskreno odgovori.

Nema točnih i netočnih odgovora, zanimaju nas tvoja zapažanja.

HVALA NA SURADNJI! ; ; ; ; ; $;$ 


\section{2. dio UPITNIK O STRAHU OD ČITANJA NA NJEMAČKOME JEZIKU}

$1=$ uopće se ne odnosi na mene

2 = uglavnom se ne odnosi na mene

$3=$ niti se odnosi niti se ne odnosi na mene

4 = uglavnom se odnosi na mene

$5=u$ potpunosti se odnosi na mene

\begin{tabular}{|c|c|c|c|c|c|c|}
\hline 1. & $\begin{array}{l}\text { Osjećam se nervozno dok čitam naglas na njemačkome pred } \\
\text { drugima. }\end{array}$ & 1 & 2 & 3 & 4 & 5 \\
\hline 2. & $\begin{array}{l}\text { Kad čitam naglas na njemačkome pred drugima, uznemirim se i } \\
\text { glas mi se promijeni i drhti. }\end{array}$ & 1 & 2 & 3 & 4 & 5 \\
\hline 3. & $\begin{array}{l}\text { Uznemiruje me kad pri čitanju u sebi naiđem na riječ ili izraz } \\
\text { koji ne razumijem. }\end{array}$ & 1 & 2 & 3 & 4 & 5 \\
\hline 4. & $\begin{array}{l}\text { Kad svi u razredu mirno slušaju i opušteni su ne osjećam } \\
\text { napetost kad čitam naglas na njemačkome. }\end{array}$ & 1 & 2 & 3 & 4 & 5 \\
\hline 5. & $\begin{array}{l}\text { Ako trebam odabrati između čitanja, pisanja, slušanja i govora } \\
\text { na njemačkome jeziku najteže mi je čitanje. }\end{array}$ & 1 & 2 & 3 & 4 & 5 \\
\hline 6. & Osjećam se ugodno dok čitam naglas na njemačkom jeziku. & 1 & 2 & 3 & 4 & 5 \\
\hline 7. & $\begin{array}{l}\text { Osjećam se nervozno dok čitam naglas i na hrvatskome i na } \\
\text { njemačkome jeziku. }\end{array}$ & 1 & 2 & 3 & 4 & 5 \\
\hline 8. & Brine me kako ću pročitati duge tekstove u sebi na njemačkome. & 1 & 2 & 3 & 4 & 5 \\
\hline 9. & Lijepo mi je čuti sebe kad čitam njemački naglas pred drugima. & 1 & 2 & 3 & 4 & 5 \\
\hline 10. & Draže mi je čitati naglas na njemačkome nego na engleskome. & 1 & 2 & 3 & 4 & 5 \\
\hline 11. & $\begin{array}{l}\text { Zbunjuje me nepodudarnost između načina pisanja i čitanja na } \\
\text { njemačkome jeziku. }\end{array}$ & 1 & 2 & 3 & 4 & 5 \\
\hline 12. & $\begin{array}{l}\text { Čini me nervoznim/om kad čitam u sebi i razumijem gotovo sve } \\
\text { riječi u rečenici, ali ne razumijem značenje rečenice. }\end{array}$ & 1 & 2 & 3 & 4 & 5 \\
\hline 13. & $\begin{array}{l}\text { Strah me da nikada neću dobro naučiti čitati njemački jer je } \\
\text { čitanje na njemačkome teško. }\end{array}$ & 1 & 2 & 3 & 4 & 5 \\
\hline 14. & $\begin{array}{l}\text { Postajem nervozan/na kad pri čitanju u sebi naiđem na } \\
\text { nepoznatu gramatiku. }\end{array}$ & 1 & 2 & 3 & 4 & 5 \\
\hline 15. & $\begin{array}{l}\text { Kad čitam naglas na njemačkome jeziku osjećam se opušteno i } \\
\text { siguran/na u sebe. }\end{array}$ & 1 & 2 & 3 & 4 & 5 \\
\hline 16. & $\begin{array}{l}\text { Dok čitam naglas na njemačkome pred drugima, srce mi jače } \\
\text { lupa. }\end{array}$ & 1 & 2 & 3 & 4 & 5 \\
\hline 17. & $\begin{array}{l}\text { Postupci nastavnika/ce me ometaju i zbunjuju dok čitam naglas } \\
\text { na njemačkome. }\end{array}$ & 1 & 2 & 3 & 4 & 5 \\
\hline 18. & $\begin{array}{l}\text { Osjećam se sigurnije kad čitam poluglasno tekst na njemačkome } \\
\text { jeziku prije čitanja naglas. }\end{array}$ & 1 & 2 & 3 & 4 & 5 \\
\hline 19. & $\begin{array}{l}\text { Kad čitam naglas ne njemačkome pred drugima nisam } \\
\text { uznemiren/a i glas mi se ne mijenja i ne drhti. }\end{array}$ & 1 & 2 & 3 & 4 & 5 \\
\hline 20. & $\begin{array}{l}\text { Ako pri čitanju u sebi naiđem na riječ ili riječi koje ne } \\
\text { razumijem, nastavljam čitati bez uznemiravanja. }\end{array}$ & 1 & 2 & 3 & 4 & 5 \\
\hline 21. & $\begin{array}{l}\text { Osjećam se sigurnije kad čitam naglas na njemačkome nego kad } \\
\text { čitam naglas na engleskome. }\end{array}$ & 1 & 2 & 3 & 4 & 5 \\
\hline 22. & Loše mi ide čitanje na hrvatskome i na njemačkome jeziku. & 1 & 2 & 3 & 4 & 5 \\
\hline 23. & $\begin{array}{l}\text { Smeta me kad me nastavnik/ca prekida i ispravlja dok čitam } \\
\text { naglas. }\end{array}$ & 1 & 2 & 3 & 4 & 5 \\
\hline
\end{tabular}




\begin{tabular}{|c|c|c|c|c|c|c|}
\hline 24. & $\begin{array}{l}\text { Dok čitam naglas na njemačkome, brine me kako ću izgovoriti } \\
\text { pojedine riječi. }\end{array}$ & $\mathbf{1}$ & 2 & 3 & 4 & 5 \\
\hline 25. & Nervozan/na sam kad čitam tekst koji nije zanimljiv. & 1 & 2 & 3 & 4 & 5 \\
\hline 26. & $\begin{array}{l}\text { Dok čitam naglas na njemačkome pred drugima osjećam da mi } \\
\text { se znoje dlanovi. }\end{array}$ & 1 & 2 & 3 & 4 & 5 \\
\hline 27. & $\begin{array}{l}\text { Nervozniji /ja sam kad čitam naglas na njemačkome nego kad } \\
\text { pišem, slušam ili govorim. }\end{array}$ & 1 & 2 & 3 & 4 & 5 \\
\hline 28. & $\begin{array}{l}\text { Ako čitam tekst na njemačkome o nepoznatoj temi postajem } \\
\text { nervozan/na. }\end{array}$ & 1 & 2 & 3 & 4 & 5 \\
\hline 29. & $\begin{array}{l}\text { Nervozniji/ja sam kad čitam naglas na njemačkome nego kad } \\
\text { čitam u sebi. }\end{array}$ & 1 & 2 & 3 & 4 & 5 \\
\hline 30. & $\begin{array}{l}\text { Smeta mi kad čitam naglas na njemačkome, a ostali učenici me } \\
\text { ne slušaju i stvaraju žamor. }\end{array}$ & 1 & 2 & 3 & 4 & 5 \\
\hline 31. & $\begin{array}{l}\text { Smeta me kad u tekstu naiđem na neki pojam iz njemačke, } \\
\text { austrijske i dr. kultura koji mi nije poznat. }\end{array}$ & 1 & 2 & 3 & 4 & 5 \\
\hline 32. & $\begin{array}{l}\text { Uznemiruje me kad čitam u sebi tekst na njemačkome, a } \\
\text { nastavnik/ca nakog toga ocjenjuje zadatke razumijevanja } \\
\text { pročitanoga. }\end{array}$ & 1 & 2 & 3 & 4 & 5 \\
\hline 33. & $\begin{array}{l}\text { Manje sam uznemiren/na kad čitam naglas na njemačkome nego } \\
\text { na engleskome. }\end{array}$ & 1 & 2 & 3 & 4 & 5 \\
\hline 34. & Strah me da će me ostali učenici ismijavati jer ne čitam dobro. & 1 & 2 & 3 & 4 & 5 \\
\hline 35. & $\begin{array}{l}\text { Pri čitanju na njemačkome u sebi zbunjuju me duge riječi koje je } \\
\text { teško pročitati. }\end{array}$ & 1 & 2 & 3 & 4 & 5 \\
\hline 36. & $\begin{array}{l}\text { Ne osjećam nesigurnost kad čitam u sebi na njemačkome nego } \\
\text { kad čitam naglas. }\end{array}$ & 1 & 2 & 3 & 4 & 5 \\
\hline 37. & $\begin{array}{l}\text { Osjećam se nesigurno kad čitam naglas na njemačkome jer } \\
\text { nemam dar za čitanje na njemačkome. }\end{array}$ & 1 & 2 & 3 & 4 & 5 \\
\hline 38. & $\begin{array}{l}\text { Uznemiren/a sam kad čitam naglas i na hrvatskome i na } \\
\text { njemačkome jeziku. }\end{array}$ & 1 & 2 & 3 & 4 & 5 \\
\hline 39. & $\begin{array}{l}\text { Uhvati me panika kad čitam naglas na njemačkome jer znam da } \\
\text { i o tome ovisi ocjena koju će mi zaključiti nastavnik/ca. }\end{array}$ & $\mathbf{1}$ & 2 & 3 & 4 & 5 \\
\hline 40. & $\begin{array}{l}\text { Ne uznemiruje me što postoji nepodudarnost između načina } \\
\text { pisanja i čitanja na njemačkome jeziku. }\end{array}$ & 1 & 2 & 3 & 4 & 5 \\
\hline
\end{tabular}




\section{Prilog 6}

\section{UPITNIK O STRAHU OD ČITANJA NA ENGLESKOME JEZIKU}

ŠIFRA:

broj broj broj broj slovo slovo

Sudjelovanjem u ovome istraživanju postaješ sudionik/ca u znanstvenome istraživanju vezanom uz učenje stranih jezika. Tvoje je sudjelovanje dobrovoljno.

Rezultati istraživanja bit će korišteni isključivo u znanstvene svrhe, a istraživač je dužan zaštititi tajnost prikupljenih podataka.

Zahvaljujemo ti na suradnji.

mr. sc. Sandra Didović Baranac, prof.

sandra.didovic-baranac@unidu.hr 


\section{DIO}

\section{Opći podatci}

1. Spol: $M$ Ž (zaokruži)

2. Koji je tvoj materinski jezik?

3. Opći uspjeh (srednja škola):

1. razred

2. razred

3. razred

4. Zaključna ocjena iz engleskoga jezika (srednja škola):

1. razred

2. razred

3. razred

5. Koje strane jezike učiš osim engleskoga i koliko dugo?

(Koliko godina u osnovnoj školi, koliko godina u srednjoj školi?)

1.

2.

jezik

3. jezik jezik

6. Kada si počeo/la učiti engleski jezik? U razredu škole.

7. Učiš li ili si učio/la engleski jezik izvan škole? DA NE

8. Ako DA, gdje, koliko dugo i koliko sati tjedno?

9. Jesi li nekada boravio/la u zemlji engleskoga govornog područja? DA NE 10. Ako DA, gdje, zašto i koliko dugo?

Sada te molimo da ispuniš priloženi upitnik.

Svaku tvrdnju pažljivo pročitaj i nemoj propustiti niti jednu tvrdnju.

Zaokruži jedan od brojeva uz svaku tvrdnju pri čemu pojedini broj ima sljedeće značenje:

1 = uopće se ne odnosi na mene

2 = uglavnom se ne odnosi na mene

$3=$ niti se odnosi niti se ne odnosi na mene

4 = uglavnom se odnosi na mene

$5=u$ potpunosti se odnosi na mene

Nemoj žuriti i iskreno odgovori.

Nema točnih i netočnih odgovora, zanimaju nas tvoja zapažanja. 


\section{DIO}

\section{Upitnik o strahu od čitanja na engleskome jeziku}

1 = uopće se ne odnosi na mene

2 = uglavnom se ne odnosi na mene

$3=$ niti se odnosi niti se ne odnosi na mene

$4=$ uglavnom se odnosi na mene

$5=u$ potpunosti se odnosi na mene

\begin{tabular}{|c|c|c|c|c|c|c|}
\hline 1. & $\begin{array}{l}\text { Osjećam se nervozno dok čitam naglas na engleskome pred } \\
\text { drugima. }\end{array}$ & 1 & 2 & 3 & 4 & 5 \\
\hline 2. & $\begin{array}{l}\text { Kad čitam naglas na engleskome pred drugima, uznemirim se i } \\
\text { glas mi se promijeni i drhti. }\end{array}$ & 1 & 2 & 3 & 4 & 5 \\
\hline 3. & $\begin{array}{l}\text { Uznemiruje me kad pri čitanju u sebi naiđem na riječ ili izraz } \\
\text { koji ne razumijem. }\end{array}$ & 1 & 2 & 3 & 4 & 5 \\
\hline 4. & $\begin{array}{l}\text { Ako trebam odabrati između čitanja, pisanja, slušanja i govora } \\
\text { na engleskome jeziku, najteže mi je čitanje. }\end{array}$ & 1 & 2 & 3 & 4 & 5 \\
\hline 5. & Osjećam se ugodno dok čitam naglas na engleskome jeziku. & 1 & 2 & 3 & 4 & 5 \\
\hline 6. & $\begin{array}{l}\text { Brinem se kako ću u sebi pročitati duge tekstove na } \\
\text { engleskome. }\end{array}$ & 1 & 2 & 3 & 4 & 5 \\
\hline 7. & $\begin{array}{l}\text { Zbunjuje me nepodudarnost između načina pisanja i čitanja na } \\
\text { engleskome jeziku. }\end{array}$ & 1 & 2 & 3 & 4 & 5 \\
\hline 8. & $\begin{array}{l}\text { Čini me nervoznim/om kad čitam u sebi i razumijem gotovo sve } \\
\text { riječi u rečenici, ali ne razumijem značenje rečenice. }\end{array}$ & 1 & 2 & 3 & 4 & 5 \\
\hline 9. & $\begin{array}{l}\text { Strah me da nikada neću dobro naučiti čitati engleski jer je } \\
\text { čitanje na engleskome teško. }\end{array}$ & 1 & 2 & 3 & 4 & 5 \\
\hline 10. & $\begin{array}{l}\text { Postajem nervozan/na kad pri čitanju u sebi naiđem na } \\
\text { nepoznatu gramatičku konstrukciju. }\end{array}$ & 1 & 2 & 3 & 4 & 5 \\
\hline 11. & $\begin{array}{l}\text { Kad čitam naglas na engleskome jeziku, osjećam se opušteno i } \\
\text { siguran/na u sebe. }\end{array}$ & 1 & 2 & 3 & 4 & 5 \\
\hline 12. & $\begin{array}{l}\text { Dok čitam naglas na engleskome pred drugima, srce mi jače } \\
\text { lupa. }\end{array}$ & 1 & 2 & 3 & 4 & 5 \\
\hline 13. & $\begin{array}{l}\text { Postupci nastavnika/ce ometaju me i zbunjuju dok čitam naglas } \\
\text { na engleskome. }\end{array}$ & 1 & 2 & 3 & 4 & 5 \\
\hline 14. & $\begin{array}{l}\text { Ako pri čitanju u sebi naiđem na riječ ili riječi koje ne } \\
\text { razumijem, nastavljam čitati a da se nisam uznemirio/la. }\end{array}$ & 1 & 2 & 3 & 4 & 5 \\
\hline
\end{tabular}


1 = uopće se ne odnosi na mene

2 = uglavnom se ne odnosi na mene

$3=$ niti se odnosi niti se ne odnosi na mene

$4=$ uglavnom se odnosi na mene

$5=u$ potpunosti se odnosi na mene

\begin{tabular}{|c|c|c|c|c|c|c|}
\hline 15. & $\begin{array}{l}\text { Smeta me kad me nastavnik/ca prekida i ispravlja dok čitam } \\
\text { naglas. }\end{array}$ & 1 & 2 & 3 & 4 & 5 \\
\hline 16. & $\begin{array}{l}\text { Dok čitam naglas na engleskome, brinem se kako ću izgovoriti } \\
\text { pojedine riječi. }\end{array}$ & 1 & 2 & 3 & 4 & 5 \\
\hline 17. & Nervozan/na sam kad čitam tekst koji nije zanimljiv. & 1 & 2 & 3 & 4 & 5 \\
\hline 18. & $\begin{array}{l}\text { Dok čitam naglas na engleskome pred drugima, osjećam da mi } \\
\text { se znoje dlanovi. }\end{array}$ & 1 & 2 & 3 & 4 & 5 \\
\hline 19. & $\begin{array}{l}\text { Nervozniji/ja sam kad čitam naglas na engleskome nego kad } \\
\text { pišem, slušam ili govorim. }\end{array}$ & 1 & 2 & 3 & 4 & 5 \\
\hline 20. & $\begin{array}{l}\text { Ako čitam tekst na engleskome o nepoznatoj temi, postajem } \\
\text { nervozan/na. }\end{array}$ & 1 & 2 & 3 & 4 & 5 \\
\hline 21. & $\begin{array}{l}\text { Smeta me kad u tekstu naiđem na neki pojam iz britanske, } \\
\text { američke ili druge kulture engleskoga govornoga područja koji } \\
\text { mi nije poznat. }\end{array}$ & 1 & 2 & 3 & 4 & 5 \\
\hline 22. & $\begin{array}{l}\text { Uznemiruje me kad čitam u sebi tekst na engleskome, a } \\
\text { nastavnik/ca nakog toga ocjenjuje zadatke razumijevanja } \\
\text { pročitanoga. }\end{array}$ & 1 & 2 & 3 & 4 & 5 \\
\hline 23. & Strah me da će me ostali učenici ismijavati jer ne čitam dobro. & 1 & 2 & 3 & 4 & 5 \\
\hline 24. & $\begin{array}{l}\text { Pri čitanju u sebi na engleskome zbunjuju me duge riječi koje je } \\
\text { teško pročitati. }\end{array}$ & 1 & 2 & 3 & 4 & 5 \\
\hline 25. & $\begin{array}{l}\text { Osjećam se nesigurno kad čitam naglas na engleskome jer } \\
\text { nemam dara za čitanje na engleskome. }\end{array}$ & 1 & 2 & 3 & 4 & 5 \\
\hline
\end{tabular}




\section{DIO}

\section{Upitnik o motivaciji za učenje engleskoga jezika}

\section{Molimo te da pažljivo pročitaš sljedeće tvrdnje u vezi s učenjem engleskoga jezika i zaokružiš odgovarajući broj (od 1 do 5) prema tome koliko se svaka tvrdnja odnosi na tebe.}

\section{Ovdje nema točnih i netočnih odgovora!}

1 = neistinito, uopće nije tako

2 = uglavnom neistinito, često nije tako

3 = nisam siguran, ne mogu se odlučiti

4 = uglavnom istinito, često je tako

$5=$ istinito, uvijek je tako

\begin{tabular}{|l|l|l|l|l|l|l|}
\hline 1. & Jako mi se sviđa engleski jezik. & $\mathbf{1}$ & $\mathbf{2}$ & $\mathbf{3}$ & $\mathbf{4}$ & $\mathbf{5}$ \\
\hline 2. & Znanje engleskoga jezika za mene je beskorisno. & $\mathbf{1}$ & $\mathbf{2}$ & $\mathbf{3}$ & $\mathbf{4}$ & $\mathbf{5}$ \\
\hline 3. & Moji roditelji smatraju važnim da znam engleski jezik. & $\mathbf{1}$ & $\mathbf{2}$ & $\mathbf{3}$ & $\mathbf{4}$ & $\mathbf{5}$ \\
\hline 4. & Zanimaju me ljudi koji govore engleski jezik. & $\mathbf{1}$ & $\mathbf{2}$ & $\mathbf{3}$ & $\mathbf{4}$ & $\mathbf{5}$ \\
\hline 5. & Zanimaju me filmovi i glazba na engleskome jeziku. & $\mathbf{1}$ & $\mathbf{2}$ & $\mathbf{3}$ & $\mathbf{4}$ & $\mathbf{5}$ \\
\hline 6. & Sati engleskoga jezika neizmjerno su mi dosadni. & $\mathbf{1}$ & $\mathbf{2}$ & $\mathbf{3}$ & $\mathbf{4}$ & $\mathbf{5}$ \\
\hline 7. & Nemam osjećaj za jezik, beznadni sam slučaj za učenje jezika. & $\mathbf{1}$ & $\mathbf{2}$ & $\mathbf{3}$ & $\mathbf{4}$ & $\mathbf{5}$ \\
\hline 8. & Lako učim engleski jezik. & $\mathbf{1}$ & $\mathbf{2}$ & $\mathbf{3}$ & $\mathbf{4}$ & $\mathbf{5}$ \\
\hline 9. & Trebalo bi mi više truda i volje da budem uspješniji/uspješnija. & $\mathbf{1}$ & $\mathbf{2}$ & $\mathbf{3}$ & $\mathbf{4}$ & $\mathbf{5}$ \\
\hline 10. & Kolikogod učio/učila, ne mogu postići bolje rezultate. & $\mathbf{1}$ & $\mathbf{2}$ & $\mathbf{3}$ & $\mathbf{4}$ & $\mathbf{5}$ \\
\hline 11. & U svoje slobodno vrijeme rado se bavim engleskim jezikom. & $\mathbf{1}$ & $\mathbf{2}$ & $\mathbf{3}$ & $\mathbf{4}$ & $\mathbf{5}$ \\
\hline 12. & Tijekom učenja engleskoga jezika često doživim neuspjeh. & $\mathbf{1}$ & $\mathbf{2}$ & $\mathbf{3}$ & $\mathbf{4}$ & $\mathbf{5}$ \\
\hline 13. & Na satima engleskoga jezika bojim se usmenog odgovaranja. & $\mathbf{1}$ & $\mathbf{2}$ & $\mathbf{3}$ & $\mathbf{4}$ & $\mathbf{5}$ \\
\hline 14. & Udžbenici po kojima učimo engleski loši su. & $\mathbf{1}$ & $\mathbf{2}$ & $\mathbf{3}$ & $\mathbf{4}$ & $\mathbf{5}$ \\
\hline
\end{tabular}




\section{Prilog 7}

\section{UPITNIK O STRAHU OD ČITANJA NA NJEMAČKOME JEZIKU}

ŠIFRA:

broj broj broj broj slovo slovo

Sudjelovanjem u ovome istraživanju postaješ sudionik/ca u znanstvenome istraživanju vezanom uz učenje stranih jezika. Tvoje je sudjelovanje dobrovoljno.

Rezultati istraživanja bit će korišteni isključivo u znanstvene svrhe, a istraživač je dužan zaštititi tajnost prikupljenih podataka.

Zahvaljujemo ti na suradnji.

mr. sc. Sandra Didović Baranac, prof.

sandra.didovic-baranac@unidu.hr 


\section{DIO}

\section{Opći podatci}

1. Spol: $M$ Ž (zaokruži)

2. Koji je tvoj materinski jezik?

3. Opći uspjeh (srednja škola):

1. razred

2. razred

3. razred

4. Zaključna ocjena iz njemačkoga jezika (srednja škola):

1. razred

2. razred

3. razred

5. Koje strane jezike učiš osim njemačkoga i koliko dugo?

(Koliko godina u osnovnoj školi, koliko godina u srednjoj školi?)

1. jezik

2. jezik

3. jezik

6. Kada si počeo/la učiti njemački jezik? U razredu škole.

7. Učiš li ili si učio/la njemački jezik izvan škole? DA NE

8. Ako DA, gdje, koliko dugo i koliko sati tjedno?

9. Jesi li nekada boravio/la u zemlji njemačkoga govornog područja? DA NE

10. Ako DA, gdje, zašto i koliko dugo?

Sada te molimo da ispuniš priloženi upitnik.

Svaku tvrdnju pažljivo pročitaj i nemoj propustiti niti jednu tvrdnju.

Zaokruži jedan od brojeva uz svaku tvrdnju pri čemu pojedini broj ima sljedeće značenje:

1 = uopće se ne odnosi na mene

2 = uglavnom se ne odnosi na mene

$3=$ niti se odnosi niti se ne odnosi na mene

4 = uglavnom se odnosi na mene

$5=\mathrm{u}$ potpunosti se odnosi na mene

Nemoj žuriti i iskreno odgovori.

Nema točnih i netočnih odgovora, zanimaju nas tvoja zapažanja. 


\section{DIO}

\section{Upitnik o strahu od čitanja na njemačkome jeziku}

1 = uopće se ne odnosi na mene

2 = uglavnom se ne odnosi na mene

$3=$ niti se odnosi niti se ne odnosi na mene

$4=$ uglavnom se odnosi na mene

$5=u$ potpunosti se odnosi na mene

\begin{tabular}{|c|c|c|c|c|c|c|}
\hline 1. & $\begin{array}{l}\text { Osjećam se nervozno dok čitam naglas na njemačkome pred } \\
\text { drugima. }\end{array}$ & 1 & 2 & 3 & 4 & 5 \\
\hline 2. & $\begin{array}{l}\text { Kad čitam naglas na njemačkome pred drugima, uznemirim se i } \\
\text { glas mi se promijeni i drhti. }\end{array}$ & 1 & 2 & 3 & 4 & 5 \\
\hline 3. & $\begin{array}{l}\text { Uznemiruje me kad pri čitanju u sebi naiđem na riječ ili izraz } \\
\text { koji ne razumijem. }\end{array}$ & 1 & 2 & 3 & 4 & 5 \\
\hline 4. & $\begin{array}{l}\text { Ako trebam odabrati između čitanja, pisanja, slušanja i govora } \\
\text { na njemačkome jeziku, najteže mi je čitanje. }\end{array}$ & 1 & 2 & 3 & 4 & 5 \\
\hline 5. & Osjećam se ugodno dok čitam naglas na njemačkome jeziku. & 1 & 2 & 3 & 4 & 5 \\
\hline 6. & $\begin{array}{l}\text { Brinem se kako ću u sebi pročitati duge tekstove na } \\
\text { njemačkome. }\end{array}$ & 1 & 2 & 3 & 4 & 5 \\
\hline 7. & $\begin{array}{l}\text { Zbunjuje me nepodudarnost između načina pisanja i čitanja na } \\
\text { njemačkome jeziku. }\end{array}$ & 1 & 2 & 3 & 4 & 5 \\
\hline 8. & $\begin{array}{l}\text { Čini me nervoznim/om kad čitam u sebi i razumijem gotovo sve } \\
\text { riječi u rečenici, ali ne razumijem značenje rečenice. }\end{array}$ & 1 & 2 & 3 & 4 & 5 \\
\hline 9. & $\begin{array}{l}\text { Strah me da nikada neću dobro naučiti čitati njemački jer je } \\
\text { čitanje na njemačkome teško. }\end{array}$ & 1 & 2 & 3 & 4 & 5 \\
\hline 10. & $\begin{array}{l}\text { Postajem nervozan/na kad pri čitanju u sebi naiđem na } \\
\text { nepoznatu gramatičku konstrukciju. }\end{array}$ & 1 & 2 & 3 & 4 & 5 \\
\hline 11. & $\begin{array}{l}\text { Kad čitam naglas na njemačkome jeziku, osjećam se opušteno i } \\
\text { siguran/na u sebe. }\end{array}$ & 1 & 2 & 3 & 4 & 5 \\
\hline 12. & $\begin{array}{l}\text { Dok čitam naglas na njemačkome pred drugima, srce mi jače } \\
\text { lupa. }\end{array}$ & 1 & 2 & 3 & 4 & 5 \\
\hline 13. & $\begin{array}{l}\text { Postupci nastavnika/ce ometaju me i zbunjuju dok čitam naglas } \\
\text { na njemačkome. }\end{array}$ & 1 & 2 & 3 & 4 & 5 \\
\hline 14. & $\begin{array}{l}\text { Ako pri čitanju u sebi naiđem na riječ ili riječi koje ne } \\
\text { razumijem, nastavljam čitati a da se nisam uznemirio/la. }\end{array}$ & 1 & 2 & 3 & 4 & 5 \\
\hline
\end{tabular}


1 = uopće se ne odnosi na mene

2 = uglavnom se ne odnosi na mene

$3=$ niti se odnosi niti se ne odnosi na mene

$4=$ uglavnom se odnosi na mene

$5=u$ potpunosti se odnosi na mene

\begin{tabular}{|c|l|c|c|c|c|c|}
\hline 15. & $\begin{array}{l}\text { Smeta me kad me nastavnik/ca prekida i ispravlja dok čitam } \\
\text { naglas. }\end{array}$ & $\mathbf{1}$ & $\mathbf{2}$ & $\mathbf{3}$ & $\mathbf{4}$ & $\mathbf{5}$ \\
\hline 16. & $\begin{array}{l}\text { Dok čitam naglas na njemačkom, brinem se kako ću izgovoriti } \\
\text { pojedine riječi. }\end{array}$ & $\mathbf{1}$ & $\mathbf{2}$ & $\mathbf{3}$ & $\mathbf{4}$ & $\mathbf{5}$ \\
\hline 17. & Nervozan/na sam kad čitam tekst koji nije zanimljiv. & $\mathbf{1}$ & $\mathbf{2}$ & $\mathbf{3}$ & $\mathbf{4}$ & $\mathbf{5}$ \\
\hline 18. & $\begin{array}{l}\text { Dok čitam naglas na njemačkome pred drugima, osjećam da mi } \\
\text { se znoje dlanovi. }\end{array}$ & $\mathbf{1}$ & $\mathbf{2}$ & $\mathbf{3}$ & $\mathbf{4}$ & $\mathbf{5}$ \\
\hline 19. & $\begin{array}{l}\text { Nervozniji/ja sam kad čitam naglas na njemačkome nego kad } \\
\text { pišem, slušam ili govorim. }\end{array}$ & $\mathbf{1}$ & $\mathbf{2}$ & $\mathbf{3}$ & $\mathbf{4}$ & $\mathbf{5}$ \\
\hline 20. & $\begin{array}{l}\text { Ako čitam tekst na njemačkome o nepoznatoj temi, postajem } \\
\text { nervozan/na. }\end{array}$ & $\mathbf{1}$ & $\mathbf{2}$ & $\mathbf{3}$ & $\mathbf{4}$ & $\mathbf{5}$ \\
\hline 21. & $\begin{array}{l}\text { Smeta me kad u tekstu naiđem na neki pojam iz njemačke, } \\
\text { austrijske ili druge kulture njemačkoga govornoga područja koji } \\
\text { mi nije poznat. }\end{array}$ & $\mathbf{1}$ & $\mathbf{2}$ & $\mathbf{3}$ & $\mathbf{4}$ & $\mathbf{5}$ \\
\hline 22. & $\begin{array}{l}\text { Uznemiruje me kad čitam u sebi tekst na njemačkome, a } \\
\text { nastavnik/ca nakog toga ocjenjuje zadatke razumijevanja } \\
\text { pročitanoga. }\end{array}$ & $\mathbf{1}$ & $\mathbf{2}$ & $\mathbf{3}$ & $\mathbf{4}$ & $\mathbf{5}$ \\
\hline 23. & $\begin{array}{l}\text { Strah me da će me ostali učenici ismijavati jer ne čitam dobro. } \\
\text { 24. }\end{array}$ & $\mathbf{1}$ & $\mathbf{2}$ & $\mathbf{3}$ & $\mathbf{4}$ & $\mathbf{5}$ \\
Pri čitanju u seb̌ki na njemačkome zbunjuju me duge riječi koje & $\mathbf{1}$ & $\mathbf{2}$ & $\mathbf{3}$ & $\mathbf{4}$ & $\mathbf{5}$ \\
\hline 25. & $\begin{array}{l}\text { Osjećam se nesigurno kad čitam naglas na njemačkome jer } \\
\text { nemam dara za čitanje na njemačkome. }\end{array}$ & $\mathbf{1}$ & $\mathbf{2}$ & $\mathbf{3}$ & $\mathbf{4}$ & $\mathbf{5}$ \\
\hline
\end{tabular}




\section{DIO}

\section{Upitnik o motivaciji za učenje njemačkoga jezika}

Molimo te da pažljivo pročitaš sljedeće tvrdnje u vezi s učenjem njemačkoga jezika i zaokružiš odgovarajući broj (od 1 do 5) prema tome koliko se svaka tvrdnja odnosi na tebe.

Ovdje nema točnih i netočnih odgovora!

$1=$ neistinito, uopće nije tako

2 = uglavnom neistinito, često nije tako

$3=$ nisam siguran, ne mogu se odlučiti

4 = uglavnom istinito, često je tako

$5=$ istinito, uvijek je tako

\begin{tabular}{|l|l|l|l|l|l|l|}
\hline 1. & Jako mi se sviđa njemački jezik. & $\mathbf{1}$ & $\mathbf{2}$ & $\mathbf{3}$ & $\mathbf{4}$ & $\mathbf{5}$ \\
\hline 2. & Znanje njemačkoga jezika za mene je beskorisno. & $\mathbf{1}$ & $\mathbf{2}$ & $\mathbf{3}$ & $\mathbf{4}$ & $\mathbf{5}$ \\
\hline 3. & Moji roditelji smatraju važnim da znam njemački jezik. & $\mathbf{1}$ & $\mathbf{2}$ & $\mathbf{3}$ & $\mathbf{4}$ & $\mathbf{5}$ \\
\hline 4. & Zanimaju me ljudi koji govore njemački jezik. & $\mathbf{1}$ & $\mathbf{2}$ & $\mathbf{3}$ & $\mathbf{4}$ & $\mathbf{5}$ \\
\hline 5. & Zanimaju me filmovi i glazba na njemačkome jeziku. & $\mathbf{1}$ & $\mathbf{2}$ & $\mathbf{3}$ & $\mathbf{4}$ & $\mathbf{5}$ \\
\hline 6. & Sati njemačkoga jezika neizmjerno su mi dosadni. & $\mathbf{1}$ & $\mathbf{2}$ & $\mathbf{3}$ & $\mathbf{4}$ & $\mathbf{5}$ \\
\hline 7. & Nemam osjećaj za jezik, beznadni sam slučaj za učenje jezika. & $\mathbf{1}$ & $\mathbf{2}$ & $\mathbf{3}$ & $\mathbf{4}$ & $\mathbf{5}$ \\
\hline 8. & Lako učim njemački jezik. & $\mathbf{1}$ & $\mathbf{2}$ & $\mathbf{3}$ & $\mathbf{4}$ & $\mathbf{5}$ \\
\hline 9. & Trebalo bi mi više truda i volje da budem uspješniji/uspješnija. & $\mathbf{1}$ & $\mathbf{2}$ & $\mathbf{3}$ & $\mathbf{4}$ & $\mathbf{5}$ \\
\hline 10. & Kolikogod učio/učila, ne mogu postići bolje rezultate. & $\mathbf{1}$ & $\mathbf{2}$ & $\mathbf{3}$ & $\mathbf{4}$ & $\mathbf{5}$ \\
\hline 11. & U svoje slobodno vrijeme rado se bavim njemačkim jezikom. & $\mathbf{1}$ & $\mathbf{2}$ & $\mathbf{3}$ & $\mathbf{4}$ & $\mathbf{5}$ \\
\hline 12. & Tijekom učenja njemačkoga jezika često doživim neuspjeh. & $\mathbf{1}$ & $\mathbf{2}$ & $\mathbf{3}$ & $\mathbf{4}$ & $\mathbf{5}$ \\
\hline 13. & Na satima njemačkoga jezika bojim se usmenog odgovaranja. & $\mathbf{1}$ & $\mathbf{2}$ & $\mathbf{3}$ & $\mathbf{4}$ & $\mathbf{5}$ \\
\hline 14. & Udžbenici po kojima učimo njemački loši su. & $\mathbf{1}$ & $\mathbf{2}$ & $\mathbf{3}$ & $\mathbf{4}$ & $\mathbf{5}$ \\
\hline
\end{tabular}




\section{Prilog 8}

Test razumijevanja teksta čitanjem za engleski jezik - A verzija

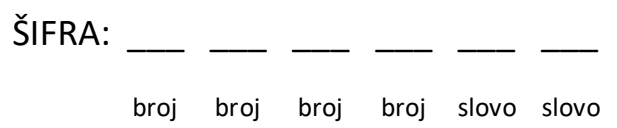

\section{ENGLESKI JEZIK}

4. razred srednje škole

\section{RAZUMIJEVANJE TEKSTA ČITANJEM}

\section{A verzija}

Broj sati engleskoga jezika tjedno:

Ocjena iz engleskoga jezika na kraju trećega razreda:

\section{Upute za rješavanje testa:}

U ovom testu naći ćeš lakše i teže zadatke. Savjetujemo ti da najprije pročitaš sve zadatke, a zatim prvo riješiš one koji su ti lakši. Upute za rješavanje zadataka na engleskom su jeziku. Uz uputu naveden je i primjer koji pokazuje što je potrebno učiniti. Rješenja upiši u za to predviđeni prostor. Ako nešto želiš ispraviti, učini to tako da je konačno rješenje jasno i nedvosmisleno.

ŽELIMO TI PUNO USPJEHA! 
Task 1: Read this text from a magazine. Match the questions $(A, B, \ldots J)$ with the answers $(1$, $2, \ldots 11)$. The first one has been done for you. There is an extra answer you don't need.

\section{Too Hot to Handle}

Geoff 'Rambocam' Mackley, 37, often risks his life to capture natural phenomena on film. Lisa Reich meets the cameraman who is no stranger to danger.

\begin{tabular}{|l|l|}
\hline A & Can you describe your job? \\
\hline B & Do you thrive on adrenaline? \\
\hline C & How did you get the name Rambocam? \\
\hline D & What's the most dangerous situation you've found yourself in? \\
\hline E & Have you ever feared for your life? \\
\hline F & Are your insurance premiums astronomical? \\
\hline G & Do you make a lot of money? \\
\hline H & What has been your finest volcano moment? \\
\hline I & When was the last time you were home? \\
\hline J & What about relationships? \\
\hline
\end{tabular}

1 During Hurricane George in the US, sheets of metal roofing hit the wall beside me; during Cyclone Vance in Australia I was blown across a hotel courtyard. That hurt. I've received countless electric shocks filming lightning and recently in the US a tornado shot across the road, missing me by inches, but wrecking a large lorry in front of me. In a hurricane, it's only possible to film from the window of a strong building. I select a place beforehand and stay there like my life depends on it, which it does.

2 I'm a freelance news cameraman and specialise in filming volcanoes, hurricanes, fires, floods and other extreme natural phenomena. I also 'storm chase', which involves strapping myself to something solid, like a pylon, and filming what's around me - hurricanes, tornadoes, cyclones... I'll do whatever it takes to get the picture.

3 My last trip to Mount Etna a few months ago was incredible. I was filming a programme for a TV company called Pioneer about volcanoes, which is due to come out this autumn on Channel 4. It had been a cloudy day and the visibility was poor - I was really disappointed. But just as the volcano erupted, the sky cleared. There was no wind and you could see the lava and its amazing brightness. It was incredible.

4 Because I sell my footage to the highest bidder, it depends entirely on what I've shot and how newsworthy it is. It's a risk. I spend thousands of pounds on my credit card on air fares and equipment and pray I shoot footage good enough to sell before the bill arrives. Then I pay it off and do it all over again.

5 Women? Are you kidding? I haven't time. 
6 It's a nickname I got in New Zealand, where I'm from. I'd found out about a horse cull in which a lot of horses were injured and killed - it was pretty grim. I hired a chopper and sneaked on to army land to film it. A rival TV station called me Rambocam and the name has stuck.

7 No, but I seek out the more spectacular occurrences, and they can be dangerous. There was a French couple who were famous volcano experts. They said they wanted to die filming volcanoes, and they did. That's not how I operate. There are about 500 volcanoes in the world and I want to see them all.

8 No. There's no point insuring myself or my equipment to the hilt. If anything goes wrong while I'm filming a volcano, I'm dead anyway.

9 It's a tough decision. The British are very much into serious stuff, while Americans will use the same footage and hype it up - turn it into an action movie.

10 Since October 1999, I've spent two days at home, but I've been to Italy, Japan, Indonesia, South America, Hawaii, the States and London. Now I'm having a break and going climbing in France.

11 No. The key to being successful and staying alive and ensuring my $£ 50,000$ camera works the next day is to know where the line is. If I get closer to what I'm filming, there's maybe a 50 per cent chance of me getting killed. So I stay where I am and use a stronger lens instead.

Put your answers in the table:

\begin{tabular}{|c|c|c|c|c|c|c|c|c|c|}
\hline \hline A & B & C & D & E & F & G & H & I & J \\
\hline 2 & & & & & & & & & \\
\hline
\end{tabular}


Task 2: Read the text and answer the questions. Put your answers (1-5) in the table below. The first one has been done for you.

\section{(T)Hanks for the memory}

From DAVID GARDNER in Houston, Texas

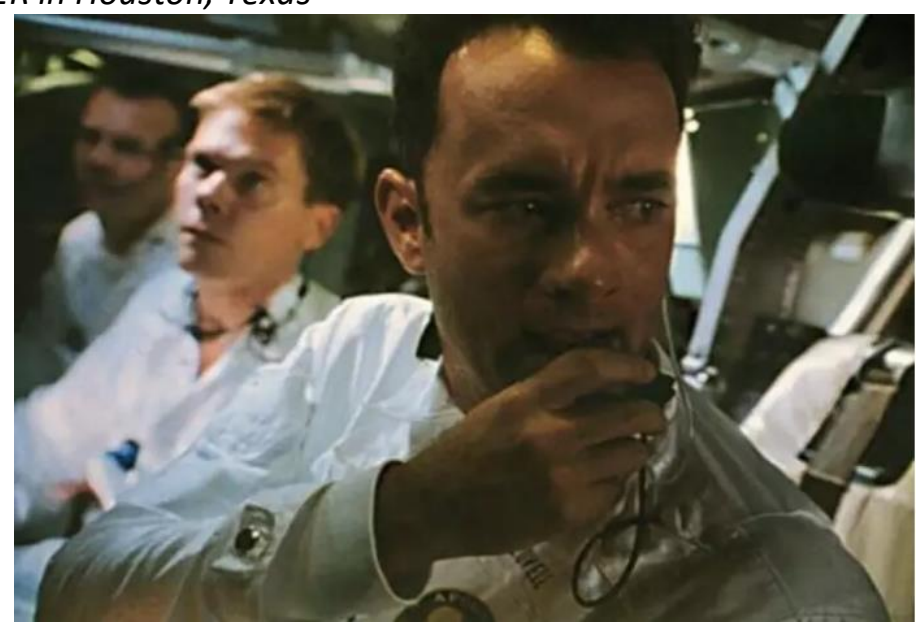

GROUND CONTROL TO COMMANDER TOM: Hanks (Lovell) with Bacon (Swigert) and Paxton (Haise) alert Houston that something is wrong on Apollo 13

It was the week the whole world held its breath. For four heart-stopping days everyone's attention was focused on three American astronauts stranded in total darkness and sub-zero temperatures 200,000 miles from home. Only a dazzling combination of technological wizardry and a display of great human spirit prevented the crippled spacecraft Apollo 13 spinning out of control for ever into deep space.

Commander Jim Lovell and his crew

became instant heroes as they splashed down safely in the Pacific. But almost as quickly, they were forgotten - their mission, after all, still a failure, no matter how heroic, in a country geared only to success.

3 Now, a quarter of a century later, Hollywood is making a movie about the unsuccessful mission, with Tom Hanks playing Lovell. Yet, the irony is that Lovell still seems destined to be the forgotten hero. The public will soon associate the familiar face of Tom Hanks with the mission, rather than the real commander of Apollo 13.

4 Hanks spent four days with him preparing for the role and Lovell remembers how the two of them were drinking in a bar when the owner asked him to sign a picture hanging on the wall. Lovell just pointed to Hanks. "I told the guy, 'Hey that's the real Jim Lovell, let him go over and sign it.' I know that once this movie comes out, it's not going to be me any more. Tom Hanks is going to be Jim Lovell.

5 I wanted him to get the feeling of what it's like to be a test pilot and an aviator and an astronaut so I decided the best way was to let him fly my light plane at night. To recreate the constricted view from a spacecraft, I installed a triangular cardboard cut-out on his side of the cockpit," says Lovell. "Then I took him out west where there were no lights. I let him control the airplane, because it's a little bit like a spacecraft. He liked it a lot."

6 When the film's makers, Universal, heard about the plan for the flight, executives went into a tailspin, terrified their superstar was not properly insured. "I told them not to worry, " says Lovell. "His best insurance would be sitting right next to him."

7 Lovell showed the same coolness back in 1970 when, halfway to the moon, his spacecraft was in deep trouble. He helped steady his crew's nerves and with the help of Houston Mission
Control they plotted a split-second manoeuvre to make it possible for them to re-enter the earth's atmosphere safely.

8 He is glad of all the renewed interest, feeling the mission has been neglected over the years "because we in the United States like to forget our failures". As if to prove his point, his study in his house is littered with awards and trophies from his first three space flights, two Geminis and Apollo 8, while the only recognition of Apollo 13 is a letter of congratulations from flying legend Charles Lindbergh.

9 As a boy who grew up with the Apollo missions, Hanks worshipped the space heroes of the Sixties and Seventies. "They were princes among men," he says. "These guys in their gold flight suits with matching jackets - they were real stars. To be an astronaut in Houston in the Sixties was like being a Beatle."

10 "Apollo 13 is the ultimate human interest story, " says Lovell. "And it's perfect for Hollywood. It's got a happy ending."

'Sunday Mirror', June 18, 1995 
Why did the whole world hold its breath? The crew of Apollo $13 . .$.

1 ... had lost all contact with the earth at a very critical moment.

2 ... seemed to be too much overcome by panic to deal with the danger they were in.

3 ... seemed to have too little fuel left to return to earth.

$4 \quad$... were in danger of never being able to come back to earth again.

C How did the American people react to the Apollo mission (paragraph 2)?

1 They first expressed great admiration for Jim Lovell and his crew and then stopped thinking about them.

2 They made it clear that they felt sorry for Jim Lovell and his crew.

3 They were disappointed in Jim Lovell and his crew because they had not managed to save the spacecraft.

1 Lovell and Hanks have become very good friends.

2 Lovell and Hanks look so much alike that the public will not see the difference between them.

3 Lovell doesn't like being famous.

4 Lovell is tired of telling people about his unsuccessful Apollo 13 mission.

5 Lovell realises that Hanks will be seen as the Apollo 13 commander after the film has appeared.

1 About how easy it is for an experienced pilot to handle a spacecraft.

2 About the risks Hanks might run as Apollo 13 commander.

3 About the training he had had for the Apollo 13 mission.

4 About the way he prepared Hanks for the role in the movie.

2 Hanks was a trained and experienced pilot.

3 Hanks was perfectly safe.

3 It gives him a chance of being asked of a new Apollo mission.

4 It is an opportunity for the public to see what exactly went wrong with Apollo 13.

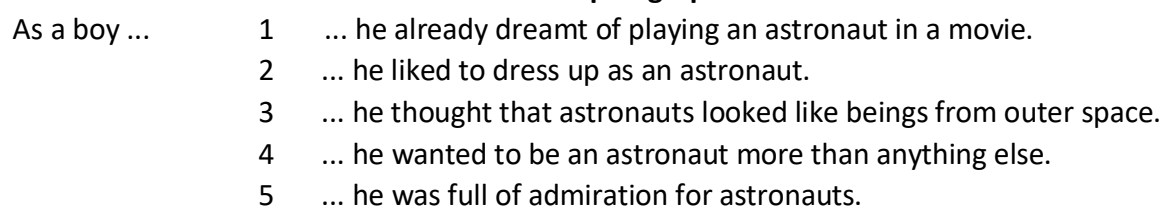

2 It is about people.

3 All participants survived.

Put your answers in the table:

\begin{tabular}{|c|c|c|c|c|c|c|c|c|c|}
\hline \hline $\mathbf{A}$ & B & C & D & E & F & G & H & I & J \\
\hline 2 & & & & & & & & & \\
\hline
\end{tabular}


Task 3: Read this text and choose the best answer from 1-4. Put your answers in the table below. The first one has been done for you.

\section{MIRACLE KITTY SURVIVES CATASTROPHE}

Precious the cat is a four-legged miracle. Somehow, the lucky puss managed to survive amid the rubble of the fallen World Trade Center towers for eighteen days without food and just sooty rain water to lap up.

The 7-year-old 9-pound Persian was rescued from the debris-covered roof of her devastated building, directly across the street from Ground Zero. She suffered eye injuries, burns to her paws and smoke inhalation. But now, New York City's luckiest kitty is on the road to recovery.

"It's an absolute miracle this cat is still alive," Suffolk Country SPCA chief Roy Gross tells GLOBE. "It's not like Precious is a streetwise survivor. She's an adored, pampered house cat." Owners Steve and D.J. Kerr were out of town that fateful Sept. 11 morning when the WTC collapsed, nearly destroying their seventh-floor loft shortly before the cat-sitter was to have arrived at $10 \mathrm{a} . \mathrm{m}$.

Somehow, Precious survived the implosion of three large picture windows facing the towers and the incoming wave of glass, metal, choking dust and smoke. Firemen raced into the building, kicking down doors looking for residents. They didn't spot Precious, but their rescue efforts unwittingly saved the gray and white kitty's life.

"Precious must have left through the busted door, gone up two flights to the terrace, then made it all the way up to the roof." D.J. tells GLOBE.

With their neighborhood cordoned off, all the desperate Kerrs could do was call shelters looking for Precious. As days turned to weeks with no luck, they began to assume the worst. "There was nothing to sustain her in that wreckage - no food, no water, not even enough air to breathe, "says D.J.

-Christy Smith

GLOBE, October 23, 2001, p. 2.

\section{Questions:}

A Where does this article come from?

B

What's the cat's name?

C How long was she missing?
1 Globe Magazine

2 London News

3 Suffolk County Club

4 Cats' Update

1 Miracle Kitty

2 Kerr

3 Precious

4 Persian

1 over two weeks

2 seven days

3 until 10 a.m.

4 nine days 
D

What did she eat?

E

Where was she found?

$\mathbf{F}$

How was she affected?

This cat was a

On September 11 her owners were

The firemen

I

H
1 cat food

2 nothing

3 some mice

4 soot

1 on the ground

2 under the WTC towers

3 on the roof

4 on the seventh floor

1 she could hardly see or walk

2 she burnt her eyes

3 she could not drink

4 she smoked

1 spoilt pet

2 streetwise survivor

3 garden cat

4 stray cat

1 at home

2 away

3 with the cat-sitter

4 in Suffolk

1 were looking for survivors

2 wanted to rescue Precious

3 saw the cat

4 saved the kitty's life

J Most probably, when the tragedy happened the cat

1 raced into the building

2 didn't spot the firemen

3 left through the roof

4 ran to the terrace

After two weeks the Kerrs

1 began to lose hope

2 stopped calling shelters

3 went to look for Precious

4 asked neighbors about Precious

Put your answers in the table:

\begin{tabular}{|l|l|l|l|l|l|l|l|l|l|l|}
\hline $\mathbf{A}$ & B & C & D & E & F & G & H & I & J & K \\
\hline $\mathbf{1}$ & & & & & & & & & & \\
\hline
\end{tabular}


Task 4: Read the following advertisements and find the missing bit from the list for each gap. Put the numbers in the box next to the missing bit. See the example.

\begin{tabular}{|c|c|c|c|}
\hline $\begin{array}{c}\text { Neel Akash } \\
\text { Tandoori Restaurant } \\
\text { Situated in one of London's } \\
\text { most popular streets, serving } \\
\text { fine North Indian \& } \\
\text { Bangladeshi cuisine in } \\
\text { elegant \& cosy surroundings. } \\
\mathbf{9 3} \text { Charlotte St, } \\
\text { London W1 } \\
\text { Tel.: +0207637 } 0050 \\
\text { www.neel-akash.com }\end{array}$ & $\begin{array}{c}\text { MONDAY-SATURDAY } \\
\text { 12.00-6.30 PM } \\
\text { CALL } \\
\mathbf{+ 4 4 1 6 1 2 4 8 8 2 8 2}\end{array}$ & $\begin{array}{c}71 \text { SHEPERDS BUSH ROAD } \\
\text { HAMMERSMITH, LONDON } \\
\text { W6 } \\
\text { Book now on } \\
\text { Tel.: } 0201253789240 \\
\text { Fax.: } 02021253789240 \\
\text { Single } \mathbf{f 4 5} \\
\text { Double/Twin } \mathbf{f 6 5} \\
\text { Brakfast included }\end{array}$ & $\begin{array}{l}\text { sun, sea and ... sand } \\
\text { Looking for the holiday o } \\
\text { a lifetime with parties, } \\
\text { and sundrenched } \\
\text { beaches? } \\
\text { Brochure order: } \\
\text { o70oo oo7 } \\
\text { 007 007 } \\
\text { Look no further than } \\
\text { Club Med } \\
\frac{\text { www.clubmed.hu }}{4}\end{array}$ \\
\hline $\begin{array}{l}\text { FREEPOST CY } 1061 \text { WEST } \\
\text { SUSSEX } \\
\text { NO STAMP NEEDED } \\
\text { For } \mathbf{f 2 1} \text { for } \\
\mathbf{1 2} \text { issues - saving } \\
\mathbf{£ 4} \text { off the full price } \\
\text { and receive a free gift } \\
\text { Please allow up to } 6 \text { weeks } \\
\text { to delivery of your first } \\
\text { issue, and up to } 28 \text { days for } \\
\text { delivery of your gift }\end{array}$ & $\begin{array}{l}\text { DO YOU WANT } \\
\text { A BETTER JOB? } \\
\text { With an ICS course it's easy } \\
\text { to study at home for the } \\
\text { skills and qualifications you } \\
\text { need to impress employers. } \\
\text { For more information call } \\
\text { today } \\
\text { Free phone: } 05005856565 \\
6 \\
\text { Choose from over } 130 \\
\text { courses in your own time. } \\
\text { For a new career }\end{array}$ & $\begin{array}{c}\text { Websites } \\
\text { universities \& colleges } \\
\text { agony aunt } \\
\text { horoscopes } \\
\text { music \& charts } \\
\text { cinema \& films } \\
\text { sports results \& news } \\
\text { personal ads } \\
\text { gossip } \\
\text { stories } \\
\text { chat } \\
\text { fun } \\
\text { The best and only site for } \\
\text { teenagers!!!!! } \\
\text { Check it out today } \\
\mathbf{7}\end{array}$ & $\begin{array}{l}\text { LEARNING FRENCH \& } \\
\text { LOST FOR WORDS? } \\
\text { wordPROF French will } \\
\text { improve your vocabulary } \\
\text { and spelling } \\
\text { EVEN TELLS YOU } \\
\text { HOW } \\
\text { MANY WORDS TO } \\
\text { LEARN EACH DAY! } \\
\text { Tel.: } 01714942929 \\
\text { Fax.: } 01714942922 \\
\mathbf{8}\end{array}$ \\
\hline
\end{tabular}

\begin{tabular}{|c|c|}
\hline $\begin{array}{c}\text { Child Care America } \\
\text { The legal way to live in the U.S.A. } \\
\text { For a free prospectus contact: }\end{array}$ & $\begin{array}{c}\text { Music Management Company } \\
\text { seeks }\end{array}$ \\
GW, 22 Upbrook Mews, London W2 3HG & $\mathbf{1 0}$ \\
GW@childcare.com & With strong original material \\
& for professional development \\
Learn about America & Send info and demo to \\
$\mathbf{9}$ & Slapback Management, \\
27 Sherbourne Drive, \\
Maidenhead SL6 3EO
\end{tabular}

Put your answers in the table:

\begin{tabular}{|c|c|c|c|c|}
\hline A & 2 & $\begin{array}{l}\text { BEST VALUE FOR TODAY'S } \\
\text { EVENING PERFORMANCES }\end{array}$ & $\mathbf{F}$ & DALMATIA HOTEL \\
\hline B & & Learn more. farn more. & G & 9000 words \& 350 topics for PC \\
\hline C & & www.thepad-uk.com & H & Open for Lunch and Dinner \\
\hline D & & $\begin{array}{l}\text { YES, I WANT TO SUBSCRIBE TO } \\
\text { TIME OUT }\end{array}$ & I & solo artists and bands \\
\hline $\mathbf{E}$ & & Experience different cultures & J & or contact your travel agent \\
\hline
\end{tabular}


Task 5: These are titles of books $(A-F)$ and short texts on what they are about $(1-12)$. Match the titles with the texts. The first one has been done for you. There is an extra text you don't need.

\section{A PEOPLE OF THE ICE \\ B THE TV BOOK \\ C I CAN MAKE COSTUMES \\ D CITYAT NIGHT \\ E BEAR AND PIG WENT TO MARKET \\ F THE CATENCYCLOPEDIA}

1. This book illustrates how the Inuit built their igloos, kayaks and sledges, made their clothing and prepared their food, played games, hunted and fished.

2. A perfect book for party time or other special dress-up occasions, kids can turn themselves into anything from witches to wizards.

3. Here's a wonderful book that gets kids to think about what they watch. It gives an exiciting insider's look at making films and shows.

4. From the ants that store honey inside their bodies to the leopards who store their food high in the trees, children will find out how animals save for their next meal.

5. Readers will find all the information they need about buying and looking after their pets: origin, size, color, character, feeding, and other needs. A book for all children's library collections.

6. This colorful book is on the biggest stars of this sport. It includes action photographs and interviews with 16 great players on the most fantastic moments of the game.

\author{
G THE HOCKEY PLAY BOOK \\ H BASKETBALL: THE LEGENDS AND \\ THE GAME \\ I HOW TO MAKE AN APPLE PIE \\ J TIME TO EAT \\ K THE WHYBOOK
}

7. Starting at eight p.m. and ending at six the next morning, we tour London, meeting bakers and TV people and just about everyone in between. It is for children who are curious about what goes on when they are asleep.

8. This illustrated book raises questions that young children would ask as they eat, travel, and play. It will encourage kids to think and to ask more and more questions.

9. This is a great guide on training techiques for young players, aged 12-17 in the following areas:

on- and off-ice training, step-by-step drills for amateurs, and goaltending.

10. This book is filled with special information on wild horses, riding tips and horse jokes. It is a volume for the horselover's library.

11. This silly story takes readers around the globe to gather ingredients - to England for the freshest milk, to Vermont for freshly picked fruits, and to France for the biggest eggs. A simple recipe is also included.

12. This funny tale is about two animals who are best friends. They want to sell their delicious cooking at the market, but business is slow, so they return home after a long day.

\section{Put your answers in the table:}

\begin{tabular}{|c|c|c|c|c|c|c|c|c|c|c|}
\hline A & B & C & D & E & F & G & H & I & J & K \\
\hline $\mathbf{1}$ & & & & & & & & & & \\
\hline
\end{tabular}




\section{Prilog 9}

Test razumijevanja teksta čitanjem za engleski jezik - B verzija

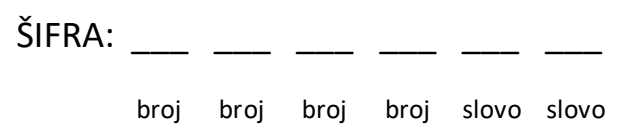

\section{ENGLESKI JEZIK}

4. razred srednje škole

\section{RAZUMIJEVANJE TEKSTA ČITANJEM}

\section{B verzija}

Broj sati engleskoga jezika tjedno:

Ocjena iz engleskoga jezika na kraju trećega razreda:

\section{Upute za rješavanje testa:}

U ovom testu naći ćeš lakše i teže zadatke. Savjetujemo ti da najprije pročitaš sve zadatke, a zatim prvo riješiš one koji su ti lakši. Upute za rješavanje zadataka na engleskom su jeziku. Uz uputu naveden je i primjer koji pokazuje što je potrebno učiniti. Rješenja upiši u za to predviđeni prostor. Ako nešto želiš ispraviti, učini to tako da je konačno rješenje jasno i nedvosmisleno.

ŽELIMO TI PUNO USPJEHA! 
Task 1: Read this text and choose the best answer from 1-4. Put your answers in the table below. The first one has been done for you.

\section{MIRACLE KITTY SURVIVES CATASTROPHE}

Precious the cat is a four-legged miracle. Somehow, the lucky puss managed to survive amid the rubble of the fallen World Trade Center towers for eighteen days without food and just sooty rain water to lap up.

The 7-year-old 9-pound Persian was rescued from the debris-covered roof of her devastated building, directly across the street from Ground Zero. She suffered eye injuries, burns to her paws and smoke inhalation. But now, New York City's luckiest kitty is on the road to recovery.

"It's an absolute miracle this cat is still alive," Suffolk Country SPCA chief Roy Gross tells GLOBE. "It's not like Precious is a streetwise survivor. She's an adored, pampered house cat." Owners Steve and D.J. Kerr were out of town that fateful Sept. 11 morning when the WTC collapsed, nearly destroying their seventh-floor loft shortly before the cat-sitter was to have arrived at $10 \mathrm{a} . \mathrm{m}$.

Somehow, Precious survived the implosion of three large picture windows facing the towers and the incoming wave of glass, metal, choking dust and smoke. Firemen raced into the building, kicking down doors looking for residents. They didn't spot Precious, but their rescue efforts unwittingly saved the gray and white kitty's life.

"Precious must have left through the busted door, gone up two flights to the terrace, then made it all the way up to the roof." D.J. tells GLOBE.

With their neighborhood cordoned off, all the desperate Kerrs could do was call shelters looking for Precious. As days turned to weeks with no luck, they began to assume the worst. "There was nothing to sustain her in that wreckage - no food, no water, not even enough air to breathe, "says D.J.

-Christy Smith

GLOBE, October 23, 2001, p. 2.

\section{Questions:}

A Where does this article come from?

B

What's the cat's name?

C How long was she missing?
1 Globe Magazine

2 London News

3 Suffolk County Club

4 Cats' Update

1 Miracle Kitty

2 Kerr

3 Precious

4 Persian

1 over two weeks

2 seven days

3 until 10 a.m.

4 nine days 
D

What did she eat?

E

Where was she found?

$\mathbf{F}$

How was she affected?

This cat was a

On September 11 her owners were

The firemen

I

H

On September 11 her owners were
The firemen

G

\author{
This cat was a
}

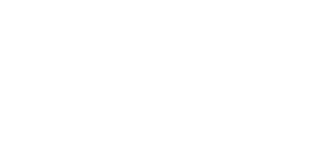

1 cat food

2 nothing

3 some mice

4 soot

1 on the ground

2 under the WTC towers

3 on the roof

4 on the seventh floor

1 she could hardly see or walk

2 she burnt her eyes

3 she could not drink

4 she smoked

1 spoilt pet

2 streetwise survivor

3 garden cat

4 stray cat

1 at home

2 away

3 with the cat-sitter

4 in Suffolk

1 were looking for survivors

2 wanted to rescue Precious

3 saw the cat

4 saved the kitty's life

J Most probably, when the tragedy happened the cat

1 raced into the building

2 didn't spot the firemen

3 left through the roof

4 ran to the terrace

After two weeks the Kerrs

1 began to lose hope

2 stopped calling shelters

3 went to look for Precious

4 asked neighbors about Precious

Put your answers in the table:

\begin{tabular}{|l|l|l|l|l|l|l|l|l|l|l|}
\hline $\mathbf{A}$ & B & C & D & E & F & G & H & I & J & K \\
\hline $\mathbf{1}$ & & & & & & & & & & \\
\hline
\end{tabular}


Task 2: Read this text from a magazine. Match the questions $(A, B, \ldots J)$ with the answers $(1$, $2, \ldots 11)$. The first one has been done for you. There is an extra answer you don't need.

\section{Too Hot to Handle}

Geoff 'Rambocam' Mackley, 37, often risks his life to capture natural phenomena on film. Lisa Reich meets the cameraman who is no stranger to danger.

\begin{tabular}{|l|l|}
\hline A & Can you describe your job? \\
\hline B & Do you thrive on adrenaline? \\
\hline C & How did you get the name Rambocam? \\
\hline D & What's the most dangerous situation you've found yourself in? \\
\hline E & Have you ever feared for your life? \\
\hline F & Are your insurance premiums astronomical? \\
\hline G & Do you make a lot of money? \\
\hline H & What has been your finest volcano moment? \\
\hline I & When was the last time you were home? \\
\hline J & What about relationships? \\
\hline
\end{tabular}

1 During Hurricane George in the US, sheets of metal roofing hit the wall beside me; during Cyclone Vance in Australia I was blown across a hotel courtyard. That hurt. I've received countless electric shocks filming lightning and recently in the US a tornado shot across the road, missing me by inches, but wrecking a large lorry in front of me. In a hurricane, it's only possible to film from the window of a strong building. I select a place beforehand and stay there like my life depends on it, which it does.

2 I'm a freelance news cameraman and specialise in filming volcanoes, hurricanes, fires, floods and other extreme natural phenomena. I also 'storm chase', which involves strapping myself to something solid, like a pylon, and filming what's around me - hurricanes, tornadoes, cyclones... I'll do whatever it takes to get the picture.

3 My last trip to Mount Etna a few months ago was incredible. I was filming a programme for a TV company called Pioneer about volcanoes, which is due to come out this autumn on Channel 4. It had been a cloudy day and the visibility was poor - I was really disappointed. But just as the volcano erupted, the sky cleared. There was no wind and you could see the lava and its amazing brightness. It was incredible.

4 Because I sell my footage to the highest bidder, it depends entirely on what I've shot and how newsworthy it is. It's a risk. I spend thousands of pounds on my credit card on air fares and equipment and pray I shoot footage good enough to sell before the bill arrives. Then I pay it off and do it all over again.

5 Women? Are you kidding? I haven't time. 
6 It's a nickname I got in New Zealand, where I'm from. I'd found out about a horse cull in which a lot of horses were injured and killed - it was pretty grim. I hired a chopper and sneaked on to army land to film it. A rival TV station called me Rambocam and the name has stuck.

7 No, but I seek out the more spectacular occurrences, and they can be dangerous. There was a French couple who were famous volcano experts. They said they wanted to die filming volcanoes, and they did. That's not how I operate. There are about 500 volcanoes in the world and I want to see them all.

8 No. There's no point insuring myself or my equipment to the hilt. If anything goes wrong while I'm filming a volcano, I'm dead anyway.

9 It's a tough decision. The British are very much into serious stuff, while Americans will use the same footage and hype it up - turn it into an action movie.

10 Since October 1999, I've spent two days at home, but I've been to Italy, Japan, Indonesia, South America, Hawaii, the States and London. Now I'm having a break and going climbing in France.

11 No. The key to being successful and staying alive and ensuring my $f 50,000$ camera works the next day is to know where the line is. If I get closer to what I'm filming, there's maybe a 50 per cent chance of me getting killed. So I stay where I am and use a stronger lens instead.

Put your answers in the table:

\begin{tabular}{|c|c|c|c|c|c|c|c|c|c|}
\hline \hline A & B & C & D & E & F & G & H & I & J \\
\hline 2 & & & & & & & & & \\
\hline
\end{tabular}


Task 3: Read the text and answer the questions. Put your answers (1-5) in the table below. The first one has been done for you.

\section{(T)Hanks for the memory}

From DAVID GARDNER in Houston, Texas

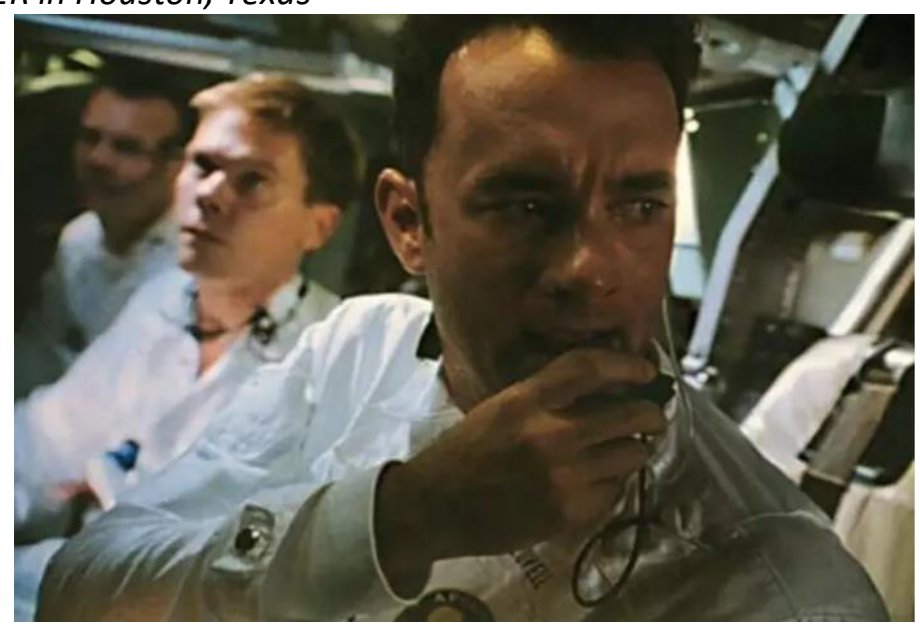

GROUND CONTROL TO COMMANDER TOM: Hanks (Lovell) with Bacon (Swigert) and Paxton (Haise) alert Houston that something is wrong on Apollo 13

It was the week the whole world held its breath. For four heart-stopping days everyone's attention was focused on three American astronauts stranded in total darkness and sub-zero temperatures 200,000 miles from home. Only a dazzling combination of technological wizardry and a display of great human spirit prevented the crippled spacecraft Apollo 13 spinning out of control for ever into deep space.

Commander Jim Lovell and his crew

became instant heroes as they splashed down safely in the Pacific. But almost as quickly, they were forgotten - their mission, after all, still a failure, no matter how heroic, in a country geared only to success.

3 Now, a quarter of a century later, Hollywood is making a movie about the unsuccessful mission, with Tom Hanks playing Lovell. Yet, the irony is that Lovell still seems destined to be the forgotten hero. The public will soon associate the familiar face of Tom Hanks with the mission, rather than the real commander of Apollo 13.

4 Hanks spent four days with him preparing for the role and Lovell remembers how the two of them were drinking in a bar when the owner asked him to sign a picture hanging on the wall. Lovell just pointed to Hanks. "I told the guy, 'Hey that's the real Jim Lovell, let him go over and sign it.' I know that once this movie comes out, it's not going to be me any more. Tom Hanks is going to be Jim Lovell.

5 I wanted him to get the feeling of what it's like to be a test pilot and an aviator and an astronaut so I decided the best way was to let him fly my light plane at night. To recreate the constricted view from a spacecraft, I installed a triangular cardboard cut-out on his side of the cockpit," says Lovell. "Then I took him out west where there were no lights. I let him control the airplane, because it's a little bit like a spacecraft. He liked it a lot."

6 When the film's makers, Universal, heard about the plan for the flight, executives went into a tailspin, terrified their superstar was not properly insured. "I told them not to worry, " says Lovell. "His best insurance would be sitting right next to him."

7 Lovell showed the same coolness back in 1970 when, halfway to the moon, his spacecraft was in deep trouble. He helped steady his crew's nerves and with the help of Houston Mission
Control they plotted a split-second manoeuvre to make it possible for them to re-enter the earth's atmosphere safely.

8 He is glad of all the renewed interest, feeling the mission has been neglected over the years "because we in the United States like to forget our failures". As if to prove his point, his study in his house is littered with awards and trophies from his first three space flights, two Geminis and Apollo 8, while the only recognition of Apollo 13 is a letter of congratulations from flying legend Charles Lindbergh.

9 As a boy who grew up with the Apollo missions, Hanks worshipped the space heroes of the Sixties and Seventies. "They were princes among men," he says. "These guys in their gold flight suits with matching jackets - they were real stars. To be an astronaut in Houston in the Sixties was like being a Beatle."

10 "Apollo 13 is the ultimate human interest story, " says Lovell. "And it's perfect for Hollywood. It's got a happy ending."

'Sunday Mirror', June 18, 1995 
Why did the whole world hold its breath? The crew of Apollo $13 \ldots$.

$1 \quad$... had lost all contact with the earth at a very critical moment.

2 ... seemed to be too much overcome by panic to deal with the danger they were in.

3 ... seemed to have too little fuel left to return to earth.

$4 \quad$... were in danger of never being able to come back to earth again.

1 They first expressed great admiration for Jim Lovell and his crew and then stopped thinking about them.

2 They made it clear that they felt sorry for Jim Lovell and his crew.

3 They were disappointed in Jim Lovell and his crew because they had not managed to save the spacecraft.

1 Lovell and Hanks have become very good friends.

2 Lovell and Hanks look so much alike that the public will not see the difference between them.

3 Lovell doesn't like being famous.

4 Lovell is tired of telling people about his unsuccessful Apollo 13 mission.

5 Lovell realises that Hanks will be seen as the Apollo 13 commander after the film has appeared.

1 About how easy it is for an experienced pilot to handle a spacecraft.

2 About the risks Hanks might run as Apollo 13 commander.

3 About the training he had had for the Apollo 13 mission.

4 About the way he prepared Hanks for the role in the movie.

\section{Why did Lovell think Universal executives had no reason to worry?}

1 Hanks was insured.

2 Hanks was a trained and experienced pilot.

3 Hanks was perfectly safe.

\section{What can be concluded about Jim Lovell from paragraph 7 ?}

During the Apollo mission... $1 \quad$... he was the only one who realised that something was wrong.

$2 \quad$... his calmness helped save the spacecraft and its crew.

3 ... the spacecraft got into problems because he had taken unnecessary risks.

3 It gives him a chance of being asked of a new Apollo mission.

4 It is an opportunity for the public to see what exactly went wrong with Apollo 13.

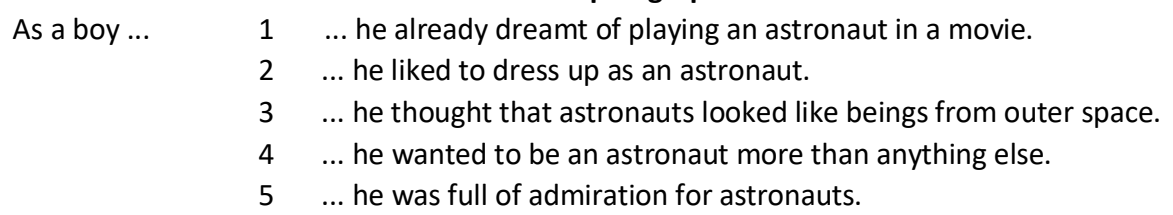

2 It is about people.

3 All participants survived.

Put your answers in the table:

\begin{tabular}{|c|c|c|c|c|c|c|c|c|c|}
\hline \hline A & B & C & D & E & F & G & H & I & J \\
\hline $\mathbf{2}$ & & & & & & & & & \\
\hline
\end{tabular}


Task 4: These are titles of books $(A-F)$ and short texts on what they are about $(1-12)$. Match the titles with the texts. The first one has been done for you. There is an extra text you don't need.

\section{A PEOPLE OF THE ICE \\ B THE TV BOOK \\ C I CAN MAKE COSTUMES \\ D CITY AT NIGHT \\ E BEAR AND PIG WENT TO MARKET \\ F THE CAT ENCYCLOPEDIA}

1. This book illustrates how the Inuit built their igloos, kayaks and sledges, made their clothing and prepared their food, played games, hunted and fished.

2. A perfect book for party time or other special dress-up occasions, kids can turn themselves into anything from witches to wizards.

3. Here's a wonderful book that gets kids to think about what they watch. It gives an exiciting insider's look at making films and shows.

4. From the ants that store honey inside their bodies to the leopards who store their food high in the trees, children will find out how animals save for their next meal.

5. Readers will find all the information they need about buying and looking after their pets: origin, size, color, character, feeding, and other needs. A book for all children's library collections.

6. This colorful book is on the biggest stars of this sport. It includes action photographs and interviews with 16 great players on the most fantastic moments of the game.

\author{
G THE HOCKEY PLAY BOOK \\ H BASKETBALL: THE LEGENDS AND \\ THE GAME \\ I HOW TO MAKE AN APPLE PIE \\ J TIME TO EAT \\ K THE WHYBOOK
}

7. Starting at eight p.m. and ending at six the next morning, we tour London, meeting bakers and TV people and just about everyone in between. It is for children who are curious about what goes on when they are asleep.

8. This illustrated book raises questions that young children would ask as they eat, travel, and play. It will encourage kids to think and to ask more and more questions.

9. This is a great guide on training techiques for young players, aged 12-17 in the following areas:

on- and off-ice training, step-by-step drills for amateurs, and goaltending.

10. This book is filled with special information on wild horses, riding tips and horse jokes. It is a volume for the horselover's library.

11. This silly story takes readers around the globe to gather ingredients - to England for the freshest milk, to Vermont for freshly picked fruits, and to France for the biggest eggs. A simple recipe is also included.

12. This funny tale is about two animals who are best friends. They want to sell their delicious cooking at the market, but business is slow, so they return home after a long day.

\section{Put your answers in the table:}

\begin{tabular}{|c|c|c|c|c|c|c|c|c|c|c|}
\hline A & B & C & D & E & F & G & H & I & J & K \\
\hline $\mathbf{1}$ & & & & & & & & & & \\
\hline
\end{tabular}


Task 5: Read the following advertisements and find the missing bit from the list for each gap. Put the numbers in the box next to the missing bit. See the example.

\begin{tabular}{|c|c|c|c|}
\hline $\begin{array}{c}\text { Neel Akash } \\
\text { Tandoori Restaurant } \\
\text { Situated in one of London's } \\
\text { most popular streets, serving } \\
\text { fine North Indian \& } \\
\text { Bangladeshi cuisine in } \\
\text { elegant \& cosy surroundings. } \\
\mathbf{9 3} \text { Charlotte St, } \\
\text { London W1 } \\
\text { Tel.: +0207637 0050 } \\
\text { www.neel-akash.com }\end{array}$ & $\begin{array}{c}\text { MONDAY-SATURDAY } \\
\text { 12.00-6.30 PM } \\
\text { CALL } \\
\mathbf{+ 4 4 1 6 1 2 4 8 8 2 8 2}\end{array}$ & $\begin{array}{c}71 \text { SHEPERDS BUSH ROAD } \\
\text { HAMMERSMITH, LONDON } \\
\text { W6 } \\
\text { Book now on } \\
\text { Tel.: } 0201253789240 \\
\text { Fax.: } 02021253789240 \\
\text { Single } \mathbf{f 4 5} \\
\text { Double/Twin } \mathbf{f 6 5} \\
\text { Brakfast included }\end{array}$ & $\begin{array}{l}\text { sun, sea and ... sand } \\
\text { Looking for the holiday o } \\
\text { a lifetime with parties, } \\
\text { and sundrenched } \\
\text { beaches? } \\
\text { Brochure order: } \\
\text { o70oo oo7 } \\
\text { oo7 007 } \\
\text { Look no further than } \\
\text { Club Med } \\
\text { www.clubmed.hu } \\
\mathbf{4}\end{array}$ \\
\hline $\begin{array}{l}\text { FREEPOST CY } 1061 \text { WEST } \\
\text { SUSSEX } \\
\text { NO STAMP NEEDED } \\
\text { For } \mathbf{f 2 1} \text { for } \\
\mathbf{1 2} \text { issues - saving } \\
\mathbf{£ 4} \text { off the full price } \\
\text { and receive a free gift } \\
\text { Please allow up to } 6 \text { weeks } \\
\text { to delivery of your first } \\
\text { issue, and up to } 28 \text { days for } \\
\text { delivery of your gift }\end{array}$ & $\begin{array}{l}\text { DO YOU WANT } \\
\text { A BETTER JOB? } \\
\text { With an ICS course it's easy } \\
\text { to study at home for the } \\
\text { skills and qualifications you } \\
\text { need to impress employers. } \\
\text { For more information call } \\
\text { today } \\
\text { Free phone: } 05005856565 \\
6 \\
\text { Choose from over } 130 \\
\text { courses in your own time. } \\
\text { For a new career }\end{array}$ & $\begin{array}{c}\text { Websites } \\
\text { universities \& colleges } \\
\text { agony aunt } \\
\text { horoscopes } \\
\text { music \& charts } \\
\text { cinema \& films } \\
\text { sports results \& news } \\
\text { personal ads } \\
\text { gossip } \\
\text { stories } \\
\text { chat } \\
\text { fun } \\
\text { The best and only site for } \\
\text { teenagers!!!!! } \\
\text { Check it out today } \\
\mathbf{7}\end{array}$ & $\begin{array}{l}\text { LEARNING FRENCH \& } \\
\text { LOST FOR WORDS? } \\
\text { wordPROF French will } \\
\text { improve your vocabulary } \\
\text { and spelling } \\
\text { EVEN TELLS YOU } \\
\text { HOW } \\
\text { MANY WORDS TO } \\
\text { LEARN EACH DAY! } \\
\text { Tel.: } 01714942929 \\
\text { Fax.: } 01714942922 \\
\mathbf{8}\end{array}$ \\
\hline
\end{tabular}

\begin{tabular}{|c|c|}
\hline $\begin{array}{c}\text { Child Care America } \\
\text { The legal way to live in the U.S.A. } \\
\text { For a free prospectus contact: }\end{array}$ & $\begin{array}{c}\text { Music Management Company } \\
\text { seeks }\end{array}$ \\
GW, 22 Upbrook Mews, London W2 3HG & $\mathbf{1 0}$ \\
GW@childcare.com & With strong original material \\
forn about America & Send info and demo to \\
$\mathbf{9}$ & Slapback Management, \\
Learn Sherbourne Drive, \\
27 Shaidenhead SL6 3EO
\end{tabular}

Put your answers in the table:

\begin{tabular}{|c|c|c|c|c|}
\hline A & 2 & $\begin{array}{l}\text { BEST VALUE FOR TODAY'S } \\
\text { EVENING PERFORMANCES }\end{array}$ & $\mathbf{F}$ & DALMATIA HOTEL \\
\hline B & & Learn more. farn more. & G & 9000 words \& 350 topics for PC \\
\hline $\mathbf{C}$ & & www.thepad-uk.com & $\mathbf{H}$ & Open for Lunch and Dinner \\
\hline D & & $\begin{array}{l}\text { YES, I WANT TO SUBSCRIBE TO } \\
\text { TIME OUT }\end{array}$ & I & solo artists and bands \\
\hline $\mathbf{E}$ & & Experience different cultures & J & or contact your travel agent \\
\hline
\end{tabular}


Prilog 10

Test razumijevanja teksta čitanjem za njemački jezik - A verzija

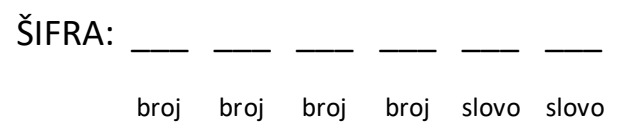

\section{NJEMAČKI JEZIK}

4. razred srednje škole

\section{RAZUMIJEVANJE TEKSTA ČITANJEM}

\section{A verzija}

Broj sati njemačkoga jezika tjedno:

Ocjena iz njemačkoga jezika na kraju trećega razreda:

Upute za rješavanje testa:

U ovom testu naći ćeš lakše i teže zadatke. Savjetujemo ti da najprije pročitaš sve zadatke, a zatim prvo riješiš one koji su ti lakši. Upute za rješavanje zadataka na njemačkome su jeziku. Uz uputu naveden je i primjer koji pokazuje što je potrebno učiniti. Rješenja upiši u za to predviđeni prostor. Ako nešto želiš ispraviti, učini to tako da je konačno rješenje jasno i nedvosmisleno.

ŽELIMO TI PUNO USPJEHA! 
Übung 1: Das sind die Sätze eines Textes. Rekonstruiere den Originaltext. Ein Beispiel haben wir angegeben.

\section{Sisis Leben}

1. Am 10.9.1898 wurde sie in Genf von dem italienischen Anarchisten Luigi Luccheni erstochen.

2. Am 24.4.1854 fand in Wien die Hochzeit statt.

3. Bald zerbrach aber ihr Glück am versteinerten Hofprotokoll des Kaiserhauses, und Sisi zog sich allmählich zurück.

4. Der Ehe entstammten die Kinder Sophie Friederike (sie starb im Alter von zwei Jahren), Gisela, Kronprinz Rudolf und Marie Valerie, und Sisi war glücklich.

5. Der Kaiser verliebte sich jedoch in Sisi und wählte die 15-jährige Prinzessin zur Braut.

6. Elisabeth von Österreich wurde am 24.12.1837 in München als Prinzessin Elisabeth („Sisi") Amalie Eugenie geboren.

7. Im Sommer 1853 fuhr ihre Familie nach Ischl, um hier eine Verlobung zwischen Sisis älterer Schwester Nene und dem Cousin Franz Joseph von Österreich einzufädeln.

8. Besonders nach dem Selbstmord ihres Sohnes Rudolf (1889) lebte Sisi ganz für sich allein. In dieser schweren Zeit war sie meist auf Reisen.

9. Sie war die zweite Tochter von Herzog Maximilian und dessen Gemahlin Prizessin Ludovika von Bayern.

(Die ganze Woche, 1998/5)

Lösung:

\begin{tabular}{|c|c|c|c|c|c|c|c|c|}
\hline A & B & C & D & E & F & G & H & I \\
\hline 6 & & & & & & & & \\
\hline
\end{tabular}


Übung 2: In einer Zeitschrift sind die wichtigsten Informationen zum Thema BSE folgendermaßen zusammengefasst worden. Wähle die passenden Titel für die Abschnitte. Pass auf, es gibt eine überflüssige Überschrift. Ein Beispiel haben wir angegeben.

ERNÄHRUNG SPECIAL; WAS IST BSE?

A

BSE (Bovine Spongiforme Encephalopathie) deutsch: schwammartige Hirnkrankheit des Rindes, auch als Rinderwahn bekannt, ist eine unheilbare Erkrankung von Rindern, die zu Veränderungen im Hirn und schlieißlich zum Tode des Tieres führt. BSE-infiziertes Rindfleisch kann bei Menschen eine neue Variante der CreutzfeldJakob-Krankheit (CJK) auslösen, die sog. vCJK. Bei dieser unheilbaren Krankheit wird das Gehirn zerstört.

B

Nach den heutigen Erkenntnissen trat der BSE-Erreger zum ersten Mal in den 80-er Jahren in Großbritannien bei Rindern auf, die mit Tiermehl gefüttert waren. Die Tiermehle enthielten Bestandteile toter Schafe, die mit Schafkrankheit infiziert waren.

C

Auch Schweine, Schafe, Ziegen und Zuchtfische wie Lachs und Forelle werden oder wurden mit Tiermehl gefüttert. Die BSE-Erreger sind allerdings bis heute nur bei Wiederkäuern (Rinder, Schafe und Ziegen) nachgewiesen worden. Schweine, Geflügel und Fische scheinen sich nicht zu infizieren.

\section{D}

Die Gefahr, sich mit VCJK infizieren, ist äußerst gering. Trotzdem schlägt die DGE (Deutsche Gesellschaft für Ernährung) vor, Rindfleisch sowie Fleischnebenprodukte zu vermeiden.

\section{E}

Bei allen geschlachteten Rindern, die über 30 Monate alt sind, sind BSE-Schnelltests vorgeschrieben. Diese Tests funktionieren nur bei Tieren in fortgeschrittenem Krankheitzustand, also bei Tieren, die mindestens 30 Monate alt sind. 60-70 Prozent der Schlachttiere in Deutschland sind aber Jungbullen im Alter zwischen 17 und 22 Monaten. Bei diesen Tieren greift der Schnelltest nicht.

$\mathbf{F}$

Die DGE warnt vor Rinfleisch- und Wurstwaren, inbesondere wenn Herkunft oder Zusammensetzung nicht zweifelsfrei gesichert sind. Außerdem können theoretisch Lamm- und Schaffleisch sowie Ziegenfleisch infiziert sein. Folgende Wustarten enthalten in der Regel Rindfleisch: Berliner Knacker, Bockwurst, Bratwurst, Brühwurst, Kochwurst, Krakauer, Salami, Wiener Würstchen. Nicht essen sollten Sie außerdem Markklößchen und Produkte, die Separatorenfleisch enthalten. Separatorenfleisch ist Restfleisch, das von grob zerkleinerten Knochen durch Hochdruck gewonnen wird. Viele Hackfleichprodukte enthalten auch einen Anteil an Rindfleisch. Vorsicht also bei Hamburgern, Beefsteak, Buletten, sowie bei Lasagne und Spaghetti Bolognese.

$\mathbf{G}$

Teile von Arzneimittel, z.B. Kapseln, werden aus Gelatine hersgestellt, manche Arzneimittel wie Insulin aus Rinderorganen. Der Einsatz von Risikomaterial in Arzneien ist allerdings seit 1998 verboten. Eine Übertragung über die Haut durch Kosmetikartikel kann nach dem jetzigen Stand der Wissenschaft ausgeschlossen werden.

0 Was ist BSE?

$1 \quad$ Wie groß ist die Gefahr für die Menschen?

2 Können Medikamente und Kosmetika gefährlich sein?

3 Können Untersuchungen beweisen, dass ein Tier BSE-frei ist?

$4 \quad$ Woher kommt BSE?

5 Welche Nahrungsmittel stellen ein BSE-Risiko dar?

6 Wie groß ist die Gefahr bei anderen Tieren, die mit Tiermehl gefüttert werden?

$7 \quad$ Wie sieht es aus mit Milch und Milchprodukten?

(QUELLE: BABY UNSER GLÜCK, 4 2001, S. 13)

\section{Lösung:}

\begin{tabular}{|c|c|c|c|c|c|c|}
\hline A & B & C & D & E & F & G \\
\hline $\mathbf{0}$ & & & & & & \\
\hline
\end{tabular}




\section{Übung 3: Lies den Text und beatworte die Fragen. Schreib die Antworten in die Kästchen. Beachte das Beispiel. \\ Cocktail}

\section{Gegen den Strich gebürstet \\ Alternative zur Robbenjagd: „, Kämmen statt skalpieren“}

\author{
"Oh, ist die \\ niedlich!" \\ Was hier zu \\ wahren \\ mütterlichen \\ (oder \\ väterlichen) \\ Gefühlen \\ verleitet, ist in \\ Kanada Objekt \\ eines alles \\ andere als \\ liebvollen \\ Geschäfts: die \\ Robbe
}

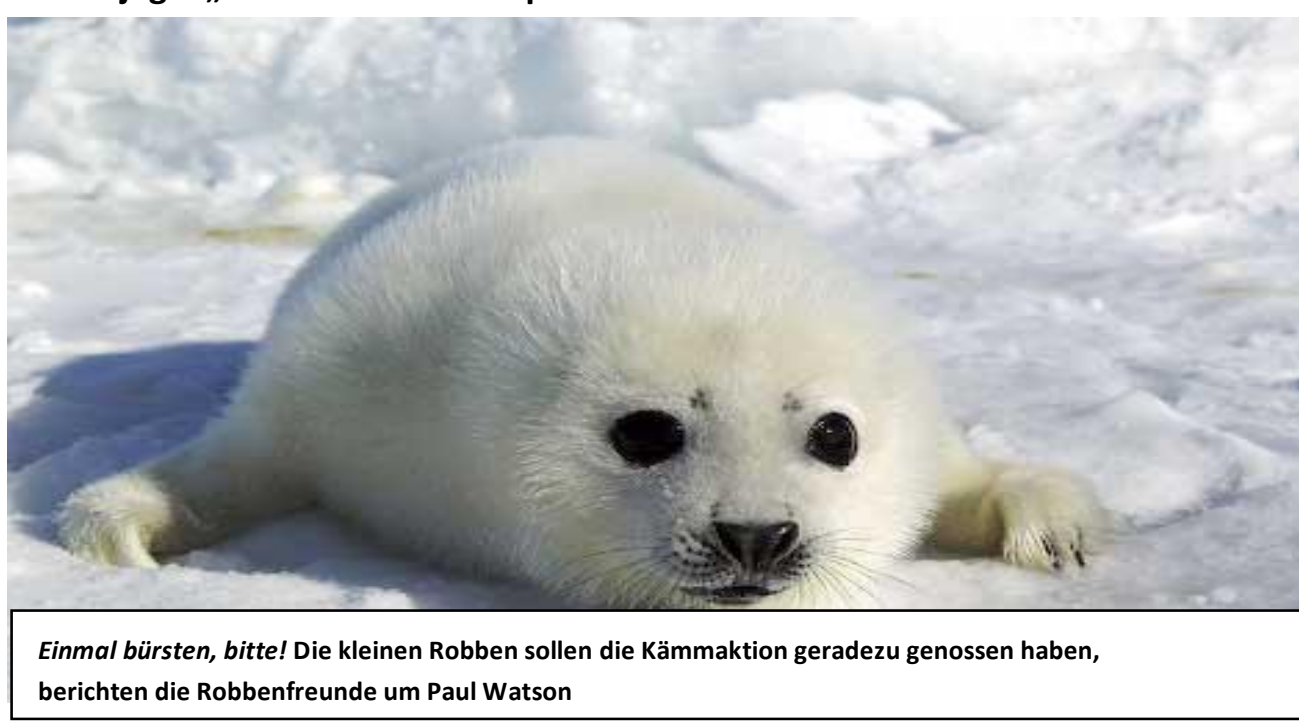

5 Einer Viertelmillion der Küstenbewohner mit den schwarzen Knopfaugen geht es in diesem Frühjahr an den

10 Pelz - so viele Tiere hat die kanadische Regierung offiziel zur Jagd freigegeben.

15 Allerdings nur erwachsene und nicht die weißen Babies, deren gewaltsames Abschlachten in den

20 80ern die Gemüter so erregte, dass es schließlich auf internationalen Druck hin verboten wurde.

25 Trotzdem stieße natürlich Ökonomie und Ökologie wieder unsanft aneinander: Die Robbenjäger

30 schulterten die Gewehre und zogen ins Eis, die Tierschützer machten sich daran, die

35 Öffentlichkeit gegen die Robbenjagd aufzubringen Paul Watson,ehemaliger Greenpeacer

40 und Gründer der Organisation Sea Shepherd Conservation Society, wagte sich jetzt

45 gedanklich von der Seite der Ökologen auf die Seite der Händler: Wovon sollen die
50 leben, wenn sie nicht jagen dürfen...? Bei einer dreitägigen

55 Expedition probierte er an der kanadischen Ostküste erstmals aus, was langsfristig eine

60 Ersatzbeschäftigung für die Robbenjagd sein könnte. Mit einer Spezialbürste kämmte er den Robbenbabies

65 das dichte Unterhaa aus - und half damit eigentlich nur der

Natur auf die Sprünge.

70 Denn die Jungen tauschen den weißen Pelz sowieso weinige Tage später gegen das kurze graue Fell der

75 ausgewachsenen Tiere. „Kämmen statt skalpieren" so bringt Watson sein Konzept auf den Punkt.

80 Deutsche Unternehme finden die Idee klasse, waren sogar selbst bei der Kämmaktion dabei.

85 Jetzt arbeitet der Naturwarenversand Origo" zusammen mit einem Bettwarenfabrikanten daran,

90 wie man die Haare am besten zu superleichten Decken verarbeiten kann.
150 Gramm Haare

95 rechnen die

Geschäftsleute pro

Robbenkind -

800 Gramm benötigt

man etwa für

100 eine Steppdecke, die dann mindestens 400 Euro kosten wird.

Bei Greenpeace setzt man der Idee

105 allerdings eine Portion Misstrauen entgegen.

"Das kann nicht die Lösung

110 für das Problem Robbenmord sein weil nicht bedach wurde, warum geschossen wird", meint

115 Meeresbiologe Stefan Flothmann. Der Pelzmarkt, geschweig denn Haare, seien schon

120 lange nicht mehr ausschalggebend. Vielmehr sei der kanadischen Regierung an toten

125 Robben gelegen, weil die keinen Kabeljau mehr fressen:

Die Fischerei, ein wichtiger Wirtschafts

130 -zweig in Kanada, habe die Küstengewässer so geschröpft, dass sie auf die anderthalb Tonnen Fisch, die jede der

135 mittlerweile gut 4.8 Millionen Robben jährlich vespeist, nicht verzichten konnten.

Zudem habe man in

140 Asien einen

Absatzmarkt für

Robbenpenisse gefunden, die dort als

potenzsteigernde

145 Mittelchen verkauf würden.

„Ob die Haare als

Ersatzprodukt ankommen?"

150 Flothmann bezweifelt den optimistischen

deutschen

Unternehmergeist. Reinhard Olle

155 von „Origo" "ässt sich nicht beirren: „Mir geht es nicht um die Marktlücke, auf die ich möglicherweise

160 gestoßen bin, sondern darum, dass unsere Welt weniger grausam wird." Jutta Schausten 


\section{Fragen:}

A

In welcher Zeitschrift wurde der Text veröffentlicht?
1 Die Zeit
2 Cocktail
3 Der Stern

B freigegeben." (Zeile 5-14) Was bedeutet das?

1 Eine Viertelmillion Kanadier hat einen Jagdschein.

2 Eine Viertelmillion kanadische Fischer lebt vom Robbenfang.

3 Eine Viertelmillion Robben darf getötet werden.

C Was wurde "auf internationalen Druck hin" (Zeile 15-24) verboten?

1 Das Morden von Robbenbabys.

2 Der freie Zugang zu den Gebieten der Robben.

3 Der Handel mit Robbenfellen.

4 Die Jagd auf erwachsene Robben.

D Was kann man aus dem 2. Absatz (Zeile 25-37) schließen?

1 Die Robbenjäger durften noch kranke Tiere töten.

2 Die Robbenjäger gaben den Streit gegen die Tierschützer auf.

3 Die Tierschützer waren noch nicht zufrieden.

4 Die Tierschützer wurden als Kontrolleure bei der Robbenjagd eingesetzt.

E Welche Aussage stimmt mit dem 3. Absatz (Zeile 37-53) überein?

1 Paul Watson nahm an einer Robbenjagd teil.

2 Paul Watson verhinderte eine Greenpeace-Aktion.

3 Paul Watson vertiefte sich in die Situation der Robbenjäger.

F Welche Ersatzbeschäftigung ist Paul Watson für Robbenjäger eingefallen? (Zeile 54-66)

1 Die Robben zu skalpieren.

2 Die Robben zu züchten.

3 Die Robben zu kämmen.

G Wie ist die Reaktion der deutschen Unternehmer? (Zeile 80-93)

1 Sie sind eher skeptisch.

2 Sie finden die Idee gut.

3 Sie wissen noch gar nichts von der Sache.

H Wie beurteilt Greenpeace (Zeile 103) Paul Watsons Idee?

Grenpeace hält sie für....

1 genial.

2 hoffnungsvoll.

3 kriminell.

4 nutzlos.

I Was meint Stefan Flottmann? (Zeile 150-154)

1 Stefan Flottmann ist zufrieden.

2 Stefan Flottmann gefällt die Idee der deutschen Unternehmer.

3 Stefan Flotmann ist skeptisch.

4 Stefan Flotmann verlässt sich auf die deutschen Unternehmer.

\section{Lösung:}

\begin{tabular}{|c|c|c|c|c|c|c|c|c|}
\hline A & B & C & D & E & F & G & H & I \\
\hline $\mathbf{2}$ & & & & & & & & \\
\hline
\end{tabular}


Übung 4: Lies den Text und kreuze an, wer was gesagt hat. Achtung, eine Aussage kann zu mehreren Personen passen. Du darfst insgesamt 12mal ankreuzen. Ein Beispiel haben wir angegeben.

\section{Was denken Jugendliche über Handys, deren Nützlichkeit und Notwendigkeit?}

Es herrscht Handy-Boom! KLARTEXT fragte Jugendliche, was sie von Handys überhaupt halten, wann sie stören und ob sie praktisch sein könnten.

Melanie Hintz, 16: Ich finde Handys in der Schule überflüssig, denn dort werden sie nun wirklich nicht benötigt. Handys sind dann sinnvoll, wenn man viel unterwegs ist und erreichbar sein muss. Ich brauche kein Handy, auch nicht, wenn alle meine Freunde eins hätten.

Valeska Laschitzki, 17: Während des Unterrichts sind Handys einfach nur störend, aber danach lassen sich damit auch nützliche Dinge erledigen, etwa ein Pizzataxi anrufen. Vielleicht werde ich mir bald ein Handy kaufen.

Jan Laschitzki, 15: Ich habe selber kein Handy und finde es für junge Schüler bis zur siebten oder achten Klasse auch eher angeberisch, wenn man durch die Schule mit einem Handy läuft. Wenn meine Eltern mir allerdings ein Handy schenken würden, würde ich es annehmen. Aber mein eigenes Geld dafür ausgeben? Nein!

Franco Livio Di Vincenco, 16, Danijel Santini, 16: Wir haben selber Handys. Und wenn sie im Unterricht auf lautlos stehen, ist das in Ordnung. Die Kosten übernehmen unsere Eltern.

Sascha Fey, 18: Handys in der Schule stören die Konzentration und nerven die Lehrer und Mitschüler, aber in der Freizeit sind sie praktisch. Ich selber habe mein Handy seit ungefähr eineinhalb Jahren.

(Solinger Tageblatt, 3.8.1999) 


\begin{tabular}{|c|c|c|c|c|c|}
\hline & 1.Melanie & 2.Valeska & 3.Jan & $\begin{array}{l}\text { 4.Franco, } \\
\text { Danijel }\end{array}$ & 5.Sascha \\
\hline $\begin{array}{l}\text { A. Ich möchte für ein Handy kein Geld } \\
\text { ausgeben. }\end{array}$ & & & $\mathbf{x}$ & & \\
\hline B. Man kann damit schnell eine Pizza bes & & & & & \\
\hline C. Handys stören in der Schule. & & & & & \\
\hline $\begin{array}{l}\text { D. Man kann Handys auch in der Schule } \\
\text { nehmen, nur sollen sie dort ausgescha } \\
\text { werden. }\end{array}$ & & & & & \\
\hline E. Ich möchte kein Handy haben. & & & & & \\
\hline $\begin{array}{l}\text { F. Wer in der Schule mit einem Handy ru } \\
\text { ist nur ein Angeber. }\end{array}$ & & & & & \\
\hline G. Für die Kosten kommen unsere Eltern & & & & & \\
\hline H. Über Handys ärgern sich die Lehrer. & & & & & \\
\hline $\begin{array}{l}\text { I. Ich hätte nichts dagegen, wenn mir } \\
\text { meine Eltern ein Handy kaufen würder }\end{array}$ & & & & & \\
\hline J. Ich habe ein Handy. & & & & & \\
\hline $\begin{array}{l}\text { K. Handys sind für Leute wichtig, die oft } \\
\text { außer Haus sind. }\end{array}$ & & & & & \\
\hline
\end{tabular}


Übung 5: Ergänze die Anzeigen mit den fehlenden Wörtern aus der Liste unten. Pass auf, ein Ausdruck bleibt übrig. Ein Beispiel haben wir angegeben.

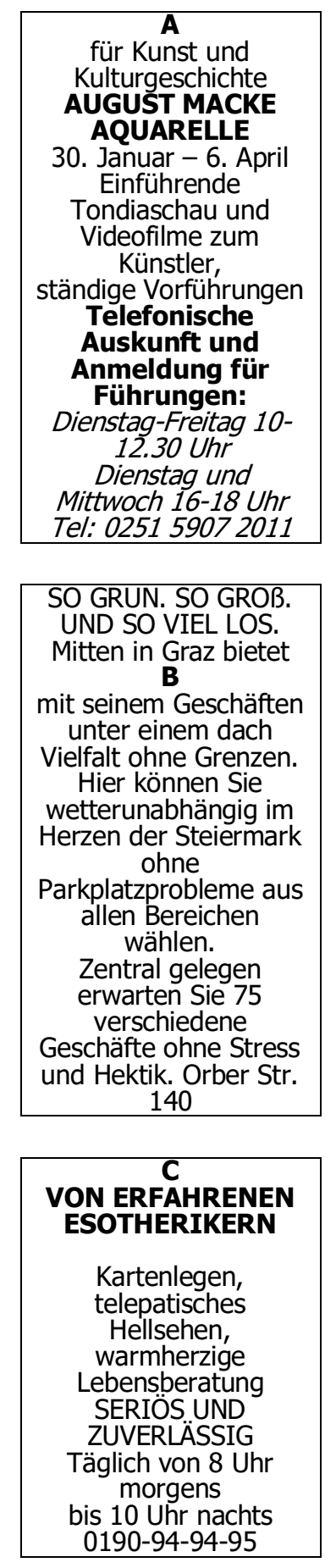

0 WESTFÄLISCHES LANDESMUSEUM

1 ZUKUNFTSPROGNOSE

2 DIÄT-EXPERIMENTE

3 GEBRAUCHTWAGENANGEBOT

4 PARKHAUS BREMER PLATZ

\begin{tabular}{|l|}
\hline \multicolumn{1}{|c|}{ AB HEUTE } \\
KEINE \\
D \\
MEHR. \\
Mit Vergnügen abnehmen- \\
geht das überhaupt? \\
Mit BCM schon. Denn \\
dieses wissenschaftlich \\
fundierte \\
Ernährungsprogramm hilft \\
Ihnen nicht nur, auf \\
gesunde Art schlanker zu \\
werden, sondern auch Ihr \\
neues Gewicht halten zu \\
können. Rufen Sie doch \\
gleich heute an! Wir \\
nennen Ihnen einen BCM \\
Berater in Ihrer Nähe. \\
Info-Telefon 0185-773422 \\
\hline
\end{tabular}

\section{$01058+$ VORWAHL + RUFNUMMER}

Einfach 01058 vorwählen und günstig $\mathbf{E}$ !

Die Auskunftsnummer mit der günstigen

Weitervermittlung für nur

$8 \mathrm{ct}$./Min. Bundesweit!

Nur vom Festnetz erreichbar!

\begin{tabular}{|c|}
\hline SCHWAIGERHOF \\
F \\
Fühle die Kraft der Natur \\
in \\
unseren Bergen! \\
Zimmer mit Dusche, WC, \\
TV \\
und Telefon. \\
Wahlmenü. Grillabend. \\
Frühstücksbuffet. \\
Dessertbuffet. Sauna. \\
Dampfbad. Whirlwanne \\
und Solarium. \\
Kinderprogramm und \\
Betreuung viermal \\
wöchentlich. \\
Tel. 368761576, $A-8970$ \\
Schladming, \\
Reiterkreuzweg 16 \\
\hline
\end{tabular}

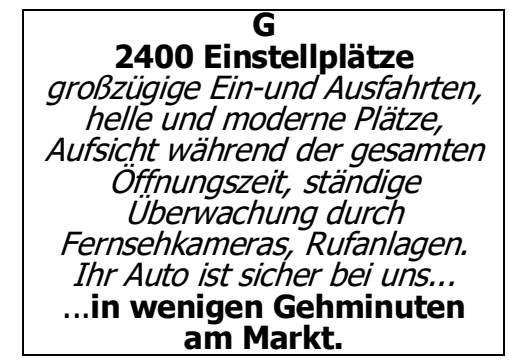

\begin{tabular}{|c|}
\hline H \\
ZU FUSS UND PER BUS \\
Ganzjährig finden \\
Rundfahrten \\
jeden Samstag und Sonntag von \\
10.30 Uhr, sowie \\
jeden Mittwoch von 14.30 \\
bis 17.00 statt. \\
Treffpunkt ist jeweils der \\
Informationsstand in der \\
Bürgerhalle des Rathauses. \\
Teilnehmerkarten zum Preis von \\
14 E sind am Informationsstand \\
erhältlich. \\
(Tel. 492-34-37) \\
\hline
\end{tabular}

\begin{tabular}{|c|}
\hline I \\
OHNE GEPÄCK \\
7, 4 oder 3 Tage durch die \\
Dachstein-Tauern-Region am \\
berühmten Panoramaweg 100. \\
Die Touren können ab Mai bis \\
Oktober zu jedem beliebigen Tag \\
begonnen werden. \\
Der Gepäckweitertransport wird von \\
uns täglich organisiert. \\
Information und Buchung: \\
Tourismusverband, Schladming. \\
Tel. 3687-222686
\end{tabular}

Lösung:

\begin{tabular}{|c|l|l|l|l|l|l|l|l|}
\hline A & B & C & D & E & F & G & H & I \\
\hline $\mathbf{0}$ & & & & & & & & \\
\hline
\end{tabular}

\begin{tabular}{|c|c|c|c|}
\hline \multicolumn{3}{|c|}{$\begin{array}{l}5 \text { TELEFONIEREN } \\
6 \text { GROßE STADTBESICHTIGUNG } \\
7 \text { WANDER- UND FERIENHOTEL } \\
8 \text { WANDERN } \\
9 \text { DAS EINKAUFSZENTRUM CITYPARK }\end{array}$} & \\
\hline$F$ & $\mathbf{G}$ & $\mathbf{H}$ & $T$ \\
\hline
\end{tabular}




\section{Prilog 11}

Test razumijevanja teksta čitanjem za njemački jezik - B verzija

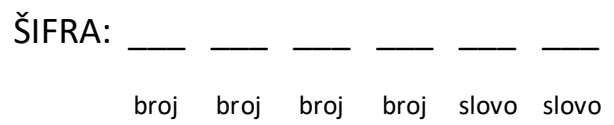

\section{NJEMAČKI JEZIK}

4. razred srednje škole

\section{RAZUMIJEVANJE TEKSTA ČITANJEM}

\section{B verzija}

Broj sati njemačkoga jezika tjedno:

Ocjena iz njemačkoga jezika na kraju trećega razreda:

\section{Upute za rješavanje testa:}

U ovom testu naći ćeš lakše i teže zadatke. Savjetujemo ti da najprije pročitaš sve zadatke, a zatim prvo riješiš one koji su ti lakši. Upute za rješavanje zadataka na njemačkome su jeziku. Uz uputu naveden je i primjer koji pokazuje što je potrebno učiniti. Rješenja upiši u za to predviđeni prostor. Ako nešto želiš ispraviti, učini to tako da je konačno rješenje jasno i nedvosmisleno.

ŽELIMO TI PUNO USPJEHA! 
Übung 1: Ergänze die Anzeigen mit den fehlenden Wörtern aus der Liste unten. Pass auf, ein Ausdruck bleibt übrig. Ein Beispiel haben wir angegeben.

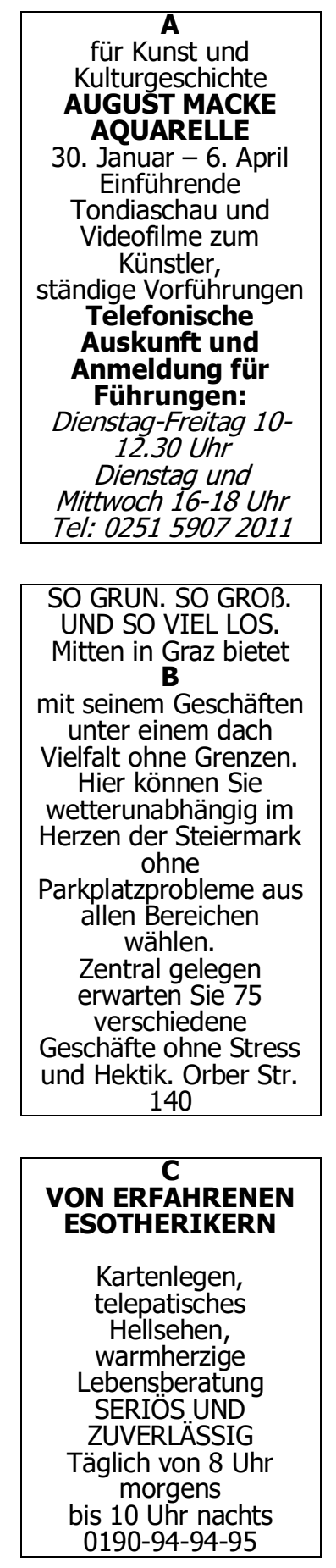

0 WESTFÄLISCHES LANDESMUSEUM

1 ZUKUNFTSPROGNOSE

2 DIÄT-EXPERIMENTE

3 GEBRAUCHTWAGENANGEBOT

4 PARKHAUS BREMER PLATZ

\begin{tabular}{|l|}
\hline \multicolumn{1}{|c|}{ AB HEUTE } \\
KEINE \\
D \\
MEHR. \\
Mit Vergnügen abnehmen- \\
geht das überhaupt? \\
Mit BCM schon. Denn \\
dieses wissenschaftlich \\
fundierte \\
Ernährungsprogramm hilft \\
Ihnen nicht nur, auf \\
gesunde Art schlanker zu \\
werden, sondern auch Ihr \\
neues Gewicht halten zu \\
können. Rufen Sie doch \\
gleich heute an! Wir \\
nennen Ihnen einen BCM \\
Berater in Ihrer Nähe. \\
Info-Telefon 0185-773422 \\
\hline
\end{tabular}

\section{$01058+$ VORWAHL + RUFNUMMER}

Einfach 01058 vorwählen und günstig $\mathbf{E}$ !

Die Auskunftsnummer mit der günstigen

Weitervermittlung für nur

$8 \mathrm{ct}$./Min. Bundesweit!

Nur vom Festnetz erreichbar!

\begin{tabular}{|c|}
\hline SCHWAIGERHOF \\
F \\
Fühle die Kraft der Natur \\
in \\
unseren Bergen! \\
Zimmer mit Dusche, WC, \\
TV \\
und Telefon. \\
Wahlmenü. Grillabend. \\
Frühstücksbuffet. \\
Dessertbuffet. Sauna. \\
Dampfbad. Whirlwanne \\
und Solarium. \\
Kinderprogramm und \\
Betreuung viermal \\
wöchentlich. \\
Tel. 368761576, $A-8970$ \\
Schladming, \\
Reiterkreuzweg 16 \\
\hline
\end{tabular}

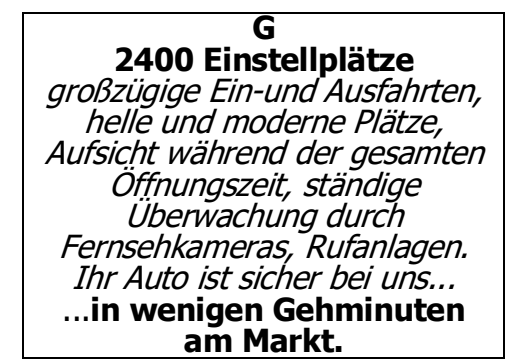

\begin{tabular}{|c|}
\hline H \\
ZU FUSS UND PER BUS \\
Ganzjährig finden \\
Rundfahrten \\
jeden Samstag und Sonntag von \\
10.30 Uhr, sowie \\
jeden Mittwoch von 14.30 \\
bis 17.00 statt. \\
Treffpunkt ist jeweils der \\
Informationsstand in der \\
Bürgerhalle des Rathauses. \\
Teilnehmerkarten zum Preis von \\
14 E sind am Informationsstand \\
erhältlich. \\
(Tel. 492-34-37) \\
\hline
\end{tabular}

\begin{tabular}{|c|}
\hline I \\
OHNE GEPÄCK \\
7, 4 oder 3 Tage durch die \\
Dachstein-Tauern-Region am \\
berühmten Panoramaweg 100. \\
Die Touren können ab Mai bis \\
Oktober zu jedem beliebigen Tag \\
begonnen werden. \\
Der Gepäckweitertransport wird von \\
uns täglich organisiert. \\
Information und Buchung: \\
Tourismusverband, Schladming. \\
Tel. 3687-222686
\end{tabular}

Lösung:

\begin{tabular}{|c|l|l|l|l|l|l|l|l|}
\hline A & B & C & D & E & F & G & H & I \\
\hline $\mathbf{0}$ & & & & & & & & \\
\hline
\end{tabular}

\begin{tabular}{|c|c|c|c|}
\hline \multicolumn{3}{|c|}{$\begin{array}{l}5 \text { TELEFONIEREN } \\
6 \text { GROßE STADTBESICHTIGUNG } \\
7 \text { WANDER- UND FERIENHOTEL } \\
8 \text { WANDERN } \\
9 \text { DAS EINKAUFSZENTRUM CITYPARK }\end{array}$} & \\
\hline$F$ & $\mathbf{G}$ & $\mathbf{H}$ & $T$ \\
\hline
\end{tabular}


Übung 2: Das sind die Sätze eines Textes. Rekonstruiere den Originaltext. Ein Beispiel haben wir angegeben.

\section{Sisis Leben}

1. Am 10.9.1898 wurde sie in Genf von dem italienischen Anarchisten Luigi Luccheni erstochen.

2. Am 24.4.1854 fand in Wien die Hochzeit statt.

3. Bald zerbrach aber ihr Glück am versteinerten Hofprotokoll des Kaiserhauses, und Sisi zog sich allmählich zurück.

4. Der Ehe entstammten die Kinder Sophie Friederike (sie starb im Alter von zwei Jahren), Gisela, Kronprinz Rudolf und Marie Valerie, und Sisi war glücklich.

5. Der Kaiser verliebte sich jedoch in Sisi und wählte die 15-jährige Prinzessin zur Braut.

6. Elisabeth von Österreich wurde am 24.12.1837 in München als Prinzessin Elisabeth (,Sisi") Amalie Eugenie geboren.

7. Im Sommer 1853 fuhr ihre Familie nach Ischl, um hier eine Verlobung zwischen Sisis älterer Schwester Nene und dem Cousin Franz Joseph von Österreich einzufädeln.

8. Besonders nach dem Selbstmord ihres Sohnes Rudolf (1889) lebte Sisi ganz für sich allein. In dieser schweren Zeit war sie meist auf Reisen.

9. Sie war die zweite Tochter von Herzog Maximilian und dessen Gemahlin Prizessin Ludovika von Bayern.

(Die ganze Woche, 1998/5)

Lösung:

\begin{tabular}{|c|c|c|c|c|c|c|c|c|}
\hline A & B & C & D & E & F & G & H & I \\
\hline 6 & & & & & & & & \\
\hline
\end{tabular}




\section{Übung 3: Lies den Text und beatworte die Fragen. Schreib die Antworten in die Kästchen. Beachte das Beispiel. \\ Cocktail}

\section{Gegen den Strich gebürstet \\ Alternative zur Robbenjagd: „, Kämmen statt skalpieren“}

\author{
"Oh, ist die \\ niedlich!" \\ Was hier zu \\ wahren \\ mütterlichen \\ (oder \\ väterlichen) \\ Gefühlen \\ verleitet, ist in \\ Kanada Objekt \\ eines alles \\ andere als \\ liebvollen \\ Geschäfts: die \\ Robbe
}

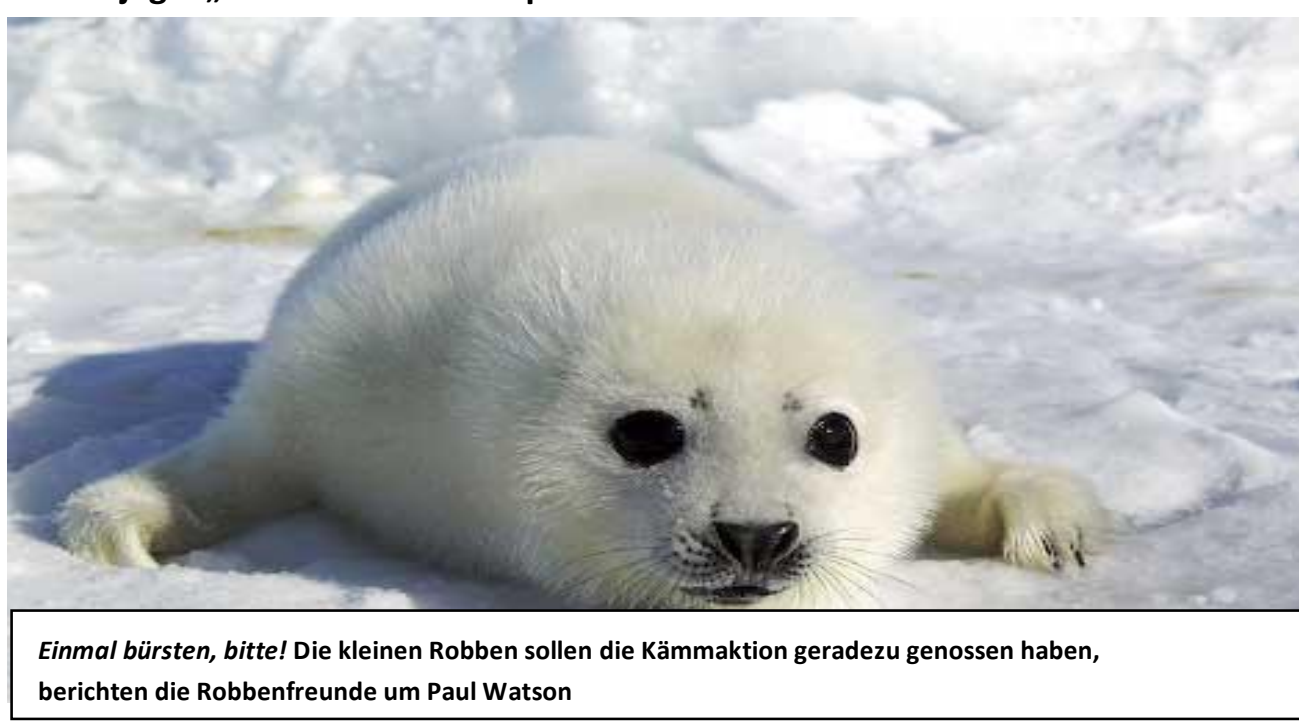

5 Einer Viertelmillion der Küstenbewohner mit den schwarzen Knopfaugen geht es in diesem Frühjahr an den

10 Pelz - so viele Tiere hat die kanadische Regierung offiziel zur Jagd freigegeben.

15 Allerdings nur erwachsene und nicht die weißen Babies, deren gewaltsames Abschlachten in den

20 80ern die Gemüter so erregte, dass es schließlich auf internationalen Druck hin verboten wurde.

25 Trotzdem stieße natürlich Ökonomie und Ökologie wieder unsanft aneinander: Die Robbenjäger

30 schulterten die Gewehre und zogen ins Eis, die Tierschützer machten sich daran, die

35 Öffentlichkeit gegen die Robbenjagd aufzubringen Paul Watson,ehemaliger Greenpeacer

40 und Gründer der Organisation Sea Shepherd Conservation Society, wagte sich jetzt

45 gedanklich von der Seite der Ökologen auf die Seite der Händler: Wovon sollen die
50 nicht jagen dürfen...? Bei einer dreitägigen

55 Expedition probierte er an der kanadischen Ostküste erstmals aus, was langsfristig eine

60 Ersatzbeschäftigung für die Robbenjagd sein könnte. Mit einer Spezialbürste kämmte er den Robbenbabies

65 das dichte Unterhaa aus - und half damit eigentlich nur der

Natur auf die Sprünge.

70 Denn die Jungen tauschen den weißen Pelz sowieso weinige Tage später gegen das kurze graue Fell der

75 ausgewachsenen Tiere. „Kämmen statt skalpieren" so bringt Watson sein Konzept auf den Punkt.

80 Deutsche Unternehme finden die Idee klasse, waren sogar selbst bei der Kämmaktion dabei.

85 Jetzt arbeitet der Naturwarenversand Origo" zusammen mit einem Bettwarenfabrikanten daran,

90 wie man die Haare am besten zu superleichten Decken verarbeiten kann.
150 Gramm Haare

95 rechnen die

Geschäftsleute pro

Robbenkind -

800 Gramm benötigt

man etwa für

100 eine Steppdecke, die dann mindestens 400 Euro kosten wird.

Bei Greenpeace setzt man der Idee

105 allerdings eine Portion Misstrauen entgegen.

"Das kann nicht die Lösung

110 für das Problem Robbenmord sein, weil nicht bedach wurde, warum geschossen wird", meint

115 Meeresbiologe Stefan Flothmann. Der Pelzmarkt, geschweig denn Haare, seien schon

120 lange nicht mehr ausschalggebend. Vielmehr sei der kanadischen Regierung an toten

125 Robben gelegen, weil die keinen Kabeljau mehr fressen:

Die Fischerei, ein wichtiger Wirtschafts

130 -zweig in Kanada, habe die Küstengewässer so geschröpft, dass sie auf die anderthalb Tonnen Fisch, die jede der

135 mittlerweile gut 4.8 Millionen Robben jährlich vespeist, nicht verzichten konnten.

Zudem habe man in

140 Asien einen

Absatzmarkt für

Robbenpenisse gefunden, die dort als

potenzsteigernde

145 Mittelchen verkauf würden.

„Ob die Haare als

Ersatzprodukt ankommen?"

150 Flothmann bezweifelt den optimistischen

deutschen

Unternehmergeist. Reinhard Olle

155 von „Origo" "ässt sich nicht beirren: „Mir geht es nicht um die Marktlücke, auf die ich möglicherweise

160 gestoßen bin, sondern darum, dass unsere Welt weniger grausam wird." Jutta Schausten 


\section{Fragen:}

A

In welcher Zeitschrift wurde der Text veröffentlicht?
1 Die Zeit
2 Cocktail
3 Der Stern

B

„Einer........... freigegeben." (Zeile 5-14) Was bedeutet das?

1 Eine Viertelmillion Kanadier hat einen Jagdschein.

2 Eine Viertelmillion kanadische Fischer lebt vom Robbenfang.

3 Eine Viertelmillion Robben darf getötet werden.

C Was wurde „auf internationalen Druck hin" (Zeile 15-24) verboten?

1 Das Morden von Robbenbabys.

2 Der freie Zugang zu den Gebieten der Robben.

3 Der Handel mit Robbenfellen.

4 Die Jagd auf erwachsene Robben.

D Was kann man aus dem 2. Absatz (Zeile 25-37) schließen?

1 Die Robbenjäger durften noch kranke Tiere töten.

2 Die Robbenjäger gaben den Streit gegen die Tierschützer auf.

3 Die Tierschützer waren noch nicht zufrieden.

4 Die Tierschützer wurden als Kontrolleure bei der Robbenjagd eingesetzt.

E Welche Aussage stimmt mit dem 3. Absatz (Zeile 37-53) überein?

1 Paul Watson nahm an einer Robbenjagd teil.

2 Paul Watson verhinderte eine Greenpeace-Aktion.

3 Paul Watson vertiefte sich in die Situation der Robbenjäger.

F Welche Ersatzbeschäftigung ist Paul Watson für Robbenjäger eingefallen? (Zeile 54-66)

1 Die Robben zu skalpieren.

2 Die Robben zu züchten.

3 Die Robben zu kämmen.

G Wie ist die Reaktion der deutschen Unternehmer? (Zeile 80-93)

1 Sie sind eher skeptisch.

2 Sie finden die Idee gut.

3 Sie wissen noch gar nichts von der Sache.

H Wie beurteilt Greenpeace (Zeile 103) Paul Watsons Idee?

Grenpeace hält sie für....

1 genial.

2 hoffnungsvoll.

3 kriminell.

4 nutzlos.

I Was meint Stefan Flottmann? (Zeile 150-154)

1 Stefan Flottmann ist zufrieden.

2 Stefan Flottmann gefällt die Idee der deutschen Unternehmer.

3 Stefan Flotmann ist skeptisch.

4 Stefan Flotmann verlässt sich auf die deutschen Unternehmer.

\section{Lösung:}

\begin{tabular}{|c|c|c|c|c|c|c|c|c|}
\hline A & B & C & D & E & F & G & H & I \\
\hline $\mathbf{2}$ & & & & & & & & \\
\hline
\end{tabular}


Übung 4: Lies den Text und kreuze an, wer was gesagt hat. Achtung, eine Aussage kann zu mehreren Personen passen. Du darfst insgesamt 12mal ankreuzen. Ein Beispiel haben wir angegeben.

\section{Was denken Jugendliche über Handys, deren Nützlichkeit und Notwendigkeit?}

Es herrscht Handy-Boom! KLARTEXT fragte Jugendliche, was sie von Handys überhaupt halten, wann sie stören und ob sie praktisch sein könnten.

Melanie Hintz, 16: Ich finde Handys in der Schule überflüssig, denn dort werden sie nun wirklich nicht benötigt. Handys sind dann sinnvoll, wenn man viel unterwegs ist und erreichbar sein muss. Ich brauche kein Handy, auch nicht, wenn alle meine Freunde eins hätten.

Valeska Laschitzki, 17: Während des Unterrichts sind Handys einfach nur störend, aber danach lassen sich damit auch nützliche Dinge erledigen, etwa ein Pizzataxi anrufen. Vielleicht werde ich mir bald ein Handy kaufen.

Jan Laschitzki, 15: Ich habe selber kein Handy und finde es für junge Schüler bis zur siebten oder achten Klasse auch eher angeberisch, wenn man durch die Schule mit einem Handy läuft. Wenn meine Eltern mir allerdings ein Handy schenken würden, würde ich es annehmen. Aber mein eigenes Geld dafür ausgeben? Nein!

Franco Livio Di Vincenco, 16, Danijel Santini, 16: Wir haben selber Handys. Und wenn sie im Unterricht auf lautlos stehen, ist das in Ordnung. Die Kosten übernehmen unsere Eltern.

Sascha Fey, 18: Handys in der Schule stören die Konzentration und nerven die Lehrer und Mitschüler, aber in der Freizeit sind sie praktisch. Ich selber habe mein Handy seit ungefähr eineinhalb Jahren.

(Solinger Tageblatt, 3.8.1999) 


\begin{tabular}{|c|c|c|c|c|c|}
\hline & 1.Melanie & 2.Valeska & 3.Jan & $\begin{array}{l}\text { 4.Franco, } \\
\text { Danijel }\end{array}$ & 5.Sascha \\
\hline $\begin{array}{l}\text { A. Ich möchte für ein Handy kein Geld } \\
\text { ausgeben. }\end{array}$ & & & $\mathbf{x}$ & & \\
\hline B. Man kann damit schnell eine Pizza bes & & & & & \\
\hline C. Handys stören in der Schule. & & & & & \\
\hline $\begin{array}{l}\text { D. Man kann Handys auch in der Schule } \\
\text { nehmen, nur sollen sie dort ausgescha } \\
\text { werden. }\end{array}$ & & & & & \\
\hline E. Ich möchte kein Handy haben. & & & & & \\
\hline $\begin{array}{l}\text { F. Wer in der Schule mit einem Handy ru } \\
\text { ist nur ein Angeber. }\end{array}$ & & & & & \\
\hline G. Für die Kosten kommen unsere Eltern & & & & & \\
\hline H. Über Handys ärgern sich die Lehrer. & & & & & \\
\hline $\begin{array}{l}\text { I. Ich hätte nichts dagegen, wenn mir } \\
\text { meine Eltern ein Handy kaufen würde }\end{array}$ & & & & & \\
\hline J. Ich habe ein Handy. & & & & & \\
\hline $\begin{array}{l}\text { K. Handys sind für Leute wichtig, die oft } \\
\text { außer Haus sind. }\end{array}$ & & & & & \\
\hline
\end{tabular}


Übung 5: In einer Zeitschrift sind die wichtigsten Informationen zum Thema BSE folgendermaßen zusammengefasst worden. Wähle die passenden Titel für die Abschnitte. Pass auf, es gibt eine überflüssige Überschrift. Ein Beispiel haben wir angegeben.

ERNÄHRUNG SPECIAL; WAS IST BSE?

A

BSE (Bovine Spongiforme Encephalopathie) deutsch: schwammartige Hirnkrankheit des Rindes, auch als Rinderwahn bekannt, ist eine unheilbare Erkrankung von Rindern, die zu Veränderungen im Hirn und schlieißlich zum Tode des Tieres führt. BSE-infiziertes Rindfleisch kann bei Menschen eine neue Variante der CreutzfeldJakob-Krankheit (CJK) auslösen, die sog. vCJK. Bei dieser unheilbaren Krankheit wird das Gehirn zerstört.

B

Nach den heutigen Erkenntnissen trat der BSE-Erreger zum ersten Mal in den 80-er Jahren in Großbritannien bei Rindern auf, die mit Tiermehl gefüttert waren. Die Tiermehle enthielten Bestandteile toter Schafe, die mit Schafkrankheit infiziert waren.

C

Auch Schweine, Schafe, Ziegen und Zuchtfische wie Lachs und Forelle werden oder wurden mit Tiermehl gefüttert. Die BSE-Erreger sind allerdings bis heute nur bei Wiederkäuern (Rinder, Schafe und Ziegen) nachgewiesen worden. Schweine, Geflügel und Fische scheinen sich nicht zu infizieren.

\section{D}

Die Gefahr, sich mit VCJK infizieren, ist äußerst gering. Trotzdem schlägt die DGE (Deutsche Gesellschaft für Ernährung) vor, Rindfleisch sowie Fleischnebenprodukte zu vermeiden.

\section{E}

Bei allen geschlachteten Rindern, die über 30 Monate alt sind, sind BSE-Schnelltests vorgeschrieben. Diese Tests funktionieren nur bei Tieren in fortgeschrittenem Krankheitzustand, also bei Tieren, die mindestens 30 Monate alt sind. 60-70 Prozent der Schlachttiere in Deutschland sind aber Jungbullen im Alter zwischen 17 und 22 Monaten. Bei diesen Tieren greift der Schnelltest nicht.

$\mathbf{F}$

Die DGE warnt vor Rinfleisch- und Wurstwaren, inbesondere wenn Herkunft oder Zusammensetzung nicht zweifelsfrei gesichert sind. Außerdem können theoretisch Lamm- und Schaffleisch sowie Ziegenfleisch infiziert sein. Folgende Wustarten enthalten in der Regel Rindfleisch: Berliner Knacker, Bockwurst, Bratwurst, Brühwurst, Kochwurst, Krakauer, Salami, Wiener Würstchen. Nicht essen sollten Sie außerdem Markklößchen und Produkte, die Separatorenfleisch enthalten. Separatorenfleisch ist Restfleisch, das von grob zerkleinerten Knochen durch Hochdruck gewonnen wird. Viele Hackfleichprodukte enthalten auch einen Anteil an Rindfleisch. Vorsicht also bei Hamburgern, Beefsteak, Buletten, sowie bei Lasagne und Spaghetti Bolognese.

$\mathbf{G}$

Teile von Arzneimittel, z.B. Kapseln, werden aus Gelatine hersgestellt, manche Arzneimittel wie Insulin aus Rinderorganen. Der Einsatz von Risikomaterial in Arzneien ist allerdings seit 1998 verboten. Eine Übertragung über die Haut durch Kosmetikartikel kann nach dem jetzigen Stand der Wissenschaft ausgeschlossen werden.

0 Was ist BSE?

$1 \quad$ Wie groß ist die Gefahr für die Menschen?

2 Können Medikamente und Kosmetika gefährlich sein?

3 Können Untersuchungen beweisen, dass ein Tier BSE-frei ist?

4 Woher kommt BSE?

5 Welche Nahrungsmittel stellen ein BSE-Risiko dar?

6 Wie groß ist die Gefahr bei anderen Tieren, die mit Tiermehl gefüttert werden?

$7 \quad$ Wie sieht es aus mit Milch und Milchprodukten?

(QUELLE: BABY UNSER GLÜCK, 4 2001, S. 13)

\section{Lösung:}

\begin{tabular}{|c|c|c|c|c|c|c|}
\hline A & B & C & D & E & F & G \\
\hline $\mathbf{0}$ & & & & & & \\
\hline
\end{tabular}




\section{Prilog 12}

\section{Deskriptivna statistika testa Razumijevanje teksta čitanjem-ENGLESKI JEZIK $\left(N_{\left.e_{-} t=160\right)}\right.$}

\section{1. zadatak}

\begin{tabular}{|l|l|l|l|l|l|l|l|l|l|}
\hline & B1 & C1 & D1 & E1 & F1 & G1 & H1 & I1 & J1 \\
\hline AS &, 61 &, 97 &, 94 &, 46 &, 66 &, 82 &, 96 &, 95 &, 98 \\
\hline Medijan & 1,00 & 1,00 & 1,00 & 0,00 & 1,00 & 1,00 & 1,00 & 1,00 & 1,00 \\
\hline SD &, 490 &, 175 &, 231 &, 500 &, 474 &, 386 &, 191 &, 219 &, 136 \\
\hline Asimetričnost &,- 439 & $-5,439$ & $-3,888$ &, 177 &,- 694 & $-1,671$ & $-4,915$ & $-4,169$ & $-7,163$ \\
\hline Zaobljenost & - & 27,935 & 13,286 & $-1,994$ & $-1,538$ &, 801 & 22,438 & 15,572 & 49,937 \\
& 1,830 & & & & & & & & \\
\hline Minimum & 0 & 0 & 0 & 0 & 0 & 0 & 0 & 0 & 0 \\
\hline Maksimum & 1 & 1 & 1 & 1 & 1 & 1 & 1 & 1 & 1 \\
\hline
\end{tabular}

$A S=$ aritmeticka sredina, $S D=$ standardna devijacija

2. zadatak

\begin{tabular}{|c|c|c|c|c|c|c|c|c|c|}
\hline & B2 & $\mathrm{C} 2$ & D2 & E2 & $\mathrm{F} 2$ & G2 & $\mathrm{H} 2$ & $\mathrm{I} 2$ & $\mathrm{~J} 2$ \\
\hline AS & ,74 & ,84 & ,79 & ,75 &, 55 &, 82 & ,67 & ,76 & ,46 \\
\hline Medijan & 1,00 & 1,00 & 1,00 & 1,00 & 1,00 & 1,00 & 1,00 & 1,00 & 0,00 \\
\hline SD & ,438 & ,364 & ,410 & ,434 & ,499 & ,386 & ,472 & ,427 & ,500 \\
\hline Asimetričnost & $-1,127$ & $-1,911$ & $-1,419$ & $-1,166$ &,- 203 & $-1,671$ &,- 724 & $-1,245$ &, 152 \\
\hline Zaobljenost &,- 739 & 1,674 &, 013 &,- 650 & $-1,984$ & ,801 & $-1,495$ &,- 455 & $-2,002$ \\
\hline Minimum & 0 & 0 & 0 & 0 & 0 & 0 & 0 & 0 & 0 \\
\hline Maksimum & 1 & 1 & 1 & 1 & 1 & 1 & 1 & 1 & 1 \\
\hline
\end{tabular}

$A S=$ aritmetička sredina, $S D=$ standardna devijacija 
3. zadatak

\begin{tabular}{|c|c|c|c|c|c|c|c|c|c|c|}
\hline & B3 & C3 & D3 & E3 & F3 & G3 & H3 & I3 & $\mathrm{J} 3$ & K3 \\
\hline AS & ,94 & ,89 & ,79 & ,74 & ,66 & ,66 & ,95 & ,69 & ,56 & ,89 \\
\hline Medijan & 1,00 & 1,00 & 1,00 & 1,00 & 1,00 & 1,00 & 1,00 & 1,00 & 1,00 & 1,00 \\
\hline SD & ,231 & ,309 &, 410 & ,441 & ,476 & ,474 & ,219 & ,462 & ,498 & ,317 \\
\hline Asimetričnost & $-3,888$ & $-2,580$ & $-1,419$ & $-1,090$ &,- 664 &,- 694 & $-4,169$ &,- 849 &,- 254 & $-2,476$ \\
\hline Zaobljenost & 13,286 & 4,714 &, 013 &,- 823 & $-1,579$ & $-1,538$ & 15,572 & $-1,296$ & $-1,960$ & 4,182 \\
\hline Minimum & 0 & 0 & 0 & 0 & 0 & 0 & 0 & 0 & 0 & 0 \\
\hline Maksimum & 1 & 1 & 1 & 1 & 1 & 1 & 1 & 1 & 1 & 1 \\
\hline
\end{tabular}

$A S=$ aritmetička sredina, $S D=$ standardna devijacija

\section{4. zadatak}

\begin{tabular}{|l|l|l|l|l|l|l|l|l|l|}
\hline & B4 & C4 & D4 & E4 & F4 & G4 & H4 & I4 & J4 \\
\hline AS &, 73 &, 65 &, 48 &, 51 &, 56 &, 63 &, 71 &, 90 &, 55 \\
\hline Medijan & 1,00 & 1,00 & 0,00 & 1,00 & 1,00 & 1,00 & 1,00 & 1,00 & 1,00 \\
\hline SD &, 569 &, 596 &, 501 &, 502 &, 498 &, 486 &, 457 &, 301 &, 499 \\
\hline Asimetričnost & 2,131 & 2,113 &, 076 &,- 025 &,- 254 &,- 521 &,- 914 & $-2,692$ &,- 203 \\
\hline Zaobljenost & 18,534 & 16,162 & $-2,020$ & $-2,025$ & $-1,960$ & $-1,750$ & $-1,179$ & 5,313 & $-1,984$ \\
\hline Minimum & 0 & 0 & 0 & 0 & 0 & 0 & 0 & 0 & 0 \\
\hline Maksimum & 1 & 1 & 1 & 1 & 1 & 1 & 1 & 1 & 1 \\
\hline
\end{tabular}

$A S=$ aritmetička sredina, $S D=$ standardna devijacija 
5. zadatak

\begin{tabular}{|c|c|c|c|c|c|c|c|c|c|c|}
\hline & B5 & C5 & D5 & E5 & F5 & G5 & H5 & I5 & J5 & K5 \\
\hline AS & ,91 & ,94 & ,90 & ,89 & ,80 & ,89 & ,91 & ,81 & 69 & ,83 \\
\hline Medijan & 1,00 & 1,00 & 1,00 & 1,00 & 1,00 & 1,00 & 1,00 & 1,00 & 1,00 & 1,00 \\
\hline SD & ,292 & 243 & ,301 & ,317 & ,401 & ,309 & ,292 & ,396 & ,462 & ,376 \\
\hline Asimetričnost & $-2,814$ & $-3,649$ & $-2,692$ & $-2,476$ & $-1,514$ & $-2,580$ & $-2,814$ & $-1,564$ &,- 849 & $-1,786$ \\
\hline Zaobljenost & 5,993 & 11,459 & 5,313 & 4,182 & ,296 & 4,714 & 5,993 &, 453 & $-1,296$ & 1,203 \\
\hline Minimum & 0 & 0 & 0 & 0 & 0 & 0 & 0 & 0 & 0 & 0 \\
\hline Maksimum & 1 & 1 & 1 & 1 & 1 & 1 & 1 & 1 & 1 & 1 \\
\hline
\end{tabular}


Prilog 13

Deskriptivna statistika testa Razumijevanje teksta čitanjem-NJEMAČKI JEZIK $\left(N_{n j \_} t=154\right)$

1. zadatak
\begin{tabular}{|l|l|l|l|l|l|l|l|l|}
\hline & B1 & C1 & D 1 & E1 & F1 & G1 & H1 & I1 \\
\hline AS &, 82 &, 56 &, 47 &, 54 &, 44 &, 50 &, 70 &, 84 \\
\hline Medijan & 1,00 & 1,00 & 0,00 & 1,00 & 0,00 &, 50 & 1,00 & 1,00 \\
\hline SD &, 381 &, 498 &, 501 &, 500 &, 498 &, 502 &, 459 &, 364 \\
\hline Asimetričnost & $-1,725$ &,- 238 &, 131 &,- 158 &, 238 & 0,000 &,- 888 & $-1,916$ \\
\hline Zaobljenost &, 987 & $-1,969$ & $-2,009$ & $-2,001$ & $-1,969$ & $-2,026$ & $-1,227$ & 1,695 \\
\hline Minimum & 0 & 0 & 0 & 0 & 0 & 0 & 0 & 0 \\
\hline Maksimum & 1 & 1 & 1 & 1 & 1 & 1 & 1 & 1 \\
\hline
\end{tabular}
AS= aritmetička sredina, SD= standardna devijacija

2. zadatak

\begin{tabular}{|l|l|l|l|l|l|l|}
\hline & B2 & C2 & D2 & E2 & F2 & G2 \\
\hline AS &, 60 &, 44 &, 56 &, 44 &, 50 &, 62 \\
\hline Medijan & 1,00 & 0,00 & 1,00 & 0,00 &, 50 & 1,00 \\
\hline SD &, 491 &, 497 &, 511 &, 510 &, 502 &, 488 \\
\hline Asimetričnost &,- 429 &, 265 &,- 089 &, 414 & 0,000 &,- 486 \\
\hline Zaobljenost & $-1,840$ & $-1,956$ & $-1,643$ & $-1,480$ & $-2,026$ & $-1,788$ \\
\hline Minimum & 0 & 0 & 0 & 0 & 0 & 0 \\
\hline Maksimum & 1 & 1 & 2 & 2 & 1 & 1 \\
\hline
\end{tabular}

$A S=$ aritmetička sredina, $S D=$ standardna devijacija 
3. zadatak

\begin{tabular}{|c|c|c|c|c|c|c|c|c|}
\hline & B3 & C3 & D3 & E3 & F3 & G3 & $\mathrm{H} 3$ & I3 \\
\hline AS & ,53 &, 53 & 21 & 37 & 47 & ,59 & ,39 & 29 \\
\hline Medijan & 1,00 & 1,00 & 0,00 & 0,00 & 0,00 & 1,00 & 0,00 & 0,00 \\
\hline SD & ,501 & ,501 & ,407 & ,484 & ,501 & ,493 & ,502 & ,456 \\
\hline Asimetričnost &,- 131 &,- 131 & 1,455 & ,543 & ,105 &,- 373 & ,613 & ,923 \\
\hline Zaobljenost & $-2,009$ & $-2,009$ &, 117 & $-1,727$ & $-2,015$ & $-1,885$ & $-1,250$ & $-1,164$ \\
\hline Minimum & 0 & 0 & 0 & 0 & 0 & 0 & 0 & 0 \\
\hline Maksimum & 1 & 1 & 1 & 1 & 1 & 1 & 2 & 1 \\
\hline
\end{tabular}

$A S=$ aritmetička sredina, $S D=$ standardna devijacija

4. zadatak
\begin{tabular}{|l|l|l|l|l|l|l|l|l|l|l|}
\hline & B4 & C4 & D4 & E4 & F4 & G4 & H4 & I4 & J4 & K4 \\
\hline AS &, 97 &, 59 &, 56 &, 69 &, 61 &, 77 &, 71 &, 73 &, 68 &, 51 \\
\hline Medijan & 1,00 & 1,00 & 1,00 & 1,00 & 1,00 & 1,00 & 1,00 & 1,00 & 1,00 & 1,00 \\
\hline SD &, 178 &, 493 &, 497 &, 465 &, 489 &, 425 &, 456 &, 447 &, 470 &, 501 \\
\hline Asimetričnost & $-5,328$ &,- 373 &,- 265 &,- 821 &,- 457 & $-1,271$ &,- 923 & $-1,031$ &,- 756 &,- 052 \\
\hline Zaobljenost & 26,732 & $-1,885$ & $-1,956$ & $-1,343$ & $-1,815$ &,- 391 & $-1,164$ &,- 950 & $-1,447$ & $-2,024$ \\
\hline Minimum & 0 & 0 & 0 & 0 & 0 & 0 & 0 & 0 & 0 & 0 \\
\hline Maksimum & 1 & 1 & 1 & 1 & 1 & 1 & 1 & 1 & 1 & 1 \\
\hline
\end{tabular}
AS= aritmetička sredina, SD= standardna devijacija

$A S=$ aritmetička sredina, $S D=$ standardna devijacija 
5. zadatak

\begin{tabular}{|l|l|l|l|l|l|l|l|l|}
\hline & B5 & C5 & D5 & E5 & F5 & G5 & H5 & I5 \\
\hline AS &, 57 &, 61 &, 66 &, 75 &, 67 &, 57 &, 62 &, 63 \\
\hline Medijan & 1,00 & 1,00 & 1,00 & 1,00 & 1,00 & 1,00 & 1,00 & 1,00 \\
\hline SD &, 496 &, 489 &, 474 &, 433 &, 472 &, 496 &, 486 &, 484 \\
\hline Asimetričnost &,- 292 &,- 457 &,- 693 & $-1,186$ &,- 725 &,- 292 &,- 514 &,- 543 \\
\hline Zaobljenost & $-1,940$ & $-1,815$ & $-1,539$ &,- 600 & $-1,495$ & $-1,940$ & $-1,759$ & $-1,727$ \\
\hline Minimum & 0 & 0 & 0 & 0 & 0 & 0 & 0 & 0 \\
\hline Maksimum & 1 & 1 & 1 & 1 & 1 & 1 & 1 & 1 \\
\hline
\end{tabular}

$A S=$ aritmetička sredina, $S D=$ standardna devijacija 


\section{Prilog 14}

Upitnik za mjerenje straha od stranoga jezika u razrednoj situaciji Foreign Language Classroom Anxiety Scale (FLCAS) (Horwitz, Horwitz i Cope, 1986)

Odredite koliko vas dobro opisuju sljedeće tvrdnje. Zaokružite odgovarajući broj prema navedenoj ljestvici:

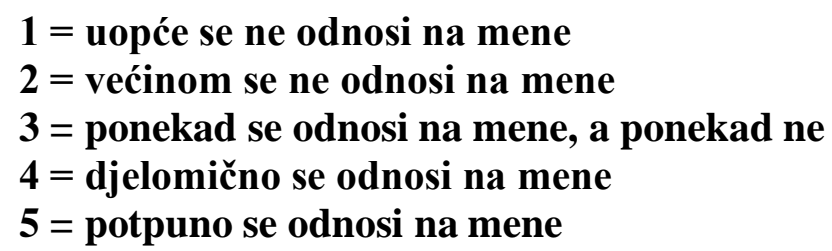

\begin{tabular}{|c|c|c|c|c|c|c|}
\hline 1. & $\begin{array}{l}\text { Nikada se ne osjećam potpuno sigurnim u sebe kada govorim na } \\
\text { satu stranoga jezika. }\end{array}$ & 1 & 2 & 3 & 4 & 5 \\
\hline 2. & Ne zabrinjavaju me pogreške koje radim na satu stranoga jezika. & 1 & 2 & 3 & 4 & 5 \\
\hline 3. & Uhvati me strah kad vidim da će me profesor prozvati. & 1 & 2 & 3 & 4 & 5 \\
\hline 4. & $\begin{array}{l}\text { Uplašim se kad ne razumijem što profesor govori na stranome } \\
\text { jeziku. }\end{array}$ & 1 & 2 & 3 & 4 & 5 \\
\hline 5. & Ne bi me smetalo da imam više sati stranoga jezika. & 1 & 2 & 3 & 4 & 5 \\
\hline 6. & $\begin{array}{l}\text { Tijekom sata često razmišljam o stvarima koje nemaju veze sa } \\
\text { stranim jezikom. }\end{array}$ & 1 & 2 & 3 & 4 & 5 \\
\hline 7. & Često mislim da drugi u razredu znaju strani jezik bolje od mene. & 1 & 2 & 3 & 4 & 5 \\
\hline 8. & $\begin{array}{l}\text { Kad imamo test (kontrolnu ili sl.) iz stranog jezik, obično sam } \\
\text { opušten. }\end{array}$ & 1 & 2 & 3 & 4 & 5 \\
\hline 9. & $\begin{array}{l}\text { Uhvati me panika kad na satu stranog jezika moram govoriti bez } \\
\text { pripreme. }\end{array}$ & 1 & 2 & 3 & 4 & 5 \\
\hline 10. & Bojim se posljedica loše ocjene iz stranog jezika. & 1 & 2 & 3 & 4 & 5 \\
\hline 11. & Ne znam zašto se neki toliko uzrujavaju oko stranoga jezika. & 1 & 2 & 3 & 4 & 5 \\
\hline 12. & $\begin{array}{l}\text { Na satu stranoga jezika mogu postati toliko nervozan da } \\
\text { zaboravim i ono što znam. }\end{array}$ & 1 & 2 & 3 & 4 & 5 \\
\hline 13. & Neugodno mi je javljati se na satu. & 1 & 2 & 3 & 4 & 5 \\
\hline 14. & $\begin{array}{l}\text { Da moram na stranom jeziku razgovarati s izvornim govornikom, } \\
\text { ne bih bio nervozan. }\end{array}$ & 1 & 2 & 3 & 4 & 5 \\
\hline 15. & $\begin{array}{l}\text { Uzrujam se kad me profesor ispravi, a ne razumijem u čemu je } \\
\text { pogreška. }\end{array}$ & 1 & 2 & 3 & 4 & 5 \\
\hline
\end{tabular}




\begin{tabular}{|c|c|c|c|c|c|c|}
\hline 16. & Čak i kad se dobro pripremim, strah me na satu stranog jezika. & 1 & 2 & 3 & 4 & 5 \\
\hline 17. & Često mi se ne ide na sat stranog jezika. & 1 & 2 & 3 & 4 & 5 \\
\hline 18. & Osjećam se sigurnim u sebe kad govorim na satu stranog jezika. & 1 & 2 & 3 & 4 & 5 \\
\hline 19. & Bojim se da moj profesor čeka da pogriješim kako bi me ispravio. & 1 & 2 & 3 & 4 & 5 \\
\hline 20. & Osjećam kako mi srce lupa kad me na satu profesor treba prozvati. & 1 & 2 & 3 & 4 & 5 \\
\hline 21. & $\begin{array}{l}\text { Kad učim za kontolnu (test ili sl.), što više učim, to sam više } \\
\text { zbunjen. }\end{array}$ & 1 & 2 & 3 & 4 & 5 \\
\hline 22. & $\begin{array}{l}\text { Ne osjećam se prisiljen da se dobro pripremam za sat stranog } \\
\text { jezika. }\end{array}$ & 1 & 2 & 3 & 4 & 5 \\
\hline 23. & Uvijek mi se čini da drugi govore strani jezik bolje od mene. & 1 & 2 & 3 & 4 & 5 \\
\hline 24. & Neugodno mi je govoriti strani jezik pred drugima u razredu. & 1 & 2 & 3 & 4 & 5 \\
\hline 25. & $\begin{array}{l}\text { Toliko brzo prelazimo gradivo iz stranog jezika da me strah da ću } \\
\text { zaostati. }\end{array}$ & 1 & 2 & 3 & 4 & 5 \\
\hline 26. & Na satu stranog jezika nervoziji sam nego na drugim satima. & 1 & 2 & 3 & 4 & 5 \\
\hline 27. & $\begin{array}{l}\text { Kad govorim na satu stranog jezika, osjećam se nervozno i } \\
\text { zbunjeno. }\end{array}$ & 1 & 2 & 3 & 4 & 5 \\
\hline 28. & Prije sata stranog jezika osjećam se opuštenim i sigurnim u sebe. & 1 & 2 & 3 & 4 & 5 \\
\hline 29. & $\begin{array}{l}\text { Postanem nervozan kad ne razumijem svaku riječ koju profesor } \\
\text { kaže. }\end{array}$ & 1 & 2 & 3 & 4 & 5 \\
\hline 30. & $\begin{array}{l}\text { Obeshrabruje me broj pravila koja treba znati da bi se govorilo } \\
\text { strani jezik. }\end{array}$ & 1 & 2 & 3 & 4 & 5 \\
\hline 31. & $\begin{array}{l}\text { Bojim se da će mi se drugi u razredu smijati kad govorim na } \\
\text { stranom jeziku. }\end{array}$ & 1 & 2 & 3 & 4 & 5 \\
\hline 32. & U društvu izvornih govornika vjerojatno bih se osjećao ugodno. & 1 & 2 & 3 & 4 & 5 \\
\hline 33. & Nervozan sam kad me profesor pita, a nisam se spremio. & 1 & 2 & 3 & 4 & 5 \\
\hline
\end{tabular}




\section{Prilog 15}

\section{Upitnik o strahu od čitanja na stranome jeziku}

\section{Foreign Language Reading Anxiety Scale (FLRAS)}

(Saito, Horwitz i Garza, 1999)

Odredite koliko vas dobro opisuju sljedeće tvrdnje. Zaokružite odgovarajući broj prema navedenoj ljestvici:

$$
\begin{aligned}
& 1=\text { uopće se ne odnosi na mene } \\
& 2=\text { većinom se ne odnosi na mene } \\
& 3=\text { ponekad se odnosi na mene, a ponekad ne } \\
& 4=\text { djelomično se odnosi na mene } \\
& 5=\text { potpuno se odnosi na mene }
\end{aligned}
$$

\begin{tabular}{|c|c|c|c|c|c|c|}
\hline 1. & $\begin{array}{l}\text { Uzrujam se kad nisam siguran/na da dobro razumijem ono što } \\
\text { čitam na engleskome. }\end{array}$ & 1 & 2 & 3 & 4 & 5 \\
\hline 2. & $\begin{array}{l}\text { Kad čitam engleski, često razumijem gotovo sve riječi, ali } \\
\text { svejedno ne shvaćam što se želi reći. }\end{array}$ & 1 & 2 & 3 & 4 & 5 \\
\hline 3. & $\begin{array}{l}\text { Kad čitam engleski, toliko se zbunim da ne mogu pratiti što } \\
\text { čitam. }\end{array}$ & 1 & 2 & 3 & 4 & 5 \\
\hline 4. & $\begin{array}{l}\text { Uhvati me strah kad vidim cijelu stranicu teksta za pročitati na } \\
\text { engleskome. }\end{array}$ & 1 & 2 & 3 & 4 & 5 \\
\hline 5. & $\begin{array}{l}\text { Narvozan/na sam kad moram čitati engleski tekst o nepoznatoj } \\
\text { temi. }\end{array}$ & 1 & 2 & 3 & 4 & 5 \\
\hline 6. & $\begin{array}{l}\text { Uzrujam se svaki put kad pri čitanju naiđem na nepoznatu } \\
\text { gramatiku. }\end{array}$ & 1 & 2 & 3 & 4 & 5 \\
\hline 7. & $\begin{array}{l}\text { Postanem nervozan/na i zbunjen/a kad pri čitanju ne razumijem } \\
\text { svaku riječ. }\end{array}$ & 1 & 2 & 3 & 4 & 5 \\
\hline 8. & $\begin{array}{l}\text { Smeta me kad pri čitanju naiđem na riječ koju ne znam } \\
\text { izgovoriti. }\end{array}$ & 1 & 2 & 3 & 4 & 5 \\
\hline 9. & Obično pri čitanju prevodim riječ po riječ. & 1 & 2 & 3 & 4 & 5 \\
\hline 10. & $\begin{array}{l}\text { Zbog kompliciranih pravila pisanja u engleskome, teško mi je } \\
\text { slijediti značenje teksta. }\end{array}$ & 1 & 2 & 3 & 4 & 5 \\
\hline 11. & $\begin{array}{l}\text { Brine me kako ću svladati engleski spelling (pravila pisanja) da } \\
\text { bih mogao/la čitati. }\end{array}$ & 1 & 2 & 3 & 4 & 5 \\
\hline 12. & Uživam čitati na engleskome. & 1 & 2 & 3 & 4 & 5 \\
\hline
\end{tabular}




\begin{tabular}{|c|c|c|c|c|c|c|}
\hline 13. & Osjećam se sigurnim/om u sebe dok čitam engleski. & 1 & 2 & 3 & 4 & 5 \\
\hline 14. & $\begin{array}{l}\text { Kad se jednom navikneš, čitanje na engleskome i nije tako } \\
\text { teško. }\end{array}$ & 1 & 2 & 3 & 4 & 5 \\
\hline 15. & Najteža stvar u engleskome za mene je naučiti čitati. & 1 & 2 & 3 & 4 & 5 \\
\hline 16. & Više bih volio/la da samo učim govoriti engleski, a ne i čitati. & 1 & 2 & 3 & 4 & 5 \\
\hline 17. & $\begin{array}{l}\text { Ne smeta me čitanje u sebi, no ne osjećam se ugodno kad } \\
\text { moram čitati naglas. }\end{array}$ & 1 & 2 & 3 & 4 & 5 \\
\hline 18. & Zadovolja/na sam kako čitam na engleskome. & 1 & 2 & 3 & 4 & 5 \\
\hline 19. & $\begin{array}{l}\text { Britanska (američka, australska, kanadska) kultura i ideje vrlo su } \\
\text { mi čudne. }\end{array}$ & 1 & 2 & 3 & 4 & 5 \\
\hline 20. & $\begin{array}{l}\text { Da bi se moglo čitati engleski, treba znati mnogo o britanskoj } \\
\text { (američkoj, australskoj, kanadskoj) kulturi. }\end{array}$ & 1 & 2 & 3 & 4 & 5 \\
\hline
\end{tabular}




\section{Prilog 16}

Analiza Cronbachova $\alpha$ nakon izbacivanja pojedinih čestica za engleski jezik

\begin{tabular}{|c|c|c|c|c|}
\hline čestica & $\begin{array}{l}\text { Prosječna } \\
\text { vrijednost } \\
\text { bez čestice }\end{array}$ & $\begin{array}{l}\text { Varijanca } \\
\text { bez čestice }\end{array}$ & $\begin{array}{l}\text { Korelacija } \\
\text { ukupnog } \\
\text { rezultata } \\
\text { s česticom* }\end{array}$ & $\begin{array}{c}\text { Cronbachov } \alpha \\
\text { bez } \\
\text { čestice }\end{array}$ \\
\hline eng_t_1 & 79,68 & 517,368 & 0,654 & 0,909 \\
\hline eng_t_2 & 79,81 & 520,187 & 0,641 & 0,909 \\
\hline eng_t_3 & 79,52 & 516,831 & 0,635 & 0,909 \\
\hline eng_t_4 & 78,74 & 542,233 & 0,116 & 0,916 \\
\hline eng_t_5 & 79,7 & 523,13 & 0,547 & 0,91 \\
\hline eng_t_6 & 79,03 & 518,554 & 0,542 & 0,91 \\
\hline eng_t_7 & 79,74 & 527,455 & 0,501 & 0,911 \\
\hline eng_t_8 & 79,88 & 530,199 & 0,499 & 0,911 \\
\hline eng_t_9 & 78,69 & 528,096 & 0,375 & 0,912 \\
\hline eng_t_10 & 79,41 & 536,623 & 0,243 & 0,914 \\
\hline eng_t_11 & 79,76 & 527,623 & 0,505 & 0,911 \\
\hline eng_t_12 & 79,6 & 522,512 & 0,556 & 0,91 \\
\hline eng_t_13 & 80,01 & 527,025 & 0,595 & 0,91 \\
\hline eng_t_14 & 79,75 & 531,098 & 0,507 & 0,911 \\
\hline eng_t_15 & 79,04 & 517,088 & 0,537 & 0,91 \\
\hline eng_t_16 & 79,69 & 524,196 & 0,597 & 0,91 \\
\hline eng_t_17 & 79,66 & 532,167 & 0,366 & 0,912 \\
\hline eng_t_18 & 78,68 & 528,4 & 0,350 & 0,913 \\
\hline eng_t_19 & 79,01 & 518,19 & 0,485 & 0,911 \\
\hline eng_t_20 & 79,1 & 530,184 & 0,327 & 0,913 \\
\hline eng_t_21 & 77,57 & 572,087 & $-0,311$ & 0,921 \\
\hline eng_t_22 & 79,91 & 532,942 & 0,441 & 0,911 \\
\hline eng_t_23 & 79,01 & 535,93 & 0,243 & 0,914 \\
\hline eng_t_24 & 79,3 & 515,43 & 0,670 & 0,908 \\
\hline eng_t_25 & 79,4 & 519,162 & 0,534 & 0,91 \\
\hline eng_t_26 & 79,89 & 525,822 & 0,592 & 0,91 \\
\hline eng_t_27 & 79,59 & 515,983 & 0,671 & 0,908 \\
\hline eng_t_28 & 79,79 & 525,266 & 0,606 & 0,91 \\
\hline eng_t_29 & 79,16 & 512,445 & 0,622 & 0,909 \\
\hline eng_t_30 & 78,86 & 536,83 & 0,225 & 0,914 \\
\hline eng_t_31 & 79,68 & 531,88 & 0,437 & 0,911 \\
\hline eng_t_32 & 79,42 & 522,055 & 0,556 & 0,91 \\
\hline eng_t_33 & 79,04 & 545,803 & 0,08 & 0,916 \\
\hline eng_t_34 & 79,81 & 525,704 & 0,545 & 0,91 \\
\hline eng_t_35 & 79,5 & 519,461 & 0,633 & 0,909 \\
\hline
\end{tabular}




\begin{tabular}{lrccr} 
eng_t_36 & 78,64 & 531,881 & 0,287 & 0,913 \\
eng_t_37 & 79,79 & 519,169 & 0,702 & 0,909 \\
eng_t_38 & 79,8 & 522,323 & 0,614 & 0,909 \\
eng_t_39 & 79,71 & 524,688 & 0,544 & 0,91 \\
eng_t_40 & 78,75 & 535,95 & 0,199 & 0,915 \\
\hline \multicolumn{4}{c}{ * ukupni rezultat ne sadrži česticu s kojom je koreliran }
\end{tabular}


Analiza Cronbachova $\alpha$

nakon izbacivanja pojedinih čestica za njemački jezik

\begin{tabular}{|c|c|c|c|c|}
\hline čestica & $\begin{array}{l}\text { Prosječna } \\
\text { vrijednost } \\
\text { bez čestice }\end{array}$ & $\begin{array}{l}\text { Varijanca } \\
\text { bez čestice }\end{array}$ & $\begin{array}{l}\text { Korelacija } \\
\text { ukupnog } \\
\text { rezultata } \\
\text { s česticom* }\end{array}$ & $\begin{array}{c}\text { Cronbachov } \alpha \\
\text { bez } \\
\text { čestice }\end{array}$ \\
\hline njem_t_1 & 93,17 & 584,104 & 0,655 & 0,916 \\
\hline njem_t_2 & 93,45 & 588,099 & 0,648 & 0,917 \\
\hline njem_t_3 & 92,93 & 587,313 & 0,611 & 0,917 \\
\hline njem_t_4 & 92,6 & 606,827 & 0,226 & 0,922 \\
\hline njem_t_5 & 93,53 & 599,793 & 0,429 & 0,919 \\
\hline njem_t_6 & 92,2 & 588,521 & 0,543 & 0,918 \\
\hline njem_t_7 & 93,49 & 597,166 & 0,518 & 0,918 \\
\hline njem_t_8 & 93,25 & 597,232 & 0,462 & 0,918 \\
\hline njem_t_9 & 92,12 & 598,384 & 0,381 & 0,919 \\
\hline njem_t_10 & 91,2 & 611,954 & 0,2 & 0,921 \\
\hline njem_t_11 & 93,08 & 603,168 & 0,37 & 0,919 \\
\hline njem_t_12 & 92,81 & 597,576 & 0,416 & 0,919 \\
\hline njem_t_13 & 93,18 & 588,406 & 0,583 & 0,917 \\
\hline njem_t_14 & 93,19 & 597,566 & 0,474 & 0,918 \\
\hline njem_t_15 & 92,09 & 590,131 & 0,518 & 0,918 \\
\hline njem_t_16 & 93,24 & 595,07 & 0,503 & 0,918 \\
\hline njem_t_17 & 93,33 & 600,858 & 0,364 & 0,92 \\
\hline njem_t_18 & 92,56 & 595,959 & 0,455 & 0,919 \\
\hline njem_t_19 & 92,66 & 579,369 & 0,645 & 0,916 \\
\hline njem_t_20 & 92,94 & 590,369 & 0,544 & 0,918 \\
\hline njem_t_21 & 93,27 & 643,712 & $-0,311$ & 0,926 \\
\hline njem_t_22 & 93,61 & 605,423 & 0,378 & 0,919 \\
\hline njem_t_23 & 92,84 & 617,63 & 0,091 & 0,923 \\
\hline njem_t_24 & 92,63 & 582,633 & 0,645 & 0,916 \\
\hline njem_t_25 & 93,19 & 590,054 & 0,537 & 0,918 \\
\hline njem_t_26 & 93,65 & 597,214 & 0,589 & 0,918 \\
\hline njem_t_27 & 93,16 & 584,535 & 0,639 & 0,916 \\
\hline njem_t_28 & 93,33 & 590,52 & 0,606 & 0,917 \\
\hline njem_t_29 & 92,58 & 576,832 & 0,686 & 0,916 \\
\hline njem_t_30 & 92,54 & 609,234 & 0,195 & 0,922 \\
\hline njem_t_31 & 93,05 & 593,723 & 0,507 & 0,918 \\
\hline njem_t_32 & 92,84 & 585,527 & 0,597 & 0,917 \\
\hline njem_t_33 & 91,25 & 617,341 & 0,108 & 0,922 \\
\hline njem_t_34 & 93,49 & 593,783 & 0,551 & 0,918 \\
\hline njem_t_35 & 92,56 & 584,645 & 0,611 & 0,917 \\
\hline njem_t_36 & 92,45 & 604,706 & 0,296 & 0,92 \\
\hline
\end{tabular}




\begin{tabular}{rrrrr} 
njem_t_37 & 93,06 & 579,643 & 0,697 & 0,916 \\
njem_t_38 & 93,44 & 595,8 & 0,532 & 0,918 \\
njem_t_39 & 93,25 & 584,147 & 0,649 & 0,916 \\
njem_t_40 & 92,41 & 603,238 & 0,28 & 0,921 \\
\hline
\end{tabular}

* ukupni rezultat ne sadrži česticu s kojom je koreliran 


\section{Prilog 18}

U svrhu izračunavanja značajnosti indirektnog efekta kod medijacijskih analiza, korišten je interaktivni on-line softver, dostupan na web stranici http://quantpsy.org/sobel/sobel.htm.

Tablica1. Rezultati za engleski jezik

\begin{tabular}{|c|c|c|c|c|}
\hline Input: & & Test statistic: & Std. Error: & $p$-value: \\
\hline a -0.618 & Sobel test: & -4.89678335 & 0.59493177 & $9.7 e-7$ \\
\hline b 4.714 & Aroian test: & -4.87943743 & 0.5970467 & 0.00000106 \\
\hline$s_{a} 0.059$ & Goodman test: & -4.91431558 & 0.5928093 & $8.9 e-7$ \\
\hline$s_{\mathrm{b}} 0.851$ & Reset all & & Calculate & \\
\hline
\end{tabular}

Tablica 2. Rezultati za njemački jezik

\begin{tabular}{|c|c|c|c|c|}
\hline Input: & & Test statistic: & Std. Error: & $p$-value: \\
\hline a -0.350 & Sobel test: & -4.1801956 & 0.48637676 & 0.00002913 \\
\hline b 5.809 & Aroian test: & -4.15144163 & 0.48974553 & 0.00003304 \\
\hline$s_{a} 0.064$ & Goodman test: & -4.20955545 & 0.48298449 & 0.00002559 \\
\hline$s_{\mathrm{b}} 0.896$ & Reset all & & Calculate & \\
\hline
\end{tabular}




\section{ŽIVOTOPIS}

Sandra Didović Baranac rođena je 12. prosinca 1972. godine u Dubrovniku. Na Filozofskome fakultetu u Zagrebu diplomirala je 1999. godine na dvopredmetnome studiju engleskoga jezika i književnosti i njemačkoga jezika i književnosti. Magistrirala je na Filozofskome fakultetu u Zagrebu 2012. godine temom Razredno ozračje kao kurikulumska sastavnica u nastavi stranoga jezika. Više puta bila je korisnica DAAD stipendije za studij anglistike i germanistike i stručno usavršavanje iz područja nastave njemačkoga jezika u Saveznoj Republici Njemačkoj.

Od 2000. do 2004. godine radila je kao stručni suradnik u nastavi engleskoga i njemačkoga jezika na Veleučilištu u Dubrovniku. Od 2004. godine radi na Sveučilištu u Dubrovniku, gdje je iste godine birana u zvanje predavača, a zatim 2012. godine u zvanje višega predavača. Godine 2018. ponovno je birana u zvanje višega predavača za anglistiku i germanistiku. Redovito sudjeluje na skupovima stručnoga usavršavanja iz područja nastave engleskoga i njemačkoga jezika te na znanstvenim skupovima iz područja primijenjene lingvistike. 


\section{POPIS OBJAVLJENIH RADOVA}

Božinović, N. i Didović Baranac, S. (2011). Strah od stranoga jezika u razrednom okruženju. U: J. Vučo i B. Milatović (ur.), Međunarodni tematski zbornik radova Stavovi promjena promjena stavova (str. 239-249). Nikšić: Filozofski fakultet Nikšić, Univerzitet Crne Gore.

Vidak, N. i Didović Baranac, S. (2012). Professional Experience and Application of English Language in the Specific Area of Shipping. U: P. Vičić, S. Orthaber, V. M. Ipavec i M. Zrinski (ur.), Proceedings of the $5^{\text {th }}$ International Language Conference on the Importance of Learning Foreign Languages for Communication Between Cultures 2012 (str. 356-362). Celje: University of Maribor, Faculty of Logistics.

Vidak, N., Didović Baranac, S. i Falkoni-Mjehović, D. (2015). Attitudes of Croatian learners towards learning English, German and Spanish in a formal environment. U: A. Peti-Stantić, M.M. Stanojević i G. Antunović (ur.), Language Varieties Between Norms and Attitudes: South Slavic Perspectives: Proceedings from the 2013 CALS Conference (str. 121-132). Frankfurt am Main: Peter Lang GmbH.

Didović Baranac, S., Falkoni-Mjehović, D. i Vidak, N. (2016). Ispitivanje stavova prema učenju engleskoga, njemačkoga i španjolskog kao stranog jezika i jezika struke. U: V. Vrtiprah (ur.), 3. Zbornik Sveučilišta u Dubrovniku (str. 11-31). Dubrovnik: Sveučilište u Dubrovniku.

Falkoni-Mjehović, D., Vidak, N. i Didović Baranac, S. (2016). Povezanost stavova i uspjeha u učenju engleskoga, njemačkog i španjolskog kao stranog jezika. U: S. L. Udier i K. Cergol Kovačević (ur.), Metodologija i primjena lingvističkih istraživanja. Zbornik radova $s$ međunarodnoga znastvenog skupa Hrvatskoga društva za primijenjenu lingvistiku (str. 377395). Zagreb: Srednja Europa, HDPL. 